\title{
ROCKY MOUNTAIN TREES
}




$$
\because
$$




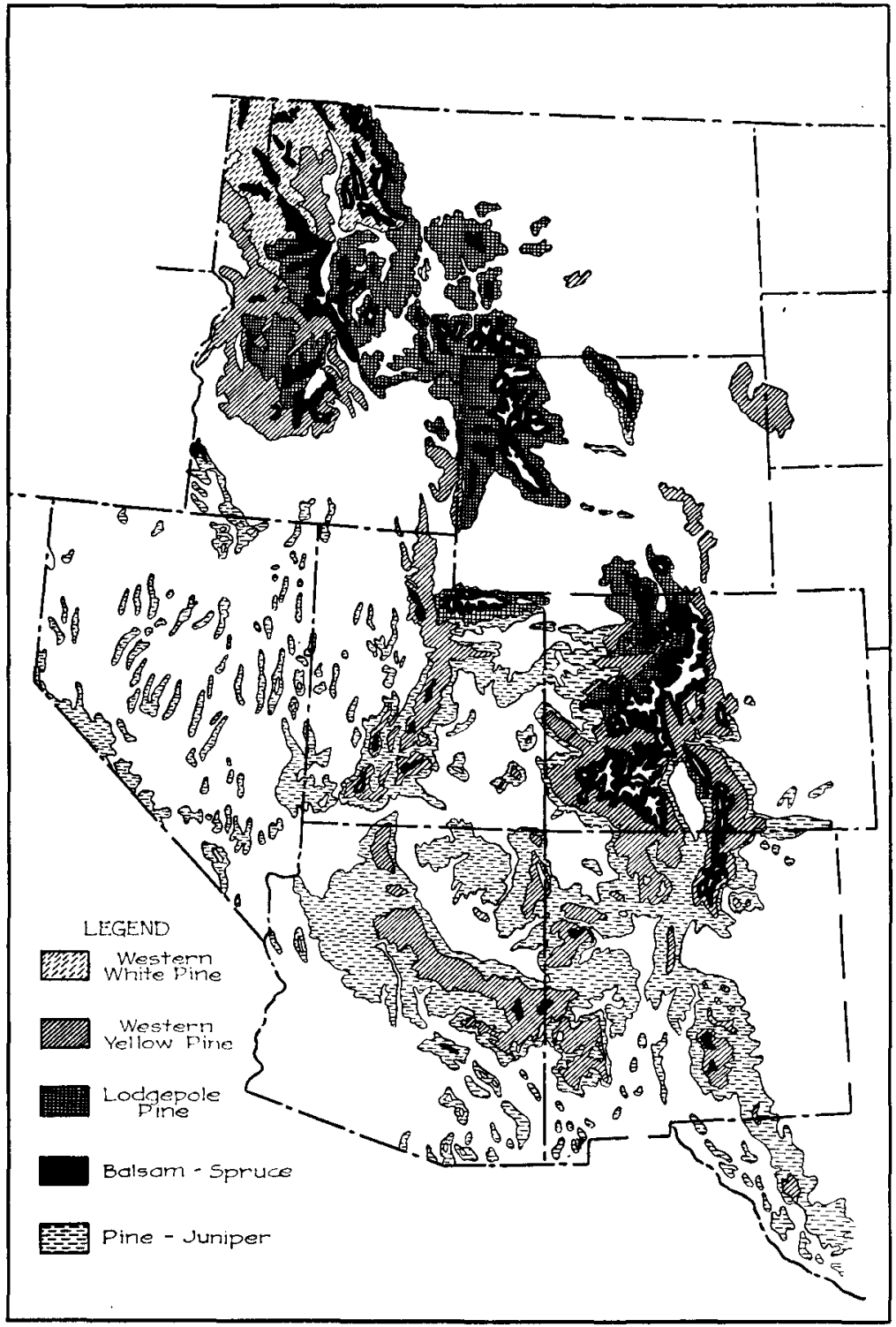




\title{
ROCKY MOUNTAIN TREES
}

A Handbook of the Native Species with Plates and Distribution Maps

\author{
by
}

RICHARD J. PRESTON, JR.

Associate Professor of Forestry, Colorado State College

\section{Ames, Iowa \\ THE IOWA STATE COLLEGE PRESS \\ 1940}


COPYRIGHT 1940 BY THE COLLEGIATE PRESS, INCORPORATED. ALL RIGHTS RESERVED. PRINTED BY THE COLLEGIATE PRESS, INCORPORATED, AMES, IOWA

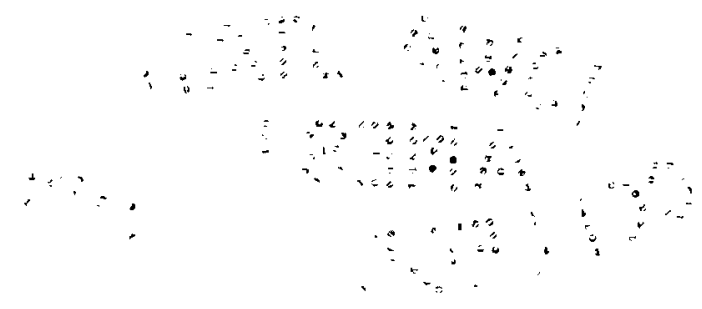


Qhe
pores

\section{TO MY PARENTS}

Who so generously and wisely made possible the experiences and opportunities that have enriched my life 
. 


\section{PREFACE}

Public interest in trees and forests has increased greatly in recent years. As a result of this awakening interest, numerous manuals of native trees have appeared in different sections of the country, making available to the people the technical knowledge necessary for the identification and understanding of the trees which they find around them. To date, no such manual has appeared for the Rocky Mountain region, and therefore this book has been written. It has been planned to meet the needs of trained foresters, students, and others interested in knowing the trees. Plates showing descriptive characters, distribution and zone maps, concise descriptions of botanical and silvical characters, check lists of species by states, and extensive keys have been included. Care has been taken to insure the inclusion of all native or naturalized trees within this region, and 252 species representing 85 genera and 40 families have been treated, as well as numerous varieties. Of the 129 full-page plates used in this manual, 77 are original, the work of Bruce Eastman, who graduated from the Division of Forestry of Colorado State College in 1938. These plates were prepared from herbarium material available either in the college herbarium or borrowed from the University of Wyoming. Care was taken to include the characters which would be most valuable in identification. The plates of the conifers, except those on pages $4,20,60$, and 90 , were made wholly or in part from drawings used in Sudworth's bulletins on the trees of the Rocky Mountains, with the permission of the United States Forest Service. The plates on pages 4 and 64 were used with the permission of the Oregon State Board of Forestry. The plates opposite pages 101, 107, $123,151,155,157,161,173,189,191,195,207,233,263$, and 277 were made from those in Otis' Trees of Michigan, 
with the permission of the University of Michigan. 'The frontispiece and the plate on page 284 were used with the permission of the United States Department of Agriculture.

The descriptions of genera and species are based largely on material secured from the sources listed under the selected bibliography. Several references were used for each species and the characters carefully checked to insure that no errors were carried into the descriptions. Additional material, not available in these references, was gathered through study of herbarium material and through correspondence or conversation with the following men who generously cooperated in giving needed characters or opinions for numerous species:

Dr. F. A. Barkley, Montana State University; W. A. Dayton, Senior Forest Ecologist, United States Forest Service; L. N. Goodding, Soil Conservation Service, Albuquerque, N. M.; Dr. I. T. Haig and staff, Division of Silvics, United States Forest Service; Dr. R. E. Mc Ardle and staff, Rocky Mountain Forest and Range Experiment Station; Dr. Aven Nelson, University of Wyoming; F. C. W. Pooler, Regional Forester, Albuquerque, N. M.; Professor E. C. Smith, Colorado State College, Dr. J. J. Thornber, University of Arizona; Dr. Ivar Tidestrom, Catholic University; A. Upson and staff, Southwestern Forest and Range Experiment Station; S. N. Wyckoff and staff, Northern Rocky Mountain Forest and Range Experiment Station.

The descriptions include not only the botanical characters of the species, but also silvical characters such as habitat, tolerance, roots, enemies, reproduction, and associates.

Extreme care was taken to make the maps showing distribution as accurate as possible in the light of our present information. All of the references in the selected bibliography were used in drawing up the original maps. These were then photostated and separate sets sent to 
each of the following individuals who kindly made such corrections or additions as he saw fit and returned them: W. A. Dayton, Senior Forest Ecologist, United States Forest Service; L. N. Goodding, Soil Conservation Service, Albuquerque, N. M.; Dr. I. T. Haig and staff, Division of Silvics, United States Forest Service; Dr. R. E. Mc Ardle and staff, Rocky Mountain Forest and Range Experiment Station; Dr. Aven Nelson, University of Wyoming; Dr. F. Shreve, Desert Laboratory, Tucson, Arizona; Dr. J. J. Thornber, University of Arizona; A. Upson and staff, Southwestern Forest and Range Experiment Station; S. N. Wyckoff and staff, Northern Rocky Mountain Forest and Range Experiment Station.

The maps were then carefully drawn into their final form on the basis of these corrections and additions.

The author also wishes to acknowledge excellent assistance in editing and preparing the manuscript from J. R. Miller, I. G. Kinghorn, R. Randall, R. C. Hall, and D. Devet.

Both the author and publisher wish to thank the United States Forest Service for the use of the photograph reproduced on the jacket of this book. 



\section{TABLE OF CONTENTS}

Preface $\ldots \ldots \ldots \ldots \ldots \ldots \ldots \ldots \ldots \ldots \ldots \ldots \ldots$ ix

INTRODUCTION $\ldots \ldots \ldots \ldots \ldots \ldots \ldots \ldots \ldots \ldots \ldots \ldots$

The Rocky Mountain Region ......... xv

Tree Characters ................

Check List of the Trees found Within Each

State by Scientific and Common Names.... xxvii Arizona $\ldots \ldots \ldots \ldots \ldots \ldots \ldots \ldots \ldots \ldots \ldots$ xxvii

Colorado $\ldots \ldots \ldots \ldots \ldots \ldots \ldots \ldots \ldots \ldots \ldots \ldots \ldots$

Idaho $\ldots \ldots \ldots \ldots \ldots \ldots \ldots \ldots \ldots \ldots \ldots \ldots x x i v$

Montana ..................... xxxvi

Nevada ...................... xxxviii

New Mexico ................... xl

Western Texas ................ xliv

Utah $\ldots \ldots \ldots \ldots \ldots \ldots \ldots \ldots \ldots \ldots$ xlviii

Wyoming $\ldots \ldots \ldots \ldots \ldots \ldots \ldots \ldots \ldots$

Key to THe Genera $\ldots \ldots \ldots \ldots \ldots \ldots \ldots \ldots$ liii

MANUAL OF ROGKY MOUNTAIN TREES. . 1 to 286

Grossary $\ldots \ldots \ldots \ldots \ldots \ldots \ldots \ldots \ldots \ldots \ldots \ldots \ldots$

Selected Bibliography $\ldots \ldots \ldots \ldots \ldots \ldots \ldots$ lxxi

INDEX $\ldots \ldots \ldots \ldots \ldots \ldots \ldots \ldots \ldots \ldots \ldots \ldots \ldots \ldots \ldots \ldots i i$ 



\section{INTRODUCTION \\ THE ROCKY MOUNTAIN REGION}

EXTENT. In this manual the Rocky Mountain region has been broadly defined as the area lying between the Great Plains and the Pacific Coast states. Montana, Idaho, Wyoming, Colorado, Utah, Nevada, Arizona, New Mexico, extreme western Texas, and the Black Hills of South Dakota are included, as well as the Canadian territory lying north of these states. Mexican species were included only when their range extended into the southwestern states.

CHARACTER. This region, while greatly diversified as to topography and climate, is, on the whole, an arid one. Tree growth is largely restricted to high elevations or to water courses at lower altitudes. The flora varies all the way from subtropical to alpine, and from that found on the humid upper mountains to true desert types. Moisture, temperature, and topography are important factors limiting the distribution of species. The aspect and steepness of the slope are major factors in determining the altitude to which a species will grow, which in itself is important in determining the range of a species. Wherever helpful, the altitudinal range has been given to supplement the distribution maps. In a region extending in latitude from Mexico into Canada, altitude alone is strictly limited in usefulness, and therefore a more important factor is discussed in some detail, i. e., the life zones into which the trees tend to group themselves.

LIFE ZONES. The work of Dr. C. Hart Merriam and others disclosed the fact that both plants and animals tend to group themselves into definite life zones or belts, and that the same or very similar forms of life usually will be found in regions having similar climatic conditions. These zones tend to increase in altitude as they become 
more remote from the polar regions, so that typical arctic plants growing near sea level in polar regions might be found at elevations of 10,000 feet in Montana, 12,000 feet in Colorado, and 13,500 feet in Arizona. It has been stated that a change of $300 \mathrm{feet}$ in elevation is approximately the equivalent of 100 miles in latitude. As an example, Dr. Merriam states that nine species of plants growing on the bleak summit of San Francisco Mountain, Arizona, were brought back from Lady Franklin Bay above the arctic circle by Lt. A. W. Greely. As a rule these life zones can be readily identified, and are a very convenient aid in determining the local distributions of species.

Six life zones or belts are recognized in the Rocky Mountain region; the three higher zones belonging to the Boreal or cooler region, and the three lower to the Austral or subtropical region. Although the tropical region enters this area in the valley of the lower Colorado River in Arizona, it is arid in nature and here classed with the Lower Sonoran. On the whole these zones become progressively warmer and dryer from the Alpine to the Lower Sonorall.

\section{Alpine or Arctic-Alpine Zone}

This area corresponds to the artic barren grounds and lies above timber line. It is a bleak region, covered with snow during the greater part of the year, and one in which the variety of life has been reduced to a minimum. Much of the vegetation consists of mosses, lichens, and dwarf willows, although flowers bloom in profusion during the short summers.

\section{Hudsonian Zone}

In the Rocky Mountains this is a region of dwarfed, stunted conifers located just below timber line and corresponding to the northern part of the great transcontinental coniferous forest. This region, while sharply defined 


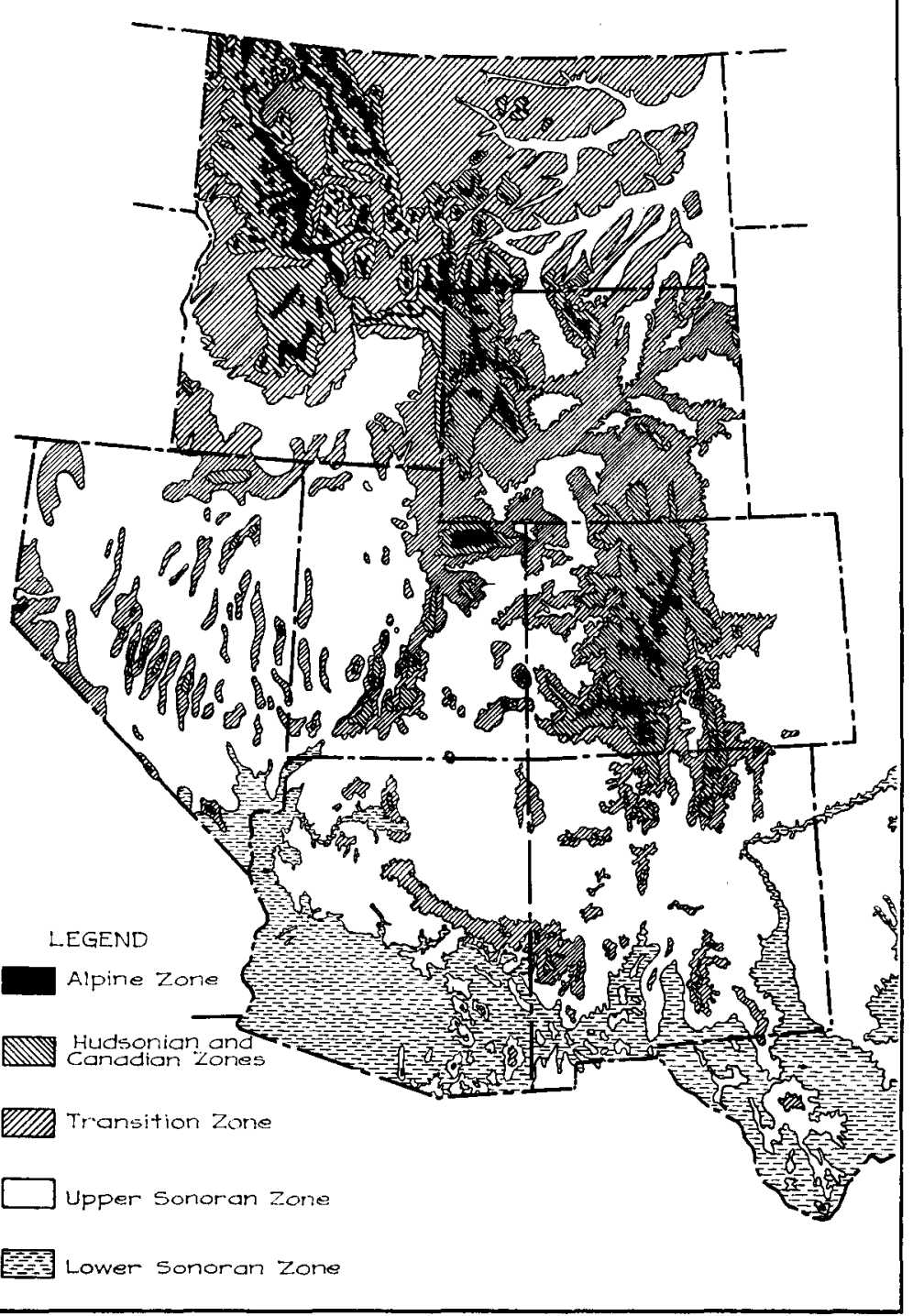

IIFE ZONES OF THE ROCKY MOUNTAIN REGION 
above by the sinuous tongues of timber-line trees, is poorly defined below, and merges almost imperceptibly into the Canadian zone. In reality this is a transitional area between the zones bordering it, and few species are restricted to it. Small, malformed Engelmann spruce and alpine fir characterize the zone, supplemented by foxtail pine in the south and alpine larch, mountain hemlock, and whitebark pine in the north.

\section{Canadian Zone}

This last of the Boreal and humid belts is located on the middle and higher mountain slopes. Sharply defined at its lower edge from the more arid species of the transitional zone, its upper border merges indistinctly into the Hudsonian zone. This is a zone with a rich flora characterized by dense stands of Engelmann spruce, true firs, western white and lodgepole pines, and aspen; while foxtail and limber pines, Douglas-fir, blue spruce, mountain maple, thinleaf alder, mountainash, balsam, poplar, and many other species are characteristic over parts of the region. Often the forests are interrupted by extensive grassland parks.

\section{Transition Zone}

This area, although classed as the upper Austral zone, is actually a neutral or transitional belt between the arid, warmer Sonoran zones and the humid, cool Boreal region, and is largely made up of species from these bordering belts. The zone is a variable one, ranging from the grassy or forested middle mountain slopes in the southern states to the yellow pine foothills and high. grassy or sage plains in the northern states. The forested portions lie largely in the southern and central states. In addition to the very characteristic western yellow pine, which is practically coextensive with the region, common tree species are: Arizona, Apache, Chihuahua, and Mexican white pines, Douglas-fir, western Iarch, cypress, vari- 
ous oaks, narrowleaf cottonwood, water birch, bigtoothed maple, southwestern locust, wild plum, chokecherry, hawthorns, serviceberry, mountain mahogany, hophornbeam, and buckthorn. From Wyoming north, this belt for the most part becomes open and treeless and so is less conspicuously characterized than in the southcentral regions. Vast plains of gray sage, rabbit brush, and other dry-land species occupy the arid sections, and tree growth is restricted to stream borders. On the moister sites are high grassy plains or, occasionally, yellow pine foothill stands. Where treeless, only the upper border of this belt is clearly defined at that point where the sage gives way to the aspens and conifers of the Canadian zone.

\section{Upper Sonoran Zone}

This arid division of the upper Austral zone is semitropical in nature and ranges from the high plains and foothills of the southern states to the low plains and valleys in the north. The zone is typified by the piñonjuniper forests or the broad-leaved cottonwoods along the streams in grassy or barren plains. Ash, elm, plum, sand cherry, black sage, boxelder, saltbrush, walnut, mexican alder, sycamore, Cowania, hackberry, mulberry, and hoptree are also found in this zone.

\section{Lower Sonoran Zone}

This lower or southern desert belt, the arid division of the lower Austral zone, is typically Mexican, extending into the United States over the low plains and along the river valleys of the southwestern states. While uniform both as to climate and species, this is a region of most extreme conditions for plant growth, rainfall being very scanty and the temperature often exceeding 120 degrees Fahrenheit. Few plants reach tree size, and these, growing along stream bottoms, are for the most part unlike those of any of the other zones. Mesquite and creosote 
bush characterize this belt, although other small tree forms are found, such as Koeberlinia, Parkinsonia, Acacia, Leucaena, Cercidium, Sophora, Eysenhardtia, desertwillow, Parosela , walnut, soapberry, Wizlizenius poplar, and cactus.

The vertical boundaries of these life zones are highly variable and for a large region can only be given as approximations. These boundaries depend upon various governing factors such as steepness of slope, exposure, wind, moisture, and deforestation, which either allow the species to grow above normal limits, or force them to levels below normal. It must be remembered, too, that on the border of each zone is a belt of varying vertical width (usually between 400-800 feet) in which the species of the two bordering zones mingle. The following table indicates the approximate elevations of the life zones in three sections of the region:

\begin{tabular}{|c|c|c|c|c|}
\hline Zone & & New Mexico & Central Colotado & Montana \\
\hline Alpine & & $12,500-13,300 \mathrm{ft}$. & $11,500-14,400 \mathrm{ft}$. & $9,000-12,000 \mathrm{ft}$. \\
\hline Hudsonian & & $11,500-12,500 \mathrm{ft}$. & $10,500-11,500 \mathrm{ft}$. & $8,000-9,000 \mathrm{ft}$. \\
\hline Canadian & & $9,000-\mathrm{Il}, 500 \mathrm{ft}$. & $8,000-10,500 \mathrm{ft}$ & $6,000-8,000 \mathrm{ft}$. \\
\hline Transition & . & $7,500-9,000 \mathrm{ft}$. & $6,000-8,000 \mathrm{ft}$. & $5,000-6,000 \mathrm{ft}$. \\
\hline Ipper & & & & \\
\hline $\begin{array}{l}\text { Sonoran } \\
\text { Lower }\end{array}$ & $\cdots$ & $4,200-7,500 \mathrm{ft}$. & $3,000-6,000 \mathrm{ft}$. & $2,000-5,000 \mathrm{ft}$. \\
\hline Sonoran & & $2,800-4,200 \mathrm{ft}$. & & \\
\hline
\end{tabular}

\section{TREE CHARACTERS}

A brief discussion of the structural and silvical characters which are necessary in identifying trees is presented here to aid students without previous botanical training.

DEFINITION OF A TREE. There is no clear-cut line of demarcation between a tree and a shrub, and it is often impossible to place a plant definitely in one group or the other. Frequently a species treelike under favorable environmental conditions will be shrublike over most of its range. In general, height, form and 
diameter must be taken into account in determining the classification of a doubtful form. In this manual, Sudworth's definition of a tree as a woody plant having one well-defined stem, a more or less definitely formed crown, and attaining a minimum height of eight feet and a diameter of not less than two inches, has been followed.

TERMINOLOGY. While appearing cumbersome to the beginner, the use of technical terms in describing characters is often necessary for a concise, accurate description. These technical terms have been avoided wherever their omission did not impair the meaning of the passage, and a glossary explaining all technical terms used has been included. The student should familiarize himself with the more commonly used terms early in his study of the trees.

NAME. Most species of trees have been given one or many common names which usually describe some character of the tree and are easily learned by students. Unfortunately, these common names have many limitations; some are merely local, others apply to two or more entirely different species, and some apply to trees belonging to different genera. Because of this, while common names may be useful and convenient, it is essential that each species of tree have a definite, individual name that can be accepted throughout the world and which cannot be applied to any other species. Botanists and scientists as a whole have agreed that these scientific names should be in Latin, as this is a dead language and not subject to change. Botanists have further agreed that the name of a tree should consist of three parts: a generic name referring the species to the group to which it belongs and which is capitalized; a specific name referring to the single species and beginning with a small letter; and the full or abbreviated name of the authority or person first describing the plant. Thus, the scientific name of western yellow pine is Pinus ponderosa Doug. When a variety of a species is recognized, the varietal name follows the spe- 
cific name, so in the case of Nogal, a larger variety of the Southwestern little walnut, the scientific name is Juglans rupestris var. major Torrey. When the names of two authorities are given, one appearing in parentheses, it indicates that the species was first described by the authority indicated in the parentheses, but placed in the wrong genus, and that this error was rectified by the second authority. This is the case with the western hemlock, Tsuga heterophylla (Rob.) Sarg. In this work the nomenclature accepted by the United States Forest Service (as amended to Jan. 23, 1940) has been followed, as it was felt that this would be of most service to foresters.

HABIT. This refers to the general appearance of a tree, usually as seen from a distance. The size; appearance and form of the trunk; shape, density and size of crown; the number, size, and direction of growth of the branches, are all factors helpful in distinguishing trees. In the conifers there is typically a trunk that extends to the tip of the tree without dividing (excurrent), while most of the hardwoods have the trunk breaking up into several large branches (deliquescent). Both the crown and branches may vary greatly in the same species depending upon whether the tree is growing in the open or in a dense stand where it is shaded on the sides by its neighbors.

LEAVES. Since leaves display characteristic patterns, they are probably the most useful organs in identifying trees. Leaves consist of an expanded portion or blade, a supporting stalk or petiole, and small leaflike or scaly structures (stipules) attached in pairs at the base of the petiole. Leaves having no stipules are termed exstipulate, and those without petioles are called sessile. Those species which are evergreen can be identified by their leaves throughout the year, while species which shed their leaves annually (deciduous) must be identified by other characters during the winter months. Leaves may be arranged alternately (with one leaf attached to the 

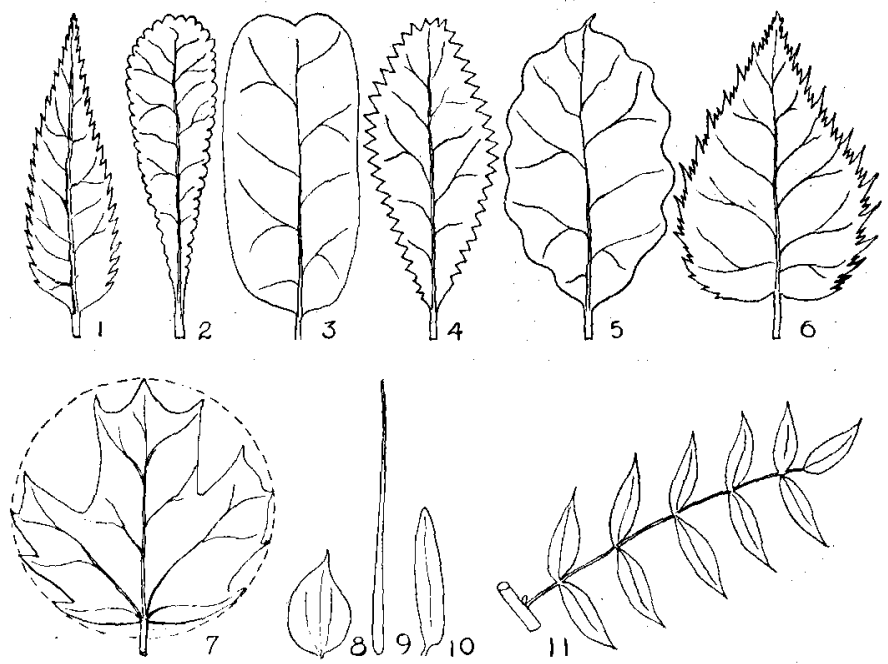

\section{I.EAF PATTERNS \\ Leaf Shapes}

1-Lanceolate. 2-Oblanceolate. 3-Oblong. 4-Elliptical. 5-Oval. 6-Ovate. 7-Orbicular. 8-Subulate. 9-Acicular. 10-Linear.

\section{Leaf Margins}

1-Serrate. 2-Crenate. 3-Entire. 4-Dentate. 5-Sinuatc. 6-Doubly serrate. 7-lobed .

\section{Leaf Apices}

1-Acuminate. 2-Rounded. 3-Emarginate. 4-Obtuse. 5-Mucronate. . 6-Acute.

\section{Leaf Bases}

1-Obtuse. 2-Cuncate. 3-Rounded. 4-Acute. 5-Rounded. 6-Cordate. 7-Truncate.

\section{Leaf Types}

1 to 10-Simple leaves. 11-Pinnately compound leaf. 
twig at a certain point), oppositely (where two leaves emerge at opposite sides from the same place on a twig), whorled (where more than two leaves emerge from one point of the twig), or fascicled (where a number of leaves emerge in a cluster or bundle.) They may be simple and consist of a single blade or expanded portion, or compound and made up of several individual leaflets. If the leaflets in a compound leaf are arranged along each side of a common axis (petiole or rachis), the leaf is said to be pinnately compound, while if the leaflets all arise from
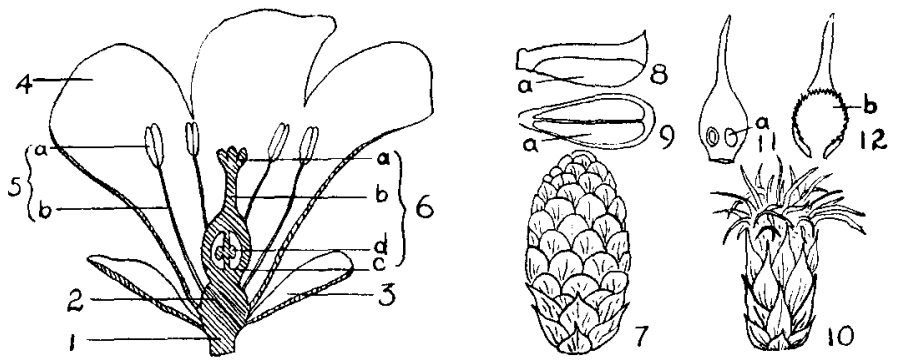

FLOWER STRUCTURE

Perfect Flower

Flowers of Pine

1-Peduncle. 2-Receptacle. 3-Sepal (Calyx). 4-Petal (Corolla). 5-Stamen; a-Anther, b-Filament. 6-Pistil; a-Stigma, b-Style, c-Ovary, d-Ovule. 7-Staminate conelet. 8 and 9-Stamen, or pollenbearing scale, showing side and lower surfaces. 10-Pistillate conelet. 11 and 12-Pistillate scale showing inner and outer surfaces respectively; a-Ovule, b-Bract.

the apex of the petiole, the leaf is termed palmately compound. Other characters used in identification are the shapes and types of margin, apex, and base (p. xxiii) . Texture, color, and the surface, whether smooth or hairy, are also useful characters.

FLOWERS. All trees have flowers, although frequently they are small and inconspicuous. These are the reproductive organs by means of which the species is perpetuated. Floral characters are the most accurate means 
of identifying many trees, although they are little used in the field because they bloom for so short a period. Flowers vary greatly in form, structure, and size. A complete flower (p. xxiv) is made up usually of leaflike sepals $($ calyx), often brightly colored petals (corolla), stamens (the male organs which bear the pollen in saclike anthers), and a pistil (the female organ consisting of a terminal stigma which catches the pollen, a style, and an ovary.) The ovary may consist of one or more compartments (cells) and contain one to many ovules which later
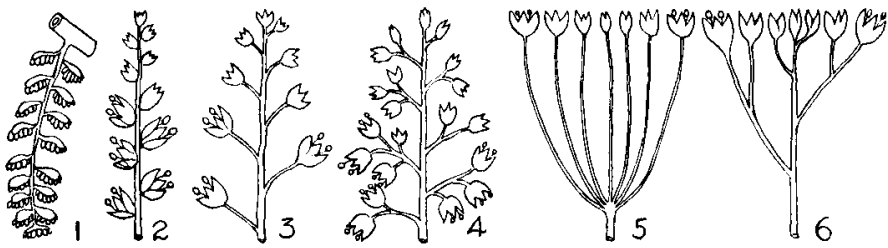

TYPES OF INFI.ORESCENSES

1-Ament. 2-Spike. 3-Raceme. 4-Panicle. 5-Umbel. 6-Corymb.

mature into seeds. In Gymnosperms the pistil is replaced by a seed-bearing scale which does not enclose the seed. If the ovary is inserted on top of the other flower parts it is superior, while if it appears enclosed within the calyx it is inferior. Flowers may be perfect (contain both stamens and pistil) or imperfect (contain one sex but not the other.) Plants having imperfect flowers are termed either monoecious (both sexes present in different flowers on the same plant) or dioecious (each sex borne on a different plant.) When the only functioning sex organs in an imperfect flower are stamens the flower is termed staminate, while one in which the pistil is the active organ is pistillate. Plants which bear some perfect and some imperfect flowers are termed polygamous. Flowers may appear singly or in clusters (inflorescences, above) .

FRUIT. While varying greatly in type and appear- 
ance, fruits are very useful in identification. The seeds included in the fruit contain the embryo plant. To the layman these are generally of secondary utility in identification.

TWIGS. The color, stoutness, central pith, or surface coverings and markings may be very useful in identifying trees, especially during the winter months. As buds, stipules, and leaves fall off they leave scars on the twig which are frequently characteristic. Buds are conspicuous on most twigs and helpful in identification. The shape, size, color, number of scales, arrangement, and the presence or absence of a terminal bud are important diagnostic characters.

BARK. The appearance of bark, while varying greatly with age and environment, is often a helpful character in identification. Color and thickness of the bark, whether it is furrowed, scaly, or smooth, and its taste, are commonly helpful features.

WOOD. The characters of the wood of trees form a separate means of identification which is more technical and difficult than the use of external characters. In this manual only the outstanding wood characters are given, such as the weight, color, and arrangement of large pores (whether ring-porous in a definite ringlike zone, or diffuse-porous and scattered throughout the wood). A statement as to importance and the uses of the woods is also included.

SILVICAL CHARACTERS. The tolerance, sites, associates, reproduction, enemies, roots, life zones, and altitudinal distributions of species are often helpful in identification, and have been included wherever possible.

In identifying trees it must be remembered that characters are variable and often overlap with those of closely related trees. Wherever possible, identification should not be based on a single character, but on as many as are available. 


\title{
CHECK LIST OF THE TREES FOUND WITHIN EACH STATE
}

\author{
BY SCIENTJFIC AND COMMON NAMES
}

ARIZONA

Conifers (25 species)

PAGE

Abies arizonica

Corkbark Fir

61

Abies concolor

White Fir

63

Abies lasiocarpa

Alpine Fir

Cupressus arizonica

Arizona Cypress

71

Cupressus glabra

Smooth Cypress

73

Juniperus gymnocarpa

Openseed Juniper

81

Juniperus megalocarpa

Bigberry Juniper $\quad 85$

Juniperus monosperma

Oneseed Juniper 81

Juniperus pachyphloea

Alligator Juniper

Juniperus pinchoti

Redberry Juniper

91

Juniperus scopulorum

Rocky Mountain Juniper

Juniperus utahensis

Utah Juniper

85

Picea engelmanni

Engelmann Spruce

Picea pungens

Pinus apacheca

Colorado Blue Spruce

45

Apache Pine

Pinus aristata

Bristlecone Pine

Pinus arizonica

Arizona Pine

Pinus cembroides

Mexican Piñon

Pinus edulis

Piñon Pine

Pinus flexilis

Limber Pine

Pinus leiophylla

Pinus monophylla

Chihuahua Pine

Singleleaf Piñon

Pinus ponderosa

Western Yellow Pine

Pinus strobiformis

Mexican White Pine

Pseudotsuga taxifolia

Douglas-fir 


$$
\text { Broadleaf Species (122) }
$$

PAGE

Acacia constricta

paucispina

Acacia farnesiana

Acacia greggii

Acer glabrum

Acer grandidentatum

Acer negundo

Ailanthus altissima

Alnus oblongifolia

Alnus tenuifolia

Amelanchier alnifolia

Amelanchier utahensis

Arbutus arizonica

Artemisia tridentata

Betula fontinalis

Bumelia lanuginosa

$$
\text { rigida }
$$

Bursera microphylla

Bursera odorata

Canotia holocantha

Carnegiea gigantea

Celtis douglasii

Cel tis laevigata brevipes

Celtis occidentalis

$$
\text { crassifolia }
$$

Celtis reticulata

Cephalanthus

$$
\text { occidentalis }
$$

Cercidium floridum

Cercidium microphyllum

Cercis occidentalis

Cercocarpus betuloides

Cercocarpus ledifolius

\section{Cercocarpus}

paucidentatus
Mescat Acacia 201

Huisache 201

Catclaw Acacia 201

Rocky Mountain Maple $\quad 237$

Bigtooth Maple 235

Boxelder 233

Tree of Heaven 223

New Mexican Alder $\quad 135$

Thinleaf Alder $\quad 129$

Western Serviceberry 175

Utah Serviceberry 175

Arizona Madronc $\quad 257$

Sage Brush 281

Water Birch 125

Gum Elastic: $\quad 259$

Elephanttree 225

Bursera 225

Canotia 229

Saguaro 251

Douglas Hackberry $\quad 165$

Arizona Sugarberry $\quad 163$

Bigleaf Hackberry I6I

Netleaf Hackberry $\quad 165$

Common Buttonbush $\quad 273$

Blue Paloverde 211

Littleleaf Paloverde 211

California Redbud $\quad 207$

Birchleaf Mountain-mahogany 183

Curlleaf Mountain-mahogany 181

Shaggy Mountain-mahogany $\quad 183$ 
Chilopsis linearis

Cornus stolonifera

Cowania stansburiana

Crataegus douglasii

Erythrina flabelliformis

Eysenhardtia polystachya

Fraxinus anomala

Fraxinus cuspidata

Fraxinus greggii

Fraxinus lowellii

Fraxinus pennsylvanica lanceolata

Fraxinus velutina

Fremontia californica

Gossypium thurberi

Holacantha emoryi

Juglans major

Koeberlinia spinosa

Lysiloma thornberi

Morus microphylla

Nicotiana glauca

Olneya tesota

Opuntia fulgida

Opuntia imbricata

Opuntia spinosior

Opuntia versicolor

Ostrya knowltonii

Parkinsonia aculeata

Parosela spinosa

Platanus wrightii

Poinciana gilliesii

Populus acuminata

Populus angustifolia

Populus fremontii

Populus tremuloides aurea
Desertwillow

273

Red-osier Dogwood

255

Cliffrose

185

Western Thornapple $\quad 179$

Coralbean

217

215

263

263

269

269

Green Ash 265

Velvet Ash $\quad 267$

Mountain Leatherwood 247

Arizona Tree Cotton 241

Corono de Cristo 249

Arizona Walnut $\quad 95$

All-thorn 249

Lysiloma $\quad 199$

Texas Mulberry $\quad 167$

Tree Tobacco 271

Tesota 221

Cholla 251

Cane Cactus 251

Tasajo 251

Cholla 251

Western Hophornbeam $\quad 119$

Jerusalem-thorn 209

Smoke Tree 217

Arizona Sycamore $\quad 169$

Bird-of-Paradise Flower $\quad 205$

Lanceleaf Cottonwood 105

Narrowleaf Cottonwood $\quad 103$

Fremont Cottonwood 113

Golden Aspen 
Populus wislizeni Prosopis chilensis Prosopis pubescens Prunus americana

Prunus emarginata

Prunus fasciculata

Prunus melanocarpa

Prunus valida

Prunus virens

Quercus arizonica

Quercus chrysolepis

Quercus diversicolor

Quercus emoryi

Quercus gambelii

Quercus grisea

Quercus gunnisonia

Quercus hypoleuca

Quercus novomexicana

Quercus oblongifolia

Quercus pauciloba

Quercus subturbinella

Quercus toumeyi

Quercus undulata

Quercus utahensis

Quercus wilcoxii

Rhamnus californica

tomentella
Ptelea trifoliata

Rio Grande Cottonwood

Common Mesquite

Fremont Screwbean

American Plum

Bitter Cherry

Desert-almond

Black Chokecherry

Chokecherry

Southwestern Chokecherry

Hoptree

Arizona White Oak

Goldencup Oak

Emory Oak

Gambel Oak

Gray Oak

Oak

Silverleaf Oak

New Mexican Oak

Mexican Blue Oak

Oak

Rhamnus crocea ilicifolia

Rhamnus purshiana

Rhus glabra

Rhus kearneyi

Rhus ovata

Ricinus communis

Robinia neo-mexicana Iuxurians
Netleaf Oak

MacDougal Oak

Toumey Oak

Wavyleaf Oak

Utah White Oak

Wilcox Oak

California Buckthorn

PAGE

109

203

205

189

193

189

195

197

197

223

149

141

115

143

153

136

136

139

136

147

136

136

149

136

153

141

243

245

Cascara Buckthorn $\quad 243$

Sumac 227

Sumac $\quad 227$

Sumac 227

Castorbean 225

Southwestern Locust

219 
PAGE

Salix bebbiana

Bebb Willow

Salix bonplandiana toumeyi

Willow

115

Salix exigua

Sandbar Willow

115

Salix gooddingii

Dudley Willow

115

Salix laevigata

Red Willow

115

Salix lasiolepis

Salix scoleriana

White Willow

115

Mountain Willow

115

Salix taxifolia

Yewleaf Willow

115

Sambucus cerulea

Blueberry Elder

277

Sambucus mexicana

Elderberry

277

Sapindus drummondi

Western Soapberry

239

Sapium biloculare

Sapium

225

Sophora affinis

Coralbean

213

Sorbus americana sitchensis

Western Mountainash

173

Tamarix gallica

Tamarisk

247

Tamarix juniperina

Tamarisk

Vauquelinia angustifolia

Vauquelinia

171

Vauquelinia californica

Torrey Vauquelinia

171

Washingtonia arizonica

Fanleaf Palm

285

Yucca brevifolia

Joshua Tree

283

Yucca elata

Soaptree Yucca

283

Yucca mohavensis

Mohave Yucca

283

Yucca schottii

Hoary Yucca

283

Yucca torreyi

Torrey Yucca

283

COLORADO

Conifers (15 species)

Abies arizonica

Corkbark Fir

61

Abies concolor

White Fir

63

Abies lasiocarpa

Alpine Fir

Juniperus gymnocarpa

Openseed Juniper

81

Juniperus monosperma

Oneseed Juniper

81

Juniperus scopulorum

Rocky Mountain Juniper

79

Juniperus utahensis

Utah Juniper 
PAGE

Picea engelmanni

Engelmann Spruce

Picea pungens

Colorado Blue Spruce

Pinus aristata

Bristlecone Pine

Pinus contorta latifolia

Lodgepole Pine

Pinus edulis

Piñon Pine

Pinus flexilis

Limber Pine

Pinus ponderosa

Western Yellow Pine

Pseudotsuga taxifolia

Douglas.fir

\section{Broadleaf Species (58)}

Acer glabrum

Acer grandidentatum

Acer negundo interius

Alnus tenuifolia

Amelanchier alnifolia

Amelanchier crenata

Amelanchier polycarpa

Amelanchier prunifolia

Amelanchier utahensis

Artemisia tridentata

Betula fontinalis

Betula papyrifera

Celtis douglasii

Celtis occidentalis crassifolia

Celtis reticulata

Cercocarpus montanus

Cercocarpus ledifolius

Cornus stolonifera

Cowania stansburiana

Crataegus chrysocarpa

Crataegus douglasii

Crataegus saligna

Crataegus succulenta

Fraxinus anomala

Fraxinus pennsylvanica

lanceolata
Rocky Mountain Maple $\quad 237$

Bigtooth Maple 235

Boxelder 233

Thinleaf Alder 239

Western Serviceberry 175

Serviceberry $\quad 175$

Serviceberry $\quad 175$

Serviceberry $\quad 175$

Utah Serviceberry $\quad 175$

Sage Brush 281

Water Birch 125

Paper Birch 123

Douglas Hackberry 165

Bigleaf Hackberry $\quad 161$

Netleaf Hackberry $\quad 165$

Mountain-mahogany $\quad 183$

Curlleaf Mountain-mahogany 181

Red-osier Dogwood 255

Cliffrose $\quad 185$

Hawthorn 177

Western Thornapple $\quad 179$

Willow Thorn $\quad 177$

Hawthorn $\quad 177$

Singleleaf Ash 263

Green Ash 
Populus acuminata

Populus angustifolia

Populus balsamifera

Populus sargentii

Populus tremuloides aurea

Populus wislizeni

Prosopis chilensis

Prunus americana

Prunus demissa

Prunus melanocarpa

Prunus pennsylvanica

Prunus pennsylvanica saximontana

Ptelea trifoliata

Quercus gambelii

Quercus gunnisonii

Quercus leptophylla

Quercus novomexicana

Quercus subturbinella

Quercus undulata

Quercus vreelandica

Rhamnus purshiana

Robinia neo-mexicana

Salix amygdaloides

Salix bebbiana

Salix exigua

Salix interior

Salix lasiandra

Salix scouleriana

Sambucus cerulea

Sapindus drummondi

Sorbus americana sitchensis
Lanceleaf Cottonwood

PAGE

Narrowleaf Cottonwood

105

Balsam Poplar

103

Plains Cottonwood

101

$11 \mathrm{~J}$

Golden Aspen $\quad 107$

Rio Grande Cottonwood $\quad 109$

Common Mesquite 203

American Plum 189

Western Chokecherry 195

Black Chokecherry 195

Pin Cherry 191

Pin Cherry 191

Hoptree 223

Gambel Oak $\quad 153$

Oak 136

Socorro White Oak 153

New Mexico Oak 136

Oak 136

Wavyleaf Oak $\quad 136$

Oak 136

Cascara Buckthorn 243

Southwestern Locust $\quad 219$

Peachleaf Willow $\quad 117$

Bebb Willow 115

Sandbar Willow $\quad 115$

Sandbar Willow 115

Western Black Willow 115

Mountain Willow 115

Blueberry Elder $\quad 277$

Western Soapberry 239

Western Mountainash $\quad 173$ 
Tamarix gallica

Viburnum lentago
Tamarisk

Nannyberry

IDAHO

Conifers (2I Species)
Abies concolor

Abies grandis

Abies lasiocarpa

Juniperus occidentalis

Juniperus scopulorum

Juniperus utahensis

Larix lyallii

Larix occidentalis

Picea engelmanni

Picea pungens

Pinus albicaulis

Pinus contorta latifolia

Pinus flexilis

Pinus monophylla

Pinus monticola

Pinus ponderosa

Pseudotsuga taxifolia

Taxus brevifolia

Thuja plicata

Tsuga heterophylla

Tsuga mertensiana

White Fir

Grand Fir $\quad 65$

Alpine Fir

Sierra Juniper $\quad 77$

Rocky Mountain Juniper $\quad 79$

Utah Juniper $\quad 85$

Alpine Larch $\quad 35$

Western Larch 33

Engelmann Spruce 43

Colorado Blue Spruce $\quad 45$

Whitebark Pine 9

Lodgepole Pine 25

Limber Pine 7

Singleleaf Piñon 15

Western White Pine 5

Western Yellow Pine 19

Douglas-fir $\quad 53$

Pacific Yew 93

Western Redcedar $\quad 67$

Western Hemlock 49

Mountain Hemlock 51

Broadleaf Species (4I)

Acer douglasii

Acer glabrum

Acer grandidentatum

Acer negundo

Ailanthus altissima

Alnus rhombifolia

Alnus sinuata

Alnus tenuifolia
Douglas Maple

Rocky Mountain Maple $\quad 237$

Bigtooth Maple 235

Boxelder 233

Tree of Heaven 223

White Alder 133

Sitka Alder 131

Thinleaf Alder 
-

Amelanchier alnifolia

Betula fontinalis

Betula papyrifera

Celtis douglasii

Celtis occidentalis crassifolia

Cercocarpus hypoleucus

Cercocarpus ledifolius

Cercocarpus montanus

Cornus nuttallii

Cornus occidentalis

Cornus stolonifera

Crataegus columbiana

Crataegus douglasii

Elaeagnus argentea

Populus acuminata

Populus angustifolia

Populus balsamifera

Populus tremuloides

$$
\text { aurea }
$$

Populus trichocarpa hastata

Prunus americana

Prunus demissa

Prunus emarginata

Prunus melanocarpa

Rhamnus purshiana

Salix amygdaloides

Salix bebbiana

Salix exigua

Salix lasiandra

Salix mackenziana

Salix scouleriana

Sambucus cerulea
Western Serviceberry

Water Birch

Paper Birch

Douglas Hackberry

Bigleaf Hackberry

161

Mountain-mahogany $\quad 183$

Curlleaf Mountain-mahogany 181

Mountain-mahogany

183

Pacific Dogwood

255

Western Dogwood

255

Red-osier Dogwood

255

Hawthorn

177

Western Thornapple

179

Silverberry

253

Lanceleaf Cottonwood

105

Narrowleaf Cottonwood

103

Balsam Poplar

101

Golden Aspen

107

Black Cottonwood

American Plum

189

Western Chokecherry

195

Bitter Cherry

193

Black Chokecherry

195

Cascara Buckthorn

243

Peachleaf Willow

117

Bebb Willow

115

Sandbar Willow

115

Western Black Willow

115

Mackenzie Willow

115

Mountain Willow

115

Blueberry Elder 
PAGE

Sorbus americana sitchensis

Western Mountainash

173

Tamarix gallica

Tamarisk

MONTANA

Conifers (2o Species)

Abies concolor

White Fir

Abies grandis

Grand Fir

Abies lasiocarpa

Alpine Fir

Juniperus occidentalis

Sierra Juniper

Juniperus scopulorum

Rocky Mountain Juniper

Larix lyallii

Alpine Larch

Larix occidentalis

Western Larch

Picea engelmanni

Engelmann Spruce

Picea glauca

albertiana

Picea pungens

Pinus albicaulis

Western White Spruce

Colorado Blue Spruce

Whitebark Pine

Pinus contorta

latifolia

Pinus flexilis

Lodgepole Pine

Pinus monticola

Limber Pine

Western White Pine

Pinus ponderosa

Western Yellow Pine

Pseudotsuga taxifolia

Douglas-fir

Taxus brevifolia

Pacific Yew

93

Thuja plicata

Western Redcedar

Tsuga heterophylla

Western Hemlock

49

Tsuga mertensiana

Mountain Hemlock

Broadleaf Species (42)

Acer douglasii

Acer glabrum

Acer grandidentatum

Acer negundo

Alnus sinuata

Alnus tenuifolia

Amelanchier alnifolia
Douglas Maple

Rocky Mountain Maple

Bigtooth Maple

Boxelder

Sitka Alder

131

Thinleaf Alder

129

Western Serviceberry 
Betula fontinalis

Betula papyrifera

Celtis occidentalis

crassifolia

Cercocarpus hypoleucus

Cercocarpus ledifolius

Cercocarpus montanus

Cornus stolonifera

Crataegus chrysocarpa

Crataegus columbiana

Crataegus douglasii

Crataegus succulenta

Crataegus williamsii

Elaeagnus argentea

Euonymus atropurpureus

Fraxinus pennsylvanica lanceolata

Populus acuminata

Populus angustifolia

Populus balsamifera

Populus sargentii

Populus tremuloides aurea

Populus trichocarpa hastata

Prunus americana

Prunus demissa

Prunus emarginata

Prunus melanocarpa

Prunus pennsylvanica

Rhamnus purshiana

Salix amygdaloides

Salix bebbiana

Salix exigua
Water Birch

125

Paper Birch

123

Bigleaf Hackberry

161

Mountain-mahogany

183

Curlleaf Mountain-mahogany 181

Mountain-mahogany

183

Red-osier Dogwood

255

Hawthorn

177

Hawthorn

177

Western Thornapple

179

Hawthorn

177

Hawthorn

177

Silverberry

253

Wahoo

229

Green Ash

265

Lanceleaf Cottonwood

105

Narrowleaf Cottonwood

103

Balsam Poplar

101

Plains Cottonwood

111

Golden Aspen

107

Black Cottonwood $\quad 99$

American Plum $\quad 189$

Western Chokecherry $\quad 195$

Bitter Cherry

183

Black Chokecherry 195

Pin Cherry

191

Cascara Buckthorn

243

Peachleaf Willow

117

Bebb Willow

115

Sandbar Willow 
PAGE

Salix mackenziana

Mackenzie Willow

115

Salix scouleriana

Mountain Willow

115

Sambucus cerulea

Blueberry Elder

277

Sorbus americana sitchensis

Western Mountainash

17.3

Viburnum lentago

Nannyberry

NEVADA

Conifers (21 Species)

Abies concolor

White Fir

Abies magnifica

Red Fir

Abies magnifica

shastensis

Shasta Red Fir

Juniperus gymnocarpa

Openseed Juniper

Juniperus monosperma

Oneseed Juniper

Juniperus occidentalis

Sierra Juniper

Juniperus scopulorum

Rocky Mountain Juniper

Juniperus utahensis

Utah Juniper

85

Libocedrus decurrens

Incense Cedar

Picea engelmanni

Engelmann Spruce

Pinus albicaulis

Whitebark Pine

Pinus aristata

Bristlecone Pine

Pinus contorta latifolia

Lodgepole Pine

Pinus flexilis

Limber Pine

Pinus jeffreyi

Jeffrey Pine

Pinus lambertiana

Sugar Pine

Pinus monophylla

Singleleaf Piñon

Pinus monticola

Pinus ponderosa

Western White Pine

Western Yellow Pine

Pseudotsuga taxifolia

Douglas-fir

Tsuga mertensiana

Mountain Hemlock

\section{Broadleaf Species (47)}

Acacia greggii

Catclaw Acacia

Acer glabrum

Rocky Mountain Maple

Acer negundo

Boxelder 
PAGE.

Amelanchier utahensis

Utah Serviceberry

175

Betula fontinalis

Water Birch

125

Castanopsis chrysophylla

Golden Chinquapin

155

Celtis douglasii

Douglas Hackberry

165

Celtis occidentalis crassifolia

Bigleaf Hackberry

161

Cercis occidentalis

California Redbud

207

Cercocarpus betuloides

Birchleaf Mountain-mahogany

183

Cercocarpus ledifolius

Chilopsis linearis

Curlleaf Mountain-mahogany

181

Desertwillow

273

Cornus occidentalis

Cornus stolonifera

Cowania stansburiana

Western Dogwood

255

Red-osier Dogwood

255

Cliffrose

185

Crataegus douglasii

Euonymus occidentalis

Fraxinus anomala

Fraxinus velutina

Populus angustifolia

Western Thornapple

179

Western Wahoo

229

Singleleaf Ash

263

Velvet Ash

265

Narrowleaf Cottonwood

103

Balsam Poplar

101

Populus fremontii

Populus tremuloides aurea

Populus trichocarpa hastata

Prosopis chilensis

Prosopis pubescens

Prunus andersonii

Prunus demissa

Prunus emarginata

Prunus fasciculata

Prunus melanocarpa

Ptelea trifoliata

Quercus chrysolepis

Quercus wilcoxii

Fremont Cottonwood

111

Golden Aspen

107

Black Cottonwood $\quad 99$

Common Mesquite 203

Fremont Screwbean 205

Nevada Wild Almond $\quad 189$

Western Chokecherry 195

Bitter Cherry 193

Desert-almond $\quad 189$

Black Chokecherry 195

Hoptree 223

Goldencup Oak 141

Wilcox Oak 136 
PAGE

Rhamnus californica tomentella

California Buckthorn

243

Robinia neo-mexicana

luxurians

Southwestern Locust

219

Salix exigua

Sandbar Willow

115

Salix gooddingii

Dudley Willow

115

Salix laevigata

Red Willow

Salix mackenziana

Mackenzie Willow

115

Salix scouleriana

Mountain Willow

115

Sambucus cerulea

Blueberry Elder

277

Sorbus americana sitchensis

Western Mountainash

173

Tamarix gallica

Yucca brevifolia

Yucca mohavensis

Tamarisk

Joshua Tree

283

Mohave Yucca

NEW MEXICO

Conifers (22 Species)

Abies arizonica

Corkbark Fir

61

Abies concolor

White Fir

Abies lasiocarpa

Alpine Fir

Cupressus arizonica

Arizona Cypress

71

Juniperus gymnocarpa

Openseed Juniper

87

Juniperus megalocarpa

Bigberry Juniper

85

Juniperus monosperma

Oneseed Juniper

81

Juniperus pachyphloea

Alligator Juniper

87

Juniperus scopulorum

Rocky Mountain Juniper

79

Juniperus utahensis

Utah Juniper

85

Picea engelmanni

Engelmann Spruce

43

Picea pungens

Pinus apacheca

Colorado Blue Spruce

45

Apache Pine

21

Pinus aristata

Pinus arizonica

Bristlecone Pine

17

Arizona Pine

21

Pinus cembroides

Mexican Piñon

Pinus edulis

Piñon Pine

Pinus flexilis

Limber Pine 
Pinus leiophylla

Pinus ponderosa

Pinus strobiformis

Pseudotsuga taxifolia
Chihuahua Pine

Western Yellow Pine

Mexican White Pine

Douglas-fir
23

19

11

53

\section{Broadleaf Species (II )}

Acacia constricta

Acacia farnesiana

Acacia greggii

Acer brachypterum

Acer glabrum

Acer grandidentatum

Acer negundo

Ailanthus altissima

Alnus oblongifolia

Alnus tenuifolia

Amelanchier alnifolia

Amelanchier crenata

Amelanchier goldmanii

Amelanchier polycarpa

Amelanchier prunifolia

Amelanchier utahensis

Arbutus arizonica

Arbutus texana

Artemisia tridentata

Betula fontinalis

Bumelia lanuginosa rigida

Bumelia monticola

Celtis laevigata

Celtis occidentalis

$$
\text { crassifolia }
$$

Celtis reticulata

Cephalanthus occidentalis

Cercidium floridum
Mescat Acacia

201

Huisache

201

Catclaw Acacia

Southwestern Maple

201

Rocky Mountain Maple

235

237

Bigtooth Maple

235

Boxelder

233

Tree of Heaven

223

New Mexican Alder

135

Thinleaf Alder

129

Western Serviceberry

175

Serviceberry

Serviceberry

175

175

Serviceberry

Serviceberry

175

175

Utah Serviceberry

175

Arizona Madrone

257

Texas Madrone

257

Sage Brush

281

Water Birch

125

Gum Bumelia

259

Brazos Bumelia

259

Sugarberry

163

Bigleaf Hackberry

161

Netleaf Hackberry

165

Common Buttonbush

275

Blue Paloverde 
PAGE

Cercocarpus ledifolius Curlleaf Mountain-mahogany 181

Cercocarpus montanus Mountain-mahogany

183

Cercocarpus

paucidentatus

Chilopsis linearis

Condalia obovata

Cordia bossieri

Cornus stolonifera

Cowania stansburiana

Shaggy Mountain-mahogany

183

Desertwillow

273

Bluewood

245

Anacahuita

271

Red-osier Dogwood

255

Cliffrose

185

Crataegus chrysocarpa

Hawthorn

177

Crataegus douglasii

Western Thornapple

179

Crataegus wootoniana

Hawthorn

177

Erythrina flabelliformis

Coralbean

217

Eysenhardtia polystachya

Forestiera pubescens

Eysenhardtia

215

Elbowbush

269

Fraxinus anomala

Fraxinus cuspidata

Singleleaf Ash

263

Fraxinus lowellii

Fragrant Ash

263

Lowell Ash

269

Fraxinus pennsylvanica lanceolata

Green Ash

Fraxinus velutina

Juglans rupestris

Velvet Ash

267

Texas Walnut 95

Juglans rupestris major

Koeberlinia spinosa

Arizona Walnut

All-thorn

249

Leucaena retusa

Littleleaf Leadtree

Morus microphylla

Mexican Mulberry

167

Nicotiana glauca

Tree Tobacco

271

Opuntia imbricata

Cane Cactus

251

Opuntia spinosior

Ostrya knowltonii

Platanus wrightii

Poinciana gilliesii

Populus acuminata

Populus angustifolia

Populus fremontii

Populus sargentii

Tasajo

251

Western Hophornbeam $\quad 119$

Arizona Sycamore $\quad 169$

Bird-of-paradise Flower 205

Lanceleaf Cottonwood 105

Narrowleaf Cottonwood $\quad 103$

Fremont Cottonwood 113

Plains Cottonwood

111 
Populus tremuloides

aurea

Populus wizlizenii

Prosopis chilensis

Prosopis pubescens

Prunus americana

Prunus demissa

Prunus emarginata

Prunus melanocarpa

Prunus valida

Prunus virens

Ptelea trifoliata

Quercus arizonica

Quercus brayi

Quercus chrysolepis

Quercus confusa

Quercus diversicolor

Quercus emoryi

Quercus gambelii

Quercus grisea

Quercus gunnisonii

Quercus hypoleuca

Quercus leptophylla

Quercus media

Quercus mühlenbergii

Quercus novomexicana

Quercus oblongifolia

Quercus subturbinella

Quercus undulata

Quercus utahensis

Quercus vreelandii

Quercus wilcoxii

Rhamnus purshiana

Rhus lanceolata
Golden Aspen

107

Rio Grande Cottonwood $\quad 109$

Common Mesquite

Fremont Screwbean

203

American Plum

205

189

Western Chokecherry

195

Bitter Cherry

193

Black Chokecherry

195

Chokecherry

197

Southwestern Chokecherry 197

Hoptree

223

Arizona White Oak

149

Bray's Oak

155

Goldencup Oak

141

Oak

196

Netleaf Oak

145

Emory Oak

143

Gambel Oak

153

Gray Oak

136

Oak

186

Silverleaf Oak

139

Socorro White Oak 153

Oak 136

Chinquapin Oak $\quad 155$

New Mexican Oak $\quad 136$

Mexican Blue Oak 147

Oak 136

Wavyleaf Oak 136

Utah White Oak 153

Oak 136

Wilcox Oak 141

Cascara Buckthorn 243

Dwarf Sumac 
PAGE

Rhus microphylla

Sumac

227

Robinia neo-mexicana

luxurians

Southwestern Locust

2 I9

Robinia rusbyi

Locust

219

Peachleaf Willow

Salix bebbiana

Bebb Willow

Salix bonplandiana toumeyi

Willow

Salix gooddingii

Dudley Willow

Salix interior

Sandbar Willow

Salix lasiandra

Salix scouleriana

Western Black Willow

Mountain Willow

Salix taxifolia

Sambucus cerulea

Yewleaf Willow

Blueberry Elder

277

Sambucus mexicana

Elderberry

Sapindus drummondi

Western Soapberry

239

Sophora secundiflora

Mescalbean

Sorbus americana sitchensis

Western Mountainash

179

Tamarix gallica

Tamarisk

Tecoma stans

Trumpetflower

275

Ungnadia speciosa

Mexican-buckeyc

Vauquelinia angustifolia

Vauquelinia

Vauquelinia californica

Torrey Vauquelinia

Yucca elata

Soaptree Yucca

283

Yucca torreyi

Torrey Yucca

WESTERN TEXAS

Conifers (15 Species)

Cupressus arizonica

Juniperus erythrocarpa

Juniperus flaccida

Juniperus gymnocarpa

Juniperus mexicana

Juniperus monosperma
Arizona Cypress

Redberry Juniper $\quad 91$

Drooping Juniper $\quad 89$

Openseed Juniper $\quad 81$

Mexican Juniper $\quad 83$

Oneseed Juniper $\quad \mathbf{8 1}$ 
PAGE

Juniperus pachyphloea

Alligator Juniper

Juniperus pinchoti

Redberry Juniper

9 I

Juniperus scopulorum

Rocky Mountain Juniper

Pinus cembroides

Mexican Piñon

Pinus edulis

Piñon Pine

Pinus flexilis

Limber Pine

Pinus ponderosa

Western Yellow Pine

Pinus strobiformis

Mexican White Pine

Pseudotsuga taxifolia

Douglas-fir

Broadleaf Species (100)

Acacia amentacea

Acacia angustissima

Acacia constricta

Acacia farnesiana

Acacia greggii

Acacia tortuosa

Acacia wrightii

Acer grandidentatum

Acer negundo

Ailanthus altissima

Arbutus texana

Bumelia lanuginosa

Bumelia monticola

Celtis douglasii

Celtis laevigata texana

Celtis occidentalis

$$
\text { crassifolia }
$$

Celtis reticulata

Cephalanthus

occidentalis

Cercidium floridum

Cercidium macrum

Cercis occidentalis

Cercocarpus montanus
Blackbrush

201

Prairie Acacia

201

Mescat Acacia

201

Huisache

201

Catclaw Acacia

201

Catclaw

201

Texas Catclaw

201

Bigtooth Maple

235

Boxelder

233

Tree of Heaven

223

Texas Madrone

257

Gum Bumelia

259

Brazos Bumelia

259

Douglas Hackberry

165

Texas Sugarberry

163

ligleaf Hackberry

161

Netleaf Hackberry

165

Common Buttonbush

273

Blue Paloverde

211

Border Paloverde

211

Mountain Redbud

207

Mountain-mahogany 
PAGF.

Cercocarpus

paucidentatus

Chilopsis linearis

Shaggy Mountain-mahogany

183

Condalia obovata

Desertwillow

273

Cordia boissieri

Bluewood

245

Crataegus montivaga

Anacahuita

271

Diospyros texana

Hawthorn

177

Euonymus atropurpureus

Texas Persimmon

259

Eysenhardtia polystachya

Wahoo

229

Forestiera pubescens

Eysenhardtia

215

Fraxinus berlandieriana

Elbowbush

269

Fraxinus cuspidata

Berlandier Ash

26.5

Fraxinus greggii

Fragrant Ash

263

Fraxinus pennsylvanica lanceolata

Gregg Ash

269

Green Ash

265

Fraxinus velutina

Velvet Ash

267

Arizona Walnut

Texas Walnut

Juglans rupestris

All-thorn

Leucaena greggii

Gregg's Leadtree

Leucaena retusa

Littleleaf Leadtree

199

Morus microphylla

Nicotiana glauca

Mexican Mulberry

167

Tree Tobacco

271

Ostrya knowltonii

Western Hophornbeam

119

Pistacia texana

Texas Pistache

227

Parkinsonia aculeata

Jerusalem-thorn

209

Poinciana gilliesii

Populus acuminata

Bird-of-paradise Flower

205

Lanceleaf Cottonwood

Populus angustifolia

Narrowleaf Cottonwood

103

Populus sargentii

Plains Cottonwood

Populus tremuloides aurea

Golden Aspen

Populus wizlizeni

Rio Grande Cottonwood

Porlieria angustifolia

Soapbush

Prosopis chilensis

Prosopis pubescens

Common Mesquite

Fremont Screwbean 


\begin{tabular}{|c|c|c|}
\hline Prunus americana & American Plum & 189 \\
\hline Prunus demissa & Western Chokecherry & 195 \\
\hline Prunus fasciculata & Desert-almond & 189 \\
\hline Prunus serotina & Black Cherry & 186 \\
\hline Prunus virens & Southwestern Chokecherry & 197 \\
\hline Ptelea trifoliata & Hoptree & 22 \\
\hline Quercus brayi & Bray's Oak & 155 \\
\hline Quercus breviloba & Oak & 136 \\
\hline Quercus canbyi & Oak & 136 \\
\hline Quercus diversicolor & Netleaf Oak & 145 \\
\hline Quercus emoryi & Emory Oak & 143 \\
\hline Quercus gambelii & Gambel Oak & $15 \%$ \\
\hline Quercus grisea & Gray Oak & 136 \\
\hline Quercus hypoleuca & Silverleaf Oak & 139 \\
\hline Quercus macrocarpa & Bur Oak & 15 \\
\hline Quercus mohriana & Shin Oak & 136 \\
\hline Quercus mühlenbergii & Chinquapin Oak & 15 \\
\hline Quercus novomexicana & New Mexican Oak & 136 \\
\hline Quercus oblongifolia & Mexican Blue Oak & 147 \\
\hline \multicolumn{3}{|l|}{ Quercus texana } \\
\hline chesoensis & 'Texas Red Oak & 13 \\
\hline \multicolumn{3}{|l|}{ Quercus texana } \\
\hline stellipila & Jeff Davis Oak & 13 \\
\hline Quercus undulata & Wavyleaf Oak & 136 \\
\hline Quercus virginiana & Live Oak & 147 \\
\hline Rhamnus purshiana & Cascara Buckthorn & 24 \\
\hline Rhus lanceolata & Dwarf Sumac & 227 \\
\hline Rhus microphylla & Sumac & 227 \\
\hline \multicolumn{3}{|l|}{ Robinia neo-mexicana } \\
\hline luxurians & Southwestern Locust & 219 \\
\hline Salix amygdaloides & Peachleaf Willow & 117 \\
\hline Salix exigua & Sandbar Willow & 115 \\
\hline Salix gooddingi & Dudley Willow & 115 \\
\hline Salix interior & Sandbar Willow & 115 \\
\hline Salix nigra facata & Black Willow & 115 \\
\hline
\end{tabular}


Salix taxifolia

Yewleaf Willow

PAGE

Sambucus cerulea

Blueberry EIder

115

Sambucus mexicana

Mexican Elder

277

Sapindus drummondi

Western Soapberry

277

Sophora affinis

Coralbean

239

Sophora secundiflora

Mescalbean

213

Tamarix gallica

Tamarisk

Tecoma stans

angustifolia

Ulmus americana

Ungnadia speciosa

Vauquelinia angustifolia

Yucca elata

Yucca torreyi
Trumpetflower

American Elm

Mexican-buckeye

Vauquelinia

Soaptree Yucca

Torrey Yucca

UTAH

Conifers (I7 Species)

Abies concolor

Abies lasiocarpa

White Fir

63

Alpine Fir

59

Juniperus gymnocarpa

Openseed Juniper

Juniperus monosperma

Oneseed Juniper

81

Juniperus occidentalis

Sierra Juniper

77

Juniperus scopulorum

Rocky Mountain Juniper

79

Juniperus utahensis

Utah Juniper

85

Picea engelmanni

Engelmann Spruce

Picea pungens

Pinus albicaulis

Pinus aristata

Colorado Blue Spruce

45

Whitebark Pine

9

Bristlecone Pine

17

Pinus contorta latifolia

Lodgepole Pine

Pinus edulis

Piñon Pine

15

Limber Pine

7

Pinus monophylla

Singleleaf Piñon

15

Pinus ponderosa

Western Yellow Pine

Pseudotsuga taxifolia

Douglas-fir

$$
\text { Broadleaf Species (6o) }
$$


Acer glabrum

Acer grandidentatum

Acer negundo

Ailanthus altissima

Alnus tenuifolia

Amelanchier alnifolia

Amelanchier crenata

Amelanchier polycarpa

Amelanchier prunifolia

Amelanchier utahensis

Betula fontinalis

Celtis douglasii

Celtis occidentalis

crassifolia

Cercis occidentalis

Cercocarpus betuloides

Cercocarpus ledifolius

Cercocarpus montanus

Chilopsis linearis

Cornus stolonifera

Cowania stansburiana

Crataegus douglasii

Elaeagnus argentea

Fraxinus anomala

Fraxinus pennsylvanica lanceolata

Fraxinus velutina

Ostrya knowltonii

Populus acuminata

Populus angustifolia

Populus fremontii

Populus tremuloides

$$
\text { aurea }
$$

Populus wizlizenii

Prosopis chilensis

Prosopis pubescens

Prunus americana
Rocky Mountan Maple

Bigtooth Maple

Boxelder

Tree of Heaven

Thinleaf Alder

Western Serviceberry

Serviceberry

Serviceberry

Serviceberry

Utah Serviceberry

Water Birch

Douglas Hackberry

Bigleaf Hackberry

161

California Redbud

207

Birchleaf Mountain-mahogany 183

Curlleaf Mountain-mahogany 181

Mountain-mahogany $\quad 183$

Desertwillow

273

Red-osier Dogwood

255

Cliffrose

185

Western Thornapple

179

Silverberry

253

Singleleaf Ash

263

Green Ash

265

Velvet Ash

267

Western Hophornbeam

Lanceleaf Cottonwood

Narrowleaf Cottonwood

103

Fremont Cottonwood

Golden Aspen

Rio Grande Cottonwood

Common Mesquite

Fremont Screwbean

American Plum 


Prunus demissa
Prunus fasciculata
Prunus melanocarpa
Prunus valida
Ptelea trifoliata
Quercus chrysolepis
Quercus gambelii
Quercus gunnisonii
Quercus novomexicana
Quercus pauciloba
Quercus undulata
Quercus utahensis
Quercus wilcoxii
Rhamnus purshiana
Robinia neo-mexicana
luxurians
Salix amygdaloides
Salix bebbiana
Salix exigua
Salix laevigata
Salix scouleriana
Sambucus cerulea
Sorbus americana
sitchensis
Tamarix gallica
Yucca brevifolia
Yucca elata

Western Chokecherry

PAGE

Desert-almond 195

Black Chokecherry

Chokecherry

Hoptree

Goldencup Oak

223

Gambel Oak

Oak

153

New Mexico Oak

MacDougal Oak

Wavyleaf Oak

Utah White Oak

Wilcox Oak

Cascara Buckthorn

Southwestern Locust

219

Peachleaf Willow

Bebb Willow

Sandbar Willow

115

Red Willow

Mountain Willow

Blueberry Elder

Western Mountainash

173

Tamarisk

247

Joshua Tree

283

Soaptree Yucca

28.3

WYOMING

Conifers (I4 Species)

Abies concolor

Abies grandis

Abies lasiocarpa

Juniperus scopulorum
White Fir

63

Grand Fir

65

Alpine Fir

59

Rocky Mountain Juniper 


Juniperus utahensis
Picea engelmanni
Picea glauca albertiana
Picea pungens
Pinus albicaulis
Pinus contorta latifolia
Pinus edulis
Pinus flexilis
Pinus ponderosa
Pseudotsuga taxifolia

Utah Juniper

PAGE

Engelmann Spruce

85

Western White Spruce

Colorado Blue Spruce

Whitebark Pine

Lodgepole Pine

Piñon Pine

25

Limber Pine

Western Yellow Pine

Douglas-fir

\section{Broadleaf Species (4r)}

Acer douglasii

Acer glabrum

Acer grandidentatum

Acer negundo

Alnus tenuifolia

Amelanchier alnifolia

Amelanchier canadensis

Amelanchier polycarpa

Betula fontinalis

Betula papyrifera

Celtis occidentalis crassifolia

Cercocarpus ledifolius

Cercocarpus montanus

Cornus stolonifera

Crataegus chrysocarpa

Crataegus douglasii

Crataegus erythropoda

Crataegus succulenta

Elaeagnus argentea

Fraxinus pennsylvanica

Fraxinus pennsylvanica lanceolata

Populus acuminata
Douglas Maple

237

Rocky Mountain Maple $\quad 237$

Bigtooth Maple 235

Boxelder

Thinleaf Alder

233

129

Western Serviceberry

175

175

175

125

123

Paper Birch

Bigleaf Hackberry

161

Curlleaf Mountain-mahogany 181

Mountain-mahogany $\quad 183$

Red-osier Dogwood 255

Hawthorn

177

Western Thornapple 179

Western Thornapple 177

Hawthorn

177

Silverberry $\quad 253$

Red Ash

265

Green Ash

265

Lanceleaf Cottonwood 
Populus angustifolia

Populus balsamifera

Populus sargentii

Populus tremuloides aurea

Prunus americana

Prunus demissa

Prunus melanocarpa

Prunus pennsylvanica

Quercus gambelii

Quercus macrocarpa

Quercus utahensis

Salix amygdaloides

Salix bebbiana

Salix exigua

Salix mackenziana

Salix scouleriana

Sorbus americana sitchensis

Ulmus americana

Viburnum lentago
Narrowleaf Cottonwood

Balsam Poplar

Plains Cottonwood

Golden Aspen

American Plum

Western Chokecherry

Black Chokecherry

Pin Cherry

Gambel Oak

Bur Oak

Utah Oak

Peachleaf Willow

Bebb Willow

Sandbar Willow

Mackenzic Willow

Mountain Willow

Western Mountainash

American Elm

Nannyberry
173

157

PAGE

103

101

111

107

189

195

195

191

153

151

153

117

115

115

115

115

277 


\section{KEY TO THE GENERA}

a. Leaves necdle-shaped, linear, or scalelike, mostly 1 -nerved..... ........................ CONIFERS and TAMARIX.

b. Leaves deciduous.

c. Leaves single, scalelike, feathery; showy flowers; fruit a capsule; south and central........... TAMARIX, p. 247.

c. Leaves in clusters on dwarf branches, linear; fruit a cone; northern...........................

b. Leaves persistent; fruit a woody cone or berry-like.

c. Leaves fascicled, in clusters of $1-5$, enclosed at base by sheath, needle-shaped..................PINUS, p. 2.

c. Leaves single, without basal sheath.

d. Leaves scattered, alternate, linear.

c. Fruit a woody cone with numerous scales and separate bracts; needles not decurrent.

f. Cones erect, their scales deciduous from axis, leaves sessile.....................ABIES, p. 54.

f. Cones pendulous, their scales persistent on axis.

g. Bracts of cone exserted, conspicuous; twigs without sterigmata.........PSEUDOTSUGA, p. 53.

g. Bracts of cone inserted; twigs roughened by sterigmata.

h. Leaves sessile, harsh to touch. PICEA, p. 36.

h. Leaves stalked, soft to touch..TSUGA, p. 46.

e. Fruit a single seed surrounded by scarlet, aril-Iike disk; needles decurrent.............TAXUS, p. 93.

d. Leaves ternate or decussate, usually scalelike.

e. Fruit a woody cone; leaves scalelike, decussate.

f. Cone oblong, 2 seeds under each scale.

g. Cone with 6 scales....... LIBOCEDRUS, p. 67.

g. Cone with 8-12 scales.......... THUJA, p. 67.

f. Cone subglobose, many seeds under each scale.....

........................ 68 .

e. Fruit a berry-like cone; leaves scalelike or awl-shaped, ternate or decussate........... JUNIPERUS, p. 74 .

aa. Leaves broad and flat, netted veined (except Yucca and Washingtonia), rarely wanting.............. (ANGIOSPERMS)

b. Leaves and buds opposite or whorled.

c. Leaves simple.

d. Leaves lobed; fruit a double samara (key) ............

d. Leaves not lobed; fruit not a double samara.

e. Leaves entire or nearly so.

f. Stipules persistent; fruit nutlike, capsule.........

.CEPHALANTHUS, p. 275. 
f. Stipules absent.

g. Leaves linear to linear-lanceolate; fruit a woody linear capsule........... CHILOPSIS, p. 273.

g. Leaves suborbicular to elliptic.

h. Fruit a slender capsule 6-15" long; leaves large heart-shaped........CATALPA, p. 273.

h. Fruit not a capsule; leaves not heart-shaped, $1-4$ " long.

i. Fruit a samara with terminal wing; leaves broadly ovate to suborbicular, 1-2" long..

i. Fruit drupaceous. FRAXINUS ANOMALA, p. 263.

j. Leaves about 1" long, pubescent; drupe blue-black......FORESTIERA, p. 269.

e. Leaves serrate.

j. Leaves over 1" long, glabrous; drupes mostly white or red...CORNUS, p. 255.

f. Buds covered by 2 , valvate, large scales; fruit a drupe................ VIBURNUM, p. 279

f. Buds many-scaled; fruit a fleshy capsule enclosed

c. Leaves compound. in thin, scarlet aril........EUONYMUS, p. 229.

d. Leaves persistent; leaflets entire; flowers showy, purple;

fruit a large, obcordate capsule... PORLIERIA, p. 221.

d. Leaves deciduous.

c. Leaflets entire or finely serrate; fruit a samara with terminal wing............... FRAXINUS, p. 260.

c. Leaflets sharply and coarsely or incisely serrate.

f. Fruit a double samara; leaves with 3 leaflets...... ACER NEGUNDO, p. 233.

f. Fruit a capsule or drupe; leaves with 5 or more leaflets.

g. Fruit clustered drupes; flowers small.........

SAMBUCUS, p. 277.

g. Fruit a linear capsule; flower showy.........

b. Leaves and buds alternate.

TECOMA, p. 275.

c. Leafless or usually appearing so; branches with spines.

d. Succulent plants (cactus) with numerous, clustered spines.

e. Branches and stems columnar; seed dark.........

$\ldots \ldots \ldots \ldots \ldots \ldots \ldots \ldots \ldots \ldots$ CARNEGIEA, p. 251.

e. Branches jointed, tuberculate; seed pale.........

OPUNTIA, p. 251.

d. Woody, treelike plants, twigs terminating in spines.

e. Leafless; twig with green thorns and black cushion-

like processes; fruit a woody capsule ............

$\ldots \ldots \ldots \ldots \ldots \ldots \ldots \ldots \ldots$. . . . . 229.

e. Leaves early deciduous, plants appearing leafless.

f. Fruit a drupe or berry; twigs bright green; leaves minute and scalelike. 
g. Fruit a black berry.... KOEBERLINIA, p. 249.

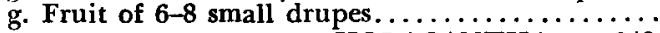
HOLACANTHA, p. 249.

f. Fruit a legume; twigs brown to pale green.

g. Leaves simple; flowers papilionaceous......... ................... pAROSELA, p. 217.

g. Leaves compound; flowers nearly regular.......

c. Leaves conspicuous and present during entire summer. CERCIDIUM, p. 211 . d. I eaves simple.

e. Leaves persistent or falling during the winter.

f. Leaves lobed.

g. Leaves pinnately lobed; fruit an achene.

h. Leaves $1 / 3^{-1 / 2}$ " long, divided by several lobes, hoary-tomentose below; achene long-tipped.. COWANIA, p. 185.

h. Leaves $1 / 2-11 / 4$ " long, 3-lobed at apex, hoarytomentose on both surfaces; achene not longtipped..............ARTEMISIA, p. 281.

g. Leaves palmately lobed.

h. Leaves 3-6 feet long, fanlike............ WASHINGTONIA, p. 285.

h. Leaves 11/2" long......FREMONTIA, p. 247.

f. Leaves not lobed.

g. Fruit a drupe or berry.

h. Leaves spinose-serrate; stipules minute..... RHAMNUS CROCEA, p. 245.

h. Leaves entire; stipules absent or present.

i. Flowers large (2" across); buds naked.... ................... 271.

i. Flowers less than 1/2" long; buds scaly.

j. Twigs often spinescent; fruit a drupe; flowers minute, not vaselike.

k. Leaves 1-31/2" long; drupe $1 / 3-1 / 2^{\prime \prime}$ in diameter.

1. Leaves rusty brown, lanuginose beneath.........BUMELIA, p. 259.

1. Leaves tomentulose beneath...... RHAMNUS, p. 243.

k. Leaves under $1 / 2$ " long; drupe under

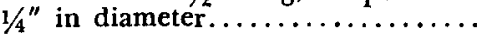
CONDALIA, p. 245.

j. Twigs not spinescent; fruit berry-like.

k. Fruit 1/3" long, red, many-seeded, calyx deciduous..ARBUTUS, p. 257.

k. Fruit 1/2-l" long, black, 3-8-seeded, calyx persistent at base...........

g. Fruit not fleshy. ........... DIOSPYROS, p. 259.

h. Fruit a nut or acorn; flowers in aments. 
i. Fruit a nut enclosed in a bur.......... CASTANOPSIS, p. 155 .

i. Fruit an acorn with a basal cup......... ............... QUERCUS, p. 136.

h. Fruit an achene or capsule, flowers with petals.

i. Fruit a long-tipped achene; leaves $1 / 2^{-1} 1^{\prime \prime}$ long............CERCOCARPUS, p. 181 .

i. Fruit a capsule; leaves $11 / 2-30^{\prime \prime}$ long.

j. Leaves $20-30^{\prime \prime}$ long, parallel veins.....

............... YUCCA, p. 283.

j. Leaves $1 \frac{1}{2}-7^{\prime \prime}$ long, netted veins.

k. Fruit a woody, 5-celled capsule; leaves

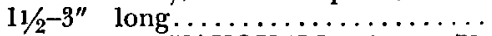
$\ldots \ldots \ldots$ VAUQUELINIA, p. 171.

k. Fruit a 2-celled capsule; leaves 2-7" long..........NICOTIANA, p. 271 .

e. Leaves deciduous.

f. Leaves small, glandular, soon deciduous; twigs spinescent; fruit a 1 -seeded legume...........

f. Leaves large, not falling until autumn.

g. Leaves entire.

h. Leaves linear or lanceolate; fruit a capsule; terminal bud absent.

i. Capsule woody, linear; buds many-scaled; stipules absent.......CHILOPSIS, p. 273.

i. Capsule soft, short; buds of 2 connate scales; stipules present.....SALIX, p. 114.

h. Leaves oblong to ovate or reniform.

i. Fruit drupaceous; leaves oblong to ovate, apex usually pointed.

j. Fruit numerous in panicles; pith thick; buds naked...........RHUS, p. 227.

j. Fruit usually solitary or few; pith thin; buds scaly.

$k$. Leaves and fruit glabrous.

1. Leaves unequal at base, acute or

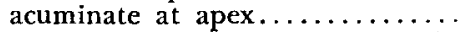
............... 158 .

1. Leaves equal at base, rounded $o r$

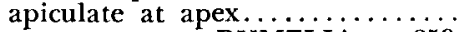
............ BUMELIA, p. 259.

k. Leaves and fruit silvery-scurfy...... ELAEAGNUS, p. 253.

i. Fruit a legume; leaves broad ovate or reniform, apex obtuse....... CERCIS, p. 207.

g. Leaves serrate to lobed.

h. Leaves serrate.

i. Fruit a pome or drupaceous. 
j. Fruit compound; juice milky.........

j. Fruit simple; juice watery.

k. Buds naked, terminal absent; fruit drupaceous.....RHAMNUS, p. 245.

k. Buds scaly, terminal present.

1. Fruit a pome.

m. Branches spiny; mature carpels bony...CRATAEGUS, p. 176.

$m$. Branches not spiny; mature carpels papery.............

1. Fruit a drupe. .....AMELANCHIER, p. 175.

m. Terminal bud present; leaves even at base.

PRUNUS, p. 186

m. Terminal bud absent; leaves oblique at base.............

i. Fruit dry, not fleshy.

............CELTIS, p. 158.

j. Plants with milky juice, fruit a 2-celled capsule............. SAPIUM, p. 225.

j. Plants with watery juice.

$k$. Leaves singly serrate; fruit a capsule.

1. Buds of 2 connate scales; terminal absent; scales of ament entire..... ................SALIX, p. 114 .

1. Buds of many scales; terminal present; scales of ament laciniate..... ............ POPULUS, p. 96.

$k$. Leaves doubly serrate; terminal bud absent; fruit not a capsule.

1. Fruit a samara; leaves oblique at base........... ULMUS, p. 157.

1. Fruit a nutlet within an involucre or strobile; leaves even at base.

$\mathrm{m}$. Nutlet wingless, enclosed within bladder-like involucre......... …...... OSTRYA, p. 119.

m. Nutlet more or less winged, in woody strobile.

n. Strobile persistent; bud of 2 connate scales............ .........ALNUS, p. 126.

n. Strobile deciduous; bud of many scales.............. \#...... BETULA, p. 120.

h. Leaves lobed or deeply sinuately toothed.

i. Fruit a capsule, juice milky or mucilaginous. 
d. Leaves compound.

j. Seed not woolly.................. .RICINUS COMMUNIS, p. 225. j. Seed woolly....... GOSSYPIUM, p. 241.

i. Fruit not a capsule, juice watery.

j. Fruit an acorn; terminal bud present... QUERCUS, p. 136.

j. Fruit a head of achenes; terminal bud absent............ PLATANUS, p. 169.

e. Fruit a legume.............. (LEGUMINOSAE)

f. Leaves doubly or more pinnate.

g. Branches armed with spines or prickles.

h. Leaves with 6 or more (rarely 4 ) pinnae, persistent; flowers yellow; stamens numerous, free; legume indehiscent...ACACIA, p. 201.

h. Leaves with 2 (rarely 4) pinnae.

i. Flowers green-white, in spikes; legume indehiscent ............ PROSOPIS, p. 203.

i. Flowers yellow, in racemes; legume dehiscent.

j. Leaflets 4-12, leaves short, caducous.... ..............CERCIDIUM, p. 211.

j. Leaftets $40-60$, leaves elongated, persistent until autumn..................

g. Branches without spines or prickles.

h. Flowers large, showy, yellow, in racemes..... .................. POINCIANA, p. 205.

h. Flowers minute, in globose heads, whitish.

i. Legume $6-10^{\prime \prime}$ long and $1 / 3-1 / 2$ " wide; flowers with 10 stamens...LEUCAENA, p. 199.

i. Legume 5-8" long and 3/4-1" wide; flowers with 12-20 stamens...LYSILOMA, p. 199.

f. Leaves once pinnate.

g. Leaflets 20-46, glandular-dotted; legume $1 / 2^{\prime \prime}$ long; twigs unarmed. .EYSENHARDTIA, p. 215.

g. Leaflets 3-21, not glandular-dotted; legume 1-7" long.

h. Leaflets 15-21; legume compressed; flowers white or pink; stipules becoming spinescent.. ...................ROBINIA, p. 219.

h. Leaflets 7-15; legume round; flowers blue, purple, or yellow.

i. Flowers yellow; leaves deciduous with 8-12 leaflets............... CARAGANA, p. 207.

i. Flowers blue or purple; leaves persistent, mostly odd pinnate.

j. Twigs armed with sharp infrastipular spines; leaflets 10-15. OINEYA, p. 221. 
j. Twigs unarmed; leaflets $7-9 \ldots \ldots \ldots$ ..................SOPHORA, p. 213.

h. Leaflets 3; flowers red; twigs spiny.

ERYTHRINA, p. 217.

c. Fruit not a legume; leaves once pinnate.

f. Leaves 3-foliolate; fruit a broad-winged samara... ..................... PTELEA, p. 223.

f. Leaves usually many foliolate; fruit not a samara.

g. Leaflets $1 / 4$ " long; rachis winged.

h. Leaflets $20-40$, deciduous; Arizona .........

BURSERA, p. 225.

h. Leaflets 9-19, semi-persistent; Texas........

PISTACIA, p. 227.

g. Leaflets 1 " or more long; rachis not winged.

h. Buds large; fruit a nut within husk; pith chambered.............. JUGLANS, p. 95 .

h. Buds small; fruit not a nut; pith solid.

i. Fruit a 3-valved capsule; leaflets 5-7, serrate............UNGNADIA, p. 241.

i. Fruit not a capsule.

j. Fruit twisted samaras in crowded clusters; leaves glandular toothed.......... . AILANTHUS, p. 223.

j. Fruit a berry, drupe, or pome; leaves not glandular.

k. Fruit a small pome; stipules present. leaflets serrate...... SORBUS, p. 173.

k. Fruit a berry or drupe; stipules absent.

1. Terminal bud absent; leaflets entire; berry $1 / 2 "$ in diameter........ ............ SAPINDUS, p. 239.

1. Terminal bud present; leaflets entire or serrate; drupe under $1 / 3$ " in diameter.........RHUS, p. 227. 


\title{
MANUAL OF ROCKY MOUNTAIN TREES
}

\author{
Including \\ DEsCRIPTION OF SPECIES \\ Plates of Diagnostic Characters \\ Distribution Maps \\ Keys To SPEcIES
}




\section{PINACEAE}

\section{The Pines \\ Characteristics of the Genus Pinus Duham}

HABIT. Evergreen trees with straight, unbranched, cylindrical trunks, and whorled, spreading branches.

LEAVES. Needle-like; in fascicles or bundles of 1-5; enclosed in bud by 6-12 scales which form a persistent or soondeciduous basal sheath; usually with several lines of stomata on each surface; juvenile leaves on young shoots differ in being spirally arranged, single, and scalelike.

FLOWERS. Monoecious; male, or pollen-producing, consisting of spirally arranged, sessile anthers, yellow, orange, or scarlet; female, or cone- and seed-producing, small, conelike bodies consisting of numerous spirally arranged, 2-ovuled scales, each subtended by a small bract.

FRUIT. A cone, usually pendent, composed of the hardened, woody scales of the flower; scales more or less thickened on the exposed terminal surface (the apophysis) with the ends of the growth of the previous year appearing as a terminal or dorsal, brown protuberance or scar (the umbo), which is often armed with a prickle; maturing in 2 (rarely 3 ) seasons. Seed: 2 borne at the base on inner face of each fertile scale; with thin, terminal, papery wing or wingless.

BUDS. Variable in size, shape, and color; covered by fringed or papery-margined overlapping scales; these component scales each protecting a tiny bud which, after the main bud unfolds, develops into a fascicle of leaves or occasionally into a female flower.

WOOD. Among our most important trees; extremely variable; numerous, large, easily visible resin ducts; resinous scent. Some species produce, in addition to lumber, naval stores and edible nuts.

GENERAL. The largest and most important genus of conifers, including about 80 species widely scattered over the Northern Hemisphere; 35 species are native to the United States, and 15 of these are found in the Rocky Mountain region; the North American species can be conveniently grouped into the soft or white pines, and hard, pitch, or yellow pines. 


\section{KEY TO THE SPECIES OF PINUS}

I. Leaf sheath deciduous; leaves with 1 fibrovascular bundle; cone scales without prickles (except in 6); Soft Pines.

A. Leaves in fascicles of 5 .

I. Cone scales thin, unarmed, cones long-stalked.

a. Cones 5-11" long, northern.....1. P. monticola, p. 5 .

b. Cones 12-18" long, Nevada....2. P. lambertiana, p. 5.

2. Cone scales thick, short-stalked (except in 5) .

a. Cones without prickles; seed longer than wing.

(1) Cones 11/2-8" long, subglobose, closed; alpine and northern.............. P. albicaulis, p. 9.

(2) Cones 3-10" long, subcylindrical, opening.

(a) Cone scales slightly reflexed; entire region..

.................. P. flexilis, p. 7 .

(b) Cone scales strongly reflexed; stalks $1 / 2-2 / 3$ "

long; southern.....5. P. strobiformis, p. 11 .

b. Cones with long, slender prickles; seed shorter than wing; central............... P. aristata, p. 17.

B. Leaves in fascicles of 1-3.

1. In 1's, stout; south-central.....7. P. monophylla, p. 15 .

2. In 2's, stout; south-central.......... P. edulis, p. 15.

3. In 3's, slender; southern......... P. cembroides, p. 13.

II. Leaf sheath persistent (except 10); leaves with 2 bundles; cone scales with prickles; Hard Pines.

A. Leaves in fascicles of 3 , sheath deciduous; cone matures in

3 years; southern.............10. P. leiophylla, p. 23.

B. Leaf sheath persistent; cone matures in 2 years.

I. Leaves in fascicles of 2; cones unsymmetrical.

a. Cones with distinct prickles; leaves $1-3^{\prime \prime}$ long; entire region..................11. P. contorta, p. 25.

b. Cones appear unarmed; leaves $3 / 4-11 / 2$ " long, divergent; extreme north . . . . . . . . 12. P. banksiana, p. 27.

2. Leaves in fascicles of 3,2 and 3 , or 5, 5-15" long; cones symmetrical.

a. Leaves in 5 's; cones $2-314^{\prime \prime}$; southern .......... $\ldots \ldots \ldots \ldots \ldots \ldots \ldots \ldots \ldots \ldots$ 13. $P$ arizonica, p. 21.

b. Leaves in 3's, or 2's and 3's; cones 3-6" long.

(1) Leaves 4-7"; yellow-green...14. P. ponderosa, p. 19.

(2) Leaves 8-15"; dark; southern............... 15. P. apacheca, p. 21. 


\section{Western White Pine}

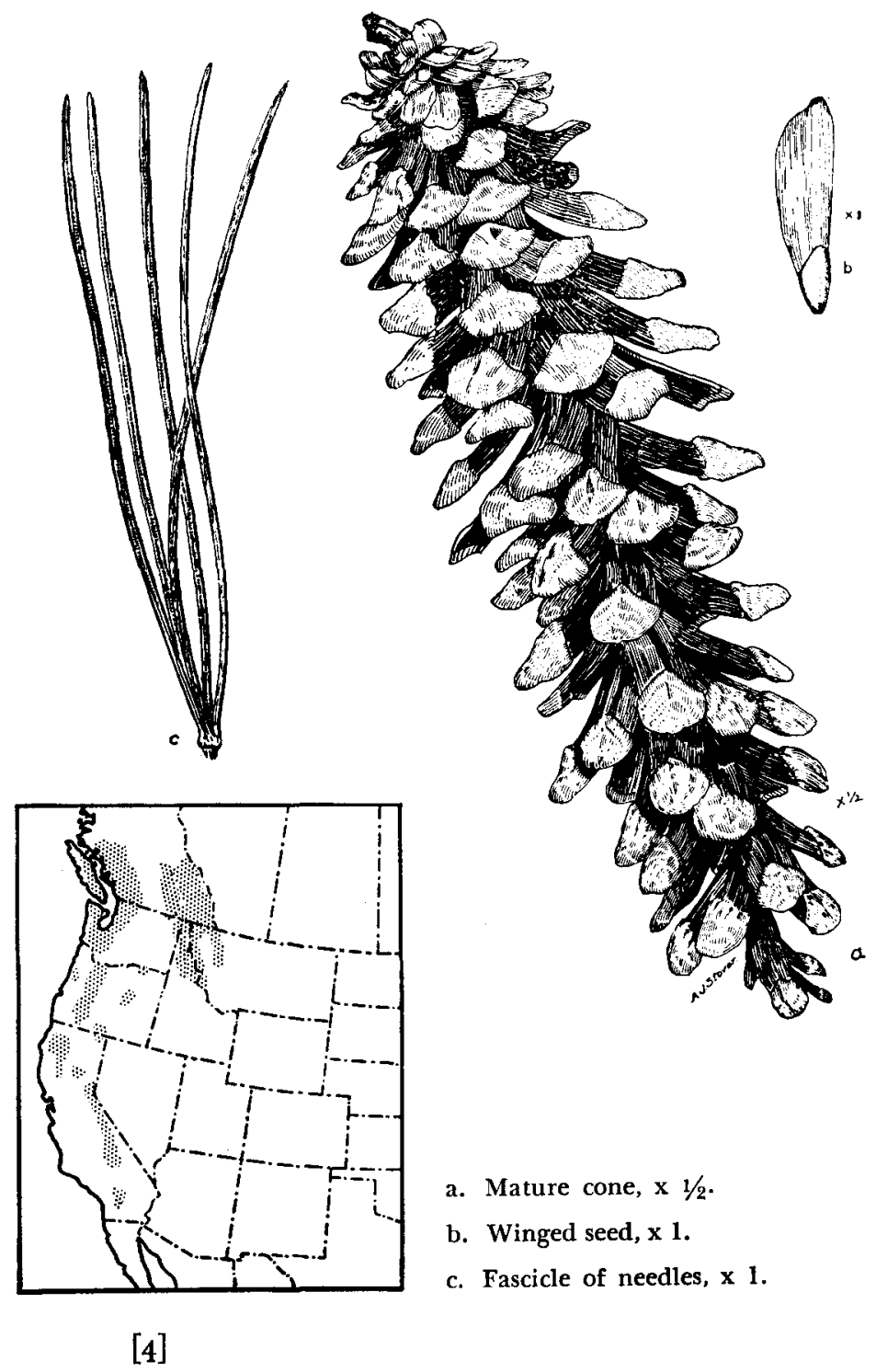




\section{PINACEAE \\ Western White Pine \\ Pinus monticola Doug.}

HABIT. A tree 90-180 feet high and 21/2-5 feet in diameter (max. 200 by 8 feet); on good sites a tall bole with narrow, symmetrical crown and slender, drooping branches.

LEAVES. In fascicles of 5; 2-4 inches long; slender; twisted; blue-green; persistent 3-4 years; sheath deciduous; margin with minute teeth; all sides marked by stomata.

FLOWERS. Male yellow; female red-purple in clusters.

FRUIT. Cones long-stalked; 5-11 inches long; narrow; scales thin, unarmed, with terminal umbo. Seed: $1 / 4$ inch long with wing about 1 inch long; red-brown.

TWIGS. Slender; at first rusty-pubescent, later smooth and red-brown to purple-brown. Winter buds: $1 / 2$ inch long; oblong ovoid.

BARK. On young stems thin, smooth, and light gray; on mature trees rarely over $11 / 2$ inches thick in square or rectangular, dark gray plates.

WOOD. Very important; soft, light in weight, and not strong; light brown heartwood; similar to eastern white pine; planing mill products, building, construction, patterns, etc.

SILVICAL CHARACTERS. Tolerant when young, becoming intolerant with age; maturity reached in 200-350 years (extreme age, 400-500 years); reproduction generally sparse: tree windfirm with well-developed tap- and lateral root system: fire, blister rust, and bark beetles cause damage.

HABITAT. Canadian zone; altitudinal range from 2,0007.000 teet; best on rich, porous, moist soils; often forming extensive pure forests and elsewhere in mixtures with other coniters.

\section{Sugar Pine}

Pinus lambertiana Doug.

This species barely enters this region, extending into Nevada in the Truckee River Cañon to a point opposite Reno. It can be distinguished from Pinus monticola by its larger cones (1026 inches long) and reddish bark. 
Limber Pine

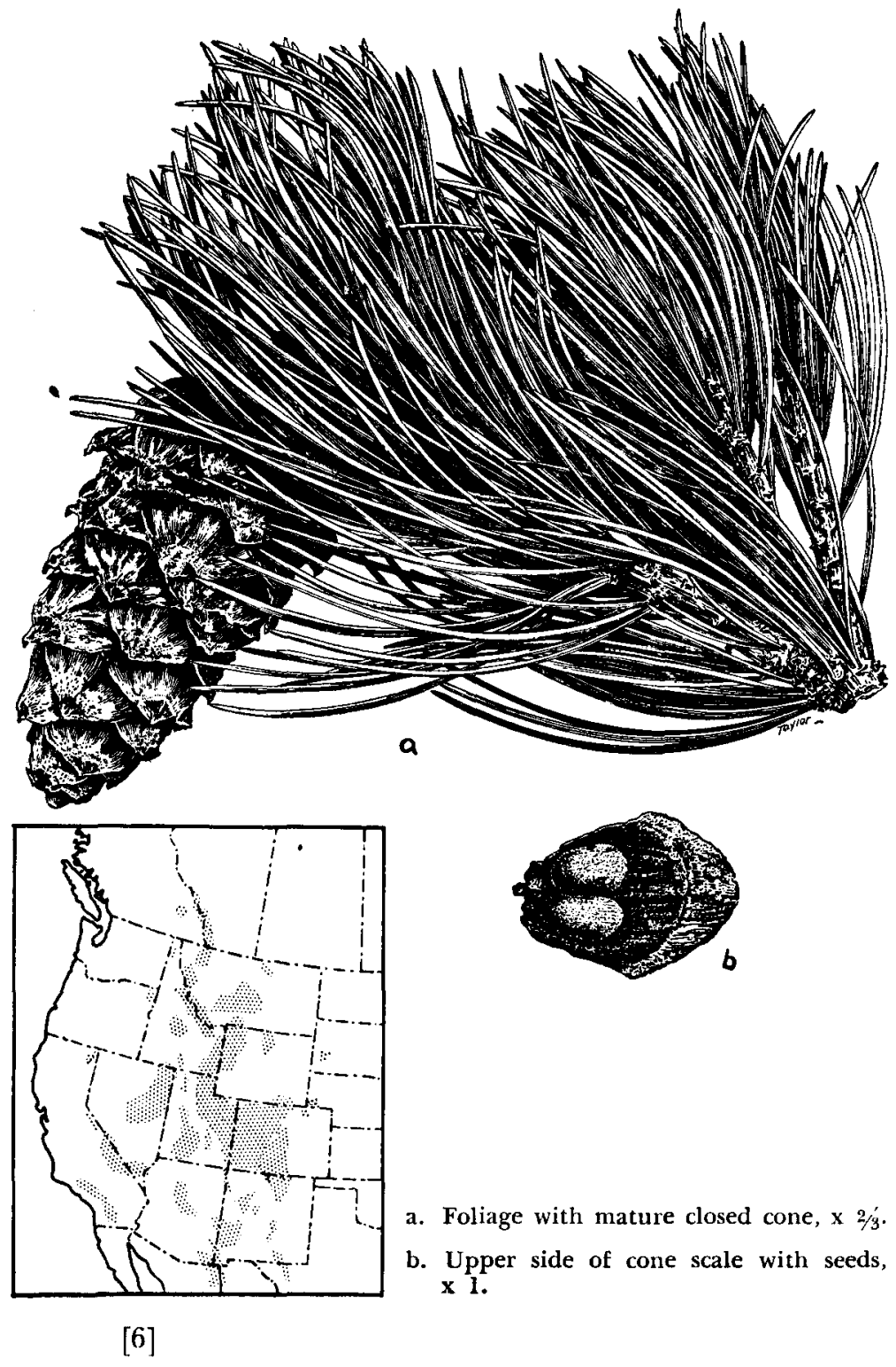




\section{PINACEAE \\ Limber Pine \\ Pinus flexilis James}

HABIT. A tree 25-50 feet high and 1-3 feet in diameter (max. 85 by $61 / 3$ feet); bole short and sharply tapered; crown broad, open, with numerous, large, plumelike, often drooping branches; shrublike at high elevations.

LEAVES. In fascicles of 5; 11/2-3 inches long; stout; rigid; dark green; persistent 5-6 years; clustered toward the end of the branchlets; sheath deciduous; margins with minute teeth; marked on all sides by rows of stomata.

FLOWERS. Male red; female clustered, red-purple.

FRUIT. Cones short-stalked; 3-10 inches long; subcylindrical; open at maturity; scales greatly thickened and often slightly reflexed, with terminal unarmed umbo. Seed: $1 / 3^{-1 / 2}$ inch long; rudimentary wing or wingless; thick, light brown shell.

TWIGS. Stout and tough; at first covered with soft, white hairs, but soon smooth and silver-white or grey. Winter buds: $1 / 3-1 / 2$ inch long; broad ovoid and pointed.

BARK. Thin, smooth, white-gray on young stems and branches; on old trunks dark brown and plated.

WOOD. Unimportant; moderately light and soft; closegrained; not strong; heartwood lemon-yellow becoming reddish on exposure; sapwood thin and white; used locally for rough construction, mine props, railroad ties, and fuel.

SILVICAL CHARACTERS. Very intolerant; growth usually slow; maturity reached in 200-300 years; reproduction generally sparse; tree very windfirm with long, sparsely branched taproot, later supplemented by several laterals. Fire, blister rust, and bark beetles cause serious damage.

HABITAT. Upper Sonoran to Hudsonian zones; large altitudinal range from 4,000-10,000 feet in north to 4,500-11,500 feet in Colorado; adapted to wide variety of sites, but typical of summits, ridge tops, and rocky foothills; occasionally in pure stands, but typically scattered with other conifers such as mountain hemlock, whitebark pine, lodgepole pine, Engelmann spruce, and Douglas-fir. 
Whitebark Pine
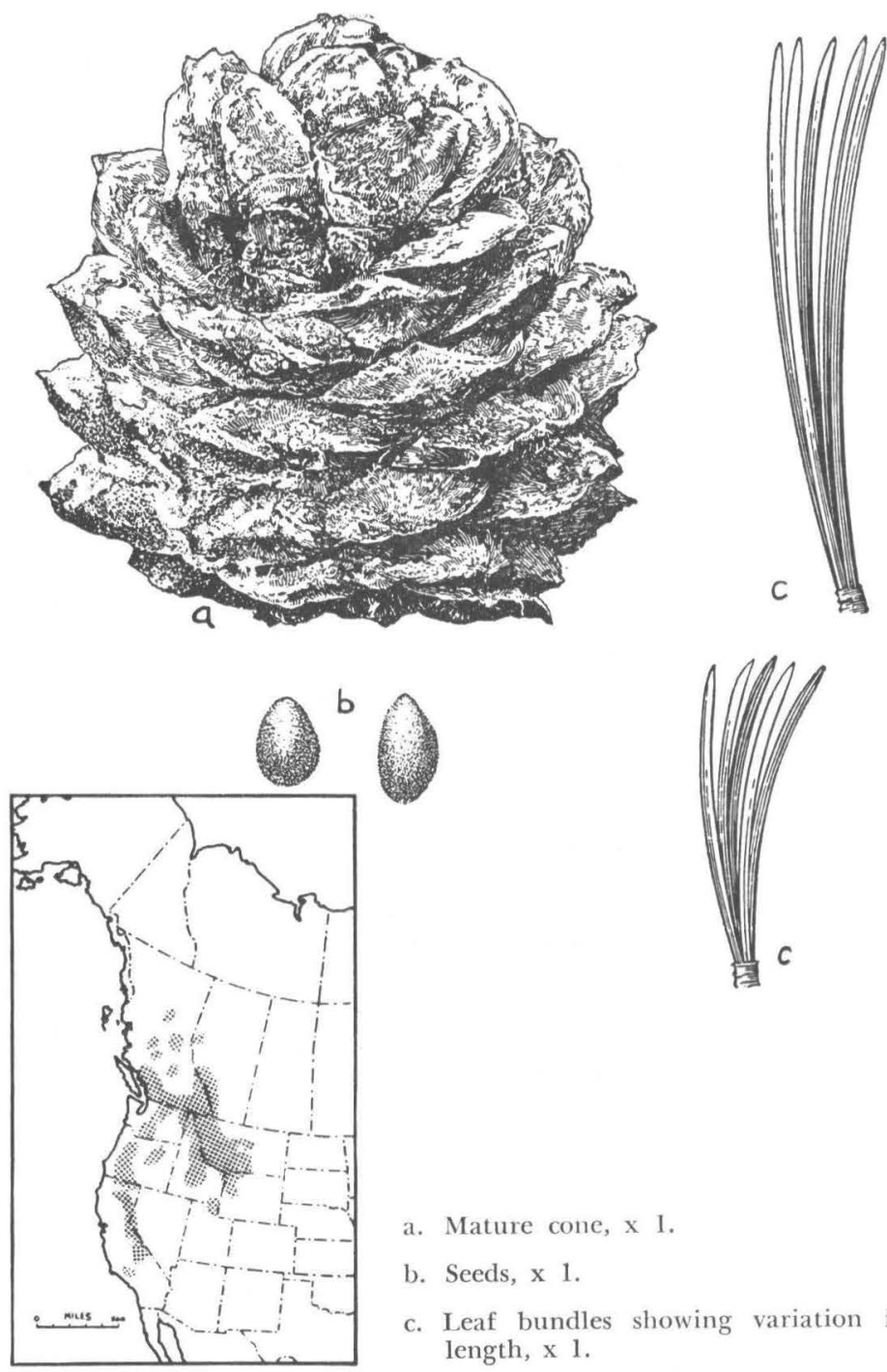

a. Mature cone, $\times 1$.

b. Seeds, $\mathrm{x} 1$.

c. Leaf bundles showing variation in length, x 1 . 


\section{PINACEAE \\ Whitebark Pine \\ Pinus albicaulis Engelm.}

HABIT. A tree 20-40 feet high and 1-2 feet in diameter (max. 60 by 4 feet); bole usually short and twisted; crown broad, open, irregular, with long, stout, flexible branches; at high elevation a low, spreading shrub.

LEAVES. In fascicles of $5 ; 11 \frac{1}{2}-21 / 2$ inches long; stout and rigid; dark green; persistent $5-8$ years; clustered toward the ends of the branchlets; basal sheath deciduous; margins usually smooth, but sometimes with minute, widely separated teeth; marked on back or dorsal side by 1-3 rows of stomata.

FI.OWERS. Male and femalc scarlet; opening in July.

FRUIT. Cones short-stalked; 11/2-3 inches long; subglobose; closed at maturity and ultimately disintegrating at the axis; scales thickened and often armed with stout, pointed, terminal umbos; purple-brown in color. Seed: large, $1 / 3-1 / 2$ inch long; wingless; with thick, hard, dark brown shell.

TWIGS. Stout and tough; pubescent for 2 years or sometimes glabrous; red-brown becoming white-gray. Winter buds: $1 / 3-1 / 2$ inch long; ovoid.

BARK. Thin, smooth, white-gray on young stems and branches; only about $1 / 2$ inch thick on old trunks, and broken into narrow, brown-white, platelike scales; inner bark redbrown.

WOOD. Unimportant; light and soft, but firm; brittle when dry; sapwood thin, whitish; heartwood pale brown when freshly cut; used only locally for fuel and mine timbers.

SILVICAL CHARACTERS. Very intolerant; growth slow; maturity reached in about 250 years; reproduction rather sparse; tree very windfirm; susceptible to fire injury and subject to attack by blister rust and bark beetles.

HABITAT. Hudsonian and Canadian zones; altitudinal range from 5,000-10,000 feet in Rocky Mountain region; adapted to wide variety of soils but typically on exposed, rocky crags or cañon walls; occasionally in pure stands, but usually in mixture with other high-altitude conifers as Engelmann spruce, Lyall's larch, and limber and lodgepole pines. 
Mexican White Pine

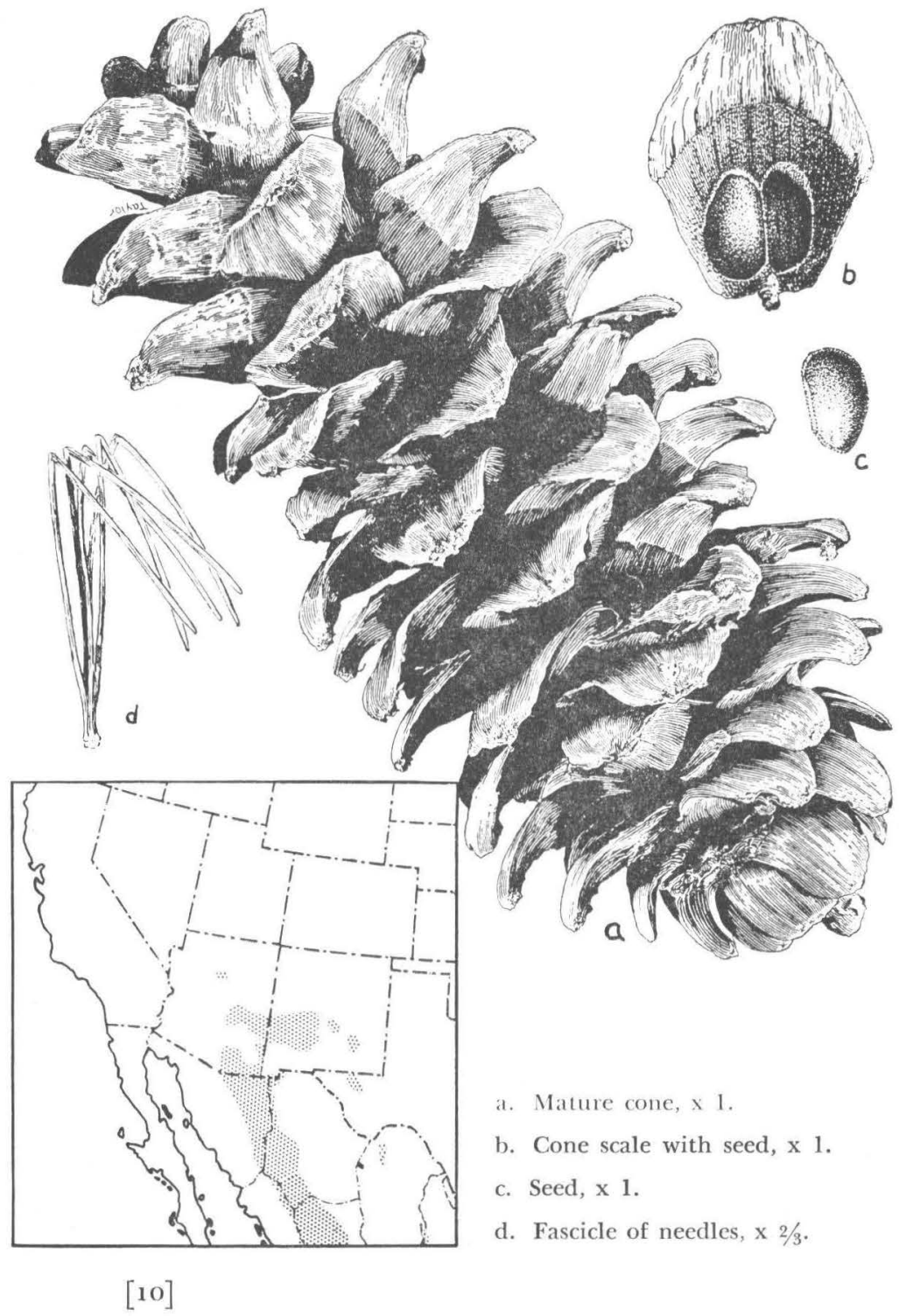




\section{PINACEAE \\ Mexican White Pine \\ Pinus strobiformis Engelm.}

HABIT. A tree 50-60 feet high and 1-1 1/2 feet in diameter (max. 100 by 3 feet); bole straight, clear, and rapidly tapering; crown narrow, short, and conical. Trees growing in protected situations resemble eastern white pine in appearance, while those on high or exposed sites are difficult to distinguish from limber pine.

LEAVES. In fascicles of $5 ; 3-4$ inches long; slender to stout; moderately stiff; pale blue-green; persistent about 4 years; basal sheath deciduous; margins with minute, remote teeth: marked only on lower sides by 3 or 4 lines of stomata.

FLOWERS. Light red to red-brown; male $1 / 3$ inch long; female paired or clustered.

FRUIT. Cones moderately long-stalked (1/2-2/3 inch); 5-9 inches long; subcylindrical; open at maturity; scales thickened and strongly reflexed; umbos terminal and unarmed. Seed: large and nutlike; $1 / 3-1 / 2$ inch long; very short wing; shell thick, dark brown, slightly tinged with red.

TWIGS. Moderately stout to slender; gray-white; at first covered with red-brown hairs which disappear the first winter. Winter buds: $1 / 3-1 / 2$ inch long; ovoid.

BARK. Dark gray, becoming $11 / 4$ inches thick and red-brown on old trunks; deeply furrowed and narrowly ridged.

WOOD. Unimportant in the United States but moderately important in Mexico, as it is relatively inaccessible, similar to western white pine and used for same purposes.

SILVICAL CHARACTERS. Intolerant; reproduction sparse; growth slow; maturity reached in about 250 years.

HABITAT. Transition zone; altitudinal range from 3,300 to 10,000 feet; at its best on moist, gravelly sites, but more common on exposed, dry, rocky ridges and cañon sides; rarely in pure stands, usually with Douglas-fir and Arizona pine.

GENERAL. Some authors consider this pine a form or variety of limber pine, Pinus flexilis var. reflexa Engelm.; others consider it a variety of the Mexican white pine, Pinus ayacahuite Ehren., which extends through Mexico into Central America. 


\section{Mexican Piñon}
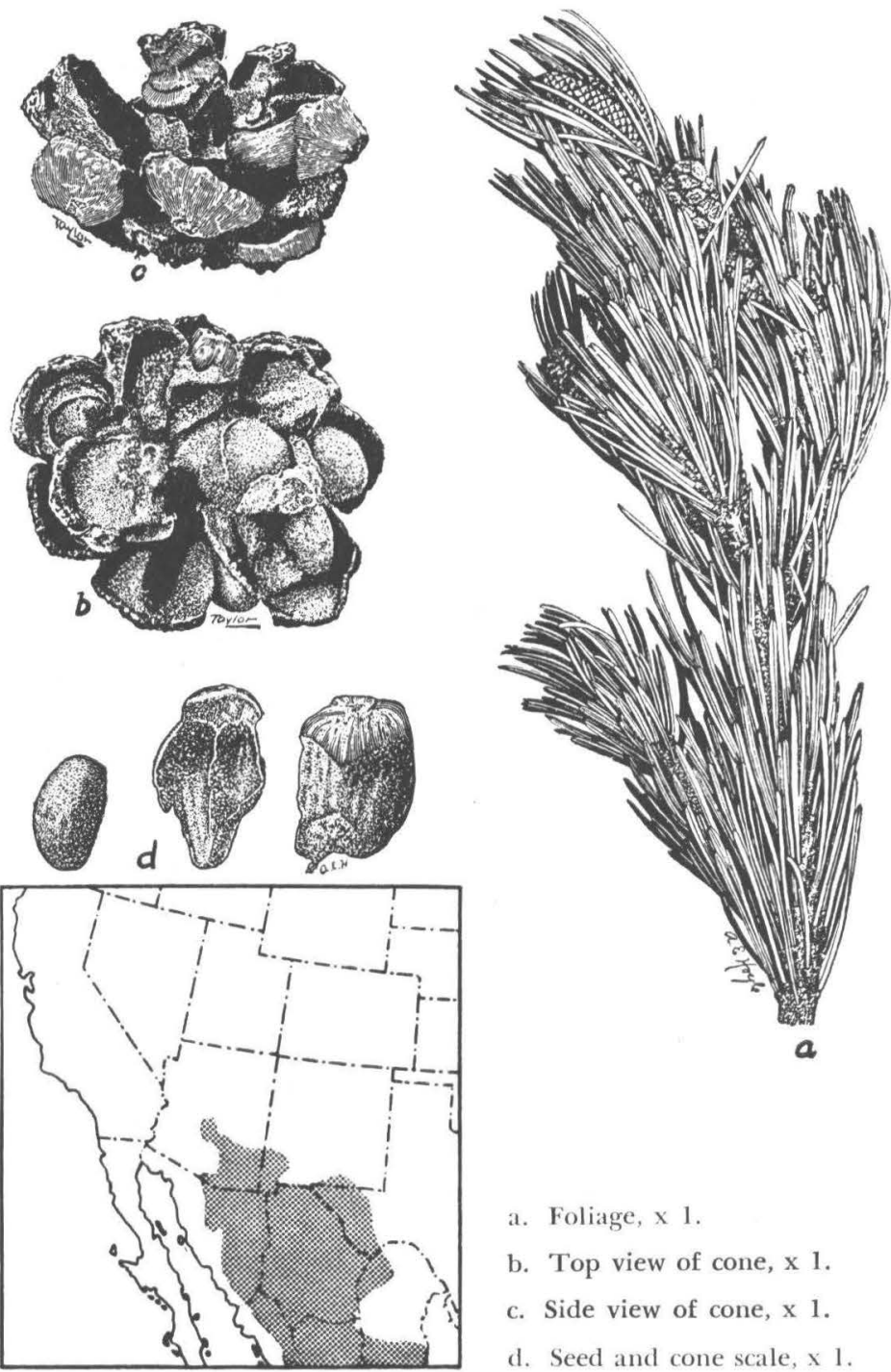

a. Foliage, $x 1$.

b. Top view of cone, $x 1$.

c. Side view of cone, $\mathrm{x} 1$.

d. Seed and cone scale, x 1. 


\section{PINACEAE}

Mrxican Piñon. Nut Pine

Pinus cembroides Zucc.

HABIT. A tree 10-40 feet high and I-2 feet in diameter (max. 50 by 3 feet); bole rapidly tapering and often divided with a spreading, rounded crown, giving the tree a bushy appearance.

LEAVES. In fascicles of 3 , or 2 and 3 (rarely from 1 to 5); 1-2 inches long; moderately slender (less than $1 \mathrm{~mm}$.); bluegreen; incurved; sharp-pointed; persistent 3-4 years; margins with minute teeth; no rows of stomata on dorsal surface; fascicle sheath only partially deciduous.

FI.OWERS. Male yellow in crowded clusters; female dark red.

FRUIT. Cone 1-21/2 inches long; ovoid to globose; scales few and unarmed; yellow-brown; maturing in August or September of second season and shedding seed soon after; immature cones with stalk $1 / 4-1 / 3$ inch long. Seed: $1 / 2-3 / 4$ inch long with rudimentary terminal wing; shell cannot be cracked with teeth.

TWIGS. Moderately stout; light orange-colored, ultimately becoming dark brown. Winter buds: Apex long tapering.

BARK. Rarely over $1 / 2$ inch thick on mature trees; irregularly divided into flattened connecting ridges separated by shallow fissures; superficially scaly; light red-brown.

WOOD. Unimportant; moderately light; rather hard; brittle, cross-grained, fine-textured; light yellow heartwood; thin, whitish sapwood; used locally for fuel, ties, and fence posts; of less importance than the large, oily seeds which are an important article of food among the Indians and Mexicans.

SILVICAL CHARACTERS. Very intolerant in all but scedling stage; growth slow; maturity reached in 250-350 years; reproduction generally sparse and scattered; tree very windfirm with extensive, shallow to moderately deep root system.

HABITAT. Upper Sonoran zone; altitudinal range, from 4,800-8,000 Seet; hot, arid, gravelly mountain slopes and cañon sides; occasionally in small pure groves, but usually in mixture with junipers and scrub oaks. 


\section{PIÑON}
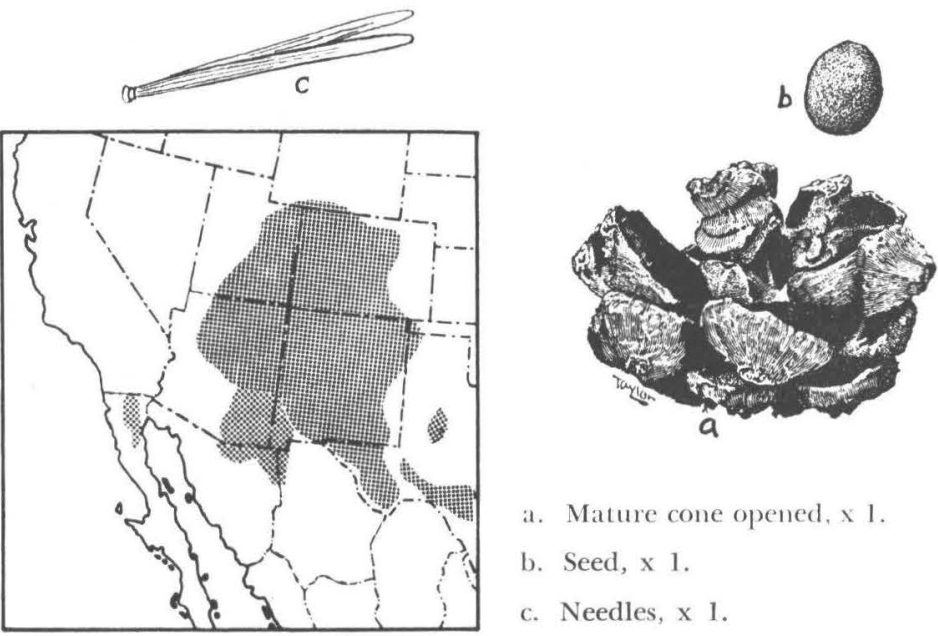

a. Mature cone opened, x 1 .

b. Seed, $\times 1$.

c. Needles, x 1 .

Singleleaf Piñon
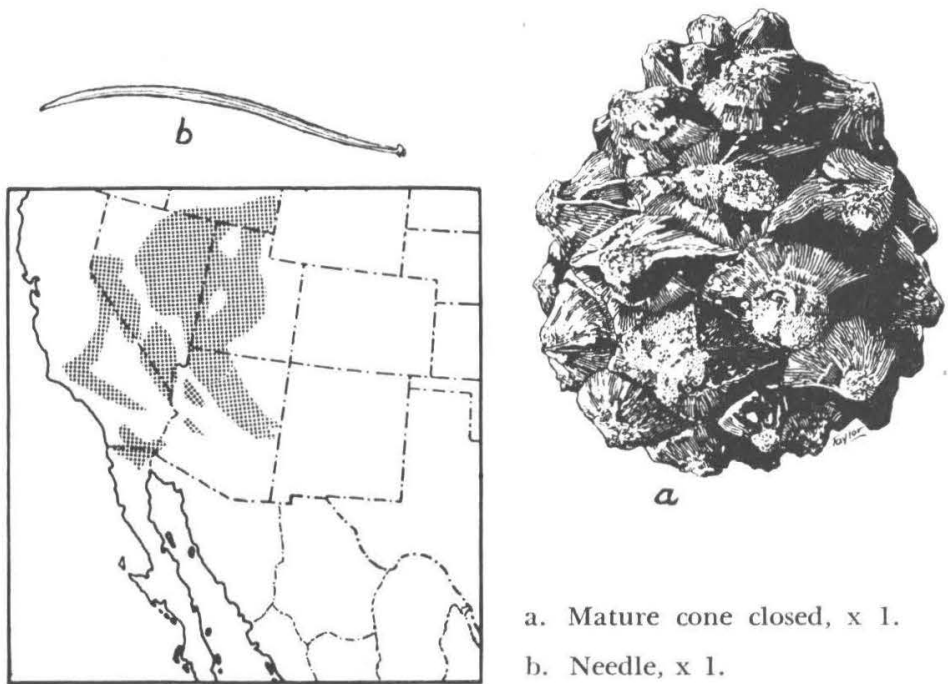

a

[14]

a. Mature cone closed, $\mathrm{x} 1$.

b. Needle, x 1 . 


\section{PINACEAE}

\section{Piñon. Nut Pine}

Pinus edulis Engelm. (Pinus cembroides var. Edulis Voss.)

A tree similar in appearance to Pinus cembroides but differing from it in distribution and the following characters:

LEAVES. In fascicles of 2, or less frequently of 1 or 3; $3 / 4-11 / 2$ inches long; stout (greater than $1 \mathrm{~mm}$.) and rigid; yellow-green; incurved; sharp-pointed; persistence not definite, falling off from the third to the ninth year; margins entire; rows of stomata on all sides (4-6 rows on dorsal surface) fascicle sheath only partially deciduous at base.

FRUIT. Immature cones short-stalked (less than $1 / 8$ inch); seed easily cracked with teeth.

WINTER BUDS. Apex short-pointed.

HABITAT. Upper Sonoran zone; altitudinal range from 5,000-9,000 feet; arid, shallow, rocky soils of foothills, mesas and cañon walls; occasionally in pure groves, but usually in mixture with juniper, oak, or yellow pine.

\section{Singleleaf Piñon}

Pinus monophylla $\mathrm{T}$. and $\mathrm{F}$.

(Pinus cembroides var. monophylla Voss.)

A tree similar in appearance to Pinus edulis but differing from it in distribution and leaf characters.

LEAVES. Usually single, but sometimes in fascicles of 2, about 13/4 inches long; stout and rigid; pale, glaucous green; incurved; sharp-pointed; persistence not definite, falling off from the fourth to twelfth year; margins entire; rows of stomata on all sides; fascicle sheath only partially deciduous.

HABITAT. Upper Sonoran zone; altitudinal range from 2,000-7,000 feet; arid, gravelly slopes and mesas; differs from other piñons in frequently forming extensive pure stands, otherwise in mixture with juniper or chaparral. 
Bristlecone Pine
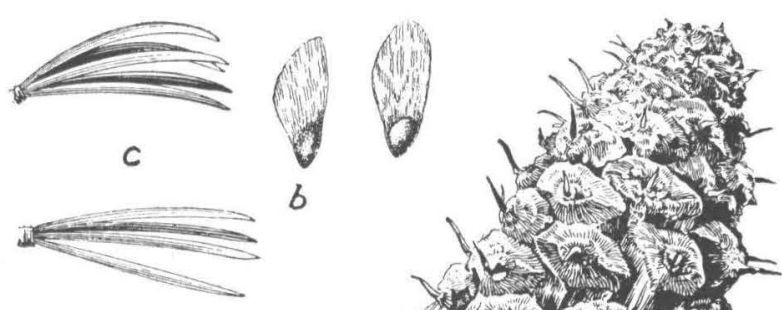

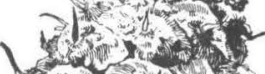
a

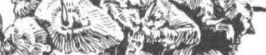

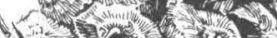

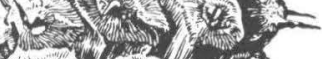
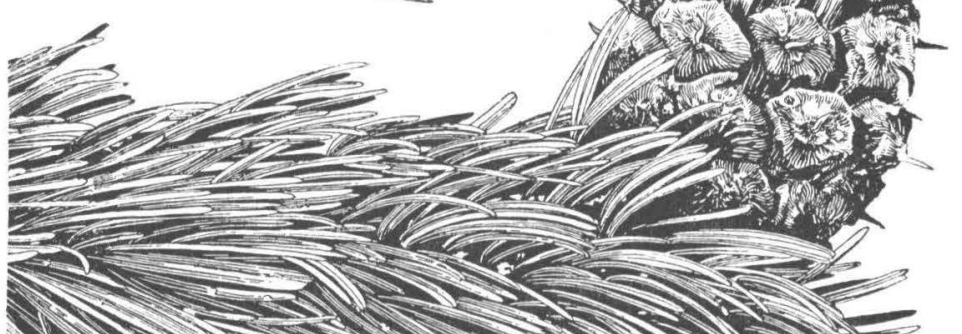
an $1=$ m a $=17$

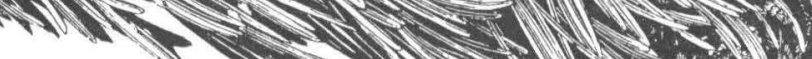
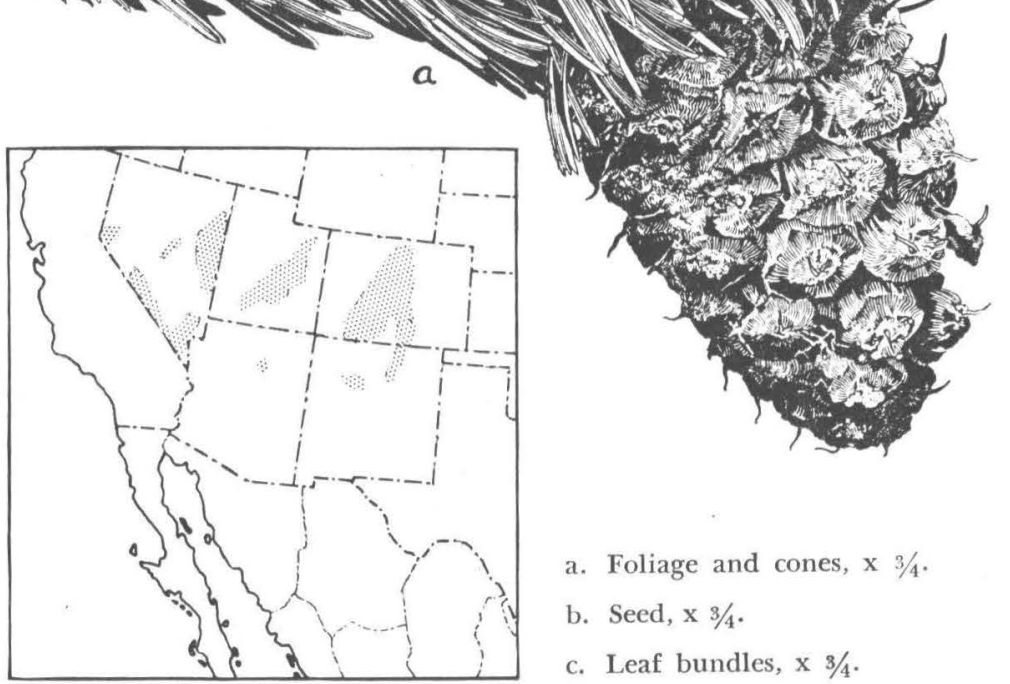

a. Foliage and cones, $x 3 / 4$.

b. Seed, $\times 3 / 4$.

c. Leaf bundles, $x 3 / 4$. 


\section{PINACEAE}

\section{Bristlecone Pine. Foxtail Pine \\ Pinus aristata Engelm.}

HABIT. An alpine tree $30-40$ feet high and $1-2$ feet in diameter (max. 60 by 3 feet) ; bole short, stocky, and commonly malformed; crown dense, irregular, bushy in appearance, and frequently clothing the stem nearly to the ground; at high elevations a prostrate shrub.

LEAVES. In fascicles of 5; 1-11/2 inches long; stout and curved; deep green; persistent for $10-17$ years; in dense, often appressed, clusters; sheath deciduous; lustrous on back, marked on lower or ventral surfaces by numerous rows of stomata; usually showing conspicuous whitish exudations of resin.

FLOWERS. Malc dark orange-red; female purple.

FRUIT. Cones short-stalked, 3-31/2 inches long; ovoidoblong; open at maturity; scales thick, with dark chocolatebrown apophysis; umbo dorsal, with long, bristle-like, fragile, incurved prickle; often covered with brown, shiny droplets of resin. Seed: 1/4 inch long; light brown, often mottled; with long terminal wing.

TWIGS. Stout; light orange-colored, becoming nearly black; long tufts of foliage at ends; glabrous, or at first puberulous. Winter buds: $1 / 3$ inch long, oblong-ovoid, brown.

BARK. Thin, smooth, and gray-white on young stems; $1 / 2-3 / 4$ inch thick on mature trunks, red-brown, and shallowly furrowed and ridged.

WOOD. Unimportant; a light, moderately soft, narrowringed, brittle wood; sapwood thin and whitish; heartwood pale brownish-red; used locally for fuel and mine props.

SILVICAL CHARACTERS. Very intolerant; growth slow; maturity reached in 200-250 years with extreme ages of 300 375 years; reproduction sparse and scattered; tree windfirm.

HABITAT. From typical Hudsonian to. Transition zones; altitudinal range from 7,500-10,800 feet; typical of exposed sites and dry, thin, rocky soils; rarely in pure, open groves, usually in mixture with limber pine, ponderosa pine, white fir and Engelmann spruce. 

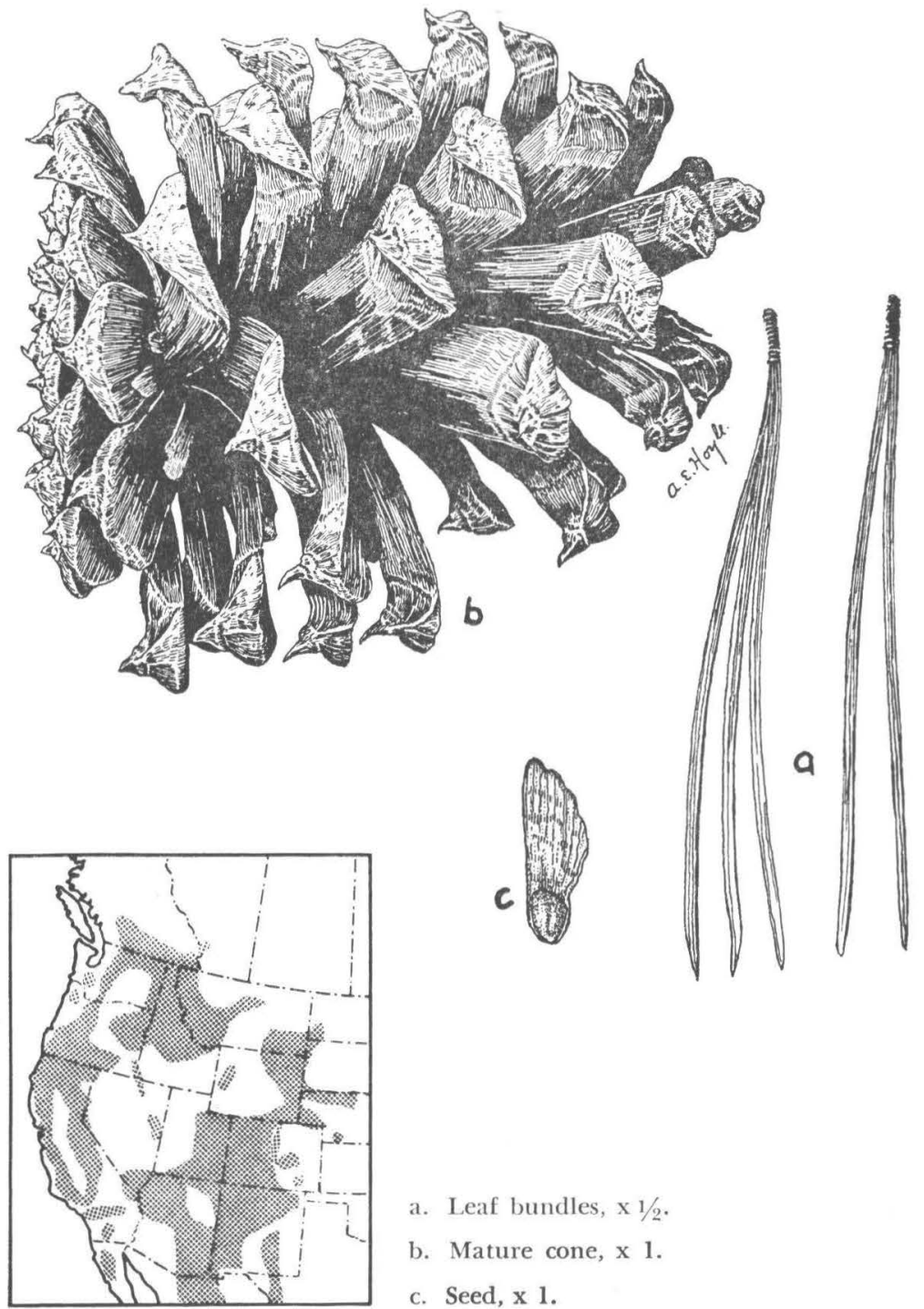

a. Leaf bundles, $\times 1 / 2$.

b. Mature cone, $\mathrm{x} 1$.

c. Seed, $\mathrm{x} 1$. 


\section{PINACEAE}

Ponderosa Pine. Western Yellow Pine

Pinus ponderosa Doug. (Pinus brachyptera Engelm.)

(Pinus ponderosa var. scopulorum Engelm.)

HABIT. A tree 150-180 feet high and 3-4 feet in diameter (max. 232 by 8 feet on Pacific coast) ; bole symmetrical, clear; crown short conical or flat-topped.

LEAVES. In fascicles of 3 , or 2 and 3 (rarely from 1-5); 4-11 inches long (mostly 5-7 inches); stout; dark to yellowgreen; persistent until third year; cross section shows $2-5$ resin ducts; basal sheath $1 / 4-3 / 4$ inch long, persistent.

FLOWERS. Male yellow; female red, clustered or paired.

FRUIT. Subsessile; $21 / 2-6$ inches long; ovoid to ellipsoidal; basal scales usually remaining attached to twig when cones shed; umbo dorsal and armed with prickles. Seed: $1 / 4$ inch long; brown-purple, often mottled; wing 1 inch long.

TWIGS. Stout; orange-colored, becoming nearly black; turpentine odor when bruised. Winter buds: about $1 / 2$ inch long; oblong to ovoid; often covered with resin.

BARK. Brown to black and deeply furrowed on young trees; on old trunks 2-4 inches thick; yellow-brown to cinnamon-red, and broken into large, flat plates.

WOOD. Very important; variable from light, soft, and finetextured to moderately heavy, hard, and coarse-textured; sapwood white and very thick with properties of white pine; heartwood light brown; wide variety of uses including construction, planing mill products, railroad ties, and mine timbers.

SILVICAL CHARACTERS. Intolerant; growth generally rather slow; maturity reached in $350-500$ years (extreme age recorded is 660 years); reproduction abundant and vigorous; a long taproot augmented in later life by a well-developed lateral system; fire and bark beetles cause greatest damage, while mistletoe and several fungi are also destructive.

HABITAT. Transition zone; large altitudinal range, varying from 2,000-7,000 feet in northern Idaho to 5,000-8,000 feet in Arizona; adapted to wide range of soils; exceedingly drought resistant; in open pure stands or more commonly the most abundant tree in mixed coniferous stands. 
Arizona Pinf

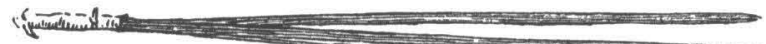
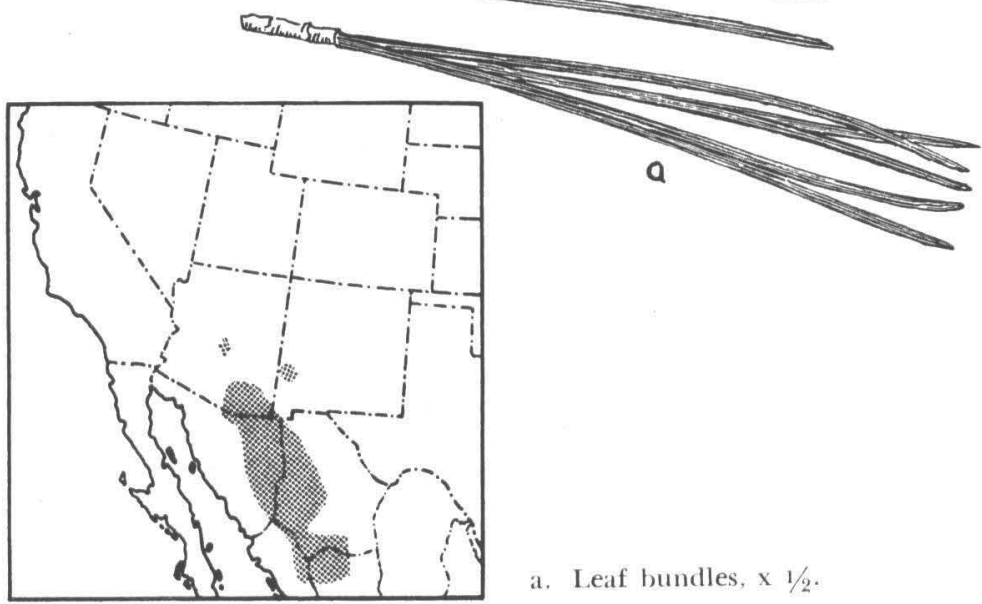

a. Leaf bundles, $\times 1 / 2$.

Apache Pine
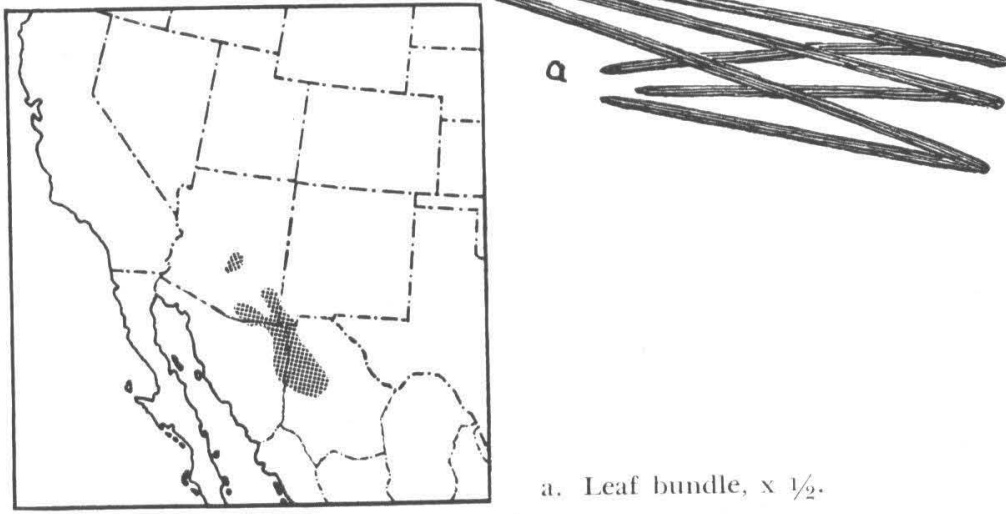

$[20]$

a. Leaf bundle, $\times 1 / 2$. 


\section{PINACEAE}

\section{Arizona Pine}

\section{Pinus arizonica Engelm. \\ (Pinus ponderosa var. arizonica Shaw.)}

A tree similar in most of its characteristics to Pinus ponderosa, and differing from it in the following ways:

HABIT. A tree 75-90 feet high and 2-3 feet in diameter (max. 120 by 4 feet.)

LEAVES. Mostly in fascicles of 5 (rarely 2-5 on same tree) ; 5-7 inches long; rigid; dark yellow-green; cross section shows 3 resin ducts.

FRUIT. Never more than $2-31 / 4$ inches long.

HABITAT. Transition zone; altitudinal range from $6,000-$ 8,000 feet; frequently in pure stands at lower elevations, but at higher levels commonly in mixture with Chihuahua, Apache, and western yellow pines, Arizona cypress, and scrub oaks.

Apache Pine

Pinus apacheca Lemm. (Pinus latifolia Sarg.)

A tree similar in most of its characteristics to Pinus ponder$o s a$, and differing from it in the following ways:

HABIT. A tree 50-60 leet high and 1-2 feet in diameter (max. 75 by 3 feet.)

LEAVES. In fascicles of 3 (occasionally 2-5); 8-15 inches long, (mostly about 10 inches) ; dark green; with conspicuously fringed margins; persistent 2 years; cross section shows 1l-14 resin ducts; basal sheath $\$ / 4-1$ inch long.

HABITAT. Transition zone; altitudinal range 5,500 8,200 feet; otherwise similar to Arizona pine.

GENERAL. Some authors consider this tree a synonym of Pinus ponderosa; it is characterized during its first few years by development of a very deep taproot and little height growth.

The Jeffrey pine, Pinus jeffreyi Grev. and Balf., is another species closely allied to Pinus ponderosa. Entering this region only in western Nevada, it is characterized by cones $5-15$ inches long, leaves 4-9 inches long and persistent 6-9 years, and nonresinous buds. 

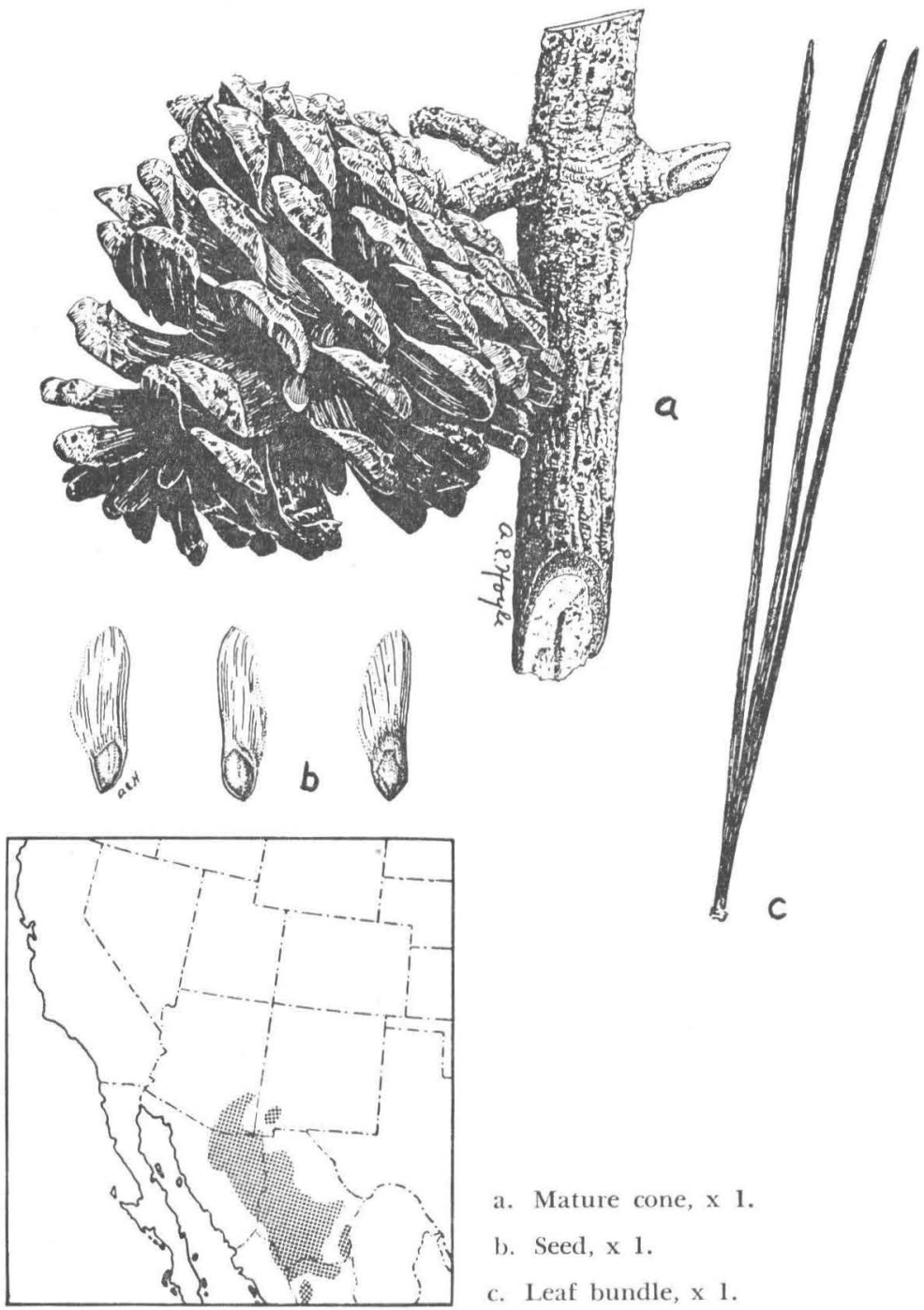
a. Mature cone, x 1 .
b. Seed, $x 1$.
c. Leaf bundle, x 1 . 


\section{PINACEAE}

\section{Ciminuahua Pine.}

\section{Pinus leiophylla Schl. and Cham.}

(Pinus chihuahuana Engelm.)

HABIT. A tree rarely over 40-50 feet high and 2 feet in diameter (larger in Mexico); bole fairly straight and clear for $1 / 2^{-2 / 3}$ of its length, crown a narrow pyramid or rounded.

LEAVES. In fascicles of $3 ; 2-4$ inches long; slender; pale glaucous green; persistent for 4 years; margins with minute teeth; marked by $6-8$ rows of stomata on all sides; cross section shows 2 resin ducts; basal sheath deciduous.

FLOWERS. Male yellow; female green; exceptional in that they do not appear until July.

FRUIT. Long-stalked; $11 / 2^{-2}$ inches long; ovoid; light chestnut-brown in color and lustrous; often remaining closed several years; scales slightly thickened, their umbos armed with minute, recurved, deciduous prickles; exceptional in that fruit matures in September of third year. Seed: $1 / 8$ inch long; thin, dark brown shell; wing $1 / 3$ inch long.

TWIGS. Slender; bright orange-brown becoming dull redbrown with age. Winter buds: 1/2 inch long; oblong-ovoid; brown.

BARK. $7 / 8-11 / 2$ inches in thickness on mature trees; color varies from a blackish-brown to bright red-brown; deeply and narrowly furrowed with broad, flat ridges between, the latter covered with thin, closely appressed scales.

WOOD. Unimportant; similar to ponderosa pine in properties and substituted for it in Mexico; in United States used locally for firewood.

SILVICAL CHARAGTERS. Intolerant; growth slow; maturity reached in 250-300 years; often forming coppice by growth of shoots from stumps of cut trees; reproduction generally sparse although seed produced abundantly.

HABITAT. Transition zone; altitudinal range from 5,5008,200 feet (usually between 6,000-7,000 feet) ; on dry, rocky, gravelly slopes and benches; typical of poor, dry soils but does well on moist, rich soils; occasionally in pure open stands, but commonly associated with Arizona, apache, and ponderosa pines. 
Lodgepole Pine

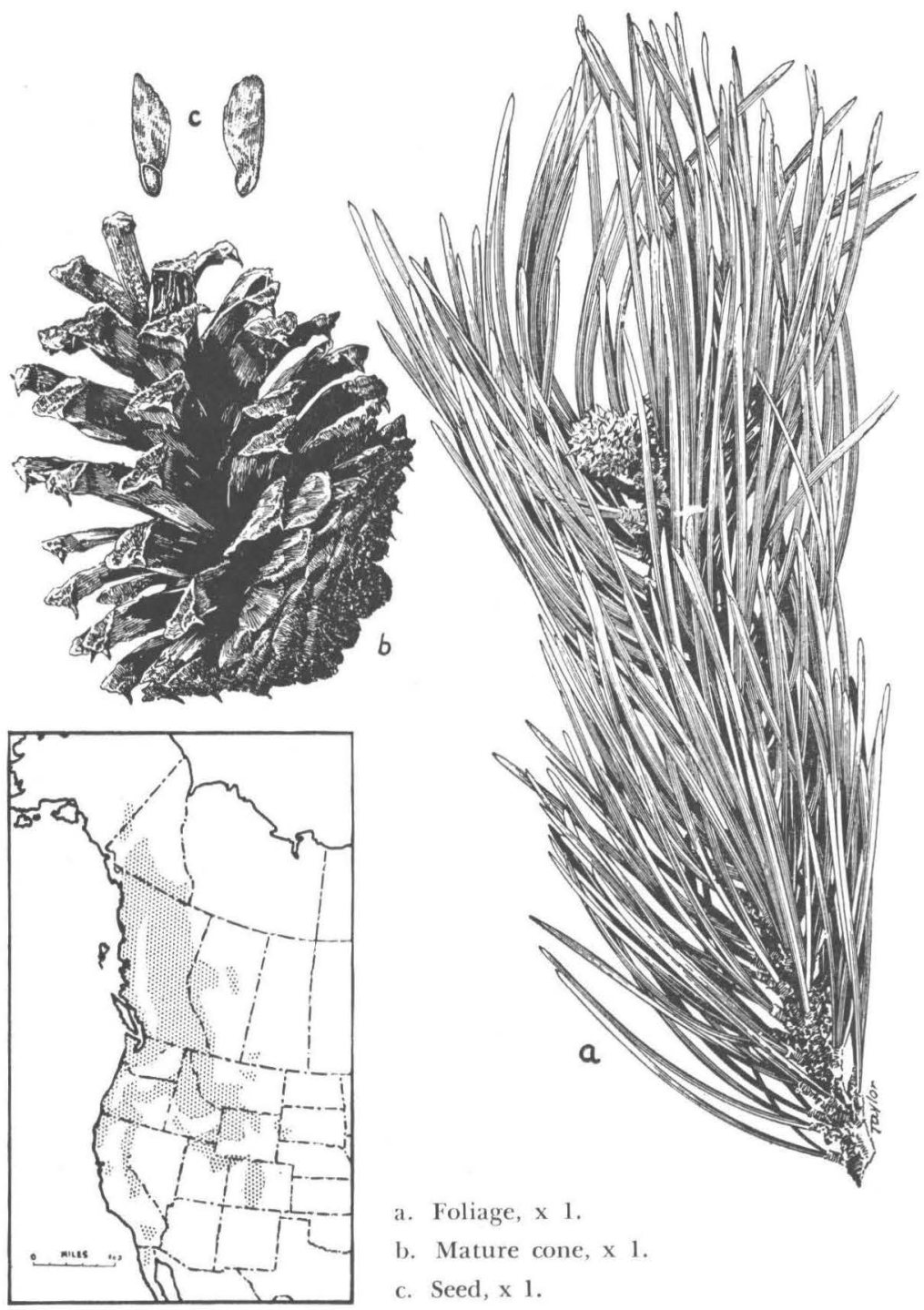




\section{PINACEAE}

\section{L.ODGEPOLE PINE}

Pinus contorta var. latifolia Engelm.

(Pinus murrayana Balf.)

HABIT. A tree 70-80 feet high and $1 \frac{1}{4}-21 / 2$ feet in diame. ter (max. 150 by 3 feet); long, clear, slender, cylindrical bole; short, narrow, rounded or pyramidal crown.

LEAVES. In fascicles of 2; 1-3 inches long; stout; often twisted; bright yellow-green; persistent 4-6 years; margins with minute teeth marked on all faces by 6-10 rows of stomata; basal sheath persistent.

FLOWERS. Orange-red; male in spikes; female clustered.

FRUIT. Subsessile; $3 / 4-2$ inches long; ovoid to subcylindrical; opening at maturity or frequently remaining closed and on the tree for many years; unsymmetrical; apophysis flattened, or those at base knoblike; umbo dorsal and armed with long, recurved, often deciduous prickle. Seed: $1 / 6$ inch long; thin, dark red-brown shell, often mottled; wings $1 / 2$ inch long.

TWIGS. Stout; light orange-brown, becoming black. Winter buds: $1 / 4$ inch long, ovoid, dark chestnut-brown, resinous.

BARK. Very thin, rarely over $2 / 5$ inch thick; orange-brown to gray; covered by thin, loosely appressed scales.

WOOD. Moderately important; soft and uniform; finetextured; sapwood thick, whitish; heartwood pale brown; tangential surface with many indentations; used for construction lumber, railroad ties, telephone poles, and mine timbers.

SILVICAL CHARACTERS. Intolerant, but recovers well from suppression; growth slow; maturity reached in about 200 years; shallow root system, trees not windfirm; reproduction vigorous, typically forming dense stands following fires; fire, bark beetles, and mistletoe cause damage; susceptible to sunscald.

HABITAT. Canadian zone; altitudinal range from 6,00011,000 feet; adapted to variety of soil types (except those of limestone origin), but best on moist, well-drained loams; in pure, dense, even-aged stands, or in mixture with various conifers.

GENERAL. The species proper, Pinus contorta Doug., commonly called Shore Pine, is a stunted, short-leaved, twisted-cone form restricted to the Pacific Coast. 
Jack Pine

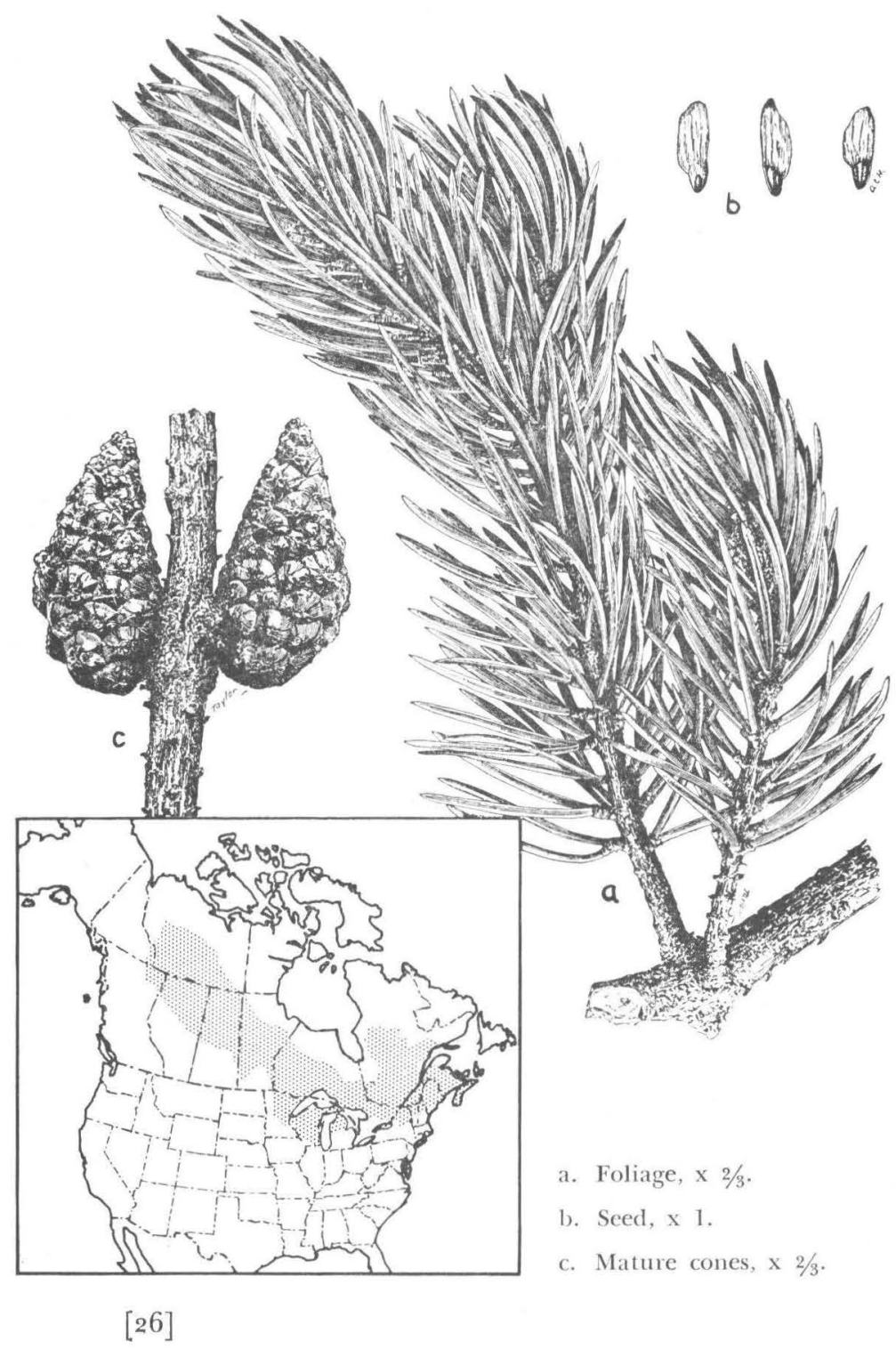




\section{PINACEAE \\ Jack Pine. Scrub Pine}

Pinus banksiana Lamb. (Pinus divaricata D.M. de C.)

HABIT. Under favorable conditions, a trec 70-80 feet high and $1-11 / 4$ feet in diameter (max. 90 by 2 feet), but usually much smaller; bole is often crooked and scraggly in appearance from long-persistent, dead lower branches; crown varies from open and symmetrical to irregular and scrubby.

LEAVES. In fascicles of $2 ; 3 / 4-11 / 2$ inches long; divergent; stout; often twisted; yellow-green; persistent $2-3$ years; margins with minute teeth; basal sheath persistent.

FLOWERS. Male yellow; female dark purple; clustered.

FRUIT. Sessile; 11/2-2 inches long; oblong-conic; unsymmetrical and often strongly incurved; erect; often remaining closed and on branches for many years; scales irregularly developed, thin and stiff; umbo dorsal, unarmed or with minute deciduous prickle. Seeds: $1 / 12$ inch long, triangular, black and roughened; wing about $1 / 3$ inch long.

TWIGS. Thin, tough, and flexible; smooth and yellowgreen first year, becoming rough and dark red-brown. Winter buds: $1 / 4$ inch long, ovoid and rounded; pale cinnamon-brown.

BARK. Thin; dark red-brown; narrow, shallow ridges separating into closely appressed scales.

WOOD. Not important; light and soft, not strong; closegrained; sapwood thick and creamy-white; heartwood yellowbrown; used for fuel, posts, and cheap grades of lumber.

SILVICAL CHARACTERS. Very intolerant; growth moderately rapid; short-lived tree, maturity being reached in about 60 years and deterioration starting soon after (trees 150 years old have been found); root system widespreading and moderately deep, with a taproot; reproduction vigorous; very drought-resistant; fire and fungi cause damage.

HABITAT. Canadian zone; growing at low altitudes, from 100-1,200 feet; essentially a Canadian tree, extending farther north than any other pine; typical of sterile sandy soils; mostly in pure stands; where its distribution overlaps that of lodgepole pine, jack pine is found at the lower elevations. 


\section{PINACEAE}

\section{The Larches}

Characteristics of the Genus Larix Adans.

HABIT. Tall, pyramidal trees; open crowns, with slender, irregularly disposed, horizontal or pendulous branches; dwarfed, short, spurlike lateral branchlets.

LEAVES. Deciduous, needle-shaped or linear; produced in dense false whorls or clusters on spurlike lateral branches; solitary and spirally arranged on new shoots; numerous lines of stomata on all surfaces; 2 resin canals in cross section.

FLOWERS. Monoecious, terminal, single, appearing with leaves; male naked, globose to oblong, consisting of several yellow, spirally arranged scales, each bearing two pollen sacs; female erect, consisting of few or many rounded, red-purple scales in the axes of much Jonger scarlet bracts, each scale bearing 2 small inverted ovules.

FRUIT. Woody, erect, short-stalked cones; maturing in one season; cone scales thin, persistent, concave, longer or shorter than their long-pointed bracts. Seed: 2 under each scale; triangular and light brown; large terminal wing.

TWIGS. Smooth and glaucous, or pubescent. Winter buds: subglobose, small, nonresinous, with accrescent inner scales which mark lateral spur branches with prominent ringlike scars.

WOOD. Rather strong and durable; small, scattered resin ducts; thin, white sapwood and sharply clefined, red to russetbrown heartwood.

SILVICAL GHARACTERS. Intolerant, slow-growing, and found on a variety of habitats; extensive forests occasionally destroyed by larch sawfly (Nematus erichsonii).

GENERAL. This genus contains about 10 species scattered through the Northern Hemisphere. In North America 4 species are native. 'The European larch (Larix decidua Mill.), an important tree, has been planted in the United States for ornamental purposes. It can be identified by its puberulous cones, $3 / 4-11 / 2$ inches long, with inserted bracts and $40-50$ suborbicular scales. 


\section{KEY TO THE SPECIES OF LARIX}

I. Cones small, $1 / 2^{-3 / 4^{\prime \prime}}$ long, with bracts inserted; twigs slender, covered at first with glaucous bloom; eastern and far northern....................... Larix laricina, p. 31.

II. Cones larger, 1-2" long, with bracts exserted; twigs stout, at first pubescent.

A. Twigs with pale pubescence, brittle; bark thick, red-brown, plated and deeply furrowed; cones 1-11/2" long; needles flatly 3-angled; western........2. Larix occidentalis, p. 33.

B. Twigs densely woolly, tough; bark thin, gray-scaly, and obscurely furrowed; cones 11/2-2" long; needles 4-angled; western alpine................. Larix lyallii, p. 35 . 
TAMARACK
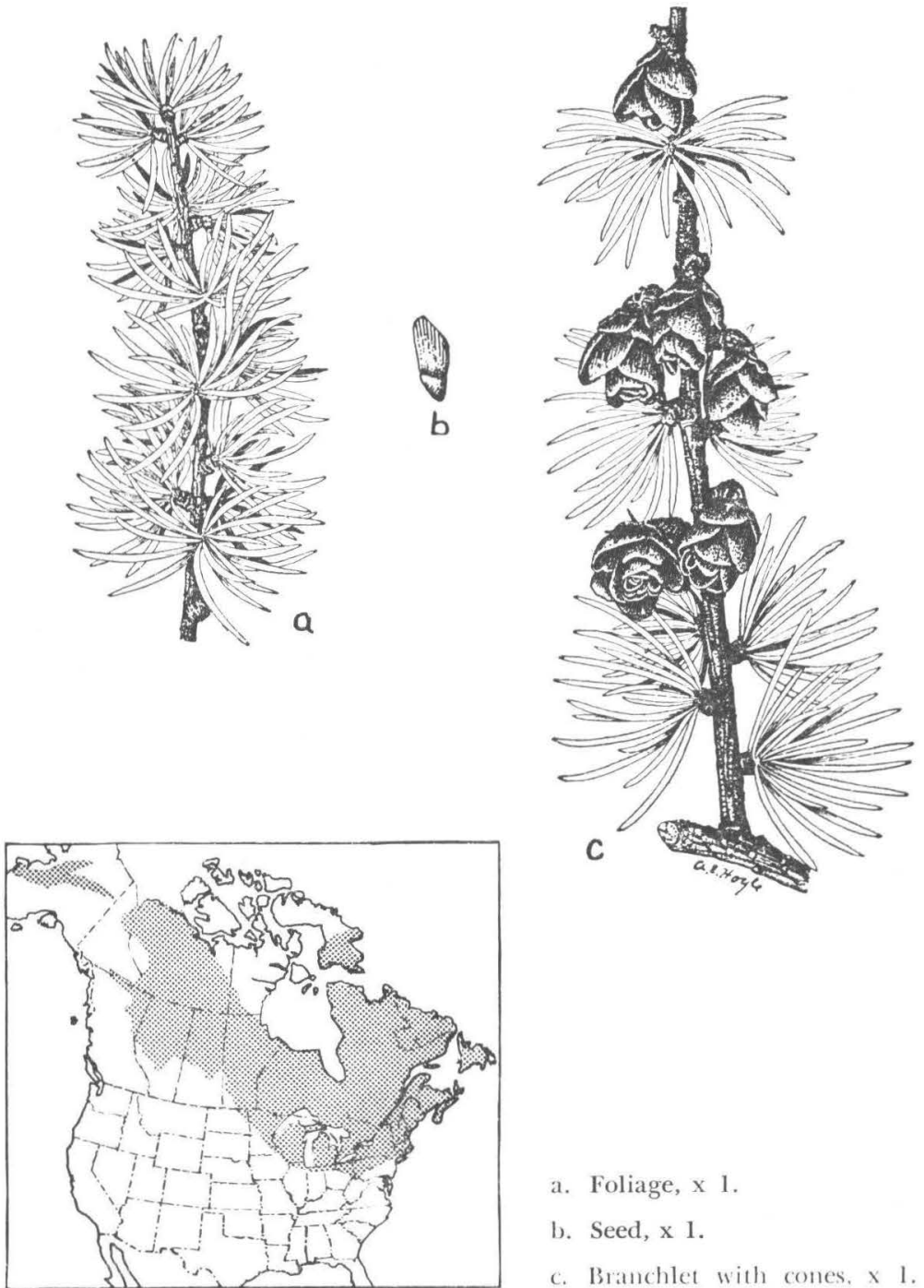

a. Foliage, $\mathrm{x} 1$.

b. Seed, $\mathrm{x} 1$.

c. Branchlet with cones, $x 1$. 


\section{PINACEAE}

\section{TAMarack. EAstern Larch \\ Larix laricina (Du Roi) K. Koch.}

HABIT. A tree seldom over 50 feet high and 12-14 inches in diameter in the northern Rocky Mountain region; long, clear, cylindrical bole; and an open, pyramidal, irregular crown with slender horizontal branches.

LEAVES. Linear; triangular in cross section; $3 / 4-11 / 4$ inches long; bright blue-green; falling in September or October; in clusters of 12-20.

FLOWERS. Male subglobose and sessile; female oblong and short-stalked.

FRUIT. $1 / 2^{-3 / 4}$ inch long; short-stalked, oblong to subglobose, chestnut-brown, and falling during second year; cone scales less than 20 , slightly longer than broad, erose at margin, glabrous and lustrous and twice as long as their bracts. Seed: $1 / 8$ inch long with light chestnut-brown wings about $1 / 4$ inch long.

TWIGS. Slender, smooth, glaucous at first, becoming orange-brown during first year. Winter buds: conspicuous, globose, small, lustrous, and dark red.

BARK. Thin and smooth on young stems; $1 / 2^{-3 / 4}$ inch thick, red-brown and scaly on mature trunks.

WOOD. Heartwood yellow-brown, medium texture, strong, hard, heavy, and durable; not widely used, chief uses being poles, railroad ties, and rough lumber.

SILVICAL CHARACTERS. Intolerant; growth moderate, maturity being reached in 100-200 years; reproduction vigorous on favorable sites; shallow root system; larch sawfly and fire cause serious damage.

HABITAT. Hudsonian and Canadian zones; altitudinal range from 600-1,700 feet; restricted to sphagnum bogs or swamps in southern part of range and making best growth on moist beaches and well-drained uplands further north; chiefly with black spruce, also balsam fir, aspen, birch, and jack pine; extending northward to limits of tree growth.

Alaska larch, Larix alaskensis Wight., restricted to coastal Alaska, is closely related to Larix laricina, and by many authorities is not considered distinct. 


\section{WeSTERN LARGil}

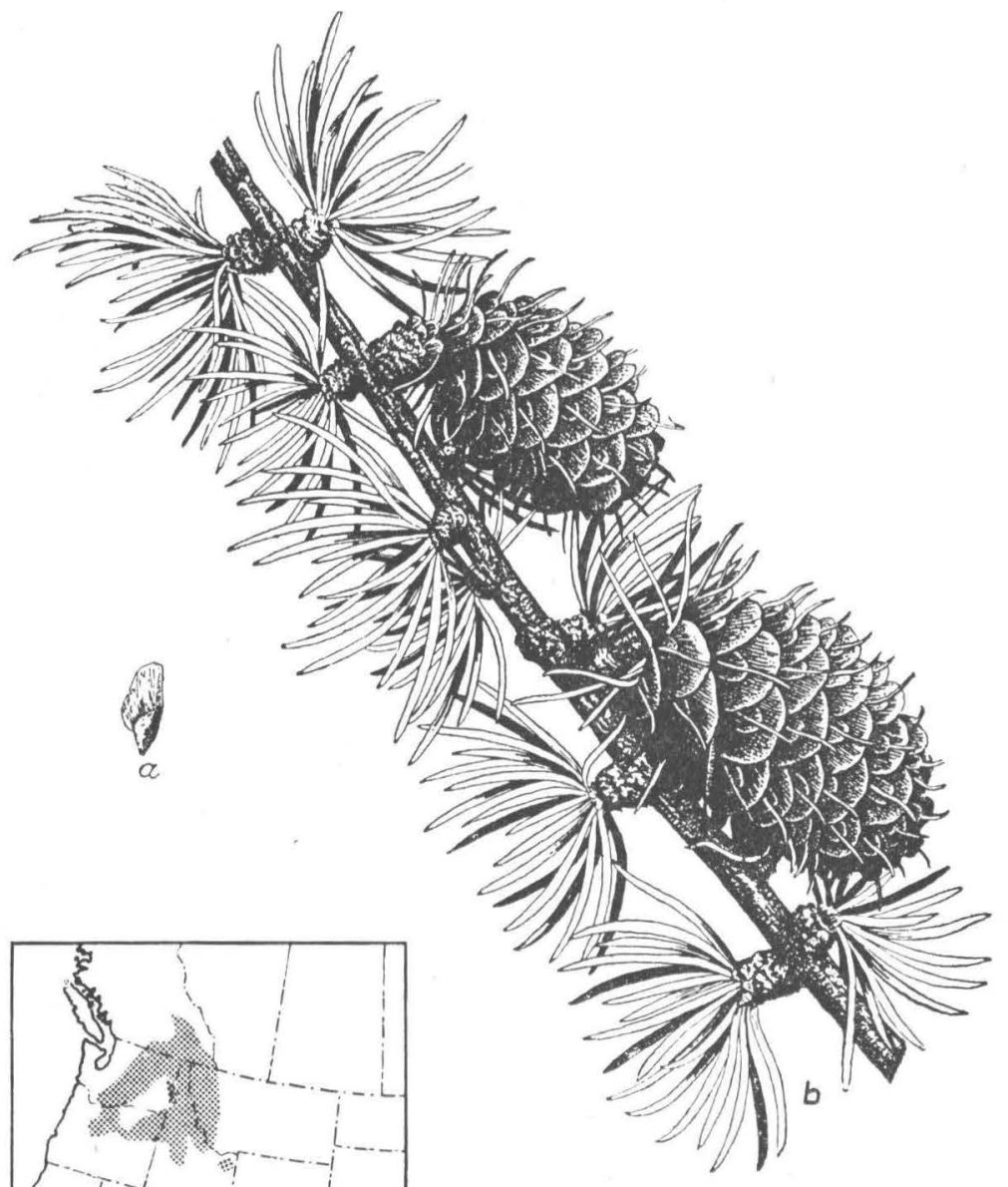

a. Seed, $x 1$.

b. Branchlet with cones, $\mathrm{x} 1$. 


\section{PINACEAE \\ WESTERN LARGH \\ Larix occidentalis Nutt.}

HABIT. A tree 140-180 feet in height and 3-4 feet in diameter; long, clear, cylindrical bole, frequently with a swollen butt; short, open, irregular, pyramidal crown of small, few, horizontal branches.

LEAVES. Linear, flatly triangular in cross section, 1-13/4 inches long, light pale green becoming ycllow, and falling in carly autumn, in clusters of 14-30.

FIOWERS. Male short, oblong; female oblong, subsessile.

FRUIT. I-1 1/2 inches long, short-stalked, oblong, purple-red to red-brown, falling during first ycar; cone scales broader than long, sometimes toothed at reflexed apex, usually white woolly on the outside, and shorter than exserted long-tipped bracts. Secd: $1 / 4$ inch long, with thin, fragile wings $1 / 2$ inch long.

TWIGS. Stout, brittle, at first with a pale pubescence, soon becoming glabrous and orange-brown. Winter buds: 1/8 inch in diameter, subglobose, chestnut-brown.

BARK. Thin and scaly on young stems; up to 4-6 inches thick, plated, and deeply furrowed on old trunks; red-brown to cinnamon-red.

WOOD. Heartwood red-brown, coarse-textured, heavy, hard. strong, and durable; similar to Douglas-fir for which it is sometimes sold; lumber, poles, ties, etc.

SILVICAL CHARACTERS. Intolerant; growth rather slow, maturity being reached in 300-400 years (trees over 700 years reported); reproduction vigorous, competing with lodgepole pine on burned areas; windfirm with decp, widespreading root system; fungi and mistletoe often cause damage.

HABITAT. Transition zone; altitudinal range 2,000-7,000 feet; best development on deep, moist, porous soils of mountain slopes and valleys, but does well on dry, gravelly slopes; in nearly pure stands or with Douglas-fir, western white, ponderosa and lodgepole pines, western hemlock, Engelmann spruce, and alpine and grand fir. 
Alpine Larch

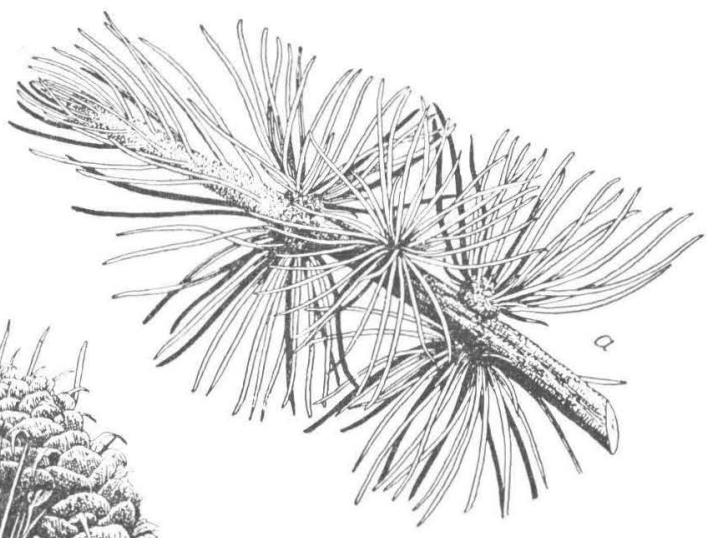

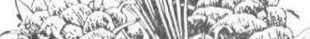
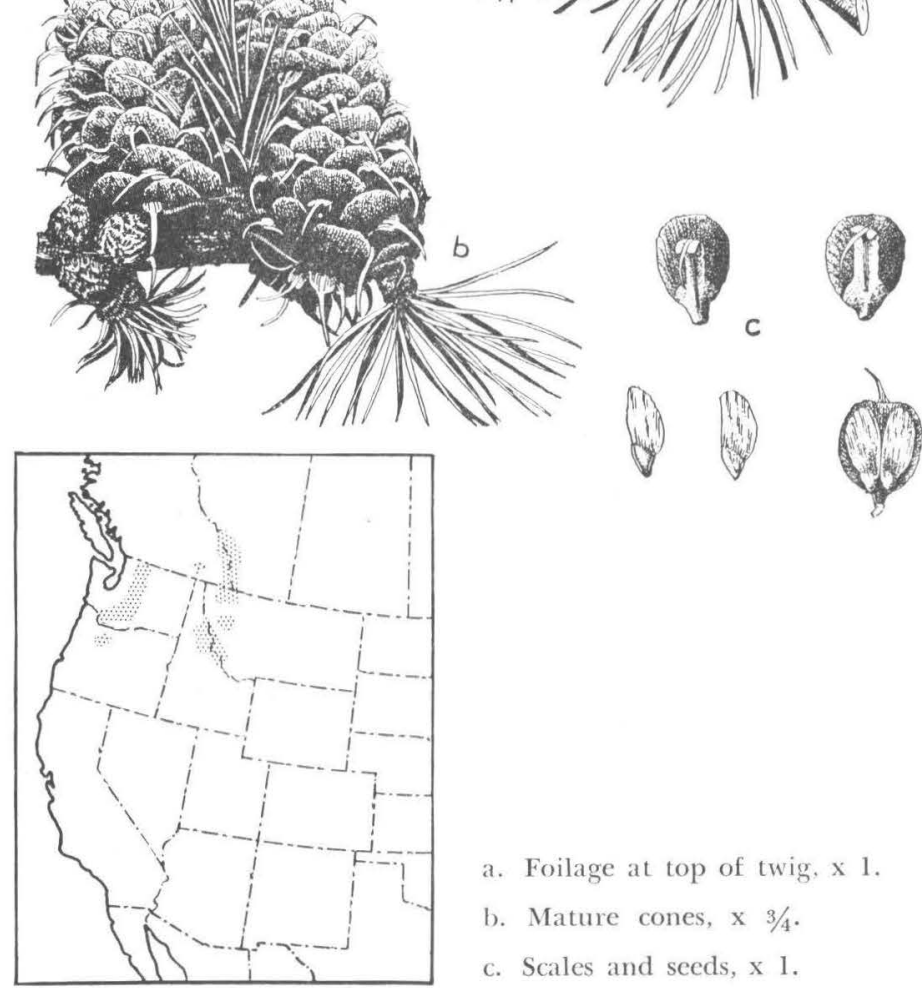

(ii)

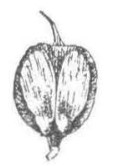

a. Foilage at top of twig, $\times 1$.

b. Mature cones, $\times 3 / 4$.

c. Scales and sceds, $\mathrm{x} 1$.

[34] 


\section{PINACEAE}

\section{Alpine Larch}

\section{Larix lyallii Parl.}

HABIT. A small, timber-line tree 25-50 feet in height and 1-2 feet in diameter (max. 80 by 3 feet); bole short and tapering, often bent; crown very irregular, open, pyramidal, with long, willowy, often drooping branches.

LEAVES. Linear, 4-angled, 1-11/2 inches long, pale bluegreen, becoming bright yellow and falling in autumn, in clusters of $30-40$ or more.

FLOWERS. Male short, oblong; female ovoid to oblong.

FRUIT. 1 1/2-2 inches long, subsessile or slender-stalked, ovoid, acute, red-purple, falling during first year; cone scales broader than long, and erose-fringed at margin, covered with matted hair on lower surface, and shorter than exserted, purple, bristle-pointed bracts. Seed: $1 / 8$ inch long, with lustrous light red wings $1 / 4$ inch long.

TWIGS. Stout, tough, densely woolly, ultimately nearly black. Winter buds: $1 / 8$ inch long, prominent, with scales fringed with long, white, matted hairs.

BARK. Thin, ash-gray, and unbroken on young trees; becoming $1 / 2-7 / 8$ inch thick, purple-brown or red-brown, and shallowly furrowed with flat, loose-scaly ridges.

WOOD. Similar to western larch but little used because of poor form, small size, and inaccessibility.

SILVICAL CHARACTERS. Intolerant; growth slow, attaining maturity at 400-500 years of age and reaching ages of 650-700 years; reproduction generally scanty; windfirm with widespreading root system.

HABITAT. Hudsonian zone, altitudinal range from 4,0008,000 feet; prefers northern aspects and sheltered vales in regions of heavy snows that fall early and remain late; will grow on poor rocky soil where moisture is abundant; in small, pure groves or with alpine fir, Engelmann spruce, mountain hemlock, and whitebark pine; appears hardier than these associates, ascending higher and showing greater vigor. 


\section{PINACEAE}

\section{The Spruces \\ Characteristics of the Genus Picea Diet.}

HABIT. Evergreen trees with sharp-pointed, pyramidal crowns, and straight, tapering trunks; branches in regular whorls.

LEAVES. Spirally arranged, linear, sessile, stiff, and single; extending from all sides of twigs; persistent 7-10 years, but deciduous when dried; mostly 4-angled; when falling, leaving basal peglike projections (sterigmata) on the twig.

FLOWERS. Monoecious, catkin-like, solitary; male, or pollen-bearing, axillary, yellow to red or purple, $3 / 4^{-1}$ inch long, consisting of numerous spirally arranged scales, each bearing two pollen sacs; female, or cone- and seed-producing, terminal, erect, yellow-green or red, $3 / 4-11 / 4$ inches long, consisting of numerous 2-ovuled, bracted scales.

FRUIT. Woody, pendent cone; matures in one season; borne mostly near top of crown; scales numerous, thin, unarmed, persistent, much longer than bracts. Seed: 2 under each fertile scale, small, compressed; highly buoyant with thin wing.

TWIGS. Roughened by sterigmata. Winter buds: ovoid or conical, of overlapping scales, and usually not resinous.

BARK. Thin and scaly (furrowed on old trunks in one species).

WOOD. Light, soft, resilient, fine-textured, long-fibered and straight-grained; small, scattered resin ducts; not resinous; high satiny luster; strong for weight; highly important for paper pulp, Iumber, boxes, etc.

SILVICAI. CHARACTERS. Tolerant; no taproot and generally shallow-rooted. Natural enemies: fire, leaf aphis (Adelges abietis) which causes conelike gall, spruce budworm (Harmologa fumiferana), which often destroys young stands, and white pine weevil (Pissodes strobi).

HABITAT. Cool, moist sites; typically in swampy areas or along the margins of streams and lakes.

GENERAL. This genus contains about 40 species, largely restricted to cooler regions in the Northern Hemisphere. In North America there are 7 indigenous species. The Norway spruce, Picea abies (L.) Karst., characterized by cones 4-7 inches long, is commonly planted throughout the United States. 


\section{KEY TO THE SPECIES OF PICEA}

I. Cone scales rounded at apex, margin smooth or erose, 2 resin ducts in cross section of leaf; northern.

A. Cones ovoid, purple, $1 / 2-11 / 2$ " long, on strongly incurved stalks, persistent many years; cone scales stiff and rigid, smooth or erose at margin; branchlets rusty pubescent; needles blunt at apex............. Picea mariana, p. 39.

B. Cones oblong-cylindric, brown, 1-21/2" long, nearly sessile, falling during first year; cone scales soft and flexible, smooth at margin; branchlets glabrous; needles pointed........... .............................2. Picea glauca, p. 41.

II. Cone scales truncate or acute at apex, margin erose, cones oblong-cylindric, brown; 1 or no resin ducts in cross section of leaf.

A. Cones 1-21/2" long, persistent 1 year; branchlets minutely pubescent; needles flexible, acute, but not very prickly to touch, no resin duct in cross section; buds $1 / 8-1 / 4$ " long with scales usually appressed; bark on mature trees thin and scaly; through Rocky Mountain region................ ....................... Picea engelmannii, p. 43.

B. Cones $21 / 4-41 / 2$ " (mostly about $31 / 2^{\prime \prime}$ ) long, persistent 2 years; branchlets glabrous; needles stiff, bristle-pointed and sharp to touch; 1 resin duct in cross section; buds $1 / 4-1 / 2$ " long with scales usually reflexed; bark on mature trees thick and deeply furrowed; central Rockies only $\ldots \ldots \ldots \ldots \ldots \ldots \ldots$ ............................ Picea pungens, p. 45. 


\section{Black Spruce}
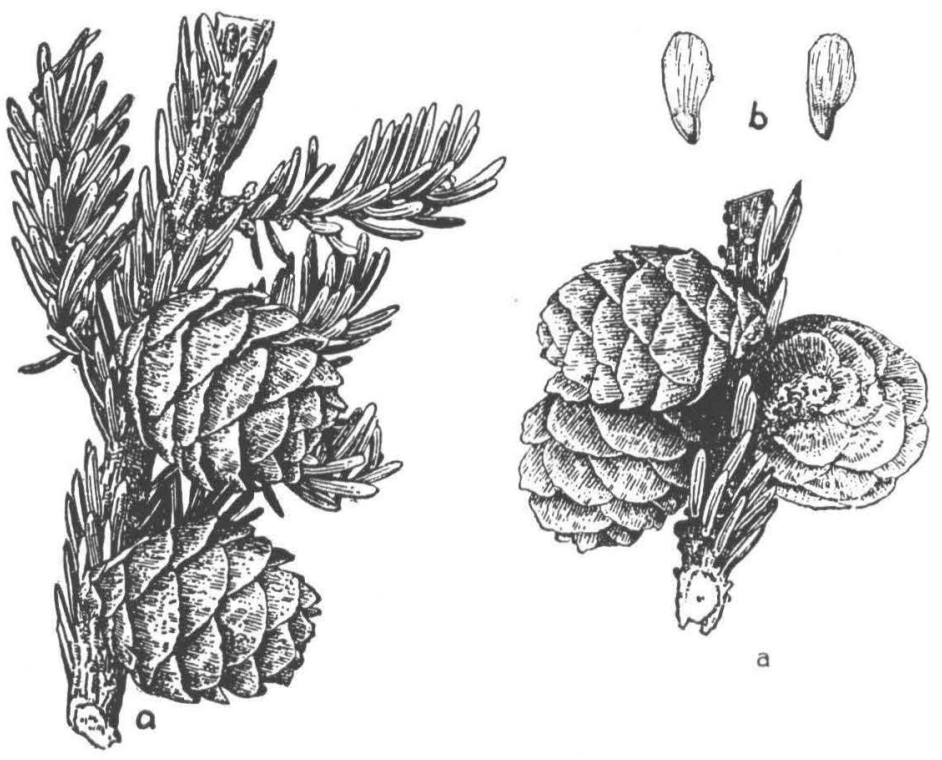

a

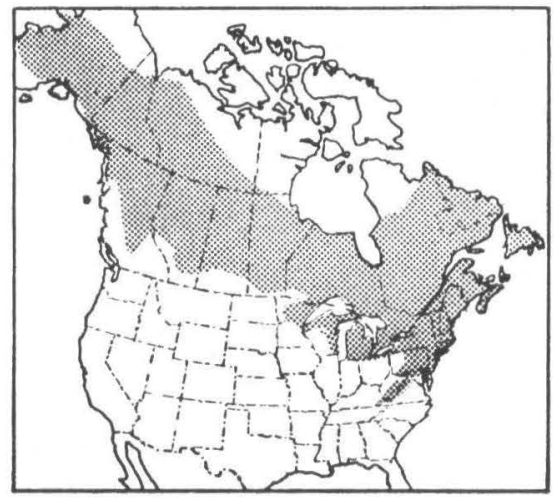

a. Branchlet with cones, $x$ l

b. Seed, $x 1$. 


\section{PINACEAE}

\section{Black Spruce}

\section{Picea mariana (M) B.S.P.}

HABIT. A tree sometimes $40-80$ feet high and $2 / 3-3$ feet in diameter, but commonly much smaller; short slender bole usually pruning poorly; crown open, conical, more or less irregular.

LEAVES. Spreading in all directions; $1 / 4-3 / 4$ inch long; pale blue-green and glaucous; blunt at apex; more or less incurved; hoary on upper surface from broad bands of stomata; lustrous and slightly stomatiferous below; 2 resin ducts in cross section.

FLOWERS. About $1 / 2$ inch long; male red; female purple.

FRUIT. 1/2-1 1/2 inches long; ovoid; on strongly incurved. short stalks; cone scales stiff, brittle, rigid, rounded, smooth or erose at apex, puberulous, and dull gray-brown; persistent many years. Seed: $1 / 8$ inch long, dark brown, with pale brown oblique wing $1 / 4-3 / 8$ inch long.

TWIGS. Rusty-pubescent and rather slender; at first green, becoming dull red-brown. Winter buds: $1 / 8$ inch long, ovoid, acute, light red-brown, puberulous.

BARK. Thin, $1 / 4-1 / 2$ inch thick; gray-brown; separated into thin, closely appressed scales or flakes; inner bark often olivegreen.

WOOD. Not important except for pulp; used interchangeably with white spruce.

SILVICAL CHARACTERS. Very tolerant, recovering from suppression at an advanced age; growth slow; tree rather short-lived, attaining an age of 200 years; shallow, spreading root system; reproduction good on moist sites; lower branches often take root, forming clusters of small trees.

HABITAT. Hudsonian and Canadian zones; typical of cold sphagnum bogs and swamps, but also found on dry slopes in Northwest; altitudinal range from 100-3,500 feet; with white spruce and tamarack, reaches northern limit of tree growth; in dense, pure stands, or in mixture with tamarack, balsam fir, white spruce, white birch, aspen, etc. 


\section{White Spruce}

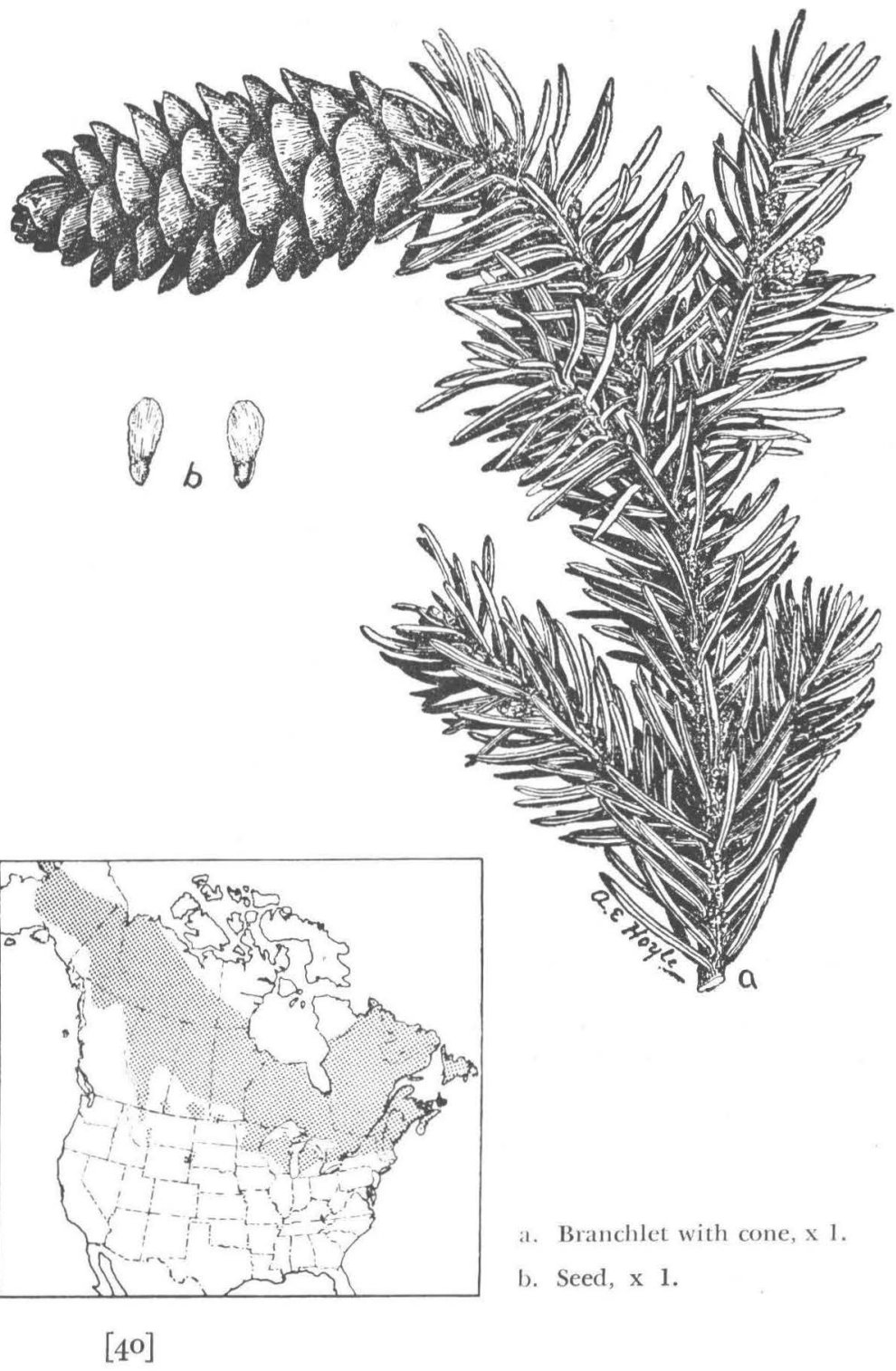




\section{PINACEAE}

\section{White Spruce}

Picea glauca (Moench) Voss. (Picea canadensis B.S. \& P.)

HABIT. A tree $60-70$ feet high and $11 / 2-2$ feet in diameter (max. 120 by 4 feet); slender symmetrical bole; crown narrowly to broadly pyramidal with long, thick branches.

LEAVES. Tending to be crowded on upper side of branch by twisting of those on lowcr side; $1 / 3-3 / 4$ inch long; blue-green, occasionally with whitish tinge; rigid acute tips; odor pungent when crushed; 2 resin ducts in cross section.

FLOWERS. Male pale red to yellow; female with red or yellow-green scales.

FRUIT. 1-21/2 inches long; oblong-cylindrical; nearly sessile; cone scales flexible, rounded and smooth at apex; light green or reddish before shedding seed, and becoming light brown and falling soon after. Seed: $1 / 8$ inch long, pale brown, oblique wing $1 / 4-3 / 8$ inch long.

TWIGS. Glabrous, or in far Northwest downy; rather slender; orange-brown; skunklike odor when bruised. Winter buds: $1 / 8^{-1 / 4}$ inch long; ovoid, obtuse, and chestnut-brown.

BARK. Thin, $1 / 4-1 / 2$ inch thick; ash-brown to silvery, separated into irregular thin plates or scales.

WOOD. Important in Northeast; used for pulp, construction lumber, boxes and crates, sounding boards, etc.

SILVICAL CHARACTERS. Tolerant of considerable shade, recovers from suppression well; growth slow, but faster than black spruce; tree attains age of 250-300 years; reproduction abundant on moist sites; shallow, spreading root system.

HABITAT. Hudsonian and Canadian zones; typical of low, damp woods, and banks of streams and lakes; altitudinal range from sea level to 5,000 feet; frequently gives way to black spruce or tamarack on wet sites, and to lodgepole pine on dry sites; often forms pure, dense forests, but also in mix. ture with black spruce, fir, birch, poplars, and willows.

GENERAL. The Western White Spruce, Picea glauca var. albertiana (S. Brown) Rehd., is the form found in the Rocky Mountain region. It is characterized by somewhat shorter and broader cones and a narrow crown. 


\section{ENGELMANN SPRUCE}

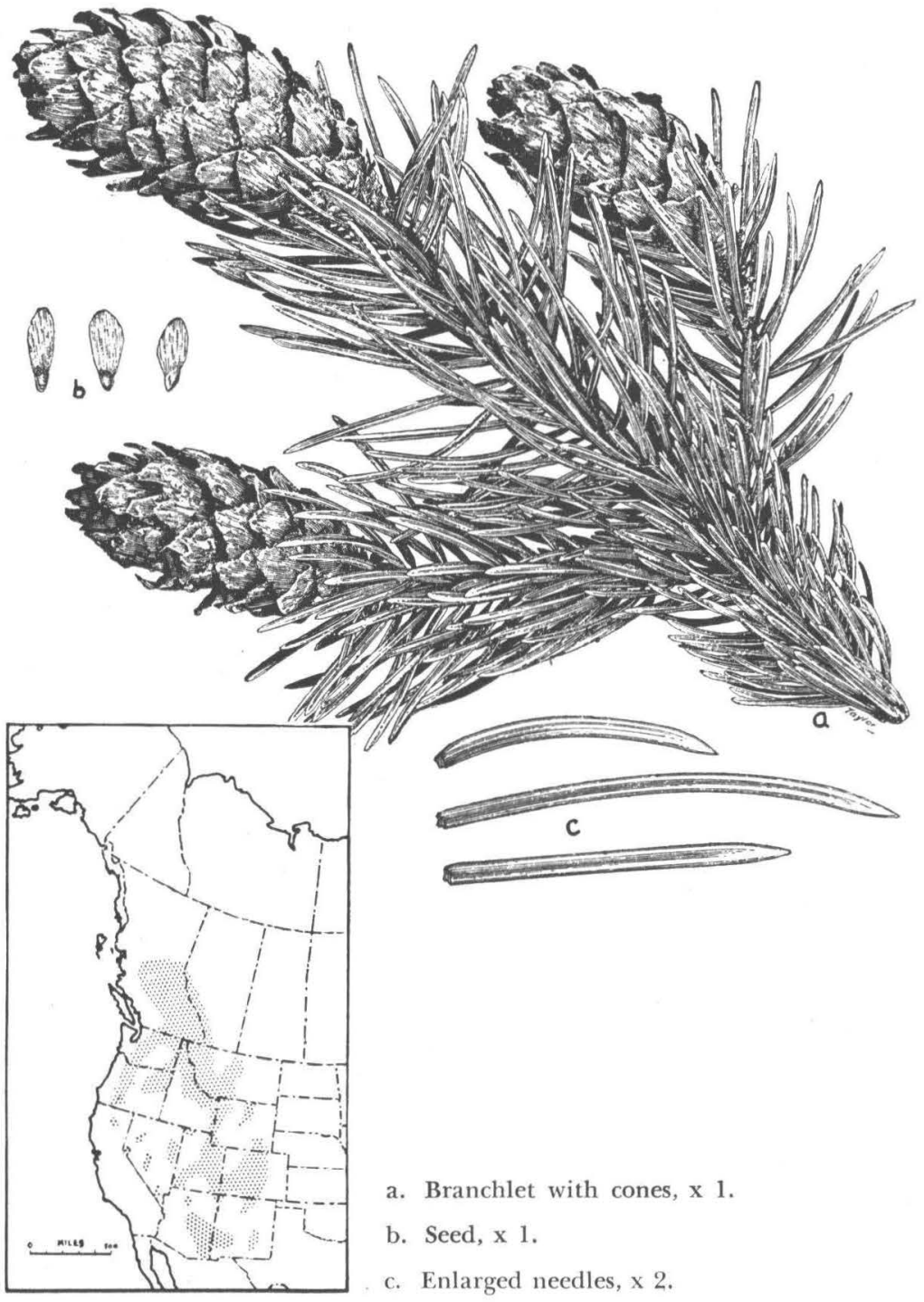




\section{PINACEAE}

\section{Engelmann Spruce}

\section{Picea engelmanni (Parry) Engelm.}

HABIT. A tree 60-120 feet high and 11/2-3 feet in diameter (max. 165 by 5 feet); bole long and clear, cylindrical; crown compact, somewhat scraggly, narrowly pyramidal, with short, whorled branches. A prostrate shrub at high elevations.

LEAVES. Tending to be crowded on the upper side of the branch by the curving of those on the lower side; $1-11 / 8$ inches long; blue-green, occasionally with whitish, glaucous bloom; blunt or acute tips (not very sharp to touch); flexible; no resin ducts in cross section.

FLOWERS. Male dark purple; female bright scarlet.

FRUIT. 1-21/2 inches long; oblong-cylindrical; sessil or short-stalked; cone scales flexible, variable in outline and erose-dentate at apex; light chestnut-brown; falling during autumn or winter of first season. Seed: $1 / 8$ inch long, nearly black; broad, oblique wing $1 / 2$ inch long.

TWIGS. Minutely pubescent (visible with hand lens); rather stout; orange-brown to gray-brown. Winter buds: $1 / 8^{-1 / 4}$ inch long; broadly ovoid to conic; pale chestnut-brown; but scales usually appressed.

BARK. Thin, $1 / 4^{-1 / 2}$ inch thick; cinnamon-red to purplebrown; broken into large, thin, loosely attached scales.

WOOD. Properties similar to white spruce; this is the longest-fibered and lightest weight spruce, but at present not widely used because inaccessible; lumber, telephone poles, railroad ties, mine timbers, and fuel.

SILVICAL CHARACTERS. Tolerant and recovering well from prolonged suppression; growth generally rather slow because of short summer season; a long-lived tree, reaching ages of $350-500$ or more years; reproduction abundant and vigorous: shallow, spreading root system.

HABITAT. Hudsonian and Canadian zones; varying from $1,500-5,000$ feet in the northern Rockies to 10,000-12,000 feet in the southern Rockies; rich, loamy soils with abundance of moisture; in pure stands or in mixture with alpine fir, lodgepole pine, and other conifers growing at high elevations. 
Colorado Blue Spruce

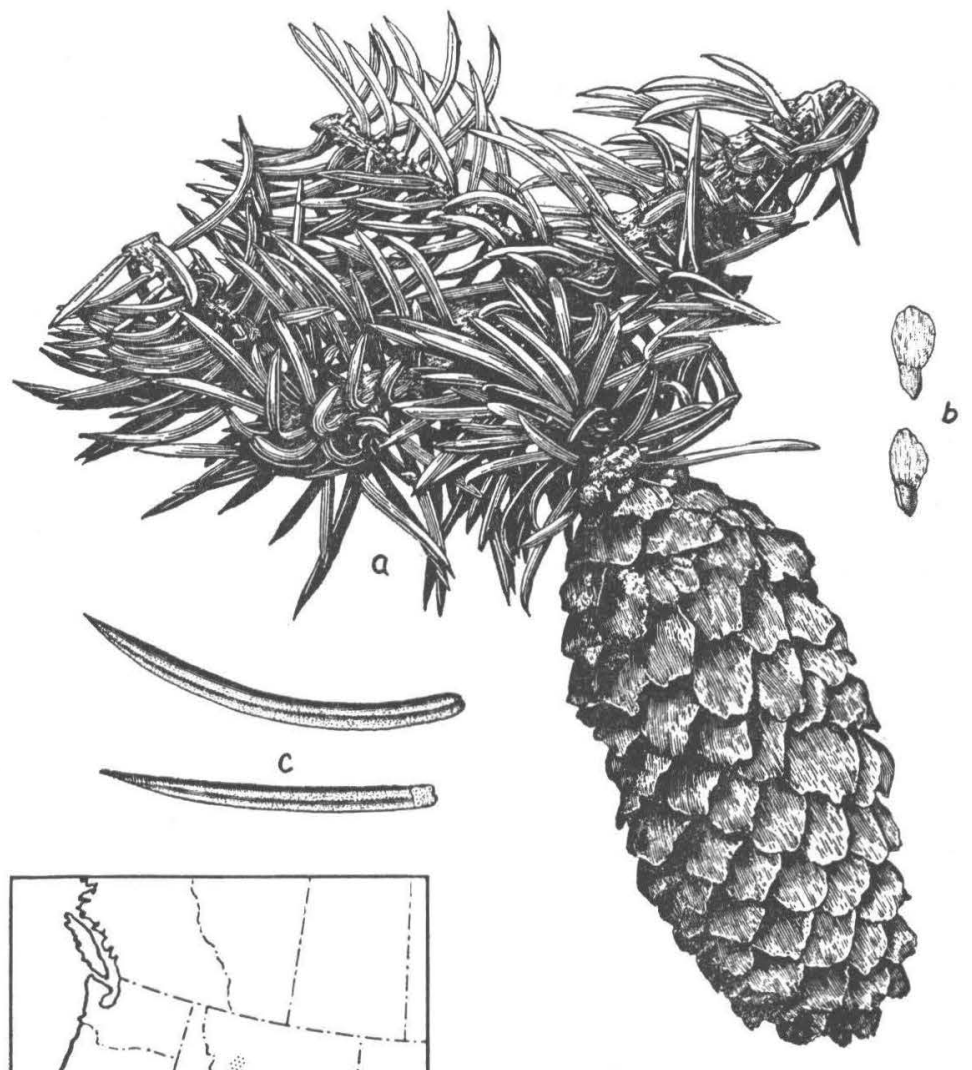

a. Branchlet with cone, $x 3 / 4$.

b. Seed, $x 1$.

c. Needles, x 11/2. 


\section{PINACEAE}

\section{Colorado Blue Spruce. Blue Spruce \\ Picea pungens Engelm. (Picea parryana Parry.)}

HABIT. A tree 80-100 feet high and 1-2 feet in diameter (max. 150 by 4 feet); bole symmetrical, tapering, knotty; crown typically dense and conical when young, becoming thin, ragged and pyramidal in age, and extending to the ground on open grown species. The State Tree of Colorado.

LEAVES. Extending at nearly right angles from all sides of twig; 1-1 1/4 inches long; blue-green, frequently with a silvery, glaucous bloom which persists for 3-4 years on young trees; rigid, tipped with long, bristle-sharp point; 1 resin duct in an angle of leaf in cross section.

FLOWERS. Male yellow, tinged with red; female pale green.

FRUIT. 21/4-41/2 (mostly 31/2) inches long, oblong-cylindrical; sessile or short-stalked; cone scales tough, stiff, spreading, with erose margins; shiny, light chestnut-brown; not falling until fall of second season. Seed: $1 / 8$ inch long, dark chestnutbrown; broad oblique wing about $1 / 2$ inch long.

TWIGS. Glabrous; stout and rigid; orange-brown to graybrown. Winter buds: $1 / 4-1 / 2$ inch long; broadly ovoid and obtuse; light chocolate-brown; bud scales usually reflexed.

BARK. Pale to dark gray; thin and scaly on young trunks, becoming $3 / 4-11 / 2$ inches thick and deeply furrowed with rounded ridges on old trunks.

WOOD. Rather similar to white spruce but brittle, knotty, and of little value. The chief use of this tree is for ornamental planting.

SILVICAL CHARACTERS. Moderately tolerant, but least so of spruces; slow-growing; long-lived; reproduction generally scanty because of dense ground cover; widespread, moderately deep root system and decidedly windfirm.

HABITAT. Transition and Canadian zones, but mostly below the Engelmann spruce belt; varying from 6,000-9,000 feet in the north to $8,000-11,000$ feet in the south; rich, moist soils, typically on stream banks; never abundant; in scattered pure groves or singly in mixture with ponderosa pine, Douglas-fir, alpine fir, Engelmann spruce, and hardwoods. 


\section{PINACEAE}

\section{The Hemlocks}

\section{Characteristics of the Genus Tsuga Carr.}

HABIT. Tall, broadly pyramidal, evergreen trees; long, slightly tapering trunks; pyramidal or conical crown with scattered, slender, horizontal, and often pendulous branches; leading shoots characteristically drooping.

LEAVES. Spirally arranged, often appearing 2-ranked by a twist of the petioles; linear; single; abruptly petiolate; flattened or rounded; persistent 3-6 years and leaving conspicuous, woody, persistent bases (sterigmata) when they fall; deciduous in drying; usually grooved above, with 2 conspicuous bands of stomata below; 1 centrally located resin duct in cross section.

FLOWERS. Monoecious, single, on twigs of previous season; male, or pollen-bearing, axillary, globose, of numerous short stamens; female, or cone- and seed-bearing, terminal, erect, of numerous, circular scales of nearly the same length as their membranous bracts.

FRUIT. Woody, pendent cones; maturing in one season; scales thin, rounded, entire-margined, several times longer than bracts. Seed: 2 under each scale; small, light, and widely disseminated; long, terminal, obovate wing; dotted with small, resin vesicles.

TWIGS. Slender; round; roughened by persistent leaf bases. Winter buds: small, nonresinous, ovoid to globose.

BARK. Rough, hard, ridged, deeply furrowed; clear chocolate-red color when broken; containing tannin.

WOOD. Moderately soft; moderately strong; resin ducts normally absent; light to red-brown; considered inferior to pine and Douglas-fir.

SILVICAL CHARACTERS. Tolerant trees; requiring abundant moisture; seldom attaining ages of more than 500 years; shallow, widespreading root system.

GENERAL. This genus contains 10 or more species widely scattered through North America and Asia. In North America there are 4 native species, 2 western and 2 eastern. 


\section{KEY TO THE SPECIES OF TSUGA}

I. Leaves flat, obtuse, Iustrous and grooved above, stomatiferous below, mostly 2-ranked; cones ovoid; 3/4-1" long, light brown.. .1. Tsuga heterophylla, p. 49.

II. Leaves rounded, bluntly pointed, stomatiferous on both surfaces, extending from all sides of twig; cones oblong-cylindric, mostly 2" long, yellow-green to purple...2. Tsuga mertensiana, p. 51 . 
Western Hemlock

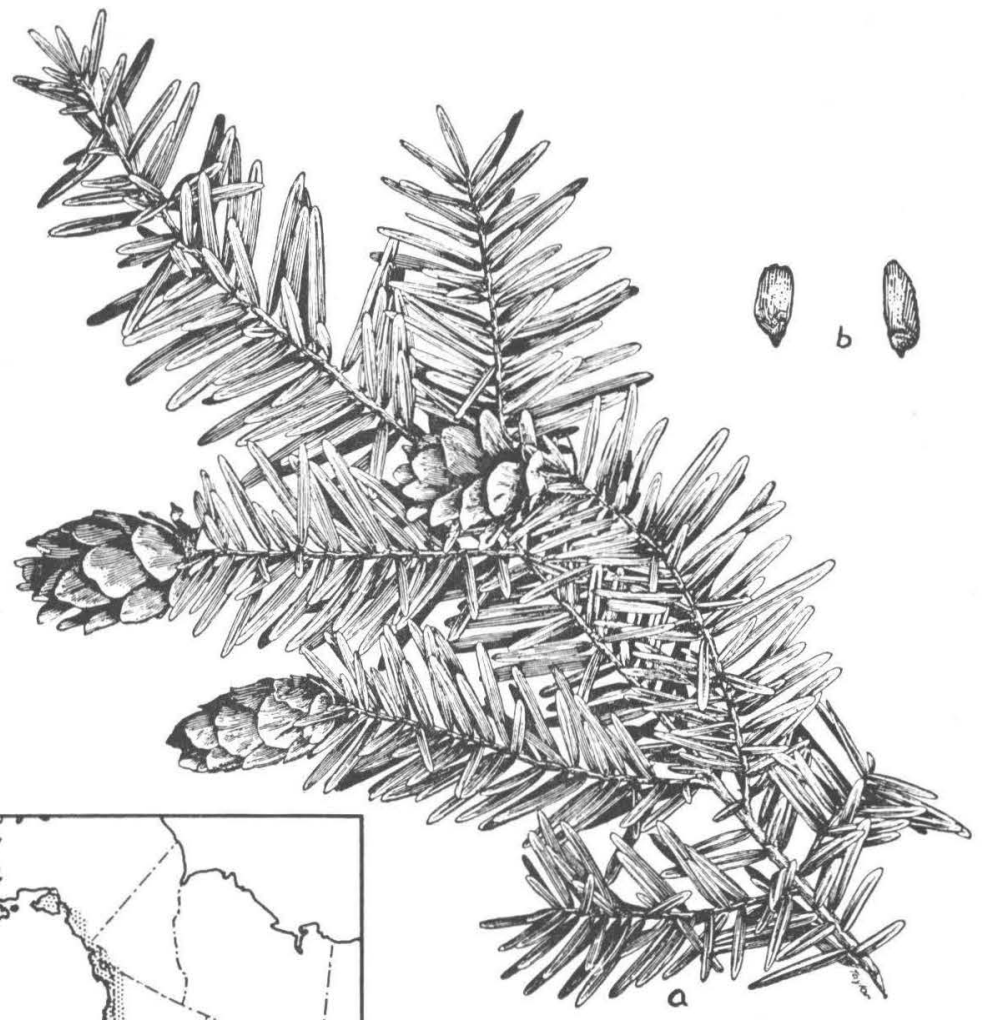

a. Branchlet with cones, $x 1$.

b. Seed, $\mathrm{x} 1$. 


\section{PINACEAE \\ Western Hemlock \\ Tsuga heterophylla (Rafn.) Sarg.}

HABIT. A tree 125-175 feet high and 2-4 feet in diameter (max. 259 by 9 feet); tall, clear trunk; short, open, pyramidal crown with typically drooping terminal leader.

LEAVES. Flattened; $1 / 4^{-3 / 4}$ inch long; dark, shiny green and grooved above, 2 broad bands of stomata below; abrupt, slender petiole; mostly 2-ranked; rounded or blunt at apex.

FLOWERS. Male yellow; female red or purple with rounded bracts shorter than scales.

FRUIT, 3/4-1 inch long, ovoid, light brown, scales suborbicular, wavy-margined. Seed: $1 / 16$ inch long; ovoid; $1 / 3$ as long as narrow, straw-colored wing.

TWIGS. Slender; pubescent for 5-6 years; pale yellowbrown becoming dark red-brown; drooping. Winter buds: ovoid, $1 / 16$ inch long, blunt, bright chestnut-brown.

BARK. Thin ( $1-1 / 2$ inches) even on largest trees; young bark scaly, russet-brown; on old trunks hard, dark russetbrown with furrows separating wide flat ridges; inner bark dark red streaked with purple; used for its tannin content.

WOOD. Superior in quality to eastern hemlock; one of 4 major timber-producing species of Pacific Northwest; uniform texture and not very harsh or splintery; suitable for all uses but heavy construction, and most important pulpwood species of region.

SILVICAL CHARACTERS. Tolerant throughout life; growth rapid, comparing favorably with Douglas-fir, seldom attaining age of over 500 years; reproduction very abundant and vigorous; shallow, widespreading root system; susceptible to fire injury, and butt rot common in old trees.

HABITAT. Transition and Canadian zones; altitudinal range from sea level to 7,000 feet; prefers deep, moist, porous soils, but hardy in drier situations; in pure, dense stands or mixed at lower levels with Douglas-fir, silver and grand firs, giant arborvitae, and hardwoods; and at higher levels with noble fir, Alaska cedar, mountain hemlock, western white and lodgepole pines. 


\section{Mountain Hemlock}

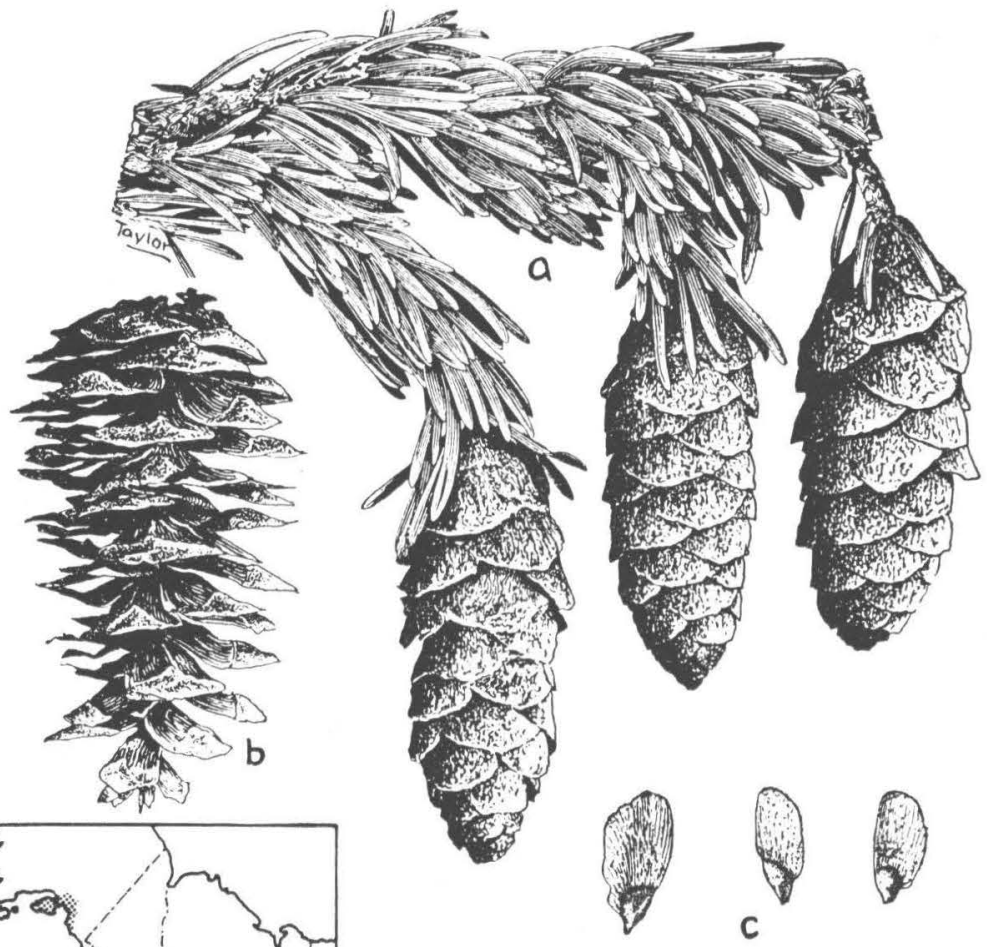

a. Branchlet with cones, $x 1$.

b. Opened cone, $\mathrm{x} 1$.

c. Seed, x 1 . 


\section{PINACEAE}

\section{Mountain Hemlock. Black Hemlock \\ Tsuga mertensiana (Bong.) Sarg.}

HABIT. An alpine tree 75-100 feet high and 21/2-31/2 feet in diameter; trunk tapering and long clear, or knotty and malformed; crown open, pyramidal, with slender, drooping branches and drooping terminal leader; a sprawling shrub at timber line.

LEAVES. Semicircular in cross section; $1 / 2-1$ inch long; pale bluish-green and stomatiferous on all surfaces; upper surface often keeled or grooved; abruptly narrowed into straight or twisted petiole; extending from all sides of twig or crowded toward upper side; bluntly pointed.

FLOWERS. Male purple on slender drooping stems; female purple or green, slender-tipped bracts longer than scales.

FRUIT. $1 / 2-31 / 2$ inches long, (mostly 2 inches); oblong. cylindric; yellow-green to purple; scales oblong-obovate and spreading at right angles or reflexed when mature. Seed: $1 / 8$ inch long; $1 / 4$ as long as wing.

TWIGS. Thin or stout; dense, short, pale, pubescence for 2-3 years; light red-brown, becoming gray-brown and scaly. Winter buds: conical, $1 / 8$ inch long, acute, red-brown, outer scales with awl-like tip.

BARK. Thin ( $1-11 / 2$ inches), early broken and rough on young trees; on old trunks hard, purplish to red-brown, with deep, narrow furrows separating narrow, rounded ridges; contains large quantities of tannin.

WOOD. Little used and inferior in quality to western hemlock; light, soft, not strong, and close-grained.

SILVICAL CHARACTERS. Tolerant; growth slow; trees over 500 years of age seldom found; reproduction generally abundant; shallow, widespreading root system.

HABITAT. Hudsonian and Canadian zones; altitudinal range from sea level (Alaska) to 11,000 feet, but mostly near timber line; at its best on cool, moist, deep soils of northern exposure, moisture being essential; in pure stands or in mixture with alpine fir, alpine larch, Engelmann spruce, whitebark, lodgepole, and western white pines. 
DOUgLAS-FIR

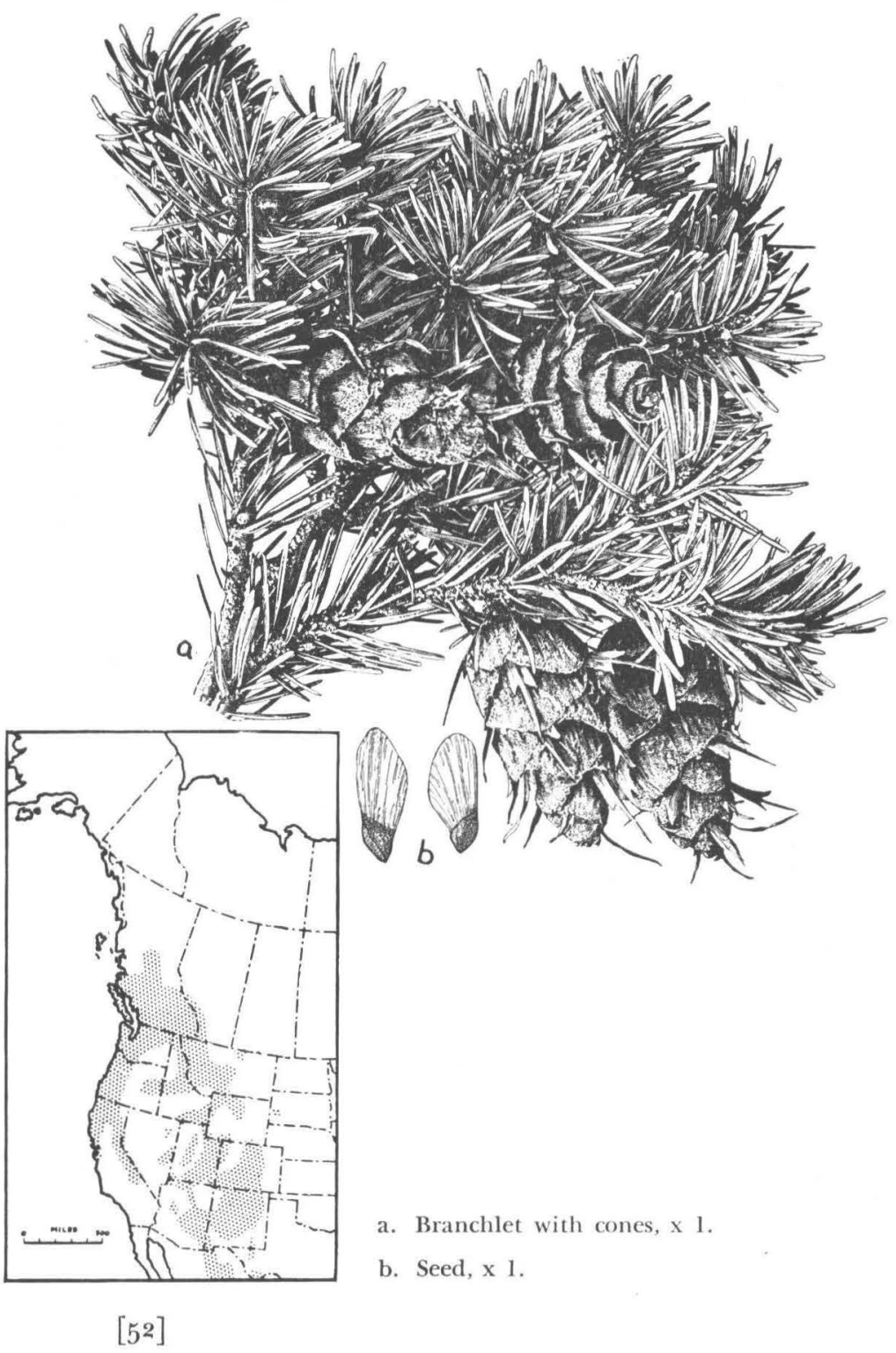




\section{PINACEAE}

\section{DOUGLAS-FIR}

Pseudotsuga taxifolia (Lamb.) Brit. [Pseudotsuga mucronata (Raf.) Sudw.] (Pseudotsuga glauca Mayr.)

HABIT. An evergreen tree rarely more than 130 feet high and 3 feet in diameter in the Rocky Mountains; narrow, compact, pyramidal crown, with irregularly disposed branches.

LEAVES. Linear, single, more or less flattened, spirally arranged, and petiolate; $\$ / 4-11 / 4$ inches long; grooved above and stomatiferous below; persistent 5-8 years or longer.

FLOWERS. Monoecious; male orange-red; female redgreen.

FRUIT. Pendent, woody cones; $2-41 / 2$ inches long, oblongovoid, maturing in one season; scales thin, rigid, rounded, much shorter than their long, exserted, 3-lobed bracts. Seed: $1 / 4$ inch long, with large, rounded, terminal wing.

TWIGS. Slender, pubescent, orange-brown, becoming graybrown. Winter buds: $1 / 4$ inch long, characteristically long conical, sharp-pointed, lustrous, brown.

BARK. Smooth gray-brown and with resin blisters on young trees; becoming thick (4-6 inches), rough, with red-brown ridges separated by deep furrows.

WOOD. Highly variable from yellowish, narrow-ringed, moderately light and soft, to red-brown, wide-ringed, with weak spring wood and very dense summer wood. Extremely valuable and widely used for lumber, ties, poles, etc.

SILVICAL CHARACTERS. Not very tolerant but more so than Rocky Mountain associates; reproduction abundant and vigorous; well-developed, widespreading, lateral root system.

HABITAT. Transition and Canadian zones; altitudinal limit in the Rocky Mountains from about 4,000 feet in the north to 11,000 feet in the south; adapted to variety of soils but best on moist, deep, porous soils of northern exposure; will endure considerable drought; in pure stands or mixed with Rocky Mountain conifers.

GENERAL. While not commonly accepted in this country, European taxonomists separate the Rocky Mountain form from the Pacific Coast Douglas-fir, designating the former Pseudotsuga glauca Mayr. 


\section{PINACEAE}

\section{The Firs}

\section{Characteristics of the Genus Abies Link}

HABIT. Tall, pyramidal, evergreen trees; dense, spirelike crowns; slender, horizontal, whorled branches; and straight, gradually tapering trunks.

LEAVES. Spirally arranged, linear, sessile, and single; usually flat and blunt; extending from all sides of twig but mostly appearing 2-ranked by a twist near their base; persistent for 7-10 years; usually grooved above and with stomatiferous lines below; 2 resin canals in cross section; when falling leaving a conspicuous, smooth, circular scar on twig.

FLOWERS. Monoecious, axillary, single; male, or pollenbearing, numerous on lower sides of lower crown branches, oval or cylindrical, with yellow to scarlet anthers; female, or coneand seed-bearing, on upper side of topmost branches, erect, globose to oblong, consisting of numerous, imbricated, 2-ovuled scales much shorter than their bracts.

FRUIT. Woody, erect cones; maturing in one season; scales thin, fan-shaped, and falling at maturity from the central, spikelike axis which persists many years. Seed: 2 under each scale; large, thin wing; peculiar, conspicuous resin-vesicles.

TWIGS. Smooth, glabrous, or pubescent. Winter buds: small, mostly subglobose or ovoid, with thin, loosely imbri. cated scales and usually thickly covered with resin.

BARK. Young bark thin, smooth, with numerous blisterlike resin pockets; old bark thicker and furrowed.

WOOD. Rocky Mountain species with light-colored, often coarse-grained, rather weak and brittle wood; no resin ducts; not durable; only little used for inferior lumber and pulp. Canada balsam obtained from resin blisters of one species.

SILVICAI, CHARACTERS. Tolerant, moisture-loving trees, of fast to slow growth, and moderately long-lived.

GENERAI. This genus contains about 35 species widely scattered through North and Central America, Europe, Asia. and northern Africa. In North America there are 10 indigenous species, 6 of these occurring in the Rocky Mountain region. 


\section{KEY TO THE SPECIES OF ABIES}

I. Cones large (6-9" long), egg-shaped; needles 4-sided; western Nevada.

A. Bracts inserted .............. Abies magnifica, p. 61 .

B. Bracts exserted and reflexed.

................ Abies magnifica var. shastensis, p. 61.

II. Cones smaller (2-5" long), oblong-cylindric; bracts shorter than scales; needles of lower branches flattened.

A. Cones dark purple; scales longer than broad; leaves of lower branches not over $13 / 4^{\prime \prime}$ long.

1. Leaves dark green above, stomatiferous only below, 2ranked on lower branches; bark of old trees with thin, easily detached scales; northern Canada to northeastern United States............ Abies balsamea, p. 57.

2. Leaves stomatiferous on both surfaces, crowded and nearly erect; mature bark not scaly.

a. Mature bark hard, tough, smooth and gray, becoming dark, with shallow fissures at base of trunk; cone scales wedge-shaped at base; entire region............ $\ldots \ldots \ldots \ldots \ldots \ldots \ldots \ldots$. Abies lasiocarpa, p. 59.

b. Mature bark soft and corky, yellow-white; cone scales mostly halberd-like at base, southern............ $\ldots \ldots \ldots \ldots \ldots \ldots \ldots \ldots$. Abies arizonica, p. 61.

B. Cones yellow to green-purple; scales broader than long; leaves of lower branches over 11/2" Iong.

1. Leaves on lower branches distinctly 2-ranked and scattered, 11/2-2" long, lustrous, dark green and deeply grooved above, 2 bands of stomata below; northern.... $\ldots \ldots \ldots \ldots \ldots \ldots \ldots \ldots \ldots$. Abies grandis, p. 65.

2. Leaves on lower branches obscurely 2-ranked or spreading from all sides of twig, crowded, 2-3" long, pale green and stomatiferous above and below; mostly central and southern............... Abies concolor, p. 63. 


\section{BALSAM FIR}

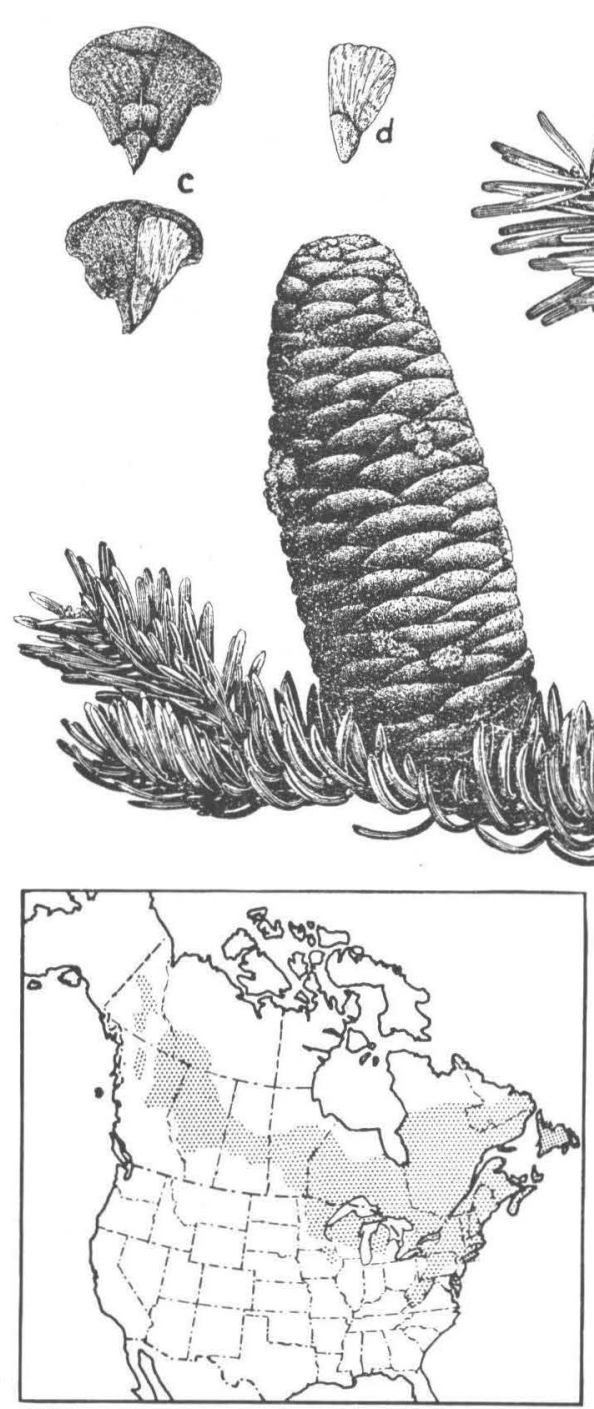

a. Lower crown branchlet.

b. Branchlet with cone, $\mathrm{x} 1$.

c. Upper and lower sides of cone scale, $\mathrm{x} 1$.

d. Seed, $\times 1$. 


\section{PINACEAE}

\section{Balsam Fir \\ Abies balsamea (L.) Mill.}

HABIT. A medium-sized tree 40-60 feet high and 1-11/2 feet in diameter (max. 85 by 2 feet); a dense, dark green, narrowly pyramidal crown with a slender spirelike tip.

LEAVES. On lower branches 2-ranked, 3/4-11/2 inches long, scattered, flattened, blunt, or notched; on upper branches shorter, spreading, and crowded; dark green above, silverybanded below.

FLOWERS. Male of yellow anthers; female of orbicular purple scales.

FRUIT. 2-4 inches long, oblong-cylindric, dark purple; scales longer than broad, and twice as long as short, pointed bracts. Seed: $1 / 4$ inch long, with broad purple-brown wings.

TWIGS. Slender; finely pubescent and yellow-green; becoming smooth and gray to purple. Winter buds: subglobosc, $1 / 8-1 / 4$ inch long, with orange-green scales.

BARK. Thin, ash-gray, smooth except for numerous resin blisters on young trees; becoming $1 / 2$ inch thick, red-brown, and broken into thin scales.

WOOD. Soft and brittle; used for pulp, boxes, etc.; resin in bark blisters is source of Canada balsam.

SILVICAL GHARACTERS. Tolerant (less so than spruce), recovering well from suppression; growth generally rapid; a short-lived tree reaching an age of 150 years, but generally defective before 90 years; reproduction plentiful and agressive; shallow root system; lower branches sometimes take root, producing new trees.

HABITAT. Canadian and Hudsonian zones; entering the Rocky Mountain region only in northern Canada, altitudinal range from sea level to 5,600 feet; demands abundant soil moisture and humid atmosphere; forms pure stands in swamps, but does best on adjacent flats in association with spruce; on higher sites in mixture with spruce, hemlock, and broadleafed species. 
Alpine Fir

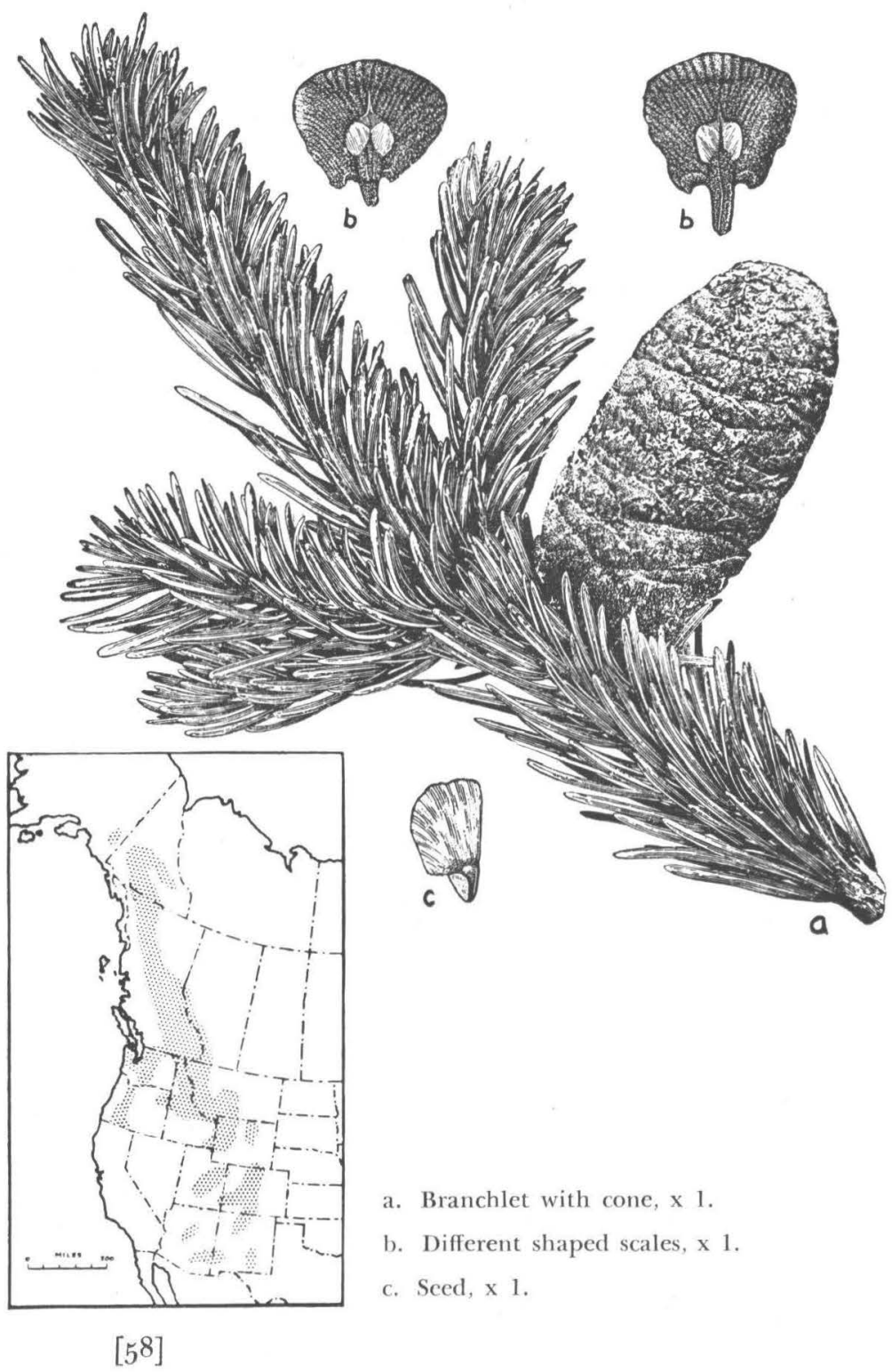




\section{PINACEAE}

\section{Alpine Fir}

\section{Abies lasiocarpa Nutt.}

HABIT. A tree 60-100 feet high and $11 / 2-2$ feet in diametcr (max. 160 by 3 feet); a dense, narrowly pyramidal, spirelike crown often extending to the ground, with short, thick branches; a prostrate shrub at timber line.

LEAVES. On lower branches, 1-1\%/4 inches long (mostly about 1 inch), flattened, blunt or notched; on upper branches $1 / 2$ inch long and pointed; deep blue-green; crowded and nearly erect by a twist at their base; stomatiferous on both surfaces (less conspicuous above) .

FLOWERS. Male dark indigo-blue; female dark violetpurple.

FRUIT. 2-4 inches long, oblong-cylindric, dark purple; scales mostly longer than broad and 3 times longer than longtipped bracts. Seed: $1 / 4$ inch long, with dark lustrous wings.

TWIGS. Stout, pubescent, and pale orange-brown; becoming smooth and gray or silver-white. Winter buds: subglobose, $1 / 8-1 / 4$ inch long, with light orange-brown scales.

BARK. Thin, gray, smooth except for numerous resin blisters on young trees; becoming $3 / 4-11 / 2$ inches thick, shallowly fissured and roughened by thickened, closely appressed, cinnamon-red scales.

WOOD. Similar to balsam fir but little used except for fuel.

SILVICAL CHARACTERS. Tolerant (of its associates, only Engelmann spruce and mountain hemlock are more so); growth not rapid, trees 15 inches in diameter often over 175 years old; reproduction abundant and vigorous; shallow root system; lower branches sometimes taking root.

HABITAT. Canadian and Hudsonian zones; growing from 3,500 feet to timber line in the north and from 10,500 feet to timber line in the south; in cool, moist sites, and best in deep, loose, moist soil; in restricted pure stands or commonly with Engelmann spruce, lodgepole, whitebark, limber, or bristlecone pines, alpine larch, cork fir, and aspen. 
Corkbark Fir
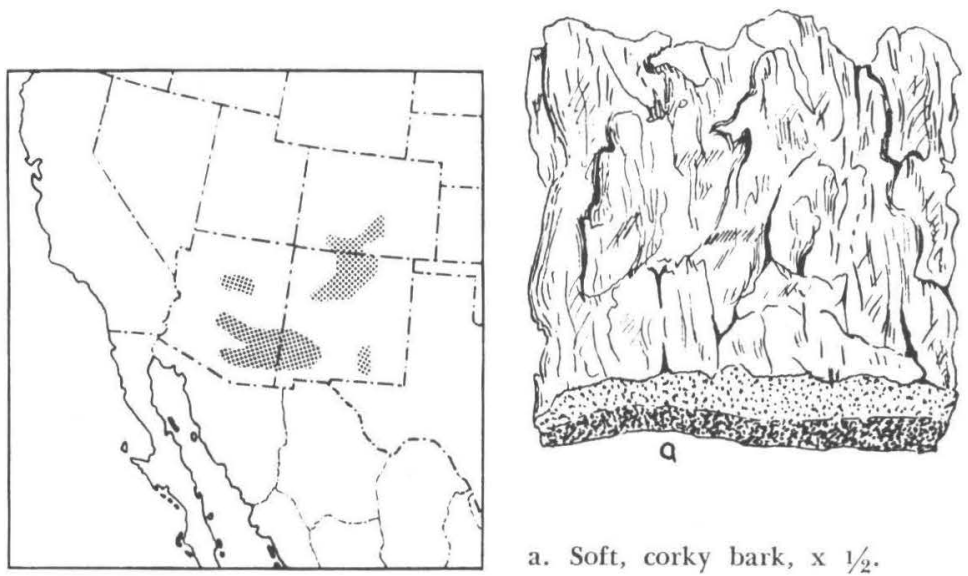

a. Soft, corky bark, $x$ 1/2.

RED FIR
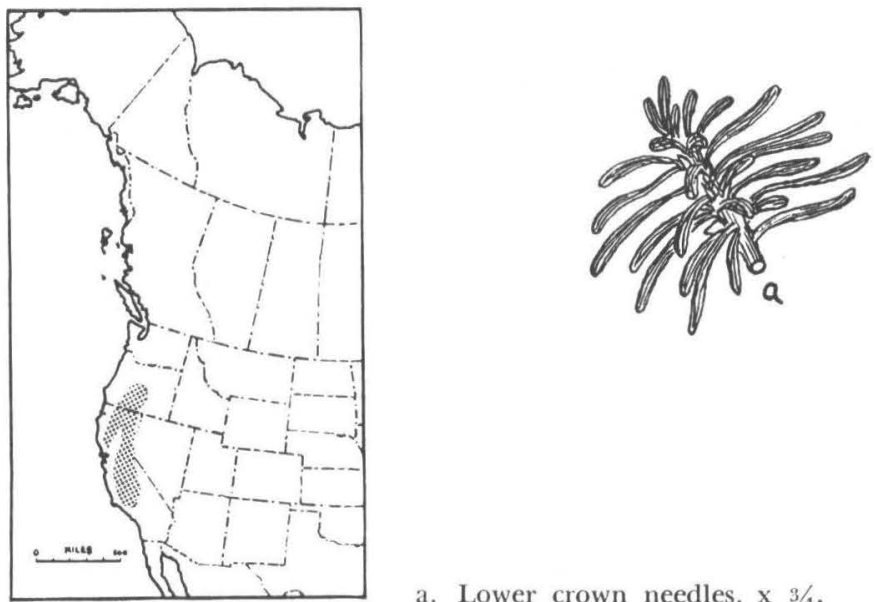

a. Lower crown needles, $x 3 / 4$.

[6o] 


\section{PINACEAE}

\section{Corkbark Fir. Cork Fir}

Abies lasiocarpa var. arizonica (Merr.) Lemm. (Abies arizonica Merr.)

This tree is more correctly considered a variety of the alpine fir, and differs from it in the following characters:

HABIT. A small tree of the southern Rocky Mountains from $50-75$ feet in height and $1-11 / 2$ feet in diameter.

FRUIT. Cones generally longer and narrower than alpine fir; cone scales often halberd-like at base while those of alpine fir are mostly wedge-shaped. As there are intergrading forms, these differences are not consistent and cannot always be relied upon.

BARK. The soft, corky, yellow-white to ash-gray trunk bark readily separates this species from all other firs, although intergrading forms are found between this bark and the typical bark of alpine fir.

HABITAT. Canadian and Hudsonian zones; altitudinal range between 8,000-10,000 feet; often growing with or displacing alpine fir; typically on thin, gravelly, or rocky soils. An unimportant tree commercially.

\section{RED FIR}

\section{Abies magnifica A. Murr.}

This large fir enters the Rocky Mountain region only along the western edge of Nevada, being primarily a Pacific Coast species. It can be readily distinguished from other Rocky Mountain species by its large, egg-shaped cones (6-9 inches long), and crowded, 4-angled needles which are stomatiferous on all surfaces. The Shasta Red Fir, Abies magnifica var. shastensis Lemm., with a similar distribution, differs from the species in having exserted, reflexed bracts. 


\section{WHITE FIR}
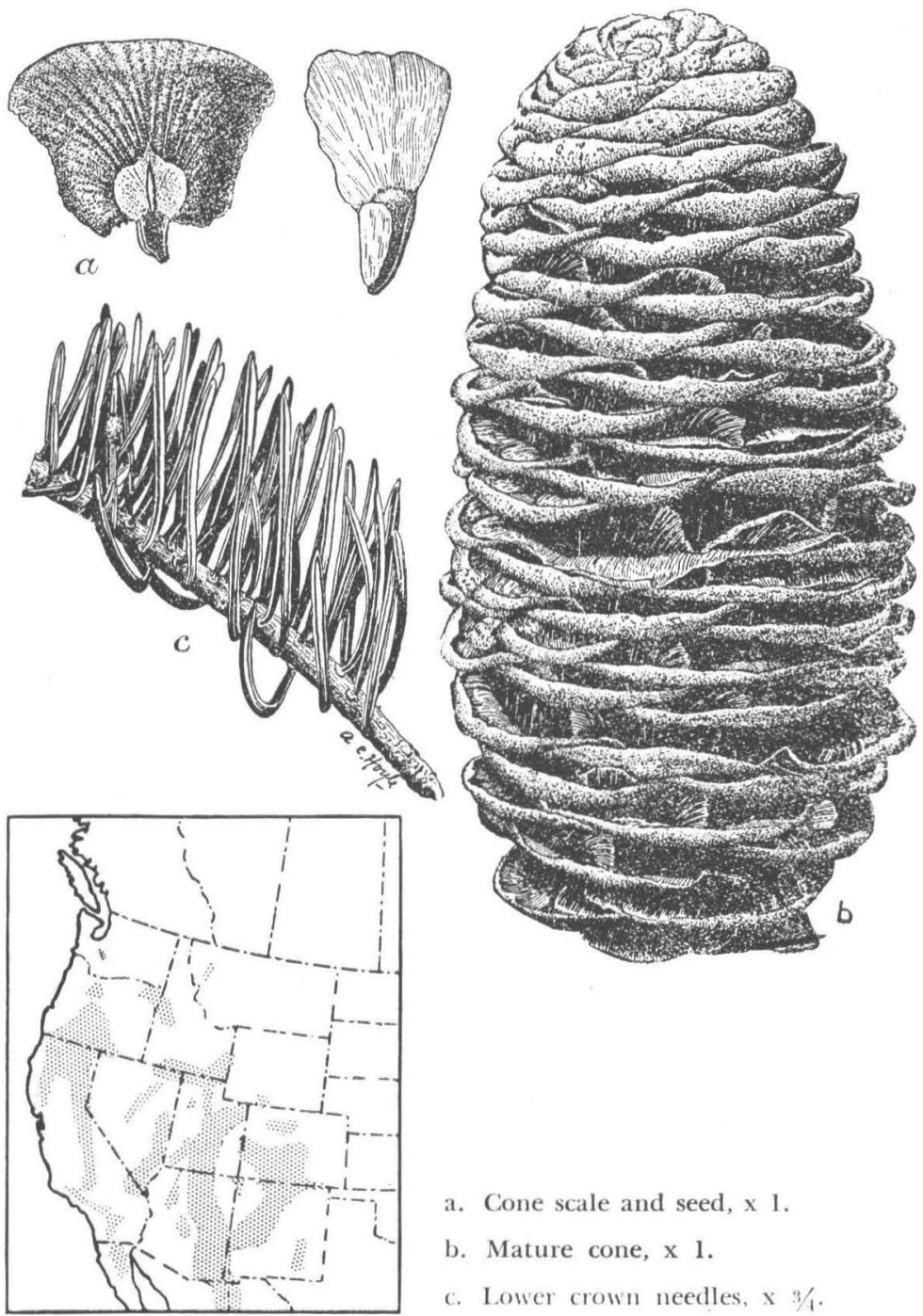

a. Cone scale and seed, $\mathrm{x} 1$.

b. Mature cone, $x 1$.

c. Lower crown needles, x $3 / 4$.

$\lceil 62\rceil$ 


\section{PINACEAE \\ WHITE FIR \\ Abies concolor Lindl.}

HABIT. A tree in the Rocky Mountain region 80-100 feet high and $11 / 2-21 / 2$ feet in diameter; a dense conelike crown with heavily foliaged, long-persisting, short branches.

LEAVES. On lower branches $2-3$ inches long, flat, straight, and acute at apex; on fertile branches, or on old trees, $3 / 4-11 / 2$ inches long, thick, kecled above, usually curved, acute or rarely notched at apex; silver-blue to silver-green; crowded; more or less obscurely 2-ranked or extending from all sides of twig; stomatiferous above and below.

FLOWERS. Male rose to dark red; female with broad, round scales.

FRUIT. 3-5 inches long, oblong, bright yellow to olivegreen or purple; scales much broader than long, and twice as long as short-tipped bracts. Seed: $1 / 3-1 / 2$ inch long, yellowbrown with rose-tinted broad wing.

TWIGS. Moderately stout, smooth, yellow-green to browngreen and ultimately gray-brown. Winter buds: subglobose, $1 / 8^{-1 / 4}$ inch long, yellow-brown.

BARK. Thin, gray, smooth except for numerous resin blisters on young trees; becoming 4-7 inches thick, ash-gray, hard and horny, with deep furrows and wide ridges.

WOOD. Similar to balsam fir; occasionally used for lumber, packing cases, or butter tubs.

SILVICAL CHARACTERS. Tolerant, although slightly less so than alpine fir; growth moderately rapid, maturity being reached in about 300 years; reproduction generally abundant and aggressive; root system normally shallow; severely damaged by mistletoe, with heart rot and wind shake common defects.

HABITAT. Transition and Canadian zones; altitudinal range from 6,000-11,000 feet; best development on moist, rich, light soils on northern slopes of benches and cañons; this species requires.less moisture than other western firs, existing surprisingly well on poor, dry, shallow sites; seldom in pure stands, usually with ponderosa and limber pine, Douglas-fir alpine fir, Engelmann spruce, and aspen. 


\section{Grand Fir}
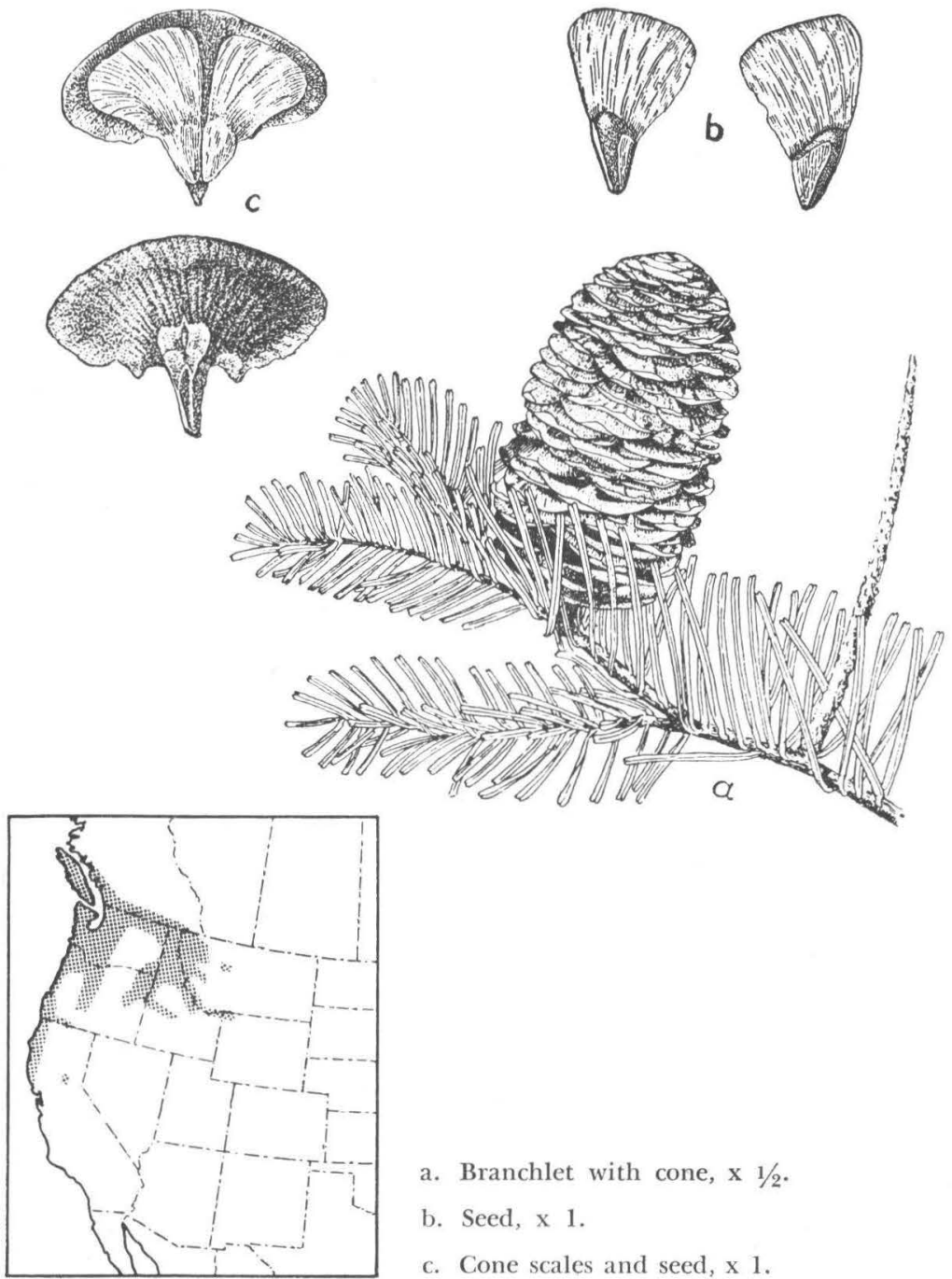

a. Branchlet with cone, $x 1 / 2$.

b. Seed, $x 1$.

c. Cone scales and seed, $\mathrm{x} 1$. 


\section{PINACEAE}

\section{Grand Fir. Lowland White Fir}

Abies grandis Lind.

HABIT. A tree in the Rocky Mountain region reaching 120 feet in height and 3 feet in diameter; rather open domelike crown, on old trees appearing wider in the middle becausc of the drooping of the lower branches.

LEAVES. On lower branches $11 / 2-2$ inches long, scattered, distinctly 2-ranked; on fertile branches $1-11 / 2$ inches long, more crowded, obscurely 2-ranked or nearly erect; blunt, flat, lustrous dark yellow-green and grooved above, white with 2 bands of stomata below.

FLOWERS. Male pale yellow; female light yellow-green.

FRUIT, 2-41/2 inches long, cylindrical, yellow-green to green-purple; scales $1 / 3$ broader than long, and 3-4 times longer than short-tipped bracts. Seed: $3 / 8$ inch long, light brown, with straw-colored wing about $3 / 4$ inch long.

TWIG. Slender, yellow-green to orange-brown, puberulous becoming glabrous in second year. Winter buds: subglobose, $1 / 8^{-1 / 4}$ inch long.

BARK. Thin, gray-brown, smooth except for resin blisters and chalky white blotches on young trees; becoming 2-3 inches thick, red-brown, plated or divided into flat ridges separated by deep furrows.

WOOD. Similar to balsam fir, but with disagreeable odor, and so known as "stinking fir"; lumber and interior finish.

SILVICAL CHARACTERS. Moderately tolerant, but less so than associated firs; growth moderate, maturity being reached in about 200 years; reproduction abundant if sufficient moisture and protection against frost present; windfirm with deep, spreading root system; subject to attack by spruce budworm and stringy brown-rot fungus.

HABITAT. Transition and Canadian zones; altitudinal range from sea level to 5,000 feet; on deep, moist, alluvial soils along streams or on mountain slopes; in limited pure stands, or more frequently in mixed hardwood and coniferous forests with ponderosa, western white, and lodgepole pines, Douglas-fir, western larch, alpine fir, Engelmann spruce, etc. 
Western RedCedar

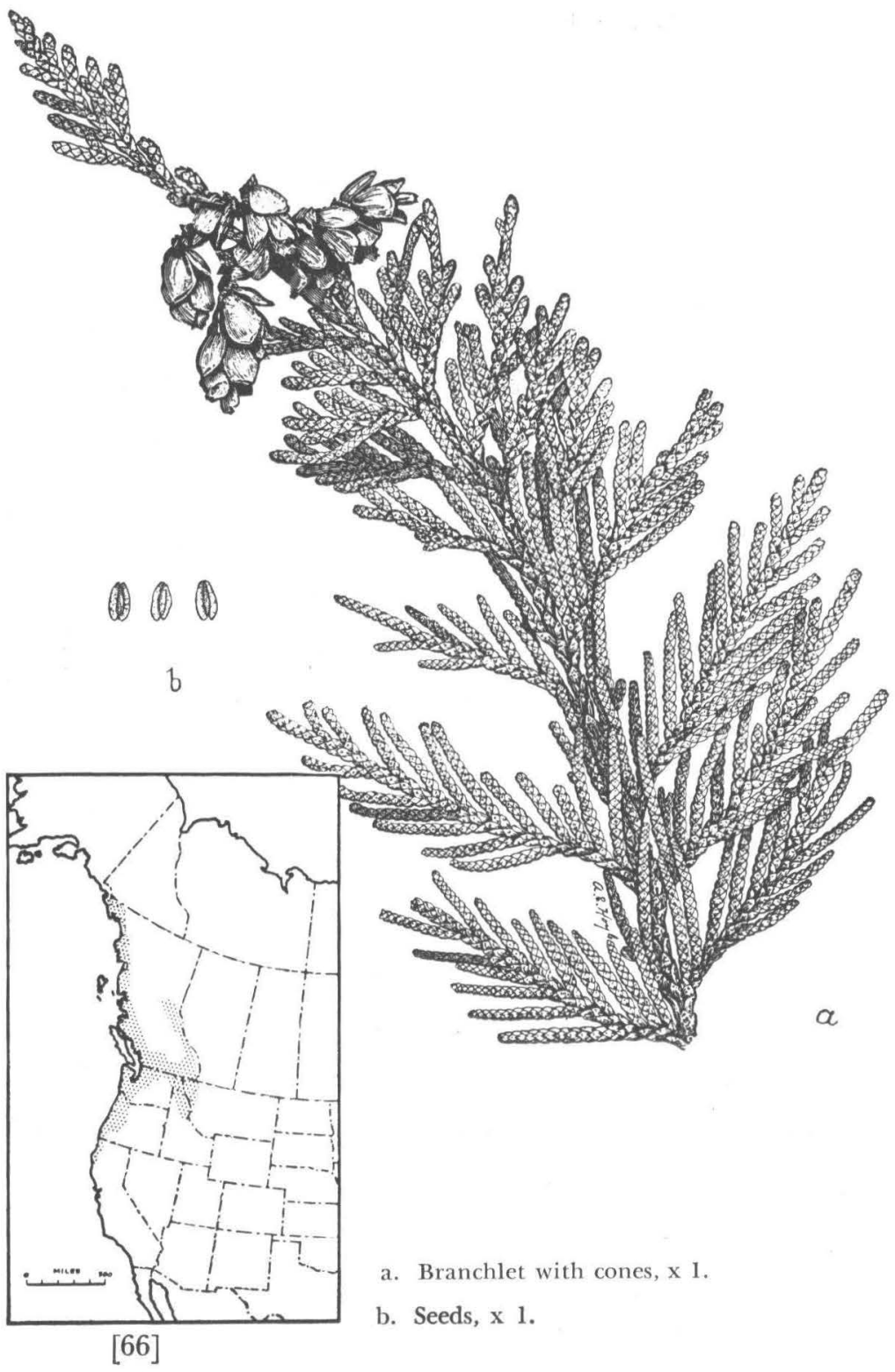




\section{CUPRESSACEAE}

\section{Westrirn Redcedar. Giant Arborvitae Thuja plicata D. Don.}

HABIT. A large tree, 150-200 feet high and 4-8 feet in diameter (max. 250 by 16 feet); tapering, fluted trunk; irregular crown of horizontal or drooping branches.

LEAVES. Small, scalelike; persistent 2-5 years; decussate; the facial leaves flattened, grooved; the lateral leaves rounded or keeled; lustrous dark yellow-green.

FLOWERS. Monoecious; terminal; dark brown; male with 3-6 pairs of decussate stamens; female 8-12 scaled.

FRUIT. Leathery or sub-woody erect cones; $1 / 2$ inch long; ovoid-oblong; maturing in one season; scales 8-12 (only 6 being fertile), thin, spine-tipped. Seed: $1 / 8$ inch long, brown, with lateral wings each about as wide as seed.

TWIGS. Slender; flattened; leaf-covered; in long drooping sprays. Winter buds: minute, naked, inconspicuous.

BARK. Thin $(1 / 2-1$ inch); fibrous; narrow interlacing ridges; cinnamon-red to gray-brown on old trunks.

WOOD. Widely used where durability rather than strength is required; sapwood white; heartwood reddish, soft, fragrant; shingles, siding, interior trim, boats, poles, etc.

SILVICAL CHARAGTERS. Tolerant; growth rather rapid; trees over 1,000 years old reported; reproduction generally plentiful; shallow, widespreading root system; fire and pecky heart rot cause serious damage.

HABITAT. Transition and Canadian zones; altitudinal range 2,000-7,000 feet in Rocky Mountains; on rich soils with abundant moisture; in mixed coniferous stands.

\section{INCENSE-CEDAR \\ Libocedrus decurrens Torr.}

This tree enters the Rocky Mountain region only along the western boundary of Nevada. It can be distinguished from other conifers with scalelike leaves by its thick (2-8 inches) bark, and oblong, leathery cone of six scales. 


\section{CUPRESSACEAE}

\section{The Cypresses}

Characteristics of the Genus Cupressus L.

HABIT. Evergreen, resinous, pyramidal trees (sometimes shrubs); sharply tapering trunks; and dense crowns of stout, erect, or horizontal branches.

LEAVES. Small, scalelike, (often awl-shaped on leading shoots); ovate; with slender, spreading, or appressed tip; thickened, rounded, and often glandular on the back; persistent 3-4 years; decussate (in pairs alternately crossing at right angles); becoming brown and woody before falling; margins finely serrate; commonly glandular on the back.

FLOWERS. Monoecious, minute, yellow, terminal; male oblong of numerous decussate stamens each bearing 2-6 subglobose anthers; female of 6-12 peltate decussate scales, each with numerous, erect, basal ovules; bract and ovuliferous scale wholly fused.

FRUIT. Subglobose, woody, erect cone; maturing in two seasons; cone scales peltate, thick, each with a central boss or mucro which is a remnant of flower scales. Seed: 6-20 in several rows on each scale, erect, with narrow lateral wings.

TWIGS. Slender, quadrangular, leaf-covered. Winter buds: minute, naked, inconspicuous.

WOOD. Strongly aromatic; light brown heartwood; pale yellow sapwood; very durable; of little commercial value because of size and poor form of tree.

SILVICAL CHARACTERS. Tolerant trees; slow-growing; demanding a warm climate and so restricted to the southern part of the region.

GENERAL. This genus contains about 12 species scattered through the southern portions of western North America, Europe, and Asia. In North America there are 7 native species, 5 of these being confined to the Pacafic Coast and 2 occurring in the southern Rocky Mountain region. 


\section{KEY TO THE SPECIES OF CUPRESSUS}

I. Leaves commonly not pitted or glandular on back, gray-green; bark of mature trunks deeply furrowed; branches horizontal.. I. Cupressus arizonica, p. 71 .

II. Leaves conspicuously pitted or glandular on back, blue-green; bark of mature trunks smooth or superficially scaly; branches strongly ascending.............. Cupressus glabra, p. 73. 

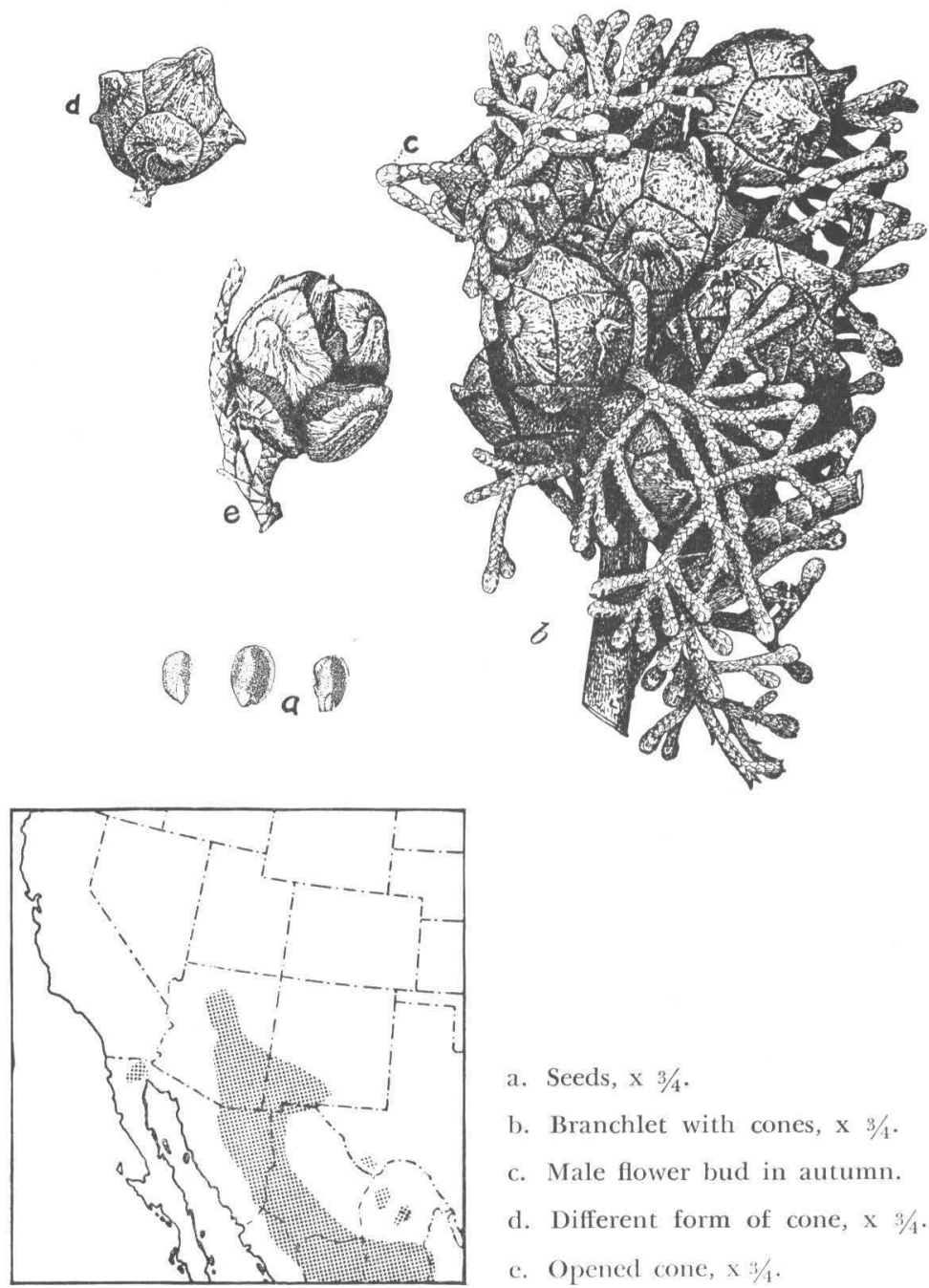

a. Seeds, $\times 3 / 4$.

b. Branchlet with cones, $x 3 / 4$.

c. Male flower bud in autumn.

d. Different form of cone, $x 3 / 4$.

c. Opened cone, $\times 3 / 1$.

[7o] 


\section{CUPRESSACEAE}

\section{Arizona Cypress \\ Cupressus arizonica Greene}

HABIT. Under favorable conditions a tree 50-60 feet high and $1-21 / 2$ feet in diameter (max. 80 by 4 feet) ; trunk short, limby, sharply tapering; crown dense, sharply conical (broad and rounded on poor sites) of short, stout, long-persisting, horizontal branches.

LEAVES. Scalelike, pointed, $1 / 10$ inch long; silvery graygreen; dying and turning red-brown the second year and falling about 4 years later; commonly without glands or pits on back; giving off a skunklike odor when bruised.

FLOWERS. Male oblong, obtuse, yellow; female subglobose.

FRUIT. 3/4-1 inch in diameter, subglobose, dark red-brown on stout stalks; of 6-8 peltate scales, each with stout, incurved, prominent boss; maturing during second summer and remaining on tree many years. Seed: $1 / 16-1 / 8$ inch long, oblong to triangular, deep red-brown; thin, narrow, lateral wings.

TWIGS. 4-angled, dark gray, loose-scaly bark with smooth, reddish inner bark visible below. Winter buds: minute, inconspicuous, naked.

BARK. Loose-scaly on young trunks and branches, showing smooth reddish inner bark below; on old trunks 11/4 inches thick, fibrous, deeply furrowed and ridged, dark red-brown.

WOOD. Slightly aromatic; durable; heartwood light brown; sapwood straw-colored; soft and light, splitting easily; used locally for fence posts, mine timbers, etc.

SILVICAL CHARACTERS. Tolerant throughout life; growth slow; trees seldom found over 400 years old; in places repeated fires have destroyed stand; reproduction generally scanty although seed produced abundantly every year, as conditions seldom favorable for germination.

HABITAT. Transition zone; altitudinal range from 4,5008,000 feet; best growth on moist, gravelly, north slopes and benches, but hardy on dry, sterile, rocky sites; commonly in pure, open stands, but occasionally with Arizona pine and huckleberry oak. 


\section{SMOOTH Cypress}

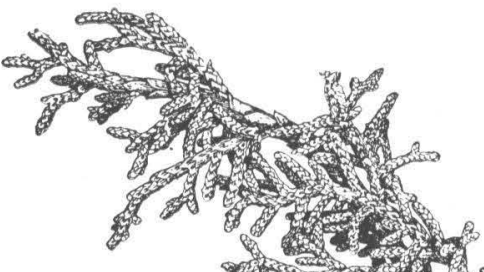

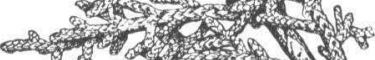

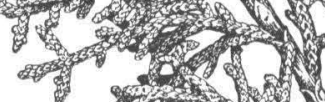

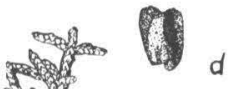
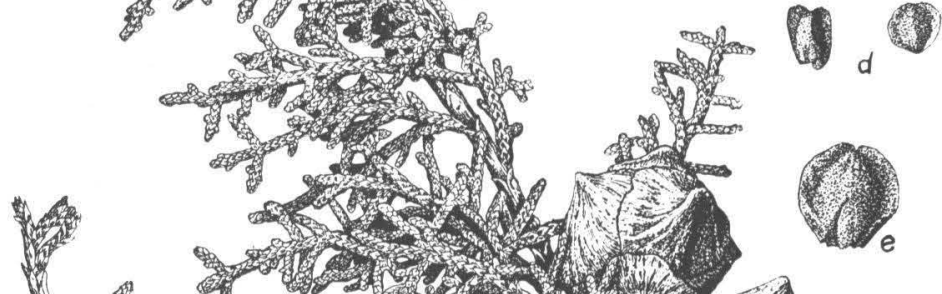
(3) (7)

(1)
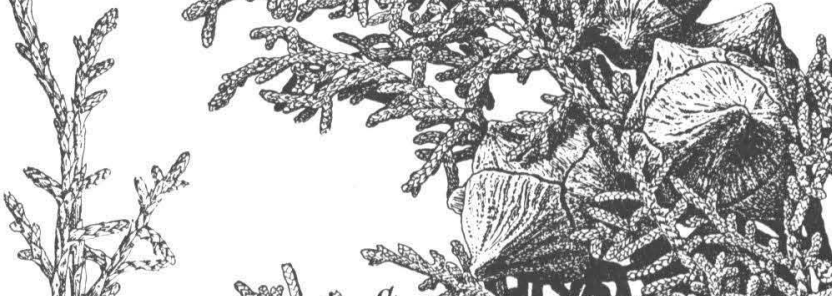

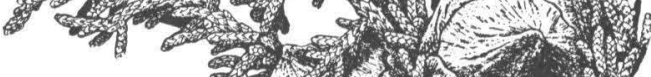

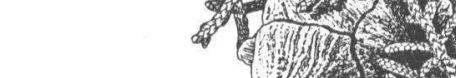

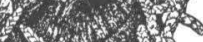

$$
\text { co }
$$

क्षी

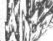

8. $c$

\section{का}

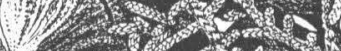

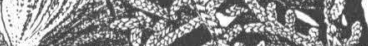
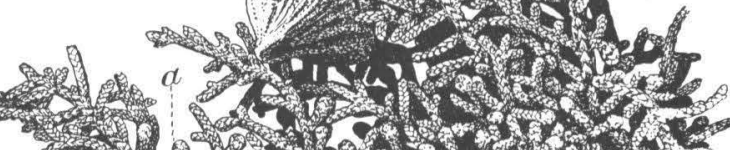

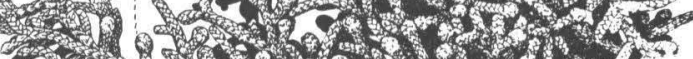

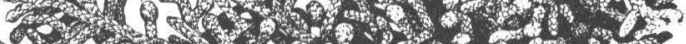

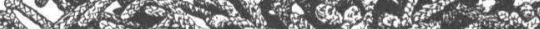

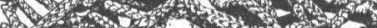

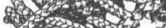

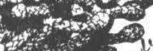
W

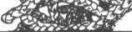

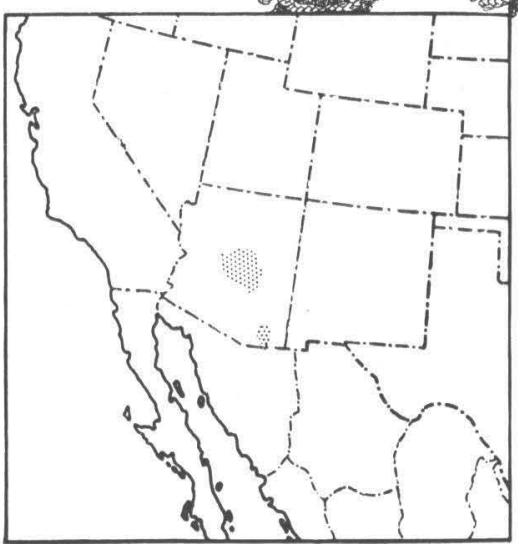

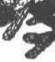

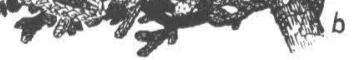

a. Male flower bud in autumn.

b. Foliage and cones, $\times 1$.

c. New shoot showing large form of leaves, $\times 1$.

d. Seed, $x 1$.

e. Seed, $\times 2$. 


\section{GUPRESSACEAE}

\section{Smooth Cypress \\ Cupressus glabra Sudw. [Cupressus arizonica var. bonita (Sudw.) Lemm.]}

HABIT. A tree 25-30 feet high and 10-14 inches in diameter; trunk tapering and upper portion sometimes divided into several branches; crown compact, conical, of strongly upright, stout, long-persistent branches.

LEAVES. Scalelike, pointed, $1 / 16$ inch long; glaucous, bluegreen; dying and turning red-brown the second year and falling about 4 years later; with prominent, oblong or circular gland or pit on keeled back of nearly every leaf.

FLOWERS. Male oblong, obtuse, yellow; female subglobose.

FRUIT. 3/4-1 inch in diameter, subglobose, dark red-brown, on stout stalks; peltate scales, each with stout, incurved boss (becoming less conspicuous on very old cones than it does in Arizona cypress); maturing second summer and often remaining on tree unopened for $14-18$ years. Seed: $3 / 16^{-5} / 16$ inch long, oblong to triangular, deep red-brown; thin, narrow lateral wings.

TWIGS. Slender, 4-angled, dark gray, loose-scaly bark with smooth, reddish inner bark visible below. Winter buds: minute, inconspicuous, naked.

BARK. Thin, smooth, dark red-brown; superficially scaly on old trunks and becoming dark gray and fibrous.

WOOD. Slightly aromatic; durable; heartwood light brown; sapwood straw-colored; rather heavy and hard; used locally for fence posts, mine timbers, etc.

SILVICAL CHARACTERS. Tolerant throughout life; growth slow; reaching age of at least 200-250 years; reproduction generally scanty although seed produced abundantly every year, as conditions are seldom favorable for germination.

HABITAT. Transition and Upper Sonoran zones; altitudinal range from 3,700-7,000 feet; best growth on moist, sheitered slopes and benches, but hardy on dry, rocky soils; not abundant; in pure open stands or in mixture with nut pines, Arizona cypress, and oaks. 


\section{CUPRESSACEAE}

\section{THe JUNipers}

Characteristics of the Genus Juniperus L.

HABIT. Evergreen, aromatic small trees or shrubs.

LEAVES. Persistent, sessile, aromatic; needle-like or awlshaped on young growth; of three types on older growth; (1) ternate, spreading, jointed at base, and entirely needle-like or subulate; (2) decussate, appressed, decurrent, and entirely scalelike; (3) a combination of the preceding types.

FLOWERS. Dioecious (rarely monoecious); minute and inconspicuous; male yellow, solitary, of numerous ternate or decussate stamens; female of 3-8 decussate or ternate pointed scales, some or all bearing 1 or 2 ovules.

FRUIT. A berry-like, succulent, indehiscent cone, formed by coalescence of flower scales; subtended by persistent flower bracts; maturing in 1-3 years. Seed: 1-12 in cone, ovoid, unwinged, marked at base by a scar (hilum).

BUDS. Small, scaly, or naked and covered by leaves.

BARK. Thin, soft, shreddy (brittle, thick and divided into nearly square plates in one species) .

WOOD. Durable; weak; close-grained; aromatic; heartwood red-purple to brown; sapwood whitish.

SILVICAL CHARACTERS. Exceedingly variable; mostly slow-growing; long-lived; seed disseminated by birds or mammals.

GENERAL. This genus contains 40-60 species widely scattered through the Northern Hemisphere, with 15 species native to the United States. Of the 13 species occurring in the Rocky Mountain region, 2 appear only as small shrubs:

(1) The dwarf juniper, Juniperus communis L., while circumpolar and extending through the region, attains tree size in North America only in southern Illinois; this species has ternate leaves, $1 / 3-1 / 2$ inch long, which are all needle-like, and axillary flowers; the prostrate, high mountain form has been designated $J$. communis var. montana Ait. ( $J$. communis var. sibirica Rydb.).

(2) The shrubby red cedar, Juniperus sabina var. prostrata Loud. ( $J$. horizontalis Moench) entering Montana from the north, differs from dwarf juniper in having closely appressed, decussate leaves, $1 / 8^{-1 / 4}$ inch long. 


\section{KEY TO THE SPECIES OF JUNIPERUS}

I. Leaves all needle-like or awl-shaped, $1 / 3-1 / 2$ " long; buds scaly; a small shrub....................... J. communis, p. 74 .

II. Leaves on mature branches scalelike, $1 / 8$ " long or less; buds indistinct, naked; flowers terminal.

A. Creeping shrub; Montana to Canada....2. J. sabina, p. 74 .

B. Small trees or large shrubs.

1. Trunk bark in thick, squarish plates; fruit red-brown. $1 / 2^{\prime \prime}$ long, usually 4 -seeded, ripening in 2 years; southwest..................... J. pachyphloea, p. 87.

2. Trunk bark fibrous and shreddy.

a. 4-12 seeds in berry $\left(1 / 3^{-1} / 4^{\prime \prime}\right.$ long, red-brown, ripening in 2 years); drooping branchlets; Texas and Mexico..

b. 1-3 seeds in berry; branchlets rarely drooping.

(1) Berry bright red, $1 / 4$ " long, 1 -seeded; southwest.

(a) Seed with large, dark ridge band and 3 concavities..........5. J. erythrocarpa, p. 91.

(b) Seed different.........6. J. pinchoti, p. 91.

(2) Berry dull red-brown or blue.

(a) Fruit red-brown; heartwood brown; seed single.

[(1)] Seed enclosed, with large hilum.

[ (a) ] Fruit $1 / 4-1 / s^{\prime \prime}$ long...........

[......7. J. utahensis, p. 85.

[(b) ] Fruit $1 / 2-3 / 4^{\prime \prime}$ long.............

[ (2) ] Seed exposed at tip................. ...........9. J. gymnocarpa, p. 81 .

(b) Fruit bluish.

[(1) ] Heartwood red; leaf margin smooth; berry $1-3$ seeded................. ….......10. J. scopulorum, p. 79.

[(2) ] Heartwood brown; leaves toothed (under lens) .

[(a) ] Berry with 2-3 thick-shelled seeds; Idaho and west......... .....11. J. occidentalis, p. 77 .

[(b) ] Berry with 1-2 thin-shelled seeds.

(1) Seed 1 (rarely 2), pale brown; leaves gray-green, acute, glandular; b a rk gray; south and central.. 12. J. monosperma, p. 81 .

(2) Seed 1-2, dark chestnutbrown; leaves blue-green, obtuse; bark red-brown; Texas and Mexico....... ...13. J. mexicana, p. 83 . 
Sierra JUNIPER

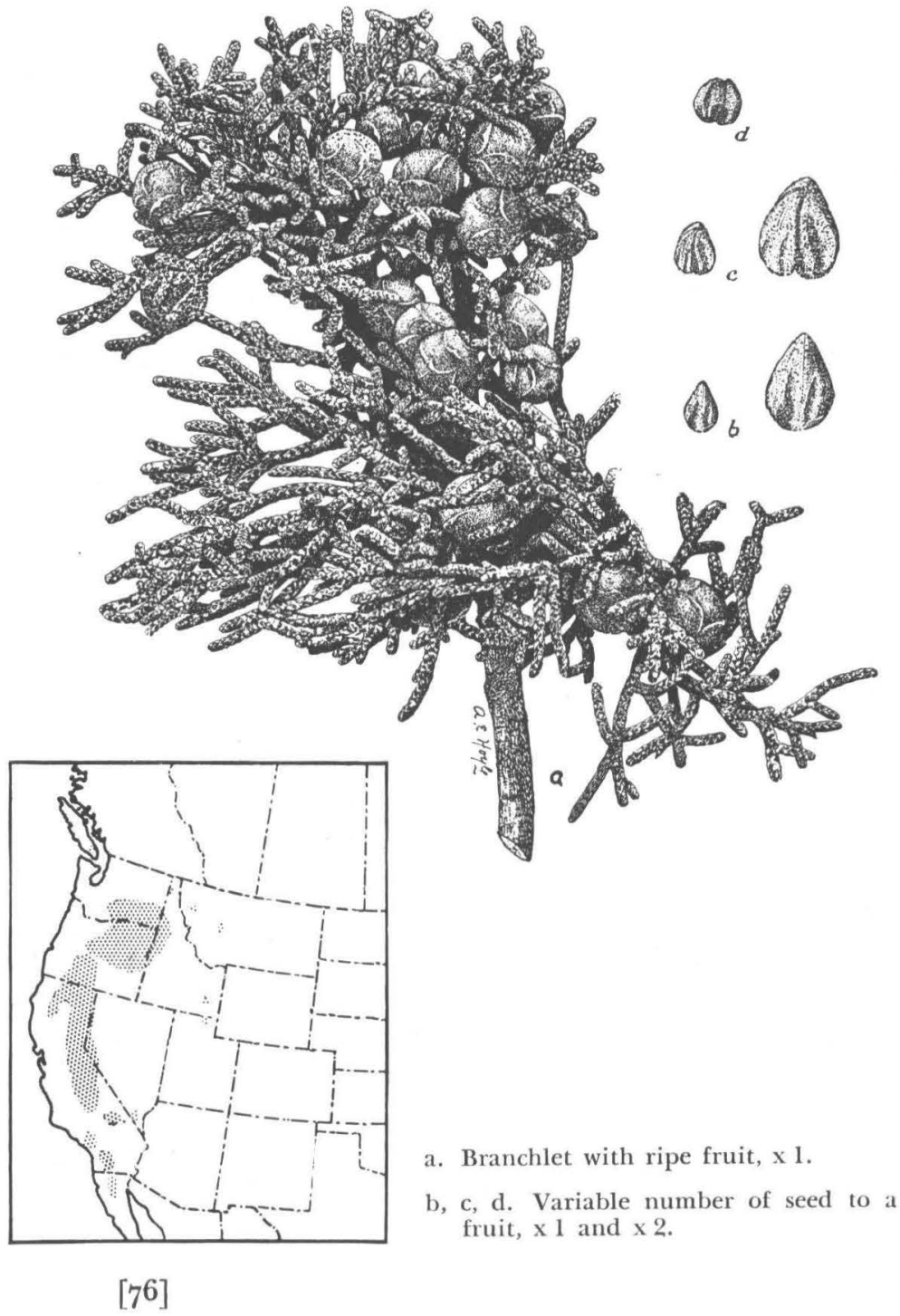




\section{CUPRESSACEAE}

\section{Sierra Juniper. Western Juniper \\ Juniperus occidentalis Hook.}

HABIT. In the Rocky Mountain region from a bushy shrub to a tree 15-30 feet high and seldom over 10 inches in diameter; short, conical, straight trunk; broad, rounded, open crown, extending nearly to ground, composed of enormous, nearly horizontal branches.

LEAVES. Ternate or decussate; closely appressed (may spread slightly at tip on young shoots); scalelike; about $1 / 8$ inch long; acute or acuminate; gray-green; conspicuously glandular-pitted on back; denticulately fringed.

FLOWERS. Dioecious; male stout, obtuse, of 12-18 stamens; female with ovate, acute, spreading scales, mostly obliterated from the fruit.

FRUIT. Glaucous; blue-black; berry-like; globose or ovoid; $1 / 4-1 / 3$ inch in diameter; flesh sweet, resinous, but scanty; skin tough, only slightly marked near top by tips of flower scales; maturing in 2 years. Seed: $2-3$ in each cone; ovoid, acute, rounded and deeply grooved or pitted on back; flattened on inner surface; about $1 / 8$ inch long; thick, bony shell.

TWIGS. Stout, rounded, bright red-brown after leaves fall, and papery-scaly. Winter buds: naked, leaf-covered.

BARK. Thin (1/2-11/4 inches); stringy; bright cinnamonred; divided by shallow furrows in to wide, flat ridges, which are superficially scaly.

WOOD. Heartwood pale brown tinged with red; sapwood white and thick; light, soft and brittle; like other brownwooded junipers, exceedingly durable; used locally for posts and fuel.

SILVICAL CHARACTERS. Intolerant; growth slow; exceedingly long-lived, the largest trees probably 800-1,000 years or older; enormous long, large roots make it windfirm on most exposed sites; reproduction scanty although seed produced abundantly.

HABITAT. Upper Sonoran to Hudsonian zones; altitudinal range in Rocky Mountains between 2,000-9,000 feet (mostly above 6,000 feet); on exposed, dry, rocky, mountain slopes where few other species exist; usually in pure, very open stands. 
Rocky Mountain Juniper

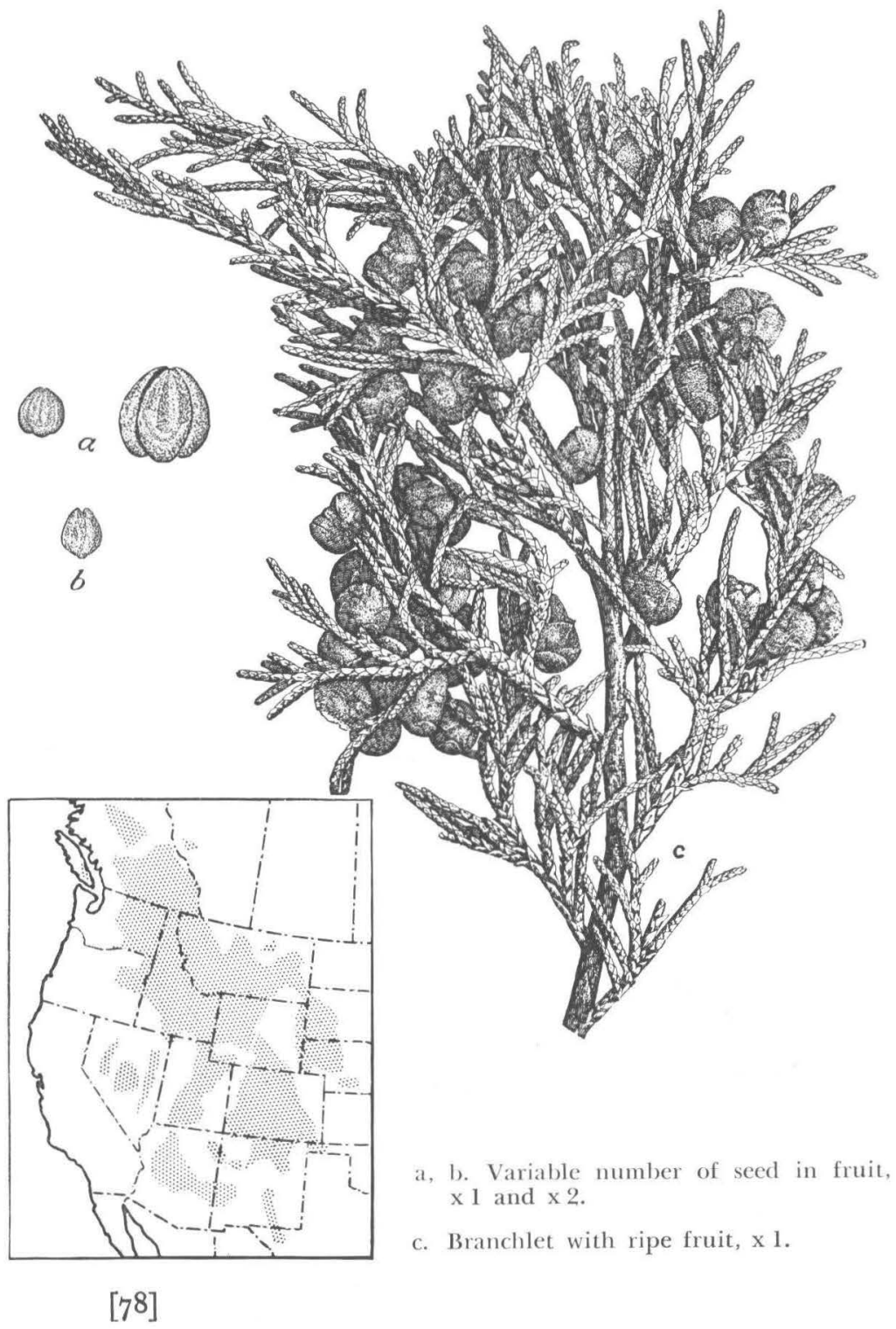




\section{CUPRESSACEAE \\ Rocky Mountain Juniper \\ Juniperus scopulorum Sarg.}

HABIT. From a bushy shrub on exposed sites to a tree $40-55$ feet high and 15-30 inches in diameter; trunk short and stout, often dividing near the ground; crown typically irregular and rounded, of thick, long, ascending branches, but in protected sites of long, slender, drooping branches.

LEAVES. Decussate; closely appressed; scalelike; about 1/s inch long; acute or acuminate; pale to dark green; obscurely glandular on back; smooth margins.

FLOWERS. Dioecious; male with about 6 stamens; female with spreading acute scales.

FRUIT. Glaucous; clear blue; berry-like; globose; $1 / 4-1 / 3$ inch in diameter; sweet, resinous flesh; thin skin maturing in 2 years. Seed: 1-2 (sometimes 3) in each cone; angled and acute; conspicuously grooved; marked at base with short, 2-lobed hilum; hard, bony outer coat.

TWIGS. Slender, leafy, 4-angled; becoming smooth, round, and pale brown. Winter buds: naked, leaf-covered.

BARK. Thin, soft, fibrous, stringy; red-brown or graybrown; divided by shallow furrows into flat interlacing ridges, which are broken on the surface in to persistent, shredded scales.

WOOD. Heartwood dull red or bright red and streaked with white; sapwood thick and white; durable, light, soft; could be substituted for eastern red cedar; used locally for posts and fuel; suitable for pencils and chests.

SILVICAL CHARACTERS. Moderately tolerant, appearance of trees in shaded situations differing markedly from open-grown species; growth very slow; ages of 300 years probably reached; deep, compact, uniformly spreading root system; reproduction rather sparse al though seed produced abundantly.

HABITAT. Upper Sonoran and Transition zones; largest distribution of any western juniper; altitudinal range in Rocky Mountain region from $5,000-9,500$ feet; very drought resistant; in pure stands or mixed with piñon and ponderosa pine, Douglas-fir, oak, and narrowleaf cottonwood. 


\section{Oneseed Juniper}
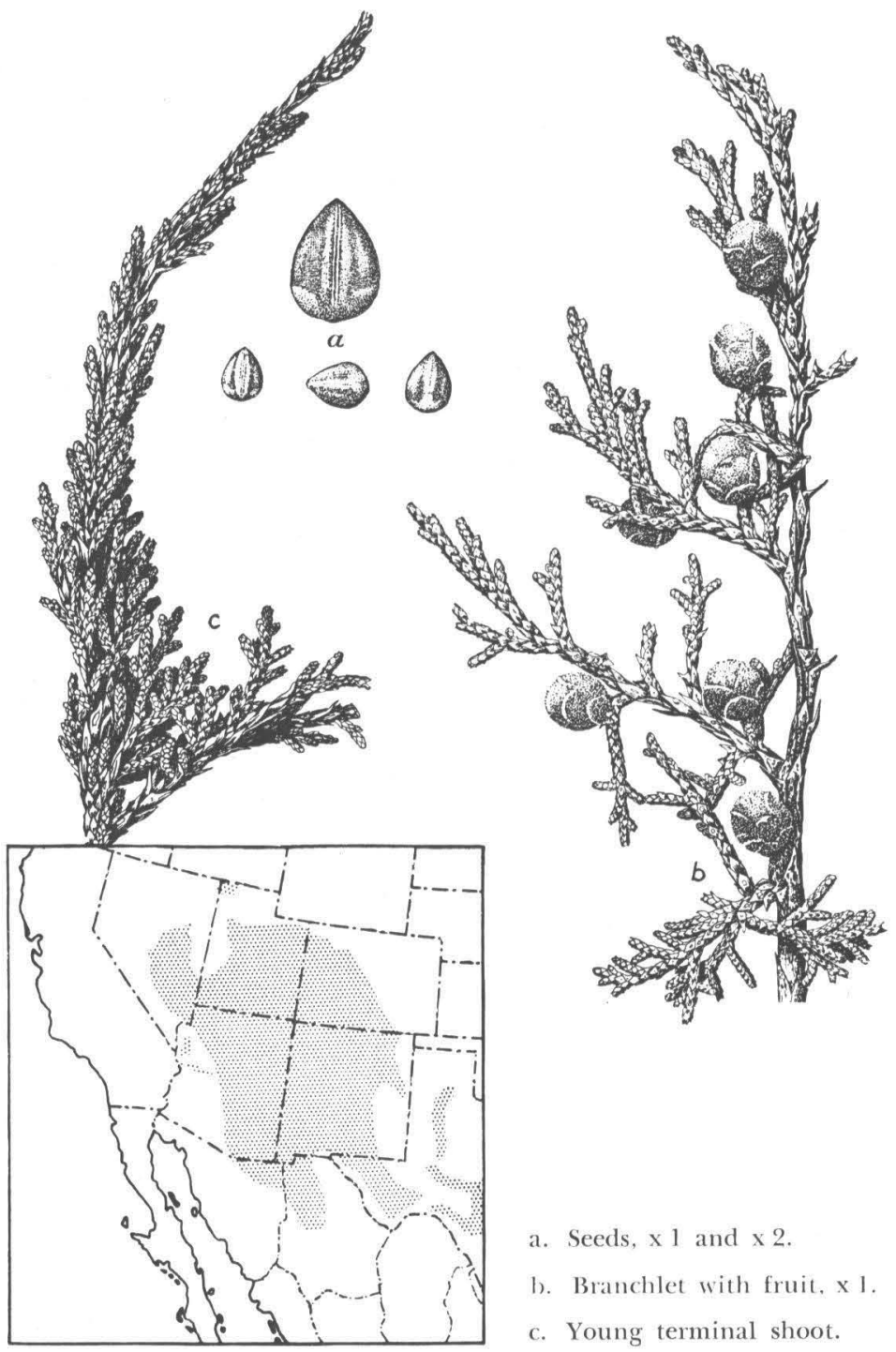

a. Seeds, $\times 1$ and $\times 2$.

b. Branchlet with fruit, $\mathrm{x}]$.

c. Young terminal shoot.

[8o] 


\title{
CUPRESSACEAE
}

\author{
Oneseed Juniper \\ Juniperus monosperma (Engelm.) Sarg. \\ [Juniperus mexicana var. monosperma (Engelm.) Cory.]
}

HABIT. A spreading shrub or small, profusely branched tree; rarely over 50 feet high and from 1-2 feet in diameter; crown open and very irregular; shrubby on desert sites as a result of large branches usually leaving the trunk at the root collar at or below the surface of the ground.

LEAVES. On old twigs decussate (rarely ternate), scalelike, slightly spreading at tips, $1 / 8$ inch long, acute, gray-green, thickened and rounded on back, denticulately fringed, usually glandular; on vigorous shoots ternate, awl-shaped, $1 / 3-5 / 8$ inch long, conspicuously glandular on back.

FLOWERS. Dioecious; male with 8-10 stamens; female with spreading, pointed scales.

FRUIT. Glaucous; copper-colored (rarely blue) ; berry-like; subglobose; $1 / 8^{-1 / 4}$ inch long; thin-fleshed; maturing in one year. Seed: I (rarely 2 ) in each cone; ovoid; often 4-angled; obtuse; marked at base by small 2-lobed hilum.

TWIGS. Slender, leafy, 4-angled, becoming round, redbrown, and loosely scaly. Winter buds: naked, leaf-covered.

BARK. Thin ( $1 / 4-3 / 4$ inch), soft, fibrous, stringy; ash-gray; separated by narrow, deep furrows into narrow, flat ridges.

WOOD. Heartwood yellow-brown to red-brown; sapwood white; durable; rather heavy and hard; used for posts and fuel.

SILVICAL CHARACTERS. Intolerant with age; growth slow; probably reaching age of 500 years; reproduction scanty.

HABITAT. Upper Sonoran zone; altitudinal range from 3,500-7,000 feet; growing on very dry, rocky, high desert plains and mountain slopes; in pure, open stands or with Utah, Pinchot's, and alligator junipers, piñon and ponderosa pines.

GENERAL. Considerable confusion exists with regard to $J$. monosperma but it seems probable that it should be considered a variety of $J$. mexicana.

A Southwestern form with a single seed exposed at the apex, formerly considered a form of $J$. monosperma, should be given specific rank as $J$. gymnocarpa (Lemm.) Cory. 
Mexican Juniper

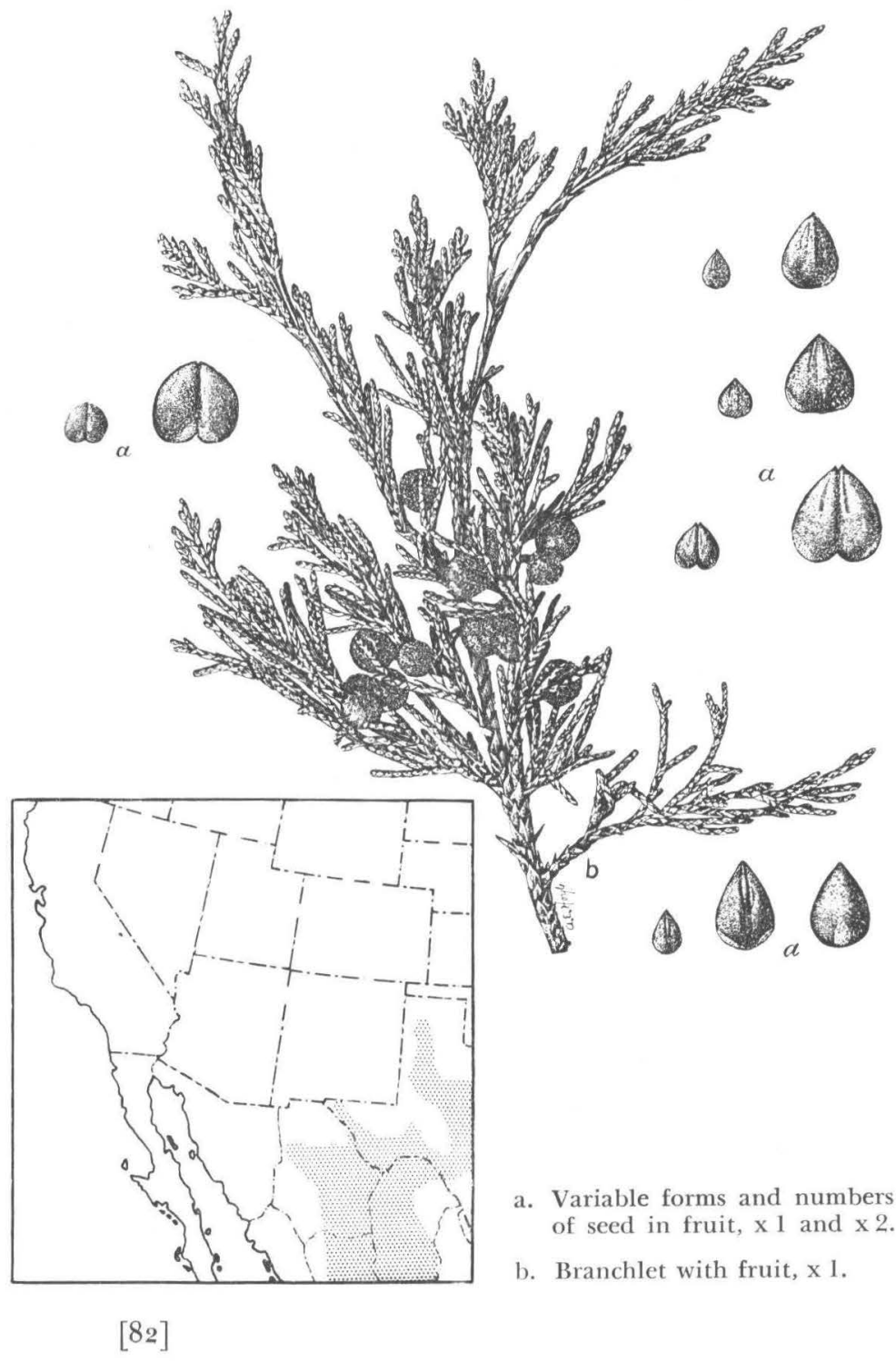




\title{
CUPRESSACEAE
}

\section{Mexican Juniper. Mountain Cedar}

\author{
Juniperus mexicana Spreng. \\ [Juniperus sabinoides (H.B.K.) Nees.]
}

HABIT. A spreading shrub or small tree; normally 12-20 feet high and 8-12 inches in diameter (max. 35 by $11 / 2$ feet); trunk short, crooked, and generally divided near the ground into large, ascending branches; often a many-stemmed shrub on dry, exposed sites; crown irregular and mostly open.

LEAVES. On old twigs decussate, scalelike, 1/16 inch long, sharp-pointed, roughish and prickly to touch, dark blue-green, thickened and keeled on back, denticulately fringed, mostly without glands; on vigorous shoots ternate, lanceolate, $1 / 4^{-1 / 2}$ inch long, rigid, sharp-pointed.

FLOWERS. Dioecious; male with 12-18 stamens; female with ovate, acute, spreading scales.

FRUIT. Glaucous; deep blue; berry-like; subglobose; 1/4-1/2 inch long; thin, pungent, sweet flesh; thick, tough skin; maturing in one season. Seed: $1-2$ in each cone; ovoid; acute; slightly grooved at top; marked at base with low, narrow hilum; thin outer coat.

TWIGS. Slender, leafy, 4-angled; becoming round and light red-brown or ash-gray. Winter buds: naked, leaf-covered.

BARK. Thin $(1 / 4-1 / 2$ inch), stringy and fibrous; brown or red-brown; furrowed and ridged or scaly.

WOOD. Heartwood cinnamon-brown and streaked; sapwood very thin and whitish; light, rather hard, brittle, very narrow-ringed, and durable; used for poles, posts, light traffic railroad ties, and fuel.

SILVICAL CHARACTERS. Very tolerant in youth, becoming less so with age; growth slow; rather long-lived; reproduction plentiful with abundant seed produced.

HABITAT. Upper Sonoran zone; altitudinal range in the United States from 600-2,000 feet; here it occurs in dense, pure, often almost impenetrable stands (cedar breaks), or in mixture with Pinchot and oneseed junipers, Mexican walnut, oaks, elm, and hackberry; on dry, rocky, gravelly, or sandy soils. 


\section{UTAH JUNIPER}

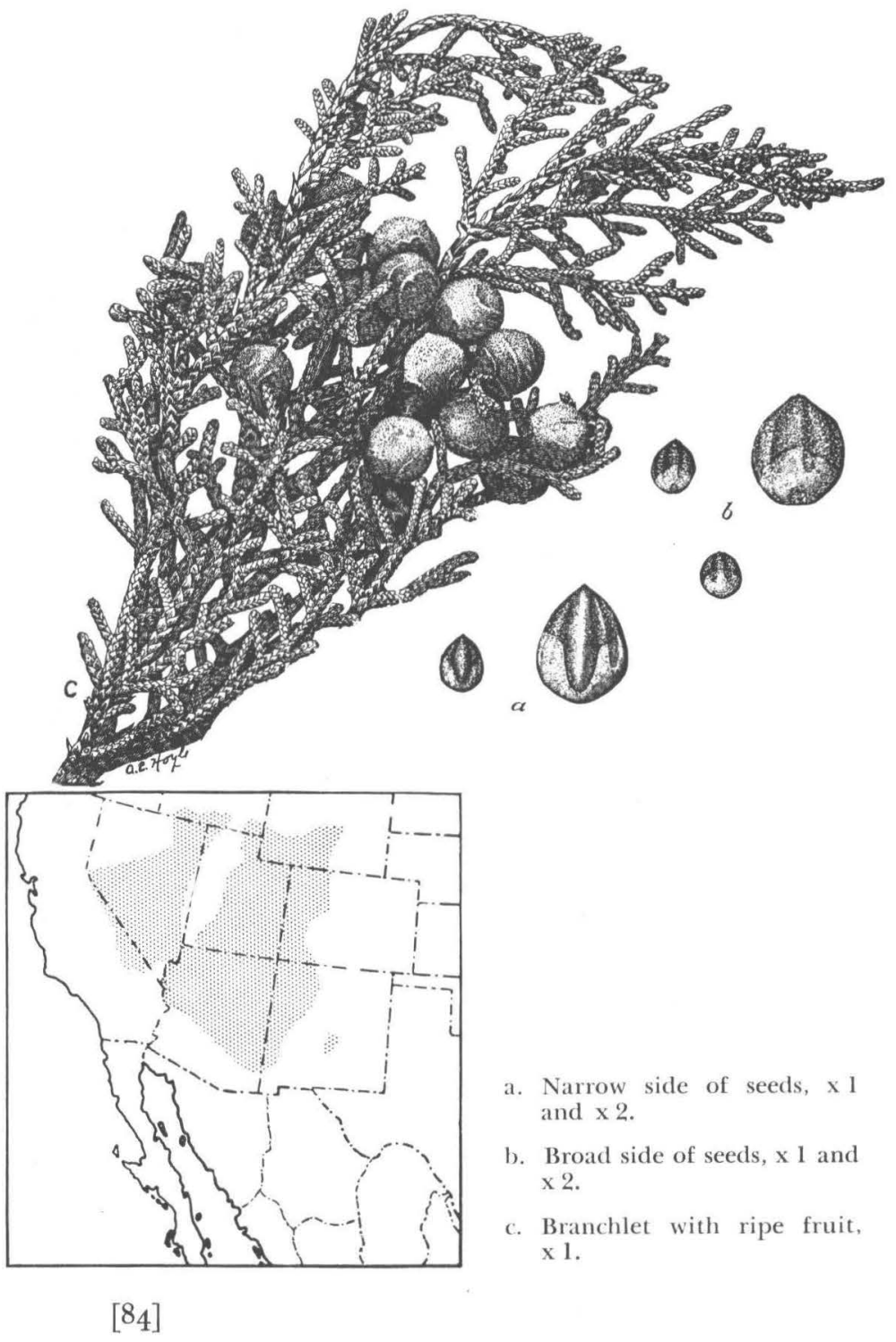




\section{CUPRESSACEAE \\ UTAH JUNIPER \\ Juniperus utahensis (Engelm.) Lemm.}

HABIT. A spreading shrub or small tree; rarely over 20 feet high or 12 inches in diameter; trunk single, or many-stemmed just above the ground; crown rounded.

LEAVES. On old twigs decussate, scalelike, $1 / 8$ inch long, acute or acuminate, pale yellow-green, minutely toothed, usually glandular, long persistent; on vigorous shoots ternate, awlshaped, much larger, sharp-pointed.

FLOWERS. Usually monoecious, sometimes dioecious; male with 18-24 stamens; female with acute, spreading scales.

FRUIT. Glaucous; red-brown; berry-like; subglobose; $1 / 4^{-1 / 3}$ inch long; thin, dry, sweet flesh; smooth, tough skin; maturing in 2 years. Seed: 1 (rarely 2) in each cone; ovoid; sharply angled; acute; marked to the middle by a conspicuous hilum; hard, bony outer coat.

TWIGS. Slender, rounded, stiff-looking; yellow-green with thin red-brown scales. Winter buds: naked, leaf-covered.

BARK. Thin $(1 / 4-3 / 8$ inch) ; ash-gray to gray-white; divided into long, thin, persistent, fibrous scales.

WOOD. Heartwood light yellow-brown; sapwood thick and white; very durable; used locally for fuel and fence posts.

SILVICAI, CHARACTERS. Intolerant with age; growth slow; probably reaching age of 300 years; reproduction scanty although seed produced abundantly.

HABITAT. Upper Sonoran zone; altitudinal range from 5,000-7,000 feet; on dry, rocky to sandy, desert foothills and mountain slopes; mostly in pure stands or with oneseed juniper, singleleaf piñon, and desert shrubs.

Juniperus megalocarpa Sudw. (Juniperus utahensis var. megalocarpa Sarg.) is a rare tree restricted to the south rim of the Grand Canyon and to the Sacramento River Valley in southwestern New Mexico; it can be identified by its large fruit $\left(1 / 2^{-3 / 4}\right.$ inch in diameter). Juniperus knightii A. Nels., reported from the Red Desert of Wyoming, is a synonym of $J$. utahensis. 


\section{Alligator Juniper}
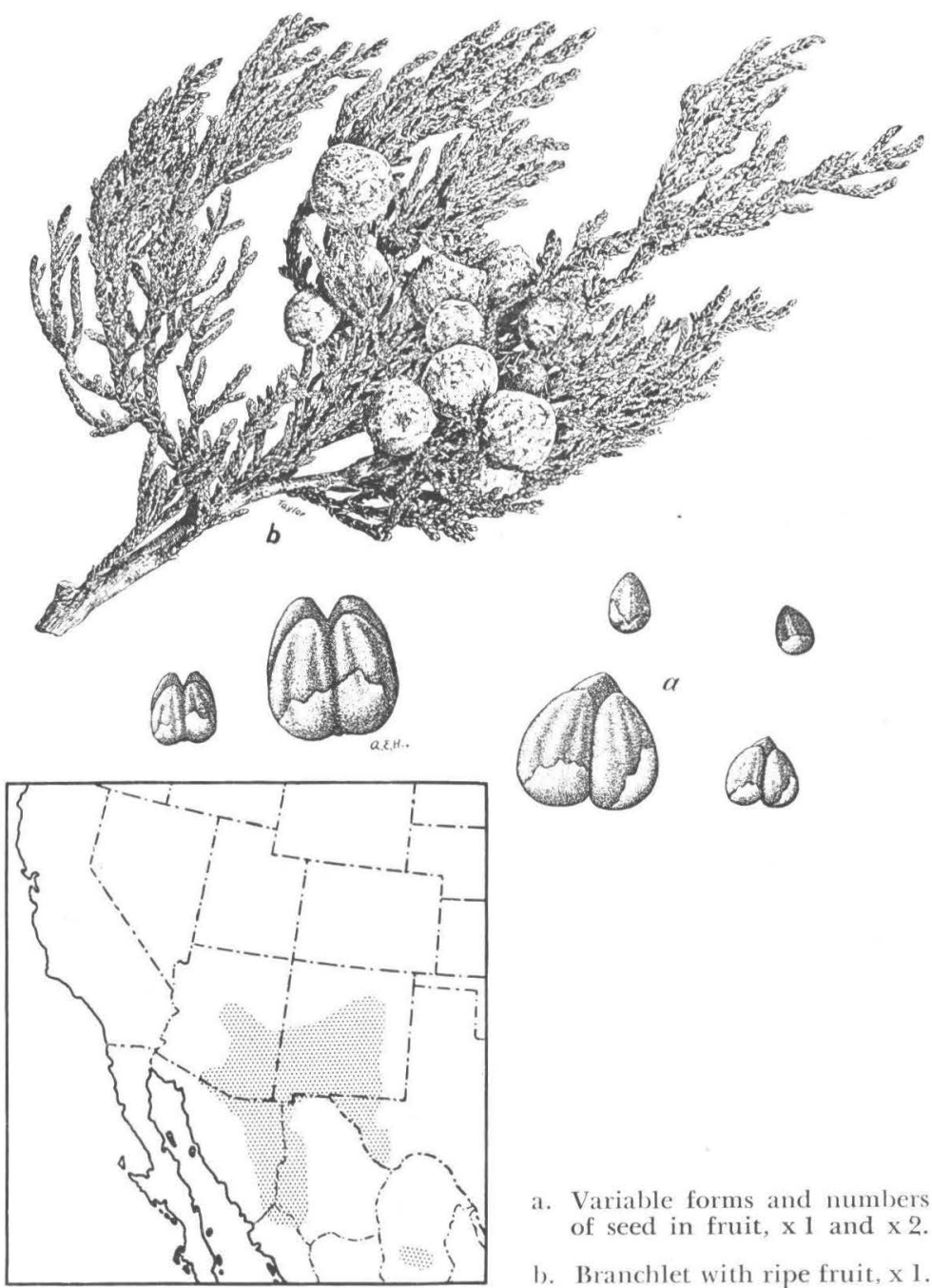

a. Variable forms and numbers of seed in fruit, $\times 1$ and $\times 2$.

b. Branchlet with ripe fruit, $\times 1$. 


\section{CUPRESSACEAE \\ Alligator Juniper \\ Juniperus pachyphloea Torr.}

HABIT. A spreading shrub or small to medium-sized tree, $30-50$ feet high and 18-32 inches in diameter (max. 60 by 6 feet); trunk short; crown broad, compact, with long, stout, spreading branches.

LEAVES. On old twigs decussate, scalelike, $1 / 8$ inch long, acute, blue-green, minutely toothed, small but conspicuously glandular; on vigorous shoots linear-lanceolate, keenly pointed, pale blue-green.

FLOWERS. Monoecious; male with 10-12 stamens; female with ovate, acuminate, spreading scales.

FRUIT. More or less glaucous; dark red-brown; berry-like; subglobose; $1 / 3-1 / 2$ inch long; thick, dry, mealy flesh; thin skin, often with knobby protuberances; usually marked with short tips of flower scales; occasionally opening and discharging the seed at apex; maturing in 2 years. Seed: 1-4 (usually 4) in cach cone; acute or obtuse, distinctly grooved; conspicuously swollen on back; marked at base by short, 2-lobed hilum; thick outer shell.

TWIGS. Slender; 4-angled in leaf, becoming red-brown, smooth or rarely scaly. Winter buds: naked, leaf-covered.

BARK. Very characteristic; $1 / 2-4$ inches thick; red-brown or gray-brown; deeply furrowed, with flat ridges cut into nearly square plates 1-2 inches across, giving tree its common name.

WOOD. Heartwood clear red-brown, often streaked with yellow; sapwood thin and white; durable, light, soft, and brittle; much used locally for fuel and fence posts, suitable for pencils.

SILVICAL CHARACTERS. Intolerant; growth slow; very long-lived, probably reaching $500-800$ years; reproduces plentifully; stumps sprout vigorously.

HABITAT. Upper Sonoran and Transition zones; altitudinal range from 4,500-8,400 feet; extremely hardy and drought resistant; typically on dry, sterile, rocky soils; of frequent occurrence in scattered, pure stands or more commonly mixed with nut pines and oaks. 
DROOPING JUNIPER

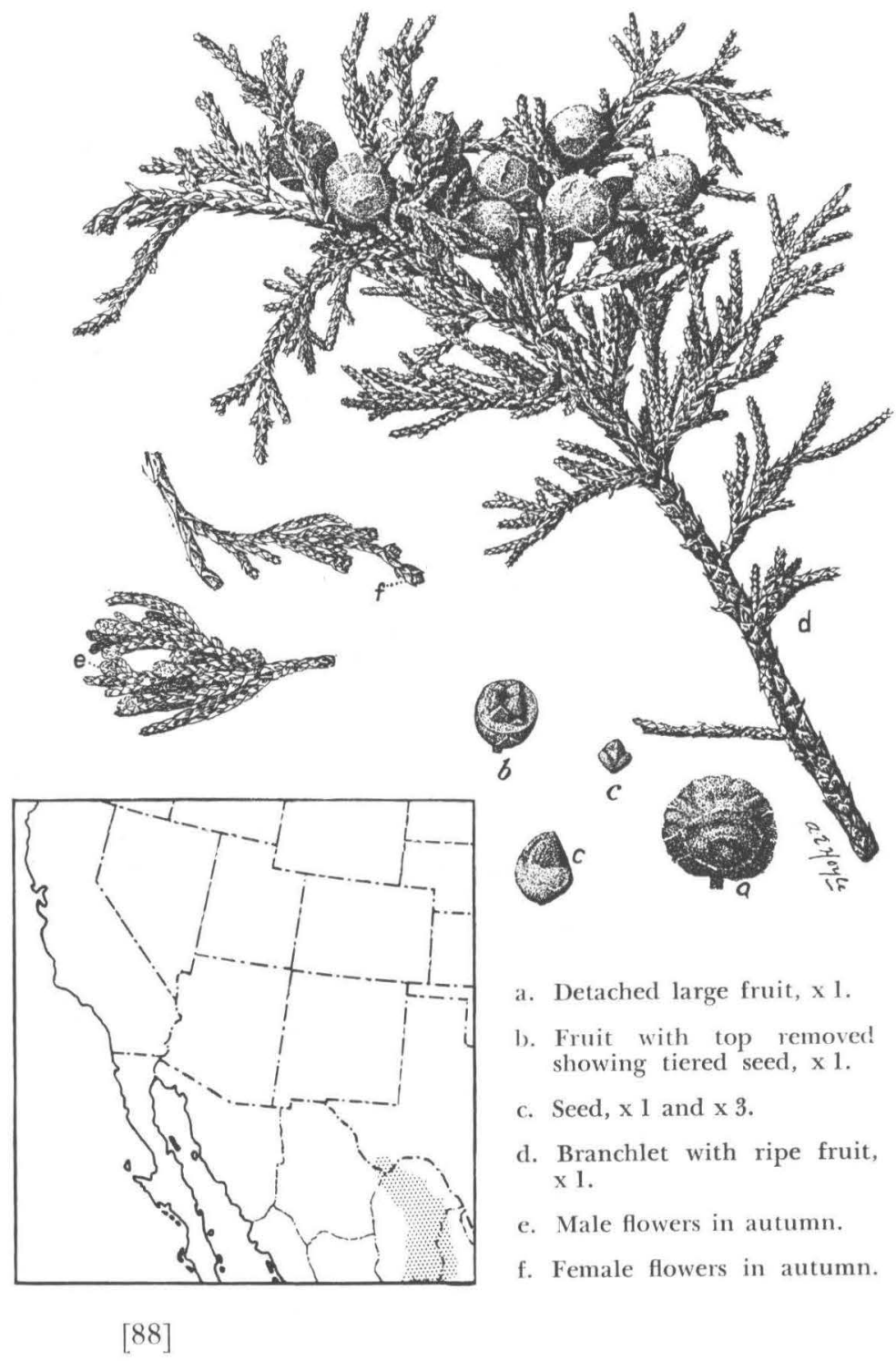




\section{CUPRESSACEAE}

\section{Drooping JUNIPER}

Juniperus flaccida Schlect.

HABIT. A spreading shrub or a small tree from 8-30 feet high and 3-20 inches in diameter; trunk straight and clear on better sites; crown open, pyramidal, of widespreading, ascending, graceful branches ending in slender, drooping branchlets.

LEAVES. On old twigs decussate, scalelike, $1 / 8$ inch long, acuminate and long-pointed, slightly spreading at apex and prickly, light yellow-green, dying on branch and turning cinnamon-red, minutely toothed, with or without glands; on vigorous shoots ternate or opposite, ovate-lanceolate $1 / 1-1 / 2$ inch long, bristle-pointed.

FLOWERS. Dioecious; male of 16-20 stamens; female with acute or acuminate spreading scales.

FRUIT. More or less glaucous; dull red-brown; berrylike; subglobose; $1 / 3-5 / 8$ inch long; thick, hard, dry, resinous flesh; close, firm skin, often with knobby protuberances; distinctly marked by tips of flower scales; maturing in 2 years. Seed: 4-12 in each cone; in several tiers; irregularly shaped; pointed; often abortive; $1 / 8-1 / 4$ inch long.

TWIGS. Slender; drooping; thin, loosely scaly, bright, cinnamon-brown bark. Winter buds: naked, leaf-covered.

BARK. 1/2-11/2 inches thick; red-brown (externally gray); firm; fibrous, and separating into long, narrow, loosely attached scales.

WOOD. Heartwood clear yellow-brown; sapwood thick and white; durable; rather heavy and hard; used locally for posts, mine timbers, and fuel.

SILVICAL CHARACTERS. Tolerant; growth slow; longlived, probably reaching 400-500 years; reproduction fair on good sites.

HABITAT. Upper Sonoran and Transition zones; essentially a Mexican tree with altitudinal range from $6,000-8,000$ feet; best in moist cañons but hardy on dry, rocky, exposed sites; in small, pure groups or mixed with alligator juniper, Mexican piñon, and hardwoods. 
REDBERRY JUNIPER
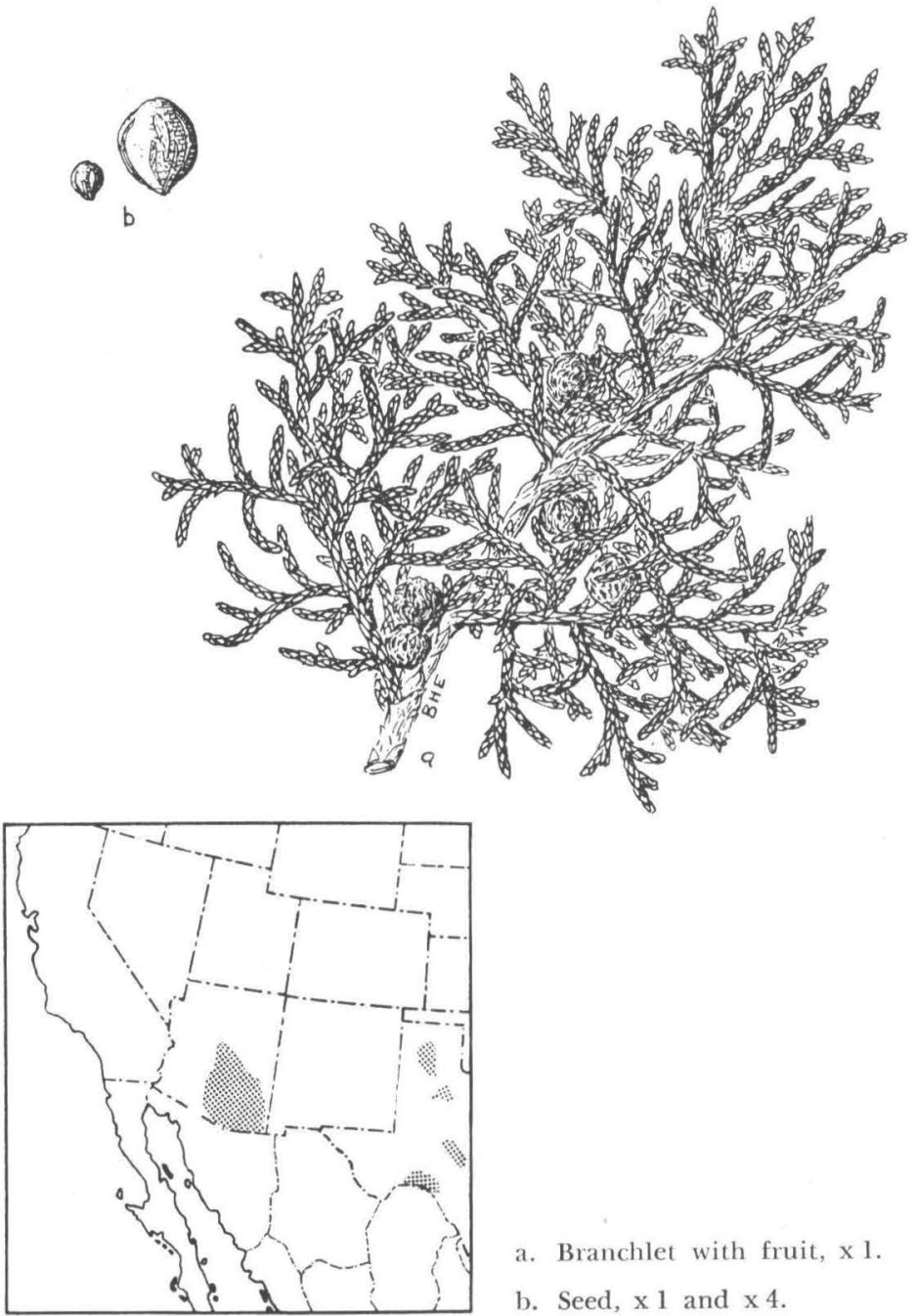

a. Branchlet with fruit, $\mathrm{x} 1$.

b. Seed, $\mathrm{x} 1$ and $\mathrm{x} 4$. 


\section{CUPRESSACEAE}

\section{REDBERRY JUNIPER \\ Juniperus pinchoti Sudw.}

HABIT. A spreading shrub with several stems 1-12 feet tall, or small tree rarely 20 feet high and 1 foot in diameter; open, irregular crown with stout, widespreading branches.

LEAVES. On old twigs ternate, scalelike, 1/16 inch long, obtusely pointed, dark yellow-green and turning light red-brown before falling, glandular-pitted and keeled on back, margins entire; on vigorous shoots linear-lanceolate, spreading, thin, acuminate, $1 / 4^{-1 / 3}$ inch long.

FLOWERS. Dioecious; male not seen; female with spreading pointed scales.

FRUIT. Bright red (rarely copper-colored); berry-like; subglobose; $1 / 4$ inch long; thick, dry, mealy, resinous flesh; thin skin; maturing in one year. Seed: 1 seed in each cone (rarely 2) ; bluntly pointed; ovoid; deeply grooved; 1/6-1/4 inch long; irregularly marked by usually 2-lobed hilum.

TWIGS. Thick to rather slender; with dark, gray-brown, scaly bark. Winter buds: naked, leaf-covered.

BARK. Thin; gray-brown; shallowly furrowed and separating into long, narrow, persistent scales; inner bark dull brown.

WOOD. Heartwood light brown, slightly tinged with red; sapwood light-colored; only moderately durable; rather soft; close-grained; used for posts and fuel.

SILVICAL CHARACTERS. Intolerant; rather slow-growing; reproduction sparse, although seed produced abundantly; stumps sprout vigorously and repeatedly, enabling tree to exist in region of common grass fires; related to Juniperus gigantea K. Koch of Mexico.

HABITAT. Upper Sonoran zone; altitudinal range from about 2,000-5,000 feet; on dry, grassy cañon bottoms or rocky, mountain slopes; local and rare; associated with J. monosperma.

A related form with a bright red fruit, but differing in that the single seed is marked by a large dark-colored ridge band and 3 concavities, has been reported from southwestern Texas and named Juniperus erythrocarpa Cory. 
Western YeW

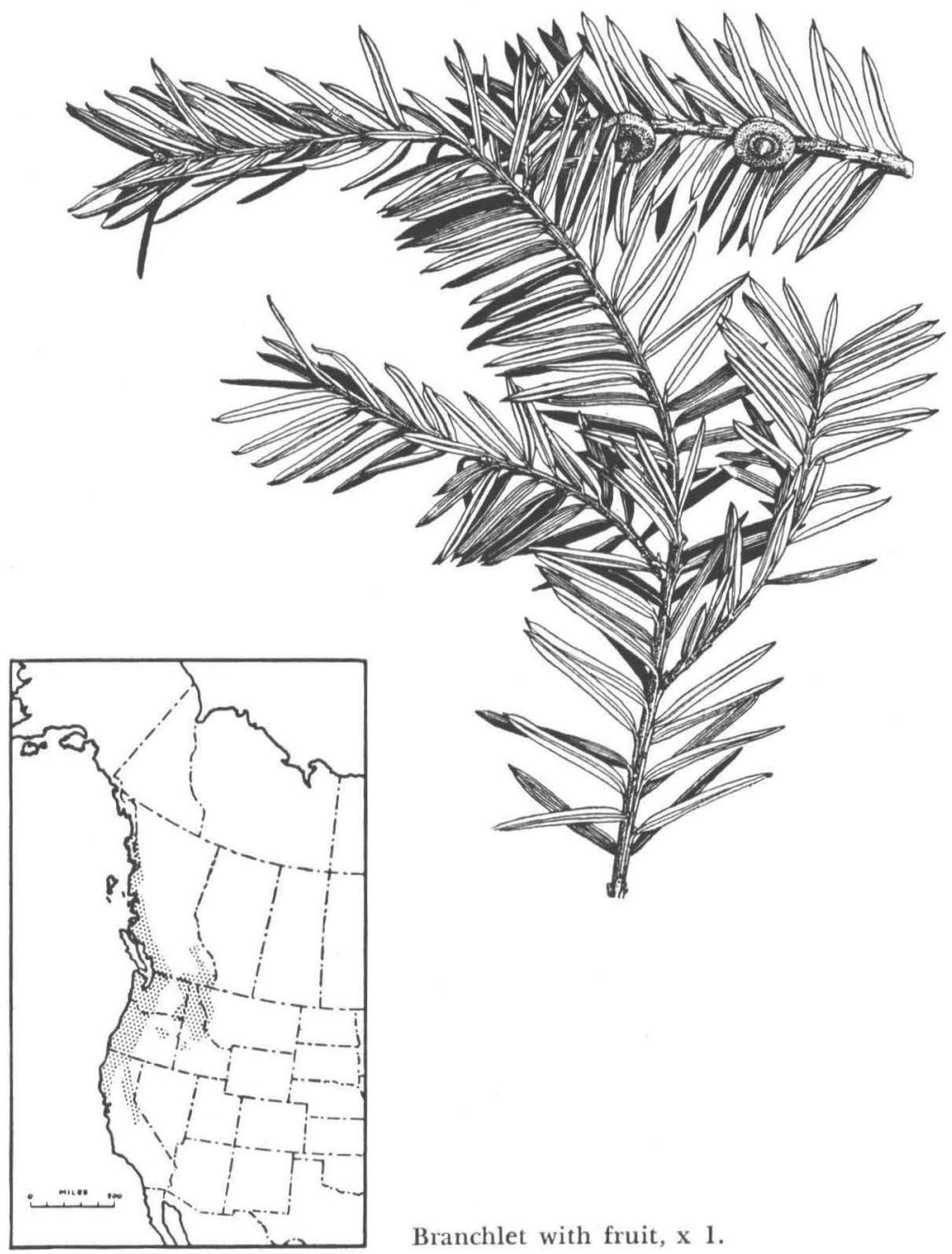

[92] 


\section{TAXACEAE \\ Western Yew. Pacific Yew \\ Taxus brevifolia Nutt.}

HABIT. A small tree or large shrub, 20-50 feet high and 1-2 feet in diameter; limby, often fluted or malformed trunks; large, open, conical crown, with long, slender, drooping branches; a sprawling shrub near timber line.

LEAVES. Persistent; linear-lanceolate; spirally arranged, appearing 2-ranked; $1 / 2-1$ inch long; sharp-pointed; petiolate: green above, paler beneath.

FLOWERS. Dioecious, solitary axillary, on twigs of previous season, surrounded by scales of bud; male in globose heads of 6-14 stamens each with 5-9 anthers, yellowish; female single, greenish, of several scales, the apical scale bearing a solitary erect ovule with a basal disk.

FRUIT. A single, erect, ovoid-oblong seed with a hard, bony shell; $1 / 3$ inch long; exposed at apex, but partially or entirely surrounded by, but free from, the thickened, scarlet, fleshy arillike disk of the flower; maturing in one season.

TWIGS. Slender, drooping. Winter buds: small, ovoid, obtuse; of numerous overlapping scales.

BARK. Very thin ( $1 / 4$ inch), scaly, dark red-purple.

WOOD. Heavy, hard, strong; often with spiral grain; durable; heartwood bright orange to rose-red; sapwood thin. yellow; unimportant, but used for bows, canoe paddles, fence posts, and turned articles.

SILVICAL CHARACTERS. Most tolerant forest tree of northwest; growth slow; maturity reached in 250-350 years; reproduction scanty to rare; deep, widespreading root system; largest trunks often with spiral grain and hollow butt.

HABITAT. Transition to Hudsonian zone; altitudinal range from 2,000 $-8,000$ feet; on deep, moist soils; in small groups or singly as an occasional understory tree in mixed coniferous forests.

GENERAL. This genus contains about 5 species in Asia and North America. Three species are native to the United States. 


\section{Texas Walnut}

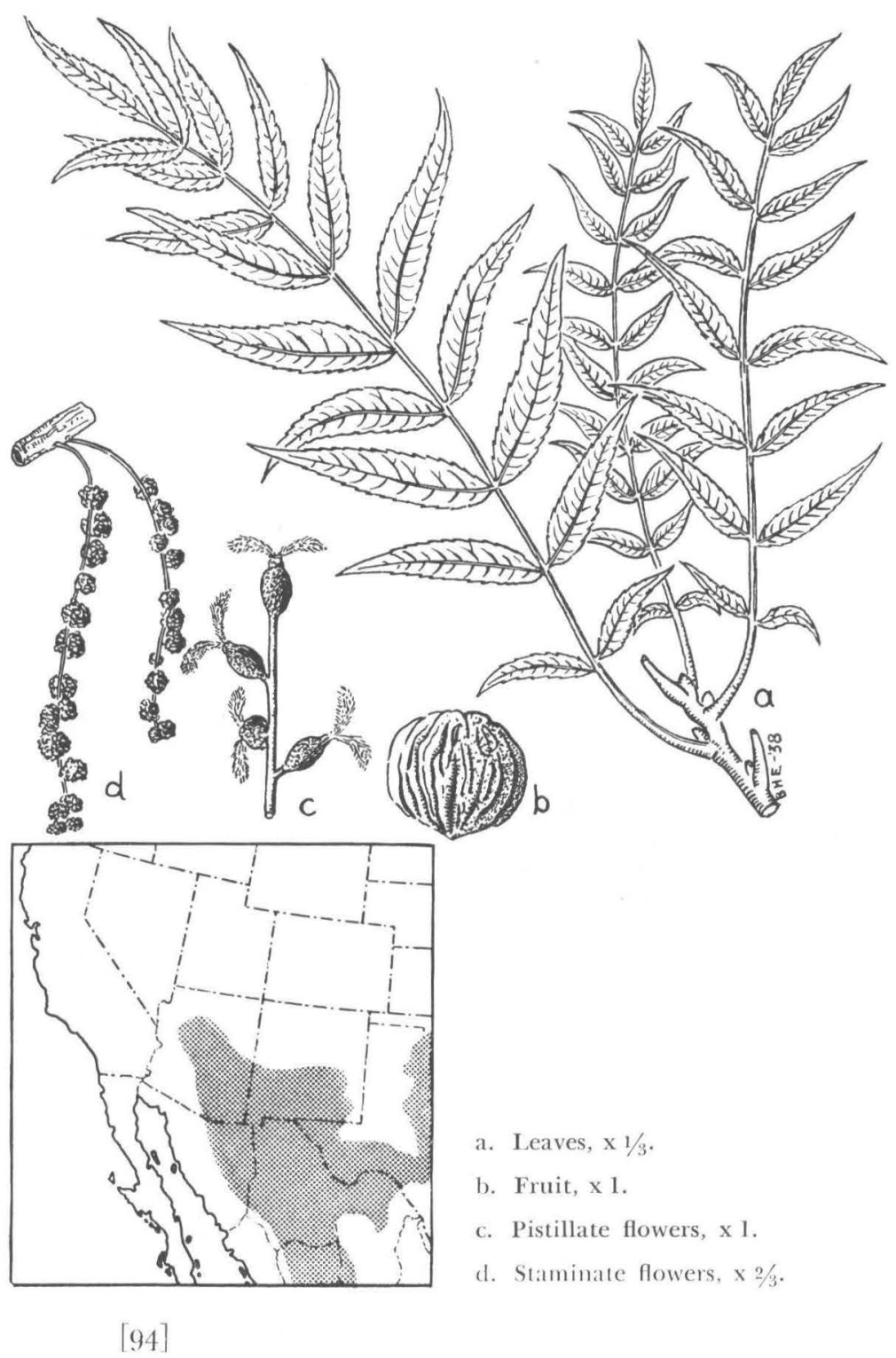




\section{JUGLANDACEAE}

\section{Texas Walnut. Little Walnut \\ Juglans rupestris Engelm.}

HABIT. A shrub or small tree seldom over 20-30 feet high and 18-30 inches in diameter; trunk often crooked; bushy, round-topped crown with large, stout branches.

LEAVES. Alternate; unequally pinnately compound; with 17-23 (rarely 13 or 15), narrow-lanceolate, acuminate, often falcate leaflets $2-3$ inches long and $1 / 3-2 / 3$ inch wide; finely serrate or nearly entire; thin; light green; mostly glabrous; deciduous; rachis round, grooved; stipules absent.

FLOWERS. Regular; monoecious; staminate in slender, axillary aments 3-4 inches long, with yellow-green, 3-5 lobed calyx and about 20 stamens; pistillate in few-flowered, terminal spikes with 1-3-celled ovary free only at apex; appearing after the unfolding of the leaves.

FRUIT. Drupaceous, consisting of a fleshy, indehiscent husk enclosing a hard, thick-walled nut; $1 / 2-3 / 4$ inch in diameter; subglobose; pubescent; tipped with remnant of calyx.

TWIGS. Rather slender; round; pubescent and orange-red at first, becoming glabrous and ash-gray; marked by pale lenticels and large, 3-lobed leaf scars; pith partitioned into chambers. Winter buds: terminal $1 / 4-1 / 2$ inch long, scaly, compressed, tomentose; lateral $1 / 8$ inch long, pubescent.

BARK. Rather thick; dark; furrowed and scaly ridged.

WOOD. Heavy; hard; not strong; durable; diffuse-porous; heartwood dark brown; sapwood thick, whitish; unimportant; stumps used for veneer.

SILVICAL CHARACTERS. Lower and Upper Sonoran zones; intolerant; borders of streams on desert, mountain sites; in rocky soils, often of limestone origin; deep taproot.

The western form, known as Arizona walnut or Nogal, with usually 9-13 (rarely 15-19), oblong-lanceolate to ovate, coarsely serrate leaflets and fruit $1-11 / 2$ inches in diameter, has been designated as either a variety Juglans rupestris var. major Torr. or a separate species Juglans major Hell. The eastern black walnut, Juglans nigra L., is extensively planted in this region. 


\section{SALICACEAE}

\section{The Poplars and CotTonwoods \\ Characteristics of the Genus Populus $\mathbf{L}$.}

HABIT. Mostly large, fast-growing, deciduous trees with bitter bark.

LEAVES. Alternate; simple; usually ovate or ovate-lanceolate; entire, dentate, or lobed; pinnately veined; turning yellow before falling in autumn; petioles mostly long and often laterally compressed; stipules present, falling as leaves unfold.

FLOWERS. Regular; dioecious; both sexes in drooping aments; appearing from separate buds, before the leaves; individual flowers solitary, apetalous, inserted on broad, cupshaped disk, subtended by dilated, lobed, and often laciniate scale or bract; staminate with 4 to many stamens; pistillate a single, l-celled, usually sessile ovary with $2-4$ placentas and 2-4 stigmas on a usually short style.

FRUIT. A 1-celled, 2-4-valved capsule containing numerous seeds. Seed: small, tufted with long silky hairs, extremely light and buoyant; vitality transient and germination must take place within few days.

TWIGS. Slender to stout; round or angled; mostly olivebrown to lustrous red-brown; marked by persistent ringlike or deltoid leaf scars; pith homogeneous, stellate in cross section. Winter buds: terminal present, resinous or nonresinous, covered by several imbricated scales; lateral similar and not much smaller; flower buds conspicuously larger.

BARK. Astringent; light-colored; deeply furrowed or smooth.

WOOD. Light; soft; weak; brittle; straight-grained; diffuseporous; not durable; heartwood light brown to whitish; used for pulp and light weight lumber.

SILVICAL CHARACTERS. Intolerant; fast-growing; shortlived; reproduction widespread and abundant; stumps and roots sprout vigorously; extensive, widespreading root systems; mostly moisture-loving trees.

GENERAL. This genus contains about 35 species scattered over the Northern Hemisphere and in Northern Africa; 13 to 15 species are native to North America, and 8 of these are listed as occurring in the Rocky Mountain region. 


\section{KEY TO THE SPECIES OF POPULUS}

I. Petioles not flattened laterally; leaves mostly at least $1 / 3$ longer than broad, without definite translucent border.

A. Leaves ovate to ovate-lanceolate, whitish below; terminal bud $9 / 4-1$ " long, ovoid, resinous-sticky.

1. Ovary and capsule usually pubescent, mostly subglobose, 3-valved; stigmas 3; stamens 40-60, anthers purple; leaves $1 / 3$ or less longer than broad; Pacific region........

1. P. trichocarpa, p. 99.

2. Ovary and capsule glabrous, ovoid-oblong, 2-valved; stigmas 2; stamens 20-30 with pink anthers; leaves mostly twice as long as broad; through northern North America..................2. P. balsamifera, p. 101.

B. Leaves lanceolate to ovate-lanceolate, green on both surfaces; terminal bud less than $3 / 4$ " long, slender.

1. Leaves lanceolate to ovate-lanceolate; petioles $1 / 3$ length of blade or less; buds 5-scaled, aromatic, rather sticky....

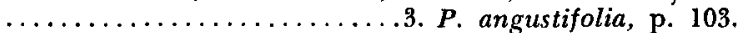

2. Leaves ovate- to rhombic-lanceolate; petioles at least $1 / 2$ length of blade; buds 6-7-scaled, nonaromatic, not sticky...................... P. acuminata, p. 105 .

II. Petioles flattened laterally; leaves little or no longer than broad, with definite translucent border (except in 5) .

A. Leaves broadly ovate to suborbicular, $1-3$ " in diameter, finely serrate; bark smooth; buds conical; stigmas 2, filiform..... ........................5. P. tremuloides, p. 107.

B. Leaves deltoid, 2-4" long, coarsely serrate; bark furrowed; buds ovoid; stigmas $3-4$, broad.

1. Pedicels longer than capsules; leaves with not more than 10 teeth on a side; Texas, New Mexico, to central Colorado......................6. $P$. wislizeni, $p .109$.

2. Pedicels shorter than capsules; leaves with more than 10 teeth on a side.

a. Buds puberulous; leaves with glands at apex of petiole; eastern foothills of Rocky Mountains.............. ..7. P. sargentii, p. 111 .

b. Buds glabrous; leaves without glands at apex of petiole; western New Mexico and Utah to California.. 8. P. fremontii, p. 113. 


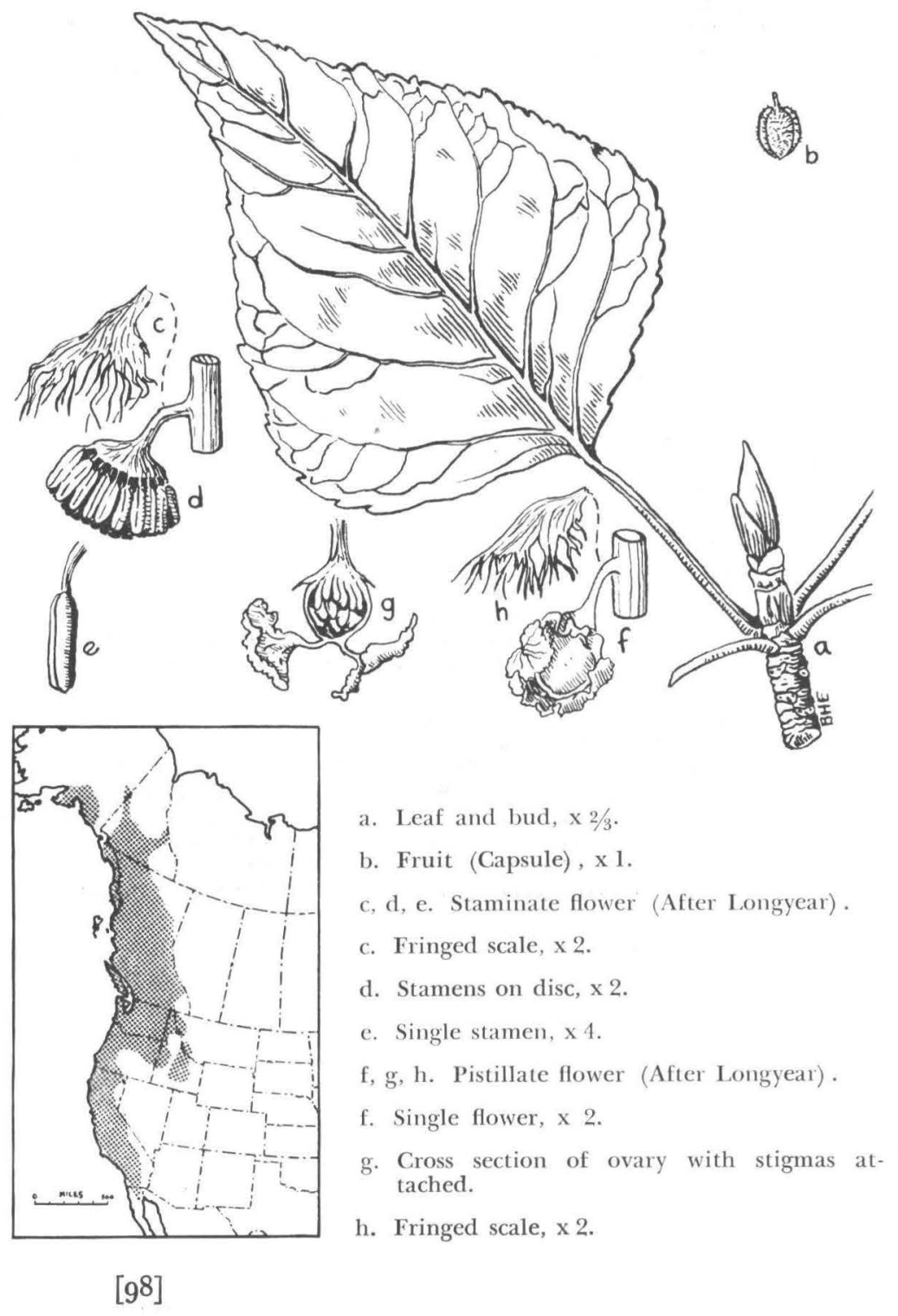




\section{SALICACEAE}

\section{Northern Black Cottonwood}

\section{Populus trichocarpa var. hastata Henry}

HABIT. The largest of American poplars and the largest broad-leaved tree in the Pacific Northwest; in the Rocky Mountain region it is seldom more than 100 feet high; long, clear. cylindrical trunk; crown open, rounded.

LEAVES. Ovate to ovate-lanceolate; 5-6 inches long and 3-4 inches wide; apex acute to long-acuminate; base rounded or slightly cordate; margin finely crenate to crenate-serrate; rather thick and leathery; dark green and glabrous above, silver-white to pale green or rusty-brown below; petioles round, long.

FLOWERS. Aments stalked, villose-pubescent to glabrous; bracts filiformly lobed; staminate in dense aments, each flower with 40-60, long-stalked, purple stamens; pistillate in loose aments, disk cup-shaped, ovary usually hoary-tomentose and subglobose with 3 nearly sessile, lobed stigmas.

FRUIT. Capsules subglobose; $1 / 3$ inch long; 3-valved; nearly sessile; mostly pubescent. Seed: $1 / 12$ inch long.

TWIGS. Moderately slender; round or slightly angled; glabrous or pubescent and red-brown at first, becoming glabrous and dark gray; marked by numerous orange lenticels and roughened by greatly enlarged and thickened elevated leaf scars. Winter buds: terminal $3 / 4$ inch long and $1 / 4$ inch broad; ovoid; curved; long-pointed; orange-brown; with 6-7 scales; covered by fragrant, yellow-brown resin.

BARK. Smooth and greenish on young stems; becoming pale gray, 1-21/2 inches thick, deeply and sharply furrowed.

SILVICAI CHARACTERS. Upper Sonoran to Canadian zones; very intolerant; shallow-rooted; on moist sandy or gravelly sites; in pure stands or in mixture with conifers.

GENERAL. According to Sudworth, the northern black cottonwood is replaced by the type species, Populus trichocarpa Torr. \& Gray, in the southern part of its range. Other taxonomists do not recognize the variety, holding that the differences between it and the species are too variable to be valid. The distribution of both species and variety is included on the map. 


\section{Balsam Poplar}
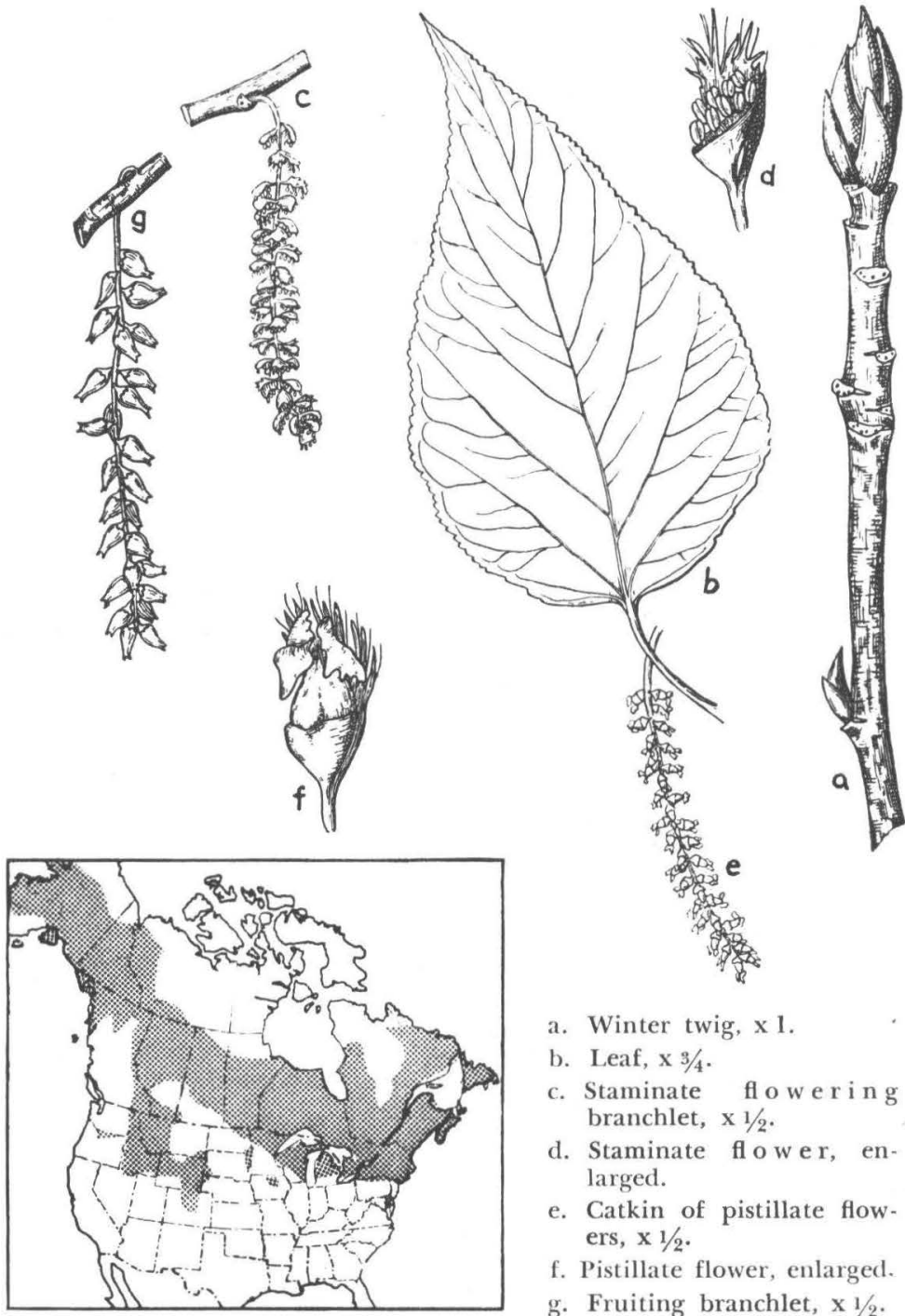

a. Winter twig, $\times 1$.

b. Leaf, $x 3 / 4$.

c. Staminate flowering branchlet, $\times 1 / 2$.

d. Staminate flower, enlarged.

e. Catkin of pistillate flowers, $\times 1 / 2$.

f. Pistillate flower, enlarged.

g. Fruiting branchlet, $\times 1 / 2$. 


\section{SALICACEAE}

\section{Balsam Poplar}

Populus balsamifera L. (Populus tacamahaca Mill.)

HABIT. A medium-sized tree seldom over $60-80$ feet high and 1-3 feet in diameter; long, cylindrical trunk; open, narrow, irregular, pyramidal crown with rather erect branches.

LEAVES. Broadly ovate to ovate-lanceolate; 3-6 inches long and 2-4 inches broad; apex abruptly acute to acuminate; base rounded or cordate; finely crenate-serrate; thin and firm; lustrous dark green and glabrous above, much paler, conspicuously veined and commonly with rusty blotches below; petioles round, slender, pubescent and 2-31/2 inches long.

FLOWERS. Aments long-stalked; bracts filiformly lobed; staminate in dense aments, each flower having 20-30 light red, short-stalked stamens; pistillate becoming 4-5 inches long, each glabrous ovary with 2 large, nearly sessile stigmas.

FRUIT. Capsules ovoid; $1 / 4-1 / 3$ inch long; 2-valved; glabrous; short-stalked. Seed: light brown, 1/12 inch long.

TWIGS. Moderately stout; round; red-brown and glabrous or pubescent at first, becoming lustrous and gray or orangebrown; marked by bright orange lenticels and roughened by thickened leaf scars. Winter buds: terminal 1 inch long, $1 / 3$ inch broad; ovoid; terete; long-pointed; chestnut-brown; covered by 5 scales; saturated by fragrant, amber-colored resin.

BARK. On young trunks smooth or roughened by dark protuberances and green-brown to red-brown; on large trunks deeply furrowed, widely ridged, and gray to gray-black.

SILVICAL CHARAGTERS. Canadian and Hudsonian zones; intolerant; characteristic of moist alluvial bottom-lands and stream banks; reaching greatest size in northwestern Canada.

GENERAL. The variety candicans (Ait.) Gray, known as the Balm of Gilead, differs from the species in having leaves which are usually broader, cordate at the base, pubescent beneath along the veins and with pubescent petioles. This variety is known only in pistillate form and is thought to be either a hybrid or an introduced form which has become naturalized. 


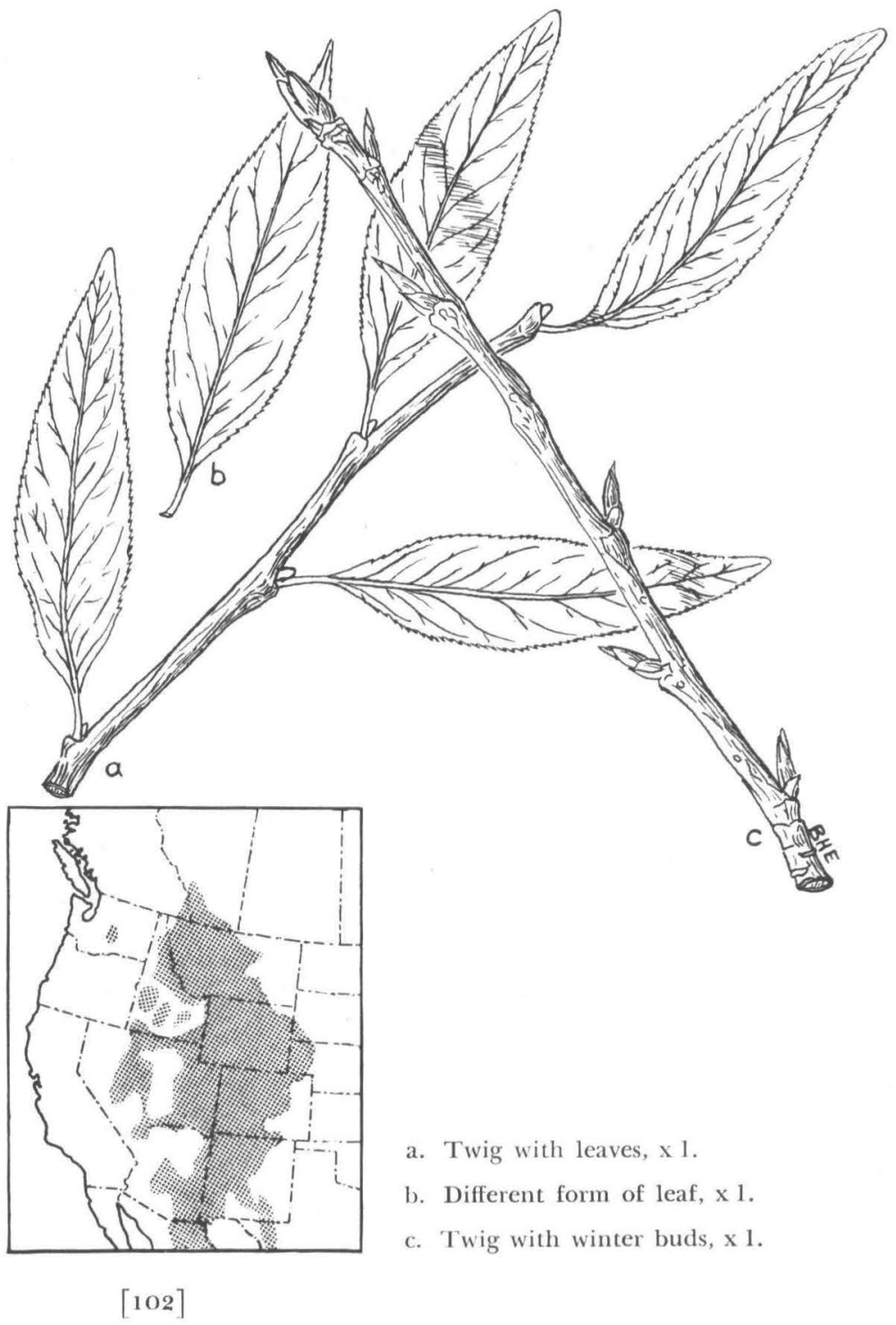




\section{SALICACEAE \\ NarRowleaf Cottonwood \\ Populus angustifolia James}

HABIT. A medium-sized tree 50-70 feet high and 12-20 inches in diameter; crown open and pyramidal with rather slender, erect branches.

LEAVES. Lanceolate to ovate-lanceolate, rarely elliptical or obovate; $2-4$ inches long and $1 / 2-11 / 2$ inches wide, on vigorous shoots sometimes $6-7$ inches long and 11/2 inches wide; apex long-tapering and acute or rounded; cuneate or rounded at base; finely to coarsely serrate; slightly revolute margin; thin and firm; bright yellow-green above, paler and usually glabrous below; petioles short (less than $1 / 3$ length of blade), slender, somewhat flattened on upper side.

FLOWERS. Aments densely flowered, glabrous, shortstalked, 1-21/2 inches long; bracts light brown, glabrous, scarious, deeply filiformly lobed; staminate with 12-30 shortstalked, large, red stamens; pistillate with cup-shaped disk, each ovary with style ending in 2 oblique stigmas.

FRUIT. Capsules broadly ovoid; $1 / 4$ inch long; thin-walled; 2-valved; often abruptly contracted above middle; shortpointed; short-stalked. Seed: light brown, hairy, nearly $1 / 8$ inch long.

TWIGS. Slender; round; yellow-green or orange, becoming ash-gray; marked by pale lenticels and small, oval leaf scars. Winter buds: terminal $1 / 4-\$ / 4$ inch long, slender, long-pointed, with usually 5 scales, chestnut-brown, very resinous and somewhat aromatic.

BARK. Light yellow-green; 3/4-1 inch thick; smooth except near base of old trees where it is divided by shallow furrows into broad ridges.

SILVICAL CHARACTERS. Upper Sonoran, Transition, and Canadian zones; decidedly intolerant; short-lived; on banks of streams at altitudes of 5,000-10,000 feet; frequently planted as street tree in Rocky Mountain region, especially at high altitudes. 


\section{LANCEleaf Cottonwood}

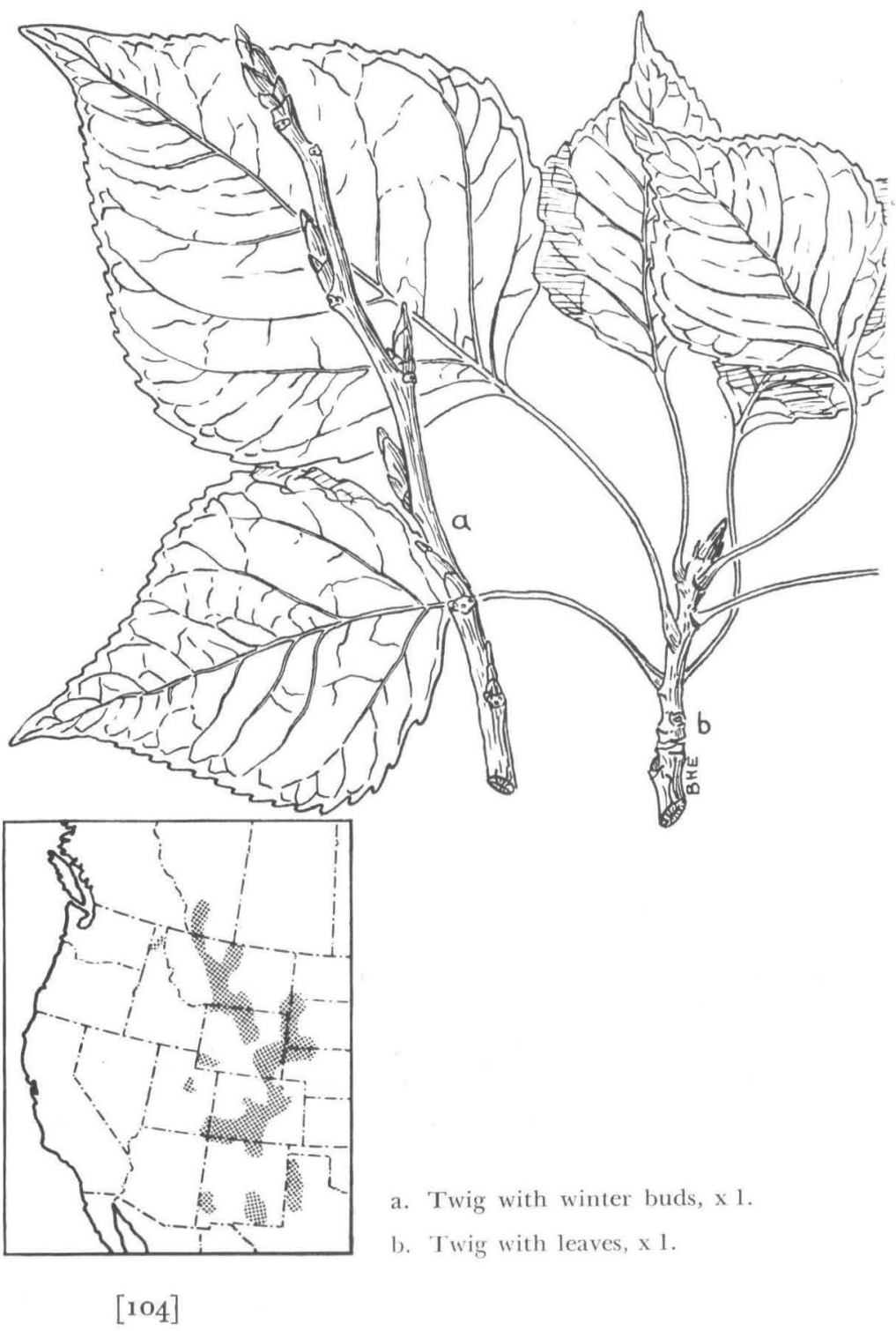




\section{SALICACEAE \\ Lanceleaf CotTonwood}

Populus acuminata Rydb.

HABIT. A medium-sized tree about 40 feet high and 1-2 feet in diameter (larger under cultivation); dense, rounded crown with large spreading and ascending branches.

LEAVES. Rhombic-lanceolate to ovate; 2-4 inches long and $3 / 4-2$ inches wide; apex abruptly acuminate; base narrowed and usually cuneate; coarsely crenate-serrate; rather thick and leathery; dark green and lustrous above, dull green below; petioles nearly round, slender, 1-3 inches long.

FLOWERS. Aments slender, short-stalked, loosely flowered, 2-3 inches long; bracts light brown, scarious, glabrous, deeply filiformly lobed; staminate with wide oblique disk containing 15-20 short-stalked, red stamens; pistillate with deep, cupshaped disk, ovary glabrous and broadly ovoid with nearly sessile, irregularly lobed stigmas.

FRUIT. Capsules oblong-ovoid; about $1 / 3$ inch long; thinwalled; acute; 3- or rarely 2-valved; on short, slender stalks. Seed: light brown, hairy, about $1 / 12$ inch long.

TWIGS. Slender; round or slightly 4-angled; pale yellowbrown; roughened by elevated, oval, horizontal leaf scars. Winter buds: terminal about $1 / 3-3 / 4$ inch long, narrow, glabrous, acuminate, with $6-7$ scales, light chestnut-brown, rather resinous and nonaromatic.

BARK. Nearly white and smooth on young trunks; on old trees gray-brown, $1 / 2$ inch thick, deeply divided into flat ridges.

SILVICAL CHARACTERS. Upper Sonoran and Transition zones; very intolerant; along stream banks in rather arid habitats; sometimes planted as shade tree in Rocky Mountain region.

GENERAL. The variety Populus acuminata var. rehderi Sarg. occurs along water courses in southeastern New Mexico; this variety differs from the species in having woolly-pubescent twigs and buds as well as larger leaves on longer petioles. $\mathrm{X}$ Populus andrewsii Sarg., reported near Boulder, Walsenburg, and in Montrose, Colorado, is believed to be a natural hybrid between $P$. acuminata and $P$. sargentii. 


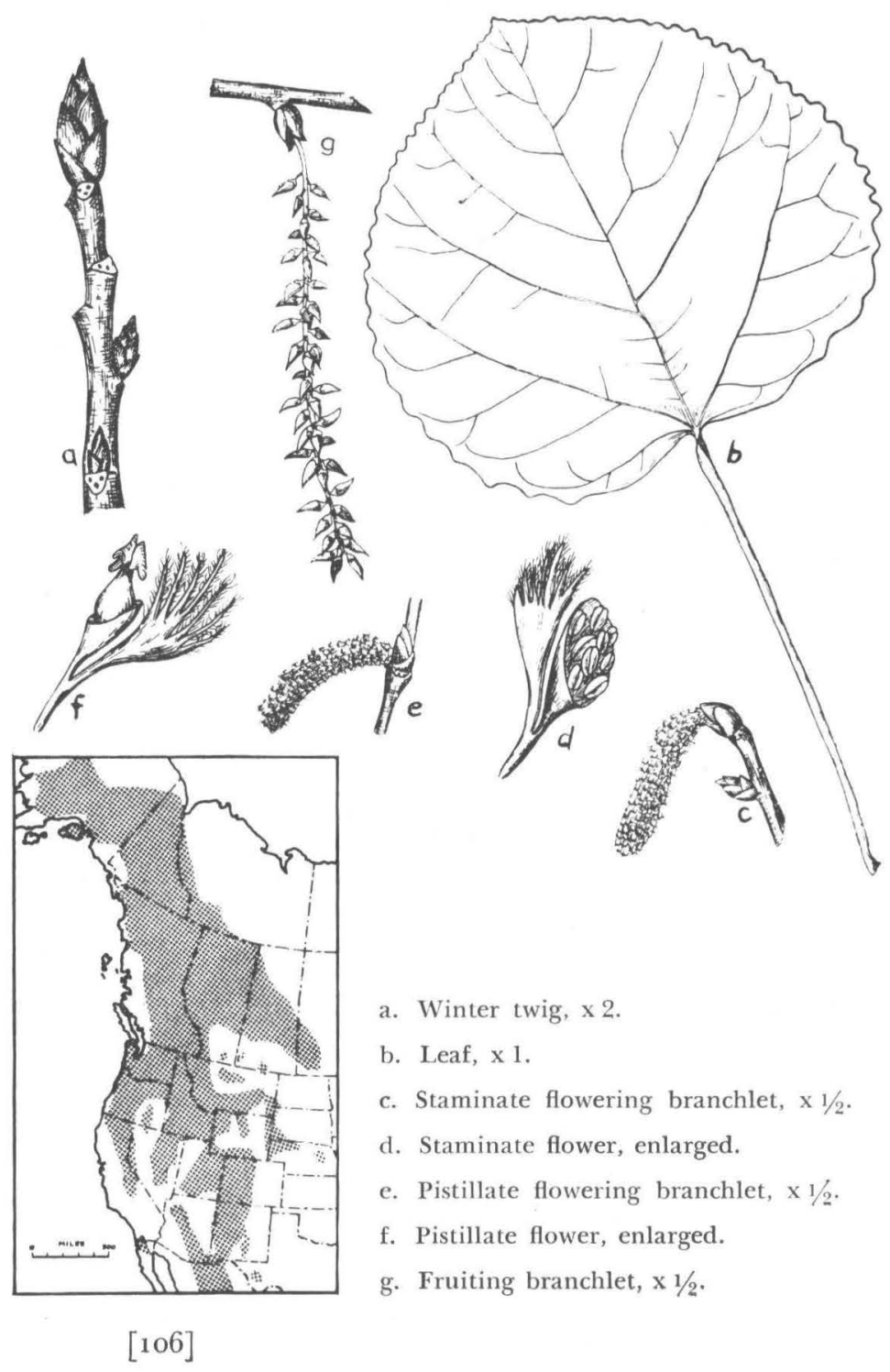




\section{SALICAGEAE \\ Golden Aspen. Poplar}

Populus tremuloides var. aurea (Tides.) Daniels

HABIT. A small to medium-sized tree seldom over 50-60 feet high and 1-2 feet in diameter; loose, rounded crown with slender, often contorted branches.

LEAVES. Semiorbicular or broadly ovate to rhombic; $11 / 2^{-}$ 3 inches in diameter; apex abruptly acute to acuminate; base rounded; finely crenate-serrate with glandular teeth; thin and firm; green and lustrous above, dull or pale below; glabrous; turning golden-yellow in autumn; petioles flattened, $11 / 2^{-3}$ inches long.

FLOWERS. Aments $11 / 2-3$ inches long, the pistillate gradually becoming longer; bracts deeply 3-5-lobed and fringed with long hairs; staminate with entire, oblique disk containing 6-12 stamens; pistillate with crenate disk, each ovary with short style and 2, erect, 2-lobed, slender, red stigmas.

FRUIT. Capsules narrowly conical; $1 / 4$ inch long; curved; 2-valved; gray-hairy when opening. Seed: light brown, $1 / 32$ inch long.

TWIGS. Slender; round; bright red-brown and lustrous, becoming gray; marked by orange lenticels and roughened by elevated leaf scars. Winter buds: terminal $1 / 4-1 / 2$ inch long, conical, sharp-pointed, red-brown, covered by $6-7$ visible scales, sometimes slightly resinous.

BARK. Smooth; green-white to cream-colored; often marked by dark, wartlike protuberances; becoming dark and furrowed near base of old trunks.

SILVICAL CHARACTERS. Canadian and Hudsonian zones; shallow-rooted; exceedingly intolerant; a prolific seeder, reproducing vigorously on cut-over or burned-over areas and forming a protective canopy for more tolerant species; in the Rocky Mountains reproduction is largely from suckers.

GFNERAL. The species, Populus tremuloides Michx., is considered as the eastern form and differs from the western variety by relatively trivial characters, the leaves being thinner and ovate and turning a pale lemon-yellow in the fall. 
Rio Grande Cottonwood

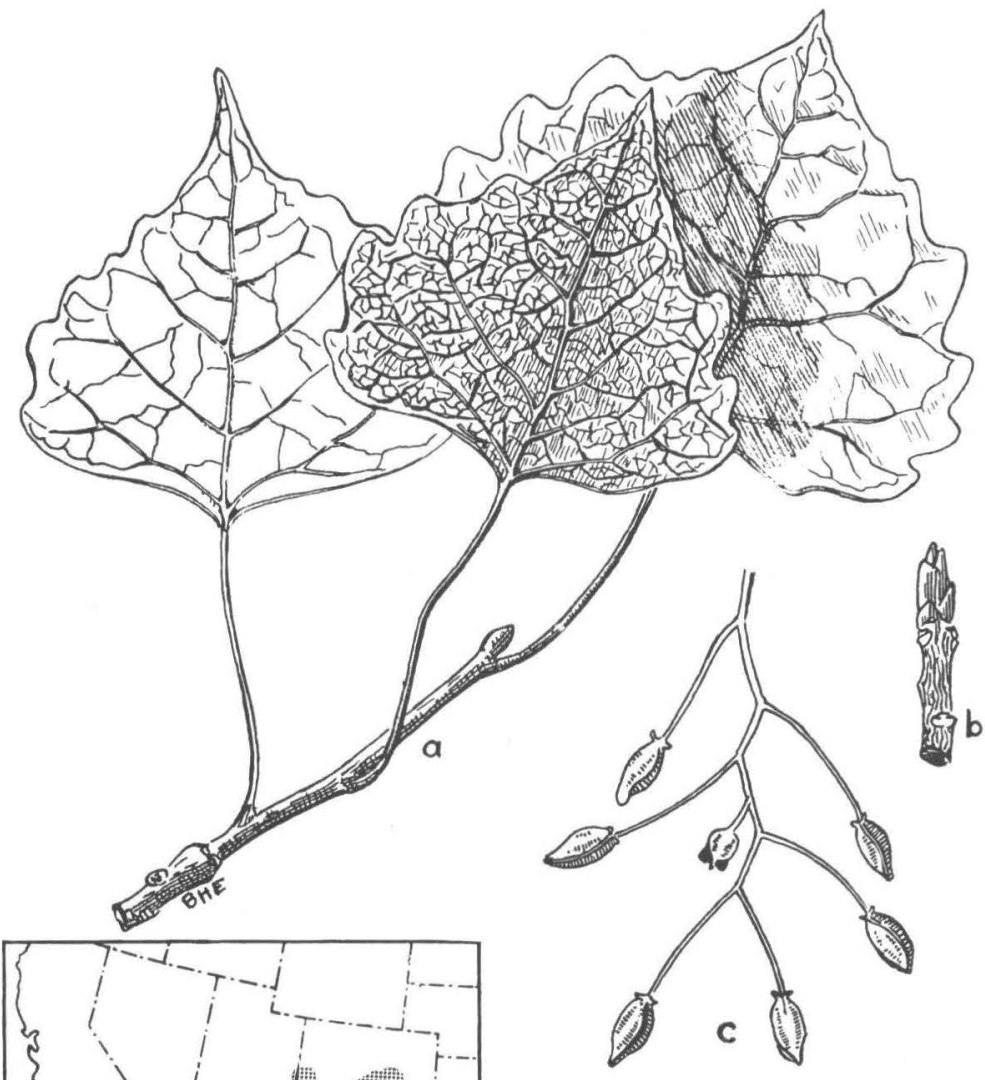

a. Twig with leaves, $\times 1$.

b. Winter bud, $\times 1$.

c. Fruit, $\mathrm{x} 1$.

[108] 


\section{SALICACEAE}

\section{Rio Grande Cottonwood}

\section{Populus wislizeni (Wat.) Sarg. (Populus fremontii var. wislizeni Wat.)}

HABIT. A large tree from 40-100 feet high and 2-4 or more feet in diameter; broad, rather flat crown with large, widespreading branches.

LEAVES. Broadly deltoid; $2-21 / 2$ inches long and 3 inches wide (larger on vigorous shoots); apex abruptly short- or long-pointed; base entire and truncate or cordate; coarsely and irregularly serrate with usually less than 10 teeth on each side of blade; thick and leathery; glabrous; yellow-green and lustrous above, paler below; turning bright lemon-yellow before falling; petioles flattened, slender, glabrous, $1 \frac{1}{2}-2$ inches long, without glands at apex.

FLOWERS. Aments 2-4 inches long, the pistillate becoming 4-5 inches; bracts scarious, light red, divided into elongated filiform lobes at apex; staminate disk broad and stamens numerous with large anthers and short filaments; pistillate disk cupshaped, enclosing the long-stalked, ovoid ovary to the middle; stigmas 3, crenulate lobed, on short style.

FRUIT. Capsules oblong-ovoid; $1 / 4$ inch long; thick-walled; acute; 3 - or 4-valved; slightly ridged; pedicels slender, $1 / 2-3 / 4$ inch long; rachis slender, glabrous, sparsely fruited. Seed: light brown, hairy tufted.

TWIGS. Stout; round; glabrous; light orange-brown, becoming gray; roughened by elevated leaf scars. Winter buds: terminal $1 / 3-3 / 5$ inch long, ovoid, acute, brown, lustrous, puberulous, resinous but nonaromatic.

BARK. 'Thick; pale gray-brown; deeply furrowed into wide, flat, connecting ridges.

SILVICAL CHARACTERS. Lower and Upper Sonoran zones; intolerant; short-lived; along streams in an arid region; widely planted as a shade tree in Texas and New Mexico.

GENERAL. Closely related to $P$. fremontii $S$. Wats. and long considered a form or variety of this species. 
Plains Cottonwood

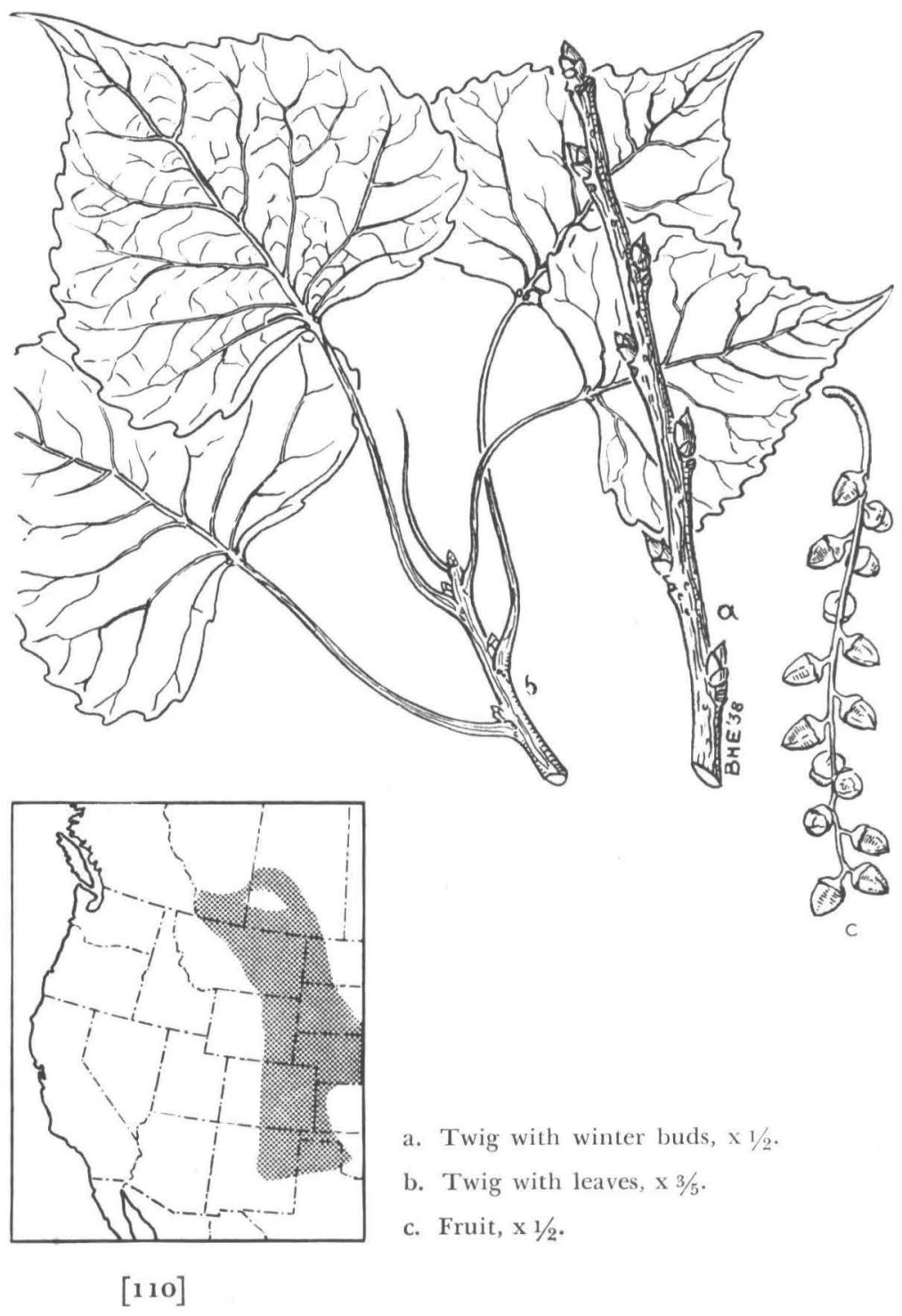




\section{SALICACEAE \\ Plains Cottonwood \\ Populus sargentii Dode \\ (Populus deltoides var. occidentalis Rydb.)}

HABIT. A large tree 60-90 feet high and often $6-7$ feet in diameter; broad, open crown with stout, erect, and spreading branches.

LEAVES. Broadly deltoid; 3-4 inches long and usually slightly longer than broad; apex abruptly contracted into slender, acuminate point (rarely rounded); base truncate or slightly cordate; coarsely crenate-serrate; thick and firm; glabrous; light green and lustrous; petiole flattened, slender, 21/2$31 / 2$ inches long, usually with 2 small glands at apex.

FLOWERS. Aments short-stalked, glabrous, not very densely flowered; bracts light brown, scarious, fringed at apex, small and appressed at base of pistillate flower; the staminate with broad disk containing 20 or more short-stalked, yellow stamens; the pistillate with small, cup-shaped disk enclosing base of subglobose ovary which bears $3-4$, broad-lobed stigmas.

FRUIT. Capsules oblong-ovoid, about $2 / 5$ inch long and 3-4 times longer than pedicel; thin-walled; gradually or abruptly narrowed to blunt apex. Seed: light brown, hairy, about $1 / 16$ inch long.

TWIGS. Stout; round or angular; glabrous and light yellow; conspicuously roughened by elevated leaf scars. Winter buds: terminal $1 / 2$ inch long, conical, acute, olive-green to brown, puberulous, coated with amber-colored, nonaromatic resin.

BARK. Gray and smooth on young trunks; on old trees gray, thick, deeply furrowed, and broadly ridged.

SILVICAL CHARACTERS. Upper Sonoran zone; intolerant; short-lived; the common cottonwood of stream banks in the eastern foothills of the Rocky Mountains from Canada to New Mexico; often planted as shade tree in Rocky Mountain region.

GENERAL. Much resembling the eastern cottonwood, $P$. deltoides var. virginiana (Cast.) Sudw., with which, in general appearance, it was long confused. 
Fremont Cottonwood
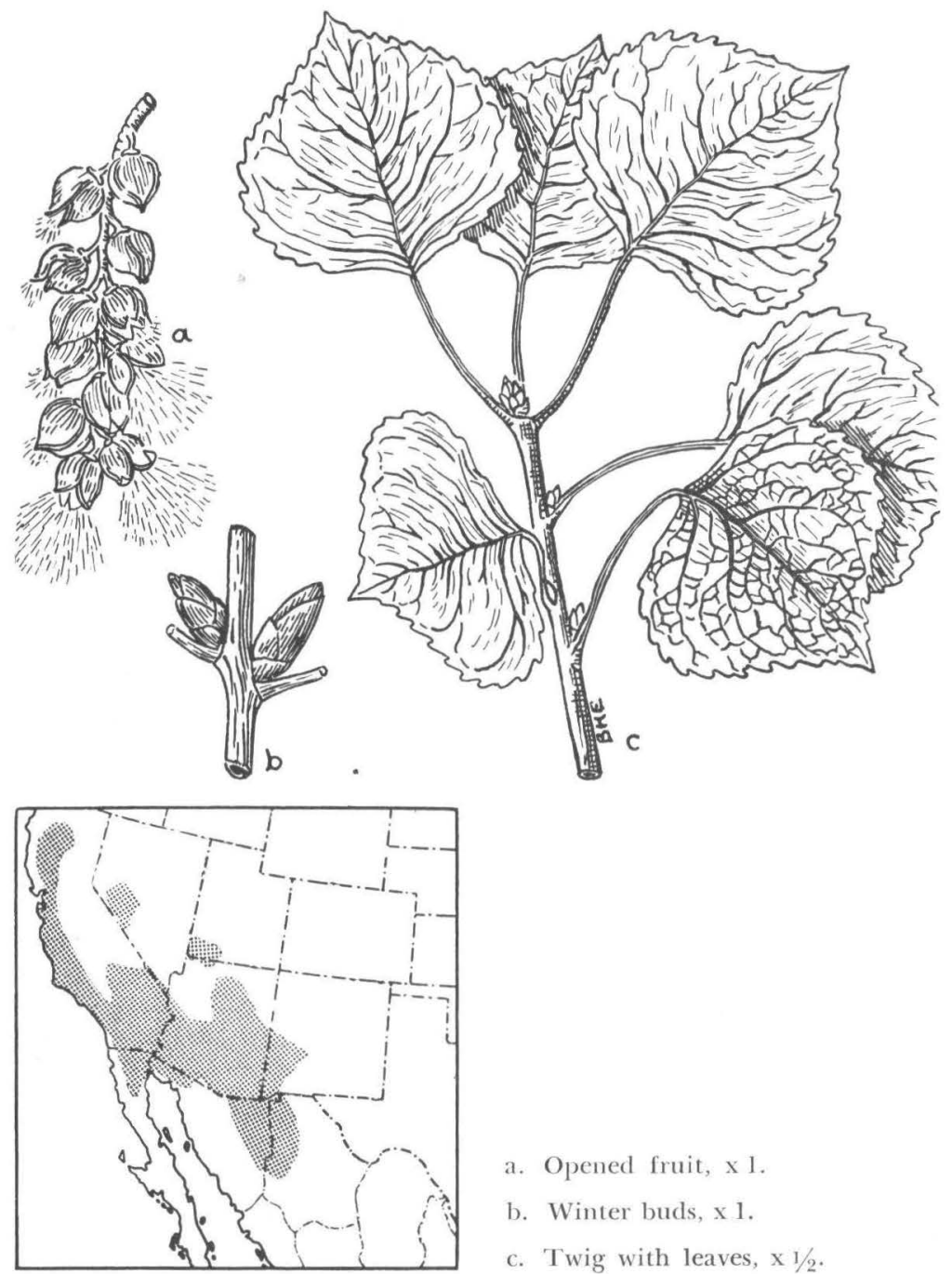

a. Opened fruit, x 1 .

b. Winter buds, $\times 1$.

c. Twig with leaves, $\times 1 / 2$.

[1 112$]$ 


\section{SALICACEAE}

\section{Fremont Cottonwood}

Populus fremontii S. Wats.

HABIT. A large tree occasionally 100 feet high and 4-6 feet in diameter; wide, open crown with stout branches.

LEAVES. Deltoid or reniform; $2-21 / 2$ inches long and $21 / 2-3$ inches wide; apex abruptly contracted into short point; base entire and cordate or cuneate; coarsely serrate; thick and firm; glabrous; bright yellow-green; petioles flattened, yellow, $11 / 2^{-3}$ inches long, without glands at apex.

FLOWERS. Staminate aments densely flowered, $11 / 2-2$ inches long, disk broad with 60 or more large red stamens; pistillate aments sparsely flowered, bracts filiformly lobed, large and dilated, disk cup-shaped, enclosing base of ovoid ovary which bears 3 or rarely 4 broad, lobed stigmas.

FRUIT. Capsules ovoid; $1 / 3-1 / 2$ inch long; thick-walled; acute or obtuse; 3- or rarely 4-valved; short-stalked. Seed: light brown, hairy, nearly $1 / 8$ inch long.

TWIGS. Stout; round; mostly glabrous and pale yellow. becoming yellow-gray; only slightly roughened by 3-lobed leaf scars. Winter buds: glabrous; terminal $1 / 3-1 / 2$ inch long, ovoid, acute, light green, much larger than lateral.

BARK. Smooth and gray-brown on young trees; on old trunks $11 / 2^{-2}$ inches thick, dark, deeply furrowed, and ridged.

SILVICAL CHARACTERS. Lower and Upper Sonoran zones; very intolerant; short-lived; along streams in arid regions.

GENERAL. Sargent has differentiated 4 varieties, namely: pubescens (with pubescent twigs) in Utah, Nevada, and California; thornberii (with ellipsoidal capsules, shorter pedicels, smaller disk, and more numerous teeth on leaves) in southern Arizona and New Mexico; toumeyi (with large disks and longpointed leaves shallowly cordate at base) in Arizona; and macrodisca (with long disks nearly enclosing fruit) in southwestern New Mexico. Two species, listed in Sudworth's Check List, $P$. macdougalii Rose and $P$. arizonica Sarg., are here considered as synonyms of $P$. fremontii, it being felt that the characters used in differentiating them do not prove constant. 


\section{The Willows \\ Characteristics of the Genus Salix L.}

HABIT. Shrubs or less frequently trees; latter often with several trunks from greatly extended rootstalk.

LEAVES. Alternate; simple; commonly lanceolate; margins entire or toothed; pinnately veined; sessile or short-petioled; stipules small and soon falling, except on vigorous shoots where they are leaflike and persistent.

FLOWERS. Regular; dioecious; in terminal and axillary aments, appearing with or before the leaves; individual flowers solitary, apetalous, on glandlike disk, subtended by pubescent, entire to dentate, deciduous or persistent scale or bract; staminate with 1-2 or 3-12 stamens inserted on base of bract; pistillate a single, I-celled, sessile or stalked ovary, containing 4-8 ovules on each of 2 placentas, style short, terminating in 2, short, 2-parted stigmas.

FRUIT, A 1-celled, 2-valved, acuminate capsule. Seed: small, dark brown, tufted with long, silky hairs, bouyant, of transient vitality.

TWIGS. Slender to stout; round; tough; often easily separated at junction with branch; marked by elevated leaf scars; pith homogeneous, terete. Winter buds: terminal absent; lateral covered by single, caplike scale.

BARK. Astringent; scaly; variously colored.

WOOD. Light; soft; weak; usually brittle; durable in some species; heartwood pale brown, often tinged with red; used to small extent for athletic goods and charcoal.

SILVICAL CHARACTERS. Intolerant; fast-growing; remarkable vitality and sprouting vigorously from stumps or cuttings; usually swamp or moisture-loving plants.

GENERAL. This genus contains about 170 species scattered over the Northern Hemisphere, with about 70 species native to North America; identification of the various species is difficult; while 13 species native to the Rocky Mountain region occasionally reach tree size, there is only one, Salix amygdaloides, which can typically be considered a tree; the key includes the 13 species occasionally attaining tree size. 


\section{KEY TO THE SPECIES OF SALIX OCCASIONALLY REACHING TREE SIZE IN THE ROCKY MOUNTAIN REGION}

I. Stamens 3 to 12; filaments free; flower bracts deciduous.

A. Leaves green below; petioles eglandular at base.

1. Capsule hairy; twigs yellow-gray......1. S. gooddingi Ball.

2. Capsule glabrous; twigs red to purple..2. S. nigra Marsh.

B. Leaves pale or bluish below; ovary and capsules glabrous.

1. Petioles without glands at base of leaf.

a. Twigs easily separable, flower bracts entire; throughout region............. S. amygdaloides Anders.

b. Twigs firmly attached; flower bracts toothed.

(1) Leaves silver-white below; capsules short-stalked; stamens usually 3; Southwest.............. 4. S. bonplandiana var. toumeyi Schn.

(2) Leaves glaucous or yellow-hairy below; capsules long-stalked; stamens 4-6; Southwest......... $\ldots \ldots \ldots \ldots \ldots \ldots \ldots \ldots \ldots . . \ldots$. . . . . . . . . . . . . .

2. Petioles glandular; twigs separable; flower bracts toothed; entire region.......6. S. lasiandra Benth.

II. Stamens 2.

A. Bracts deciduous, yellowish; filaments free, more or less hairy; stipe of ovary much shorter than bract.

1. Leaves $1 / 3^{-11 / 3 " ~ l o n g, ~ l i n e a r ; ~ s t i g m a s ~ l i n e a r ; ~ s o u t h w e s t-~}$ ern ...................... S. taxifolia H. B. K.

2. Leaves over 11/3" long, mostly linear-lanceolate; stigmas short.

a. Leaves white-hairy below; stipules minute or wanting; entire region................ 8. s. exigua Nutt.

b. Leaves nearly glabrous below; stipules large, deciduous; eastern.............. S. interior Rowlee.

B. Bracts persistent, darker; filaments glabrous.

I. Stipe of ovary longer than bract; filaments free.

a. Ovary and capsule glabrous; bracts dark brown, hairy at base; northern..........10. S. mackenziana Barr.

b. Ovary and capsule hairy; bracts light, hairy; entire region..................11. S. bebbiana Sarg.

2. Stipe of ovary and capsule much shorter than bract.

a. Filaments somewhat united; capsules glabrous; southwest................ 12. S. lasiolepis Benth.

b. Filaments free; capsule pubescent; entire region..... ..................... S. scouleriana Barr. 

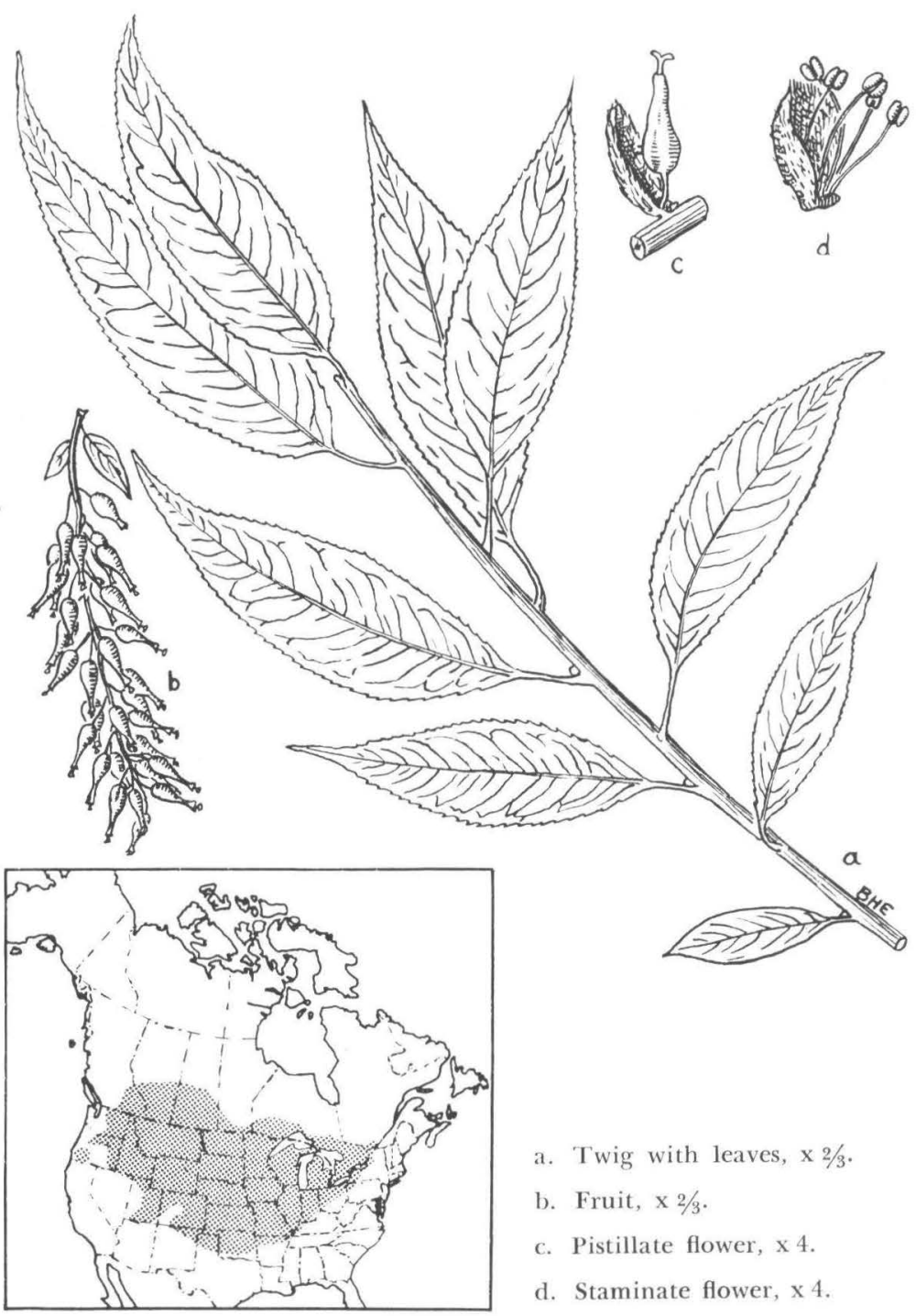

a. Twig with leaves, $\times 2 / 3$.

b. Fruit, $\times 2 / 3$.

c. Pistillate flower, $\mathrm{x} 4$.

d. Staminate flower, $\mathrm{x} 4$. 


\section{SALICACEAE \\ Peachleaf Willow \\ Salix amygdaloides Anders.}

HABIT. A tree rarely $60-70$ feet high and 2 feet in diameter; trunk single, columnar; rather narrow, rounded crown with straight, ascending branches.

LEAVES. Lanceolate to ovate-lanceolate; $2-5$ inches long and 3/4-11/4 inches wide; apex long acuminate; cuneate or rounded and often unequal at base; finely serrate; thin and firm; light green and lustrous above, pale and glaucous below; petioles slender, round, $1 / 2-3 / 4$ inch long, without glands at base of leaf.

FLOWERS. Aments stalked, hairy, slender, 2-3 inches long; bracts yellow, entire, densely hairy on inner surface; staminate with 3-9 stamens, filaments free and hairy at base; pistillate with long-stalked, glabrous, oblong-conic ovary with short style and notched stigmas.

FRUIT. Capsules globose-conic; 1/4 inch long; long-stalked; glabrous; light yellow-red. Seed: minute, hairy-tufted.

TWIGS. Slender; glabrous, lustrous, dark orange or redbrown, becoming light orange-brown; marked by scattered pale lenticels; easily separable from branch. Winter buds: $1 / 8$ inch long, broadly ovoid, swollen on one side, dark brown.

BARK. Brown, often tinged with red; $1 / 2-3 / 4$ inch thick; divided by irregular furrows into broad, flat, connecting ridges.

SILVICAL CHARACTERS. Upper Sonoran and Transition zones; intolerant; reproduction not abundant; in moist sites along banks of streams.

GENERAL. This willow is the only species native to the Rocky Mountain region which is typically a tree; other species occasionally attain tree size, but they are typically shrubs; the variety, Salix amygdaloides var. wrightii (Anders.) Schn., a southwestern form, differs from the species chiefly in its yellow or yellow-brown glabrous branches. 


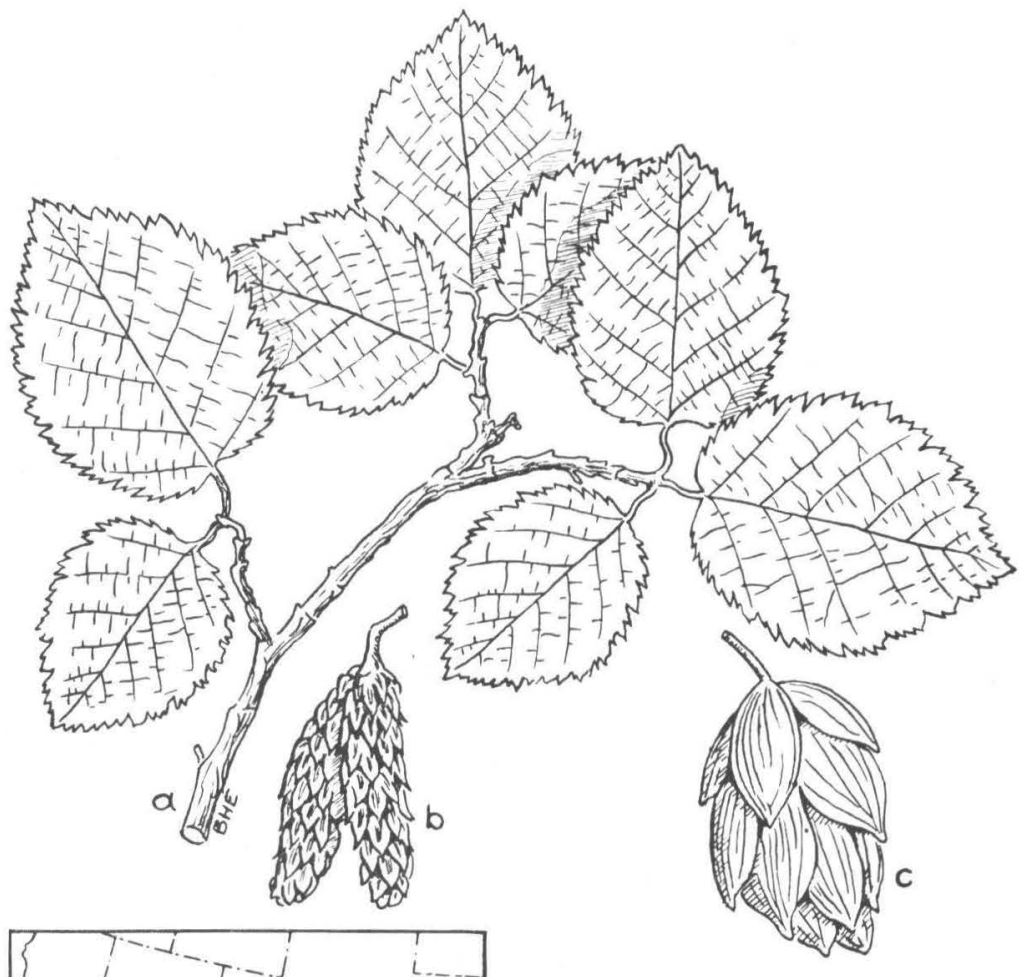

a. Twig with leaves, $\mathrm{x} 1$.

b. Staminate flower, $\times 1$.

c. Fruit, x 1 . 


\section{WESTERN HOPHORNBEAM. IRONWOOd \\ Ostrya knowltonii Cov.}

HABIT. A small tree 20-30 feet high and 12-18 inches in diameter; trunk frequently dividing; crown narrow, roundtopped with slender, pendulous, often contorted branches.

LEAVES. Alternate; simple; elliptic to ovate; $1-2$ inches long and 1-11/2 inches wide; acute or round at apex; margins sharply serrate; thin and tough; dark yellow-green and pilose above, pale and soft-pubescent below; deciduous; turning dull yellow in autumn; petioles $1 / 8-1 / 4$ inch long, slender, hairy; stipules $1 / 2$ inch long and wide, yellow-green, fugacious.

FLOWERS. Regular; monoecious; perianth absent; appearing with leaves; staminate in long, clustered, persistent aments, each flower composed of 3-14 stamens crowded on a hairy receptacle and attached to base of ovate, green and red scale; pistillate in erect, loose, terminal aments, in pairs at base of leaflike scale, enclosed in hairy sacklike involucre, single ovule in each cell of 2-celled ovary.

FRUIT. Small ( $1 / 4$ inch long), 1-celled, l-seeded, ovoid, flat, unwinged nut; enclosed in enlarged ( 1 inch long), pale, membranaceous, involucre of flower; in loose, suspended strobiles $1-1 \frac{1}{2}$ inches long, resembling clusters of hops.

TWIGS. Slender; round; dark green and hoary-tomentose at first, becoming dark brown and glabrous; marked by numerous pale lenticels. Winter buds: terminal absent; lateral $1 / 8$ inch long, pointed, ovoid, dark brown-red, scaly.

BARK. Thin ( $1 / 8$ inch); light gray, tinged with red; separating into loose, platelike scales; inner bark bright orange.

WOOD. Heavy; hard; strong; close-grained; diffuse-porous; heartwood light red-brown; sapwood thin; unimportant.

SILVICAL CHARACTERS. Upper Sonoran and Transition zones; restricted and rare on cañon slopes in the piñon belt.

GENERAL. $O$. baileyi Rose is here considered a synonym of $O$. knowltonii; the eastern species, $O$. virginiana (Mill.) Koch., entering this region in the foothills of South Dakota and in northwestern Nebraska, differs from the southwestern species in its larger oblong-lanceolate leaves. 


\section{BETULACEAE}

\section{The Birches \\ Characteristics of the Genus Betula L.}

HABIT. Deciduous, graceful trees and shrubs; crown on young trees narrow, pyramidal, symmetrical; branches short and slender, more or less erect on young trees and becoming horizontal or pendulous on older trees.

LEAVES. Alternate; simple; mostly ovate to triangular; serrate, dentate, or lobulate; petioled; stipules fugacious; scarious.

FLOWERS. Regular; monoecious; apetalous; appearing before or with leaves; staminate in 1-3-clustered, long, pendulous aments produced early the previous season, every bract with 3 individual flowers, each of 4 stamens adnate to a 4-parted calyx; pistillate in solitary, small, slender aments appearing on ends of spurlike lateral branches below the staminate flowers, individual flowers naked, in clusters of 3, and subtended by 3-lobed bract.

FRUIT. Small, compressed, laterally winged nutlet; in erect or pendent strobiles; scales deciduous from persistent cone axis at maturity, releasing the nutlets.

TWIGS. Slender; round; marked by horizontal lenticels and small leaf scars; spur shoots with paired leaves commonly present on old growth; pith small, round, homogeneous. Winter buds: terminal absent, lateral with imbricated scales; twig lengthening by one of upper lateral buds.

BARK. Smooth; resinous; marked by horizontally elongated lenticels; often peeling off in thin, papery layers.

WOOD. Rather heavy and hard; diffuse-porous; some species highly valued for timber.

SILVICAL CHARACTERS. Mostly short-lived and adapted to planting on poor, sandy or boggy soil; many used for ornamental planting because of handsome foliage and showy bark.

GENERAL. This genus contains about 40 species of trees and shrubs scattered through the Northern Hemisphere; the European white birch (Betula pendula Roth.) and especially its cut-leaf, weeping variety (dalecarlica Schn.) are often planted in this country. 


\section{KEY TO THE SPECIES OF BE TULA}

I. Bark separating freely into papery layers.

A. Bark red-brown or nearly white; branchlets densely glandular; leaves rhombic to deltoid-ovate; Alaska............ $\ldots \ldots \ldots \ldots \ldots \ldots \ldots \ldots \ldots$. Betula neoalaskana, p. 125 .

B. Bark cream-white or occasionally orange-brown; branchlets not glandular, or sparingly so; leaves ovate; northern (onc locality in Colonado) ........2. Betula papyrifera, p. 123. 1. Leaves $3^{\prime \prime}$ or longer.

a. Strobile $1 \% / 4-2^{\prime \prime}$ long, scales with slender base twice as long as expanded upper portion, middle lobe slightly longer than lateral lobes; northern Montana and Idaho....................... montanensis.

b. Strobile 11/4-11/2" long, scales with base not twice as long as expanded upper portion, middle lobe much Jonger than lateral Jobes; northern Montana and Idaho into Canada................. var. occidentalis.

2. Leaves not over $21 / 2 "$.

a. Strobile 1-11/2" long, scales puberulous, middle lobe much longer than lateral lobes; northern Montana and Idaho into Canada............... var. subcordata.

b. Strobile 1" long, scales glabrous but ciliate, middle lobe scarcely longer than lateral lobes; Alaskan coast. .

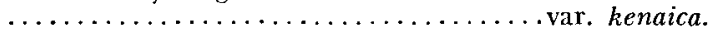

II. Bark not separating into thin layers; branchlets glandular.

A. Leaves truncate or rounded at broad base, acute or acuminate at apex; strobiles $1-11 / 4$ " long and $1 / 2$ " wide; through region................. Betula fontinalis, p. 125.

B. Leaves cuneate at base, acute or rounded at apex; strobiles $1 / 2^{-3 / 4}$ " long and $1 / 6^{\prime \prime}$ wide.

1. Leaves coarsely serrate, 1-11/2" long; Canadian and Alaskan shrub or small tree.... 4 . Betula eastwoodae, p. 125.

2. Leaves crenate-dentate, less than $1 / 2$ " long; low, alpine shrub extending south to Colorado.............. $\ldots \ldots \ldots \ldots \ldots \ldots \ldots \ldots$. Betula glandulosa, p. 125. 


\section{PAPER BirCh}
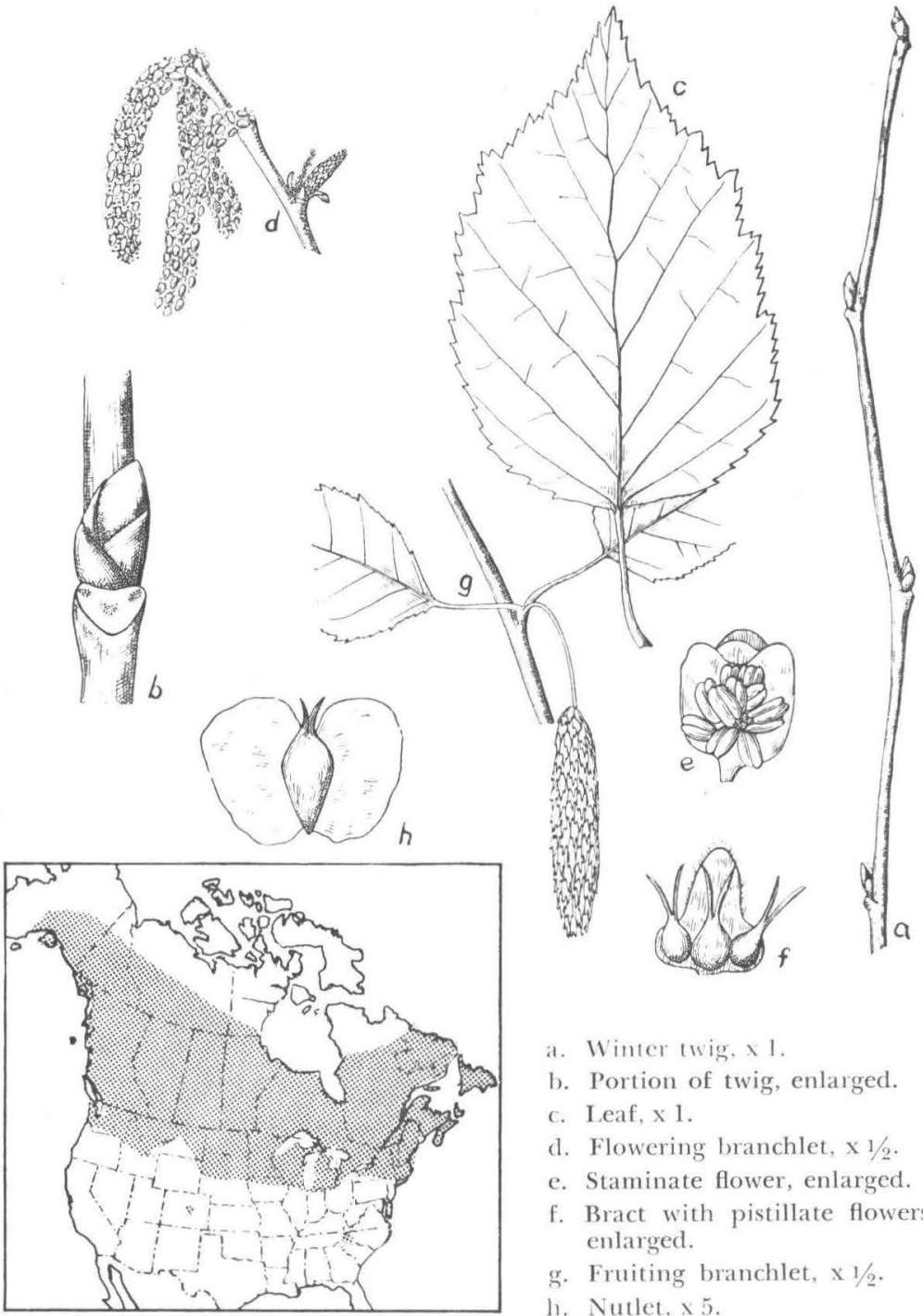

a. Winter twig. $x 1$.

b. Portion of twig, enlarged.

c. Leaf, $\times 1$.

d. Flowering branchlet, $\times 1 / 2$.

e. Staminate flower, enlarged.

f. Bract with pistillate flowers, enlarged.

g. Fruiting branchlet, $\times 1 / 2$.

h. Nutlet, $\times 5$. 


\section{BETULACEAE}

\section{PAPER BIRCH \\ Betula papyrifera Marsh.}

HABIT. A tree 60-70 feet high and 2-3 feet in diameter (rarely larger); old trees with open crowns and short, pendulous branches.

LEAVES. Ovate; $2-5$ inches long and 1-21/4 inches wide; acute or abruptly acuminate; coarsely, irregularly, and usually doubly serrate; thick and firm; dull dark green and glabrous above, light yellow-green, black-glandular and glabrous or puberulous below; turning light, clear yellow in autumn; petioles stout, $1 / 2-3 / 4$ inch long, yellow, glandular; stipules light green, ovate, acute, ciliate on margins.

FLOWERS. Staminate aments $3 / 4-11 / 4$ inches long during winter, becoming 3-4 inches long, slender, brownish, pendent; pistillate aments about $11 / 2$ inches long, slender, erect, greenish; styles bright red.

FRUIT. Nut narrower than its wing, ellipsoidal, $1 / 16$ inch long; strobiles 11/2 inches long, cylindric, glabrous, longstalked; scales lobed, hairy on margins.

TWIGS. At first green, hairy, and marked by scattered, orange-colored, oblong lenticels; becoming dark orange-brown, lustrous, and ultimately covered with white papery bark. Winter buds: $1 / 4$ inch long, obovoid, acute, dark chestnutbrown, glabrous.

BARK. Cream-white; separating into thin, papery layers; marked by long, narrow, raised lenticels; inner bark orange.

WOOD. Moderately heavy; hard; strong; tough; closegrained; heartwood light brown, tinged with red; sapwood thick, whitish; used for pulp, lumber, turned articles, and fuel.

SILVICAL CHARACTERS. Canadian zone; intolerant; short-lived; shallow roots; reproduction vigorous, taking over extensive areas following fire; rich or sandy soils.

GENERAL. 'Three varieties [subcordata (Rydb.) Sarg., montanensis (Butl.) Sarg., and occidentalis (Hook.) Sarg.] are differentiated in the Rocky Mountain region; a similar Alaskan form has been designated as either Betula kenaica Evans. or Betula papyrifera var. kenaica A. Henry. These 4 forms have been included in the Key and distribution map. 


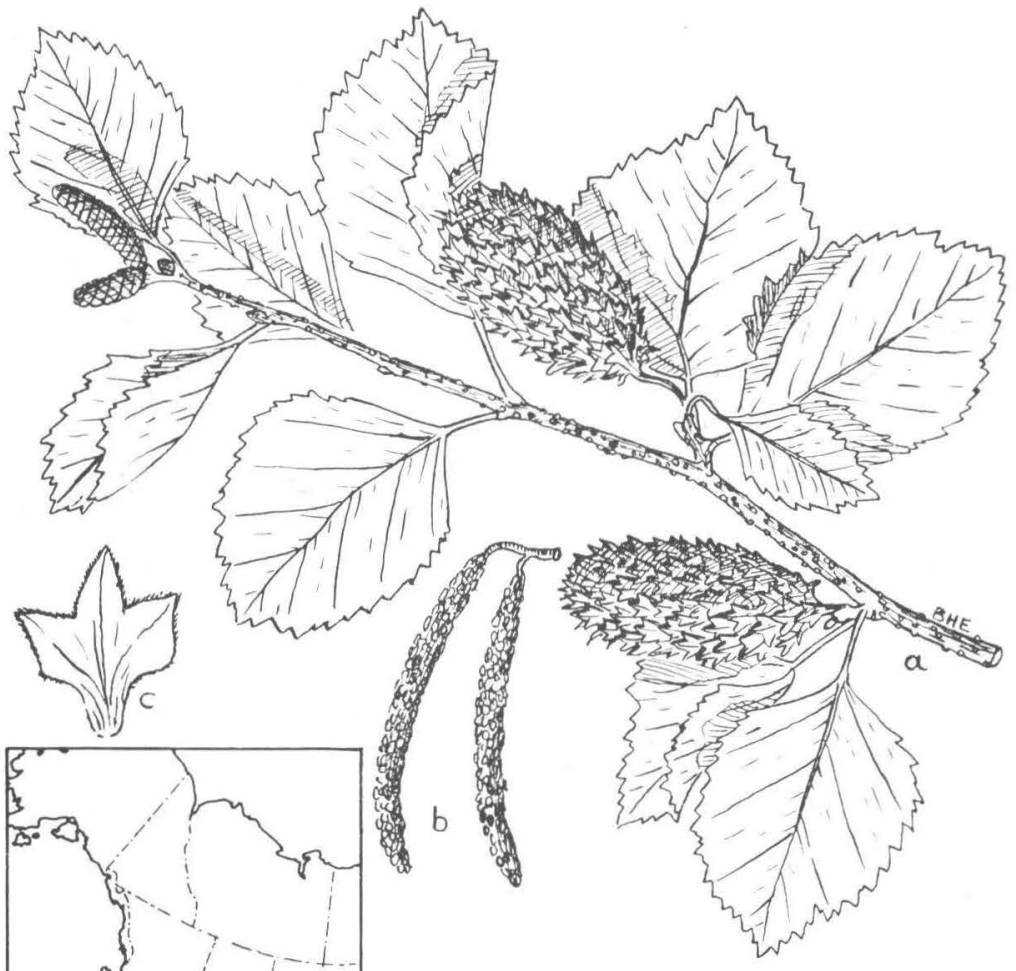

a. Twig with leaves and fruit, $\mathrm{x} 1$.

b. Staminate aments, $\times 1 / 2$.

c. Scale of fruit, $\mathrm{x} 4$. 


\section{Water Birch. ReD Birch}

Betula fontinalis Sarg. (Betula occidentalis Nutt.)

HABIT. A shrub or small tree 20-25 feet high and 12-14 inches in diameter; broad, open crown with ascending branches; frequently in crowded, dense thickets.

LEAVES. Ovate; 1-2 inches long and 3/4-1 inch wide; acute or acuminate; sharply and often doubly serrate; sometimes slightly lobed; thin and firm; glabrous; dark dull green above, pale yellow-green and minutely glandular below; turning dull yellow in autumn; petioles stout, $1 / 3-1 / 2$ inch long, light yellow, glandular-dotted; stipules bright green, slightly ciliate.

FLOWERS. Staminate aments $1 / 2-3 / 4$ inch long during winter, becoming $2-21 / 2$ inches long, chestnut-brown; pistillate aments about $3 / 4$ inch long, green; styles bright red.

FRUIT. Nut nearly as wide as its wing, ovoid or obovoid; strobiles $1-11 / 4$ inches long, cylindric, puberulous or glabrous, long-stalked; scales lobed, ciliate.

TWIGS. At first light green and glandular, becoming dark red-brown; marked by horizontal lenticels. Winter buds: $y$ inch long, ovoid, acute, very resinous, chestnut-brown.

BARK. Thin ( $1 / 4$ inch); smooth; lustrous dark bronze; marked by pale horizontal lenticels, becoming on old trunks 6-8 inches long and $1 / 4$ inch wide.

WOOD. Rather light and soft; strong; heartwood light brown; sapwood thick, light-colored; not important; used locally for fencing and fuel.

SILVICAL CHARACTERS. Upper Sonoran and Transition zones; intolerant; shallow root system; reproduction abundant in moist, mineral soil; generally along borders of streams in moist mountain valleys and cañons.

Two other species of birch reach tree size in Canada or Alaska; Betula neoalaskana Sarg. and Betula eastwoodae Sarg. The latter is closely related to the resin birch, Betula glandulosa Michx., a shrubby form common to peat bogs and high mountains in the west. 


\section{BETULACEAE}

\section{The Alders \\ Characteristics of the Genus Alnus L.}

HABIT. Deciduous shrubs or small to medium-sized trees.

LEAVES. Alternate; simple; usually serrate or dentate; pinnately veined; falling without change of color; petioled; stipules fugacious, ovate, acute, scarious.

FLOWERS. Regular; monoecious; apetalous; mostly appearing before or with leaves (rarely opening in autumn); in 1-3-flowered cymes; formed during previous season; staminate in long, pendulous aments, every scale bearing 3-6 flowers, each flower subtended by 3-5 bractlets and composed of 4parted calyx and 4 (rarely 1-3) stamens; pistillate in erect, stalked, ovoid or oblong aments, appearing below staminate flowers, individual flowers in pairs, composed of a naked ovary surmounted by 2 stigmas and subtended by $2-4$ bractlets.

FRUIT. Small, flat, chestnut-brown, wingless or laterally winged nutlet, bearing remnants of style at apex; in persistent, semi-woody strobiles, each scale bearing 2-4 nutlets.

TWIGS. Slender to moderately stout; round; reddish or tinged with red; marked by raised leaf scars and lenticels; pith homogeneous, triangular in cross section. Winter buds: terminal absent; lateral-stalked, 2-3-scaled, usually red; twig lengthening by one of upper lateral buds.

BARK. Astringent; mostly gray; smooth, except at the base of trunks of large trees.

WOOD. Light; soft; straight-grained; diffuse-porous; durable in water; heartwood red-brown; sapwood very thick and whitish.

SILVICAL CHARACTERS. Tolerant to intolerant; rather short-lived; shallow, spreading roots; on moist or wet sites, commonly along streams or on mountain slopes.

GENERAL. This genus contains about 30 species scattered through the cooler portions of the Northern Hemisphere and extending into the mountains of South America; 9 species are native to the United States, 6 of these attaining tree size; only 1 species is of commercial importance, the red alder Alnus rubra bong. native to the Pacific Coast. 


\section{KEY TO THE SPECIES OF ALNUS}

I. Wings of nut broad; winter buds dark purple, pubescent; flowers opening in spring with or after leaves; stamens 4; leaves ovate, lobulate, doubly serrate; west from Montana and Alberta........................ Alnus sinuata, p. 131.

II. Wings of nut reduced to narrow border; winter buds red; flowers opening in winter or in spring before unfolding of leaves.

A. Stamens 4; leaves oblong-ovate, mostly rounded at base, lobulate, doubly serrate, not glandular-dotted; winter buds $1 / 4-1 / 3^{\prime \prime}$ long, bright red, puberulous; through region to northern New Mexico.........2. Alnus tenuifolia, p. 129.

B. Stamens 1-3; leaves ovate, oval, or oblong-lanceolate, cuneate at base, not lobulate, frequently glandular-dotted; winter buds $1 / 2$ " long, dark red.

1. Leaves ovate or oval, rounded or acute, seldom doubly serrate; winter buds pubescent; west from northern Idaho............... Alnus rhombifolia, p. 133.

2. Leaves oblong-lanceolate, acute, usually doubly serrate; winter buds glabrous; southern New Mexico and Arizona................. Alnus oblongifolia, p. 135. 


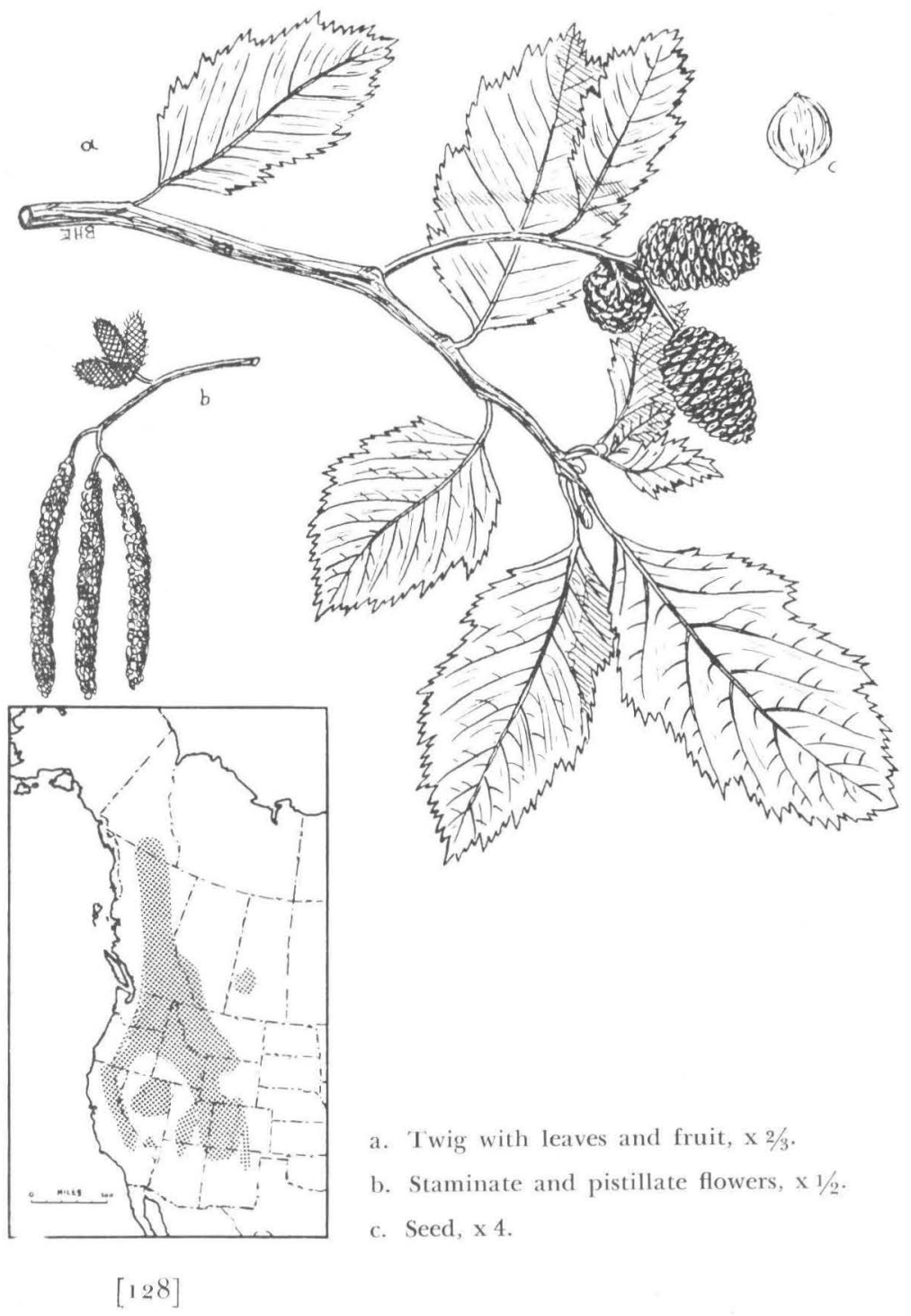




\section{BETULACEAE}

\section{I'hinleaf Alder. Mountain Alder \\ Alnus tenuifolia Nutt.}

HABIT. A shrub or small tree occasionally 30 feet high and 6-8 inches in diameter; crown narrow and round-topped with slender, spreading, slightly pendulous branches.

LEAVES. Ovate-oblong; $2-4$ inches long and $11 / 2-21 / 2$ inches wide; mostly rounded at base; acute or acuminate; slightly, acutely and laciniately lobed; doubly serrate; thin and firm; clark green and glabrous above, pale yellow-green and glabrous or puberulous below with a stout, orange-colored midrib; petioles stout, slightly grooved, orange-colored, $1 / 2-1$ inch long; stipules $1 / 2$ inch long, thin, pale-pubescent.

FLOWERS. Staminate aments $3 / 4-1$ inch long and light purple during winter, becoming $11 / 2-2$ inches long in spring, calyx lobes shorter than the 4 stamens; pistillate aments $1 / 4$ inch long, dark red-brown.

FRUIT. Nut nearly circular to slightly obovoid, wing reduced to thin, membranaceous border; strobiles $1 / 3-1 / 2$ inch long, obovoicl-oblong; scales truncate, much thickened, 3-lobed at apex.

TWIGS. Slender; pubescent, pale brown and marked by few, large orange-colored lenticels at first, becoming glabrous and light brown or gray. Winter buds: $1 / 4^{-1 / 3}$ inch long, bright red, puberulous.

BARK. Thin ( $1 / 2$ inch); bright red-brown; broken on surface into closely appressed scales on old trunks.

WOOD. Heartwood light brown; unimportant because of small size.

SILVICAL CHARACTERS. Upper Sonoran to Canadian zones; tolerant when young, becoming intolerant with age; on moist, well-drained sites; banks of mountain streams and cañons; the common alder of the Rocky Mountain region. 


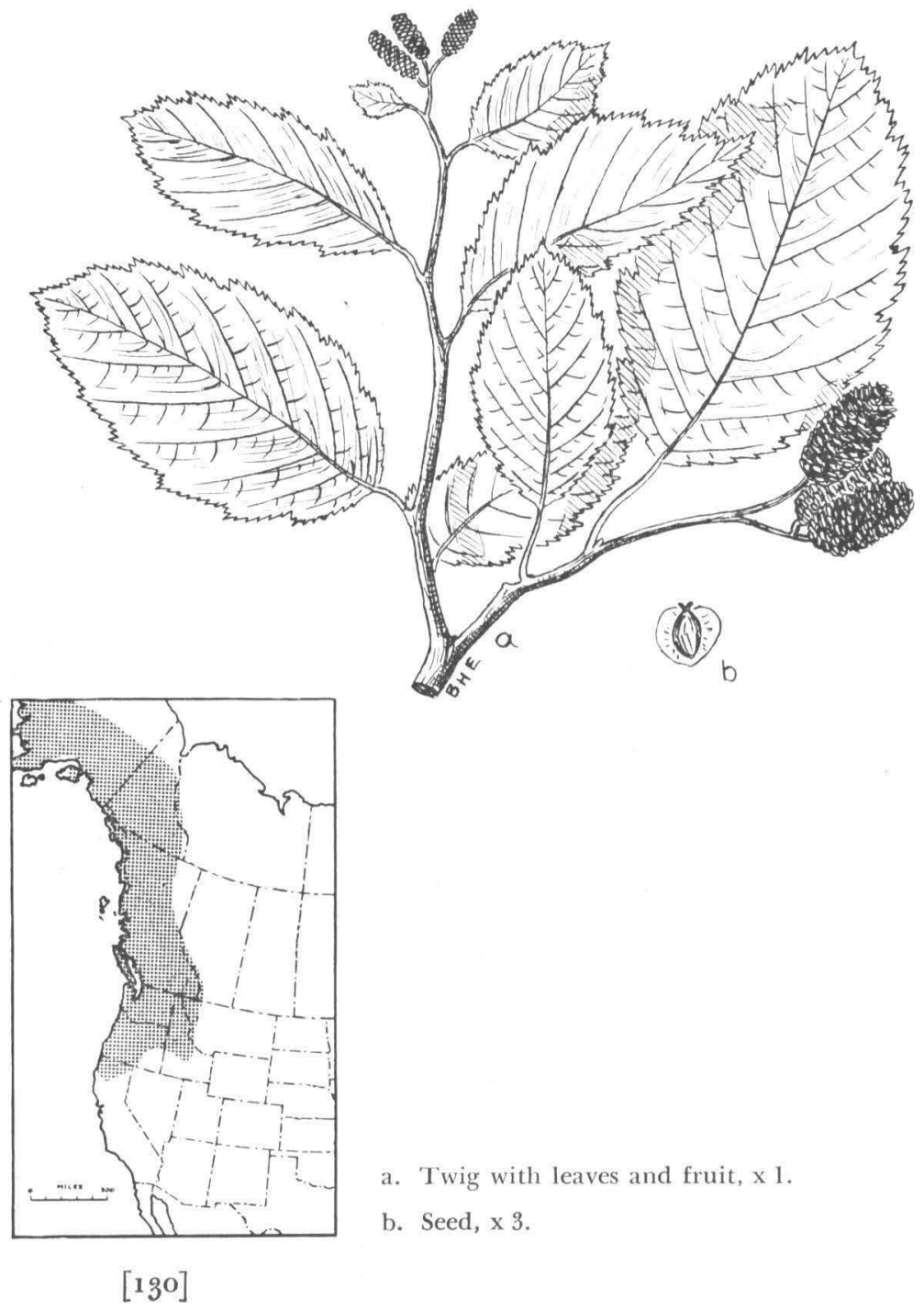




\section{BETULACEAE}

\section{SI'TKA ALDER}

Alnus sinuata (Regel) Rydb. (Alnus sitchensis Sarg.)

HABIT. A shrub or small tree rarely 40 feet high and 7-8 inches in diameter; crown narrow and open with short, small, horizontal branches; often forming broad thickets.

LEAVES. Ovate; 3-6 inches long and 11/2-4 inches wide; acute; usually divided into numerous, short, lateral lobes; sharply and doubly serrate; membranaceous; yellow-green above, pale, lustrous, and glabrous or villose along midrib below; petioles stout, grooved, enlarged at base, $1 / 2-3 / 4$ inch long; stipules $1 / 4$ inch long, puberulous, rounded at apex.

FLOWERS. Staminate aments $1 / 2$ inch long during winter becoming 4-5 inches long in spring, calyx lobes shorter than the 4 stamens; pistillate aments $1 / 3$ inch long, long-peduncled, in elongated panicles.

FRUIT. Nut oval, about as wide as its wings; strobiles $1 / 2-3 / 4$ inch long and about $1 / 3$ inch wide; truncate scales thickened at apex; on slender peduncles; in elongated, leafy panicles.

TWIGS. Slender; slightly zigzag; puberulous, glandular and orange-brown at first, becoming smooth, light gray and marked by numerous large, pale lenticels and crowded, elevated leaf scars. Winter buds: $1 / 2$ inch long, acuminate, dark purple, finely pubescent.

BARK. Thin; blue-gray; bright red inner bark.

WOOD. Heartwood light brown; unimportant because of small size.

SILVICAL GHARACTERS. Transition and Canadian zones; tolerant when young, becoming rather intolerant with age; in moist flats and along stream borders; generally a shrub in the United States and British Columbia, but frequently a tall tree in southeastern Alaska; growing at elevations of more than 3,000 feet. 
White Alder

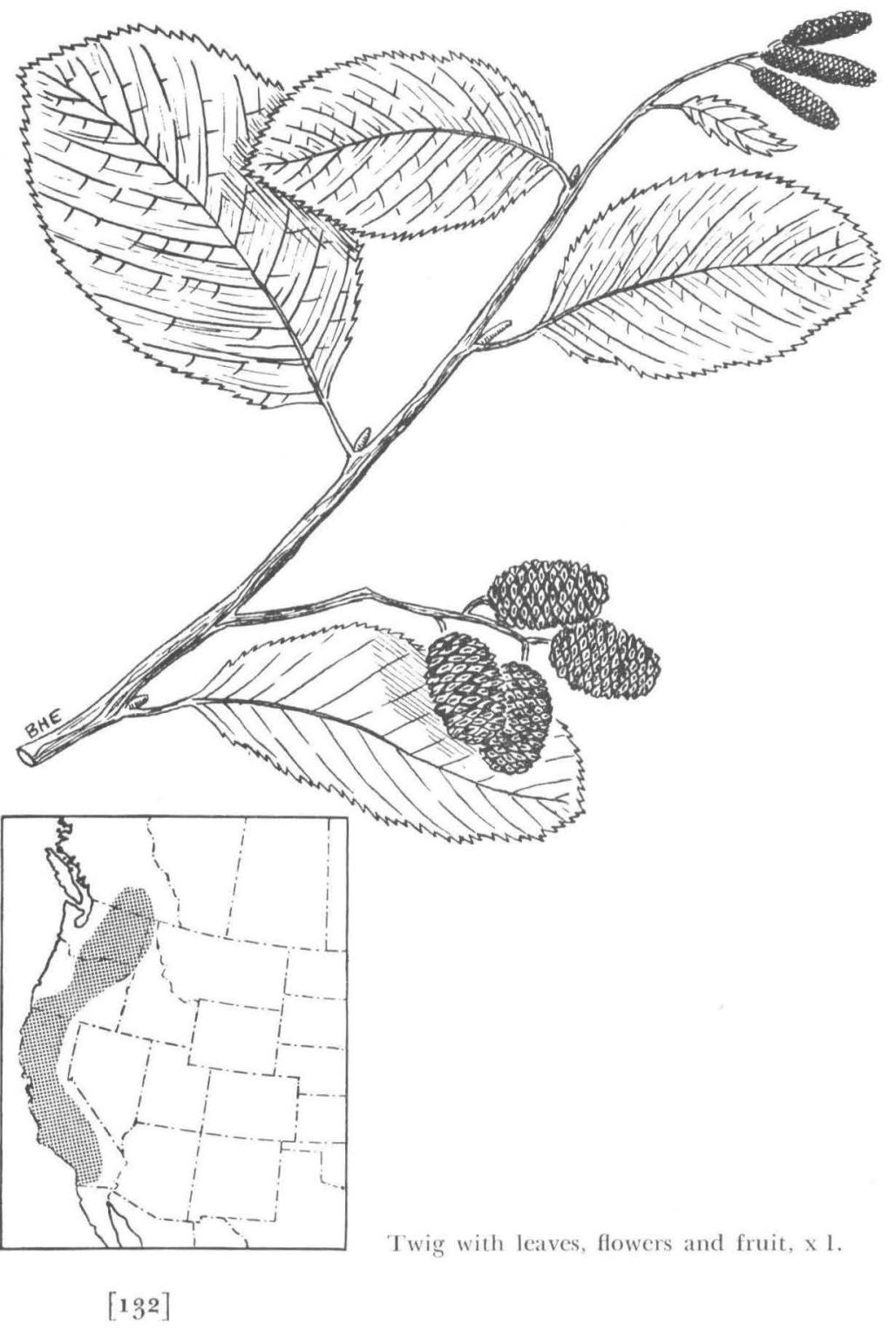




\section{BETULACEAE}

\section{White Alder \\ Alnus rhombifolia Nutt.}

HABIT. A tree frequently 70-80 feet high and 2-3 feet in diameter; trunk tall and straight; crown broad and roundtopped with long, slender, pendulous branches.

LEAVES. Ovate, oval, or sometimes orbicular; 2-3 inches long and 11/2-2 inches wide; cuneate at base, rounded or acute at apex; finely, coarsely, or doubly serrate; slightly thickened and reflexed on somewhat undulate margins; dark green and lustrous above, light yellow-green and puberulous below, with a stout, yellow midrib; frequently marked with minute, glandular dots; petioles slender, yellow, hairy, flattened and grooved above, $1 / 2-3 / 4$ inch long; stipules $1 / 4$ inch long, puberulous, acute.

FLOWERS. Staminate aments $3 / 4^{-1}$ inch long first summer, lengthening through winter and becoming 4-6 inches long in January, deciduous in February before appearance of leaves, calyx shorter than 1-3 stamens; pistillate aments in short, pubescent racemes, emerging from bud in December.

FRUIT. Nut broadly ovoid, narrowly margined; strobiles $1 / 3-1 / 2$ inch long, oblong; scales thin, slightly thickened and lobed at apex; remaining closed until tree flowers in following year.

TWIGS. Slender; pubescent and light green at first, becoming glabrous and dark orange-red; marked by small, scattered lenticels. Winter buds: $1 / 2$ inch long, very slender, dark red, pale-pubescent.

BARK. On old trunks 1 inch thick; dark brown; irregularly furrowed and scaly plated.

WOOD. Light; soft; close-grained; not strong; brittle; heartwood light brown; sapwood thick whitish; little used, but possibly suitable for cabinet work.

SILVICAL CHARACTERS. Transition zone; rather tolerant throughout life; on moist sites; stream banks and cañon bottoms. 
New Mexican Alder
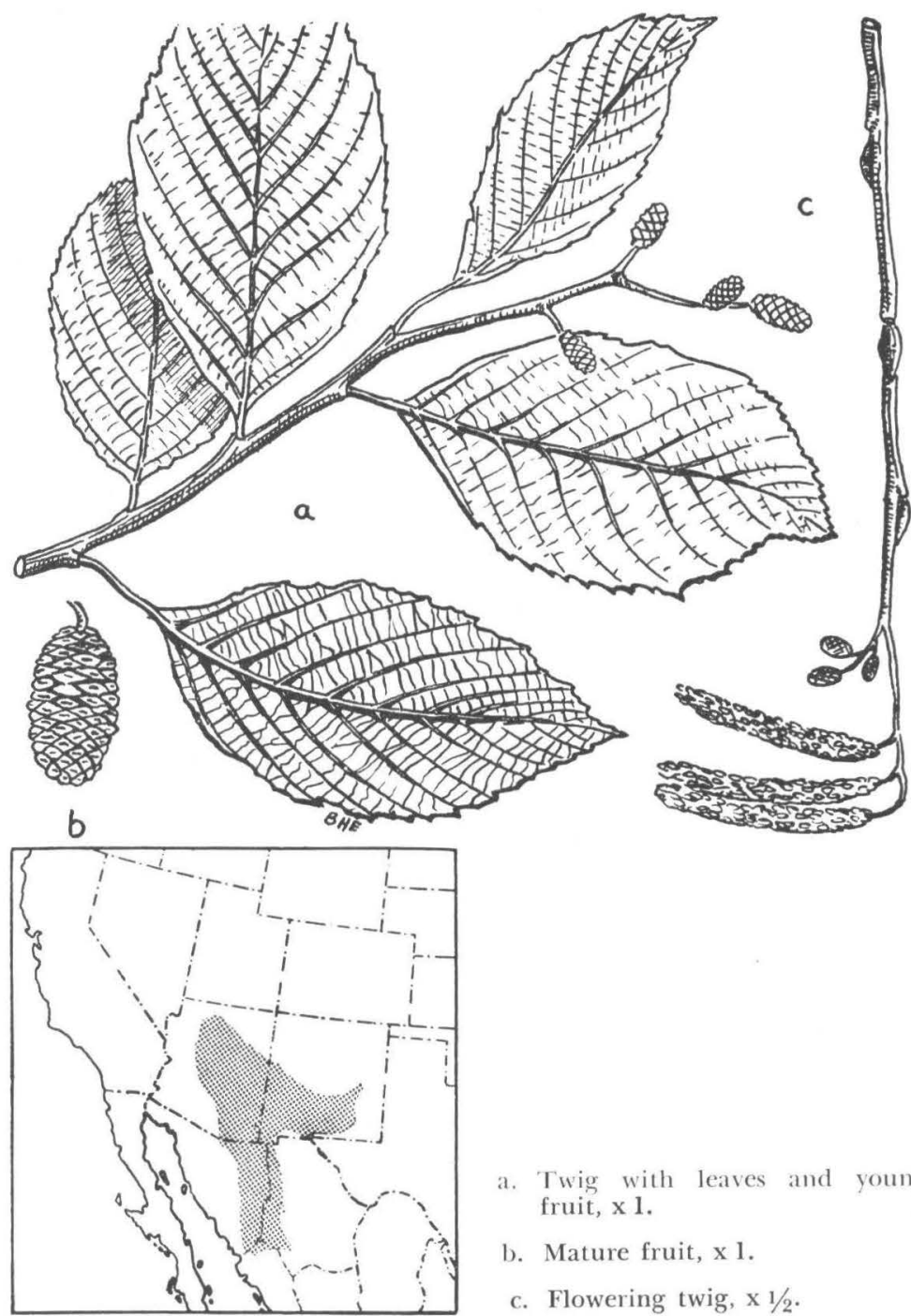

a. Twig with leaves and young fruit, $\times 1$.

b. Mature fruit, $\mathrm{x} 1$.

c. Flowering twig, $\times 1 / 2$. 


\section{BETULACEAE}

\section{New Mexican Alder \\ Alnus oblongifolia Torr.}

HABIT. A shrub or small tree rarely more than 20-30 feet high and 8 inches in diameter; crown open and round-topped with long, slender, spreading branches.

LEAVES. Oblong-lanceolate and acute, or rarely obovate and rounded at apex; 2-3 inches long and about 11/2 inches wide; cuneate at base; sharply and usually doubly serrate; dark yellow-green and glabrous or puberulous above, pale and glabrous or puberulous along yellow midrib below; more or less thickly covered with black glands; petioles slender, grooved, pubescent, $3 / 4$ inch long; stipules $1 / 4$ inch long, brown, scarious.

FLOWERS. Staminate aments $1 / 2-3 / 4$ inch long and light yellow during winter, becoming $2-21 / 2$ inches long and orangebrown in spring before leaves appear, calyx shorter than the 2-3 stamens; pistillate aments $1 / 8-1 / 4$ inch long and light brown, stigmas bright red.

FRUIT. Nut broadly ovoid, narrowly margined; strobiles $1 / 2^{-1}$ inch long; scales thin, truncate, slightly thickened.

TWIGS. Slender; slightly puberulous and orange-red at first, becoming lustrous and dark red-brown or gray; marked by small, conspicuous, pale lenticels and elevated leaf scars.

Winter buds: $1 / 2$ inch long, acute, red, Iustrous, glabrous.

BARK. Thin; light brown, tinged with red; smooth.

WOOD. Heartwood light brown; unimportant because of small size.

SILVICAL CHARACTERS. Transition zone; rather intolerant; on moist, well-drained sites; banks of mountain streams and cañons at elevations of 4,000-6,000 feet. 


\section{FAGACEAE}

\section{The OAks}

Characteristics of the Genus Quercus L..

HABIT. Deciduous or evergreen trees or shrubs; with astringent properties; pubescence of fascicled hairs.

LEAVES. Alternate; simple; deciduous or persistent; shape and size often variable on same tree; stipulate.

FLOWERS. Regular; monoecious; vernal; staminate in clustered aments, individual flowers with a 4-7-lobed calyx enclosing 6 (rarely 2-12) stamens; pistillate solitary or in 2 to many-flowered spikes, individual flowers with a 6-lobed calyx surrounding a 3-(rarely 4-5-) celled ovary with 1-2 ovules in each cell, the whole partly enclosed in an involucre.

FRUIT. An acorn; 1-seeded by abortion; maturing in 1-2 ycars; partially enclosed by scaly cup (modified involucre).

TWIGS. Slender to stout; angled; pith homogeneous, stellate; marked by pale lenticels and semicircular lear scars. Winter buds: clustered at end of twig; terminal present; with many chestnut-brown scales imbricated in 5 ranks.

BARK. Scaly or dark and furrowed.

WOOD. Heavy; hard; brittle; with prominent rays.

GENERAL. A variable genus containing 75-80 native species which are often difficult to identify. The native oaks have been separated into the white oaks (with leaves rarely bristletipped; fruit maturing in l year, glabrous on the inner surface of shell and usually sweet to the taste) and the red or black oaks (with leaves commonly bristle-tipped; fruit maturing in 2 years, hairy on inner surface of shell and usually bitter to the taste).

The following shrubby southwestern species have been reported as occasionally forming small trees: Q. breviloba Sarg. (Q. annulata Buckl.), Q. canbyi Trel., Q. confusa W. \& S., Q. gambelii Nutt., Q. grisea Liebm., Q. gunnisonii Rydb., $Q$. media W. \& S., Q. mohriana Buckl., Q. novomexicana Rydb., $Q$. pauciloba Rydb., Q. subturbinella Trel., Q. undulata Torr. and $Q$. vreelandii $\mathrm{Rydb}$. 


\section{KEY TO THE ARBORESCENT SPECIES OF QUERCUS}

I. Acorns mature in 2 seasons; nut shell toncntose within; leaves commonly bristle-tipped................. Black Oaks. A. Leaves deciduous; Texas............ Q. texana, p. 139.

B. Leaves persistent $1-4$ years.

1. Leaves persistent 1 year; western Texas to southern Arizona.................... Q. hypoleuca, p. 139.

2. Leaves persistent $3-4$ years; Arizona.............. $\ldots \ldots \ldots \ldots \ldots \ldots \ldots \ldots \ldots$. Q. chrysolepis, p. 141.

II. Acorns mature in 1 scason; nut shell glabrous within (except 4) ; leaves seldom bristle-tipped............White Oaks.

A. Leaves persistent through winter.

1. Leaves yellow-green.

a. Inner surface of nut tomentose; fruit short-stalked; Southwest................4. Q. emoryi, p. 143.

b. Fruit long-stalked, clustered; western Texas and southeast...............5. Q. virginiana, p. 147.

2. Leaves blue-green.

a. Fruit mostly in many-fruited, long-stalked clusters; southwest.............6. Q. dizersicolor, p. 145.

b. Fruit solitary or paired and subsessile.

(1) Leaves glabrous below; nut enclosed for $1 / 3$ its length in cup with scales fringed at rim; southwest............7. Q. oblongifolia, p. 147.

(2) Leaves hairy below; nut enclosed for $1 / 2$ its length in cup without fringe.

(a) Leaves $1 / 2-3 / 4^{\prime \prime}$ long; nut $1 / 2-2 / 3$ " long; Arizona............ 8. Q. toumeyi, p. 149 .

(b) Leaves 1-4" long; nut 3/4-1" long; southwest. . . . . . .....9. Q. arizonica, p. 149 .

B. Leaves deciduous in fall.

1. Leaves deeply lobed.

a. Leaves pubescent below.

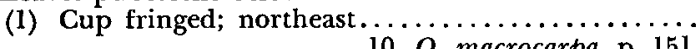

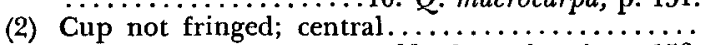

$\ldots \ldots \ldots \ldots \ldots \ldots \ldots \ldots$. Q. utahensis, p. 153.

b. Leaves glabrous or puberulous below; southern Colorado and New Mexico......12. Q. leptophylla, p. 153.

2. Leaves toothed; southwest.

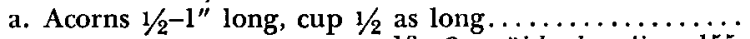
$\ldots \ldots \ldots \ldots \ldots \ldots \ldots \ldots$. $Q$. mühlenbergii, p. 155.

b. Acorns over $1^{\prime \prime}$ long, cup deeper...14. Q. brayi, p. 155. 

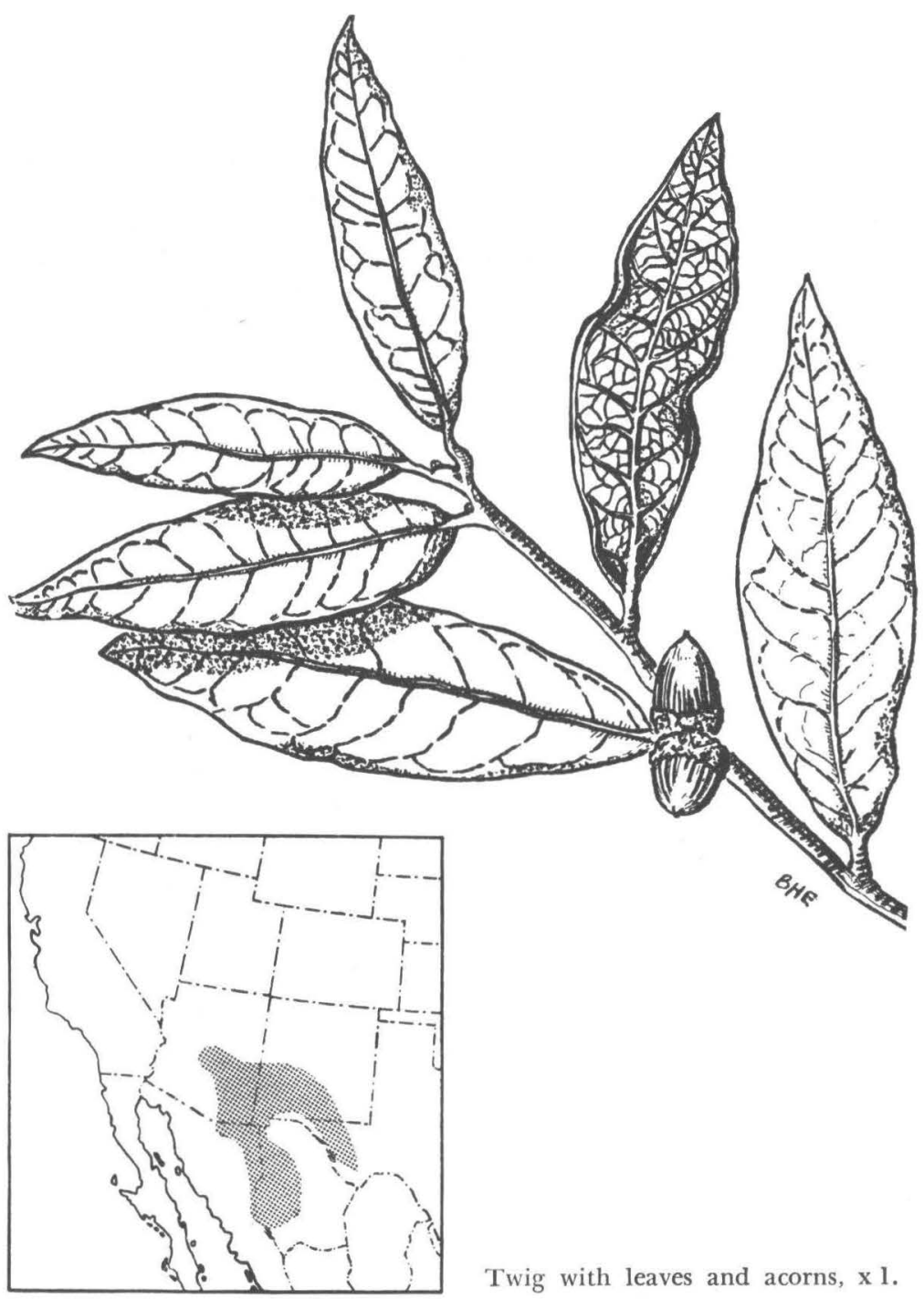

[138]

Twig with leaves and acorns, $\mathrm{x} 1$. 


\section{FAGACEAE}

\section{Silverleaf OAK. Whiteleaf OAK}

\section{Quercus hypoleuca Engelm.}

HABIT. An evergreen shrub or small tree 20-30 feet high (rarely 60 feet) and $10-15$ inches in diameter; narrow, inversely conic, round-topped crown with slender branches.

LEAVES. Lanceolate or oblong-lanceolate to elliptic; occasionally falcate; $2-4$ inches long and $1 / 2-1$ inch wide; acute; entire or with a few coarse teeth near apex; revolute margins; thick and leathery; dark yellow-green and lustrous above, covered below with thick tomentum; turning yellow or brown and falling during the spring after appearance of new leaves; petioles stout, $1 / 8^{-1 / 4}$ inch long, hairy.

FLOWERS. Staminate aments 4-5 inches long, slender, hairy, with 4-5-lobed, hairy calyx; pistillate mostly solitary, with dark red stigmas.

FRUIT. Ovoid; $1 / 2-2 / 3$ inch long; acute or rounded at narrow, hoary-pubescent apex; dark green, becoming light chestnut-brown; sessile or peduncled; usually solitary; shell thick and lined with white tomentum; annual, but often maturing in second year; enclosed for about $1 / 3$ its length in turbinate, thick cup, pubescent inside and out.

TWIGS. Stout; rigid; hoary-tomentose at first, becoming glaucous and red-brown to black. Winter buds: $1 / 8$ inch long, ovoid, obtuse, light chestnut-brown.

BARK. Rather thick ( $3 / 4-1$ inch); nearly black; deeply furrowed into broad, thick-scaled ridges.

WOOD. Heavy; hard; very strong; close-grained; heartwood dark brown; sapwood thick, lighter colored.

SILVICAL CHARACTERS. Upper Sonoran and Transition zones; on low, dry, mountain sites; scattered but nowhere abundant through pine forests at elevations of $6,000-7,000$ feet.

Quercus texana Buckl. is characterized by deeply lobed, bristle-tipped deciduous leaves. Two varieties occur in western Texas: var. stellipila Sarg. with pubescent leaves and twigs; and var. chesoensis Sarg. ( $Q$. gravesii Sudw.) with acuminately lobed leaves and smaller acorn cup. 


\section{GOLdENCUP OAK}

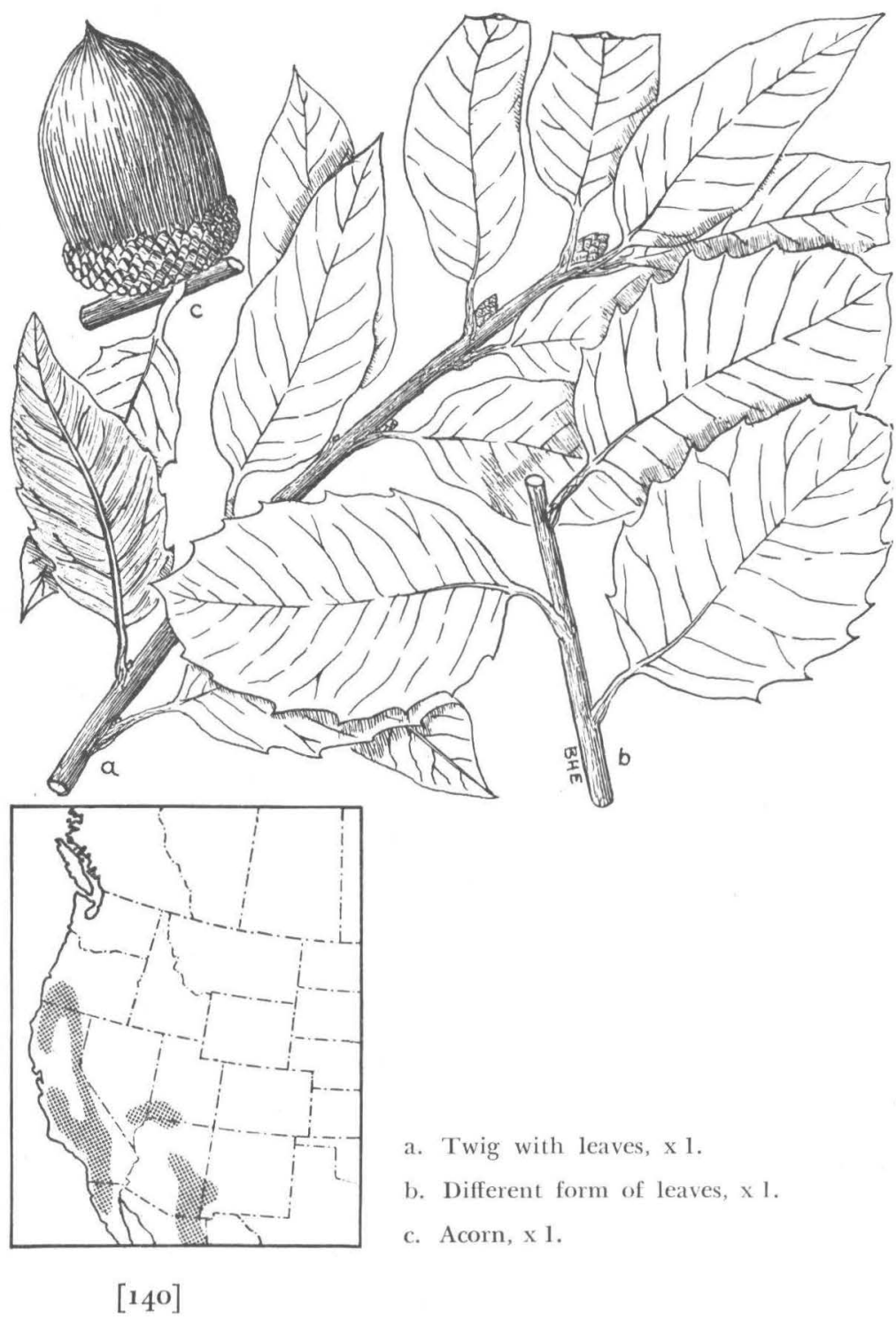




\section{Goldencup OaK. Cañon Live OaK \\ Quercus chrysolepis Liebm.}

HABIT. An evergreen shrub or small to medium-sized tree 60-80 feet high and 1-5 feet in diameter; very large, spreading crown, with huge, horizontal branches; forming dense thickets on exposed, mountain slopes.

LEAVES. Oblong-ovate to elliptic; 1-4 inches long and $1 / 2-2$ inches wide; acute, cuspidate; dimorphous, mostly entire on old trees and dentate or sinuate-dentate on young trees, or the 2 forms appearing together; revolute margins; thick and leathery; bright yellow-green and glabrous above; tawnytomentose, becoming glabrous and blue-green below; persistent 3-4 years; petioles rarely $1 / 2$ inch long, yellow.

FLOWERS. Staminate aments 2-4 inches long, slender, tomentose, with 5-7-lobed, yellow and red tipped, pubescent calyx; pistillate with bright red stigmas.

FRUIT. Ellipsoidal or ovoid; $1 / 2-2$ inches long; acute or rounded at apex; light chestnut-brown; sessile or short-stalked; usually solitary; shell thick and lined with loose tomentum; maturing in second year; enclosed only at base in turbinate or hemispheric cup, pubescent or densely tomentose.

TWIGS. Slender; rigid or flexible; tomentose at first, becoming tomentose to glabrous and brown or gray. Winter buds: $1 / 8$ inch long, ovoid or oval, acute, light chestnut-brown.

BARK. Rather thick (3/4-11/2 inches); gray-brown, tinged with red; smooth except for small scales.

WOOD. Heavy; hard; very strong; tough; close-grained; heartwood light brown; sapwood thick and darker colored; used to some extent for tools, wagons, etc.

SILVICAL CHARACTERS. Upper Sonoran and Transition zones; tolerant when young; adapted to dry, gravelly soils; in mountain cañons or exposed slopes.

GENERAL. The variety palmeri Engelm. (probably better designated as $Q$. wilcoxii Rydb.), growing in Arizona, New Mexico, Utah, and Nevada, differs from the species in being usually shrubby and having rigid, oblong or semiorbicular, spinose-dentate leaves. 
EMORY OAK

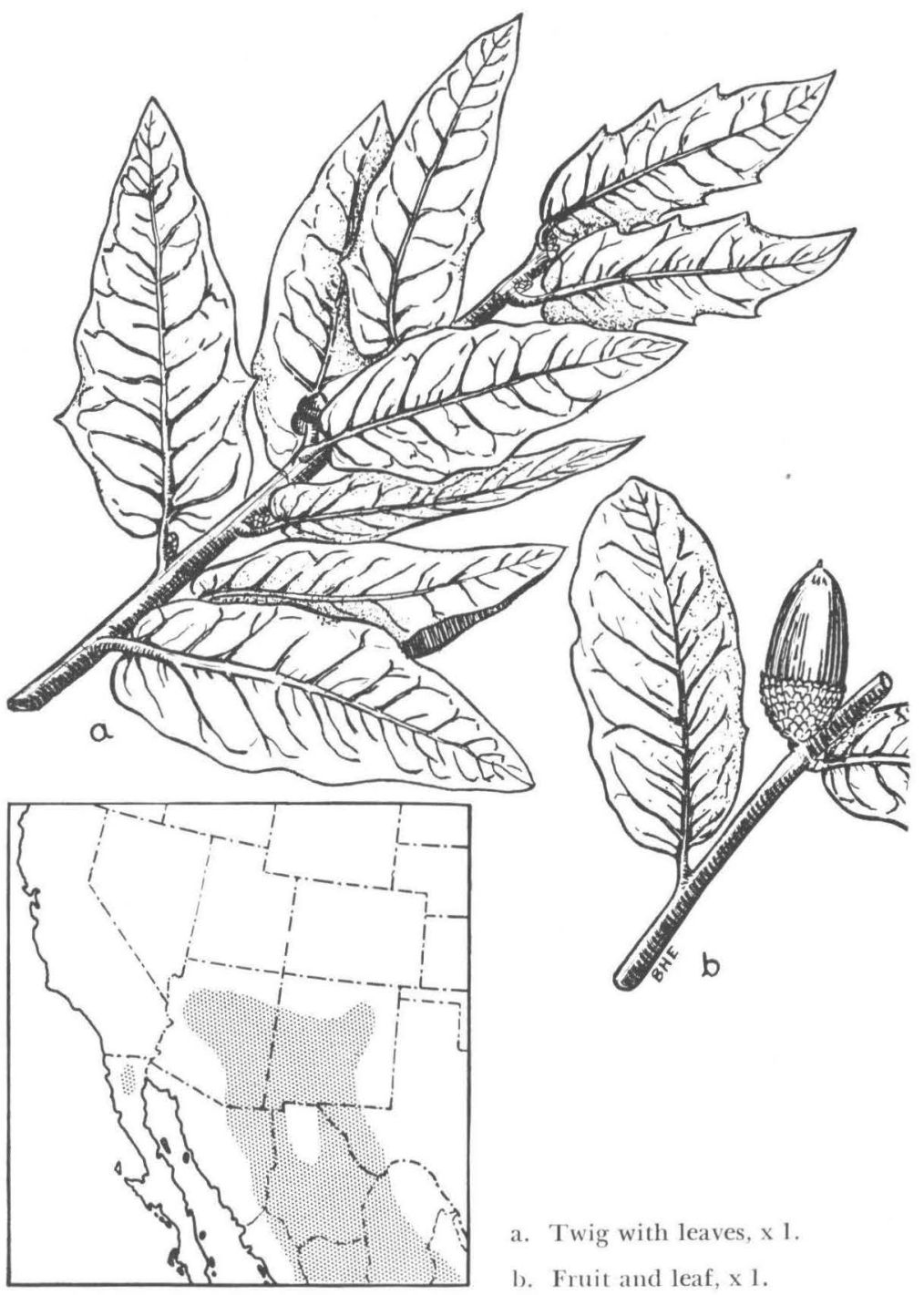




\section{FAGACEAE}

\section{EMORY OAK. BLACK OAK}

\section{Quercus emoryi Torr.}

HABIT. An evergreen shrub or small tree rarely 40-60 feet high and 2-5 feet in diameter; round-topped, symmetrical crown with stout, rigid, drooping branches.

LEAVES. Oblong-lanceolate; $1-21 / 2$ inches long and $1 / 2-1$ inch wide; acute and mucronate at apex; entire or remotely repand-serrate; thick, rigid, leathery; dark green above, pale below; both surfaces glabrous or puberulous, with tufts of white hairs at base of slender midrib; falling in April with appearance of new leaves; petioles stout, $1 / 4$ inch long, pubescent.

FLOWERS. Staminate aments 2-3 inches long, hoarytomentose, with 5-7-lobed, yellow, hairy calyx; pistillate hairy, styles slightly spreading.

FRUIT. Oblong, oval, or ovoid; $1 / 2-3 / 4$ inch long; rounded at narrow, pilose apex; light green, becoming dark brown or nearly black; sessile or short-stalked; solitary; shell thin and lined with thick tomentum; maturing in one year; enclosed for $1 / 3-1 / 2$ its length in shallow or hemispheric cup, pubescent inside and out.

TWIGS. Slender; rigid; tomentose and bright red at first, becoming glabrous and dark brown. Winter buds: $1 / 4$ inch long, ellipsoidal, acute, chestnut-brown, pubescent toward apex.

BARK. Thick (1-2 inches); dark brown or nearly black; deeply furrowed and scaly plated.

WOOD. Heavy; hard; strong; brittle; close-grained; heartwood dark brown or nearly black; sapwood thick, bright brown; unimportant.

SILVICAL CHARACTERS. Upper Sonoran, occasionally extending down into Lower Sonoran zone; on foothill and mountain slopes, at elevations of 4,000-10,000 feet; very abundant, forming a large percentage of forests; growth generally slow and shrubby; coppices freely; acorns are sweet and an important article of human food; evergreen leaves and acorns important winter food for wild and domestic animals. 


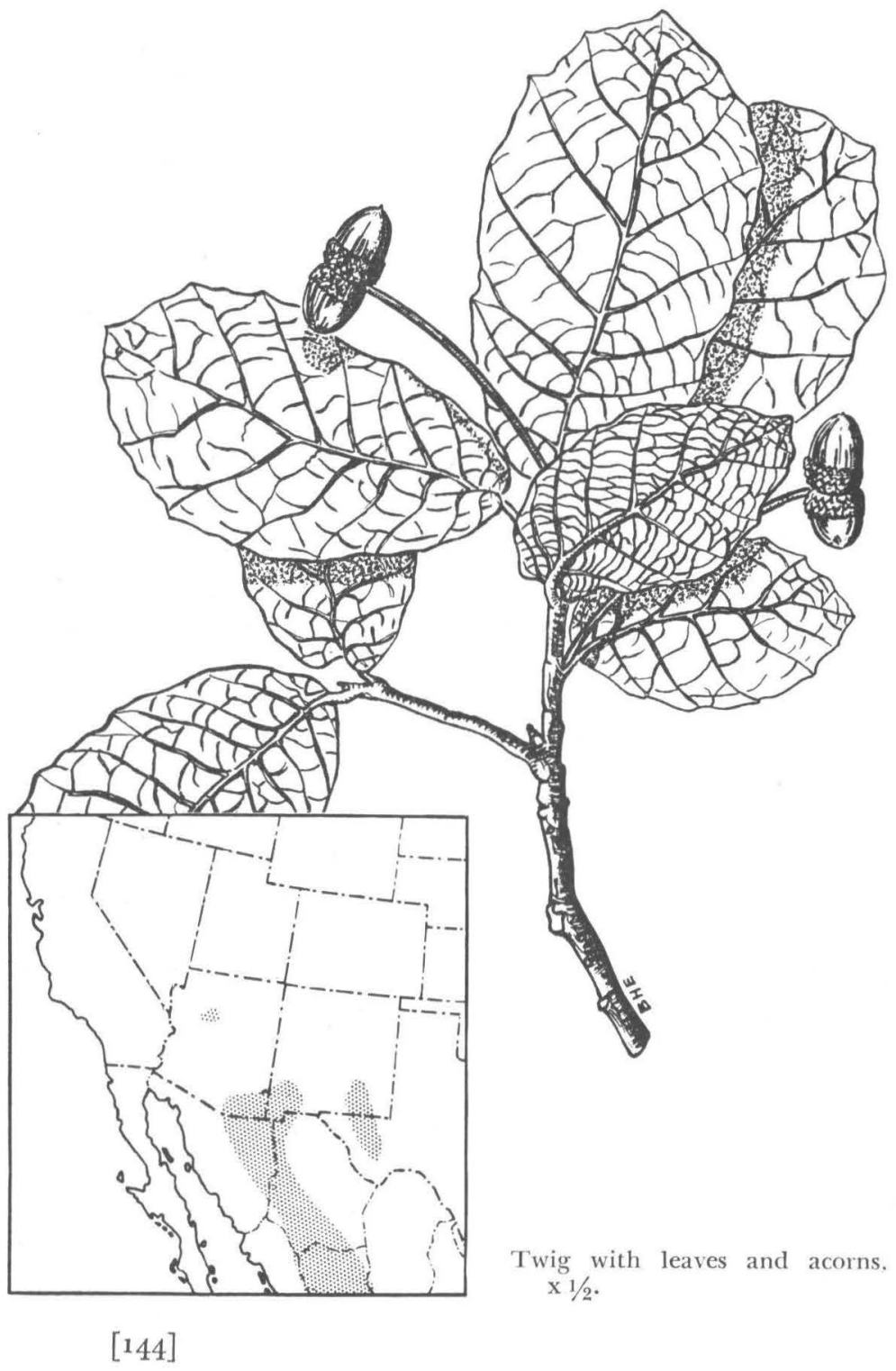




\section{FAGACEAE}

\section{NetLEAF OAK}

Quercus diversicolor Trel. (Quercus reticulata Engelm.)

HABIT. An evergreen shrub or (rarely in the United States) a tree seldom over 40 feet high and 12 inches in diameter; round-topped crown with thick, large branches.

LEAVES. Broadly obovate; $1-5$ inches long and 3/4-4 inches broad; obtuse and rounded (rarely acute) at apex; entire below and repandly spinose-dentate toward the apex; thick and firm; dark blue and covered with scattered, fascicled hairs above, paler and thickly fulvous-pubescent below; conspicuous reticulate veins; persistent until new leaves form; petioles stout, $1 / 4$ inch long.

FLOWERS. Staminate aments about $1-1 / \frac{1}{8}$ inches long, tomentose, with 5-7-lobed, yellow, hairy calyx; pistillate in spikes on long peduncles, tomentose, with dark red styles.

FRUIT. Oblong; 1/2 inch long; rounded or acute at pilose apex; broad at base; in pairs or many-fruited spikes (rarely solitary); on slender peduncles; shell glabrous within; maturing in first year; enclosed for $1 / 4$ its length in shallow, dark brown, hairy cup with scales thick-corky on back.

TWIGS. Stout; fulvous-tomentose and light orange at first, becoming more or less pubescent and ash-gray or light brown. Winter buds: $1 / 8$ inch long, ovoid or oval, light red scales ciliate on margin, often surrounded by persistent stipules of upper leaves.

BARK. Thin ( $1 / 4$ inch); dark or light brown; covered by small, closely appressed scales.

WOOD. Very heavy; hard; close-grained; heartwood dark brown; sapwood thick, lighter colored; unimportant.

SILVICAL CHARACTERS. Lower and Upper Sonoran zones, extending into Transition zone; near summits of mountain ranges; at elevations of 7,000-10,000 feet; attaining large size only on the Sierra Madre Mountains of Mexico. 
Mexican Blue OAK
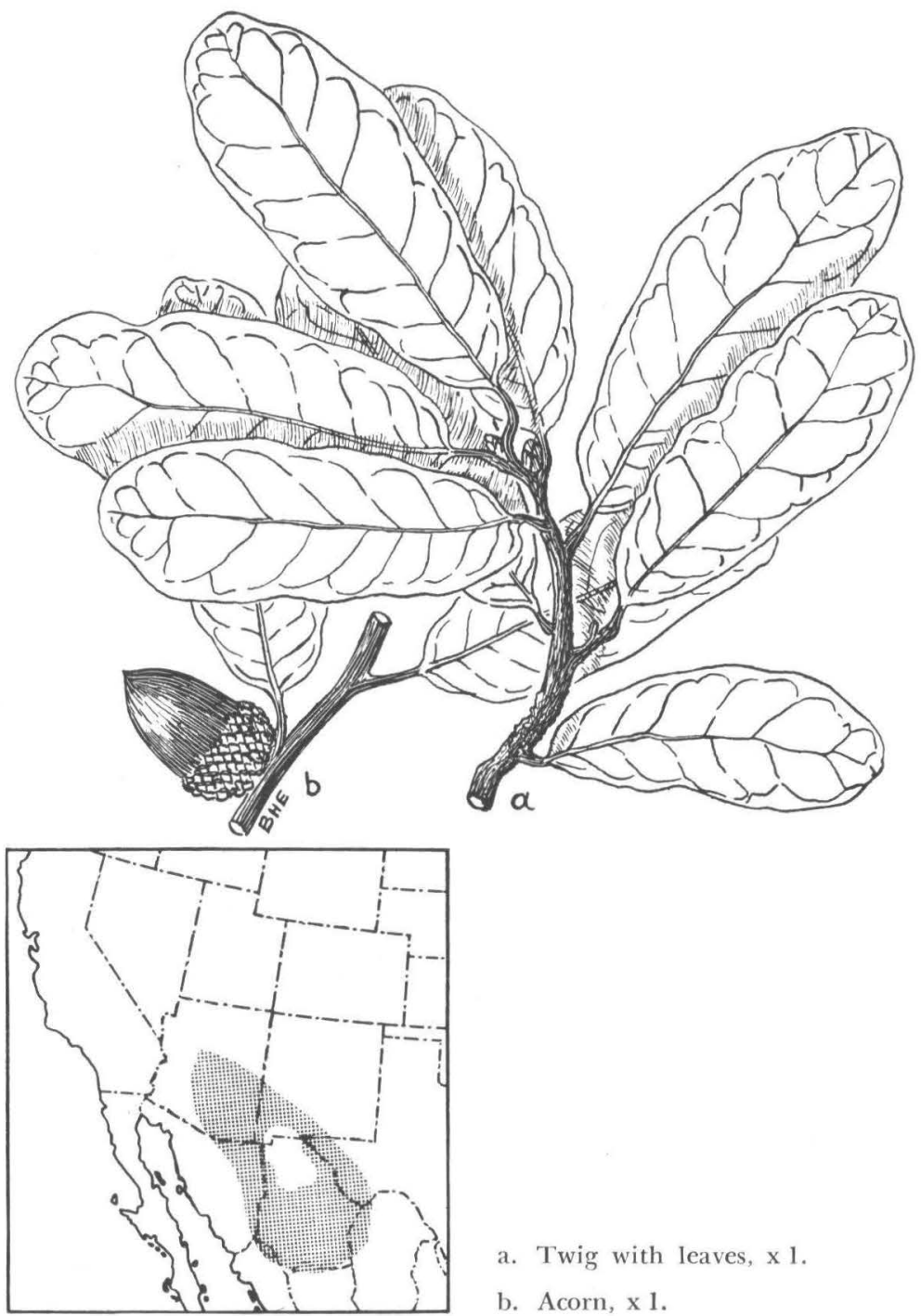

a. Twig with leaves, $\mathrm{x} 1$.

b. Acorn, x 1.

[146] 


\section{FAGACEAE}

\section{Mexican Blue Oak. White Oak \\ Quercus oblongifolia Torr.}

HABIT. An evergreen shrub or tree rarely 30 feet high and 18-30 inches in diameter; handsome, symmetrical, roundtopped crown with stout, spreading branches.

LEAVES. Ovate or elliptic; $1-2$ inches long and $1 / 2^{-3 / 4}$ inch wide; rounded or acute at apex; entire and sometimes undulate with margins thick and revolute, or rarely coarsely toothed on vigorous shoots; thin and firm; glabrous; blue-green and lustrous above, paler below; conspicuous veins; persistent until appearance of new leaves; petioles stout, $1 / 4$ inch long.

FLOWERS. Staminate aments about $1 \frac{1}{2}$ inches long, hoarytomentose, with 5-6-lobed, bright yellow, pilose calyx; pistillate sessile or short-stalked, styles light red.

FRUIT. Ovoid to obovoid; $1 / 2-3 / 4$ inch long; full and rounded at apex; dark chestnut-brown, becoming lighter; sessile or rarely long-stalked; usually solitary; shell glabrous within; maturing in first year; enclosed for $1 / 3$ its length in cup, yellow-green and pubescent within, hoary-tomentose without, with scales slightly fringed at rim.

TWIGS. Slender; rigid; slightly hairy and reddish at first, soon becoming glabrous and ash-gray. Winter buds: $1 / 16^{-1 / 8}$ inch long, oblong, obtuse, chestnut-brown.

BARK. Rather thick ( $3 / 4-11 / 2$ inches); ash-gray; broken into nearly square, platelike scales.

WOOD. Very heavy; hard; strong; brittle; checks badly; difficult to split; heartwood dark brown or nearly black; sapwood thick, brown; unimportant; used for fuel.

SILVICAL CHARACTERS. Upper Sonoran zone; abundant on foothills of Arizona and New Mexico; at elevations of 4,500-6,500 feet; with Emory and Arizona oaks.

A related species, the live oak of commerce, Quercus virginiana Mill., enters this region in the mountains of western Texas. It differs from Mexican blue oak in its yellow-green leaves, 2-5 inches long and pubescent below; and in its clustered, long-stalked, ellipsoidal fruit. 
Arizona White OAK
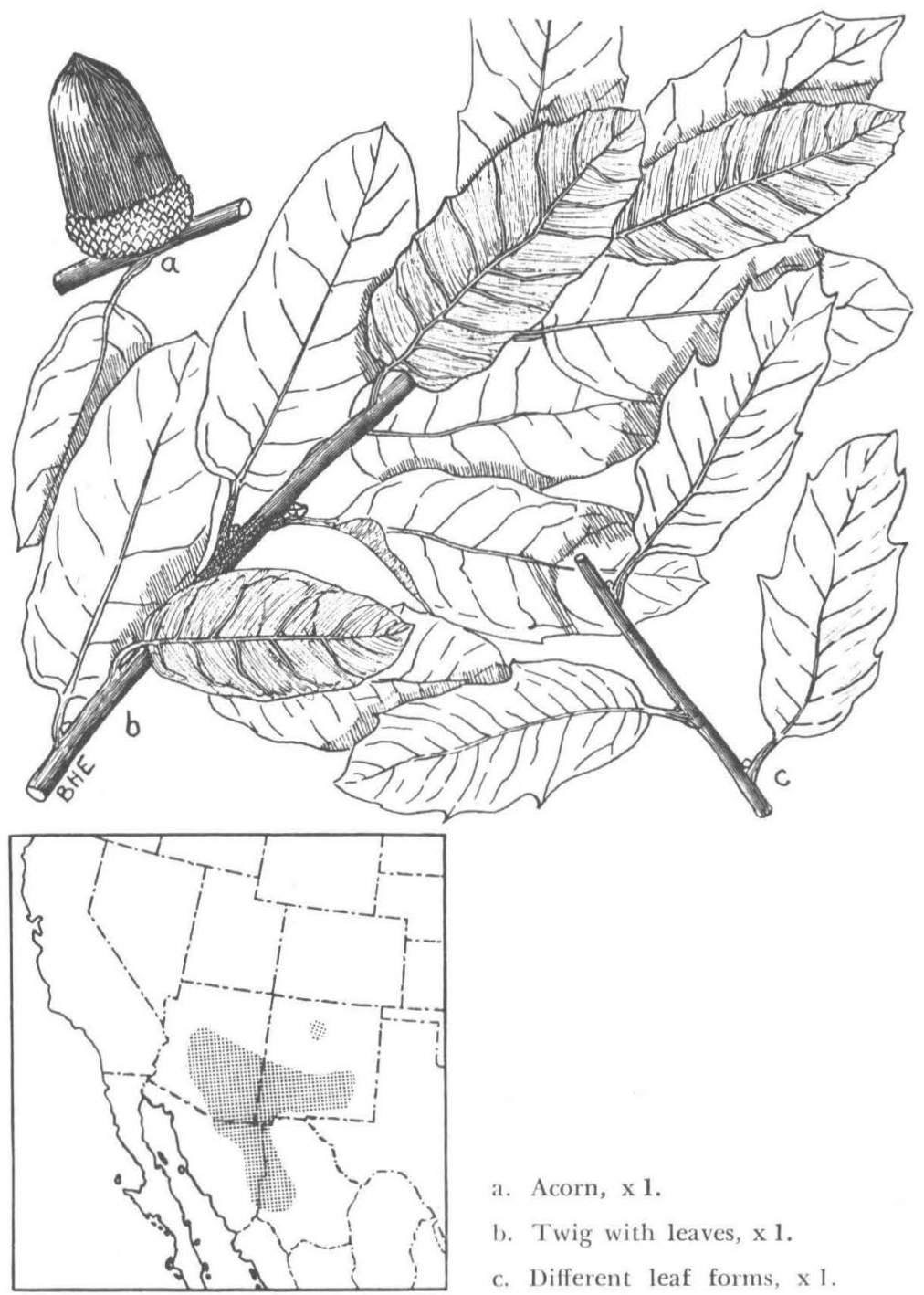

a. Acorn, x 1.

b. Twig with leaves, $\mathrm{x} 1$.

c. Different leaf forms, $\times 1$. 


\section{FAGACEAE}

\section{Arizona White OAK \\ Quercus arizonica Sarg.}

HABIT. Nearly evergreen shrub or tree rarely $40-60$ feet high and 3-4 feet in diameter; handsome, large, round-topped crown with massive, contorted, nearly horizontal branches.

LEAVES. Oblong-lanceolate to broadly ovate; 1-4 inches long and $1 / 2-2$ inches wide; acute or rounded; entire or repandly spinose-dentate above; thickened, revolute margin; thick, firm and rigid; dull, dark, blue-green and glabrous above, paler and densely pubescent below; coarse, reticulate veins; persistent until spring just before appearance of new leaves; petioles stout, $1 / 4-1 / 2$ inch long, tomentose.

FLOWERS. Staminate aments 2-3 inches long, tomentose, with 4-7-lobed, pale yellow, pubescent calyx; pistillate shortstalked, tomentose.

FRUIT. Oblong, oval, or slightly obovoid; $3 / 4-1$ inch long; rounded at puberulous apex; dark chestnut-brown, becoming light brown; sessile or hairy-stalked; shell glabrous within; maturing in first year; enclosed for $1 / 2$ its length in hairy cup with scales thick-corky and red-tipped.

TWIGS. Stout; fulvous-tomentose and red-brown at first, becoming glabrous and dark red-brown. Winter buds: $1 / 16$ inch long, subglobose, chestnut-brown, ciliate on margins.

BARK. Rather thick (1 inch); pale or ash-gray; furrowed and ridged.

WOOD. Very heavy; hard; strong; close-grained; checks badly; difficult to split; heartwood dark brown or nearly black; sapwood thick, lighter colored; unimportant.

SILVICAL CHARACTERS. Upper Sonoran zone; most common live oak of Southwest; on dry mountain slopes; at elevations of 5,000-10,000 feet; with piñons and junipers.

A similar species, the Toumey oak, Quercus toumeyi Sarg., of southeastern Arizona differs from the Arizona white oak in its smaller leaves $1 / 2-3 / 4$ inch long, ovate to ovate-oblong and puberulous below; and in its smaller nut, $1 / 2-2 / 3$ inch long. 
Bur OAK
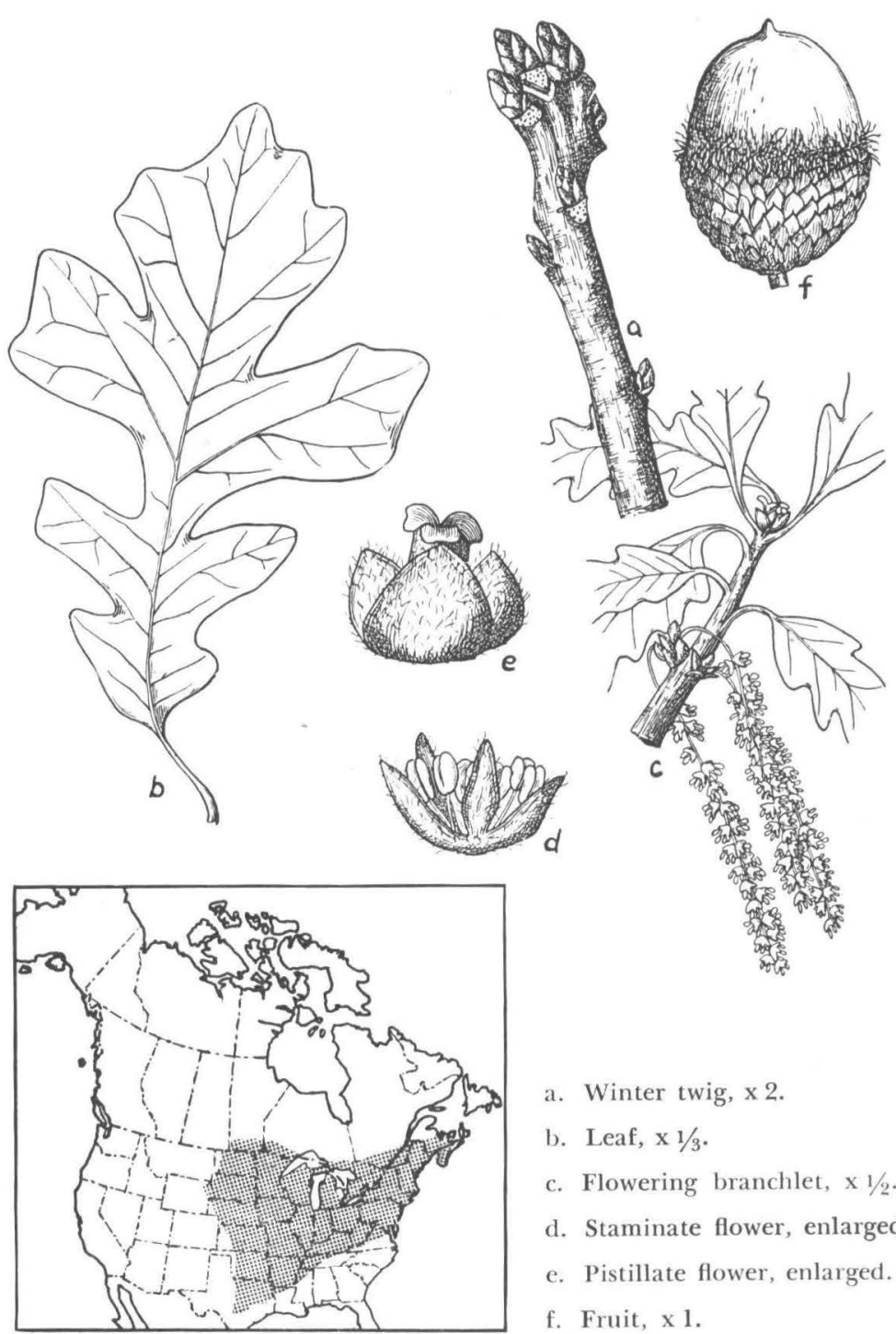

a. Winter twig, $\mathrm{x} 2$.

b. Leaf, $\times 1 / 3$.

c. Flowering branchlet, $\times 1 / 2$.

d. Staminate flower, enlarged.

e. Pistillate flower, enlarged.

f. Fruit, $\times 1$. 


\section{FAGACEAE}

\section{BUR OAK \\ Quercus macrocarpa Michx.}

HABIT. A shrub or tree in the northeastern portion of the Rocky Mountain region; crown broad with large, spreading branches.

LEAVES. Obovate to oblong; 6-12 inches long and 3-6 inches wide; rounded or acute apex; wedge-shaped at base; crenately 5-9-lobed, usually cut nearly to midrib by two, opposite, central sinuses; lobes often crenately lobed; thick and firm; dark green and lustrous above, pale green or silverwhite and soft-pubescent below; deciduous in autumn; petioles stout, $1 / 3-1$ inch long.

FLOWERS. Staminate aments $4-6$ inches long, slender, with 4-6-lobed, yellow-green, pubescent calyx; pistillate sessile or stalked, tomentose, with bright red styles.

FRUI'T. Variable in size or shape; ellipsoidal to broadovoid; $3 / 5$ inch long in region (sometimes 2 inches long in South); rounded at obtuse or depressed hairy apex; brown; sessile or long-stalked; usually solitary; shell glabrous within; maturing in first year; enclosed for $1 / 3$ to all of its length in tomentose, short-fringed cup; edible.

TWIGS. Stout; yellow-brown and pubescent at first, becoming ash-gray to brown and glabrous; sometimes developing corky wings. Winter buds: $1 / 8-1 / 4$ inch long, broadly ovoid, red-brown, pubescent.

BARK. Thick (1-2 inches); gray-brown; deeply furrowed and ridged.

WOOD. Heavy; hard; strong; tough; close-grained; durable; heartwood dark to light brown; sapwood thin, lighter; important.

SILVICAL CHARACTERS. Transition zone; moist, rich bottom-lands to low, dry hills in Northwest; extending farthest Northwest of eastern oaks; common and attaining large size in Crook County, Wyoming. 
Utah White OAK

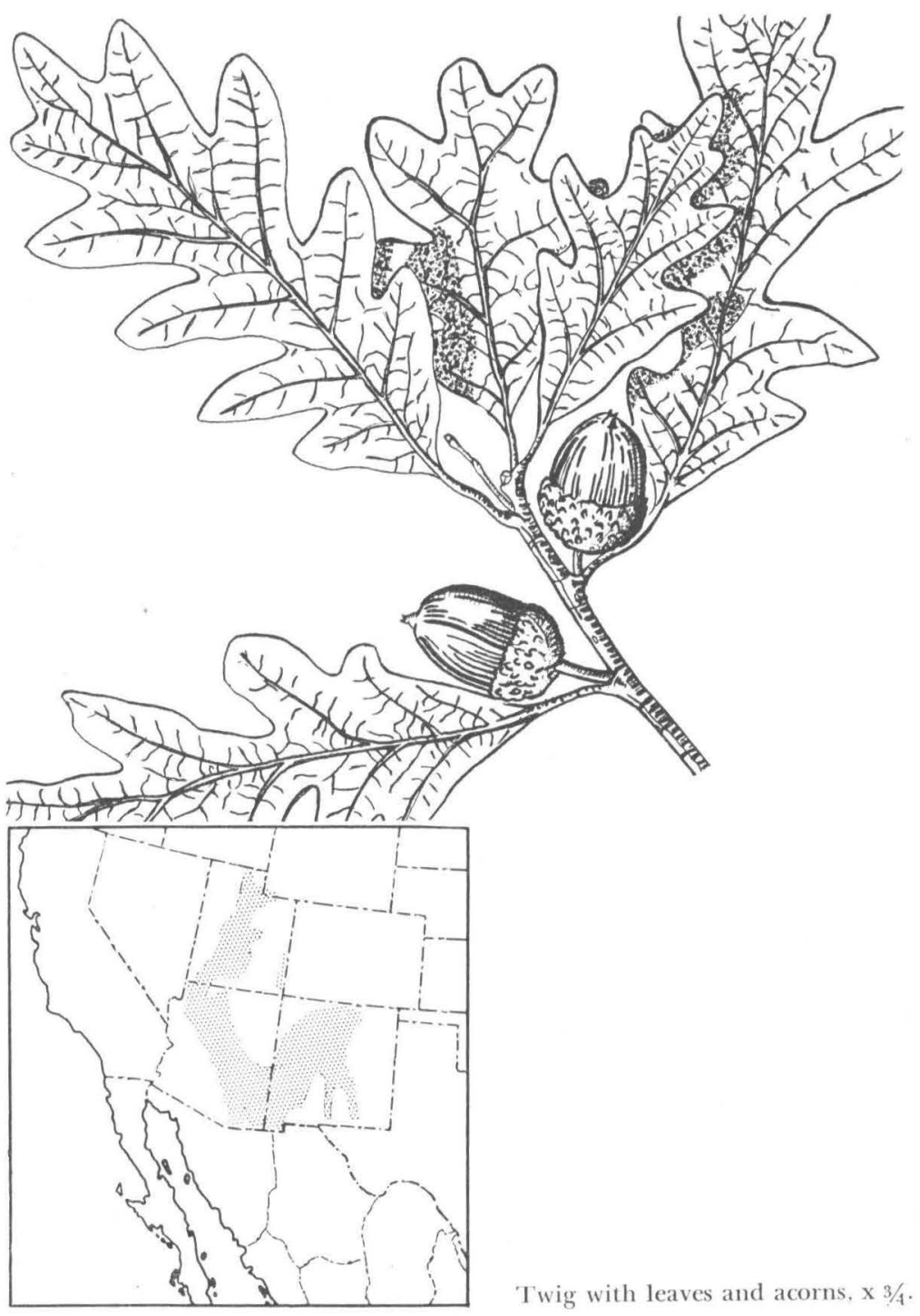

$[152]$ 


\section{FAGACEAE}

Utah White Oak. Rocky Mountain White Oak Quercus utahensis (A.DC.) Rydb.

HABIT. A shrub or small tree 25-35 feet high and 6-10 inches in diameter; narrow, open crown with thick, erect branches.

LF.AVES. Oblong-obovate; $21 / 2-7$ inches long and $1 \frac{1}{2}-31 / 2$ inches wide; rounded at apex; divided, often nearly to midrib, into 3-5 pairs of lateral lobes; thick and firm; dark green and nearly glabrous above, pale and soft-pubescent below; deciduous in autumn; petioles stout; $2 / 5-1$ inch long, tomentose becoming glabrous.

FI.OWERS. Staminate aments $2-21 / 2$ inches long, hairy, with scarious calyx; pistillate usually solitary, tomentose.

FRUIT. Ovoid; 3/5-3/4 inch long; broad and rounded at ends; sessile or short-stalked; usually solitary; shell glabrous within; maturing in first year; enclosed for about $1 / 2$ its length in thick, hemispheric, pubescent cup, with scales thickened on back.

TWIGS. Stout; red-brown and pubescent at first, becoming orange-brown. Winter buds: $1 / 8-1 / 4$ inch long, brown, hairy.

BARK. Thin; gray-brown; rough and superficially scaly.

WOOD. Heavy; hard; close-grained; lumber used locally.

SILVICAL CHARACTERS. Upper Sonoran and Transition zones; dry foothills and cañon walls; the only abundant deciduous oak tree in the low Rocky Mountain forests.

GENERAL. This species passes in to the variety, submollis (Rydb.) Sudw., reported from Nevada, Arizona, and New Mexico, with thinner scales on the lower part of the fruit cup. Botanists have difficulty distinguishing between $Q$. utahensis and $Q$. gambelii Nutt., and they should perhaps be considered as synonyms.

A related species, $Q$. leptophylla Rydb., the largest of Colorado oaks, is differentiated by leaves puberulous on their lower surface and by a thin, densely hoary-tomentose fruit cup; at present this species is known only from Huerfano County, southern Colorado and Socorro County, New Mexico. 


\section{Chinguapin Oak}

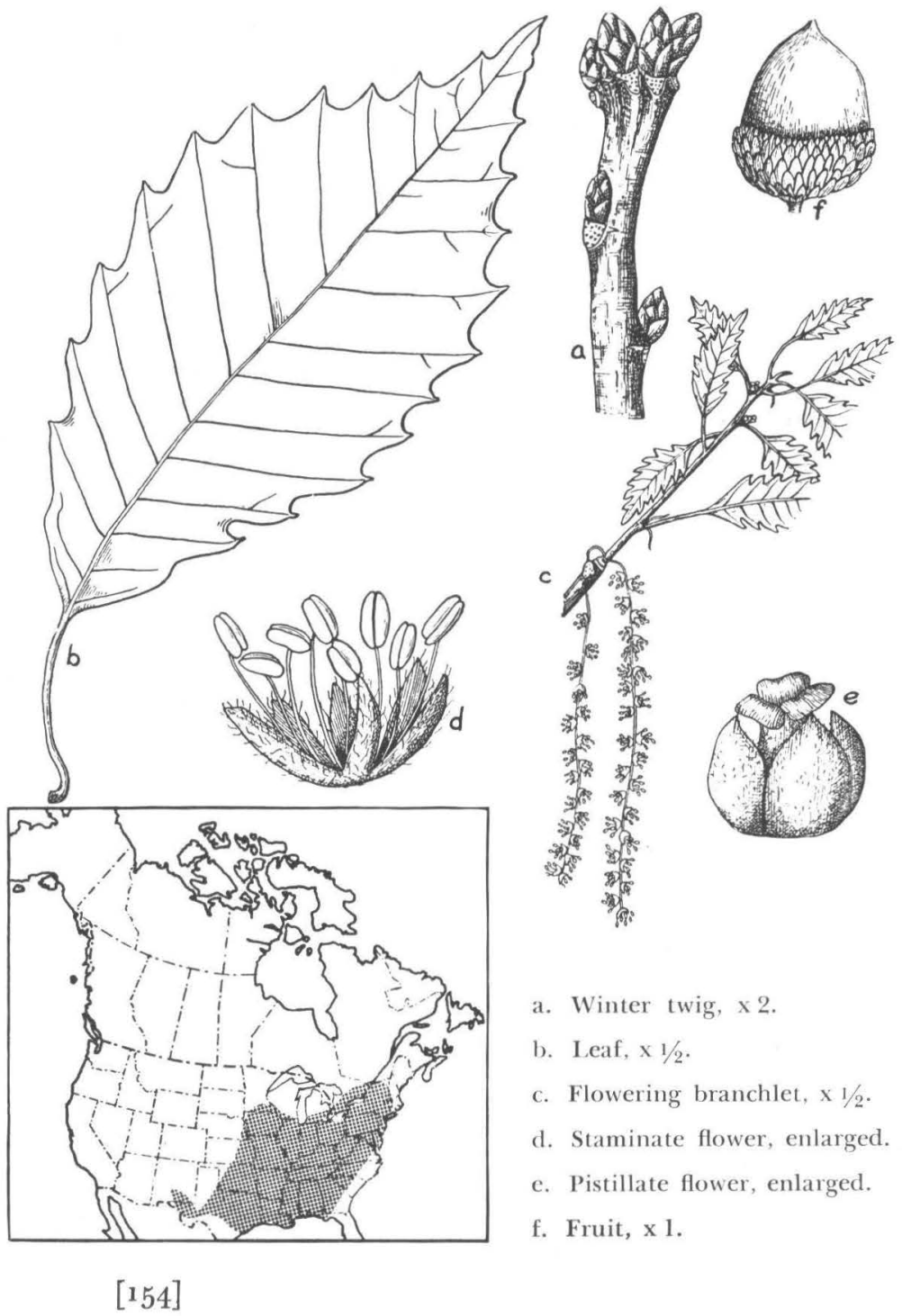




\section{FAGACEAE}

\section{Chinquapin Oak. Chestnut Oak}

\section{Quercus mühlenbergii Engelm.}

HABIT. A small tree 20-30 feet high in the Rocky Mountain region, but much larger farther east; narrow crown.

LEAVES. Oblong-lanceolate to broad-obovate; 4-7 inches long and 1-4 inches wide; acute or acuminate at apex; coarsely serrate with large, glandular-tipped teeth; thick and firm; light yellow-green and glabrous above, pale and short-pubescent below; deciduous; petioles slender, $3 / 4-11 / 2$ inches long.

FLOWERS. Staminate aments 3-4 inches long, pilose, with 5-6-lobed, light yellow, hairy calyx; pistillate solitary or spiked, tomentose, with bright red styles.

FRUIT. Broad-ovoid; $1 / 2-1$ inch long; narrowed and rounded at apex; light chestnut-brown; sessile or short-stalked; solitary or paired; shell glabrous within; maturing in first year; enclosed for about $1 / 2$ its length in thin, tomentose cup.

TWIGS. Slender; orange-brown to gray; glabrous. Winter buds: $1 / 8^{-1 / 4}$ inch long, ovoid, acute, chestnut-brown.

BARK. Thin (rarely over $1 / 2$ inch); ash-gray; more or less rough and scaly.

WOOD. Heavy; very hard; strong; durable; close-grained; heartwood light brown; sapwood thin, light-colored; used for cooperage, fencing, ties, etc.

SILVICAL CHARACTERS. Upper Sonoran and lower part of Transition zones; intolerant; moist to dry sites.

A related form, Bray's oak, $Q$. brayi Small [Q. mühlenbergii var. brayi (Small) Sarg.] becomes a large tree in New Mexico and western Texas. This is differentiated by larger acorns ( $11 / 4$ inches long) and deeper cups up to 1 inch in diameter.

\section{Giant Chinquapin. Golden Chinquapin Castanopsis chrysophylla A.DC.}

A Pacific Coast tree which barely enters this region in western Nevada. While resembling the oaks, to which it is closely related, it can be readily identified by the spiny bur covering the nut and by the persistent leaves golden-scaly below. 


\section{American Elm}
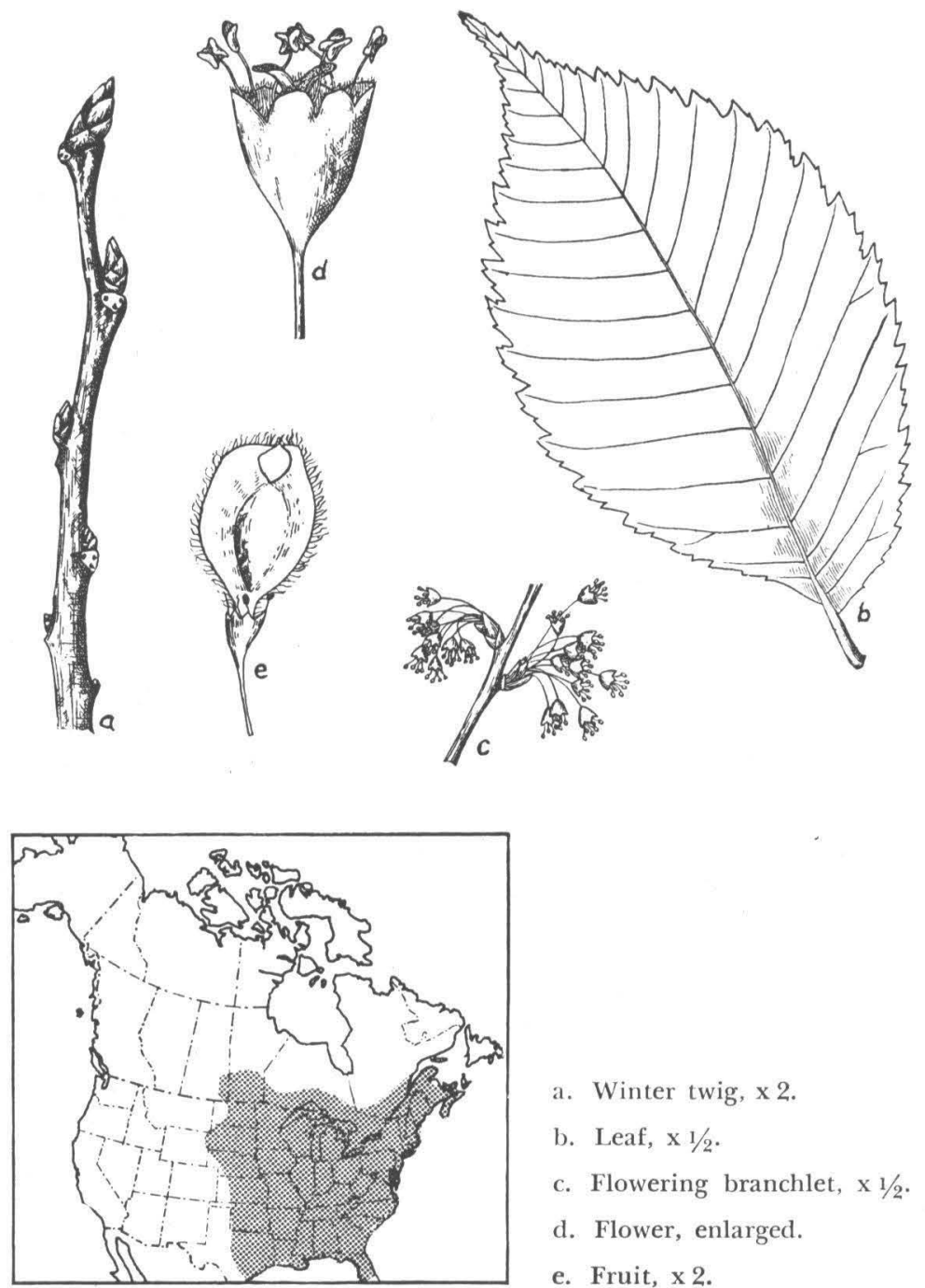

a. Winter twig, x 2 .

b. Leaf, $\times 1 / 2$.

c. Flowering branchlet, x 1/2.

d. Flower, enlarged.

e. Fruit, x 2 . 


\section{ULMACEAE \\ American Elm. White Elm \\ Ulmas americana $\mathrm{L}$.}

HABIT. A handsome tree sometimes 100-120 feet high and 6-11 feet in diameter; trunk sometimes single, usually divided near the ground into several erect limbs; symmetrical, vaseshaped crown.

LEAVES. Alternate; simple; obovate-oblong to elliptical; 4-6 inches long and 1-3 inches wide; acuminate; unequal and oblique at base; margins coarsely doubly serrate; dark green and glabrous or scabrous above, pale and pubescent or rarely glabrous below; turning clear yellow in autumn; deciduous; petioles $1 / 4$ inch long, stout; stipules linear, $1 / 2-2$ inches long, fugacious.

FLOWERS. Regular; perfect; small; in 3-4-flowered, shortstalked fascicles; on long, slender, drooping pedicels; appearing before leaves; calyx 7-9-lobed, green, puberulous and ciliate; corolla absent; stamens 5-6, anthers bright red; ovary usually l-celled by abortion, l-ovuled, flattened, light green, ciliate, with 2-lobed style.

FRUIT. Flattened, ovoid to obovoid-oblong samara $1 / 2$ inch long; seed cavity encircled by thin, membranaceous, notched wing; ciliate on margins.

TWIGS. Slender; round; light green and pubescent at first, becoming red-brown, glabrous and marked by pale lenticels and large, raised leaf scars. Winter buds: terminal absent; lateral $1 / 8$ inch long, scaly, ovoid, acute, brown.

BARK. Thick (1-11/2 inches); ash-gray; interspersed with light-colored, corky layers; diamond-shaped ridges common.

WOOD. Heavy; hard; strong; tough; coarse-grained; ringporous; heartwood light brown; sapwood thick, lighter colored; important for specialty uses.

SILVICAL CHARACTERS. Upper Sonoran and Transition zones; moderately tolerant; shallow-rooted; adapted to variety' of sites; seriously threatened by Dutch Elm disease.

GENERAL. The American elm, rock elm (U. thomasii Sarg.), slippery elm (U. fulva Michx.), and Siberian elm (U. pumila L.) are commonly planted as ornamental trees in this region. 


\section{ULMACEAE \\ The HackBerries}

Characteristics of the Genus Celtis L.

HABIT. Shrubs or trees often planted for shade or ornamentals; irregularly pinnate branching.

LEAVES. Alternate; simple; lanceolate to ovate; acute or acuminate at apex; often oblique at base; serrate or entire margins; membranaceous or subcoriaceous; deciduous; mostly long petiolate; stipules thin, caducous, fugacious, enclosing leaf in bud.

FLOWERS. Regular; polygamo-monoecious or rarely monoecious; minute; the staminate in fascicles toward the base of twig; above these the pistillate or perfect, solitary or in fewflowered fascicles; pedicellate; appearing soon after the unfolding of the leaves; calyx 4-5-lobed, green-yellow, deciduous; corolla absent; stamens as many as calyx lobes and opposite them; ovary 1-celled, ovoid, sessile, green and lustrous.

FRUIT. Subglobose or ovoid drupe; tipped with remnants of style; thick firm skin; thin, pulpy flesh; nutlet bony, thickwalled, reticulate-pitted; ripening in autumn and often remaining long after leaves fall. Seed: filling cavity in nutlet.

TWIGS. Round; unarmed or spinose. Winter buds: terminal absent; lateral small, scaly; branchlets prolonged by an upper lateral bud.

BARK. Usually gray and smooth, sometimes with conspicuous, corky, warty excrescences.

WOOD. Rather heavy; fairly hard; not strong; odorless; ring-porous; moderately important; often sold as elm.

GENERAL. This genus consists of about 70 species scattered through the north temperate and tropical regions; six species and several varieties have been listed for the United States; native species often disfigured by gall-making insects distorting the buds and producing broomlike clusters of branchlets; this genus is in a confused state and needs revision; distributions have not been accurately determined. 


\section{KEY TO THE SPECIES OF CELTIS}

I. Fruit dark purple, on pedicels somewhat longer than petioles of leaf; leaves sharply serrate with numerous teeth, veinlets not conspicuous on lower surface.

.................. Celtis occidentalis var. crassifolia, p. 161 .

II. Fruit orange-red to yellow; leaves entire or sparingly toothed.

A. Fruit on pedicels shorter or only slightly longer than petioles of leaf; leaves rarely sparingly toothed; veinlets not conspicuous.

1. Fruit dark orange-red; leaves oval to lanceolate; Texas and southern New Mexico.

2. Celtis laevigata var. texana, p. 163.

2. Fruit canary-yellow; leaves ovate; central and southern Arizona........3. Celtis laevigata var. brevipes, p. 163.

B. Fruit on pedicels much longer than petioles of leaf; leaves broadly ovate; veinlets conspicuous on lower surface.

1. Fruit pedicels often 3-4 times as long as leaf petioles: leaves pale on lower surface; leaf margins coarsely serrate; fruit light orange-brown; northern Arizona and north... 4. Celtis douglasii, p. 165.

2. Fruit pedicels usually not more than twice as long as leaf pedicels; leaves yellow-green on lower surface; leaf margins entire; fruit orange-red or yellow; western Texas, Arizona, New Mexico, and Colorado.................. .......................5. Celtis reticulata, p. 165 . 

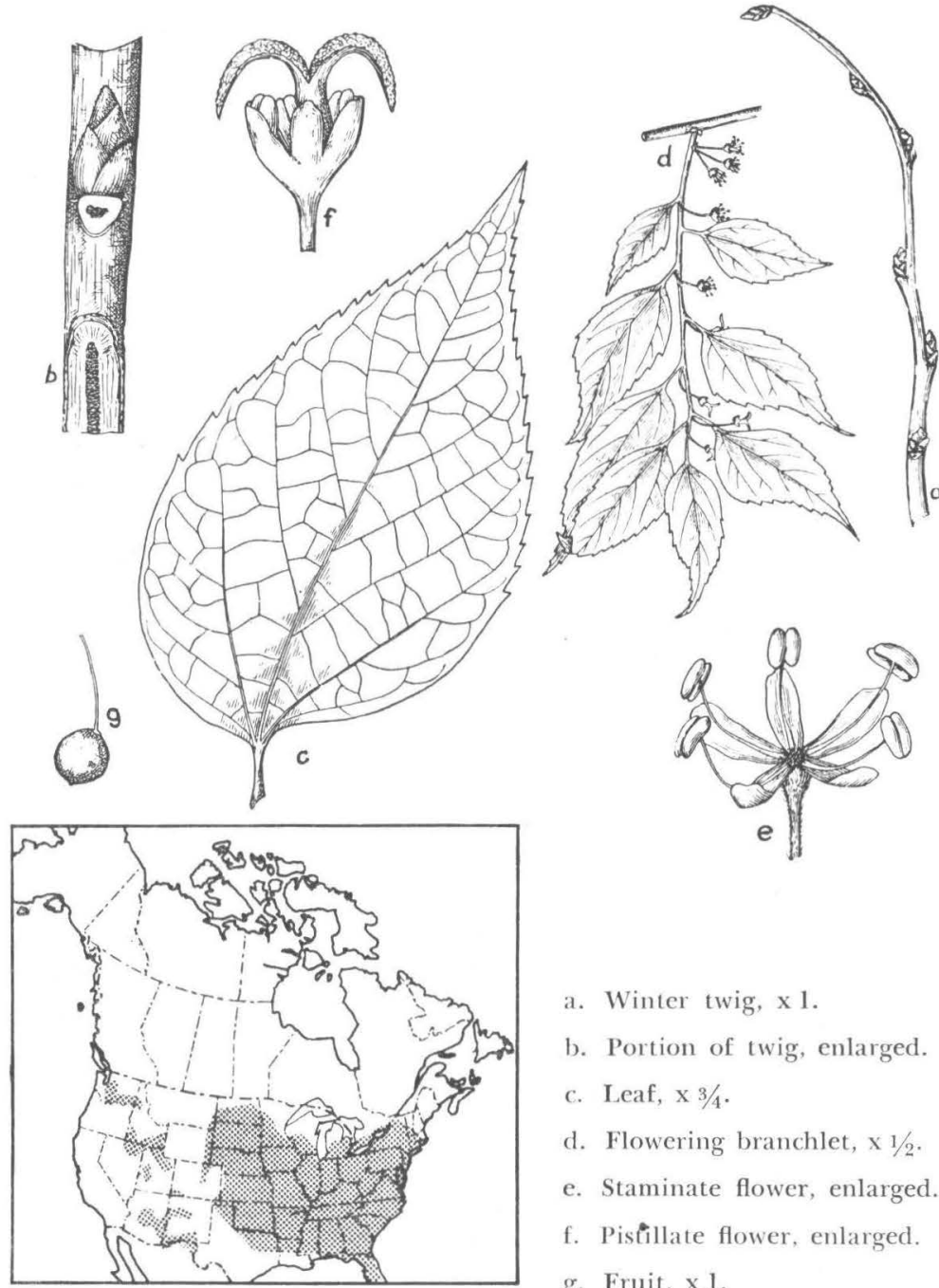

[160]

a. Winter twig, $\times 1$.

b. Portion of twig, enlarged.

c. Leaf, $x 3 / 4$.

d. Flowering branchlet, $\times 1 / 2$.

e. Staminate flower, enlarged.

f. Pisfillate flower, enlarged.

g. Fruit, $\mathrm{x} 1$. 


\section{ULMACEAE \\ BIGLEAF HACKBERRY \\ Celtis occidentalis var. crassifolia (Lam.) Gray}

HABIT. Occasionally shrubby, but usually a rather large tree 100-120 feet high and 1-2 feet in diameter; crown rounded and of large, spreading, often pendulous branches.

LEAVES. Ovate to ovate-lanceolate; $21 / 2-4$ inches long and $11 / 2-2$ inches wide in Rocky Mountain region; long-acuminate apex; obliquely rounded base; coarsely serrate or rarely almost entire; rather thin; light, dull green and rough above, slightly paler and pilose along veins below; turning light yellow in autumn; petioles $1 / 4-1 / 2$ inch long, villose-pubescent or rarely glabrous.

FLOWERS. On drooping pedicels; calyx with 5 linear, acute, thin, scarious lobes more or less laciniately cut, often hairy-tufted at apex; receptacle hoary-tomentose.

FRUIT. 1/3 inch in diameter; subglobose, ovoid, or obovoid; dark purple; on stems $1 / 2-3 / 4$ inch long; thick, tough skin; dark orange-colored flesh; oblong, pointed, light brown, slightly rugose nutlet. Seed: pale brown.

TWIGS. Slender; ridged; light brown, becoming darker; pubescent or glabrous; marked by pale, oblong lenticels; pith finely chambered at nodes. Winter buds: $1 / 4$ inch long, ovoid, pointed, pubescent, chestnut-brown.

BARK. Rather thick (1-1 1/2 inches); dark brown; smooth, or more or less roughened by irregular wartlike excrescences or by long ridges.

WOOD. Heavy; rather soft; not strong; coarse-grained; heartwood clear, light yellow; sapwood thick, lighter colored; of little use in the west.

SILVICAL CHARACTERS. Upper Sonoran and lower portions of Transition zone; moderately tolerant; rapid growing; the largest and most handsome member of the genus; frequently planted in west because of drought resistance: adapted to variety of sites, doing best on moist, rich soils, and stunted and scraggly on poor, dry sites.

GENERAL. This variety is the most widely distributed form of the species and differs from it by relatively trivial characters. The distribution shown is for the entire species. 

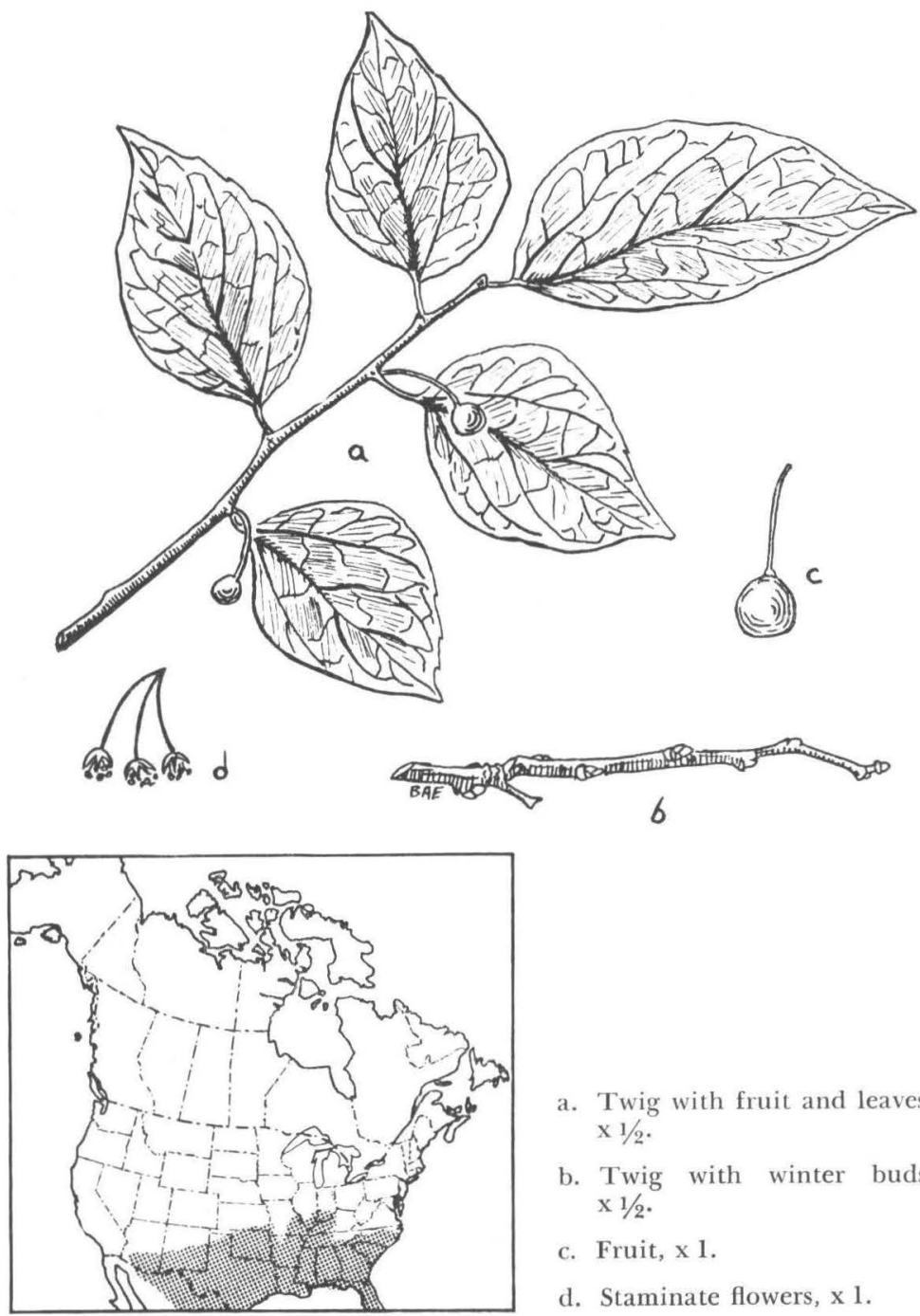

a. Twig with fruit and leaves, $\mathrm{X} 1 / 2$.

b. Twig with winter buds, $\mathrm{x} 1 / 2$.

c. Fruit, x 1 .

d. Staminate flowers, $\mathrm{x} 1$. 


\section{ULMACEAE \\ TeXas Sugarberry. HACKberRY \\ Celtis laevigata var. texana (Scheele) Sarg. \\ (Celtis mississippiensis Bose.)}

HABIT. A shrub or small tree rarely over 25 feet high and 12 inches in diameter; crown broad with spreading or pendulous branches; often growing in clusters.

LEAVES. Ovate to lanceolate; $11 / 2-3$ inches long and $3 / 4-11 / 2$ inches wide; acuminate apex; unsymmetrically rounded or cordate at base; entire or sparingly and irregularly serrate; often subcoriaceous; dark green and smooth or granulate above, paler and glabrous or hairy along veins below; veinlets not conspicuous; petioles $1 / 5-1 / 4$ inch long, slender, pale-pubescent.

FLOWERS. On slender, glabrous pedicels; calyx divided into 5 , ovate-lanceolate, glabrous or puberulous, scarious lobes hairy-tufted at apex.

FRUIT. 1/4 inch long; subglobose or short-oblong; dark orange-red; on glabrous or puberulous pedicels slightly longer than petioles; nutlet slightly rugose.

TWIGS. Slender; red and glabrous or gray-brown and pubescent; marked by pale, oblong lenticels and narrow, elevated leaf scars. Winter buds: $1 / 16^{-1 / 8}$ inch long, ovoid, pointed, puberulous, chestnut-brown.

BARK. Rather thin ( $1 / 3-2 / 3$ inch); pale or grayish; rough; not often covered with wartlike excrescences.

WOOD. Heavy; soft; not strong; close-grained; heartwood light yellow; sapwood thick and lighter colored; unimportant.

SILVICAL CHARACTERS. Upper Sonoran zone; site varies from moist to rocky bluffs and dry hillsides; southern New Mexico and east.

The variety Celtis laevigata var. brevipes (S. Wat.) Sarg. is a small tree with thinner, ovate leaves; slender, glabrous, red-brown branches; and canary-yellow fruit; limited in its distribution to central and southern Arizona. The species proper, Celtis laevigata Willd., is distributed through the southeastern portions of the United States, extending west to eastern Texas. The distribution shown includes both the species and its varieties. 


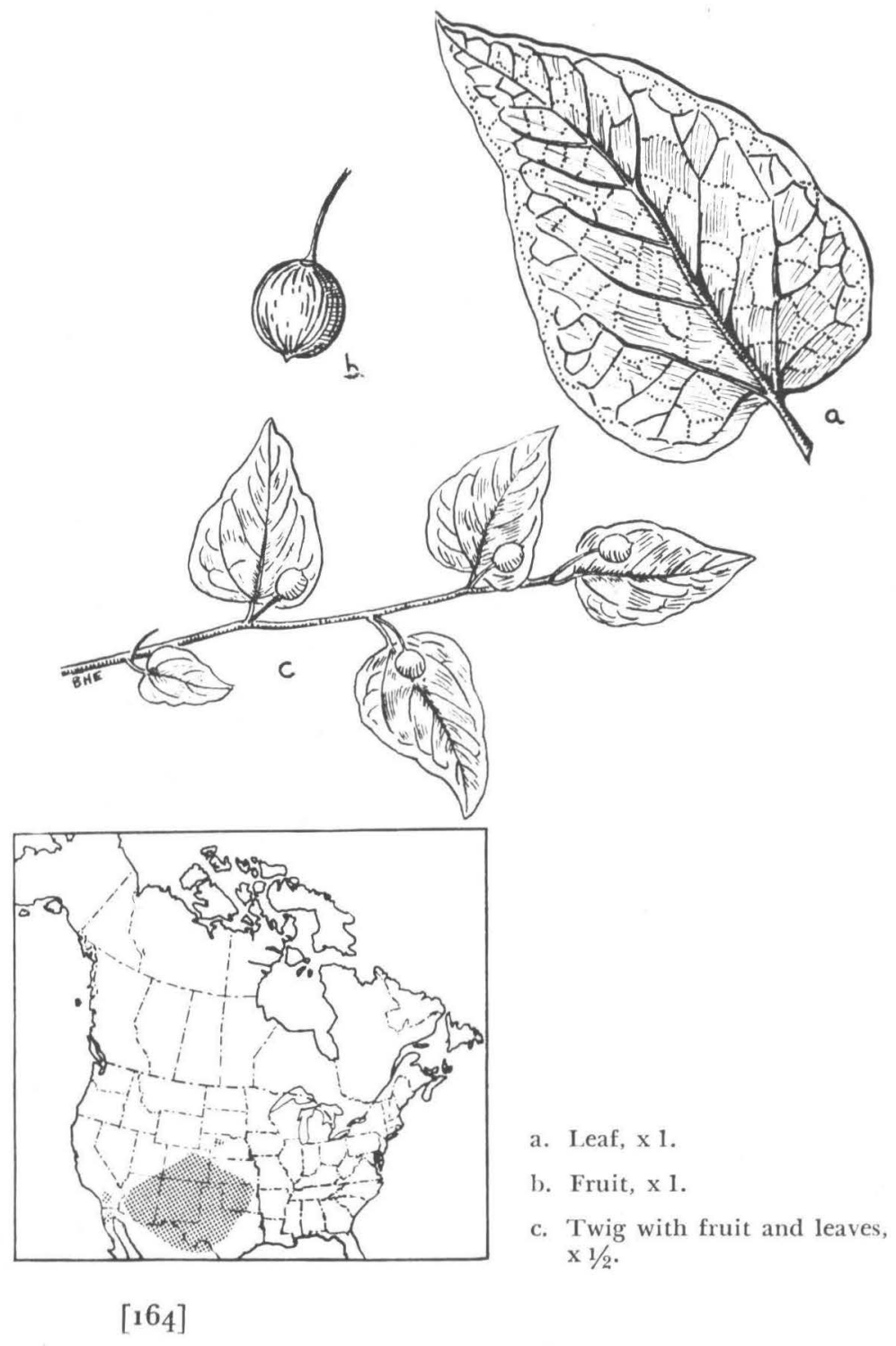




\section{ULMACEAE}

\section{Netleaf Hackberry. Palo Blanco}

Celtis reticulata Torr.

HABIT. A shrub or small tree rarely 30 feet high and 6-12 inches in diameter; crown open and irregular with stout, ascending branches.

LEAVES. Broadly ovate; $11 / 4-3$ inches long and $3 / 4-11 / 2$ inches wide; acute or acuminate apex; obliquely rounded at base; entire margins or with a few broad teeth; thick; dark green and rough or smooth above, yellow-green, somewhat hairy, and with conspicuous reticulate veinlets below; petioles $1 / 8-1 / 4$ inch long, stout, more or less densely pubescent.

FLOWERS. On slender, pubescent pedicels; calyx divided into 5, linear, acute, scarious lobes laciniately cut at apex; receptacle hoary-tomentose.

FRUIT. $1 / 4$ inch in diameter; subglobose to ellipsoidal; lustrous; orange-red or yellow; on pubescent pedicels, $1 / 3^{-1 / 2}$ inch long.

TWIGS. Slender; green and pubescent or tomentose at first, becoming red-brown and pubescent or glabrous; marked by small, pale lenticels.

BARK. Thick; ash-gray; rough with prominent, short, projecting ridges.

WOOD. Rather heavy; soft; not strong; heartwood clear, light yellow; sapwood thick, lighter colored; unimportant.

SILVICAL CHARAGTERS. Upper Sonoran zone; in mountain ravines and on dry, rocky hillsides and cañon slopes.

A closely related species, Celtis douglasii Plan., can be distinguished by the following characters: Leaves rough above, pale below, and coarsely serrate; fruit light orange-brown, with pedicels often 3-4 times as long as leaf petioles; distribution is in the Upper Sonoran zone from Arizona (south slope of Grand Cañon), western Texas and Colorado (eastern foothills) into Utah, Idaho, California, Oregon, Washington, and British Columbia. 

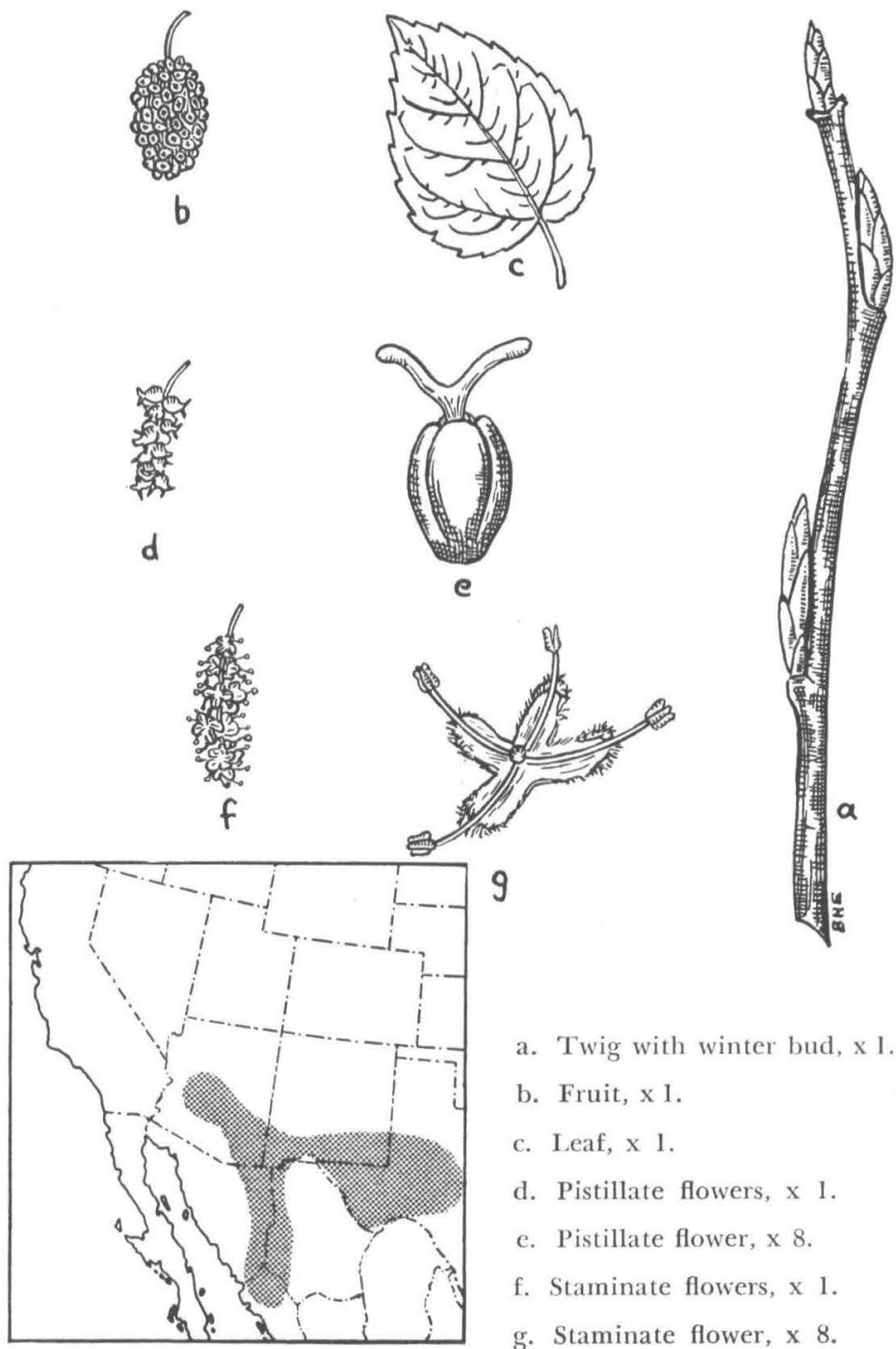

9

a. Twig with winter bud, $\mathrm{x} 1$.

b. Fruit, $\times 1$.

c. Leaf, $\times 1$.

d. Pistillate flowers, $\mathrm{x} 1$.

c. Pistillate flower, $\mathrm{x} 8$.

f. Staminate flowers, $\mathrm{x} 1$,

g. Staminate flower, $\mathrm{x} 8$. 


\section{MORACEAE}

\section{Mexican Mulberry. Texas Mulberry \\ Morus microphylla Buckl.}

HABIT. A shrub or small tree 15-20 feet high and 12-14 inches in diameter; crown scraggly and irregular.

LEAVES. Alternate; simple; ovate; 1-2 inches long; entire or shallowly 3-lobed; acute or acuminate; margins coarsely serrate; thin and firm; dark green and often roughened by tubercles above, paler and glabrous or pubescent below; deciduous; petioles slender, hairy, $1 / 3$ inch long; stipules white, tomentose, $1 / 2$ inch long, linear-lanceolate, acute, enclosing leaf in the bud.

FLOWERS. Regular; dioecious (rarely monoecious); minute; staminate in many-flowered spikes; pistillate in fewflowered spikes; calyx 4-lobed, dark green, hairy; corolla absent; stamens 4, anthers bright yellow; ovary 2-celled (one of cells smaller and disappearing), ovoid, flat, included within calyx, green and glabrous.

FRUIT. Drupaceous, enclosed in thickened, berry-like calyx and united into a compound fruit (syncarp); $1 / 2$ inch long; subglobose or short ovoid; red, becoming nearly black; sweet and palatable; drupe $1 / 6$ inch long, ovoid, with thin-walled brown nutlet. Seed: ovoid, pointed, pale yellow.

TWIGS. Slender; round; unarmed; pubescent, becoming glabrous; orange-red; marked by small lenticels and elevated, nearly orbicular leaf scars. Winter buds: scaly, terminal absent, branchlets prolonged by upper axillary bud, ovoid, acute, lustrous, chestnut-brown.

BARK. Thin (rarely $1 / 2$ inch); light gray, tinged with red; furrowed and scaly.

WOOD. Heavy; hard; close-grained; ring-porous; heartwood dark orange or brown; sapwood thick, light-colored; unimportant.

SILVICAI CHARACTERS. Upper Sonoran zone; intolerant; fibrous roots; dry hills and mountain cañons; possibly not distinct from the Mexican species, Morus celtidifolia H.B.K.

The eastern Red Mulberry, Morus rubra L., while not native in this region is commonly planted as an ornamental. 


\section{Arizona Sycamore}

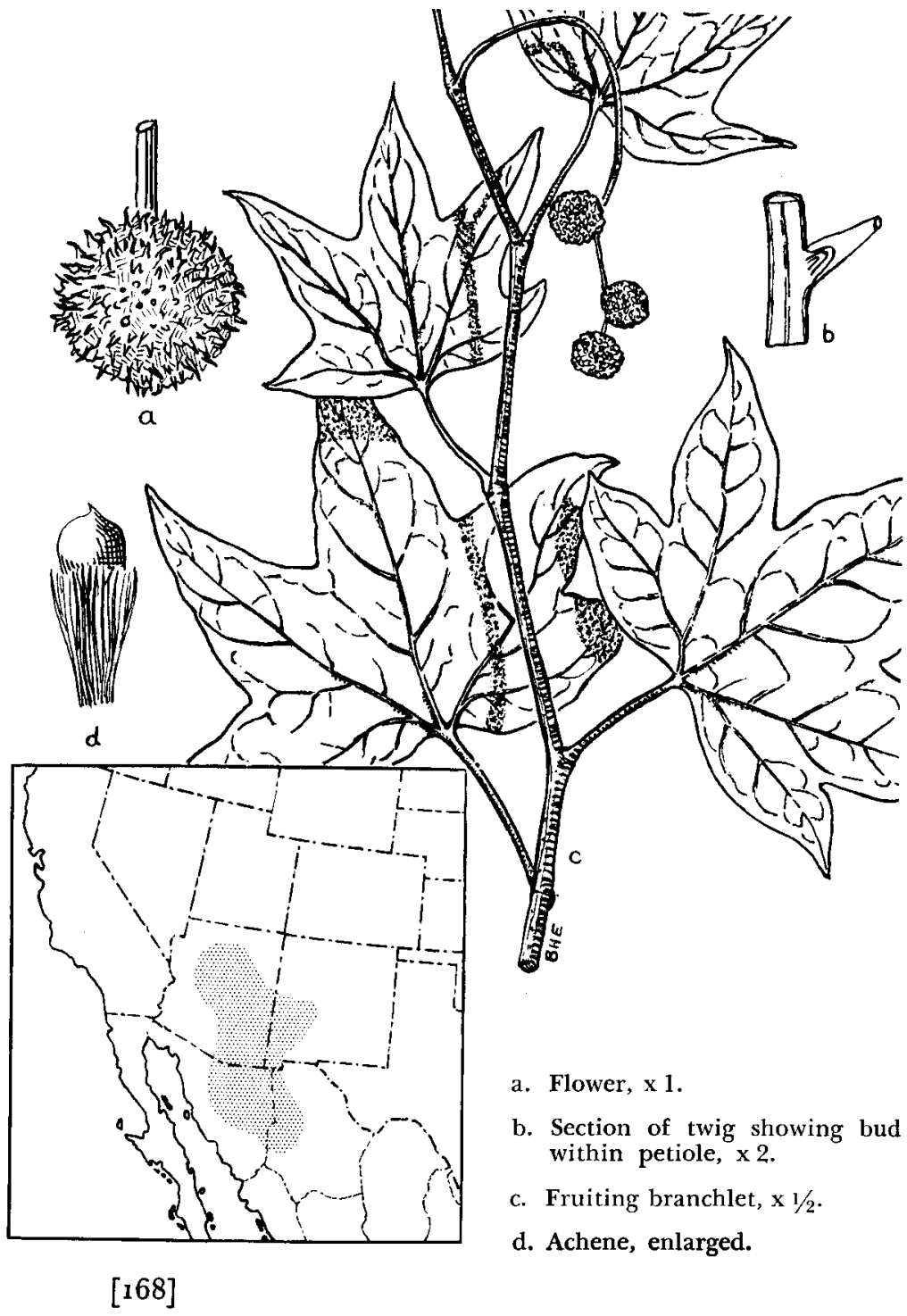




\section{PLATANACEAE}

\section{Arizona Sycamore. Arizona Plane \\ Platanus wrightii S. Wat.}

HABIT. A tree often $60-80$ feet high and $4-5$ feet in diameter; trunk erect or divided and more or less reclining; crown broad and open with large, contorted branches.

LEAVES. Alternate; simple; broadly ovate; 6-8 inches long and broad; deeply divided into 3-7, acute lobes; entire or dentate margins; thin and firm; light green and glabrous above, pale pubescent below; deciduous; petioles $11 / 2-3$ inches long, enlarged at base and enclosing buds; stipules membranaceous, united into tube surrounding twig.

FLOWERS. Regular; monoecious; minute; in dense, racemose heads; on hoary-tomentose peduncles; the staminate red on axillary peduncles, the pistillate light green on terminal peduncles; calyx 3-6-sepaled; corolla 3-6-petaled; stamens as many as sepals and opposite them; ovaries as many as sepals, superior, surrounded at base by pale hairs persistent around the fruit; ovules 1 or rarely 2.

FRUIT. Numerous, elongated achenes; in 1-4 globose heads; in slender, glabrous, pendulous racemes; surmounted by persistent styles; 1-seeded; light yellow-brown; coriaceous. Seed: light chestnut-brown.

TWIGS. Slender; round; zigzag; ash-gray or brown; tomentose at first, becoming glabrous; marked by minute, scattered lenticels; pith conspicuous. Winter buds: terminal absent; lateral $1 / 8$ inch long, smooth, lustrous, 3-scaled, nearly covered at base by narrow leaf scar.

BARK. At base of old trunks thick (3-4 inches), furrowed and ridged; on young trunks thin, cream-white, tinged with green, exfoliating in large, thin, brittle plates.

WOOD. Heavy; hard; not strong; cross-grained; diffuseporous; with broad rays; heartwood light brown, tinged with red; sapwood thick, lighter colored; used locally for fabrication products.

SILVICAL CHARACTERS. Upper Sonoran zone; intolerant; reproduction scanty; in moist sites on banks of streams in mountain cañons. 


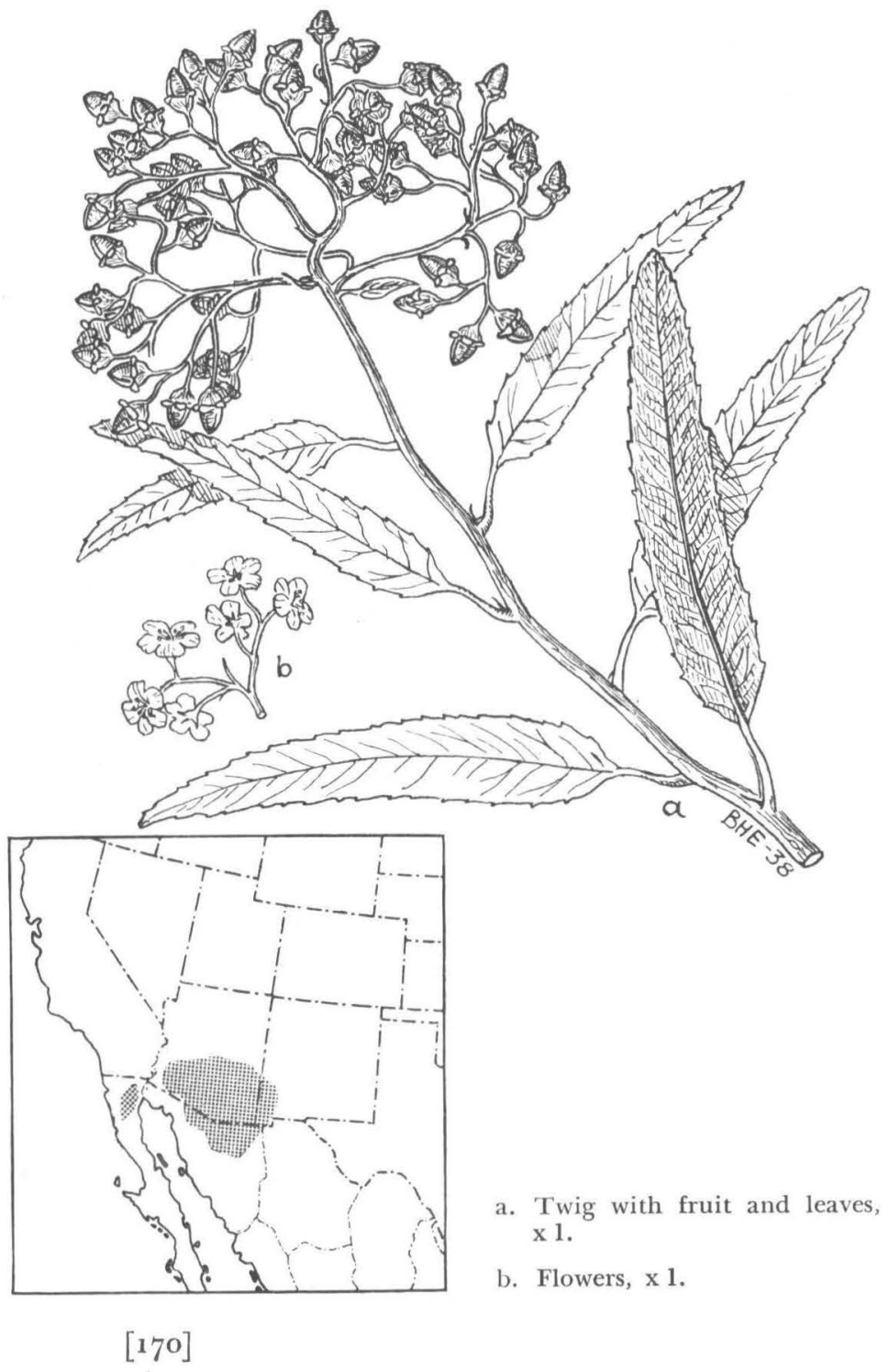




\section{ROSACEAE}

\section{TORrey Vauquelinia}

\section{Vauquelinia californica (Torr.) Sarg.}

HABIT. A shrub or rarely a small tree 18-20 feet high and 5-6 inches in diameter; trunk slender, often hollow; branches upright, stiff, and crooked.

LEAVES. Alternate or rarely opposite; simple; oblong to narrowly lanceolate; $11 / 2-3$ inches long and $1 / 4-1 / 2$ inch wide; acuminate or rarely rounded at apex; remotely serrate with minute, glandular teeth; coriaceous; bright yellow-green; glabrous above, tomentose below; persistent through winter; long-petiolate; stipules minute, acute, deciduous.

FLOWERS. Regular; perfect; small; in terminal, leafy, hoary-tomentose panicles 2-3 inches across; on slender, hairy, bracted pedicels; calyx short, obconic, leathery, persistent; corolla white, $1 / 4$ inch in diameter, of persistent, oblong, reflexed petals; stamens $15-25$, in 3-4 rows, persistent filaments; 5 carpels united below into 5-celled, hairy ovary.

FRU1T. Woody, ovoid, 5-celled, tomentose capsule; subtended by remnants of flower; adherent below and splitting down the back at maturity; long persistent on branches. Seed: $1 / 12$ inch long, 2 in each cell, winged.

TWIGS. Slender; round; bright red-brown, becoming light brown or gray; tomentose; marked by large, elevated leaf scars. Winter buds: axillary, minute, acuminate, red-brown, pubescent.

BARK. Thin ( $1 / 16$ inch); dark red-brown; broken on surface into small, square, persistent, platelike scales.

WOOD. Very hard and heavy; close-grained; diffuse-porous; heartwood dark brown, streaked with red; sapwood thick, lighter colored; unimportant.

SILVICAL CHARACTERS. Transition zone; intolerant; on grassy slopes or in rocky gulches of mountain ranges; reaching tree size at altitudes of about 5,000 feet in the Santa Catalina Mountains of Arizona.

$V$. angustifolia Rydb., a similar shrub or small tree has been reported from southern parts of western Texas, New Mexico and Arizona. 


\section{Western Mountainash}
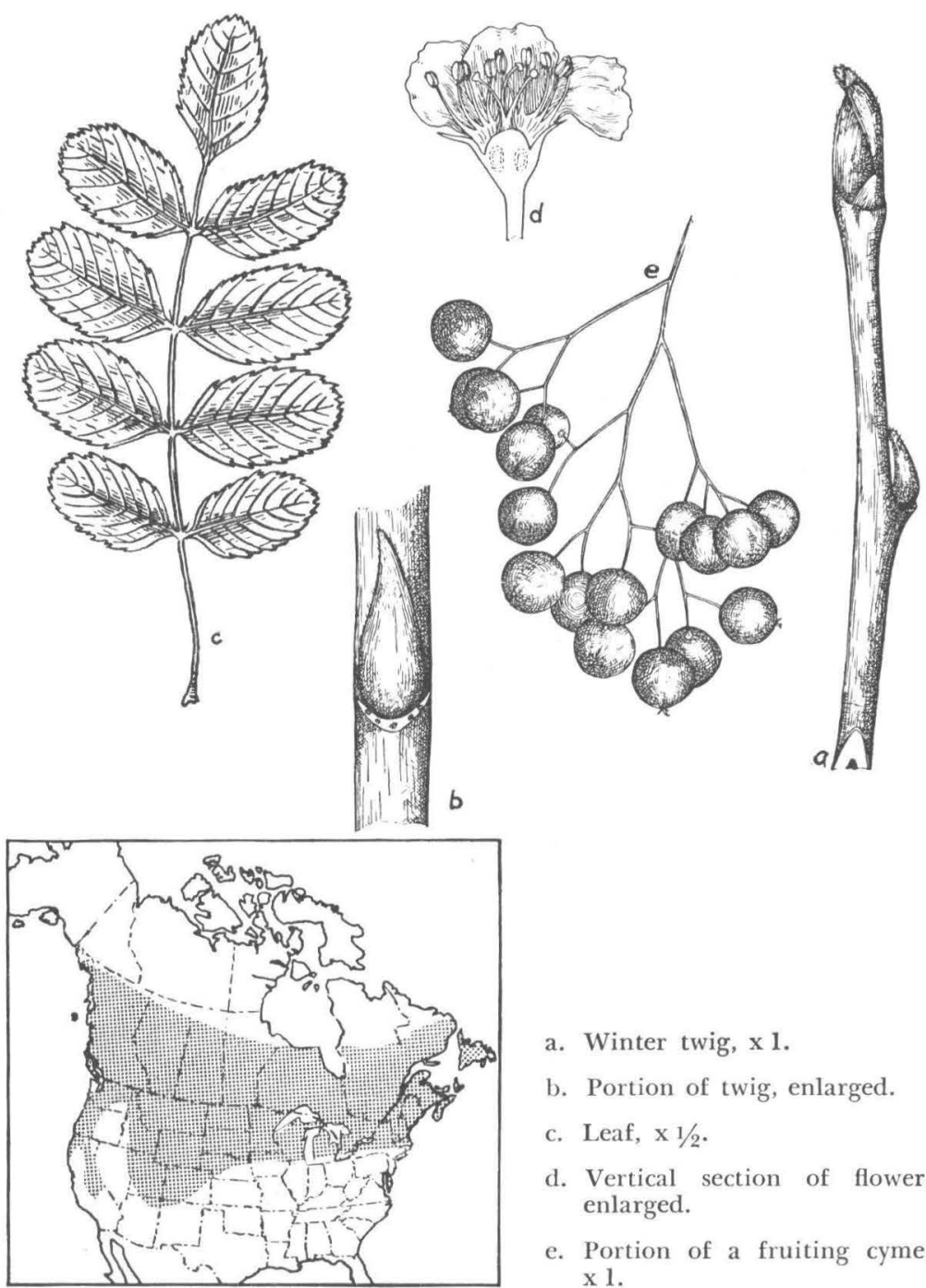

a. Winter twig, $\times 1$.

b. Portion of twig, enlarged.

c. Leaf, $\times 1 / 2$.

d. Vertical section of flower, enlarged.

e. Portion of a fruiting cyme, $\mathrm{x} 1$. 


\section{ROSACEAE}

\section{Western Mountainash}

Sorbus americana var. sitchensis (Roem.) Sudw. (Sorbus sitchensis Roem.) (Pyrus sambucifolia A. Gray)

HABIT. A shrub or rarely a small tree, seldom 30 feet high and 12 inches in diameter; crown round-topped, handsome; with spreading, slender branches.

LEAVES. Alternate; pinnately compound; 4-6 inches long; with 7-13 mostly sessile leaflets; oblong-oval to ovate-lanceolate; $2-4$ inches long and $1 / 2-1$ inch wide; apex rounded, usually short-pointed; sharply serrate; glabrous; blue-green above, pale below; deciduous; petioles stout, usually red, 11/2-2 inches long; stipules foliaceous, free from petiole.

FLOWERS. Regular; perfect; small; in broad, flat cymes 3-4 inches across; on short, stout pedicels; appearing after leaves; calyx tube urn-shaped, puberulous, persistent; corolla cream-white, 1/4 inch in diameter; stamens usually 20 in 3 rows; $2-5$, usually 3 , carpels, partly united and half-superior or wholly united and inferior; ovules 2 in each cell.

FRUIT. Berry-like pome; subglobose; $1 / 4-1 / 2$ inch in diameter; bright orange-red; thin, acid flesh; papery carpels. Seed: 2, or 1 by abortion, in each cell, $1 / 8$ inch long, ovoid, brown.

TWIGS. Stout; round; red-brown and pubescent, becoming dark brown and glabrous; marked by large leaf scars and oblong lenticels. Winter buds: terminal $1 / 4-3 / 4$ inch long, acute, dark red, pilose, with gummy exudation.

BARK. Thin ( $1 / 8$ inch); light gray; smooth or slightly roughened by scales; inner bark fragrant.

WOOD. Light; soft; weak; close-grained; diffuse-porous; heartwood pale brown; sapwood thick and lighter colored.

SILVICAL CHARACTERS. Transition and Canadian zones; intolerant; slow-growing; abundant seeder; fibrous roots; prefers moist, rich sites on borders of streams, but grows well on rocky hillsides and mountains; often cultivated.

GENERAL. The taxonomy within this genus is so confused that it is impossible to show accurate distributions; Sorbus scopulina Greene is here considered a form of Sorbus americana var. sitchensis, and its distribution is included in the map. 


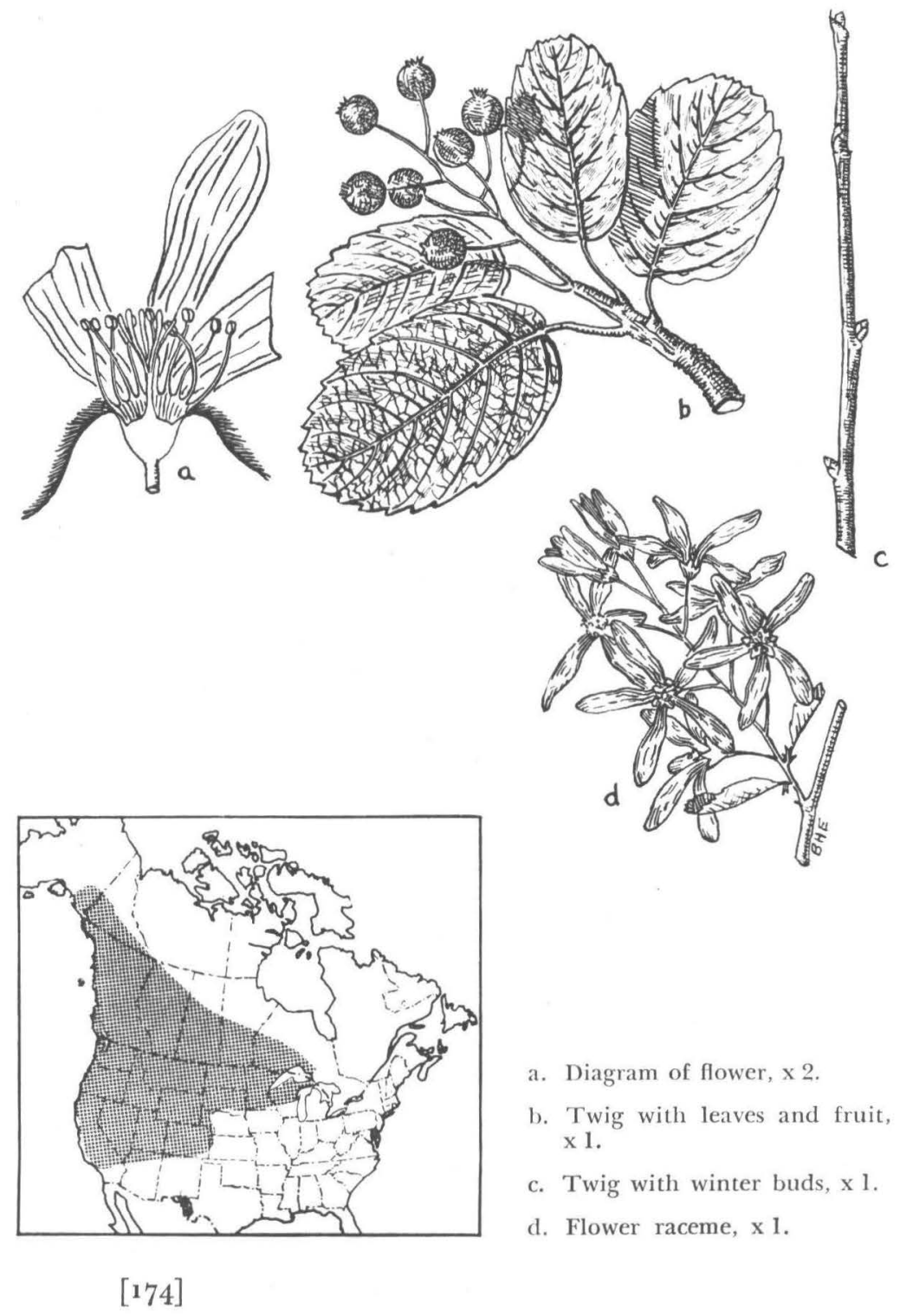




\section{ROSACEAE}

\section{Western Serviceberry. Western Sarvis}

Amelanchier alnifolia Nutt. (Amelanchier florida Lindl.)

(Amelanchier mormonica Schn.)

HABIT. A shrub or rarely a small tree 25-40 feet high and 8-14 inches in diameter; crown open and oblong.

LEAVES. Alternate; simple; oblong-ovate to oval or ovate; $11 / 2-21 / 2$ inches long and $1-11 / 2$ inches wide; rounded or rarely acute at apex; coarsely serrate only above the middle; thick or thin; dark green and glabrous above, pale below; deciduous; petioles slender, $1 / 2-1$ inch long; stipules rose color, linear, clongated.

FLOWERS. Regular; perfect; in erect, crowded racemes; appearing with leaves; calyx tube campanulate, persistent on fruit; corolla white, $1 / 2-3 / 4$ inch long, of 5 , oblong-obovate, clawed petals; stamens usually 20 in 3 rows, filaments persistent on fruit; ovary 5-celled with each cell divided by partition, densely tomentose at summit; ovules 2 in each cell, erect.

FRUIT. Berry-like pome; short oblong or ovoid; $1 / 4^{-1 / 2}$ inch in diameter; dark blue; more or less covered with glaucous bloom; flesh sweet and succulent; open at summit. Seed: 10 or often 5 by abortion, dark chestnut-brown.

TWIGS. Slender; round; becoming glabrous and red-brown to dark gray-brown. Winter buds: terminal $1 / 6-1 / 4$ inch long, ovoid to ellipsoidal, acute or acuminate, chestnut-brown.

BARK. Thin ( $1 / 8$ inch); light brown, tinged with red; smooth or slightly furrowed.

WOOD. Heavy; hard; close-grained; diffuse-porous; heartwood light brown; sapwood thick, lighter colored; unimportant.

SILVICAL CHARACTERS. Upper Sonoran to Canadian zones; tolerant when young; abundant seeder; deep fibrous roots capable of sprouting repeatedly; moist valleys, prairies, and borders of streams to dry mountain slopes.

GENERAL. A highly variable species. . Other similar shrubby southwestern forms that sometimes become small trees are: $A$. crenata Greene, $A$. goldmanii W. \& S., $A$. polycarpa Greene, and $A$. prunifolia Greene, $A$. utahensis Koehnex. The Eastern Serviceberry, A. canadensis (L.) Medic., is reported from eastern Wyoming. 


\section{ROSACEAE}

\section{The Hawthorns}

\section{Characteristics of the Genus Crataegus $\mathbf{L}$.}

HABIT. Deciduous shrubs or small trees; usually spiny; crown generally rounded and widespreading.

LEAVES. Alternate; simple; deciduous; usually serrate and often more or less lobed; membranaccous to coriaceous: stipules persistent until autumn or early deciduous, small to leaflike, often bright-colored; petiolate.

FLOWERS. Regular; perfect, in few- or many-flowered terminal corymbs; pedicellate; calyx 5-lobed, tubular, persistent on fruit or deciduous; corolla 5-petaled, white, inserted on edge of disk lining calyx-tube; stamens 5-25; ovary inferior, of 1-5 carpels connate at base, with 2 ovules in each cell; styles as many as carpels.

FRUIT. Small, variously colored pome with 1-5 bony, 1seeded nutlets; flesh usually dry and mealy; generally open or concave at apex.

TWIGS. Round; rigid; more or less zigzag; generally armed with stiff, sharp thorns; marked by oblong lenticels and small leaf scars. Winter buds: small, globose, scaly, lustrous, brown.

BARK. Dark red to gray; scaly or shallowly furrowed.

WOOD. Heavy; hard; tough; close-grained; diffuse-porous; heartwood red-brown; sapwood thick, light-colored; unimportant; used for tool handles, canes, and turned articles.

SILVICAL CHARACTERS. Intolerant; reproduction aggressive; growth slow.

GENERAL. An extremely large and complex genus containing several hundred species, the identification of which presents great difficulties even to the specialist; the number of stamens, which is variable but usually within constant limits, and the color of the anthers appear to be the most satisfactory characters for the identification of species. Some 10 species have been listed as occurring in the Rocky Mountain region; of these, $C$. douglasii is the most important and is described individually; the other species are keyed out. 


\section{KEY TO THE SPEGIES OF GRATAEGUS}

I. Mature fruit black.

A. Spines numerous, mostly over $1^{\prime \prime}$ long.

1. Leaves broad obovate to ovate, incisely lobed; stamens 1-8; Wyoming............... . C. erythropoda Ashe.

2. Leaves narrow rhombic to oval, scarcely lobed; stamens 20; Colorado................2. C. saligna Greene.

B. Spines few, mostly under $1^{\prime \prime}$ long.

1. Leaves broad obovate to ovate, incisely lobed, lustrous above; north from northern Nevada and Wyoming...... 3. C. douglasii Lindl.

2. Leaves lanceolate to narrow oblong-obovate, scarcely lobed, dull above; south from southern Idaho and Wyoming....4. C. douglasii var. rivularis (Nutt.) Sarg.

II. Mature fruit red.

A. Southwestern.

1. Leaves concave-cuneate at base, coarsely serrate with gland-tipped teeth; west Texas....5. C. montivaga Sarg.

2. Leaves truncate at base, finely serrate or doubly serrate with eglandular teeth; central and southern New Mexico.................. C. wootoniana Eggles.

B. Central and northern.

1. Teeth of leaves not glandular; fruit villous, dark red; nutlets deeply pitted; eastern foothills of Rockies and east.......................7. C. succulenta Schrad.

2. Teeth of leaves glandular; fruit not villous; nutlets not pitted.

a. Leaves suborbicular; eastern Colorado and Wyoming and east................. C. chrysocarpa Ashe.

b. Leaves ovate, oval or obovate, more or less cuneate at base.

(1) Fruit scarlet; leaves 3/4-21/4" long; North Dakota, Idaho, Oregon, British Columbia............

Fruit red ........... C. columbiana Howell. tana.................10. C. williamsii Eggles. 
Black Hawthorn

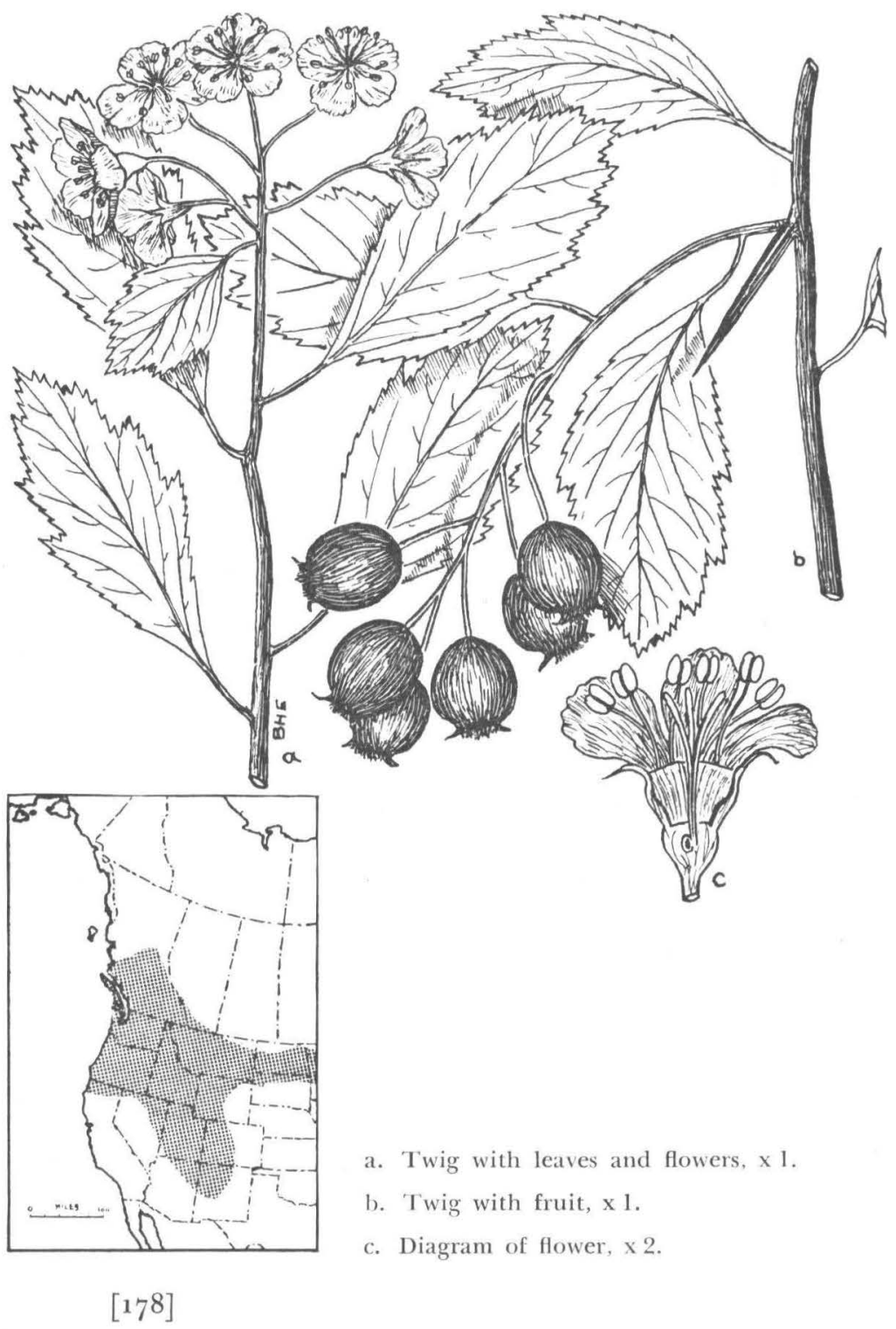




\section{ROSACEAE}

\section{Black Hawthorn. Western Thornapple}

Crataegus douglasii Lindl. (Crataegus brevispina) Hel.

HABIT. A shrub or small tree rarely 35 feet high or 20 inches in diameter; compact, round-topped crown with spreading and ascending branches.

LEAVES. Broad obovate to ovate; $1-2$ inches long and $1 / 2^{-}$ $11 / 2$ inches wide; often incisely lobed toward acute apex; base cuneate, entire; coarsely serrate above middle with glandular teeth; thin; glabrous and lustrous dark green above, paler below; petioles slender, $1 / 2-3 / 4$ inch long, wing margined above, villose becoming glabrous.

FLOWERS. In broad, glabrous corymbs; on long, slender, glabrous pedicels; with linear caducous bracts; calyx tube obconic, glabrous, lobes bright red at apex; corolla $1 / 2$ inch in diameter; stamens 10 or rarely 5 by abortion, anthers pale rose color; styles $2-5$, surrounded at base by tufts of long pale hairs.

FRUIT. About $1 / 2$ inch in diameter; short-oblong; black and lustrous; on slender pedicels; in compact, many-fruited, drooping clusters; calyx persistent; flesh sweet and succulent. Seed: nutlets usually 5 , about $1 / 4$ inch long.

TWIGS. Slender; glabrous; bright red or orange-red; lustrous; unarmed or with straight, blunt spines $1 / 3-1$ inch long. Winter buds: terminal usually present, $1 / 8$ inch, globose, scaly, lustrous, brown.

SILVICAL CHARACTERS. Upper Sonoran to Canadian zones; intolerant; banks of mountain streams or in rich bottomlands; at elevations of 900-5,500 feet; often forming dense thickets.

GENERAL. A closely related form is here considered a variety $C$. douglasii var. rivularis although many authors consider it a distinct species $C$. ritularis Nutt. This more southern form differs from the species in its narrower, thinner leaves, dull blue-green above, not lobed, and finely serrate; and in its slender, less numerous spines. 


\section{Curlleaf Mountain-mahogany}
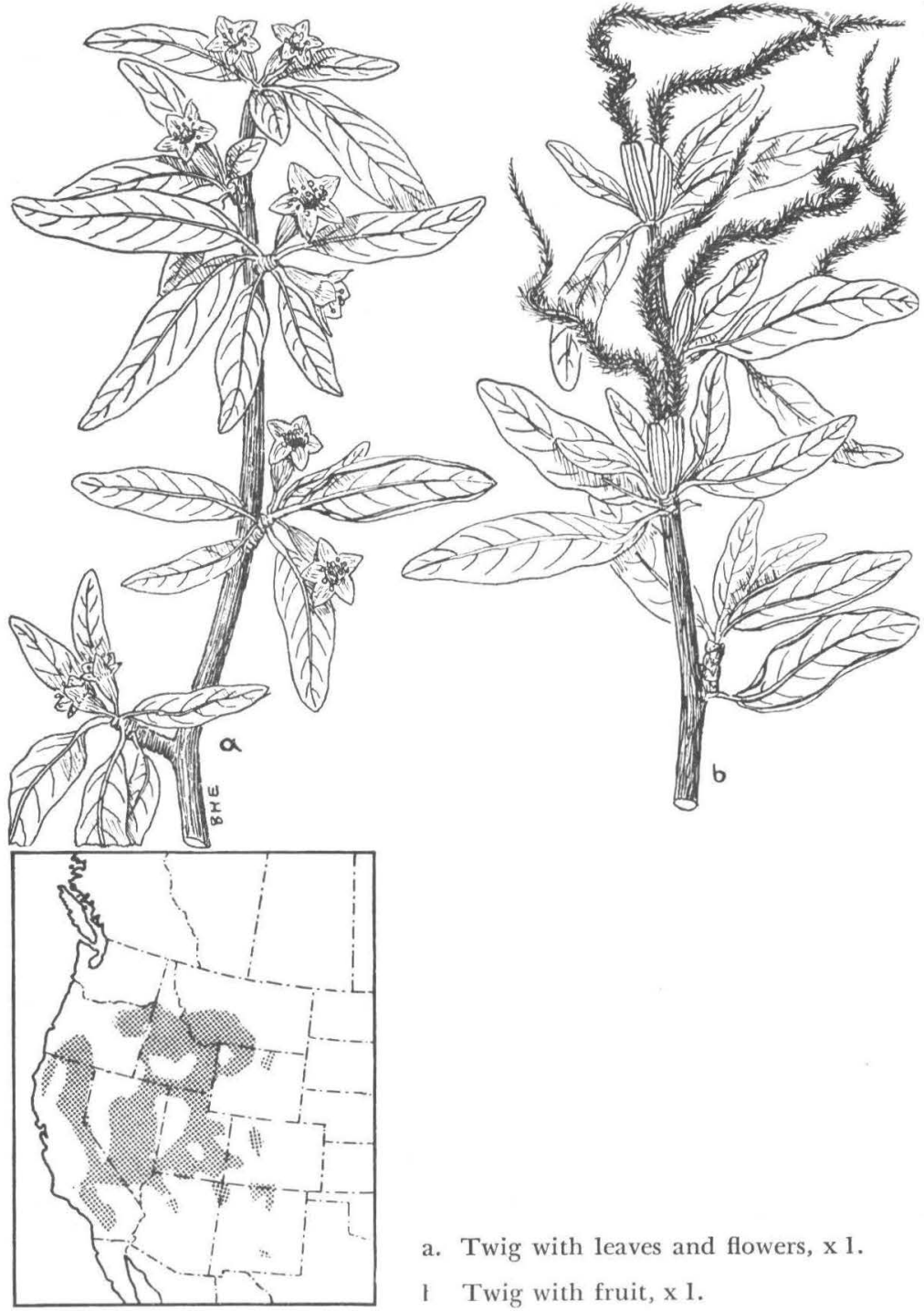

a. Twig with leaves and flowers, $\mathrm{x} 1$.

l Twig with fruit, $\mathrm{x} 1$. 


\section{ROSACEAE}

\section{Curlleaf Mountain-mahogany}

\section{Cercocarpus ledifolius Nutt.}

HABIT. A shrub or small tree rarely 40 feet high and 30 inches in diameter; trunk short and crooked; crown round and compact with stout, more or less crooked, spreading branches.

LEAVES. Alternate; simple; narrow-lanceolate, lance-elliptic, or oblanceolate; $1 / 2-1$ inch long and $1 / 3-2 / 3$ inch wide; acute at ends; entire; coriaceous; thick, revolute margins; dark green, lustrous and glabrous above, pale and tomentulose below; resinous; persistent for 2 years; short-petiolate; stipules triangular, minute, deciduous.

FLOWERS. Regular; perfect; solitary; inconspicuous; sessile in axils of leaves; calyx tube long, hoary-tomentose, whitish; corolla absent; stamens $15-30$, in 2-3 rows, free, anthers hairy; ovary inferior, composed of 1 carpel and ovule.

FRUIT. Linear-oblong, coriaceous achene $1 / 4$ inch long, enclosed in persistent calyx tube $1 / 2$ inch long; chestnut-brown; covered with long hairs; tipped with persistent, hairy, elongated style 2-3 inches long. Seed: solitary, linear, acute.

TWIGS. Stout; round; rigid; red-brown and pubescent at first, becoming dark brown or silver-gray and glabrous; often covered with glaucous bloom; conspicuously marked for many years by elevated, crowded, narrow leaf scars; spurlike lateral branches. Winter buds: minute, scaly, pubescent.

BARK. Thick on old trunks ( 1 inch); red-brown; hard; firm; furrowed and scaly.

WOOD. Exceedingly heavy and hard; brittle; close-grained; diffuse-porous; warping badly; heartwood clear red or dark brown; sapwood rather thin, yellow; unimportant.

SILVICAI, CHARACTERS. Upper Sonoran to lower parts of Canadian zones; intolerant; rather long-lived; slow-growing; between 2,000-5,000 feet in the north, and up to 9,000 feet in the south; on dry, gravelly, wind-swept slopes.

GENERAL. The high mountain form, growing chiefly in the southern Rocky Mountains, has been designated as C. ledifolius var. intricatus (Wat.) Jones; this is a small shrub with very small, narrow, curved leaves and smaller fruit. 

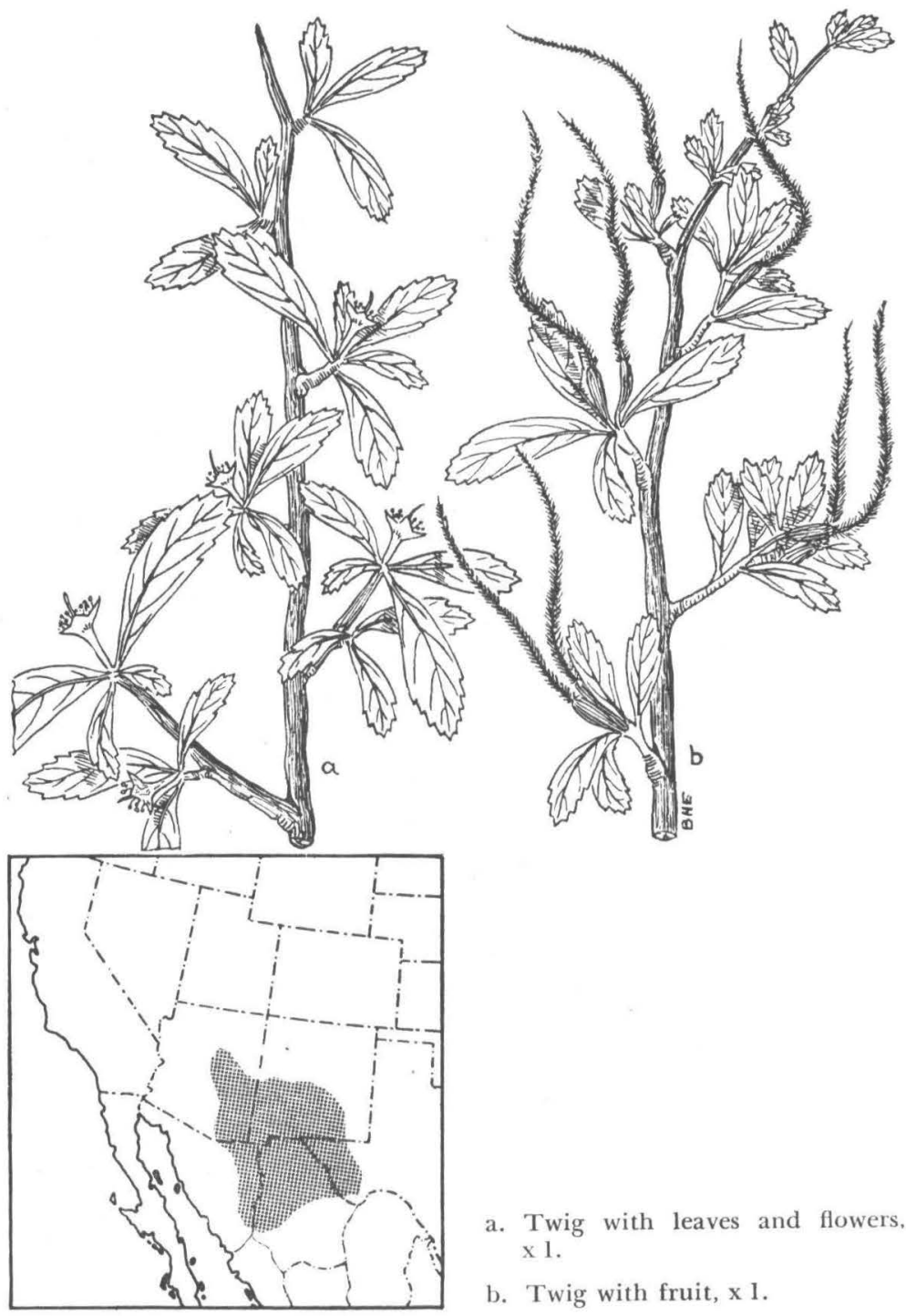

a. Twig with leaves and flowers, $\mathrm{x} 1$.

b. Twig with fruit, $\mathrm{x} 1$.

[182] 


\section{ROSACEAE}

\section{Shaggy Mountain-Mahogany}

Cercocarpus paucidentatus (S. Wat.) Britt.

[Cercocarpus eximius (C. Schneid.) Rydb.]

HABIT. A shrub or small tree 20-25 feet high and 6-8 inches in diameter; crown narrow, open, or irregular.

LEAVES. Alternate; simple; oblong-obovate to narrowelliptic; $1 / 2-1$ inch long and $1 / 4-1 / 2$ inch wide; acute or rounded at apex; entire, or dentate toward apex with few, small teeth; thick; revolute, often undulate margins; gray-green and hairy or nearly glabrous above, pale and tomentulose below; persistent; short-petiolate; stipules, tomentose, decidous.

FLOWERS. Regular; perfect; inconspicuous; solitary, in pairs, or in 3-flowered clusters; nearly sessile in axils of crowded leaves; calyx tube slender, densely white-hairy; corolla absent; stamens $15-30$, in 2-3 rows, free, anthers hairy; ovary inferior, composed of 1 carpel with solitary ovule.

FRUIT. Linear-oblong, coriaceous achene included in persistent, red-brown calyx tube; $1 / 4$ inch long; covered with long white hairs; tipped with persistent, hairy, elongated style $1-11 / 2$ inches long. Seed: solitary, linear, acute, erect.

TWIGS. Slender; round; rigid; bright red-brown and hairy at first, ultimately becoming ash-gray or red-gray and glabrous; marked by large, scattered, pale lenticels; spurlike lateral branches. Winter buds: minute, pubescent, scaly.

BARK. Thin ( $1 / 8$ inch); light red-brown, shallow furrows, and scaly.

WOOD. Exceedingly heavy and hard; brittle; close-grained; diffuse-porous; warping badly; heartwood red-brown; sapwood lighter; unimportant; used for fuel.

SILVICAL CHARACTERS. Upper Sonoran zone; intolerant; at elevations of about 5,000 feet; on dry ridges of mountains; in pure and oak forests.

Other shrubby species occasionally forming small trees are: C. montanus Raf. with ovate, toothed leaves and growing throughout the region; $C$. betuloides Nutt. with oval, finely toothed leaves in south central parts of the region; and C. hypoleucus Rydb. in Montana. 


\section{Ciliffrose}
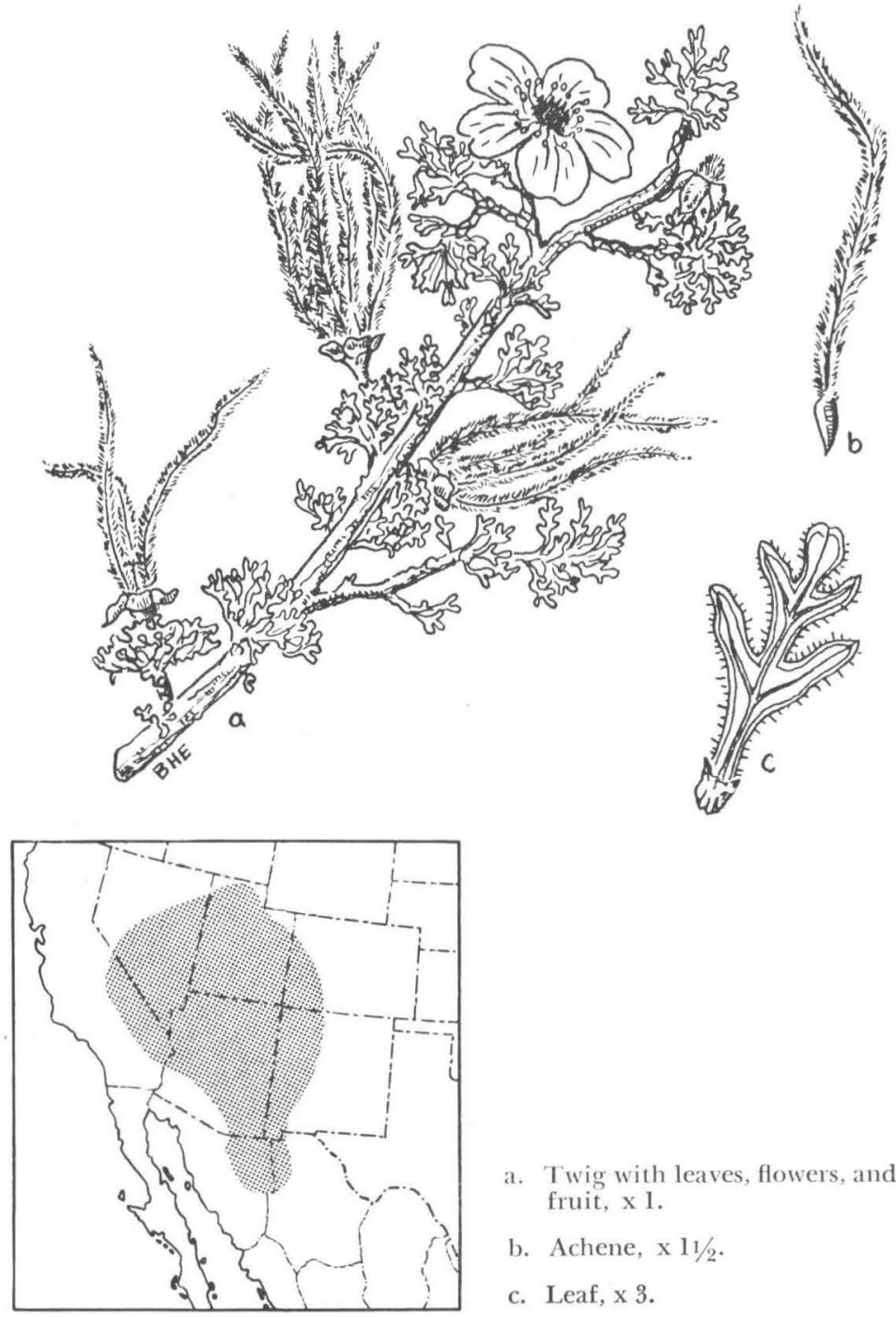

a. Twig with leaves, flowers, and fruit, $\times 1$.

b. Achene, $\times 11 / 2$.

c. Leaf, x 3 . 


\section{ROSACEAE}

\section{Gliffrose. Quininebush}

Cowania stansburiana Torr. (Cowania mexicana D. Don.)

(Cowania davidsonii Rydb.)

HABIT. A spreading shrub or rarely a small tree 20-25 feet high and 6-8 inches in diameter; crown narrow with short, stiff, spreading branches.

LEAVES. Alternate; simple; 3-(rarely 5-) lobed above the middle; $1 / 3^{-1 / 2}$ inch long; lobes linear, entire, or slightly divided; rounded at apex; revolute at margins; coriaceous; dark green above, hoary-tomentose below; glandular-dotted on upper surface; short-petioled; stipules adnate to base of petiole, ciliate on margins, acute, persistent; tardily deciduous or persistent until spring; on vigorous shoots occasionally linear and entire.

FLOWERS. Perfect; regular; showy solitary at ends of lateral branchlets; appearing in early spring; calyx tube turbinate, persistent, hoary-tomentose, and covered with rigid, glandular hairs, attenuate into short pedicel; corolla 5-petaled, pale yellow or nearly white, 1 inch in diameter, larger than calyx; stamens numerous, in 2 rows, persistent; carpels 5-12, inserted at base of calyx tube, free, villose, 1-celled and 1ovuled.

FRUIT. 5-12, 1-celled, ellipsoidal achenes; about $1 / 4$ inch long; included in tube of calyx; tipped with persistent, whitehairy styles; often 2 inches long; coriaceous. Seed: linearobovoid, erect, filling cavity of carpel.

TWIGS. Slender; round; rigid and rather brittle; red and glandular, becoming dark red-brown and glabrous.

BARK. Thin; pale gray; shreddy.

WOOD. Diffuse-porous; unimportant.

SILVICAL CHARACTERS. Upper Sonoran zone; intolerant; dry rocky foothill slopes and mesas; between altitudes of $4,000-8,000$ feet, extending to the lower limits of the yellow pine belt; common and of largest size near southern rim of Grand Cañon and on lower slopes of San Francisco Mountains, Arizona; an important browse species, although herbage is bitter. 


\section{ROSACEAE}

\section{Ihe Cherries and Plums}

Characteristics of the Genus Prunus L.

HABIT. Shrubs or usually small trees, only a few species reaching sizes of commercial importance.

LEAVES. Alternate; simple; deciduous or persistent; usually serrate, rarely entire; stipules free from petiole, early deciduous; petiolate.

FLOWERS. Regular; perfect or rarely dioecious; solitary or in terminal or axillary racemes, corymbs, or umbels; appearing from separate buds with, before, or after leaves; calyx 5-lobed, tubular; corolla 5-petaled, usually white, deciduous, stamens usually 15-20; ovary inserted in bottom of calyx tube, inferior or superior, 1-celled, 2-ovuled.

FRUIT. Thin dry, or thick fleshy, 1-seeded drupe; stone bony, smooth or rugose; indehiscent; important as food in several species. Seed: filling cavity of nut, suspended, thincoated, pale brown.

TWIGS. Slender or stout; round; astringent; red to brown; marked by lenticels and usually by small, elevated, horizontal leaf scars. Winter buds: terminal usually present, lateral nearly equal in size, scales imbricated and the inner accrescent and often colored.

BARK. Astringent; gray to dark brown; plated or scaly.

WOOD. From light to heavy and hard; close-grained; diffuse-porous; durable; heartwood light or dark brown, often reddish; sapwood lighter colored; a few species are important timber trees.

GENERAL. About 30 species of Prunus are native to the United States, 24 of these being arborescent at times. In the Rocky Mountain region there are 10 unimportant tree species and 5 others which never reach tree size, namely: $P$. besseyi Bailey, $P$. corumbulosa Rydb., $P$. havardii Mason, $P$. minutiflora Engelm. and $P$. pumila L. Prunus serotina Ehrh., the eastern black cherry, which enters this region in western Texas. is the only native species important for its wood. Many species are cultivated for their edible fruit or showy flowers and a few for their edible seeds. 


\section{KEY TO THE SPECIES OF PRUNUS}

I. Fruit pubescent, with thin, dry flesh; leaves fascicled, entire or with crenulate, glandless teeth. Almonds.

A. Leaves oblanceolate, acute; petals orbicular; southern $\mathrm{Ne}$ vada, Arizona, and Utah........ Prunus fasiculata, p. 189.

B. Leaves spatulate, mostly obtuse; petals spatulate; central Nevada.................2. Prunus andersonii, p. 189.

II. Fruit glabrous, with pulpy flesh; leaves alternate, with glandtipped teeth.

A. Fruit more than 1/2" in diameter, grooved; flowers in 2-5flowered, sessile, axillary umbels, calyx tube bright red without; eastern foothills and northeastern Utah. Plum........ .......................... Prunus americana, p. 189.

B. Fruit less than $1 / 2$ " in diameter, not grooved; calyx tube green without. Cherries.

1. Flowers in 2-12-flowered, axillary umbels or corymbs.

a. Leaves mostly oblong-lanceolate, acuminate or rarely acute at apex; flowers in 2-5-flowered umbels or corymbs; fruit sour-fleshed; northern and eastern..... ................. Prunus pennsylvanica, p. 191.

b. Leaves oblong-obovate, usually obtuse or rarely acute at apex; flowers in 6-12-flowered corymbs; fruit with intensely bitter flesh; northern, western, and in New Mexico.............5. Prunus emarginata, p. 193.

2. Flowers in many-flowered, terminal racemes.

a. Calyx lobes deciduous from fruit.

(1) Pedicels glabrous, persistent, longer than red or purple fruit; peduncles slender.

(a) Leaves glabrous below..

.........6. Prunus melanocarpa, p. 195.

(b) Leaves pubescent below................... ..............7. Prunus demissa, p. 195.

(2) Pediceis pubescent, deciduous, shorter than black fruit; peduncles stout...8. Prunus valida, p. 197. b. Calyx lobes persistent under fruit; fruit black.

(1) Petioles without glands; leaves elliptic to ovate; Arizona, New Mexico, and south into Mexico.... .................... Prunus virens, p. 197.

(2) Petioles biglandular near apex; leaves oblonglanceolate; western Texas and east.

.................. Prunus serotina, p. 186. 


\section{American Plum}
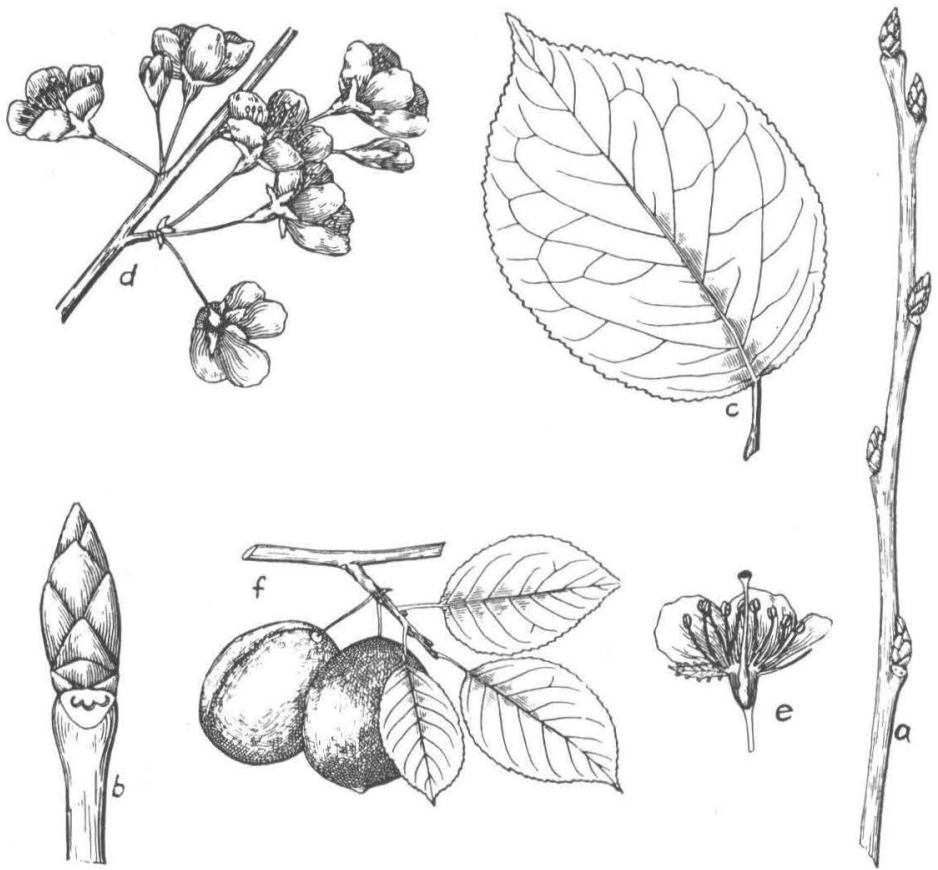

a. Winter twig, $\mathrm{x} 1$.

b. Portion of twig, enlarged.

c. Leaf, $x 1 / 2$.

d. Flowering branchlet, $x$ 1/2.

e. Vertical section of flower, $\mathrm{x} 1$.

f. Fruiting branchlet, $\mathrm{x} 1 / 2$. 


\section{ROSACEAE}

\section{American Plum \\ Prunus americana Marsh.}

HABIT. A shrub or small tree 25-30 feet high and rarely 12 inches in diameter; trunk short, usually dividing near the ground; crown broad, with many spreading branches; usually spreading by shoots from the roots into dense thickets.

LEAVES. Oval to slightly oblong-oval, or sometimes obovate; acuminate at apex; sharply and often doubly serrate; thick and firm; dark green above, pale and glabrous below; $3-4$ inches long and $11 / 2-13 / 4$ inches wide; petiole slender, $1 / 2-3 / 4$ inch long.

FLOWERS. In 2-5-flowered umbels; on slender, glabrous pedicels $1 / 2-2 / 3$ inch long; appearing before or with leaves; illscented; calyx tube narrow, bright red without, green and pubescent within; corolla white, 1 inch in diameter.

FRUIT. Subglobose; about 1 inch in diameter; red and often spotted at maturity; thick-skinned; nearly free from bloom; flesh bright yellow, juicy, acid; used for jellies; stone oval, rounded at apex, $3 / 4^{-1}$ inch long.

TWIGS. Slender; glabrous; bright green at first, becoming orange-brown and marked by minute, circular, raised lenticels; sometimes spiny-tipped. Winter buds: terminal absent, lateral $1 / 8^{-1 / 4}$ inch long, acute, chestnut-brown.

BARK. Up to $1 / 2$ inch thick; dark brown, tinged with red; outer layer forming persistent plates.

WOOD. Heavy; hard; close-grained; strong; heartwood dark brown, tinged with red; sapwood thin, lighter colored.

SILVICAL CHARACTERS. Upper Sonoran and Transition zones; intolerant; on moist bottomlands to banks of intermittent streams on dry uplands and mountain slopes.

The Desert-almond, Prunus fasciculata Gray. (Emplectocladus fasciculatus Torr.), a thorny, densely branched shrub or small tree, extends from southern Nevada and Utah through Arizona into southern and lower California, and is also reported in west Texas. It is characterized by dioecious flowers; pubescent, thin-fleshed fruit; and fascicled, entire or nearly entire leaves. The similar, shrubby Nevada Wild Almond, $P$. andersonii Gray, of central Nevada, occasionally becomes a small tree. 


\section{Pin Cherry}
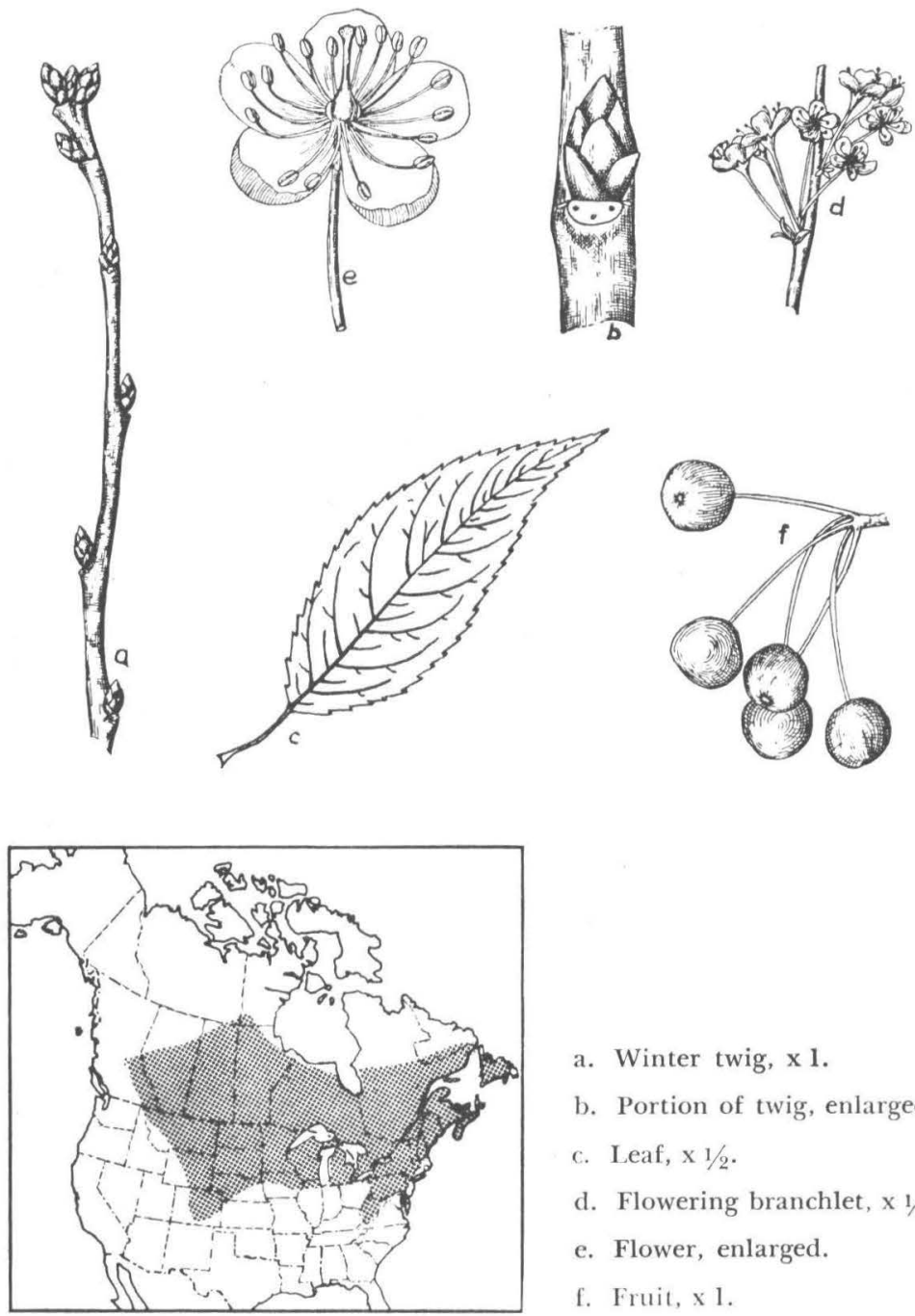

a. Winter twig, $\mathbf{x} 1$.

b. Portion of twig, enlarged.

c. Leaf, $\times 1 / 2$.

d. Flowering branchlet, $x 1 / 2$.

e. Flower, enlarged.

f. Fruit, $\times 1$.

$\lceil 100\rceil$ 


\section{ROSACEAE}

\section{Pin Cherry. Wild Red Cherry}

Prunus pennsylvanica var. saximontana Rehd.

HABIT. A shrub or small tree rarely $30-40$ feet high and 18-20 inches in diameter; short trunk; crown narrow, rounded or flat-topped, with slender, horizontal branches.

LEAVES. Obovate to oblong-lanceolate; acuminate or acute at apex; sharply and coarsely serrate, with incurved teeth; glabrous; bright green and lustrous above, paler below; 3-4 inches long and 1-2 inches broad; turning bright yellow in autumn; petiole slender, glabrous or pilose.

FLOWERS. In 2-5-flowered, sessile umbels; on slender pedicels nearly 1 inch long; appearing when leaves half grown; calyx tube glabrous, marked by conpicuous, orange band in mouth of throat; corolla cream-white; $1 / 2$ inch in diameter.

FRUIT. Globose; $1 / 4^{-1 / 3}$ inch in diameter; on slender pedicels; light red; thick-skinned; flesh thin, quite sour; occasionally made into jelly; stone oblong, thin-walled, pointed, $3 / 10$ inch long, ridged.

TWIGS. Slender; round; puberulous and light red at first, becoming glabrous and bright to dull red; marked by orangecolored, raised lenticels; bark easily separable from green inner bark; lateral branchlets short, spurlike. Winter buds: terminal $1 / 8$ inch long, acute, ovoid, bright red-brown.

BARK. Thin $(1 / 3-1 / 2$ inch); red-brown, marked by orangecolored bands of lenticels; smooth or scaly.

WOOD. Light; soft; close-grained; heartwood light brown; sapwood thin, yellow; unimportant.

SILVICAL CHARACTERS. Transition to Canadian zones; intolerant; fast-growing; short-lived; the abundant reproduction often completely taking over burned areas.

GENERAL. The species Prunus pennsylvanica L. extends from the east through the Rocky Mountain region to the slopes of coast ranges in the Fraser River Valley of British Columbia. This differs from its variety in having longer, narrower, more finely serrate leaves; usually more flowered umbels or corymbs; smaller fruit; and larger size. The distribution of both forms is included on the map. 


\section{Bitter Cherry}

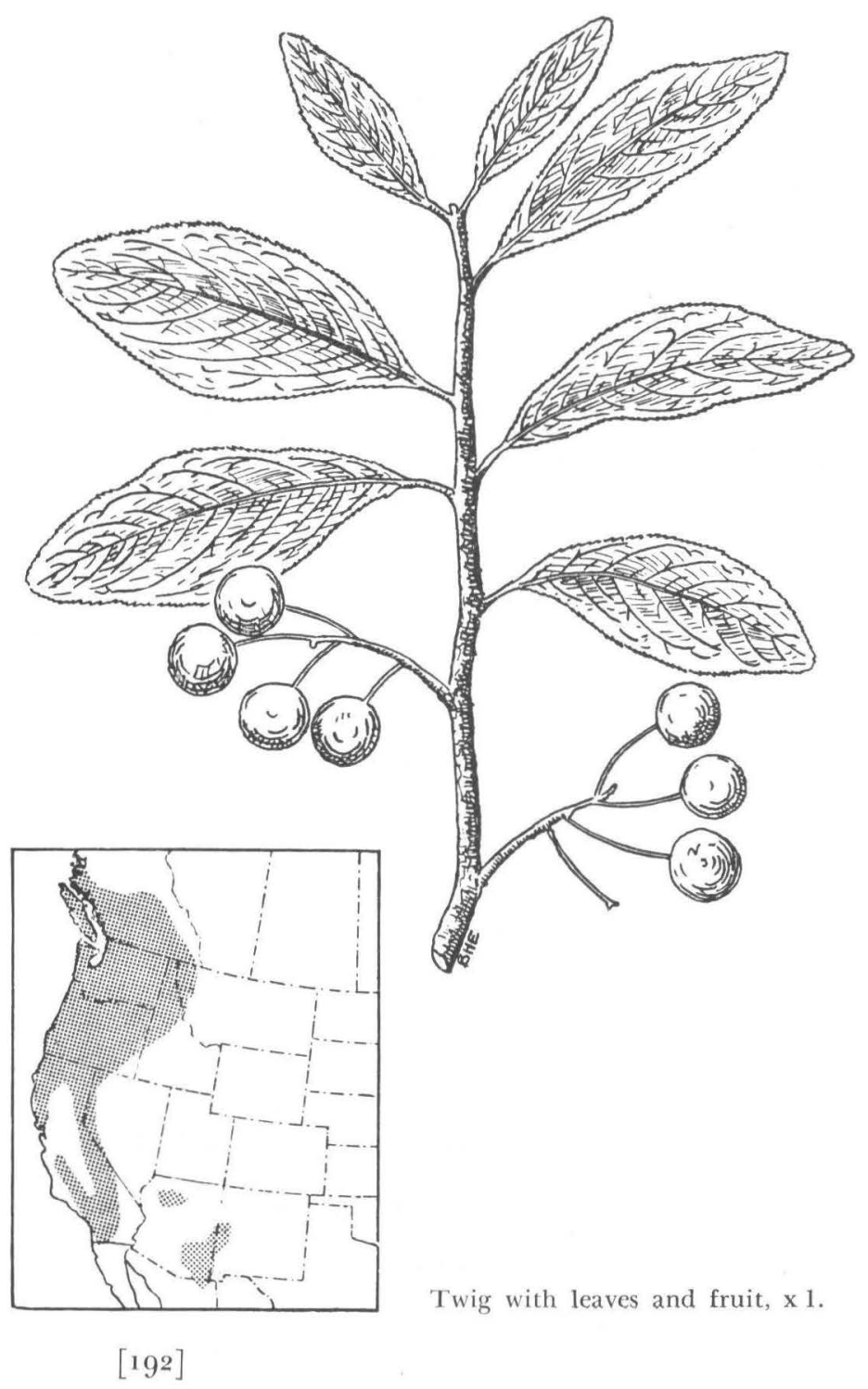




\section{ROSACEAE}

\section{Bitter Cherry \\ Prunus emarginata (Doug.) Walp.}

HABIT. A low shrub or a small tree 35-40 feet high and 6-14 inches in diameter; trunk straight, clean; crown symmetrical and oblong with slender, rather upright branches.

LEAVES. Oblong-obovate to oblanceolate; rounded and usually obtuse at apex; glandular at base; serrate with subulate, glandular teeth; dark green above, paler and glabrous or pubescent below; $1-3$ inches long and $1 / 3-11 / 2$ inches wide; petioles usually pubescent, $1 / 8-1 / 4$ inch long.

FLOWERS. In 6-12-flowered, glabrous or pubescent corymbs; on slender pedicels; appearing when leaves are half grown; calyx tube glabrous or pubescent, bright orange in the throat; corolla white tinged with green, $1 / 3-1 / 2$ inch in diameter.

FRUIT. Globose; $1 / 4-1 / 2$ inch in diameter; on slender pedicels; in long-stalked corymbs; bright red, becoming almost black; more or less translucent; thick-skinned; flesh thin, extremely bitter, astringent; stone ovoid, turgid, $1 / 8$ inch long, pointed, pitted and grooved walls.

TWIGS. Slender; round; flexible; pubescent and greenish at first, becoming glabrous, bright red, and marked conspicuously by large, pale lenticels; short, lateral branchlets. Winter buds: terminal $1 / 8$ inch long, acute, chestnut-brown.

BARK. Thin ( $1 / 4$ inch); dark brown; smooth, marked by horizontal, light gray bands and by rows of oblong, orangecolored lenticels; very bitter.

WOOD. Rather light; soft; close-grained; brittle; rots quickly in contact with earth; heartwood dull brown, streaked with green; sapwood thick and lighter colored; unimportant.

SILVICAL CHARACTERS. Upper Sonoran to Canadian zones; intolerant; short-lived; abundant seeder; in moist sites near banks of streams and less commonly on dry hillsides; frequently forms dense thickets at higher elevations; altitudinal range from sea level to 8,000 feet.

GENERAL. The form with large leaves pubescent below, which occurs within the range of the species, has been designated as Prunus emarginata var. villosa Sudw. 


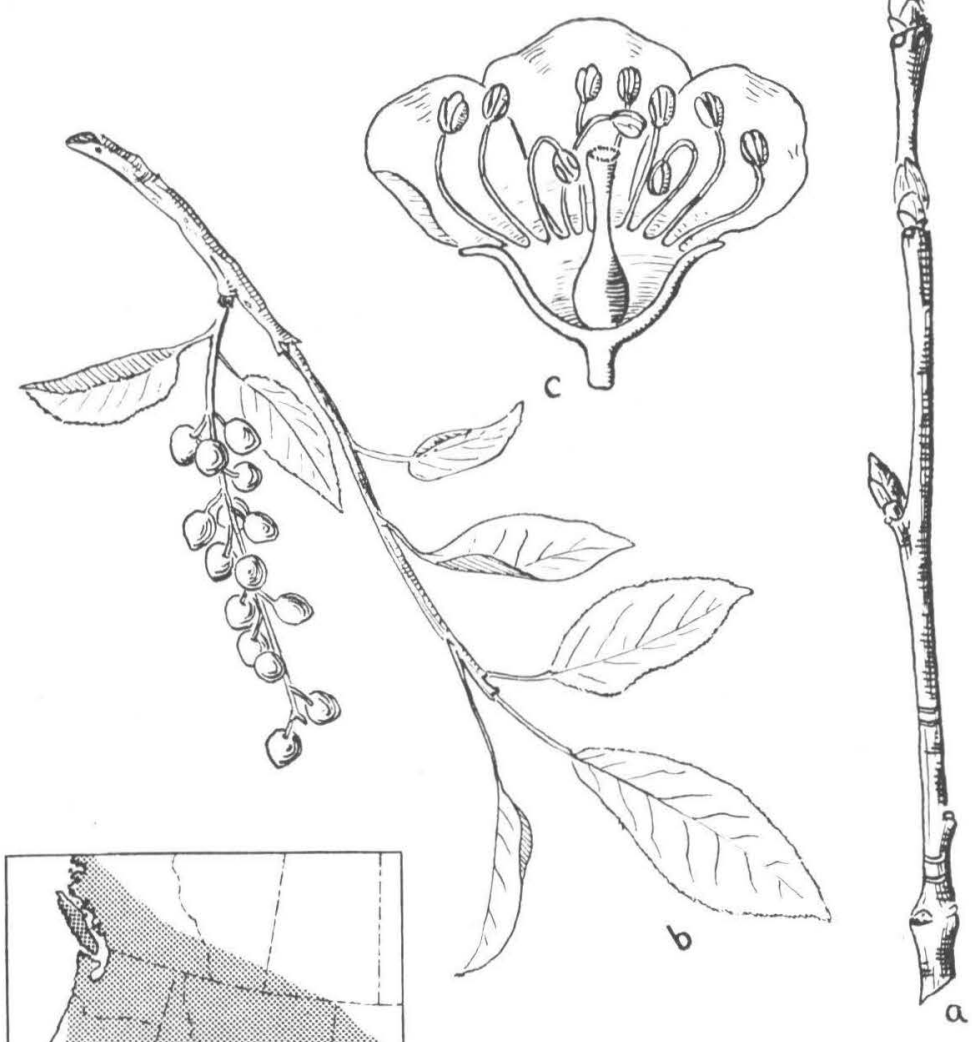

a. Twig with winter buds, $\times 1$.

b. Twig with leaves and fruit, $\times 2 / 3$.

c. Diagram of flower, $\times 3$. 


\section{ROSACEAE \\ Western Chokecherry

Prunus demissa Nutt. [Prunus virginiana var. demissa (Nutt.) Torr.] (Cerasus demissa Nutt.)

HABIT. A shrub or rarely a small tree 20-50 feet high and 6-8 inches in diameter; trunk slender, often crooked; crown spreading with small, erect or horizontal branches; often forming dense thickets.

LEAVES. Oval, oblong, or obovate; abruptly acute at apex; usually cordate at base; sharply and often doubly serrate with spreading, sharp teeth; thick; glabrous, dark green and lustrous above, pale and pubescent below; $2-4$ inches long and 1-2 inches wide; turning bright yellow before falling; petiole slender, $1 / 2-1$ inch long, biglandular near apex.

FLOWERS. In many-flowered, erect or nodding racemes 3-6 inches long, on slender pedicels; opening from April to June; calyx tube cup-shaped, globose; corolla white, $1 / 3-1 / 2$ inch in diameter, petals orbicular and contracted below into claw.

FRUIT. Globose; $1 / 4^{-1 / 3}$ inch in diameter; in dense, cylindrical racemes; lustrous, bright red, becoming scarlet or nearly black; thick-skinned; flesh dark, juicy, astringent; stone oblongovoid, broadly ridged on one suture.

TWIGS. Slender; round; glabrous; red-brown or orangebrown; lustrous, marked by pale lenticels. Winter buds: terminal $1 / 8^{-1 / 4}$ inch long, acute or obtuse, pale chestnut-brown.

BARK. Thin ( $1 / 8$ inch); red-brown; slightly furrowed and scaly; strongly and disagreeably scented.

WOOD. Heavy; hard; close-grained; brittle; heartwood light brown; sapwood thick and whitish; unimportant.

SILVICAL CHARACTERS. Upper Sonoran to Canadian zones; intolerant; short-lived; abundant seeder with aggressive reproduction; mountain slopes, stream borders and on dry hills.

GENERAL. The Black Chokecherry, Prunus melanocarpa A. Nels. [Prunus virginiana var. melanocarpa (A. Nels.) Sarg.], also extending through the Rocky Mountain region, differs from the form Prunus demissa in having thicker leaves glabrous below and darker, often less astringent fruit. 


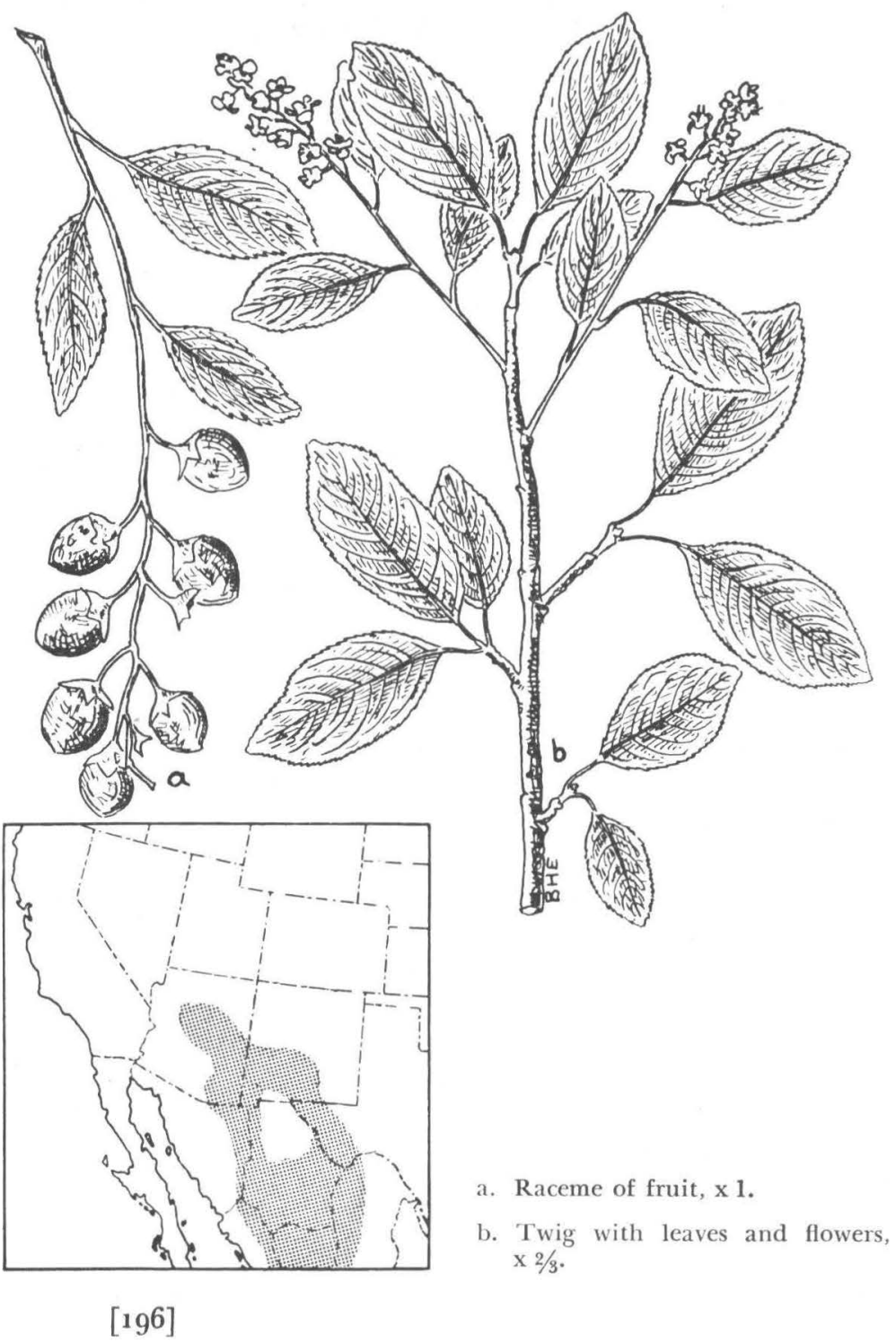




\section{ROSACEAE}

\section{SOUThWESTERn ChokecherRy}

\section{Prunus virens (Woot. \& Standl.) Shreve}

HABIT. A shrub or small tree 25-30 feet high and 18-20 inches in diameter; small, drooping or widespreading branches.

LEAVES. Elliptic, ovate, or rarely slightly obovate; acute or rounded at apex; finely crenately serrate; glabrous; light green and lustrous above, paler below; $11 / 2-2$ inches long and $3 / 4-1$ inch wide; petiole slender, glabrous, $1 / 4-1 / 2$ inch long, without glands.

FLOWERS. In many-flowered, glabrous or puberulous, erect or spreading racemes 3-6 inches long; on slender, glabrous pedicels; appearing when leaves nearly full grown; calyx tube saucer-shaped, glabrous, persistent under fruit; corolla white, $1 / 4$ inch in diameter, petals broad-ovoid.

FRUIT. Subglobose or short-oblong; $1 / 4^{-1 / 2}$ inch in diameter; in erect or spreading racemes; purple-black and lustrous; flesh thin, juicy, acrid; stone obovoid, compressed, 1/4 inch in diameter.

TWIGS. Slender; round; glabrous; pendulous; red-brown to gray-brown; marked by small, pale lenticels. Winter buds: terminal $1 / 16^{-1 / 8}$ inch long, acute or acuminate, red-brown, slightly villose.

BARK. Thin (up to $1 / 4$ inch) red-brown to nearly black; marked by narrow, oblong, horizontal lenticels; smooth or furrowed and scaly on base of old trunks.

WOOD. Rather light; hard; strong; close-grained; heartwood light brown; sapwood yellowish.

SILVICAI. CHARACTERS. Upper Sonoran zone; intolerant; cañons and mountain slopes; widely and generally distributed at altitudes of $5,000-8,000$ feet, but nowhere abundant.

GENERAL. This species passes into the variety rufula Sarg., in the Gila river valley in Arizona; it differs from the species in the rusty brown pubescence on the twigs, lower side of the midrib of the leaves and petiole.

Prunus valida (W. \& S.) Rydb., ranging from the mountains of western New Mexico to northeastern Arizona and southeastern Utah, is characterized by many-flowered racemes with pubescent, deciduous pedicels shorter than the black fruit, thick leaves and stout peduncles. 


\section{LysILOMA}

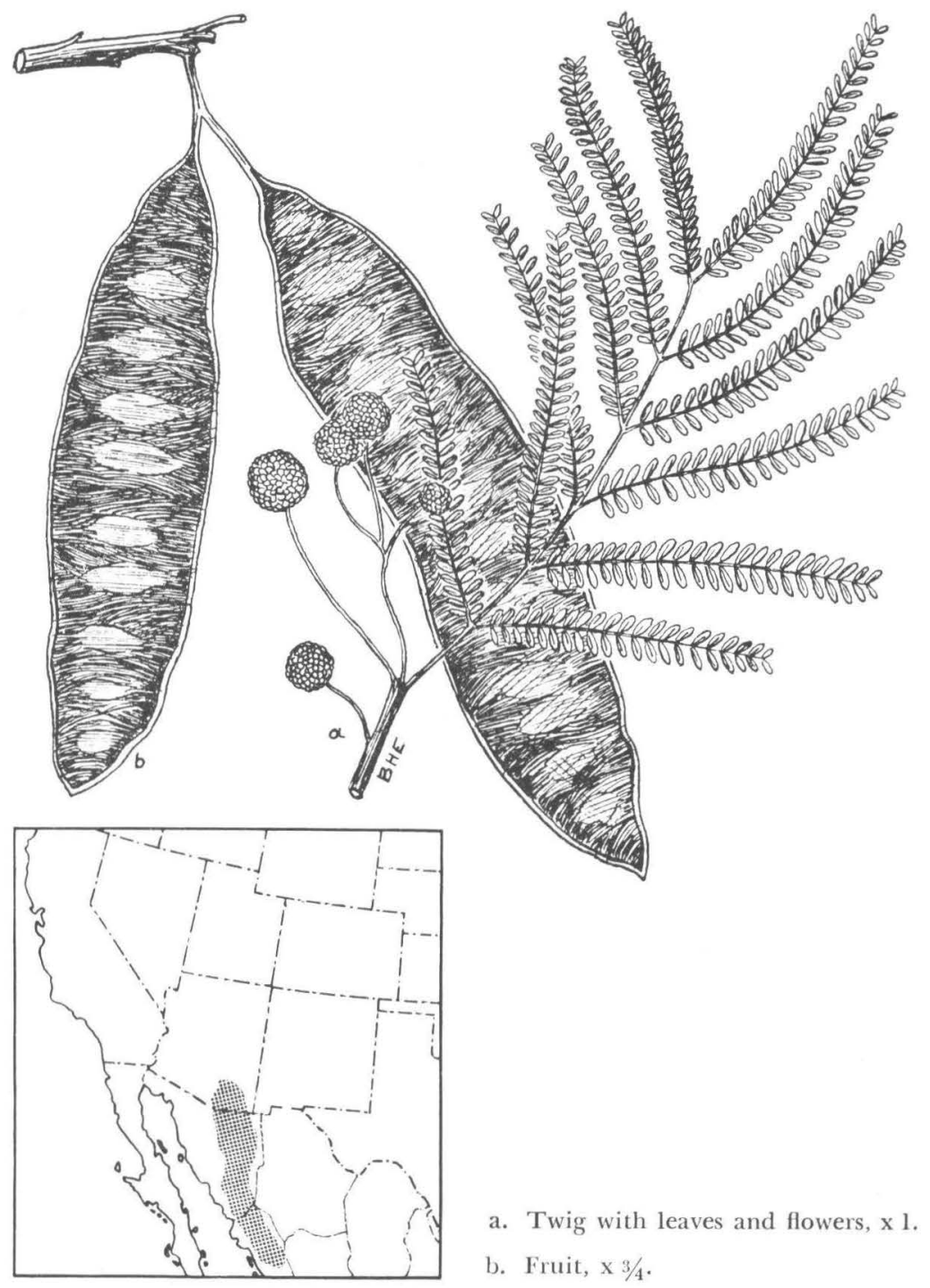

[198] 


\section{LEGUMINOSAE}

\section{LYSILOMA}

Lysiloma thornberi Britt. \& Rose. (Lysiloma watsoni Rose)

HABIT. A shrub or small tree rarely more than 9 feet high and $31 / 2$ inches in diameter.

LEAVES. Alternate; doubly compound with 15-45 pairs of leaflets on each of 4-8 pairs of pinnae; rachis densely pilose; petiole $1 / 2-3 / 4$ inch long, bearing large conic gland; stipules large, membranaceous; leaflets linear-oblong, $1 / 6^{-1 / 3}$ inch long, papery, obtuse, pubescent on both surfaces; persistent.

FLOWERS. Nearly regular; perfect, minute; dense globose heads; calyx campanulate, 5-toothed; coralla funnel-form, deeply 5-lobed, green-white; stamens 12-30, long, exserted, filaments united into tube; ovary sessile, contracted into slender style with minute stigma.

FRUIT. Linear-oblong, straight, compressed legume 5-8 inches long and 3/4-1 inch broad; glabrous; acute; submembranaceous. Seed: $1 / 3$ inch long, oblong-oval, compressed.

TWIGS. Slender; round; unarmed; densely hairy; covered with small wartlike excrescences. Winter buds: minute.

WOOD. Heavy; hard; not strong; tough; close-grained; unimportant.

SILVICAL CHARACTERS. Lower and Upper Sonoran zones; reported only from the south slopes of the Rincon Mountains in the United States.

\section{LITTLELEAF LEADTREE}

Leucaena retusa Benth.

A shrub or small tree rarely 25 feet high and 6-8 inches in diameter which enters this region only in the rocky hillsides of southwestern Texas. While resembling Lysiloma in leaves and flowers (except that it has but 10 stamens), it can be distinguished by its fruit $6-10$ inches long and $1 / 3-1 / 2$ inch wide, which is on a peduncle $3-5$ inches long. Leucaena greggii Wats., Gregg's Leadtree, is a similar Texas species. 


\section{Catclaw Acacia}
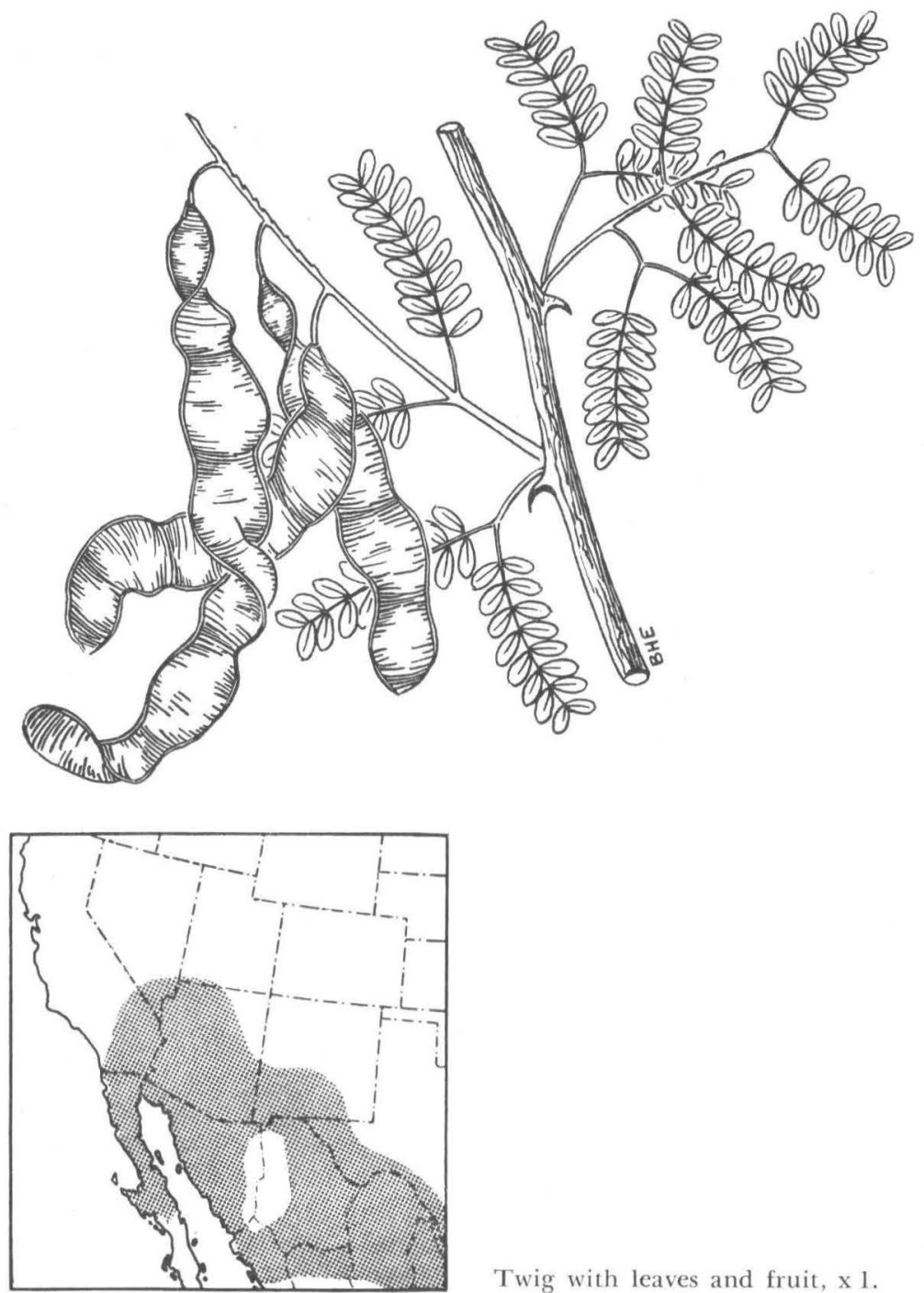

Twig with leaves and fruit, $\mathrm{x} 1$.

[200] 


\section{LEGUMINOSAE}

\section{Catclaw Acacia. Paradise Flower Acacia greggii Gray.}

HABIT. A shrub or small tree rarely 30 feet high and 10-12 inches in diameter; trunk short; crown irregular.

LEAVES. Alternate; evenly doubly pinnate; 1-3 pairs of pinnae, each with 4-5 pairs of obovate, obtuse, thick, pubescent leaflets $1 / 16^{-1 / 4}$ inch long; persistent; petiole short, glandular near middle; stipules linear, caducous.

FLOWERS. Nearly regular; perfect or polygamous; fragrant; in dense, pubescent spikes; calyx 5-lobed, puberulous; corolla 5-petaled, bright yellow, $1 / 8$ inch long; stamens numerous, exserted, 1/4 inch long; ovary stalked and hairy.

FRUIT. Linear-oblong, flat, much-curved and contorted, indehiscent, light brown legume 2-6 inches long and $1 / 2-3 / 4$ inch wide; contracted between the seeds; valves thin and membranaceous. Seed: compressed, dark brown, lustrous, $1 / 4$ inch long.

TWIGS. Slender; angled; puberulous or glabrous; pale brown; armed with stout, broad, recurved, infrastipular spines $1 / 4$ inch long, giving tree its common name.

BARK. Thin ( $1 / 8$ inch); furrowed and scaly; light graybrown; astringent.

WOOD. Very heavy; hard; strong; close-grained; durable; ring-porous; heartwood red-brown; sapwood thin, light yellow.

SILVICAL CHARACTERS. Lower Sonoran zone; intolerant; vigorous reproducer; thrives in driest and poorest soils; on dry mesas, plains, and in low cañons.

Six other species of Acacia reach tree size in the southwest:

1. A. amentacea D. C., with long spines, yellow flowers in spikes, and a flattened arcuate legume; southwestern Texas. 2. A. angustissima Kuntze, with no spines, white flowers in capitate heads, and flat legume; southwest. 3. A. constricta var. paucispina Woot., with long spines, yellow flowers in capitate heads, and a terete legume; Texas to Arizona. 4. A. farnesiana Willd., with spines, yellow flowers in capitate heads, and a terete legume; Texas. 5. $A$. tortuosa Willd., like No. 4 but with longer pod (3-5"); Texas. 6. $A$ vrightii Benth., yellow flowers in spikes; short spines; Texas. 


\section{Common Mesouite}

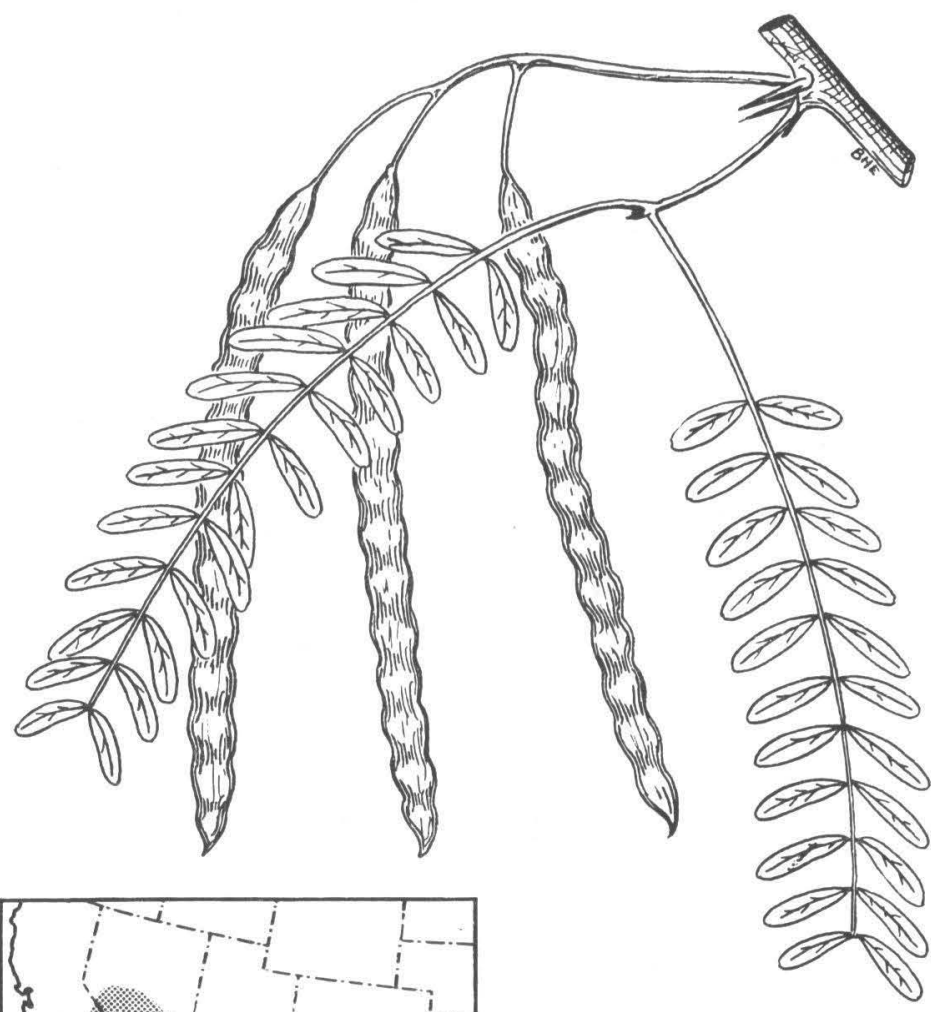

Twig with leaves and fruit, $\times 1 / 2$.

[202] 


\section{LEGUMINOSAE}

\section{Common Mesquite}

Prosopis chilensis (Mol.) Stuntz. [Prosopis juliflora (Swartz) DC.]

HABIT. A shrub or small tree rarely 20 feet high and 6-8 inches in diameter; trunk short; crown loose and straggling with numerous, irregularly arranged, crooked branches.

LEAVES. Alternate; evenly, doubly (rarely 3-4-) pinnate; pinnae with 12-30 linear to linear-oblong, small, deciduous, glabrous leaflets $1 / 2^{-2}$ inches long; petioles glandular and spine-tipped; stipules membranaceous, deciduous.

FLOWERS. Nearly regular; perfect; fragrant; minute; in axillary, pedunculate spikes $11 / 2-4$ inches long; calyx 5-toothed, glabrous, deciduous, corolla green-white, 5-petaled; stamens 10 , twice as long as corolla, free; ovary villose.

FRUIT. Linear, flat to subterete, indehiscent, yellowish, straight or falcate legume $4-9$ inches long and $1 / 4-1 / 2$ inch wide; constricted and pulpy between the 10-20 seeds; edible. Seed: oblong, compressed, light brown, $1 / 4$ inch long.

TWIGS. Slender; round; smooth; mostly zigzag; pale yellow-green first year, becoming darker; usually armed with sharp, supra-axillary, persistent spines $1 / 2-2$ inches long. Winter buds: terminal absent; lateral small, obtuse, dark brown.

BARK. Thick; dark red-brown; furrowed and scaly.

WOOD. Very heavy; hard; close-grained; not strong; very durable; ring-porous; heartwood dark brown or red; sapwood clear yellow, thin; used for posts, fuel, etc.

SILVICAL CHARACTERS. Lower and Upper Sonoran zones; intolerant; long-lived; adapted to desert sites by huge taproot descending 40-50 feet; abundant seeder; aggressive; confined to areas below 6,000 feet in elevation.

GENERAL. This variable species ranges from the United States to Chile; intergrading forms make it unfeasible to break this into several species; in this region are two tree varieties: Prosopis chilensis var. glandulosa (Torr.) Standl., with larger leaflets ( $1 / 4-2$ inches long) and usually glabrous, found throughout the southwest; and Prosopis chilensis var. velutina (Woot.) Standl., with smaller leaflets $(1 / 4-1 / 2$ inch long) and hairy throughout, found in southern Arizona and Mexico. 
Fremont Screwbean
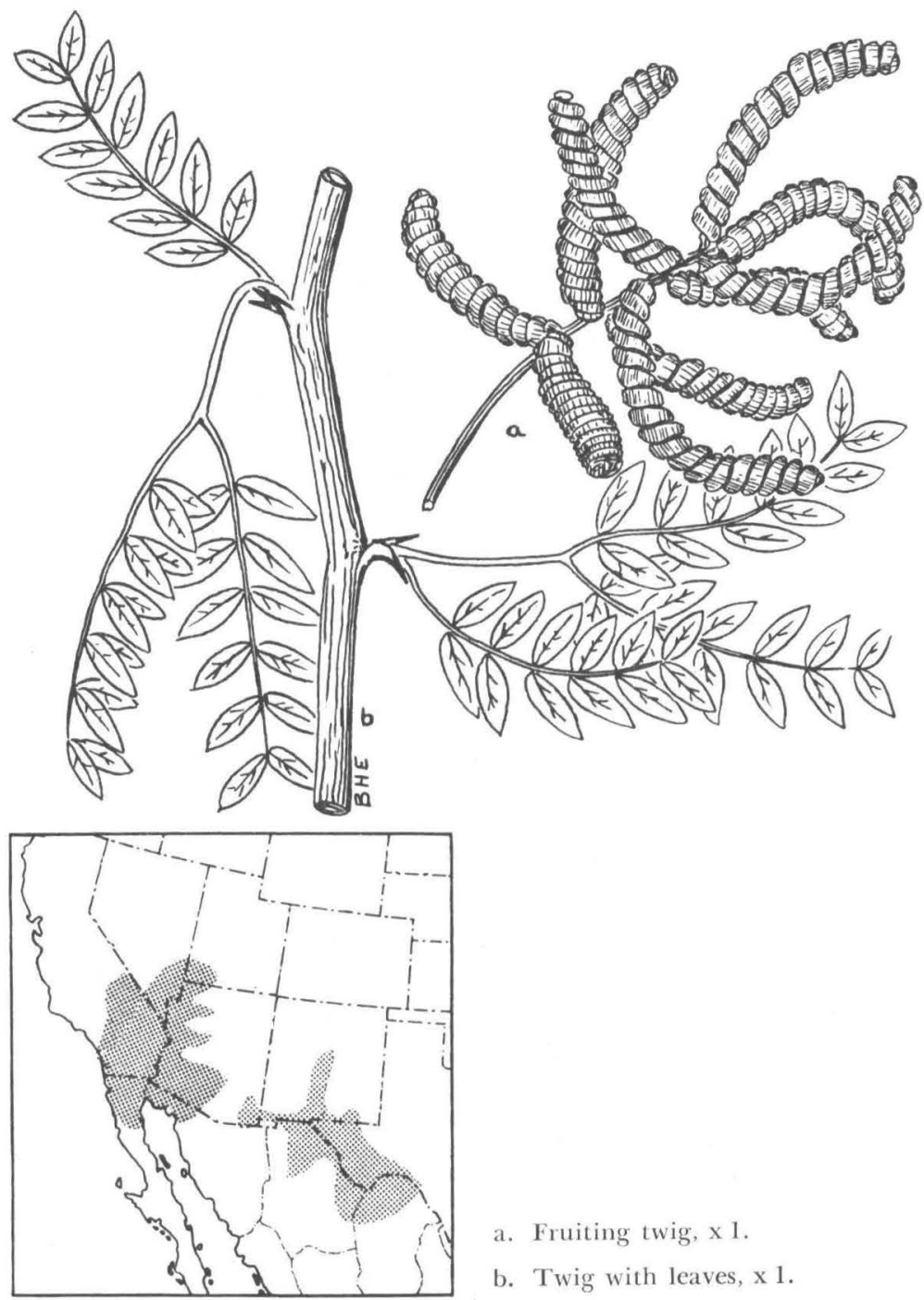

a. Fruiting twig, x 1 .

b. Twig with leaves, $\mathrm{x} 1$.

[204] 


\section{LEGUMINOSAE}

Fremont Scrfwbean. Screwbean Mesquite Prosopis pubescens Benth. (Prosopis odovata Torr. \& Frem.) [Strombocarpa odorala (Torr.) A. Gray]

HABIT. A shrub or small tree 15-30 feet high and 3-12 inches in diameter; trunk short; crown open.

LEAVES. Alternate; evenly, doubly (rarely 3-4-) pinnate; pinnae with 10-16, oblong or falcate, small, deciduous, acute, pubescent leaflets $1 / 3-2 / 3$ inches long; petioles glandular at apex and base, spine-tipped; stipules spinescent, deciduous.

FLOWERS. Nearly regular; perfect; fragrant; minute; in cylindric spikes 2-3 inches long; calyx obscurely 5-lobed, pubescent, deciduous; corolla green-white, 5-petaled, tomentose; stamens 10, slightly exserted, free; ovary hoary-tomentose.

FRUIT. Linear, thick, indehiscent, pale yellow legume 1-2 inches long; twisted by 12-20 turns into a narrow, straight spiral; pulpy within, between the 10-20 seeds; valued as fodder. Seed: obovate, pale brown, 1/16 inch long.

TWIGS. Slender; round; slightly zigzag; glabrous and light red-brown; armed with sharp, persistent spines $1 / 3-1 / 2$ inch long. Winter buds: terminal absent; lateral small, obtuse, dark brown.

BARK. Thick; light brown, tinged with red; separating into long, persistent, thin, shaggy strips.

WOOD. Very heavy; hard; close-grained; not strong; very durable; ring-porous; heartwood light brown; sapwood thin, light-colored; contains much tannin; used for fuel and fencing.

SILVICAL CHARACTERS. Lower Sonoran zone; intolerant; long-lived; adapted to desert sites by deep taproot system; abundant seeder; in desert river bottoms, water holes and cañons; confined to areas below 5,000 feet in elevation.

\section{Bird-OF-PARADISE Flower}

Poinciana gilliesii Hook. (Caesalpinia gilliesii Wall.)

An ill-scented shrub or small tree naturalized in southern Texas, New Mexico, and Arizona. Characterized by large bipinnate leaves with very numerous small leaflets; large, perfect, nearly regular, yellow flowers, with long-exserted, red stamens and pistil. Commonly planted as ornamental and frequently escaping. 


\section{California Redbud}
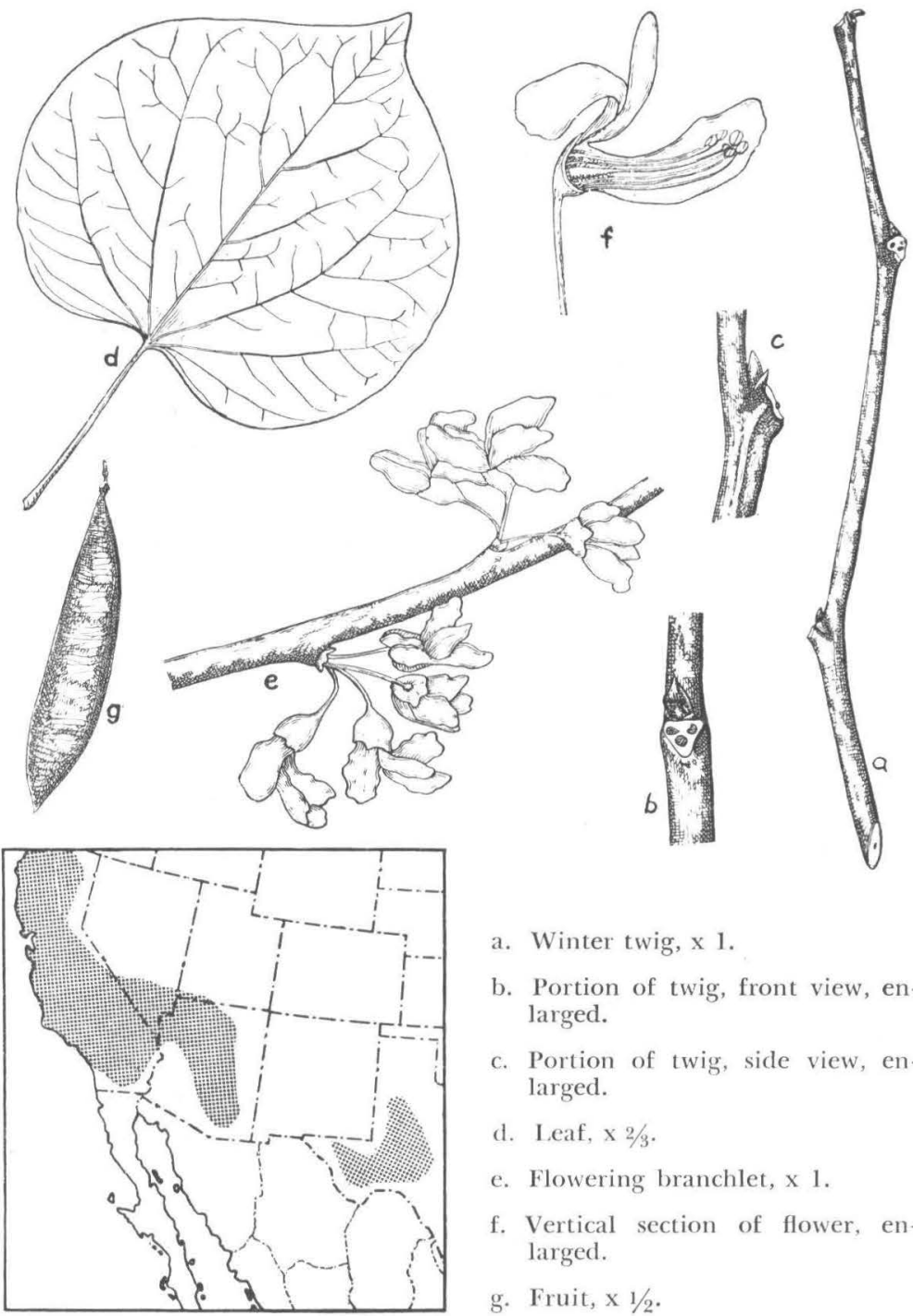

a. Winter twig, $\mathrm{x} 1$.

b. Portion of twig, front view, enlarged.

c. Portion of twig, side view, enlarged.

d. Leaf, $x 2 / 3$.

c. Flowering branchlet, $\mathrm{x} 1$.

f. Vertical section of flower, enlarged.

g. Fruit, $x 1 / 2$.

[206] 


\section{LEGUMINOSAE}

\section{California Redbud. Mountain Redbud \\ Cercis occidentalis Torr.}

HABIT. Usually a shrub, but not infrequently a small tree up to 25 feet high and 13 inches in diameter; frequently planted as an ornamental.

LEAVES. Alternate; simple; broad ovate to reniform; 2-3 inches in diameter; apex obtuse; base cordate; margins entire; glabrous; deciduous; petioles long, slender; stipules small, membranaceous, caducous.

FLOWERS. Irregular (subpapilionaceous) ; perfect; in simple fascicles; appearing before the leaves; calyx short, topshaped, purple, 5-toothed, persistent; corolla 5-petaled, rosecolored; stamens 10, free, inserted in 2 rows on margin of thin disk, persistent; ovary short-stalked; ovules numerous in 2 ranks.

FRUIT. Stalked, flat, oblong, russet-brown legume 2-3 inches long; tipped with remnant of style. Seed: $1 / 4$ inch long, ovoid or oblong, compressed, red-brown.

TWIGS. Slender; round; unarmed; marked by numerous pale lenticels and elevated leaf scars. Winter buds; terminal absent; axillary small, scaly, obtuse, chestnut-brown.

BARK. Thin; gray; smooth or becoming scaly on old trunks.

WOOD. Heavy; hard; not strong; ring-porous; heartwood dark yellow-brown; sapwood white, thin; unimportant.

SILVICAL CHARACTERS. Upper Sonoran zone; rather tolerant; reproduction vigorous; in dry, gravelly soils; along mountain streams or on dry hills and cañons; has been reported in tree form from Bright Angel Trail in the Grand Cañon in Arizona and from California.

\section{Siberian Pea Tree}

Caragana arborescens Lam.

This introduced form has been extensively planted in the eastern portions of the region for shelterbelts and as an ornamental. It is characterized by even pinnate leaves with 8-12 leaflets; and papilionaceous, yellow flowers, $1 / 2-3 / 4$ inch long, in fascicles of 1-4. 


\section{JERUSALEM-THORN}

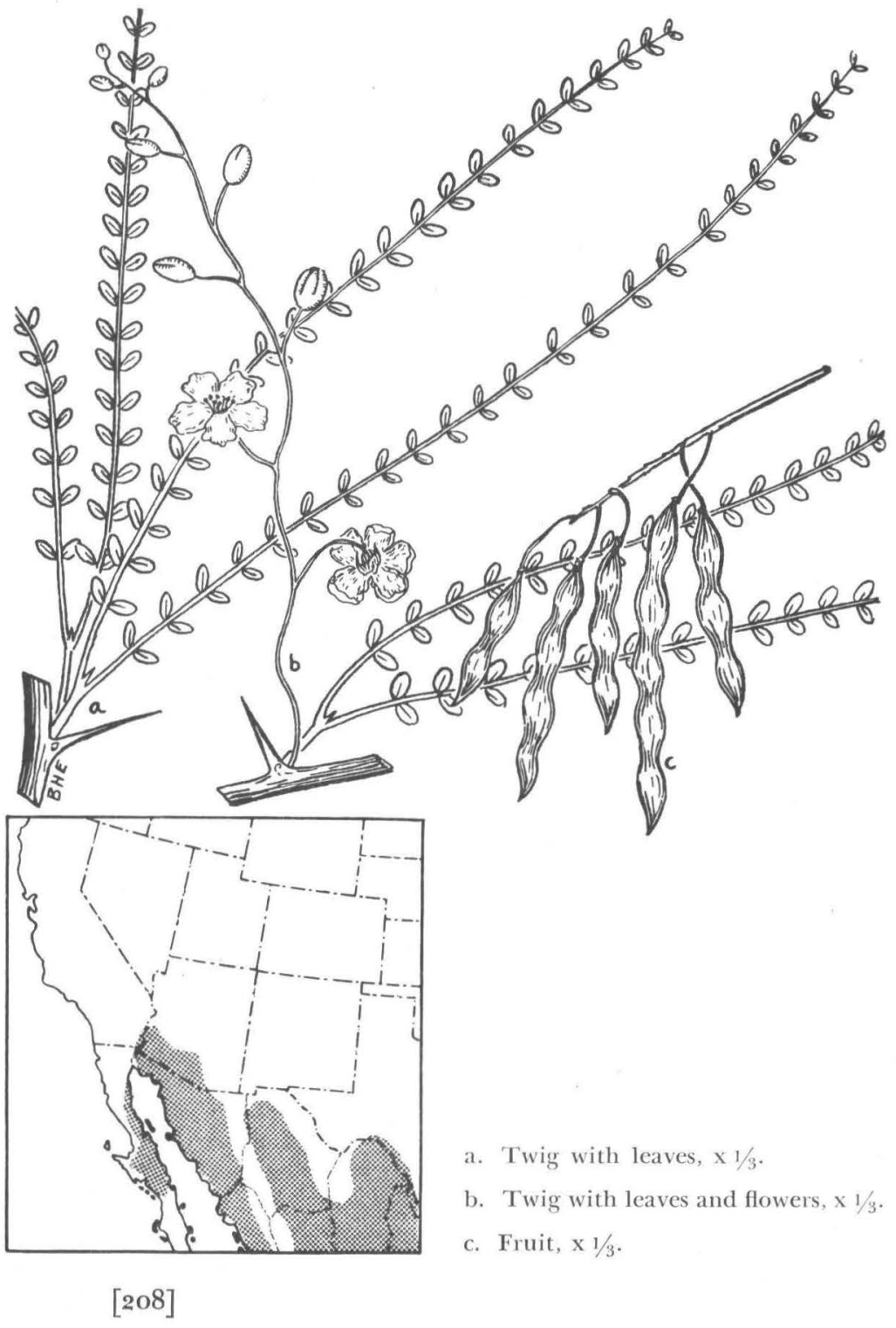




\section{LEGUMINOSAE}

\section{Jerusalem-Thorn. Horsebean}

Parkinsonia aculeata L.

HABIT. A graceful, striking shrub or small tree 15-30 feet high and 4-12 inches in diameter; trunk short; crown broad and graceful with slender, spreading, pendulous branches.

LEAVES. Alternate; obscurely doubly pinnate; light green; mostly glabrous; short-petiolate; persistent; of 2 forms; primary leaves on young branches with 2-4 pinnae and a rachis which develops into a stout spine appearing forked by spiny stipules; secondary leaves fascicled from axils of primary leaves, with pinnae 6-18 inches long, each bearing 25-30 pairs of ovate or obovate leaflets $1 / 16^{-1 / 8}$ inch long.

FLOWERS. Nearly regular; perfect; in slender, erect racemes 5-6 inches long; on slender, jointed pedicels $1 / 3-1 / 2$ inch long; fragrant; calyx 5-lobed, deciduous; corolla 5-petaled, bright yellow, the upper marked on inside with conspicuous red spots, imbricated in bud, 1 inch in diameter; stamens 10 , shorter than petals; ovules numerous.

FRUIT. Linear, torulose, long-tapering, brown legume 2-10 inches long; contracted between the remote 1-8 seeds; hanging on pedicels $1 / 2-3 / 4$ inch long; in racemes. Seed: nearly terete, $1 / 3$ inch long.

TWIGS. Round; slender; slightly zigzag; with spines, and themselves spinelike; puberulous and yellow-green at first, becoming glabrous and gray or orange-colored. Winter buds: terminal absent; lateral minute.

BARK. Thin ( $1 / 8$ inch) ; smooth or broken into small, persistent, platelike scales; brown, tinged with red.

WOOD. Heavy; hard; close-grained; ring-porous; heartwood light brown; sapwood very thick and yellowish; unimportant.

SILVICAL CHARAG'TERS. Lower Sonoran zone; intolerant; in low, moist, hot sites; cultivated for ornamental hedge and fodder; resistant to alkaline conditions; free from pests; introduced from tropical America. 
Blue Paloverde
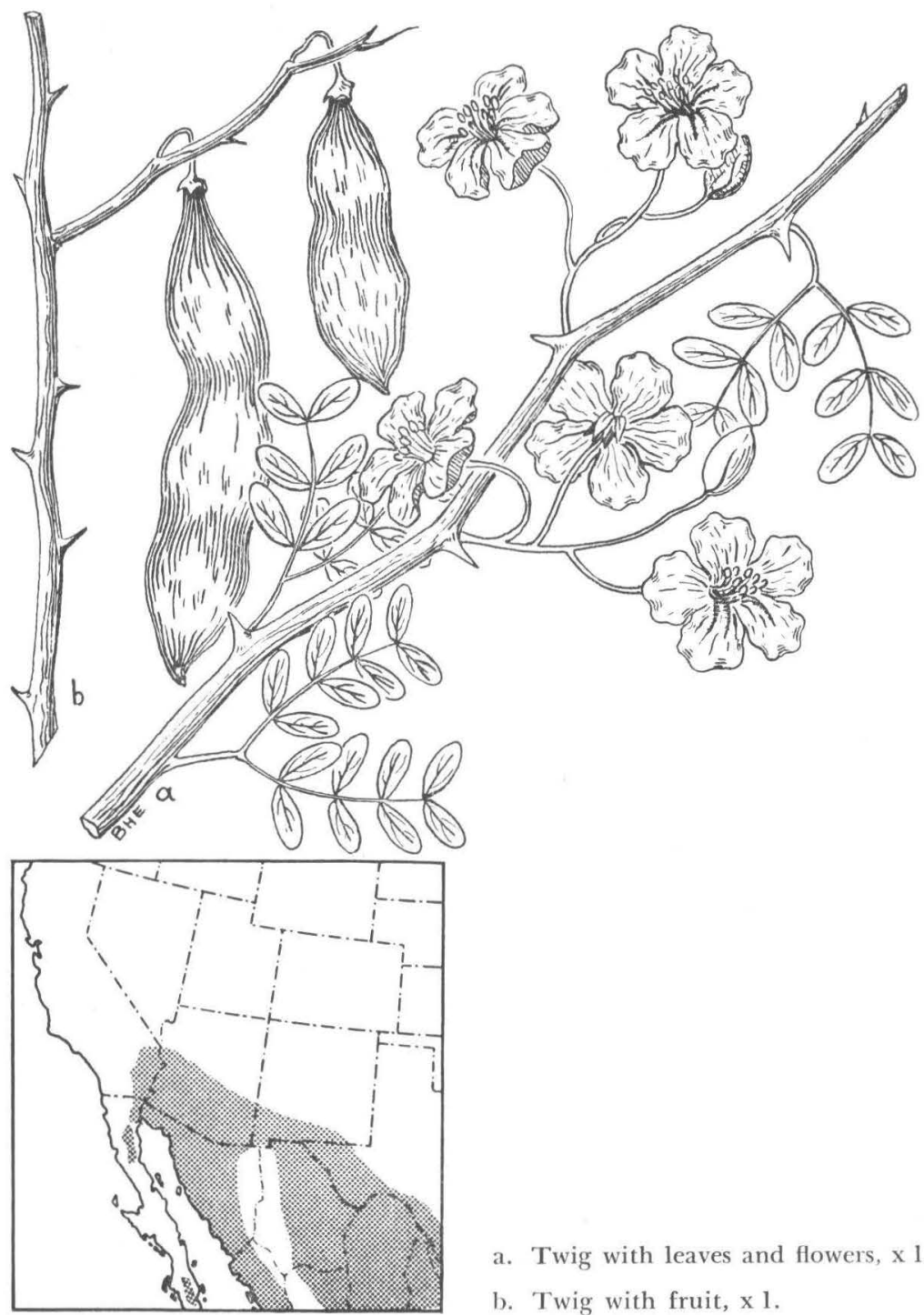

a. Twig with leaves and flowers, $\mathrm{x} 1$.

b. Twig with fruit, $\mathrm{x} 1$.

[210] 


\section{LEGUMINOSAE}

Blue Paloverde. Greenbarked Acacia

Cercidium floridum Benth. [Cercidium torreyanum

(Wat.) Sarg.]

HABIT. A thorny shrub or small tree $15-30$ feet high and 10-20 inches in diameter; trunk short, often inclined; wide, irregular, open crown with stout, tortuous branches.

LEAVES. Alternate; doubly and evenly pinnate with 2-3 pairs of oblong, obtuse, glaucous leaflets $1 / 12^{-1 / 6}$ inch long on each of 2 pinnae; few and totaling less area than green twigs; falling soon, but frequently bearing a second crop during the rainy season of July and August.

FLOWERS. Nearly regular; perfect; in conspicuous 4-5flowered, axillary racemes; on slender pedicels $3 / 4-1$ inch long; calyx 5-lobed, reflexed; corolla of 5 , clawed, bright yellow petals, $3 / 4$ inch in diameter; stamens 10 , free, exserted.

FRUIT. Oblong, compressed or somewhat turgid legume $3-4$ inches long and $1 / 4-1 / 3$ inch wide; straight or somewhat contracted between the $2-8$ seeds. Seed: ovoid, compressed.

TWIGS. Stout; rounded; slightly zigzag; glabrous and glaucous; light yellow or pale olive-green; armed with thin, straight or curved spines $1 / 4$ inch long. Winter buds: minute.

BARK. Thin ( $1 / 8$ inch); smooth and pale olive-green on young trunks, becoming furrowed, scaly, and red-brown.

WOOD. Rather heavy; soft; weak; close-grained; ringporous; heartwood light brown; sapwood clear, light yellow, rather thick; unimportant; used as fuel.

SILVICAL CHARACTERS. Lower Sonoran zone; intolerant; abundant seeder; typical of arid, desert sinks, cañons, and depressions; in sandy or gravelly soil.

Two other species of Cercidium reach tree size:

1. C. microphyllum (Torr.) R. \& J. (Parkinsonia microphylla Torr.), the Littleleaf Paloverde, a desert species reaching tree size only in Maricopa County, Arizona, although a shrub in California and northern Mexcio. This species has leaves with 4-6 pairs of leaflets, each $1 / 6$ inch long, twigs terminating in spines, and a 1-2-seeded legume.

2. C. macrum Johnst. (C. floridum of auth.), the Border Paloverde, of Southern Texas and adjacent Mexico. This species has leaflets $1 / 16$ inch long, slightly glandular and dull green, and a 2-3-seeded legume. 


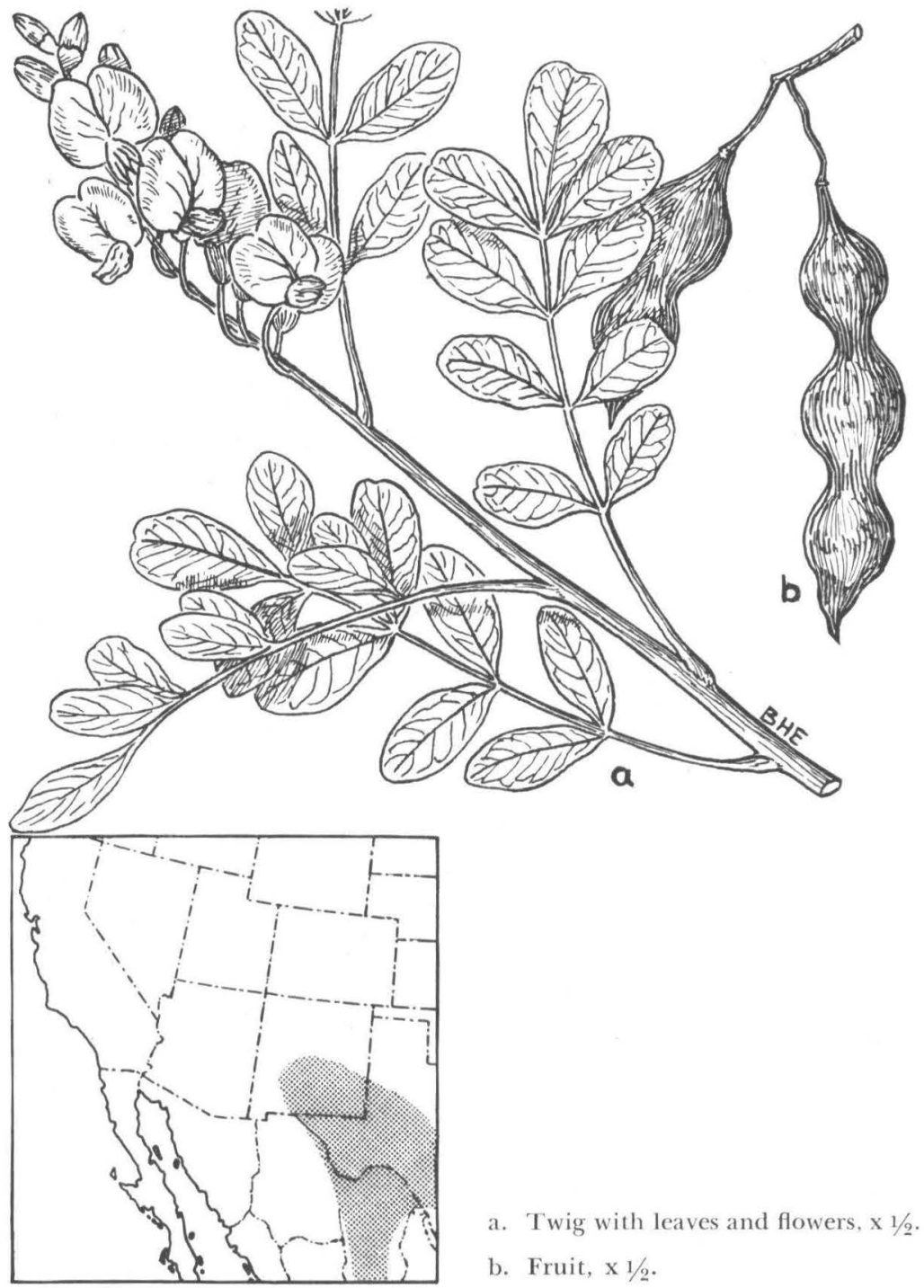

[2 12 2] 


\title{
LEGUMINOSAE
}

\author{
Mrscialblan. Frijolito \\ Sophora secundiflora (Orteg.) Lag. (Broussonelia \\ secundiflora Orteg.)
}

HABIT. A shrub or rarely a small tree 20-35 feet high and $6-8$ inches in diameter; crown narrow with numerous upright branches; commonly thicket-forming.

LEAVES. Alternate; unequally pinnate with 7-9 oblongelliptic, coriaceous, glabrous, entire, thick-margined leaflets $1-21 / 2$ inches long and $1 / 2-11 / 2$ inches wide; rounded at apex; lustrous and yellow-green above, paler below; persistent; stout, puberulous petiole.

FLOWERS. Irregular (papilionaceous); perfect; fragrant: appearing with leaves; in conspicuous I-sided, canescent, terminal racemes; on stout pedicels; calyx campanulate, 2 upper teeth larger; corolla 1 inch long, of 5 , clawed, violet-blue or rarely white, petals, the standard broad, erect; stamens 10 , mostly free or slightly diadelphous at base; ovary coated with long, silky, white hairs; ovules numerous.

FRUIT. Oblong, terete, indehiscent legume I-7 inches long and $1 / 2$ inch broad; thick, woody valves; much contracted between seeds; covered with dense, hoary tomentum; tipped with remnant of style. Seed: short-oblong, rounded, $1 / 2$ inch long, bright scarlet, contain sophorin and are very poisonous.

TWIGS. Slender; round; unarmed; tomentose at first, becoming glabrous and pale orange-brown. Winter buds: terminal absent; lateral minute, scaly.

BARK. Thin, red-brown.

WOOD. Very heavy; hard; close-grained; ring-porous; heartwood orange, streaked with red; sapwood thick, bright yellow; unimportant.

SILVICAL CHARACTERS. Lower Sonoran zone; intolerant; fibrous roots; moist sites; borders of streams, and seacoasts: rarely more than a shrub in the Rocky Mountain region.

The Texas Sophora, Sophora affinis Torr. and Gray, enters the Rocky Mountain region in southwestern Arizona; this species differs from $S$. secundiflora in having thin, deciduous leaves, a fleshy legume, and white flowers in axillary racemes. 
4
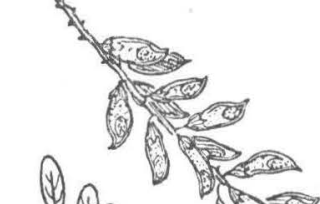

40 in

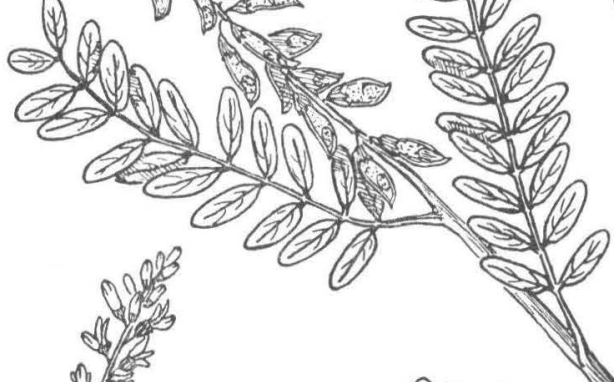

sines

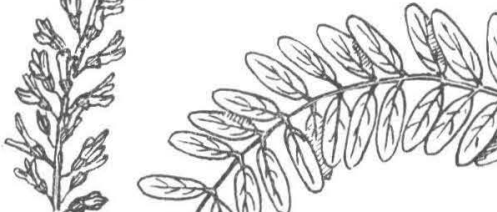

b

b)

)

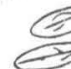

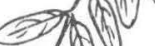

Q5 10

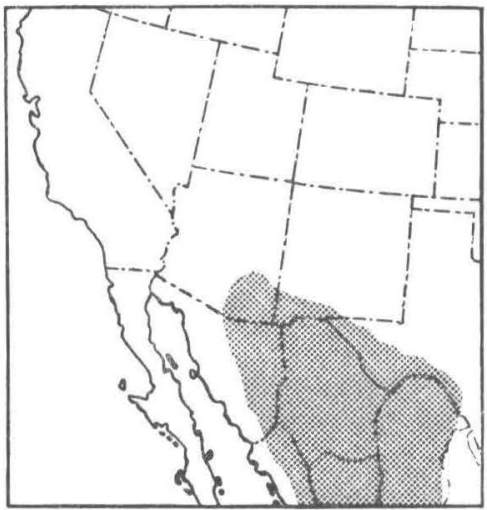

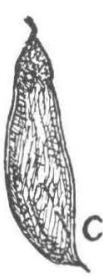
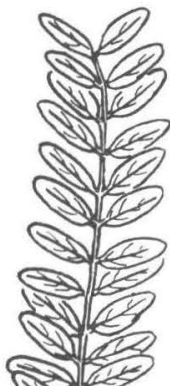

$\therefore 4$

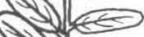

.

(
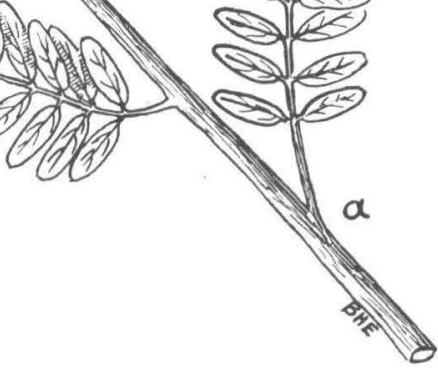

a. Twig with leaves and fruit, $\mathrm{X} 1 / 2$.

b. Flower raceme, $x 1 / 2$.

c. Fruit, $\mathrm{x} 2$. 


\section{LEGUMINOSAE}

\section{Eysenharitia. KidneywoOd}

Eysenhardtia polystachya (Orteg.) Sarg. (Eysenhardtia orthocarpa S. Wat.) [Viborquia orthocarpa (Gray) Cock.]

HABIT. Commonly a low, rigid shrub, reaching tree size only near the summit of the Santa Catalina Mountains in Arizona, where it becomes $18-25$ feet high and 6-8 inches in diameter.

LEAVES. Alternate; equally pinnate with 10-23 pairs of oval, rounded or slightly emarginate, thin, short-petioluled leaflets $1 / 2-2 / 3$ inch long and $1 / 8^{-1 / 4}$ inch wide; pale, gray-green and glabrous above; pubescent and conspicuously brownglandular below; thickened, revolute margins; minute, awlshaped, soon-falling stipules; pubescent, grooved rachis; deciduous.

FIOWERS. Slightly irregular; perfect; in axillary, pubescent spikes; on slender, pubescent pedicels; opening in May; calyx campanulate, 5-toothed, many-ribbed, pubescent, conspicuously glandular, persistent; corolla subpapilionaceous, white, $1 / 2$ inch long, erect, free, with 5 petals nearly equal in size and shape; stamens 10, diadelphous; ovary superior, 1-celled, oblique, ovules $2-3$, rarely 4 .

FRUIT. Small ( $1 / 2$ inch long), pendent, compressed, oblong, straight or slightly falcate legume; usually with single seed (rarely 2) near apex. Seed: oblong-reniform, compressed, light red-brown, $1 / 4$ inch long.

TWIGS. Slender; round; unarmed; at first gray-pubescent, later glabrous, red-brown and roughened by numerous, glandular excrescences. Winter buds: minute.

BARK. Thin ( $1 / 16$ inch), light gray, broken into large, platelike scales, exfoliating on the surface into thin layers.

WOOD. Heavy; hard; close-grained; ring-porous; heartwood light red-brown; sapwood thin, clear yellow; not important; known for its fluorescent properties.

SILVICAL CHARACTERS. Lower and Upper Sonoran zones; intolerant; on arid slopes and dry ridges; in gravelly soil; valuable browse plant. 
SMOKETHORN

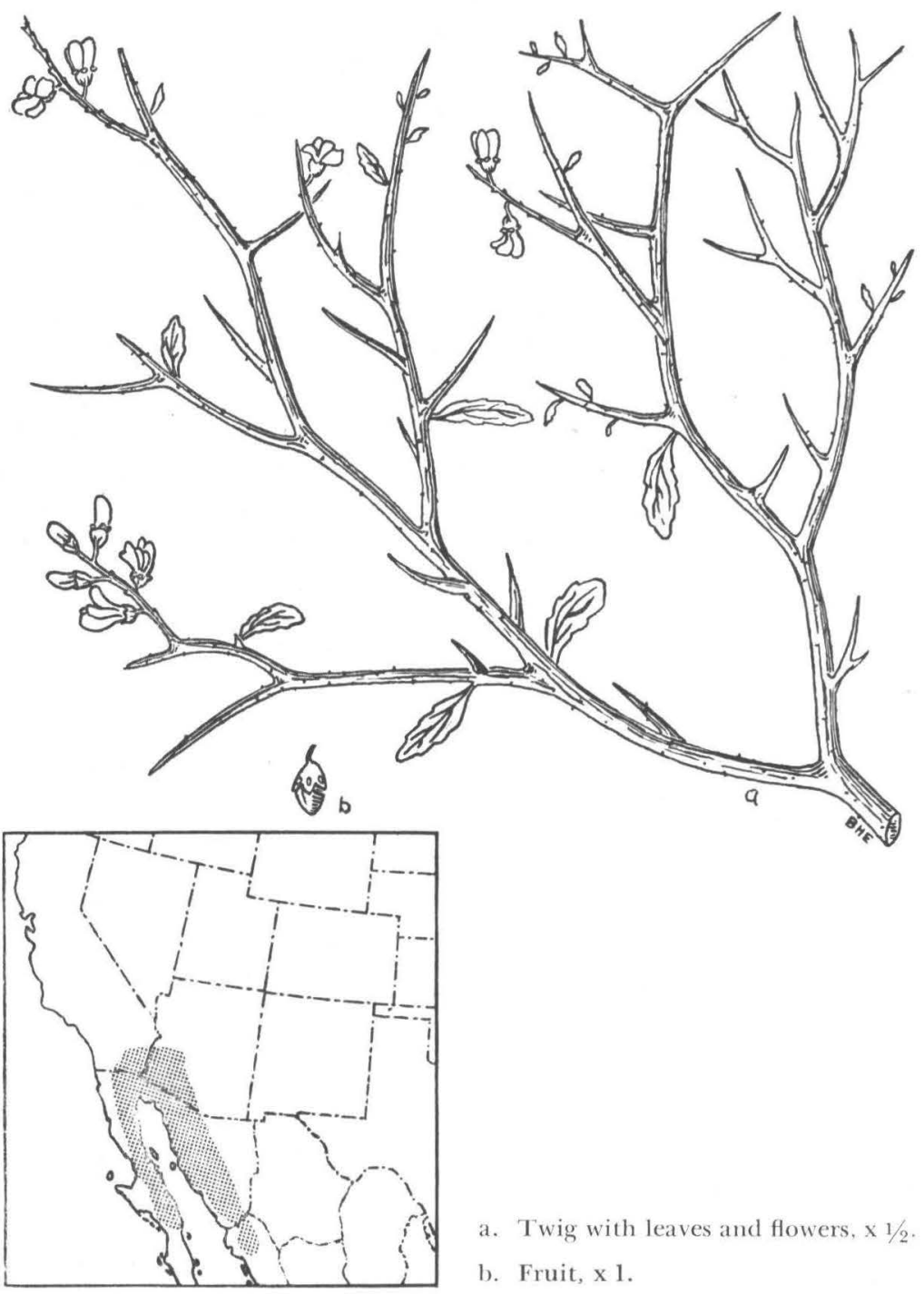

[2 16$]$ 


\section{LEGUMINOSAE}

\section{SMOKETHORN. Indigo Bush}

Parosela spinosa (Gray) Heller. (Dalea spinosa Gray)

HABIT. Usually a spiny shrub, but occasionally a small tree 18-20 feet high and 8-12 inches in diameter.

LEAVES. Alternate, simple and few on young trees; minute or absent on old trees; cuneate or linear-oblong; subsessile; hoary-pubescent; glandular-dotted; entire or remotely serrate; falling early, causing plant usually to appear leafless.

FLOWERS. Irregular (papilionaceous); perfect; in axillary racemes 1-1 1/2 inches long; on short pedicels; calyx 5-lobed, 10-ribbed, ciliate; corolla papilionaceous, indigo blue, 1/2 inch long, standard cordate and reflexed; stamens 10, diadelphous; ovary superior, pubescent, glandular-dotted; ovules 4-6.

FRUIT, Ovoid, pubescent, glandular-dotted, beaked, 1-seeded legume; twice as long as enclosing calyx; membranaceous. Seed: kidney-shaped, pale brown, often mottled, $1 / 8$ inch long.

TWIGS. Reduced to slender, sharp spines: at first with dense, white pubescence, and bearing minute triangular bracts; becoming glabrous and pale brown in third year; marked by lenticels; bark exfoliates showing pale green inner bark.

BARK. Thin ( $1 / 4$ inch), dark gray-brown, furrowed and roughened by persistent scales.

WOOD. Moderately soft; light; coarse-grained; ring-porous; heartwood walnut-brown; sapwood thick and nearly white; fuel.

SILVICAL GHARACTERS. Lower Sonoran zone; intolerant; reproduction sparse and species nowhere abundant; adapted to very dry, desert plains in rocky or gravelly soil.

\section{Coralbean}

\section{Erythrina flabelliformis Kearney}

A Mexican shrub or small tree extending into southern Arizona and New Mexico. Characterized by spiny branches; alternate, pinnately compound leaves, with 3 broad leaflets, each $11 / 2-3$ inches long; showy flowers in dense racemes, with a red, narrow standard $11 / 2^{-2}$ inches long; and a linear legume sometimes 12 inches long, with 2 to many, large, red seeds. 
SOUTHWESTERN LOCUST






\section{LEGUMINOSAE}

\section{SOUTHWESTERN LOCUST}

Robinia neo-mexicana var. luxurians Dieck.

HABIT. A prickly shrub or small tree 20-25 feet high and 6-8 inches in diameter.

LEAVES. Alternate; unequally pinnate, with 15-21 ultimately glabrous, short-petioluled, elliptic-oblong, entire, roundtipped, mucronate leaflets 11/2 inches long; deciduous; rachis stout and pubescent; stipules papery and becoming spines.

FLOWERS. Irregular (papilionaceous); perfect; in short, pendulous, many-flowered, glandular-hispid racemes; on long, slender, glandular-hispid pedicels; calyx campanulate, 5-lobed; corolla pale rose to nearly white, 1 inch long, with broad standard hardly longer than wings; stamens 10, diadelphous; ovary superior, 1-celled; ovules numerous.

FRUIT. Glandular-hispid, compressed legume; 3-4 inches long and about $1 / 3$ inch wide; thin-valved; many-seeded. Seed: oblong-oblique, dark brown, thin-coated, $1 / 16$ inch long.

TWIGS. Slender; spiny; mostly round or slightly angled; zigzag; at first covered with glandular hairs, becoming smooth, red-brown, and marked by small scattered lenticels. Winter buds: terminal absent; lateral minute, naked, subpetiolar, depressed-globose, 3-4 superposed together.

BARK. Thin; slightly furrowed; light brown; the surface separating into small, platelike scales.

WOOD. Very heavy; hard; strong; close-grained; ringporous; heartwood yellow, streaked with brown; sapwood thin, light yellow; unimportant; fence posts, stakes, etc.

SILVICAL CHARACTERS. Transition zones; intolerant; on dry hills or banks of mountain streams.

GENERAL. The species Robinia neo-mexicana Gray, differing from this variety in not having the hairs on the fruit glandularhispid, is typically a small shrub restricted in its range to Grant County, New Mexico.

R. rusbyi W. \& S., a shrub or tree with glabrous fruit, is found in southern New Mexico. The eastern black locust, $R$. pseudo acacia has proved hardy when planted as far north as Idaho. 


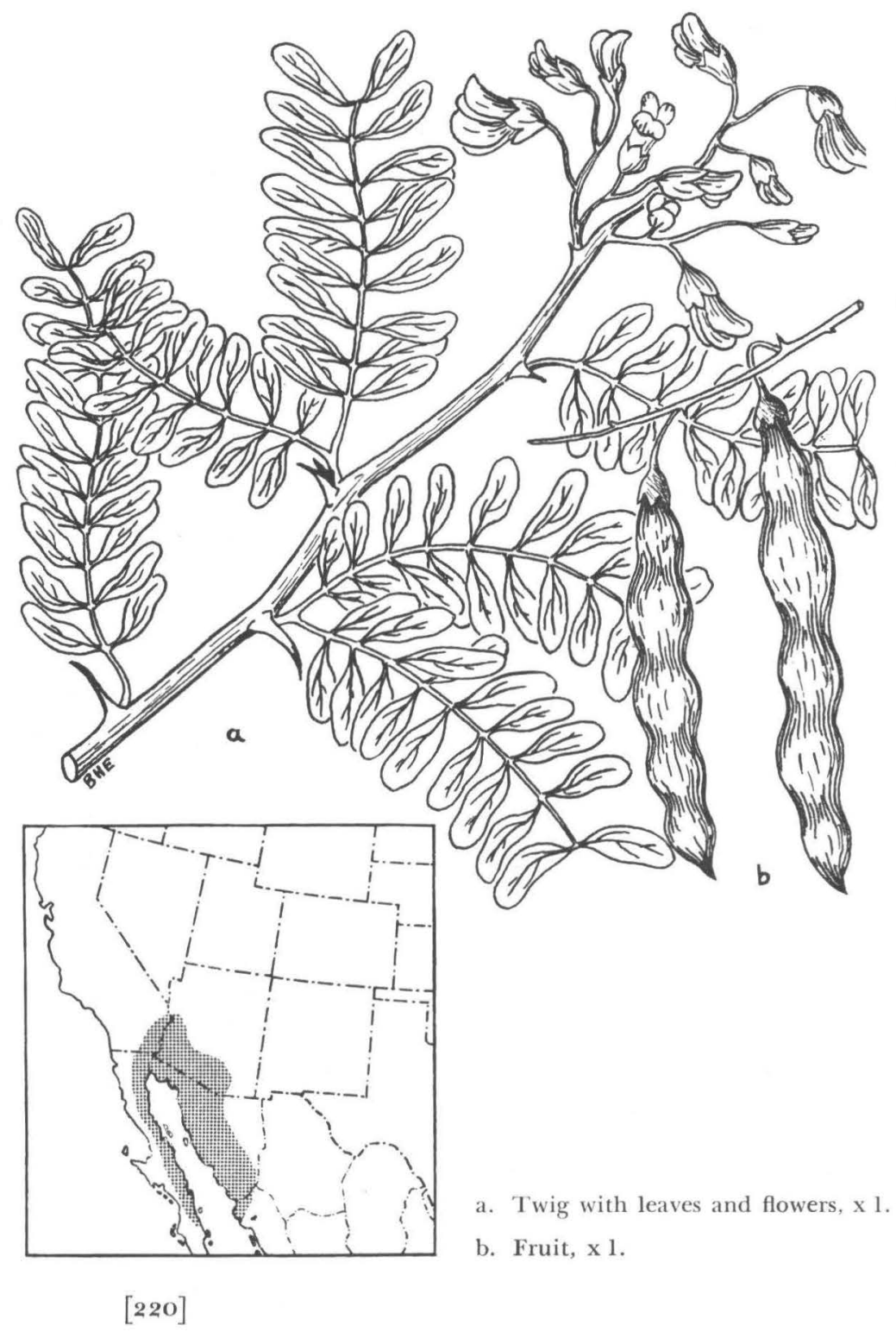




\section{LEGUMINOSAE}

\section{IESOTA. IronwOOd \\ Olneya tesota Gray.}

HABIT. A beautiful, spiny shrub or small, bushy tree sometimes 25-30 feet high and 8-18 inches in diameter.

LEAVES. Alternate; equally or unequally pinnate with 10-15 hoary-canescent, short-petioluled, oblong or obovate, entire, obtuse and often mucronate leaflets $1 / 2-3 / 4$ inch long; persistent until new leaves appear; stipules absent.

FLOWERS. Irregular (papilionaceous); perfect; in short, axillary, few-flowered, hoary-canescent racemes; calyx hoarycanescent; 6-lobed; corolla papilionaceous, purplish, 1/2 inch long, with orbicular standard appendaged at base; stamens 10 , diadelphous; ovary superior, 1-celled, pilose; ovules numerous.

FRUIT. Oblique, compressed, glandular-haired legume 221/2 inches long; light brown; thick and leathery; 1-5-seeded. Seed: broad ovoid, flattened, bright chestnut-brown, edible.

TWIGS. Slender; hoary-canescent at first, becoming smooth and brown; armed with stout, sharp, paired spines.

BARK. Thin, scaly, red-brown, peeling off in long strips.

WOOD. Exceedingly heavy; hard; strong; heartwood chocolate-brown streaked with red; sapwood thin, clear yellow; unimportant; used locally for canes, small articles, and fuel.

SILVICAL CHARAGTERS. Lower Sonoran zone; intolerant; thrives in hot, desert regions, sides of depressions, and dry water courses; a monotypic genus; attacked by mistletoe.

\section{ZYGOPHYLLACEAE}

\section{SOAPBUSH \\ Porlieria angustifolia (Engelm.) Gray. (Guaiacum angustifolium Engelm.)}

A shrub or small tree entering this region in southwestern Texas. Characterized by persistent, opposite, pinnately compound leaves with 8-16, entire, smooth leaflets; stipules persistent; flowers perfect, regular, purple, $1 / 2-8 / 4$ inch in diameter, sweet-scented; fruit an obcordate, 2-lobed capsule containing 2 large, yellow seeds. Wood very durable, hard and heavy; used for fence posts. An important honey plant. 
Hoptree
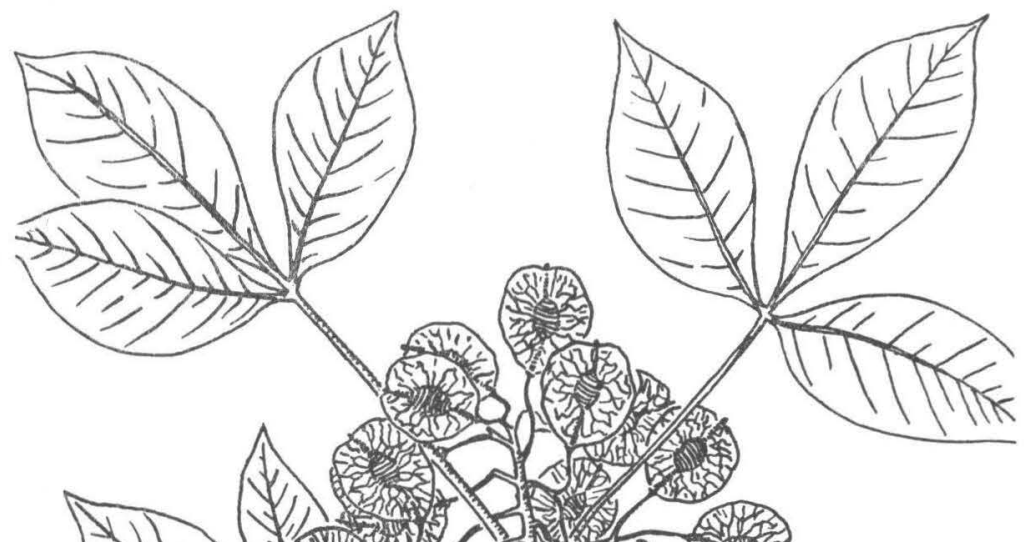

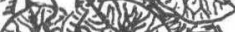

Nins
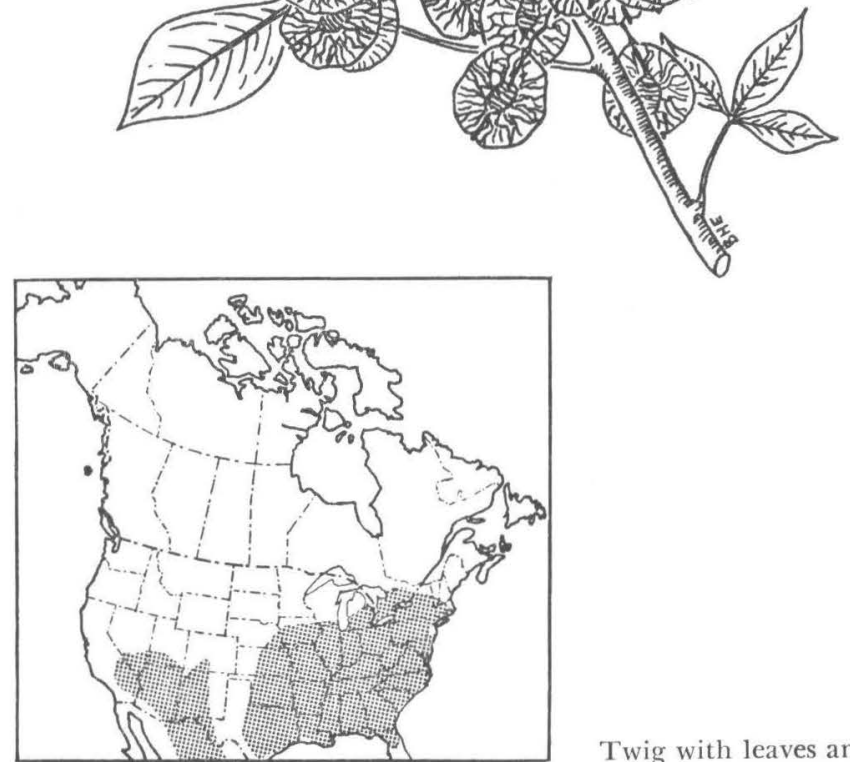

Twig with leaves and fruit, $\times 1 / 2$. 


\section{RUTACEAE}

Hoptree. WAFER Ash

Ptelea trifoliata L. (Ptelea baldwinii Torr. \& Gray)

(Ptelea tomentosa Raf.)

HABIT. An unarmed shrub or small tree 20-25 feet high and $6-8$ inches in diameter; crown round-topped with small branches.

LEAVES. Alternate or rarely opposite; compound with 3 (rarely 5) subsessile, ovate to oblong leaflets; acuminate at apex; entire or crenulate-serrate margins; becoming glabrous and rather leathery; dark green above, pale and dotted with transparent glands below; deciduous; long-petioled; without stipules.

FLOWERS. Regular; polygamous; in terminal cymes or compound umbels; on pubescent pedicels; calyx 4-5-parted, pubescent; corolla green-white; 4-5-petaled; stamens 3-4; ovary superior, 2-3-celled, compressed, puberulous; ovules, 2 in each cell.

FRUIT. Dehiscent samara; 2-3-celled; broad, thin, almost orbicular wing, nearly $\mathrm{I}$ inch across; in drooping clusters on slender pedicels; persisting on branches through winter. Seed: $1 / 3$ inch long, oblong, acute, dark red-brown.

TWIGS. Slender; round; pubescent at first, becoming glabrous, dark brown, lustrous and marked by wartlike excrescences and conspicuous leaf scars. Winter buds: terminal absent; lateral small, depressed, nearly round, pale-colored, tomentose.

BARK. Smooth; thin; bitter; ill-scented; dark brown on old trunks; that of the roots sometimes used as a tonic.

WOOD. Rather heavy; hard; close-grained; ring-porous: heartwood yellow-brown; sapwood thin; unimportant.

SILVICAL CHARACTERS. Lower Sonoran and Transition zones; in the Southwest found mostly on dry hills and cañons.

\section{SIMAROUBACEAE}

Ailanthus. Tree of Heavfen Ailanthus altissima (Mill.) Swinglc.

(Ailanthus glandulosa Desf.)

A large, fast-growing tree introduced from China and naturalized over much of the country. Characterized by alternate, pinnately compound leaves, 1-2 feet long, the leaflets glandular-toothed at base; fruit of clustered samaras; and thick-pithed twigs. Coppices freely and is aggressively spontaneous. 


\section{ElephantTREe}

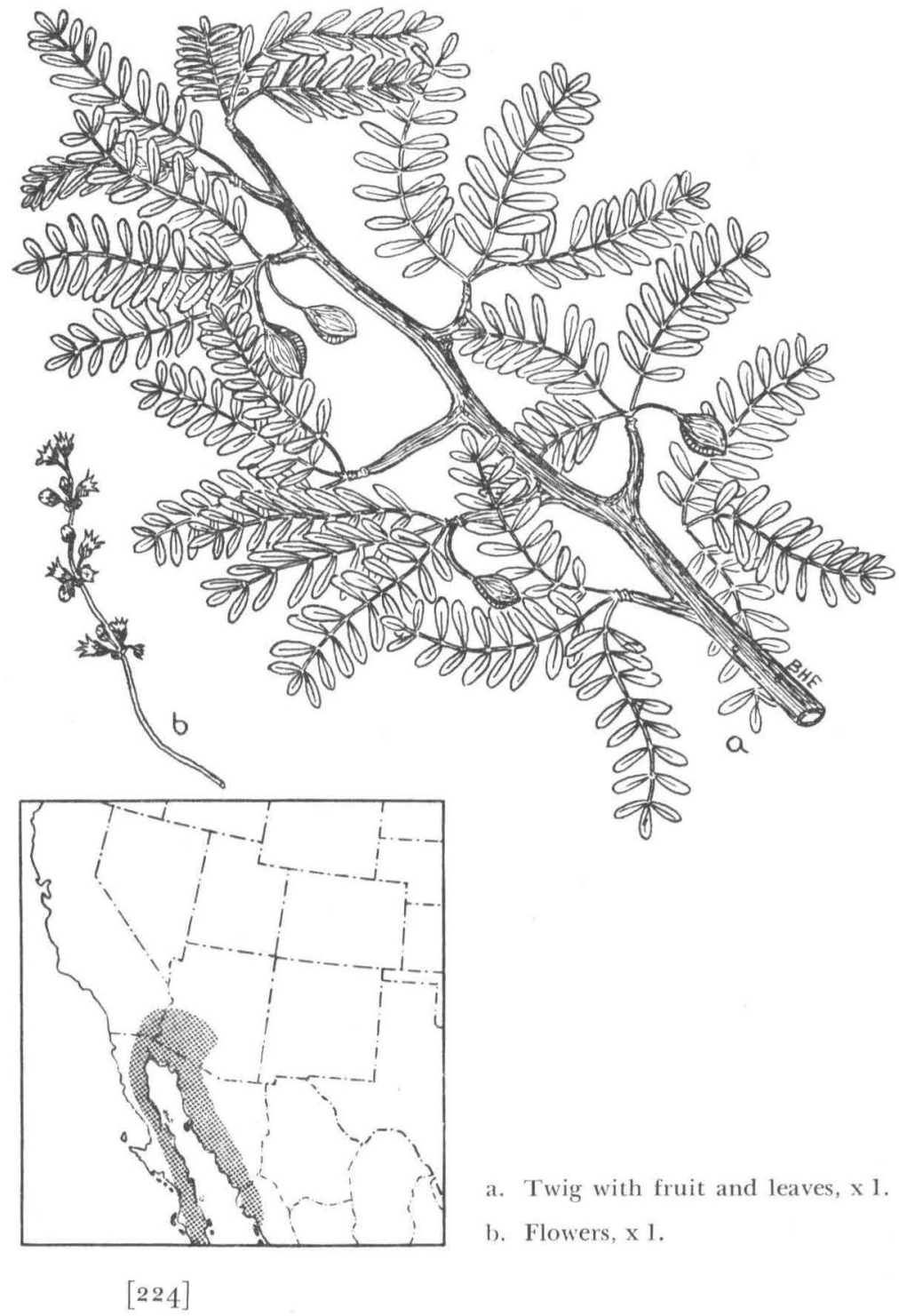




\section{BURSERACEAE}

\section{Elephanttree. Bursera}

Bursera microphylla Gray (Elaphrium microphyllum Rose.)

HABIT. A low shrub or small tree 10-12 feet high and 4-8 inches in diameter; trunk rapidly tapering; crown wide.

LEAVES. Alternate; unequally pinnately compound; 1-11/4 inches long with usually 10-20 pairs of leaflets; deciduous; leaflets opposite, 1/4 inch long, oblong or oblong-obovate, sessile, rounded at apex, entire or subserrate, thin.

FLOWERS. Regular; polygamous, small ( $1 / 6$ inch long); calyx minute; corolla 5-petaled, white, 3-4 times longer than calyx, stamens 10, shorter than petals; ovary superior, 3-celled with 2 ovules in each cell; styles united; stigma 3-lobed.

FRUIT. Capsule-like drupe; $1 / 4$ inch long; ellipsoid or slightly obovoid; red; glabrous; splitting into 3 valves; drooping on thickened pedicels; flesh leathery; nutlets 1-3, usually solitary, ovoid, acute, thin-walled, 3-angled, gray.

TWIGS. Slender; glabrous; red; roughened during first year by crowded leaf scars.

BARK. Thin ( $1 / 2$ inch); pale yellow, separating into membranaceous, red-brown scales; the outer layer thin and firm, the inner layer corky; resinous.

WOOD. Hard; close-grained; pale yellow; diffuse-porous; resinous; unimportant.

SILVICAL CHARACTERS. Upper and Lower Sonoran zones; in sterile, rocky soil; on dry plains and low mountains.

A similar species, Bursera odorata Brandeg., is a small tree found in the Arizona desert.

\section{EUPHORBIACEAE}

Two members of this family rarely become trees in southern Arizona: Sapium biloculare (S. Wats.) Pax., with alternate, simple, glabrous, narrow-oblong leaves, 1-3 inches long; milky, poisonous juice; and a 2-celled capsular fruit, 1/2 inch long. Castorbean, Ricinus communis L., with alternate, simple palmately lobed leaves, often 12 inches long; and a large, 3-seeded, capsular fruit containing the important castorbeans. 
Sugar Sumac

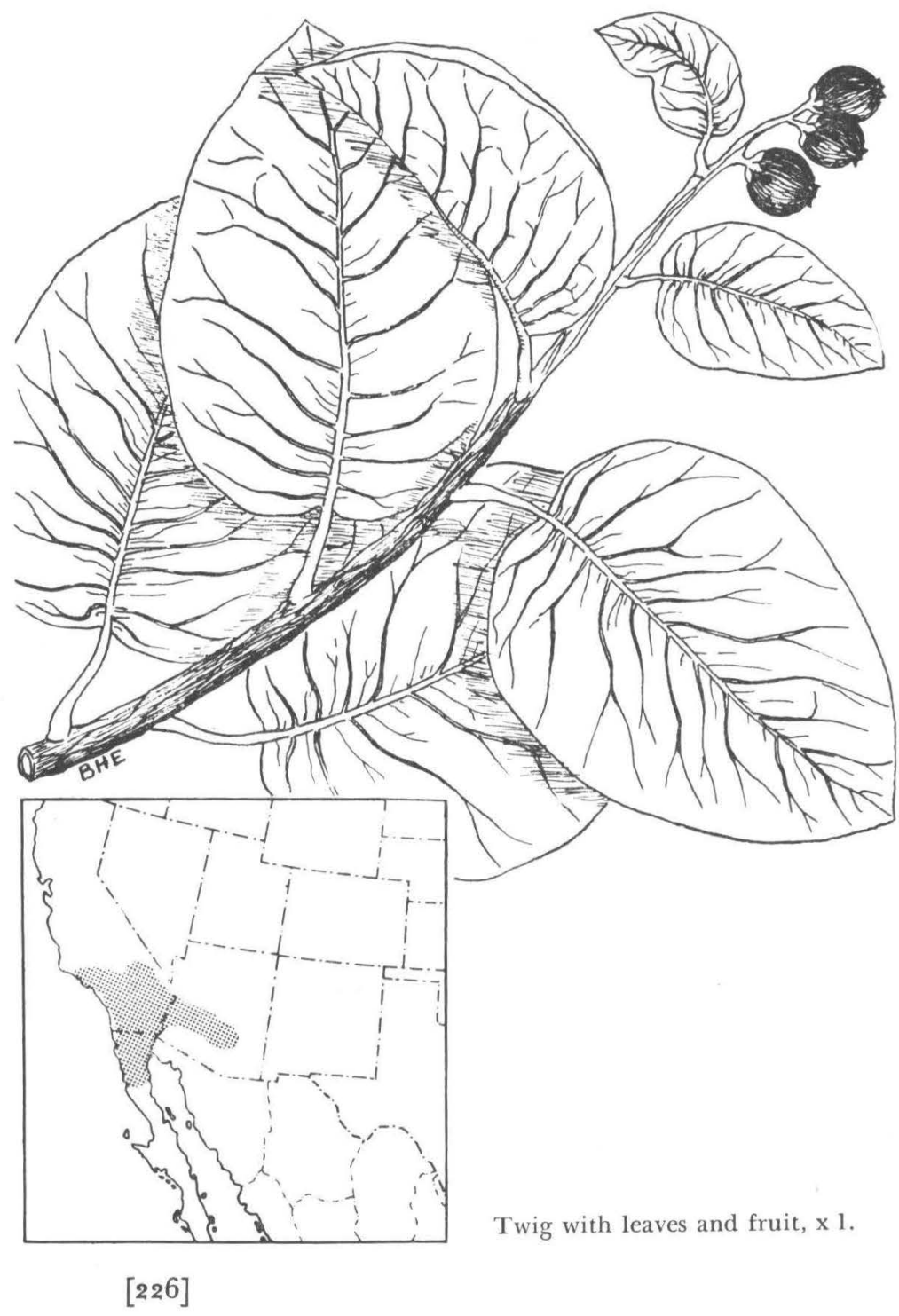




\section{ANACARDIACEAE}

\section{Sugar Sumac}

\section{Rhus ovata S. Wats.}

HABIT. A shrub or small tree rarely 30 feet high; trunk short, stocky; crown open, irregular.

LEAVES. Alternate; simple (rarely 3-foliate); ovate-elliptic to broadly ovate; $2-31 / 2$ inches long; apex acute; margins entire, revolute; thick and leathery; lustrous yellow-green; glabrous; deciduous; tending to fold along midrib; petioles stout, $1 / 2$ inch long, purplish, glabrous; stipules absent.

FLOWERS. Regular; dioecious or rarely polygamous; minute; in large, dense, terminal compound spikes; bracts ovate, ciliate; calyx 5-lobed; corolla 5-petaled, pink or white; stamens 5 , alternate to petals and inserted with them on disk; ovary superior, 1-celled, 1-ovuled.

FRUIT. Drupaceous; globose; $1 / 3$ inch in diameter; covered by sweet, waxy exudate; pubescent; thin, dry outer coat enclosing bony seed.

TWIGS. Stout; round; chocolate-brown and puberulent, soon becoming glabrous; pith terete, not large. Winter buds: small, ovate, hairy, gray-brown.

BARK. Thin; generally smooth; gray-brown.

SILVICAL CHARAGTERS. Lower and Upper Sonoran zones; intolerant; on dry, rocky hillsides and ridges; coppices rapidly after burning; important for soil protection and wildlife cover.

GENERAL. Rhus kearneyi Borkl., a related form, is a small evergreen tree in southwestern Arizona. Rhus lanceolata (Gray) Engler. (Rhus copallina var. lanceolata Gray) is a small tree entering this region in the Chisos Mountains of western Texas. Rhus glabra L., distributed over most of the United States, has been reported as a small tree, but not from the Rocky Mountain region. Rhus microphylla Engelm., reported as a small tree, occurs in Mexico and Texas to west central New Mexico.

The Texas Pistache, Pistacia texana Swing., a shrub or tree of western Texas and Mexico, is characterized by alternate, pinnately compound, persistent leaves with 9-19, spatulate, small leaflets; dioecious flowers; and a small, red-brown drupe. 


\section{Canotia}

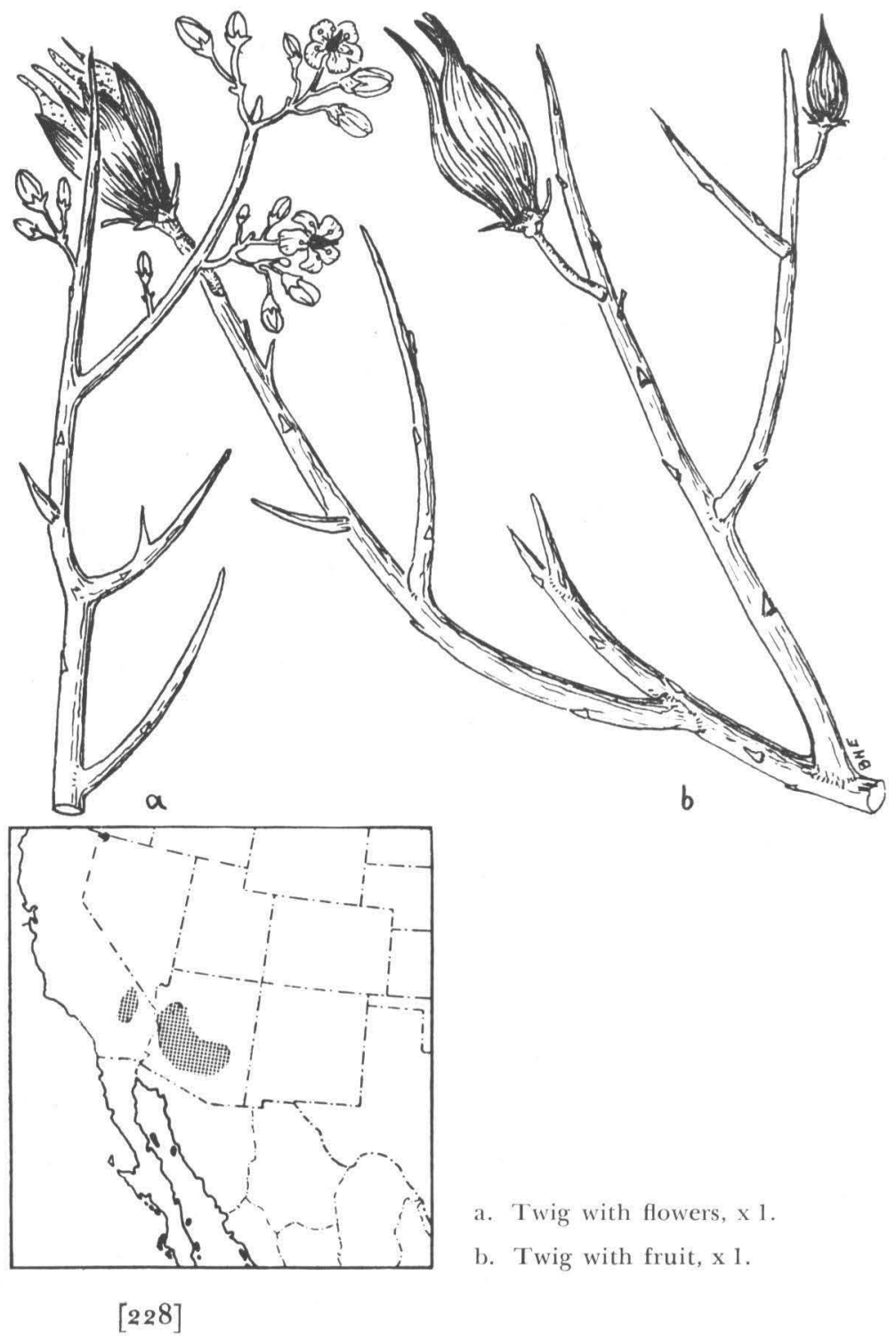




\section{CELASTRACEAE}

\section{Canotia. Mohavethorn}

\section{Canotia holacantha Torr.}

HABIT. An odd, leafless shrub or small shrublike tree 20-30 feet high and rarely 12 inches in diameter; trunk short and stocky; branches rushlike.

FLOWERS. Regular, perfect, small $(1 / 8-1 / 4$ inch in diameter) ; in 3-7-flowered fascicles; calyx 5-lobed, persistent, minute; corolla 5-petaled, white, reflexed, deciduous; stamens 5, opposite lobes of calyx, filaments shorter than petals, persistent on fruit; ovary 5-celled, papillose-glandular; ovules 6 in each cell, in 2 ranks.

FRUIT. Dry, woody, ovoid, acuminate capsule 1 inch long; crowned with subulate, persistent style; 5-valved, splitting open at top. Seed: solitary or paired; about $\$ / 4$ inch long; flattened; seed coat subcoriacious, papillate, produced below into a subfalcate, membranaceous wing.

TWIGS. Slender, rushlike, round, alternate, glabrous, rigid, and spine-tipped; pale green and carrying on photosynthetic functions; characteristic, black, triangular, cushion-like processes located at base of each twig and flower cluster.

BARK. Light brown and deeply furrowed.

WOOD. Heavy; hard; close-grained; light brown; diffuseporous; unimportant.

SILVICAL CHARACTERS. Lower Sonoran zone; this monotypic genus has been placed in 3 other families; grows on dry, mountain slopes and mesas between 2,000-4,000 feet; often in pure stands; the loss of leaves apparently aids the plant in enduring the hot, dry climate.

\section{Wahoo. Burning Bush \\ Euonymus atropurpureus Jacq.}

A shrub through this region, this species reaches tree size in Arkansas and eastern Texas. It can be distinguished by its opposite, petioled leaves; 4-parted flowers; and fleshy, capsular fruit enclosed in a thin scarlet aril. The western Wahoo, $E$. occidentalis Nutt. enters this region in western Nevada. 


\section{ACERACEAE}

\section{The Maples}

Characteristics of the Genus Acer L.

HABIT. Deciduous trees or shrubs, with handsome foliage, usually assuming brilliant colors in autumn.

LEAVES. Opposite; simple or compound; deciduous; petioled; without stipules; simple leaves palmately 3-7-lobed; compound leaves pinnate, with 3-7 leaflets.

FLOWERS. Regular; polygamous, dioecious, or rarely perfect; small; borne either in lateral fascicles from separate flower buds and appearing before the leaves, or in lateral and terminal racemes, panicles, or corymbs and appearing with or after the leaves; calyx colored, generally 5-parted; corolla usually 5-petaled or absent; stamens 4-12, usually 7-8; ovary 2-celled, 2-lobed, compressed, with 2 styles; ovules 2 in each cell, ascending.

FRUIT. Double samara united at base (key); each nutlike carpel laterally compressed and produced into large, obovate wing. Seed: usually solitary by abortion, ovoid, compressed.

TWIGS. Slender to moderately stout; round; pith homogeneous, round; marked at base by bud scales with ringlike scars; leaf scars more or less U-shaped, with 3 (rarely 5-7) bundle scars. Winter buds: with valvate or imbricated scales, inner scales accrescent, terminal buds larger than lateral.

BARK. Astringent and variable.

WOOD. Variable from soft to heavy and hard; diffuseporous; pores all small and not crowded; rays distinct on cross section without lens; widely used for interior finish, etc., sap of some species manufactured into sugar.

SILVICAL CHARACTERS. Mostly tolerant; fibrous root systems; widely used for ornamental and shade trees.

GENERAL. This genus contains, over 600 species of trees widely scattered through the Northern Hemisphere with one species extending into Sumatra and Java. In the United States there are 14 native species, 5 of these reaching tree size in the Rocky Mountain region. 


\section{KEY TO THE SPECIES OF ACER}

I. Leaves compound; winter buds enclosed by tomentose scales; twigs encircled by crescent-shaped leaf scars..............

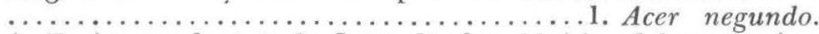

A. Entire or dentate leaflets; slender, bluish, glabrous twigs;

Idaho.................... varolaceum, p. 233.

B. Serrate leaflets; moderately stout, greenish twigs.

1. Glabrous petioles and twigs; New Mexico and Arizona....................... arizonicum, p. 233.

2. Puberulous petioles and twigs; entire region.......... $\ldots \ldots \ldots \ldots \ldots \ldots \ldots \ldots \ldots \ldots \ldots \ldots \ldots \ldots$ vanterius, p. 233.

II. Leaves simple (rarely compound in glabrum); winter buds not enclosed by tomentose scales; twigs not encircled by leaf scars.

A. Leaves sharply and doubly serrate; flowers with petals.

1. Leaves with deep, narrow sinuses, lobes not toothed to base; south and central........2. Acer glabrum, p. 237.

2. Leaves with shallow, open sinuses, lobes toothed to base; northwestern................ Acer douglasii, p. 237.

B. Leaves with entire margins; flowers without petals.

1. Conspicuously hairy leaf scars; lobes of leaf distinctly lobulate; bark of young trees scaly and dark brown; rare

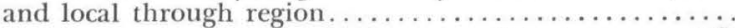
...................... Acer grandidentatum, p. 235.

2. Glabrous leaf scars; lobes of leaf slightly lobed or entire; bark of young trees smooth and chalky white; New Mexico..............5. Acer brachypterum, p. 235. 
BOXELDER
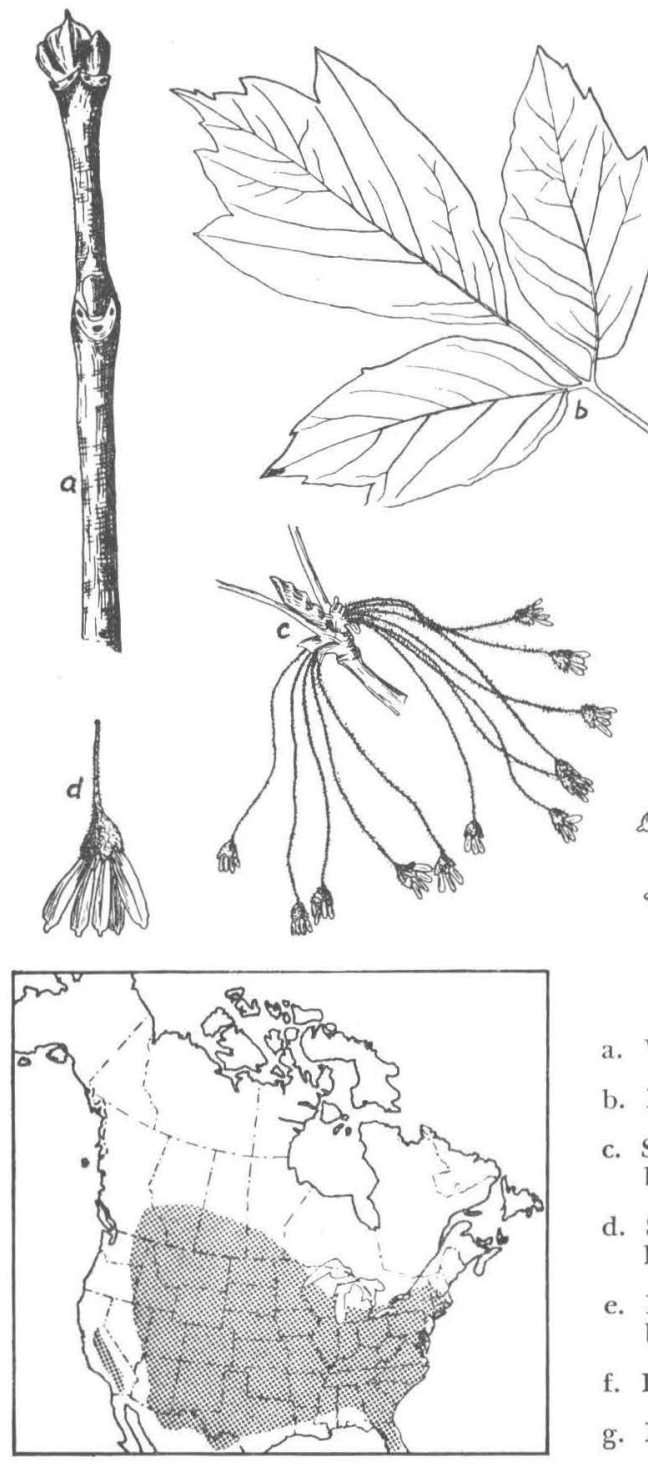

a. Winter twig, $\mathrm{x} 1$.

b. Leaf, $\times 1 / 2$.

c. Staminate flowering branchlet, $\times 1 / 2$.

d. Staminate flower, enlarged.

e. Pistillate flowering branchlet, $\times 1 / 2$.

f. Pistillate flower, enlarged.

g. Fruit, x 1 . 


\section{ACERACEAE \\ BOXELDER \\ Acer negundo var. interius (Britt.) Sarg.}

HABIT. A small tree, rarely 75 feet high and 4 feet in diameter; trunk usually irregular and dividing near ground into several, stout, widespreading branches.

LEAVES. Compound, 3 (rarely $\mathfrak{5}-7$ ) leaflets; petiole long, slender, puberulous; leaflets ovate to lanceolate, 3-4 inches long and $11 / 2-4$ inches wide, glabrous, acuminate, coarsely serrate and sometimes 3-lobed at base.

FLOWERS. Dioecious; minute; the male fascicled; the female in drooping racemes; appearing with leaves or a little before them; calyx 5-lobed, hairy, yellow-green; corolla absent; stamens 4-6, with slender, exserted, hairy filaments; ovary hairy, partly enclosed by calyx.

FRUIT. Pendent; 1-2 inches long; glabrous; ripening in autumn; in drooping racemes $6-8$ inches long. Seed: narrowed at the ends, smooth, bright red-brown, $1 / 2$ inch long.

TWIGS. Moderately stout; greenish; pubescent, or rarely nearly glabrous; marked by conspicuous bud scale scars and crescent-shaped leaf scars which surround the twig. Winter buds: acute, $1 / 8^{-1 / 4}$ inch long, tomentose.

BARK. Thin $(1 / 4-1 / 2$ inch); pale gray or light brown; deeply divided by furrows into broad, rounded ridges.

WOOD. Light, soft, close-grained, weak; heartwood creamwhite to yellow-brown, often streaked; sapwood thick; used occasionally for cheap furniture, woodenware, etc.

SILVICAL CHARACTERS. Upper Sonoran and Transition zones; moderately tolerant; shallow-rooted, except on deep soils; hardy to extremes of climate; rapid grower but shortlived and usually of poor form; reproduction by sprout and seed plentiful.

GENERAL. Two other varieties enter this region: Acer negundo var. violaceum Kirch. in the north, with slender, bluish, glabrous twigs and entire or dentate leaves pubescent on the lower surfaces; and Acer negundo var. arizonicum Sarg. in the south, with glabrous twigs and serrate, glabrous leaves with glabrous petioles. The distribution of the entire species is shown on the map. 
Bigtooth Maple
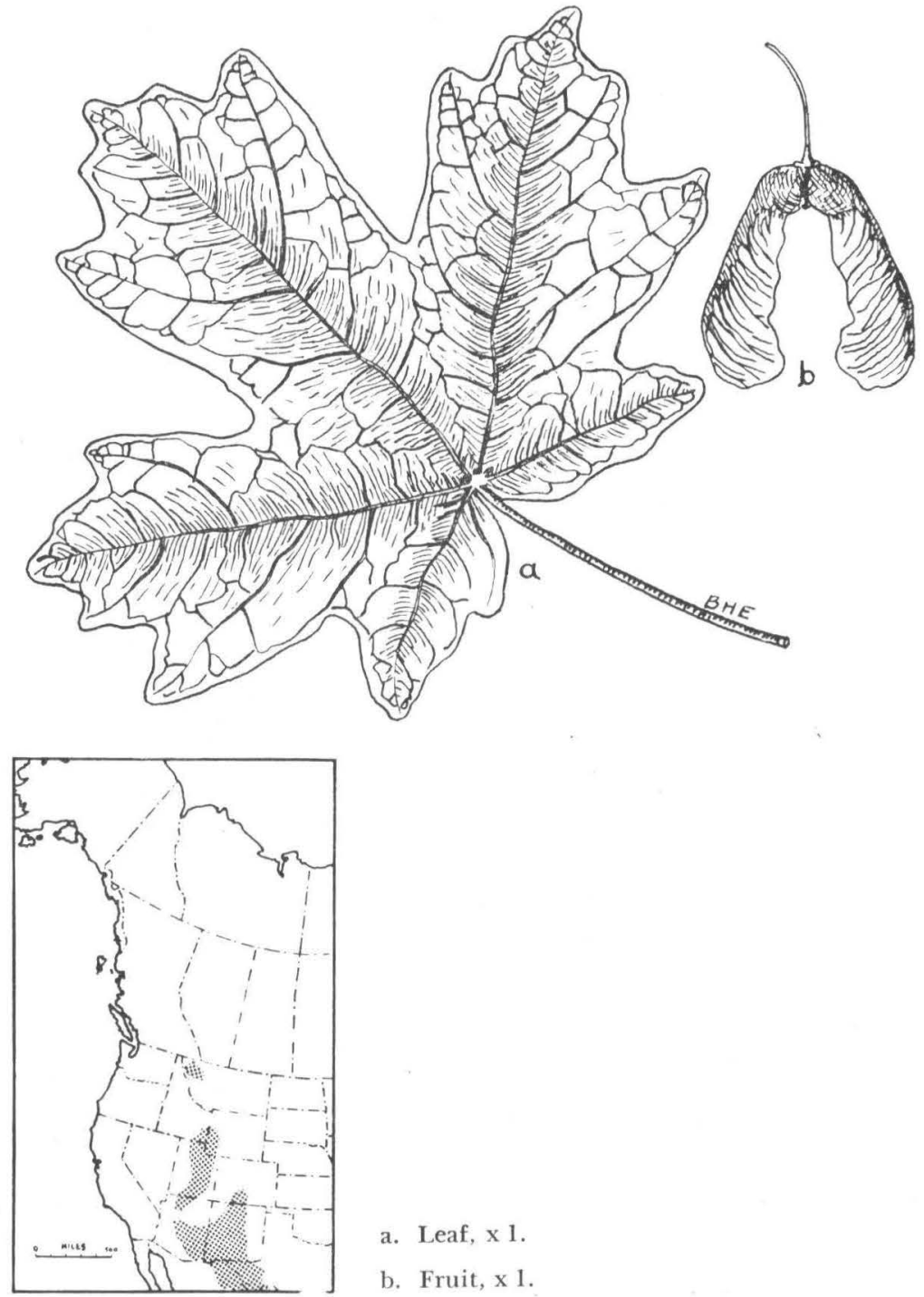

a. Leaf, x 1 .

b. Fruit, $\mathrm{x} 1$. 


\section{ACERACEAE}

\section{Bigtooth Maple}

Acer grandidentatum Nutt. [Acer saccharum var. grandidentatum (Nutt.) Sudw.]

HABIT. A tree 30-40 feet high and 8-10 inches in diameter; branches stout and usually erect.

LEAVES. Simple; 3-5-lobed by broad, shallow sinuses; distinctly lobulate; 2-5 inches in diameter; dark green and lustrous above, pale and usually pubescent below; petioles stout, glabrous; turning yellow and scarlet before falling.

FLOWERS. Polygamous, small ( $1 / 4$ inch); in short-stalked corymbs; calyx yellow, villose, often persistent under fruit; corolla absent; stamens 7-8; ovary usually glabrous.

FRUIT. Spreading or erect wings, $1 / 2-1$ inch long; glabrous or sparingly hairy; of ten rose-colored in summer, green at maturity. Seed: smooth, light red-brown, about $1 / 4$ inch long.

TWIGS. Slender, glabrous, bright red; nearly encircled by narrow leaf scars with conspicuous bands of long hair in their axils. Winter buds: terminal acute, $1 / 16$ inch long, bright redbrown, with puberulous-ciliate outer scales.

BARK. Thin, dark brown, separating on surface into platelike scales.

WOOD. Heavy; hard; close-grained; heartwood light brown to nearly white; sapwood thick and white.

SILVICAL CHARAGTERS. Upper Sonoran to Canadian zones; rather tolerant; shallow root system; on moist sites along mountain streams and on sides of cañons usually at altitudes of $5,000-8,000$ feet.

\section{Southwestern Maple}

Acer brachypterum Woot. \& Stan. (Acer floridanum var. villipes Rehd.)

A small tree entering this region only in the San Luis Mountains of southwestern New Mexico. This species can be distinguished from the bigtooth maple by the slightly lobed or nearly entire leaves, glabrous leaf scars, smooth, pale bark on young trees, and shorter wing of the fruit ( $3 / 8-3 / 4$ inch long). 
Rocky Mountain Maple

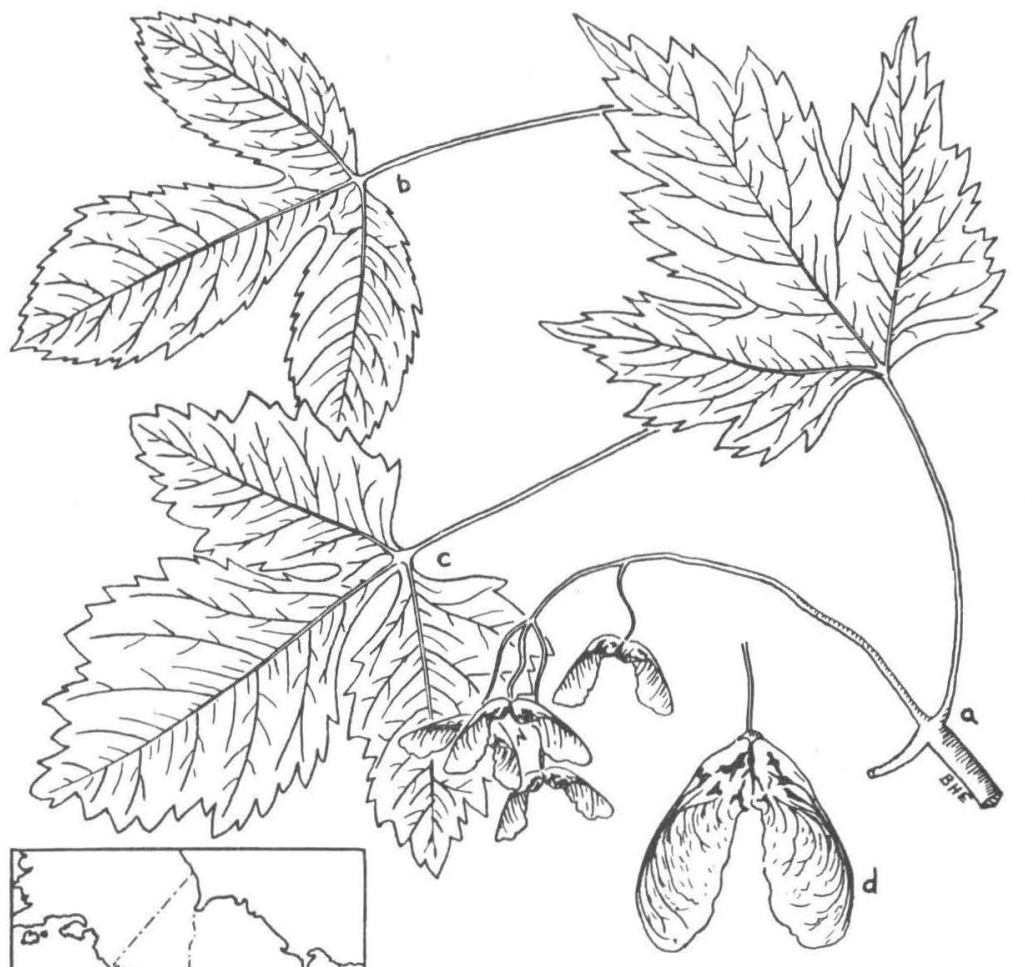

a. Twig with leaf and fruit, $\times 1 / 2$.

b and c. Different forms of leaves, $x 1 / 2$.

d. Fruit, $x 1$.

[236] 


\section{ACERACEAE \\ Rocky Mountain Maple. Dwarf Maple \\ Acer glabrum Torr.}

HABIT. A shrub or small tree rarely $20-30$ feet high and 6-12 inches in diameter; narrow crown with small branches.

LEAVES. Mostly 3-5-lobed and simple, but sometimes divided into 3 leaflets; rounded in outline; $3-5$ inches in diame ter; sharply and doubly serrate; glabrous; thin; dark green above, paler below; petioles glabrous, stout, grooved, 1-6 inches long, often bright red.

FLOWERS. Mostly dioecious; small ( $1 / 8$ inch long); in loose, glabrous, few-flowered, racemose corymbs, on slender drooping peduncles from the end of 2-leaved branches; calyx oblong, obtuse, petal-like; petals yellow-green; stamens 7-8, with glabrous, unequal filaments; ovary glabrous.

FRUIT. Slightly spreading or nearly erect, broad wings, $3 / 4-7 / 8$ inch long; glabrous; often rose-colored in summer. Seed: ovoid, bright chestnut-brown, about $1 / 4$ inch long.

TWIGS. Slender; glabrous; pale green-brown at first, becoming bright red-brown; conspicuously marked by encircling bud scale scars and crescent-shaped leaf scars. Winter buds: acute, $1 / 8^{-1 / 4}$ inch long, bright red or rarely yellow scales tomentose on the inner surface.

BARK. Thin, smooth, dark red-brown.

WOOD. Heavy; hard; close-grained; heartwood light brown or nearly white; sapwood white and very thick.

SILVICAL CHARACTERS. Upper Sonoran to Canadian zones; rather intolerant; in moist locations along stream banks or cañon sides; at elevations of $5,000-6,000$ feet in the north to $8,000-9,000$ feet in the south.

GENERAL. A variable species including several different forms which have been treated as separate species by some authors. The northwestern form, Acer douglasii Hook. [Acer glabrum var. douglassii (Hook) Dipp.], typically differs in having leaves with shallow, open sinuses and lobes .toothed all the way to the base, and fruit with more erect and broader wings. This form extends north and west from northwestern Wyoming. 


\section{Western SOAPBERry}

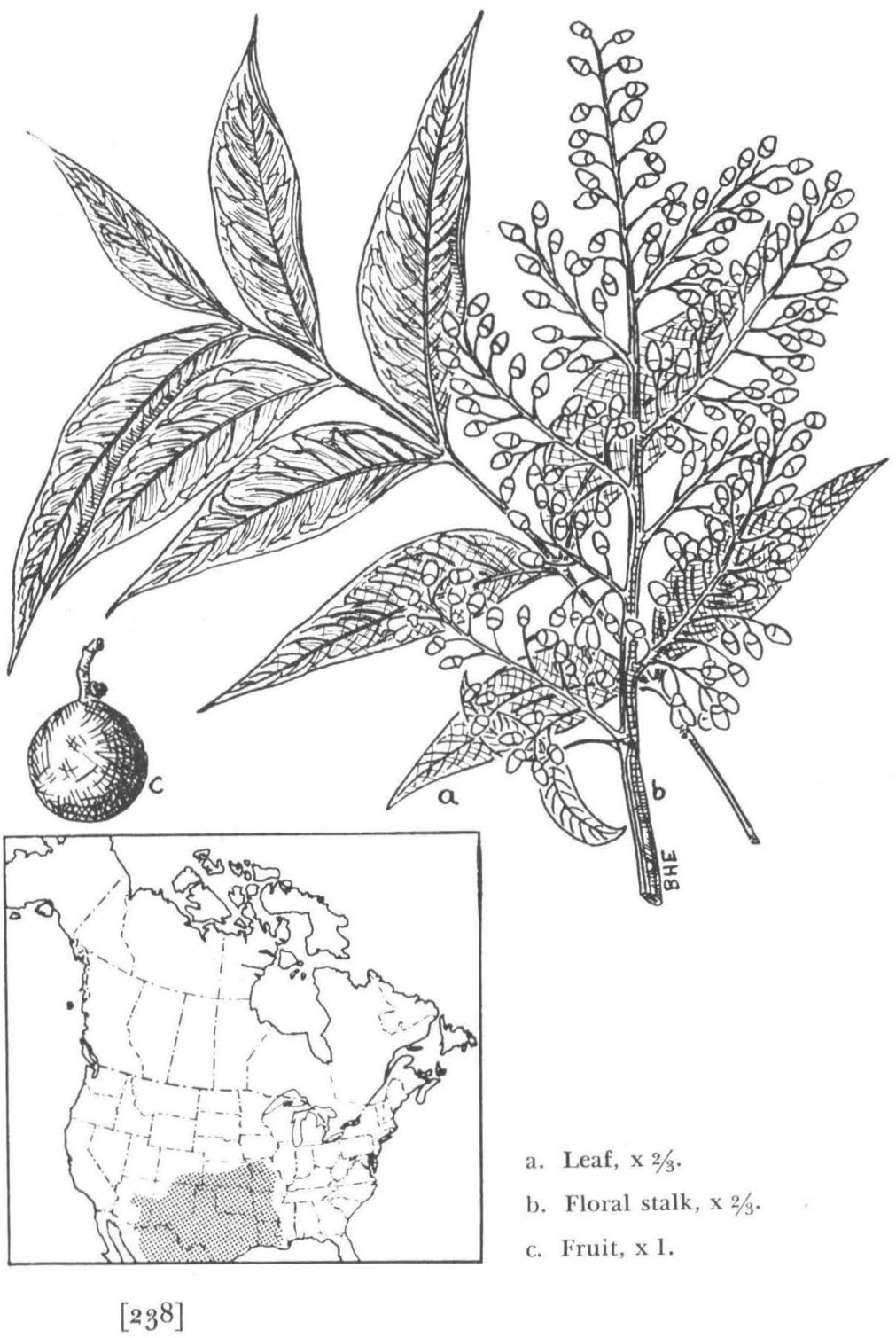




\section{SAPINDAGEAE \\ Western Soapberry. Chinaberry \\ Sapindus drummondi Hook. \& Arn.}

HABIT. A shrub or small tree rarely $40-50$ feet high and $1 \frac{1}{2}-2$ feet in diameter; branches round, usually erect.

LEAVES. Alternate; pinnately compound with 4-9 pairs of alternate, obliquely lanceolate, acuminate, short-petioled leaflets, each 2-3 inches long and $1 / 2-2 / 3$ inch wide; margins entire; glabrous above and pubescent beneath; pale yellow-green; deciduous; rachis slender, grooved, puberulous, without wings; stipules absent.

FLOWERS. Regular; polygamo-dioecious; minute; in manyflowered clusters 6-9 inches long; caylx of 4-5 acute sepals; corolla of 4-5 white petals, contracted into a claw hairy on inner surface, furnished with deeply cleft scale at base; stamens 8-10, filaments hairy; ovary superior, 2-4-celled; ovules solitary and ascending in each cell.

FRUIT. Drupaceous, ripening into a leathery, 1-3-celled and seeded berry; $1 / 2$ inch in diameter; glabrous; yellow, turning black in drying; persistent on branches until spring; formerly used as soap. Seed: solitary in each carpel; obovoid; dark brown; with a smooth, bony coat.

TWIGS. Moderately stout; round; at first pubescent and pale yellow-green, becoming puberulous, gray, and marked by large, obcordate leaf scars and numerous small lenticels; pith rather large, pale, continuous. Winter buds: terminal absent; lateral small, globose, often superposed in pairs.

BARK. Thin (1/3-1/2 inch); red-brown; furrowed into long, superficially scaly plates; bitter and astringent.

WOOD. Heavy; hard; strong; close-grained; ring-porous; similar to ash in appearance; heartwood light brown, tinged with yellow; sapwood thick and whitish; used for baskets, boxes, crates, furniture, and pack saddle frames.

SILVICAL CHARACTERS. Lower and Upper Sonoran zones; intolerant; roots fleshy; growth rapid; on moist clay soils or dry limestone uplands; in mountain valleys and cañons up to the woodland type and seldom over 6,000 feet in elevation; contains large quantities of saponin, a severe poison. 
MeXican-buckeye

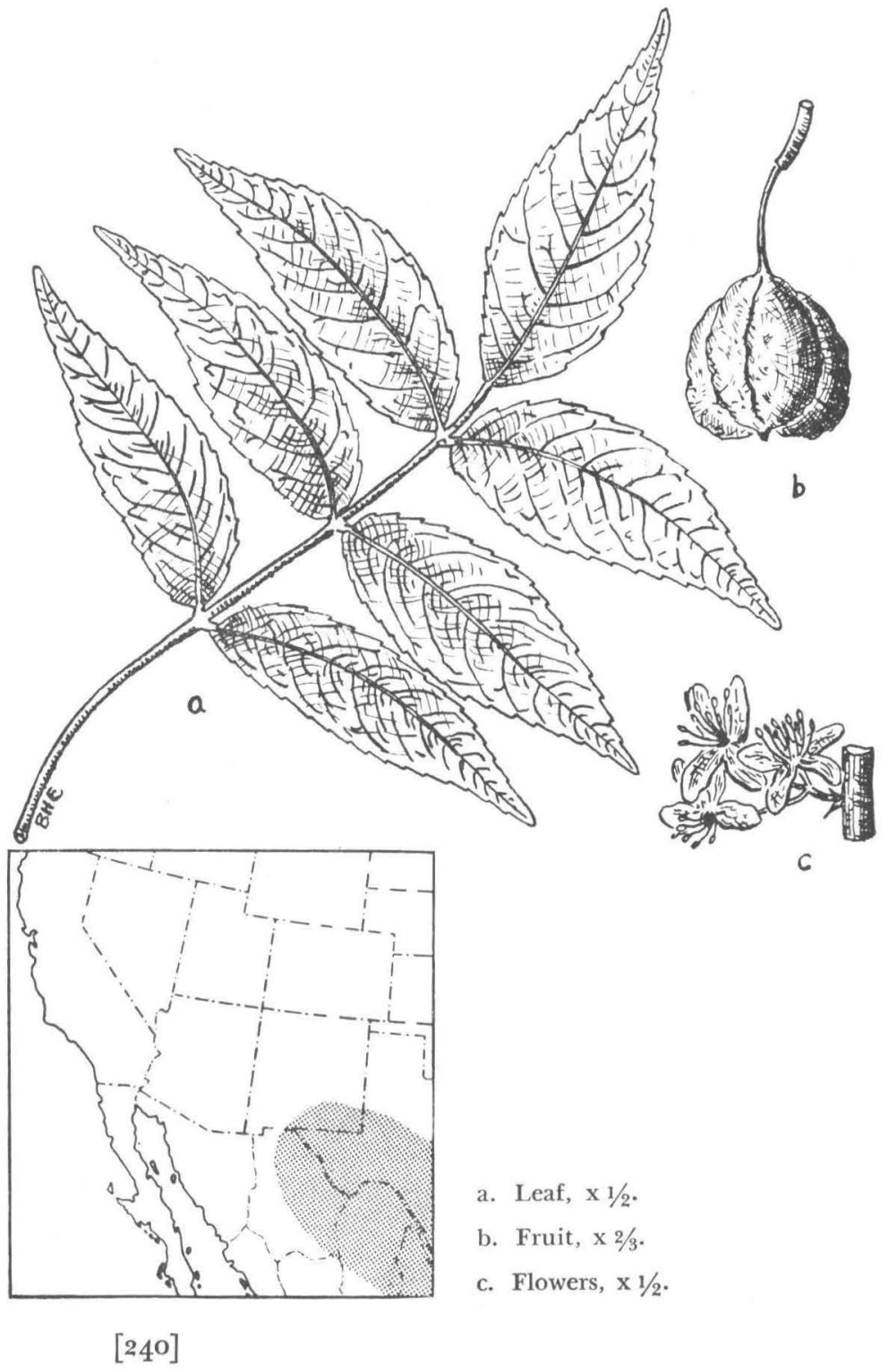




\section{SAPINDACEAE}

\section{Mexican-buckeye. Spanish Buckeye \\ Ungnadia speciosa Endl.}

HABIT. A shrub, or rarely a small tree $25-30$ feet high and 6-8 inches in diameter; numerous, small, upright branches.

LEAVES. Alternate; odd-pinnately compound; 6-12 inches long with petiole 2-6 inches long; leaflets 5-7 (rarely 3); ovate-lanceolate, 3-5 inches long; acuminate; crenulate-serrate; rather coriaceous; dark green and lustrous above, pale, and at first tomentose below; deciduous; stipules absent.

FLOWERS. Irregular; polygamous; in small, crowded, pubescent fascicles or corymbs $11 / 2^{-2}$ inches long; appearing just before or with leaves; calyx 5-lobed, campanulate, deciduous; corolla 4-5-lobed, one inch across, bright rose color; stamens 7-10, exserted; ovary superior, hairy, 3-celled.

FRUIT. Loculicidally 3-valved capsule; coriaceous; broad ovoid; 2 inches wide; stalked; crowned with remnant of style; wrinkled; dark red-brown; empty pods persistent. Seed: solitary; subglobose; $1 / 2-5 / 8$ inch in diameter; seed coat coriaceous, shiny, nearly black, reputed to be poisonous.

TWIGS. Slender, round, and slightly zigzag; finely hairy at first, becoming glabrous and marked by lenticels and conspicuous leaf scars; pale brown. Winter buds: terminal absent; lateral small ( $1 / 8$ inch in diameter), obtuse, subglobose, scaly.

BARK. Thin ( $1 / 4$ inch or less); light gray; numerous, reticulated furrows.

WOOD. Heavy; rather soft; brittle; close-grained; heartwood red, tinged with brown; sapwood light; unimportant.

SILVICAL CHARACTERS. Upper Sonoran zone; a monotypic genus; mountain cañons, limestone hillsides, and along streams.

\section{MALVACEAE}

\section{Arizona Tree CotTon}

Gossypium thurberi Tod. (Thurberia thespesioides Gray)

A shrub or tree 18-20 feet high in southern Arizona and adjacent Mexico, characterized by simple, alternate, lobed leaves and a capsular fruit, the seed covered with long cotton. 


\section{Cascara Buckthokn}
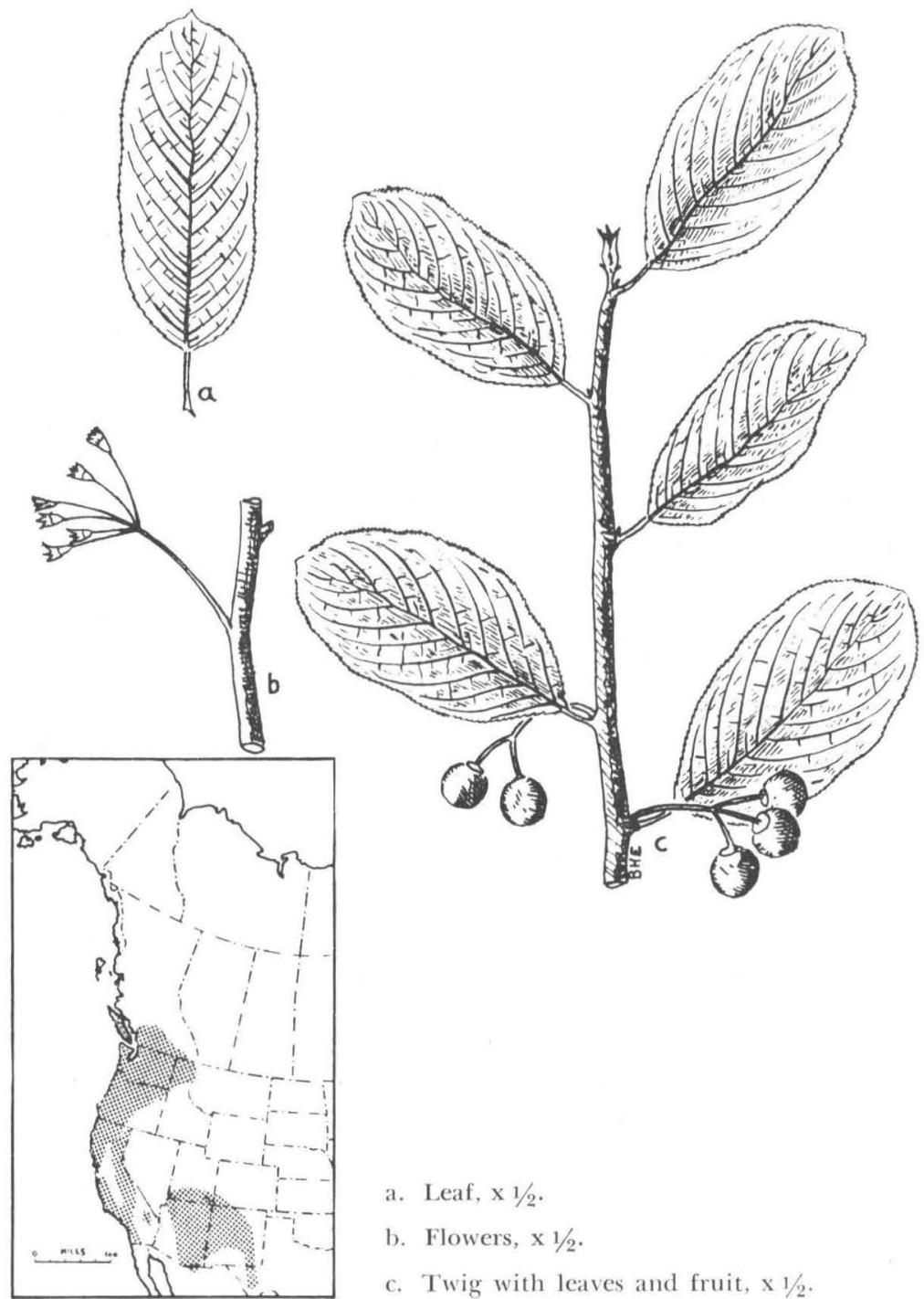

a. Leaf, $x 1 / 2$.

b. Flowers, $\times 1 / 2$.

c. Twig with leaves and fruit, x $1 / 2$.

[242] 


\section{RHAMNAGEAE \\ Cascara Buckthorn \\ Rhamnus purshiana DC.}

HABIT. A shrub or tree 20-40 feet high and 6-20 inches in diameter; wide, open crown with numerous, stout branches.

LEAVES. Alternate, or rarely obliquely opposite; simple; broad-elliptic; 11/2-7 inches long and 11/2-2 inches wide; apex obtuse or bluntly pointed; base rounded; undulate margins finely serrate or nearly entire; thin; villous below and on veins above; deciduous; turning pale yellow before falling; petioles stout, hairy, $1 / 2^{-1}$ inch long; stipules minute, deciduous.

FLOWERS. Regular; perfect; small; in axillary peduncled cymes; long-pedicelled; calyx campanulate, 5-lobed; corolla greenish, minute, 5-lobed, folded around short stamens; stamens 5, alternate to calyx lobes; ovary superior, 2-4-celled; ovules solitary, erect.

FRUIT. Drupaceous; subglobose; $1 / 3-1 / 2$ inch in diameter; black; bearing remnants of style; flesh thin and juicy; with 2-3 obovoid, l-seeded nutlets with a thin gray or yellow-green shell. Seed: erect, obtuse, yellow-brown.

TWIGS. Slender; round; pubescent, usually becoming glabrous; yellow-green or red-brown; marked by elevated, oval, horizontal leaf scars. Winter buds: terminal absent; lateral small, naked, hoary-tomentose.

BARK. Thin ( $1 / 4$ inch); gray to dark brown, often tinged with red; scaly; important because of laxative properties.

WOOD. Rather light; soft; not strong; ring-porous; heartwood brown, tinged with red; sapwood thin and light-colored; used rarely for turnery, furniture, and fuel.

SILVICAL. CHARACTERS. Upper Sonoran and Transition zones; moderately tolerant; prolific seeder and coppices freely; no taproot; hardy tree with few enemies; rich bottomlands to dry hillsides; usually in coniferous forests.

Rhamnus californica var. tomentella (Benth.) B. \& W., California Buckthorn, is a common shrub or small tree in the mountain cañons of Arizona and western Nevada between 3,500 and 6,000 feet. It can be distinguished from Cascara Buckthorn by its persistent leaves which are tomentulose beneath. 


\section{Hollyleaf Buckthorn}
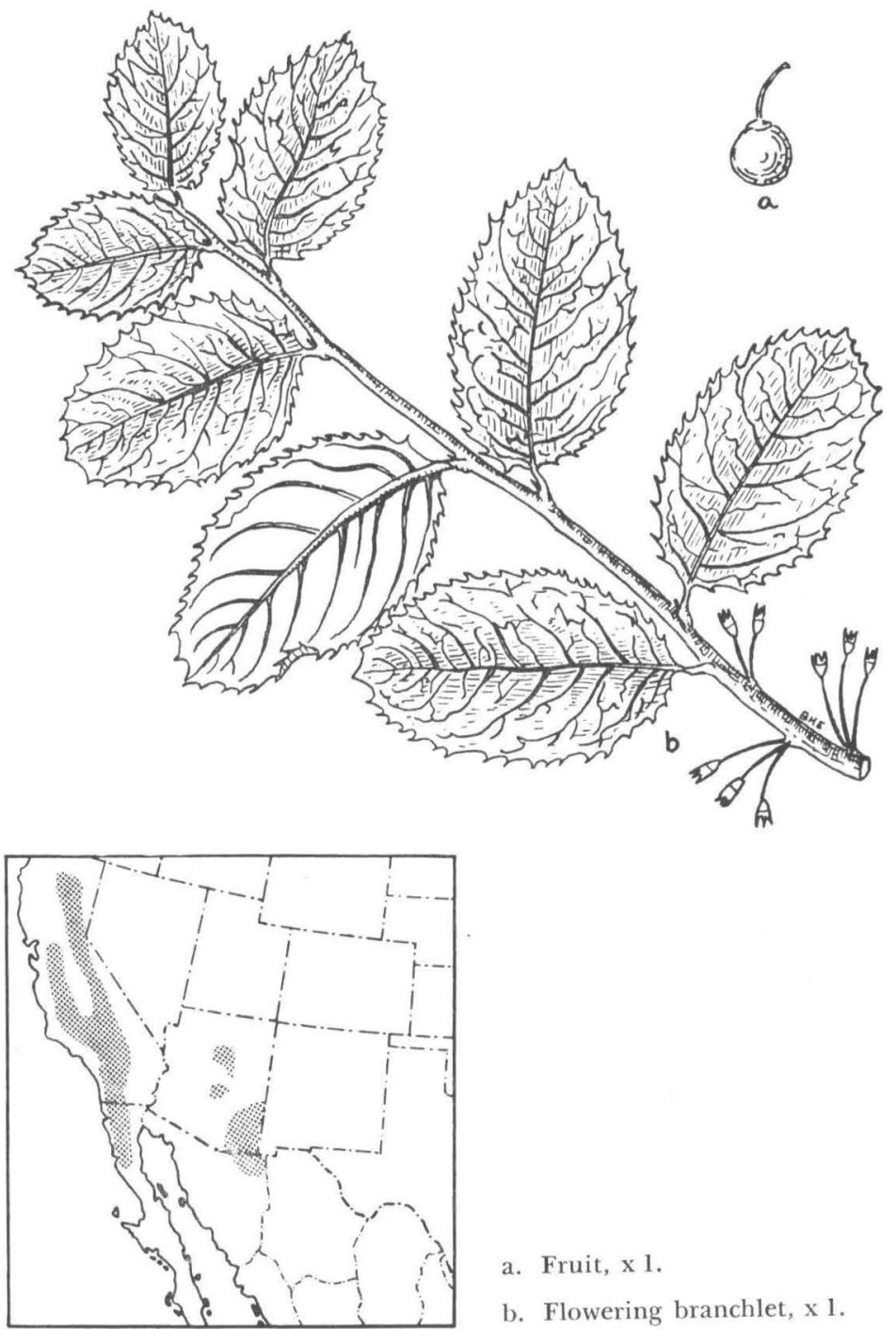

a. Fruit, x 1 .

b. Flowering branchlet, $\mathrm{x} 1$. 


\section{RHAMNACEAE \\ Hollyleaf Buckthorn \\ Rhamnus crocea var. ilicifolia (Kell.) Greene.}

HABIT. A shrub or small evergreen tree rarely 25 feet high and 6-8 inches in diameter; crown round; branches stout.

LEAVES. Alternate or obliquely opposite; simple; oval or orbicular; $1-11 / 2$ inches long and $3 / 4-1$ inch wide; apex roun ded; margin spinulose-dentate; thin and leathery; glabrous; yellow-green and lustrous above, often golden below; persistent; petioles short and stout; stipules minute, acuminate.

FLOWERS. Regular; polygamo-dioecious; in small clusters from axils of leaves; calyx about $1 / 8$ inch long, 4- (or rarely 5-) lobed; petals absent; stamens short, as many as calyx lobes and alternate to them; ovary superior, 2-4-celled.

FRUIT. Drupaceous; obovoid; $1 / 4$ inch in diameter; red; flesh thin and dry; with 2-3 nutlets. Seed: 1/8 inch long, hard, erect, broadly ovoid, pointed, grooved, chestnut-brown.

TWIGS. Slender; round; rigid and often spinescent; redbrown; glabrous. Winter buds: terminal absent; lateral 1/16 inch long, scaly, obtuse, scales hairy-fringed.

BARK. Thin $\left(1 / 16^{-1 / 8}\right.$ inch $)$; dark gray; slightly roughened by minute tubercles; acrid and bitter.

WOOD. Moderately heavy and hard; brittle; fine-grained; ring-porous; heartwood light yellow-brown; unimportant.

SILVICAI CHARACTERS. Upper Sonoran zone; prolific seeder; on hot, dry hillsides, cañons, and mountain slopes; in pure groups or scattered with chaparral and shrubby trees.

\section{Bluewood. Logwood}

Condalia obovata Hook.

This velvety-pubescent shrub or small tree is one of the common chaparral species of western Texas and southeastern New Mexico, commonly forming dense thickets. It is characterized by small $(1 / 2-3 / 4$ inch long), entire, alternate or fascicled leaves; small axillary flowers; and a deep red, subglobose drupe $1 / 5$ inch in diameter. 
Fremontia
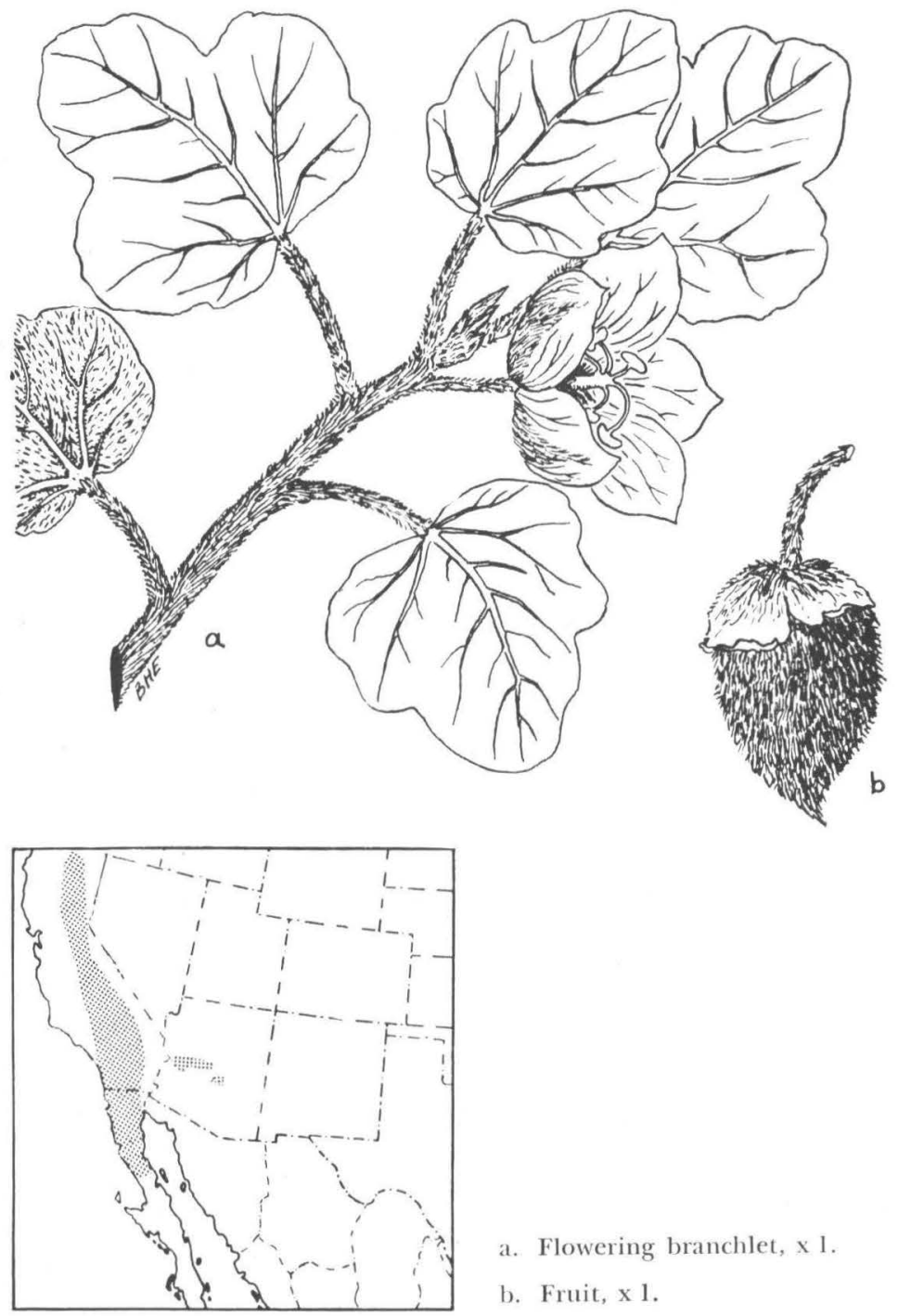

a. Flowering branchlet, $\times 1$.

b. Fruit, $\times 1$. 


\section{STERCULIACEAE}

Fremontia. Flannelbush

Iremonlodendron californicum Cov. (Fremontodendron mexicanum Davids.) (Fremontia californica var. mexicana Davids.)

HABIT. A shrub or small tree 20-30 feet high and 12-14 inches in diameter; crown open with stout branches.

LEAVES. Alternate, simple; broadly ovate; $11 / 2$ inches in diameter; usually 3-lobed; thick; stellate rusty-pubescent below; persistent 2 years; petioles stout, $1 / 2-2 / 3$ inch long.

FLOWERS. Regular; perfect; solitary; on spurlike branches; calyx campanulate, deeply 5 -lobed, yellow, 1 inch long; corolla absent; stamens 5, filaments united; ovary 5-celled; styles elongated; ovules numerous.

FRUIT. Ovoid, acuminate, 4-valved capsule; 1 inch long; densely woolly dehiscent; inner surface villose-pubescent. Seed: oval, small (about $3 / 16$ inch long), very dark brown.

TWIGS. Stout; round; stellate rusty-pubescent at first, becoming glabrous and light red-brown. Winter buds: naked.

BARK. Thin (rarely over $1 / 4$ inch thick); furrowed; dark red-brown; inner bark mucilaginous and used locally for poultices.

WOOD. Heavy; hard; close-grained; ring-porous; heartwood red-brown; sapwood thick and whitish; not used commercially.

SILVICAL CiHARACTERS. Upper Sonoran and Transition zones; intermediate in tolerance; usually an abundant seeder; on very poor, dry, rocky foothills and lower mountain slopes; often forming dense, extensive thickets; a monotypic genus.

\section{TAMARICACEAE \\ Tamarix. Tamarisk Tamarix gallica L.}

A large shrub or small tree introduced from Europe but more or less naturalized in the south and central parts of the region. Characterized by alternate, scalelike, feathery, sparse leaves (resembling those of conifers); showy, pink flowers; and 3-5-valved, capsular fruit containing many, minute seeds. Tamarix juniperiana Bunge is a small tree on the river floodplains of southern Arizona. 

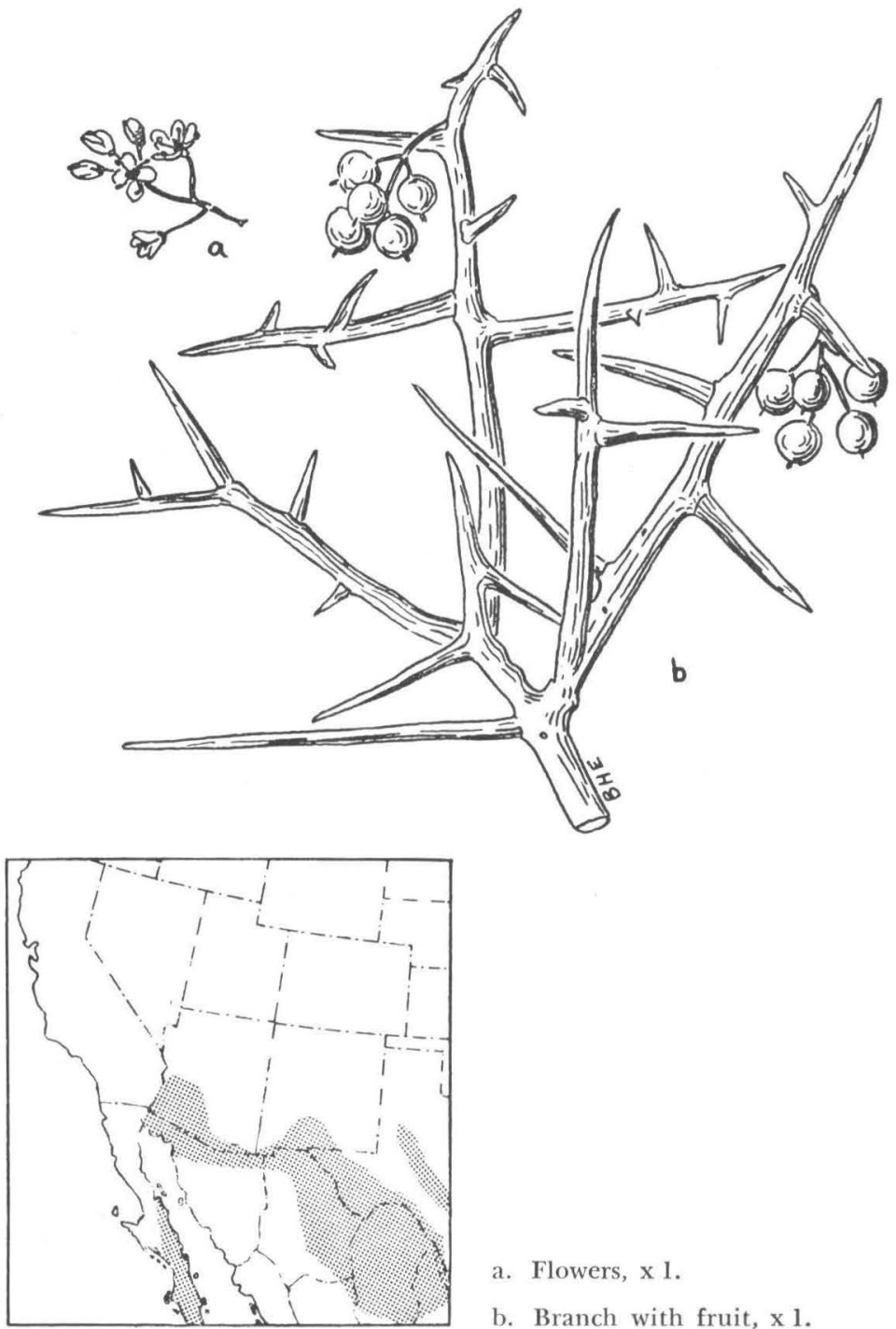

a. Flowers, $\mathrm{x} 1$.

b. Branch with fruit, $x 1$.

[248] 


\section{KOEBERLINACEAE}

\section{All-thorn. Corono de Cristo}

\section{Koeberlinia spinosa Zucc.}

HABIT. A shrub forming extensive, impenetrable thickets, or a small bushy tree rarely 20-25 feet high and 12 inches in diameter; trunk short, thorny, crooked; often appearing to bear neither leaf, flower, nor fruit.

LEAVES. Alternate; simple; early deciduous, the tree usually leafless; scalelike and minute (not over $1 / 8$ inch long); narrow obovate; rounded at apex.

FLOWERS. Regular; perfect; small ( $1 / 4$ inch in diameter); in short umbel-like racemes; on short peduncles; calyx of 3-5 minute, deciduous sepals; petals 4, green-white, much longer than sepals; stamens 8 , as long as, or shorter than petals; ovary 2-celled, contracted, at base into a short stalk and above into a simple style with terminal stigma; ovules numerous.

FRUIT. Small ( $3 / 16^{-1} / 4$ inch), subglobose, 2-celled, black berry; tipped with remnants of pointed style; flesh thin and succulent; cells 1-2-seeded. Seed: vertical, coiled and shellshaped; seed coat brittle and wrinkled.

TWIGS. Stout; glabrous; terminating in sharp, rigid spine; pale green in color. Winter buds: minute and inconspicuous on spinelike twigs.

BARK. Thin, red-brown, scaly.

WOOD. Very hard; heavy (sp. gr. 1.12) ; close-grained; diffuse-porous; heartwood dark brown, somewhat streaked with orange; sapwood thin, yellow, or nearly white; rich in oil; used occasionally for canes, handles, and turned articles.

SILVICAL CHARACTERS. Lower Sonoran zone; on dry, gravelly plains, mesas, and foothills; a monotypic botanical curiosity.

Closely resembling Koeberlinia in leaves (present only on seedlings) and twigs and also known as Corono de Cristo is Holacantha emoryi Gray; this belongs to the Simaroubaceae family and is a much-branched shrub or small tree up to 9 feet in height, which is native to southern Arizona and Mexico; it differs in its dioecious, 7- or 8-petaled flowers and fruit of 6-8 small, nutlike drupes. 


\section{CACTACEAE}

Characteristics of the Cactus Family

HABIT: Shrubs or seldom trees, rarely 50-60 feet high and 2 feet in diameter; stems commonly columnar, fluted, succulent, and branched; numerous spines springing from cushions of small bristles (areolae).

LEAVES. Alternate; simple; mostly reduced to spines or scales or absent; photosynthetic processes taking place in the green parts of the fleshy stems.

FLOWERS. Regular; perfect; usually single; large and showy; calyx of numerous sepals forming a tube, those of inner series petal-like; corolla showy, of numerous petals; stamens many, inserted on calyx tube; ovary inferior, 1-celled, with several parietal placentae and numerous horizontal ovules, styles united into one, stigmas as many as placentae.

FRUIT. 1-celled, fleshy (rarely dry) berry, often edible. Seed: numerous and small.

WOOD. An internal, woody frame or skeleton, made up of a cylinder or a meshed network of strands.

BUDS. Modified into pulvini or cushions which are usually depressions often consisting of a complex series of spines, wool, glands, and growing points.

SILVICAI CHARACTERS. Very intolerant; although seed generally produced abundantly, natural reproduction by seed is rather scanty because of unfavorable environment; vegetative reproduction common; typical of very dry desert areas where they are often the only woody plants.

GENERAL. This family contains about 120 genera and 1,200 species; there are 2 genera and 5 species reaching tree size in the United States in southern California, Arizona and New Mexico. 


\section{KEY TO THE ARBORESCENT SPEGIES OF CACTACEAE}

I. Branches and stems columnar, ribbed, not tuberculate, continuous; areoles (growing centers) without glochids (minute bristles) ; leaves spinelike; tube of flower elongated; seeds darkcolored; spines not barbed; a tree often 50-60 feet high; the

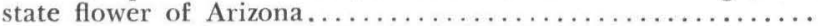
1. Carnegiea gigantea (Engelm.) B\&:R. (Cereus giganteus Engelm.); Saguaro.

II. Branches and stems slender, columnar, tuberculate, conspicuously jointed; areoles with both glochids and spines; leaves small and fleshy on young parts; tube of flower short; seed light-colored; spines retrorsely barbed; small plants not over

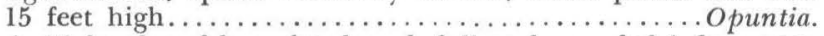

A. Tubercles of branches broad, full and rounded below areolae; flowers pink or purple; fruit sparingly spiny or without spines.

1. Flowers pink; fruit green, proliferous (one growing from another), usually spineless; joints pale olive-green, readily detached, freely falling, their tubercles broad and ovoid; spines yellow..2. Opuntia fulgida Engelm.; Cholla.

2. Flowers purple; fruit yellow, rarely proliferous, spiny; joints green or purple, not readily detached, persistent, their tubercles elongated; spines white to red-brown.... ......3. Opuntia spinosior (Engelm.) Toumey; Tasajo.

B. Tubercles of branches narrow, high and flattened laterally. Flowers purple, or green tinted with red or yellow.

1. Fruit smooth or but slightly tuberculate, spiny, green; branch tubercles 2/3" long; spines 5-11, 1/8" long or less, dark red-brown; flowers green, tinted with red or yellow...........4. Opuntia versicolor Engelm.; Cholla.

2. Fruit manifestly tuberculate, naked, yellow; branch tubercles 3/4-1" long; spines 8-30, 3/4-11/4" long, brown,

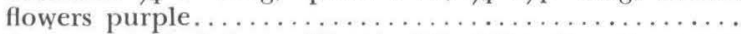

5. Opuntia imbricata (Haw.) DC (Opuntia arborescens Engelm.); Cane Cactus. 


\section{SilverberRy}
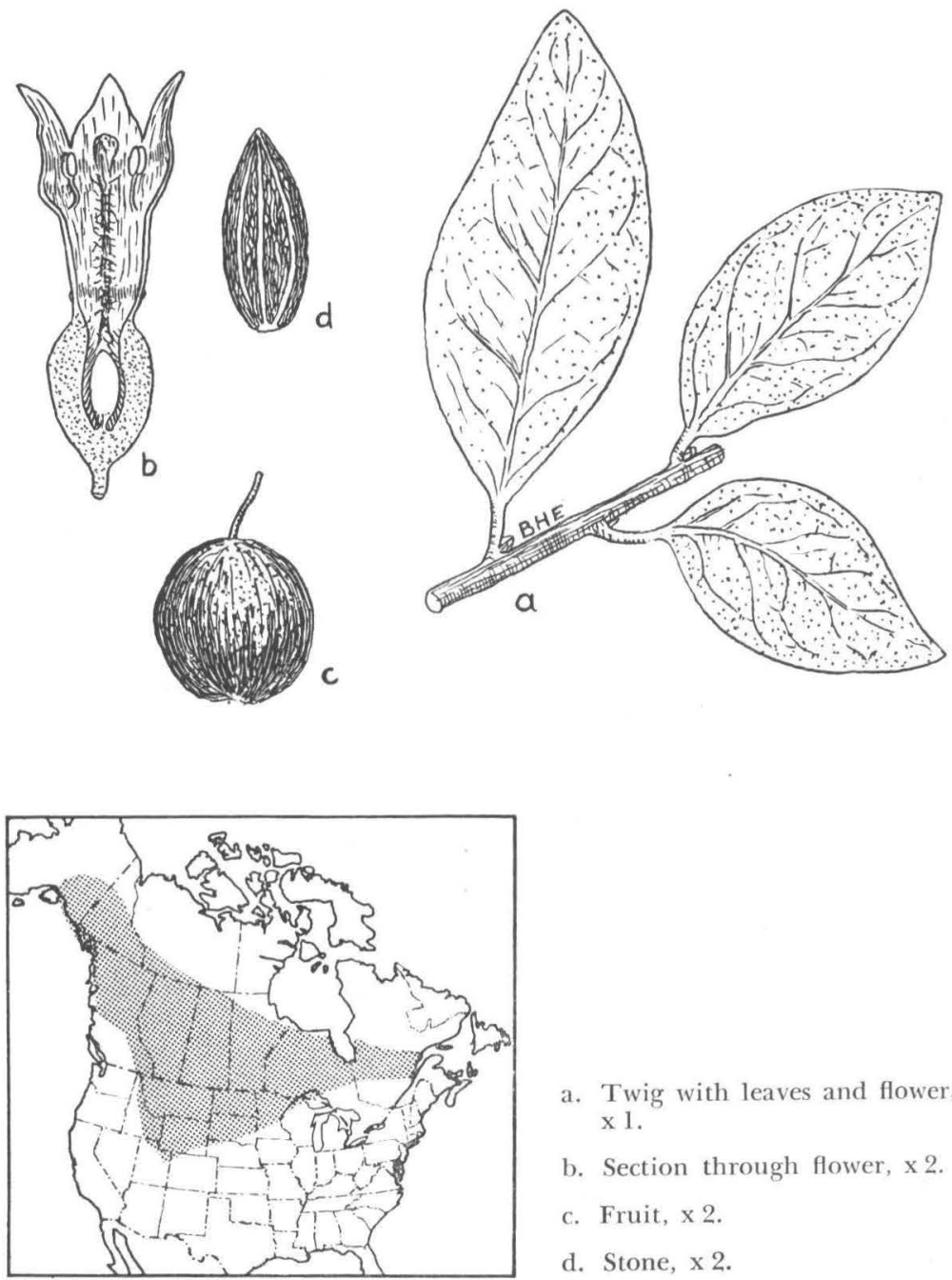

a. Twig with leaves and flower, $\mathrm{x} 1$.

b. Section through flower, $\times 2$.

c. Fruit, $\times 2$.

d. Stone, $\times 2$. 


\section{ELAEAGNACEAE \\ Silverberry. Silverbush}

Elaeagnus argentea Pursh. (Elaeagnus commutata Bernh.)

HABIT. A bushy, silvery shrub or small tree rarely 15-16 feet high, stoloniferous and thicket-forming.

LEAVES. Alternate; simple; elliptic to oblong; 1-3 inches long and $1 / 3-1$ inch wide; rounded or acute at apex; margin entire; densely silvery-scurfy on both faces; thick; deciduous; petioles stout, $1 / 4$ inch long.

FLOWERS. Regular; polygamous; $1-3$ in axil of each leaf; appearing after leaves; calyx tube silvery without, $1 / 4$ inch long, 4-lobed; corolla lacking; stamens 4, short, attached near calyx throat; ovary enveloped in receptacle.

FRUIT. Drupe; globose to oval; $1 / 3-1 / 2$ inch long; silvery; flesh mealy; the stone with about 8 longitudinal ridges.

TWIGS. Rather slender; round; rusty-brown and covered with scurfy scales; leaf scars minute. Winter buds: $1 / 8^{-1 / 4}$ inch long, oblong, scales scurfy.

BARK. Thin; dull gray; smooth or slightly furrowed.

WOOD. Light; soft; weak; coarse-grained; heartwood dark brown; fairly durable; unimportant.

SILVICAL CHARACTERS. Upper Sonoran to Alpine zones; along streams or on moist to dry hillsides.

\section{Russian Olive}

\section{Elaeagnus angustifolia $\mathrm{L}$.}

An introduced shrub or small tree which has become established in parts of the region. Hardy, very drought and alkaline resistant and much planted as a dry area ornamental and for windbreaks. Characterized by lanceolate, silvery-scurfy leaves; silvery and often spiny branches; and yellow fruit. 
WESTERN DOGWOOD

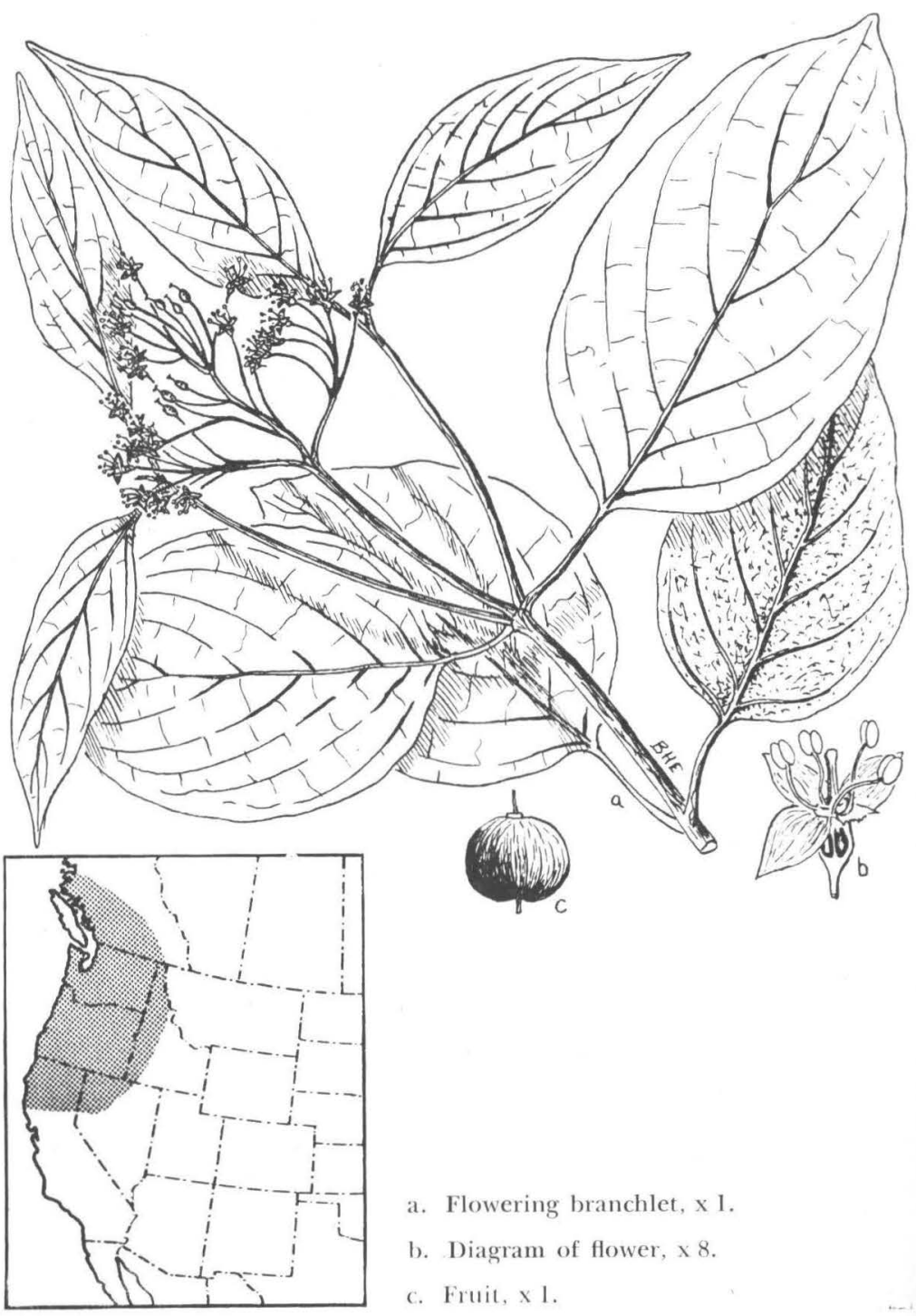




\section{Western Dogwood. Western Cornel}

Cornus occidentalis Cov. (Cornus pubescens Nutt.)

(Cornus californica var. pubescens Macbr.)

HABIT. Usually a shrub, but not infrequently a small tree 20 feet high.

LEAVES. Opposite; simple; elliptic to ovate; $11 / 2-4$ inches long; apex short acuminate to obtuse; margins entire; thick and firm; slightly pubescent above; glaucous and pubescent below; deciduous; petioles slender, $1 / 2-1$ inch long.

FLOWERS. Regular; perfect; small; in dense cymes 2 inches broad; calyx tube minutely 4-toothed; corolla yellow-white, 4-petaled, oblong-ovate, inserted on margin of disk; stamens 4. alternate to petals, filaments exserted; ovary 2-celled and 2-ovuled, inferior; style exserted with capitate stigma.

FRUIT. Drupaceous; white; ovoid or oblong; flesh thin and succulent; stone bony, 2-celled, much broader than long.

TWIGS. Slender; round; purple; glabrous or sparingly pubescent; pith large, round, light-colored. Winter buds: terminal present, $1 / 4$ inch long, covered by 2 valvate scales; axillary buds appressed.

BARK. Thin; brown; smooth or scaly on old trunks; astringent.

WOOD. Heavy; hard; strong; diffuse-porous; heartwood pale brown; sapwood cream-white, thick; unimportant.

SILVICAL CHARACTERS. Upper Sonoran and Transition zones; moderately tolerant; often common on bottomlands, stream banks, and other moist alluvial soils at altitudes of from $2,500-6,500$ feet.

GENERAL. About 16 shrubby species of Cornus are native to the western United States; the Pacific flowering dogwood, Cornus nuttallii And., becomes a good-sized tree; it has been reported in the Rocky Mountains in the valleys of northwestern Idaho; the red-osier dogwood or cornel, Cornus stolonifera Michx., is common throughout the region; while usually a shrub characterized by bright red branches, this species sometimes becomes a small tree. 


\section{MAdRONE}
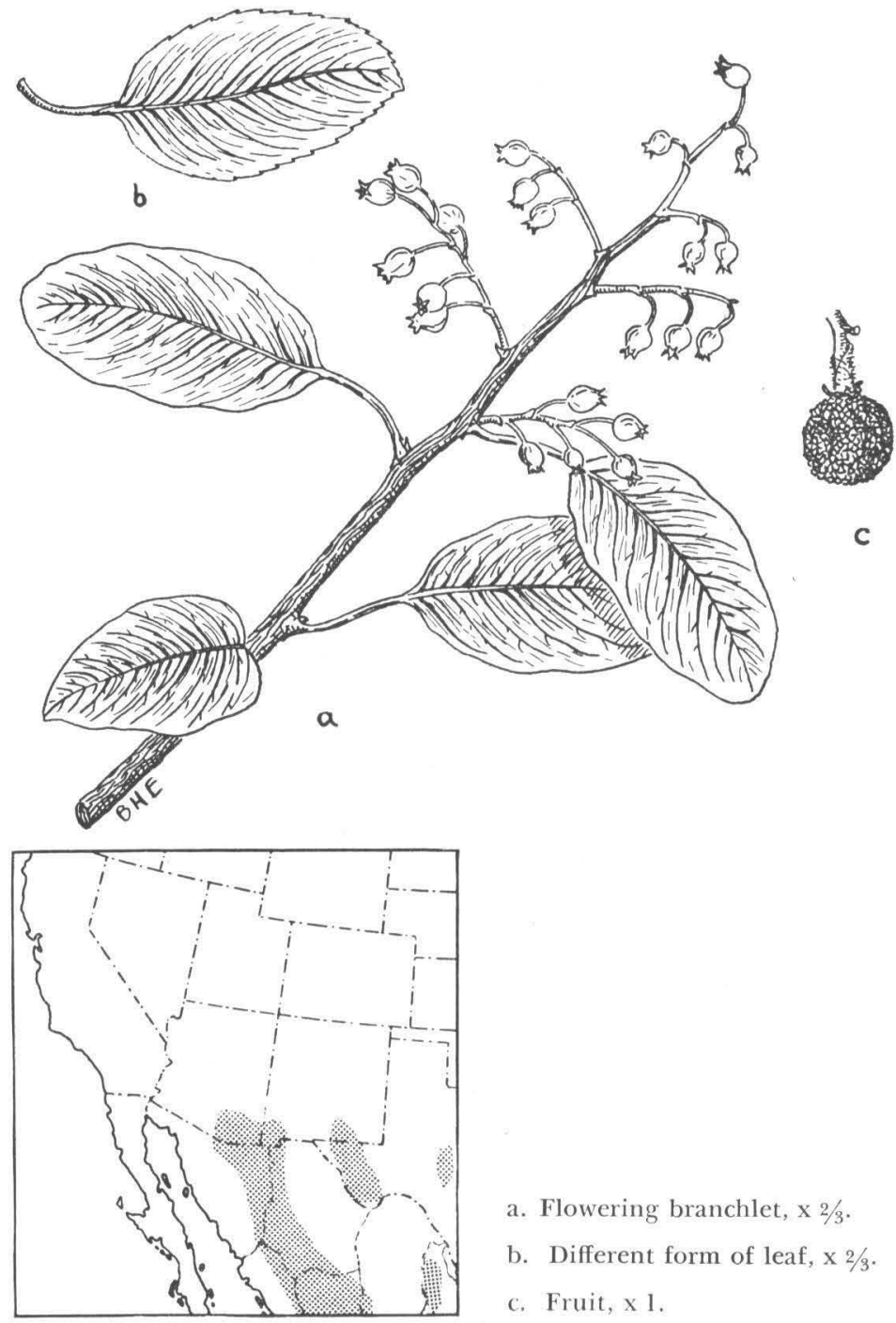

a. Flowering branchlet, $x 2 / 3$.

b. Different form of leaf, $\times 2 / 3$.

c. Fruit, $\times 1$.

[256] 


\section{ERICACEAE \\ Texas Madrone \\ Arbutus texana Buckl.}

HABIT. A shrub or small tree rarely 18-20 feet high and 8-10 inches in diameter; bole often crooked and branching.

LEAVES. Alternate; simple; oval, ovate, or lanceolate; 1-3 inches long and $2 / 3-11 / 2$ inches wide; rounded or acute at apex; margins entire to serrate; thick and leathery; dark green and glabrous above; pale and usually slightly pubescent below; evergreen; petioles stout, pubescent, 1-11/2 inches long.

FLOWERS. Regular; perfect; small ( $1 / 4$ inch long); in terminal panicles; calyx 5-parted, persistent; corolla white, 5-toothed; stamens 10, shorter than corolla; ovary superior, pubescent, 4-5-celled; ovules numerous on central placenta.

FRUIT. Drupaceous, ripening into a granular-coated berry; $1 / 3$ inch in diameter; dark red; flesh dry and mealy; stone more or less completely formed. Seed: numerous in each of 5 cells, compressed, small, puberulous.

TWIGS. Stout; round; light red and pubescent at first, becoming dark red-brown and covered with small scales. Winter buds: scaly, $1 / 8$ inch long, rounded at apex, tomentose.

BARK. Furrowed and broken into dark, square plates at base of old trunks; elsewhere thin, tinged with red, separating into papery scales exposing light red inner bark.

WOOD. Heavy; hard; close-grained; diffuse-porous; heartwood brown, tinged with red; sapwood thick and lighter colored; sometimes used for handles of small tools.

SILVICAL CHARACTERS. Upper Sonoran zone; intolerant; on dry limestone hills and on low mountains; thick, hard roots.

\section{Arizona Madrone}

Arbutus arizonica (Gray) Sarg.

Arizona and Mexico; similar to Texas madrone; both formerly were considered as belonging to Mexican madrone, Arbutus xalapensis H.B.K., and differing from it in having a glabrous ovary and glabrous lower surface on the leaf. 


\section{Gum Bumelia}

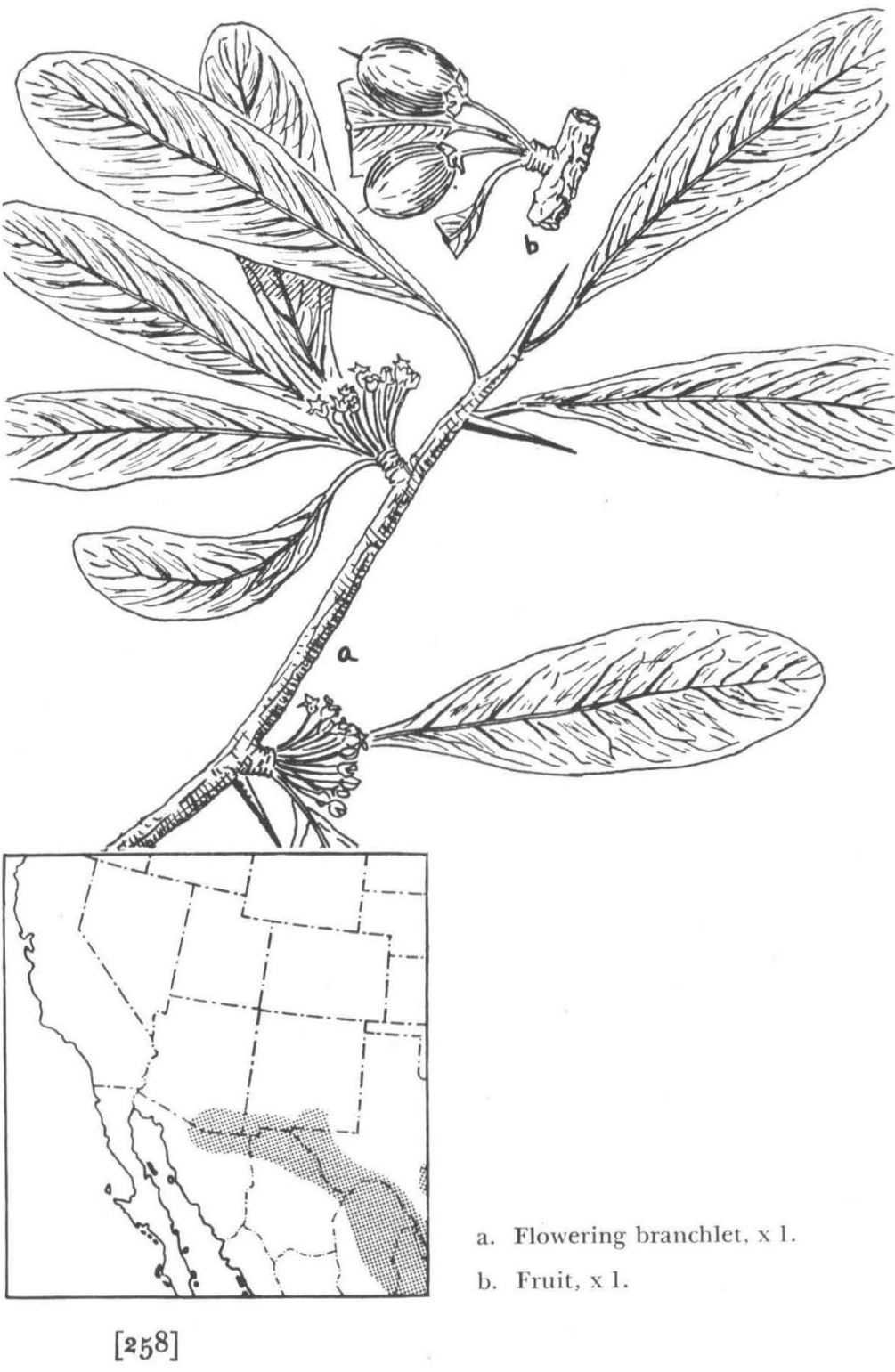




\section{SAPOTACEAE}

\section{Gum Bumelia. Gum Elastic}

Bumelia lanuginosa var. rigida Gray

HABIT. A shrub or small tree 40-50 feet high and 1-2 feet in diameter; narrow crown with short, spiny branches.

LEAVES. Alternate; simple; 1-31/2 inches long; oblanceolate to obovate; rounded or apiculate at apex; margins entire; thin and firm; dark green above; soft, reflexed, rusty-brown hairs below; tardily deciduous in winter; stipules absent.

FLOWERS. Regular; perfect; minute (1/8 inch long); in 16-18-flowered, axillary clusters; on pubescent pedicels; calyx persistent, ovoid, 5-lobed, tomentose; corolla white, campanulate, 5-lobed; stamens 5 , with 5 sterile, alternating filaments; ovary 5-celled; ovules solitary.

FRUIT. Drupe; oblong or slightly obovoid; $1 / 2$ inch long; black; solitary or in 2-3-fruited clusters; thick flesh; usually 1-celled and 1-seeded; remnant of style at apex; on slender, drooping stalk. Seed: $1 / 4$ inch long, short-oblong, shiny.

TWIGS. Slender; rounded; somewhat zigzag; usually armed with stout spines; red-brown to ash-gray. Winter buds: scaly, small, obtuse, rusty-tomentose.

BARK. Thin ( $1 / 2$ inch) ; dark gray-brown; divided into narrow ridges which are broken into thick scales.

WOOD. Heavy; rather soft; not strong; close-grained; ringporous; heartwood light brown or yellow; sapwood thick and lighter colored; producing clear, viscid gum.

SILVICAL CHARACTERS. Upper Sonoran zone; intolerant; dry hills and cañons, or along streams; generally shrubby in Texas and forming high, dense thickets in Arizona.

The Brazos Bumelia, Bumelia monticola Buckl., with glabrous, thick, deciduous leaves, forms a small tree in western Texas.

\section{EBENACEAE}

The Texas Persimmon, Diospyros texana Scheele, a shrub or tree entering west Texas is characterized by simple, alternate leaves; and a 3-8-seeded, black berry, $1 / 2-1$ inch long. 


\section{OLEACEAE}

\section{The Ashes \\ Characteristics of the Genus Fraxinus L.}

HABIT. Deciduous trees, or rarely shrubs; ornamental with handsome foliage; several species are important timber trees.

LEAVES. Opposite; odd-pinnately compound (rarely reduced to a single leaflet); without stipules; petiolate; leaflets serrate or entire, sessile or petiolulate.

FLOWERS. Regular; perfect, dioecious, or polygamous; small, but quite conspicuous in slender-branched panicles; appearing before or with the leaves; calyx 4-lobed or wanting; corolla usually 4-lobed or wanting; stamens usually 2 (rarely 3 or 4); single 2-celled ovary (rarely 3-celled); ovules suspended in pairs from inner angle of the cell.

FRUIT. Samara; 1-, rarely 2- or 3-seeded; with an elongated terminal wing. Seed: oblong, compressed, filling cavity in the fruit, chestnut-brown, albuminous.

TWIGS. Slender to stout; glabrous or pubescent; pith thick, rounded, homogeneous; leaf scars suborbicular to semi-circular, sometimes notched on the upper edge; bundle scars numerous. Winter buds: terminal larger than lateral, both with 1-3 pairs of scales, the inner accrescent.

BARK. Thick and furrowed or rarely thin and scaly.

WOOD. Ring-porous; late wood with rather few pores not in distinct radial lines and with tangential bands of parenchyma; tough; straight-grained; not structural timber but important for specialty purposes; sapwood not durable.

SILVICAL CHARACTERS. Rather intolerant trees; rapid growing; fibrous root system; reproducing well naturally and artificially; comparatively free from destructive attacks by insects and fungi.

GENERAL. This genus contains about 65 species of trees scattered through the Northern Hemisphere and extending into the tropical forests of Java and Cuba. In North America there are 18 recognized native species, 7 of which are found in the Rocky Mountain region. 


\section{KEY TO THE SPECIES FRAXINUS}

I. Flowers with corolla, in terminal panicles; usually a shrub; Texas, New Mexico, Arizona, and Mexico................. l. F. cuspidata, p. 263.

II. Flowers without corolla, in axillary panicles; commonly reaching tree size in the United States.

A. Leaves 10-12" long with 7-9 leaflets; fruit narrowly lanceolate, 1-21/2" long; twigs round; widely distributed throughout region......2. F. pennsylvanica var. lanceolata, p. 265.

B. Leaves $11 / 2-7$ " long with 1-9 leaflets; fruit oblong to obovate; $1 / 2-11 / 2$ " long; southern and central.

1. Leaflets usually 1 (rarely $2-3$ ) ; fruit not over $1 / 2^{\prime \prime}$ long, obovate; wing surrounding and shorter than compressed seed cavity; twigs 4-angled; southern and central....... ......................... F. anomala, p. 263.

2. Leaflets 3-9; fruit over $1 / 2$ " long, oblong-ovate; wing not surrounding seed cavity; southern.

a. Leaves $11 / 2-3^{\prime \prime}$ long; leaflets $1 / 2-3 / 4$ " long with winged petioles, obscure veins and black dots on lower surface; fruit $1 / 2-2 / 3^{\prime \prime}$ long........... F. greggii, p. 269.

b. Leaves 3-7" long; leaflets $1-4^{\prime \prime}$ long, with prominent veins and no black dots; fruit $3 / 4-11 / 2$ " long.

(1) Twigs 4-angled; wing extending to base of muchcompressed seed cavity; leaflets usually $5 . \ldots \ldots$. .5. F. lowellii, p. 269.

(2) Twigs round; wing not extending to base of rounded seed cavity; leaflets $3-5$.

(a) Fruit $1 / 2-3 / 4$ " long; leaves and twigs pubescent or glabrous; southwest.................

(b) Fruit $1-11 / 2$ " long; leaves and twigs glabrous; Texas.......7. F. berlandieriana DC., p. 265. 


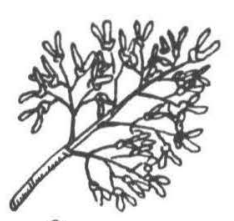

a
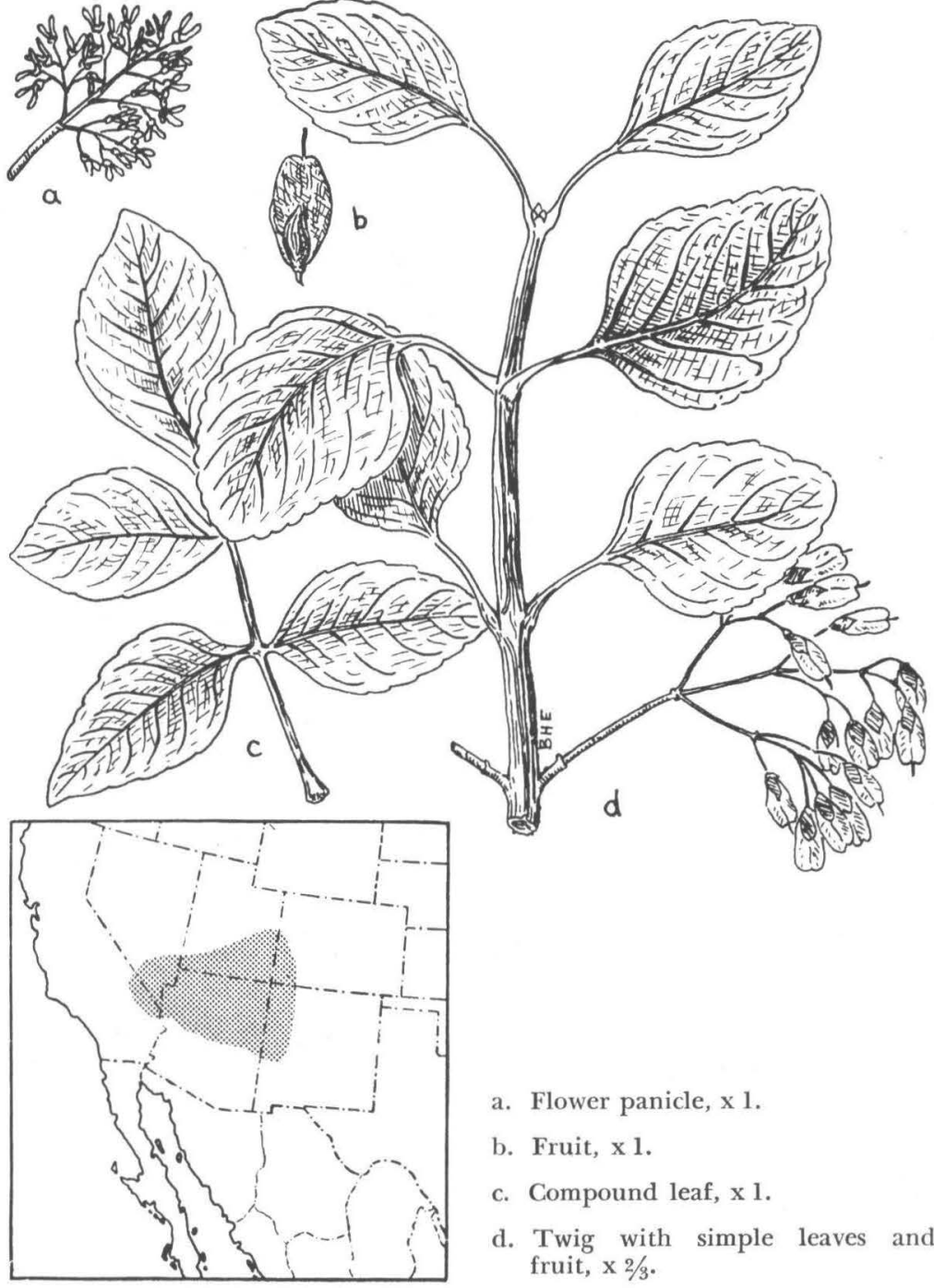

a. Flower panicle, $\times 1$.

b. Fruit, $\mathrm{x} 1$.

c. Compound leaf, x 1 .

d. Twig with simple leaves and fruit, $\times 2 / 3$. 


\section{OLEACEAE}

\section{Singleleaf Ash. Dwarf Ash \\ Fraxinus anomala Torr.}

HABIT. A shrub or small tree 18-20 feet high with a short trunk 6-7 inches in diameter; crown round-topped, with contorted branches; a distinct and interesting species.

LEAVES. Usually single but rarely with 2-5 leaflets; broadly ovate or suborbicular; 1-2 inches long and 1-2 inches wide (smaller if compound); apex rounded or acute; base cuneate or cordate; margins entire or sparingly crenate-serrate above middle; glabrous and dark green above, paler below and pubescent when young; thin but rather leathery; petiole $1 / 2-11 / 2$ inches long, rusty-pubescent when young.

FLOWERS. In short, compact, pubescent panicles; appearing when leaves about $2 / 3$ grown; perfect or unisexual by abortion of stamens (both forms in same panicle); calyx cupshaped, minutely 4-toothed; corolla absent; anthers orangecolored, on slender filaments nearly as long as stout, columnar. style.

FRUIT. Obovate-oblong; $1 / 2$ inch long; wing rounded or emarginate at apex, surrounding flattened seed cavity.

TWIGS. Quadrangular, slightly winged, puberulous, orange-colored and marked by pale lenticels and lunate leaf scars at first; later round and ash-gray. Winter buds: terminal broad ovoid, $1 / 8^{-1 / 4}$ inch long, covered by orange tomentum.

BARK. Thin ( $1 / 2$ inch); dark brown slightly tinged with red; divided by shallow furrows into narrow, scaly ridges.

WOOD. Heavy; hard; close-grained; heartwood light brown; sapwood lighter colored and thick; of no importance.

SILVICAL GHARACTERS. Lower and Upper Sonoran zones; intolerant; in the neighborhood of streams or on dry hillsides.

Fragrant Ash. Flowering Ash

Fraxinus cuspidata Torr.

A handsome shrub or low tree with showy white flowers and small leaves; seldom a tree in the United States; Upper Sonoran zone of Texas, New Mexico, Arizona, and Mexico. 

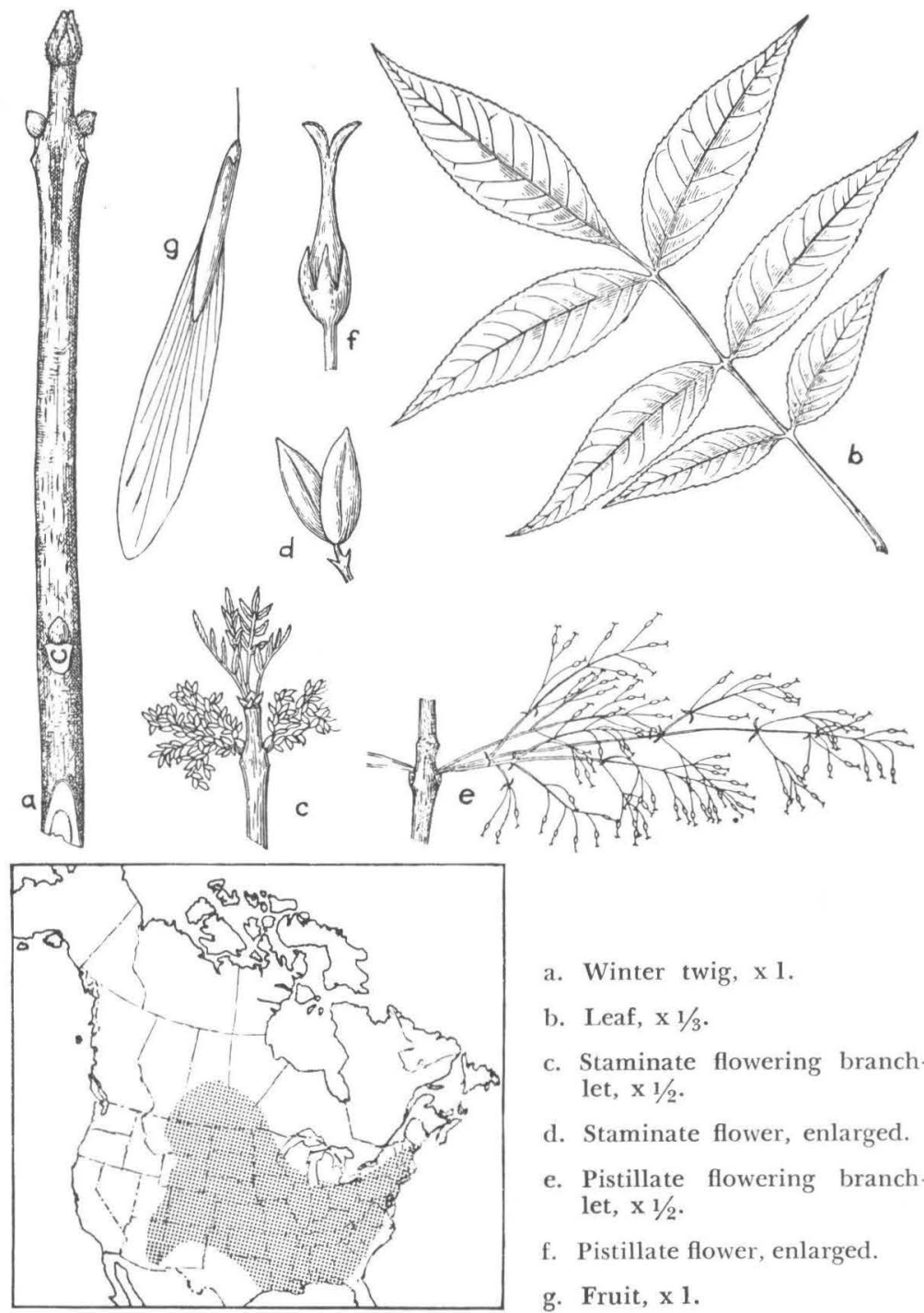

a. Winter twig, $\times 1$.

b. Leaf, $\mathrm{x} 1 / 3$.

c. Staminate flowering branchlet, $\times 1 / 2$.

d. Staminate flower, enlarged.

e. Pistillate flowering branchlet, $\times 1 / 2$.

f. Pistillate flower, enlarged.

g. Fruit, x 1. 


\section{OLEACEAE}

\section{GREeN AsH}

Fraxinus pennsylvanica var. lanceolata (Borkh.) Sarg.

(Fraxinus viridis Michx.) (Fraxinus campestris Britt.)

HABIT. A tree rarely more than 60 feet high or 2 feet in diameter; irregular, compact, round-topped crown with spreading or upright branches.

LEAVES. 10-12 inches long; 7-9 leaflets, narrowly elliptical, 4-6 inches long and $1-11 / 2$ inches wide, long-pointed, finely serrate to nearly entire, bright green on both surfaces, usually glabrous; terminal petiolule up to 1 inch long, lateral petiolules $1 / 8-1 / 4$ inch long.

FLOWERS. In compact panicles; appearing with leaves; dioecious; calyx-toothed and cup-shaped; corolla absent; anthers light green, linear-oblong; ovary nearly enclosed in calyx, narrowed into elongated style having 2 green stigmas.

FRUIT. Narrowly lanceolate; $1-21 / 2$ inches long, $1 / 4^{-1 / 3}$ inch wide; wing thin, longer than and extending to the middle of the seed cavity; seed cavity terete, slender, many-rayed.

TWIGS. Rounded; stout; mostly glabrous; ash-gray and marked by pale lenticels and straight or only slightly notched leaf scars. Winter buds: the terminal about $1 / 8$ inch long, ovoid, acute, with 3 pairs of rusty-pubescent scales.

BARK. Thin ( $1 / 2-2 / 3$ inch); brown or dark gray; longitudinal, shallow furrows and scaly ridges.

WOOD. Heavy; hard; rather strong; brittle; coarse-grained; light brown heartwood; thick, lighter brown sapwood; second to white ash in commercial importance.

SILVICAI CHARACTERS. Upper Sonoran and Transition zones; intolerant; reproduction aggressive on moist sites; growth rapid; best on moist bottomlands, but exceedingly hardy to climatic extremes; shallow, wide-spreading root system.

GENERAL. Although typical specimens of this variety can be identified readily, it is sometimes impossible to distinguish certain individuals from red or white ash. Red Ash, Fraxinus pennsylvanica Mar. enters this region in eastern Wyoming.

$F$. berlandieriana D.C., of Texas and Mexico, differs from Green Ash in having 3-5 leaflets, and fruit $1-1 \frac{1}{2}$ inches long. 

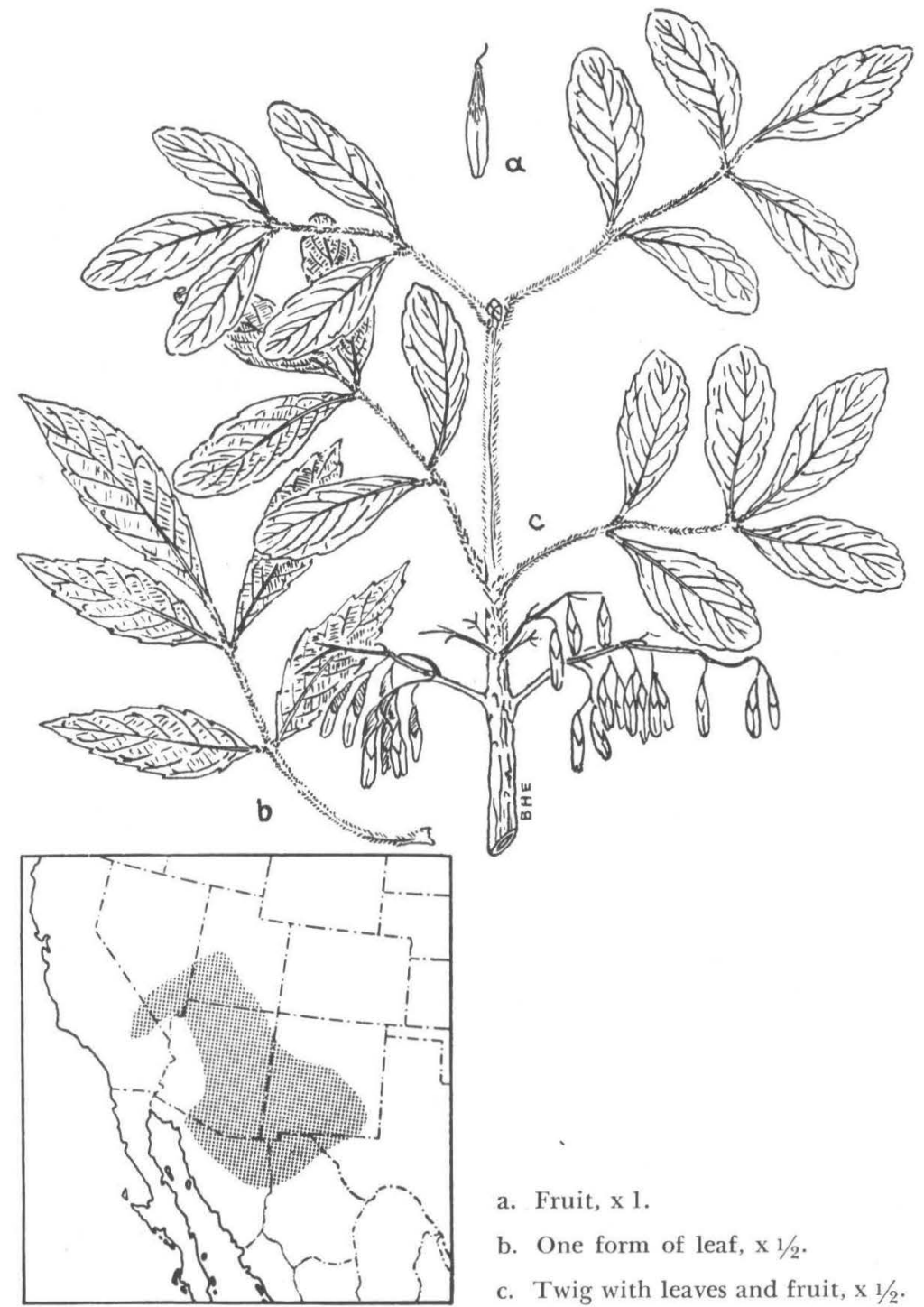

a. Fruit, $\times 1$.

b. One form of leaf, $\times 1 / 2$.

c. Twig with leaves and fruit, $\times 1 / 2$. 


\section{OLEACEAE}

\section{Velvet Ash}

Fraxinus velutina Torr. (Fraxinus pistaciaefolia Torr.)

HABIT. A small, slender tree 20-30 feet high (rarely 40-50 feet) and 12-18 inches in diameter; symmetrical, round-topped crown with stout, often spreading branches.

LEAVES. 4-5 inches long, with a broad, grooved, densely villous petiole; $3-5$ leaflets; elliptic to ovate; $1-11 / 2$ inches long and $\$ / 4-1$ inch wide; mostly acute at apex; finely crenateserrulate above the middle; thick; pale green, glabrous above, tomentose below; tardily deciduous; terminal petiolule $1 / 2$ inch long, lateral petiolules $1 / 6$ inch or less.

FLOWERS. In elongated, pubescent panicles; from leafless, axillary buds; appearing with leaves; dioecious; calyx cupshaped, densely pubescent; corolla absent; anthers oblong, apiculate; ovary nearly enclosed in calyx, shorter than nearly sessile lobes of stigma.

FRUIT. Oblong-obovate to elliptic; rarely more than $3 / 4$ inch long and $1 / 6$ inch wide; wing shorter than and extending to below middle of terete seed cavity.

TWIGS. Rounded; slender; velvety pubescent first year; glabrous, ash-gray, and marked with large, obcordate, dark leaf scars in second year. Winter buds: the terminal $1 / 8$ inch long, acute, with 3 pairs of tomentose scales.

BARK. Thin ( $1 / 3-1 / 2$ inch); gray, slightly tinged with red; divided by furrows into broad, scaly ridges.

WOOD. Heavy; rather soft; not strong; close-grained; heartwood light brown; sapwood lighter colored and thick.

SILVICAL CHARACTERS. Lower Sonoran to Transition zones; intolerant; in mountain cañons up to 6,000 feet, and on banks of streams; hardy, growing well under arid conditions and in alkaline soils where few trees survive; extremely variable.

GENERAL. F. standleyi Rehd. is here considered a variety of $F$. velutina; $F$. velutina passes into the following varieties: 1. coriacea Rehd., with thicker, leathery leaves. 2. glabra Rehd., with glabrous leaves and branches. 3. toumeyi Rehd., with lanceolate, acuminate leaflets, having petioles $1 / 8^{-1 / 2}$ inch long. 


\section{Lowell Ash}

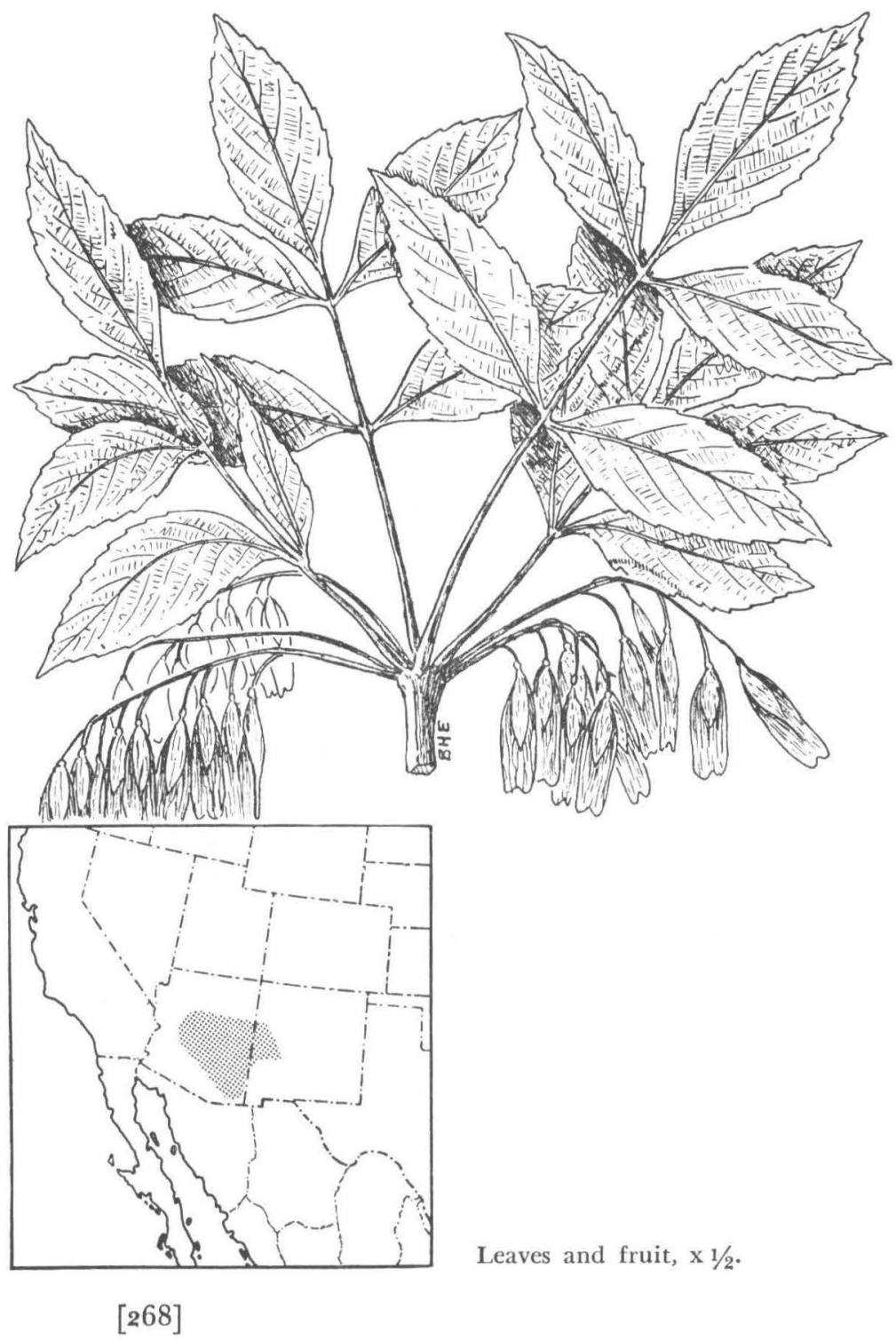




\section{OLEACEAE}

\section{Lowell Ash}

Fraxinus lowellii Sarg.

HABIT. A small tree 20-25 feet high.

LEAVES. 31/2-6 inches long, with a stout petiole; 5 (rarely 3-7) leaflets, ovate to elliptic-ovate, $21 / 2-3$ inches long, cuneate at base, remotely and slightly serrate, yellow-green, glabrous or slightly pubescent along midrib; on vigorous shoots leaves sometimes single and broadly ovate.

FLOWERS. Axillary; corolla absent.

FRUIT. In long glabrous panicles; oblong-obovate to oblong-elliptic; $1-11 / 2$ inches long and $1 / 4-1 / 3$ inch wide; wing broad or gradually narrowed, rounded or emarginate at apex, and extending to base of seed cavity; seed cavity thin, compressed, many-rayed, about $3 / 4$ the length of the fruit; ripening in July.

TWIGS. Quadrangular; often winged; stout; orange-brown.

BARK. Rather thick; dark; deeply furrowed.

SILVICAL CHARACTERS. Upper Sonoran zone; intolerant; on dry, rocky slopes and in cañons; possibly related to F. anomala.

\section{Gregg Ash. Littleleaf Ash}

\section{Fraxinus greggii Gray}

This shrub or small tree, rarely 25 feet high, is characterized by 3-7 leaflets which are less than 1 inch long, usually entire, covered below with small, black dots, and obscurely veined; the twigs are slender and round, and the bark is thin and separates into papery scales; it has been reported from Santa Cruz County, Arizona, western Texas, and Mexico.

\section{ELBOWBUSH}

Forestiera pubescens Nutt.

Typically a shrub, but rarely a small tree of Texas and eastern New Mexico. Characterized by opposite, simple, pubescent, serrulate, obovate leaves, about 1 inch long; small dioecious flowers; and a small, blue-black, oblong, l-celled, 1-seeded drupe. 
Anacahuita
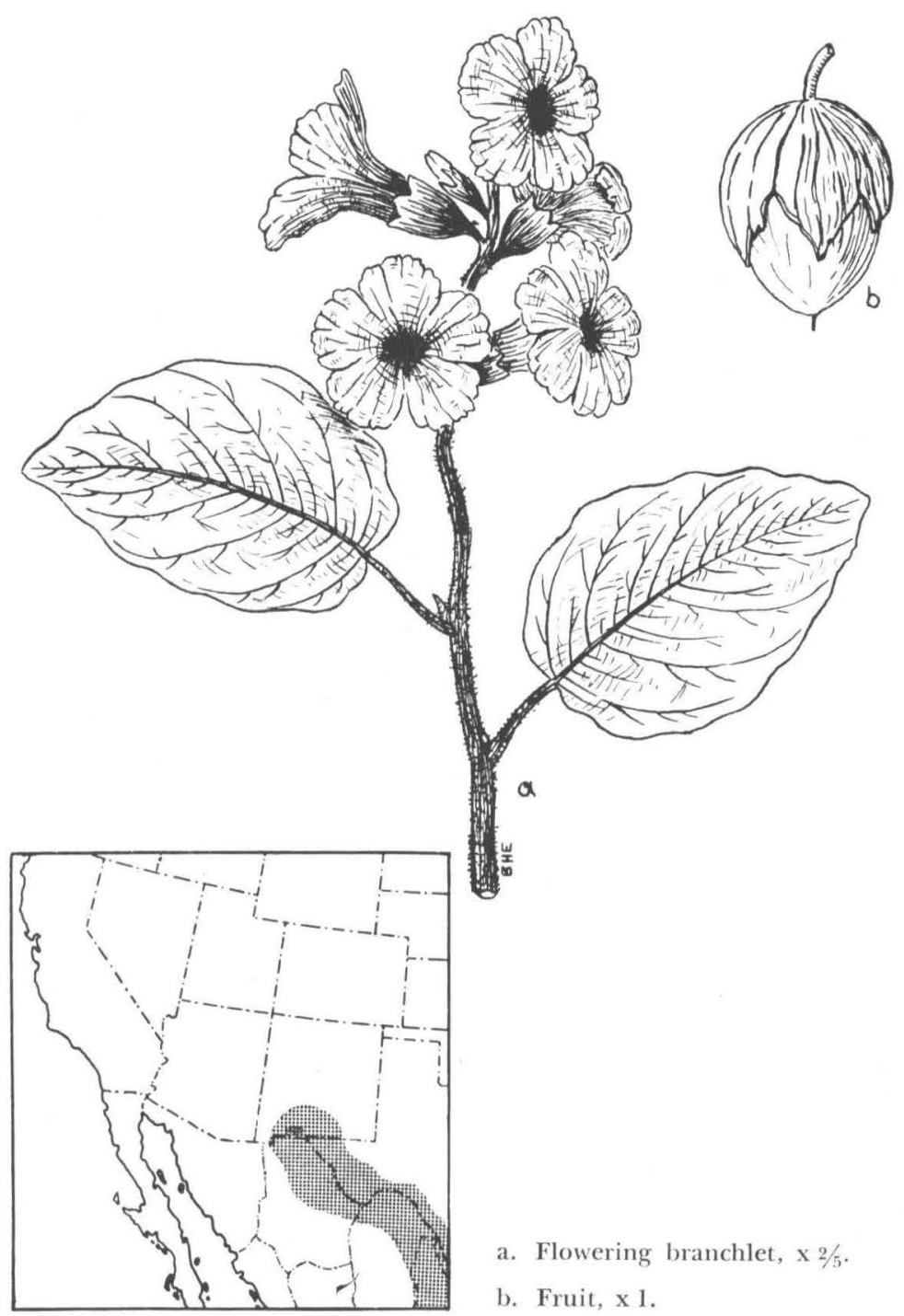

a. Flowering branchlet, $\times 2 / 5$.

b. Fruit, $x 1$.

[270] 


\section{BORRAGINAGEAE}

\section{Anacahuita \\ Cordia boissieri A. DC.}

HABIT. An aromatic shrub or small tree 20-25 feet high and 6-8 inches in diameter; bole often crooked; crown roundtopped.

LEAVES. Alternate; simple; oval to oblong-ovate; 4-5 inches long; acute or rounded at apex; entire or obscurely crenulate-serrate; thick and firm; dark green, wrinkled and more or less scabrous above, coated below with thick tomentum; pinnately veined; tardily deciduous at end of first year; petioles stout, tomentose, $1-11 / 2$ inches long; stipules absent.

FLOWERS. Regular; perfect; in terminal cymes; calyx tubular, 5-toothed, persistent; corolla funnel-form, 2 inches across, white with yellow spot in throat; stamens 5, on corolla tube; ovary single, with solitary ovule in each of 4 cells.

FRUIT. Drupaceous; ovoid; 1 inch long and 3/4 inch broad; acute; lustrous, bright red-brown; enclosed entirely or partially by thin, fibrous, orange-brown, tomentose calyx; flesh thin, sweet, and pulpy; stone thick-walled, hard and bony, ovoid, light brown. Seed: $1-2$ in each fruit; $1 / 4$ inch long; acute.

TWIGS. Stout, dark gray or brown, puberulous, marked by occasional large lenticels and by elevated obcordate leaf-scars.

BARK. Thin; gray, tinged with red; irregularly divided into broad, flat ridges; the surface with long thin scales.

WOOD. Light; rather soft; close-grained; diffuse-porous, dark brown heartwood; thick, light brown sapwood.

SILVICAL CHARACTERS. Lower Sonoran zone; intolerant; dry limestone ridges and depressions; planted as ornamental.

\section{SOLANACEAE \\ Tree Tobacco \\ Nicotiana glauca Graham}

A South American shrub or small tree naturalized from southwestern Texas to southern California. Characterized by persistent, alternate, simple, entire, glaucous leaves, 2-7 inches long; white, regular, perfect flowers, $\mathrm{I} 1 / 2$ inches long; and a 2-celled capsule about $1 / 2$ inch long. 


\section{Desertwillow}
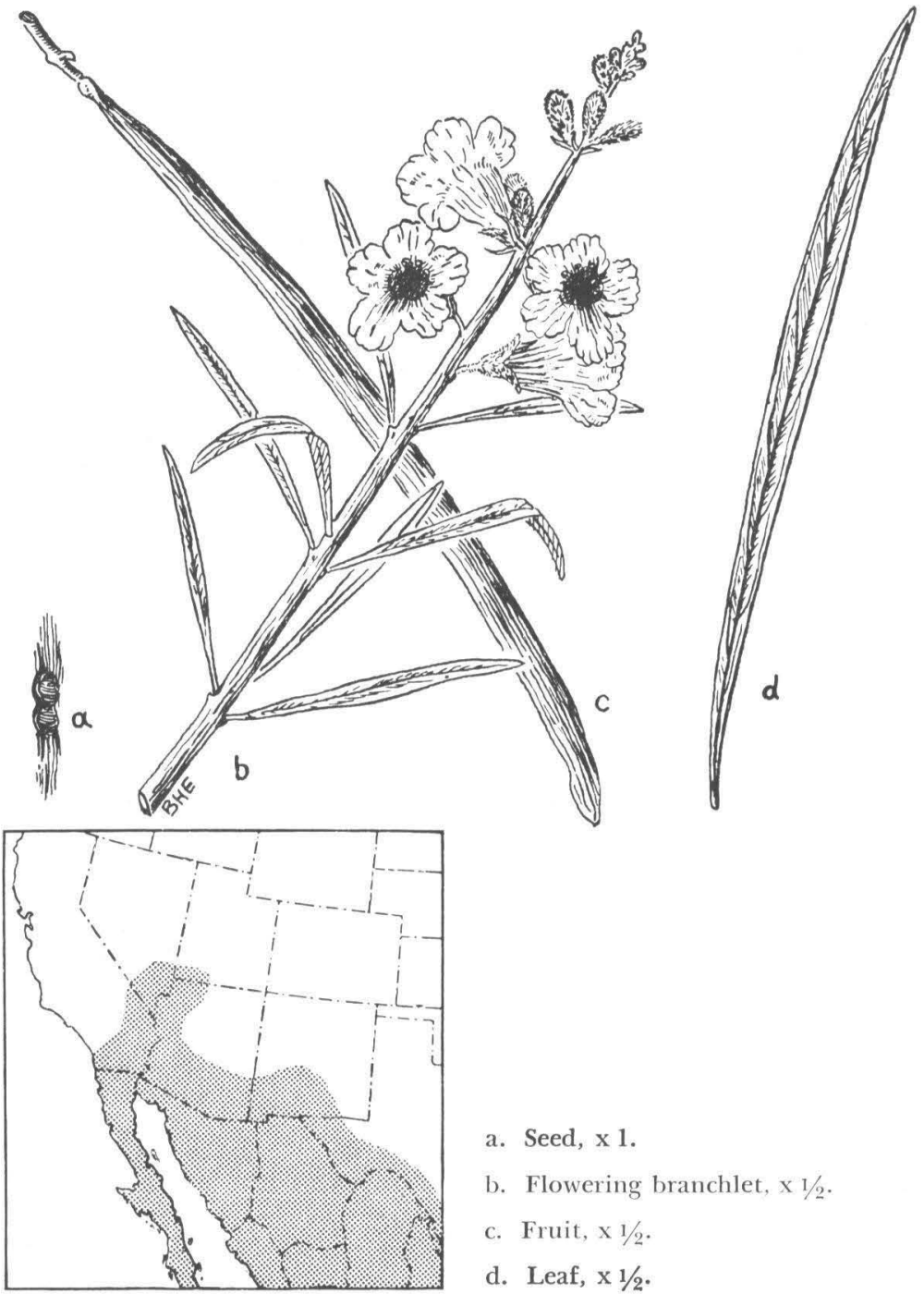
a. Seed, $\times 1$.
b. Flowering branchlet, $\mathrm{x}_{1 / 2}$.
c. Fruit, $\mathrm{x} 1 / 2$.
d. Leaf, $\times 1 / 2$.

[272] 


\section{BIGNONIACEAE}

\section{DeserTWILlow}

Chilopsis linearis (Cav.) Sweet. (Chilopsis saligna Don.)

HABIT. A shrub or small tree rarely 20-30 feet high; trunk usually reclining; crown narrow with slender, upright branches.

LEAVES. Opposite, alternate, or scattered; simple; linear or linear-lanceolate; $5-12$ inches long and $1 / 4-1 / 3$ inch wide; acuminate; entire margins; 3-nerved; thin; light green; smooth or glutinous; deciduous during following winter; short-petioled or sessile; without stipules.

FLOWERS. Irregular; perfect; showy; in racemes or panicles 3-4 inches long; appearing in summer; calyx palepubescent, closed before anthesis; corolla white tinged with purple, yellow-spotted in throat, $3 / 4-11 / 2$ inches long and $3 / 4-11 / 4$ inches wide, 2-lipped; stamens 4 , inserted; ovary 2 -celled, conic, glabrous; ovules inserted in many series on a central placenta.

FRUIT. Slender, elongated, thin-walled capsule, 7-12 inches long and $1 / 4$ inch thick; splitting into 2 concave valves; persistent into the winter. Seed: numerous; $1 / 3$ inch long and $1 / 8$ inch wide; compressed; oblong; seed coat thin, light brown, produced into broad, fringed, lateral wings.

TWIGS. Slender, glabrous or densely tomentose, light chestnut-brown becoming darker. Winter buds: terminal absent; lateral minute, compressed, scaly, rusty-pubescent.

BARK. Thin $\left(1 / 8^{-1 / 4}\right.$ inch); dark brown; furrowed.

WOOD. Soft; not strong; close-grained; ring-porous; heartwood brown, streaked with yellow; sapwood very thin and light-colored; durable; used locally for fence posts.

SILVICAL CHARACTERS. Lower Sonoran zone; intolerant; short-lived; banks of desert and low mountain water courses; usually dry, well-drained sandy and gravelly soils; at elevations from sea level to 5,000 feet; a monotypic genus.

\section{Western Catal.pa \\ Catalpa speciosa Engelm.}

An eastern species but much planted in warmer portions of the region. A showy tree with handsome flowers; large, heartshaped leaves (3-8 inches long); and fruit a cigar-like pod 6-15 inches long. 
Common Buttonbush
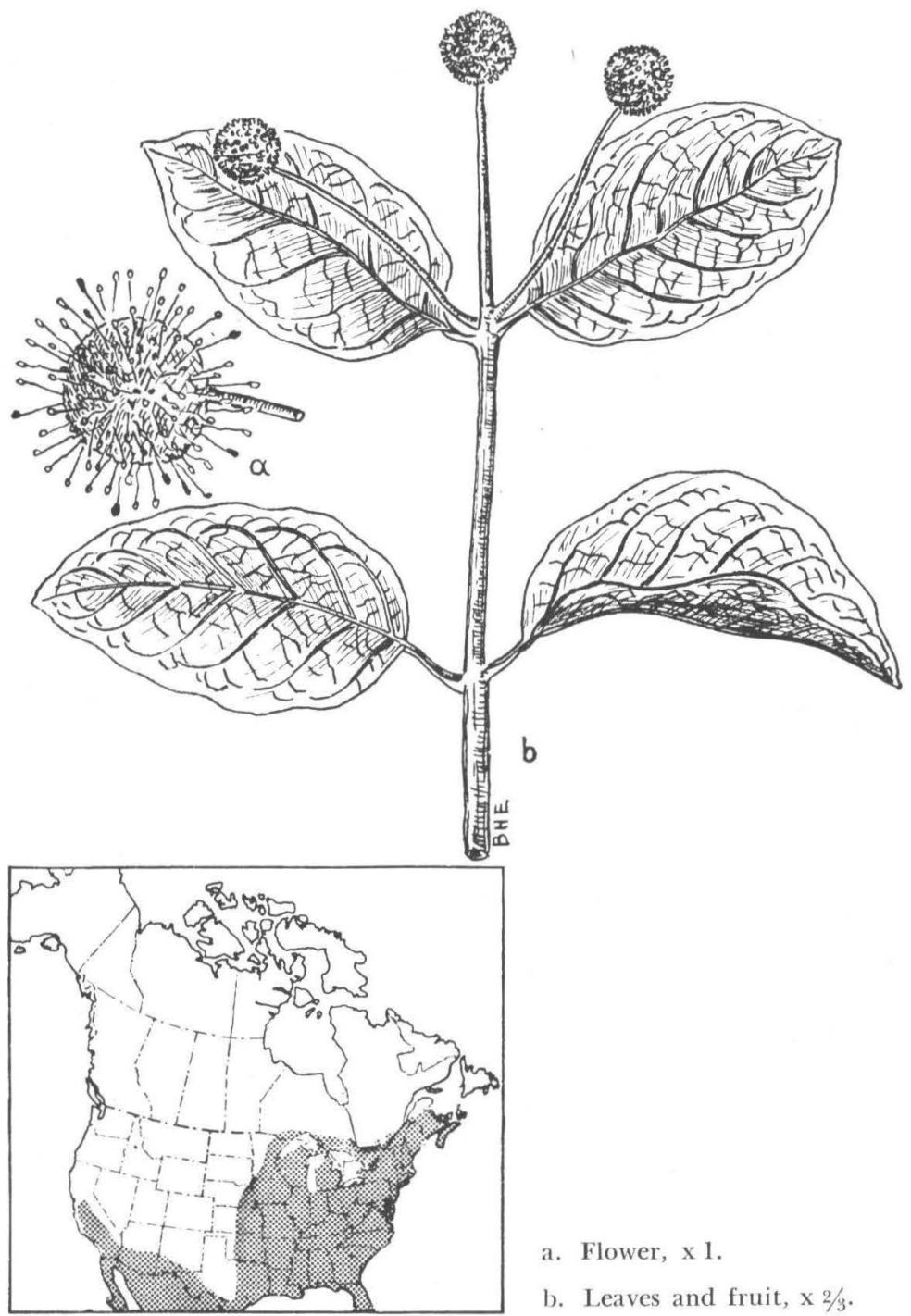

a. Flower, x 1.

b. Leaves and fruit, $\times 2 / 3$. 


\section{RUBIACEAE}

\section{Common Buttonbush}

Cephalanthus occidentalis $\mathrm{L}$.

HABIT. A shrub or rarely a small tree up to 50 feet high and 1-2 inches in diameter; open, spreading crown.

LEAVES. Opposite or whorled in 3's; simple; ovate, lanceolate, or elliptic; 2-7 inches long; acute or acuminate at apex; margins entire; thin; dark green and glabrous above; paler below, with yellow midrib; tardily deciduous during winter; petioles stout, grooved, glabrous, $1 / 2-3 / 4$ inch long.

FLOWERS. Regular; perfect; minute; in dense, globose heads 1-1 1/2 inches in diameter; fragrant; calyx tube 4-5-lobed; corolla cream-white, salver-form, 4-5-lobed; stamens as many as and alternate with corolla lobes; ovary inferior, 2-celled, with protruding, threadlike style and capitate stigma.

FRUIT. Nutlike capsule; inversely pyramidal; splitting from base upwards into 2-4 closed, 1-seeded portions; in heads $5 / 8-3 / 4$ inch in diameter; green tinged with red, becoming dark red-brown. Seed: small, oblong, pendulous.

TWIGS. Stout; glabrous; thick pith; marked by large lenticels; opposite or in whorls of 3; light green at first, becoming red-brown. Winter buds: terminal absent; lateral minute, nearly immersed in the bark.

BARK. Thin; dark brown to nearly black; with broad, flat, superficially scaly ridges; contains tannin.

WOOD. Moderately heavy and hard; fine-grained; diffuseporous; light red-brown; unimportant.

SILVICAL CHARACTERS. Lower Sonoran to Transition zones; rather tolerant; reproduction abundant; on moist sites or in dry stream beds; often forming dense thickets.

\section{BIGNONIACEAE}

\section{TRUMPETFLOWER \\ Tecoma stans (L) H.B.K.}

A shrub or small tree extending through Mexico into the southern parts of Texas, New Mexico, and Arizona. Characterized by showy, bright yellow flowers; opposite, pinnately compound leaves with 5-13 leaflets; and a linear capsule, 4-8 inches long. 


\section{Blueberry Elder}

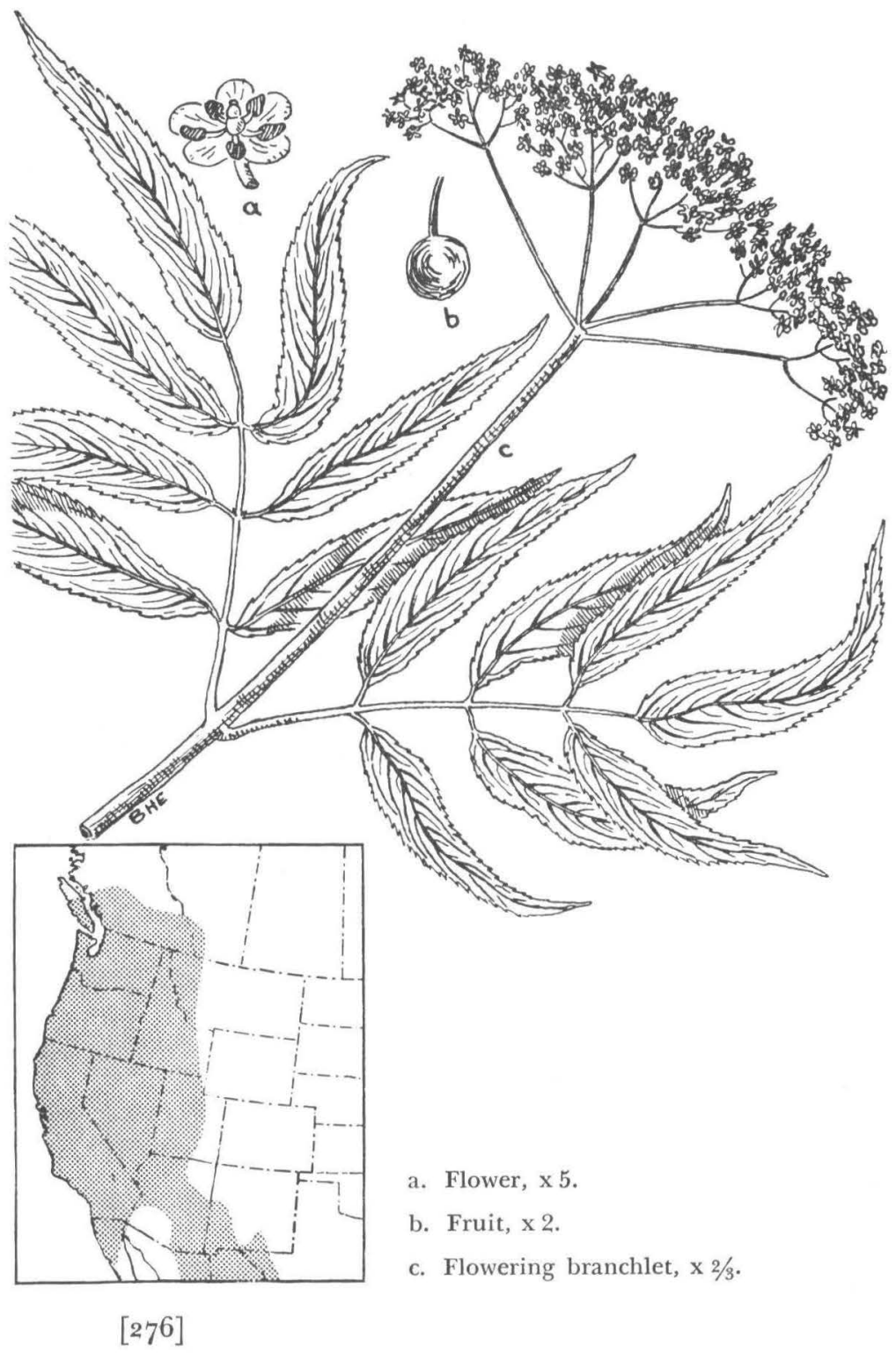




\section{CAPRIFOLIACEAE}

\section{BLUEBERRY ELder}

Sambucus cerulea Raf. (Sambucus glauca Nutt.) (Sambucus neomexicana Woot.)

HABIT. A shrub or small tree 30-50 feet high and 12-18 inches in diameter; compact, round-topped crown with stout, spreading branches.

LEAVES. Opposite; unequally pinnately compound; petiolate; deciduous; 5-7 inches long; leaflets 5-9, ovate or narrow oblong, acuminate at apex, coarsely serrate margin, 1-6 inches long and $1 / 3-11 / 2$ inches wide, green above, pale and glabrous to pubescent below, thin and rather firm, on slender petiolules.

FLOWERS. Regular; perfect; small ( $1 / 8$ inch in diameter); in broad, terminal, long-branched corymbose cymes; calyx ovoid, red-brown, 5-lobed; corolla yellow-white, rotate, 5-lobed, as long as stamens; stamens 5, alternate to corolla lobes; ovary inferior, 3-5-celled, with solitary ovule in each cell.

FRUIT. Dense clusters of small, blue, berry-like drupes; each drupe subglobose, $1 / 4$ inch in diameter, with sweet, juicy flesh, used for jellies, pies, etc. Seed: $3-51$-seeded nutlets in each drupe.

TWIGS. Stout; somewhat angled; pubescent first year; redbrown; nearly encircled by large, triangular leaf-scars marked by conspicuous bundle-scars; thick, soft, whitish pith. Winter buds: terminal absent; lateral scaly, greenish.

BARK. Thin; dark brown, tinged with red; irregularly furrowed and ridged.

WOOD. Light; soft; weak; coarse-grained; diffuse-porous; heartwood yellow tinged with brown, durable; sapwood thin and lighter colored; unimportant.

SILVICAL CHARACTERS. Upper Sonoran to Canadian zones; intolerant; short-lived; reproduction abundant but scattered, coppices freely; moist porous soils; along streams, ravines, or moist hillsides; occurring in scattered mixture with Douglas-fir, ponderosa pine, and various hardwoods.

GENERAL. Passes into the varieties arizonica Sarg. and velutina Rehd. in the Southwest. A related form, S. mexicana Presl., extending from western Texas to southern Arizona and south into Mexico sometimes attains tree size. 


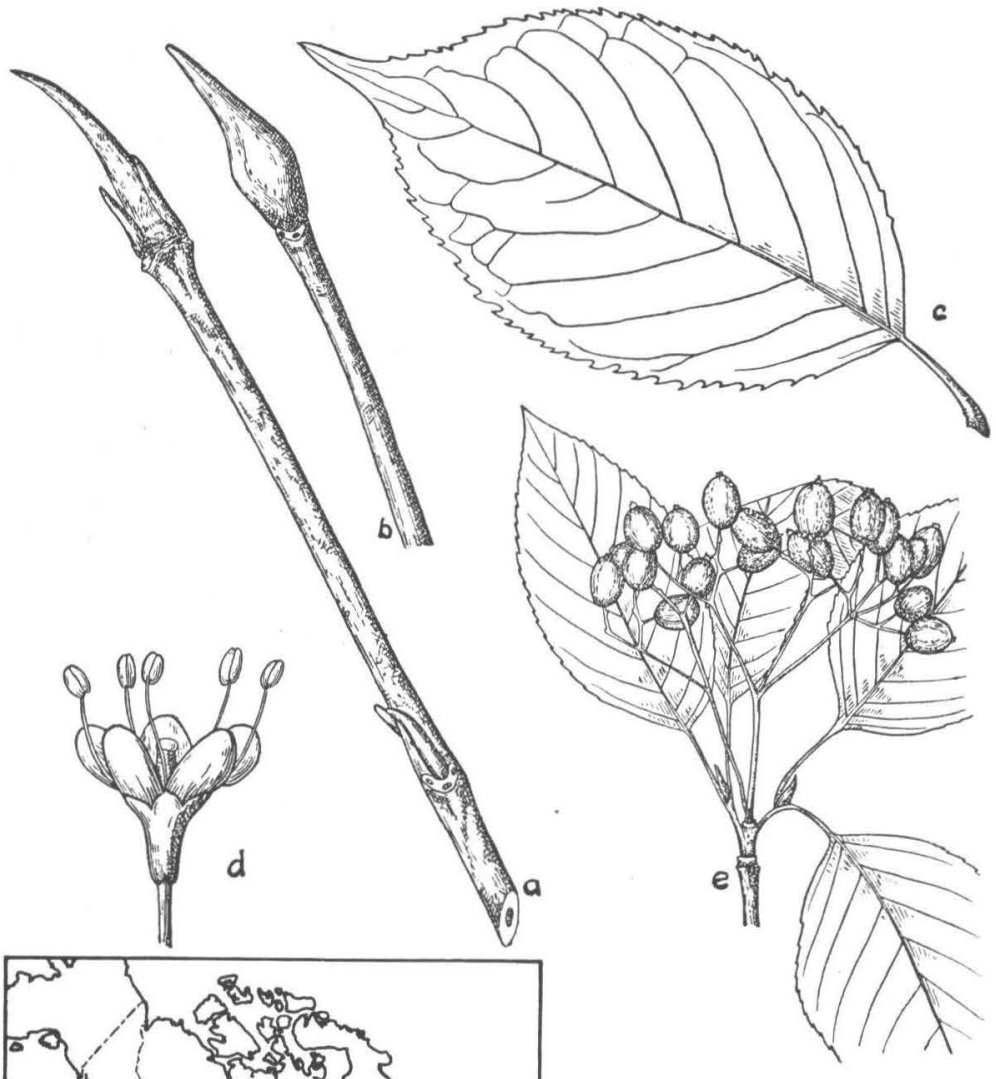

a. Winter twig, with leaf buds, $\mathrm{x} 1$.

b. Winter twig, with flower bud, $x 1$.

c. Leaf, $x 3 / 4$.

d. Flower, enlarged.

e. Fruiting branchlet, $\times 1 / 2$. 


\section{CAPRIFOLIACEAE}

\section{NANNYBERRY \\ Viburnum lentago $\mathrm{L}$.}

HABIT. A shrub or small tree 15-30 feet high and 6-10 inches in diameter; bushy, compact, rounded crown with slender, tortuous, rather pendulous branches.

LEAVES. Opposite; simple; ovate; $2-4$ inches long and 1--2 inches wide; acuminate or sometimes rounded at apex; sharply serrate; thick and firm; lustrous and bright green above; yellowgreen and marked with minute, black dots below; deciduous; petioles broad, grooved, more or less winged, about 1 inch long; turning orange and red in autumn.

FLOWERS. Regular; perfect; small ( $1 / 4$ inch in diameter); fragrant; in stout-branched, scurfy, terminal cymes $3-5$ inches across; calyx tubular, 5-lobed; corolla tubular, 5-lobed, creamcolored to white; stamens 5 , with yellow anthers, inserted on tube of corolla and alternate to its lobes; ovary inferior, 1-celled, with short, thick style and broad stigma; ovule solitary, suspended from apex of cell.

FRUIT. Few-fruited, red-stemmed clusters of small, juicy, blue-black, berry-like drupes; each drupe oval or ovoid, flattened, and covered with glaucous bloom. Seed: solitary within oval, rough, flattened nutlet.

TWIGS. Slender; tough and flexible; light green and rustypubescent at first, becoming dark red-brown. Winter buds: large, scurfy-pubescent, enclosed by one pair of valvate scales; flower buds $3 / 4$ inch long, grayish, swollen at base and longpointed; terminal leaf bud 1 inch long, light red, narrow, and long-pointed; lateral leaf buds much smaller.

BARK. Red-brown; irregularly broken into small, thick plates which are superficially scaly.

WOOD. Heavy; hard; close-grained; diffuse-porous; illscented; heartwood dark orange-brown; sapwood thin and whitish.

SILVICAL CHARACTERS. Transition zone; very hardy; prefers rich, moist soils bordering forests, rivers, or marshes, but is found on rocky hillsides; an attractive small ornamental tree; coppices freely; endures city smoke. 


\section{Sage Brush}
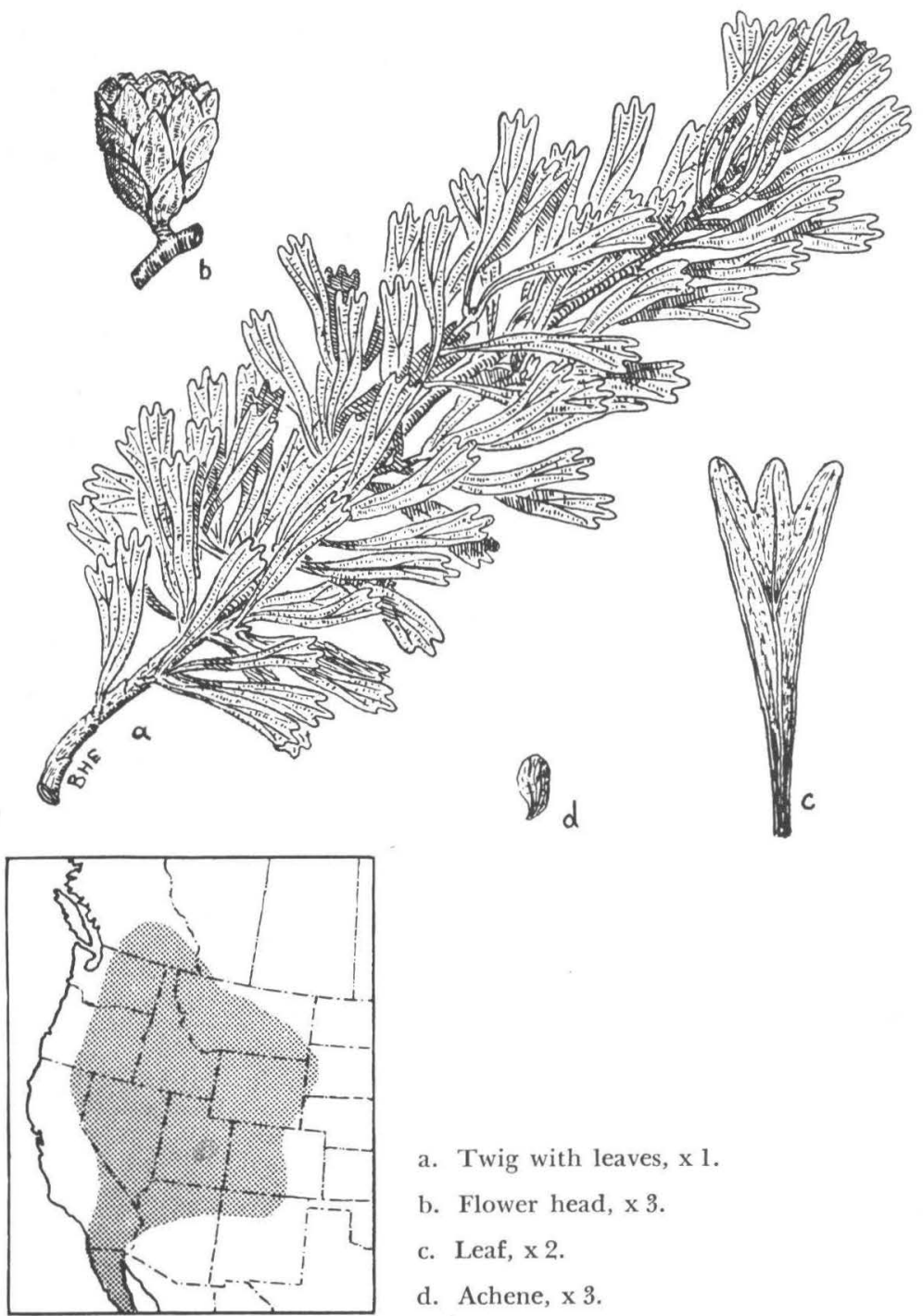

a. Twig with leaves, $\mathrm{x} 1$.

b. Flower head, x 3 .

c. Leaf, x 2 .

d. Achene, x 3 .

[280] 


\section{COMPOSITAE}

\section{Sage Brush. Black Sage}

\section{Artemisia tridentata Nutt.}

HABIT. Usually a shrub, but on moist sites occasionally becoming a small tree 8-20 feet high and 4-12 inches in diameter; trunk sinuous and malformed; branches erect or ascending.

LEAVES. Alternate; simple; $1 / 2-11 / 4$ inches long; wedgeshaped; 3-toothed at broad apex, or upper leaves not toothed; narrowed to nearly sessile base; margins entire; gray with appressed hairs on both surfaces; persistent; stipules absent; odor characteristic; taste bitter.

FLOWERS. Regular; perfect; minute; in 5-8-flowered heads, about $1 / 8$ inch long; in large, dense panicles at end of branches; involucral bracts nearly or quite as long as flowers; ray flowers absent; calyx wanting; corolla tubular, yellow or greenish; stamens 4-5, with anthers united laterally; ovary inferior, oblong or linear, 1-celled, 1-ovuled, narrowed above into slender style which branches into 2 stigmas.

FRUIT. Obovoid or oblong achene; rounded at apex; without crown of bristles (pappus).

TWIGS. Slender; round; at first gray-green and covered with closely matted hairs, soon becoming roughened. Winter buds: minute, hairy.

BARK. Thin; gray; rough; shreddy.

WOOD. Moderately soft and light; tending to fall apart at growth rings; ill-scented; fine-grained; ring-porous; heartwood dark brown; sapwood lighter colored; unimportant.

SILVICAL CHARACTERS. Upper Sonoran and Transition zone; intolerant; the most abundant shrub of the western arid and semi-arid plains; reported reaching tree size from southern Colorado and New Mexico; root system two-storied, shallow-fibrous and deep-spreading; indicator of deep soils largely free from alkali.

GENERAL. About 200 species are recognized in this genus, most of them being herbaceous; plants of this group are known as wormwood, and some are grown for drug products. 
SoAPtree Yucca

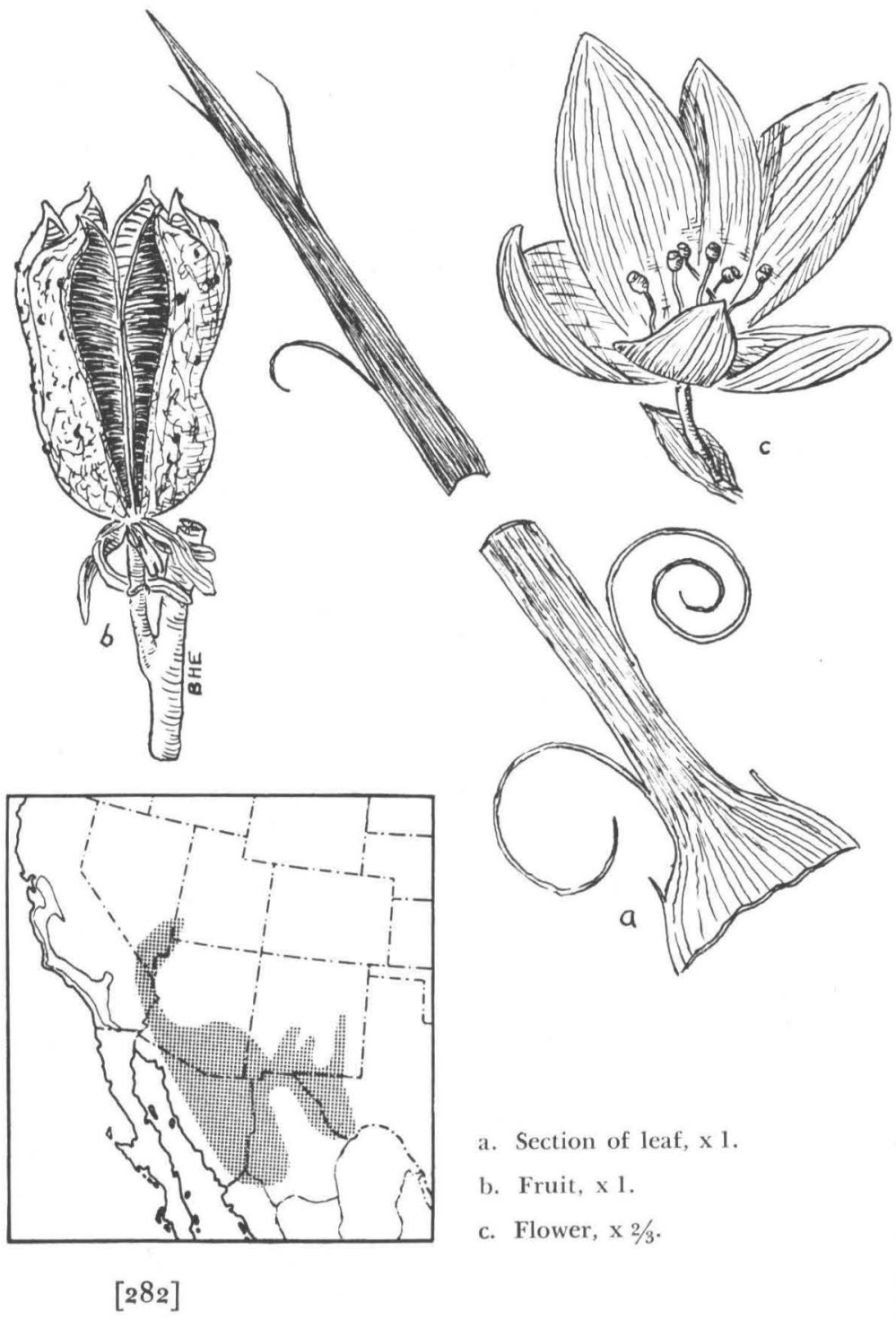




\section{LILIACEAE}

\section{SoAPtRee YucGa. SPanish-Bayonet}

Yucca elata Engelm.

HABIT. A tree often 15-20 feet high and 7-8 inches in diameter with a deep, branched, underground stem; simple or branched at top; covered with pendent, persistent dead leaves.

LEAVES. Alternate; simple; 20-30 inches long and 1/4-1/2 inch wide; thin and flat above, rounded below; glabrous; yellow-green; entire pale margins soon splitting into slender flaments; parallel-veined; persistent; stipules absent.

FLOWERS. Regular; perfect; in compound, terminal panicles, 4-6 feet high; perianth cup-shaped, white 31/2-4 inches across; stamens 6; ovary 6-sided, 3-celled; ovules numerous.

FRUIT. Erect, oblong capsule, 11/2-2 inches long; 3-valved; light brown, thin and woody outside; light yellow inside; edible. Seed: numerous, black, $1 / 3$ inch wide.

BARK. Dark brown; with thin plates; $1 / 4$ inch thick.

WOOD. Light; soft; spongy; pale brown or yellow; in concentric layers.

SILVICAL CHARACTERS. Lower Sonoran zone; intolerant; on high, desert plateaus; large roots used as substitute for soap.

Five species of Yucca reach tree size in the Southwest:

I. Fruit erect, dehiscent; flower clusters long-stalked; leaves filamentose, thin, pale yellow-green.............. Y. elata.

II. Fruit pendent, indehiscent; flower clusters sessile or shortstalked; leaves concave above the middle.

A. Fruit with thin, dry flesh; leaves blue-green, serrate; southwestern Utah to California........................ 2. Y. brevifolia Engelm.; Joshua Tree.

B. Fruit with thick, succulent flesh; leaves yellow-green.

1. Panicle hoary-tomentose; leaves flexible, $21 / 2-3$ feet long; margins not filamentous; southern Arizona........... 3. Y. schottii Engelm.; Hoary Yucca.

2. Panicle glabrous or puberulous; leaves rigid, $11 / 2-2$ feet long, margins filamentous.

a. Style elongated; western Texas to eastern Arizona.... ............... Y. torreyi Shaf.; Torrey Yucca.

b. Style short; southeastern Nevada, northwestern Arizona........5. Y. mohavensis Sarg.; Mohave Yucca. 
Arizona Washingtonia

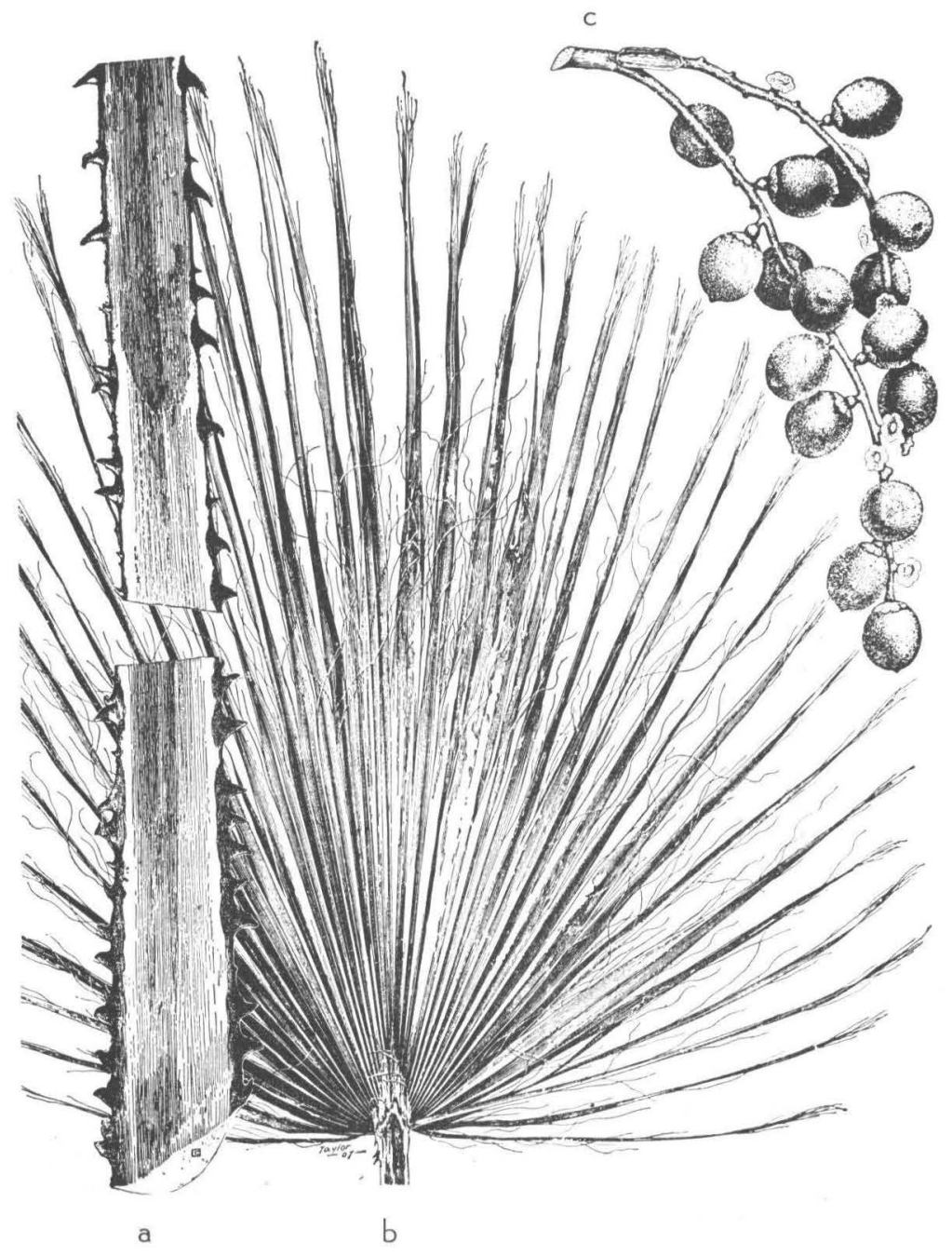

a. Leaf petiole, x $1 / 3$.

b. Leaf, $x 1 / 9$.

c. Part of fruit cluster, $x 2 / 3$. 


\section{PALMAE}

\section{Arizona Washingtonia. Fanleaf Palm}

Washingtonia arizonica Cook (Washingtonia robusta Wendl.)

HABIT. An evergreen tree 30-50 feet high and 1-2 feet in diameter; crown broad, consisting of large leaves; columnar trunk clothed with thatchlike mass of pendent dead leaves and remains of sheaths and petioles, becoming smooth with age.

LEAVES. Clustered at top of stem; 3-6 feet long; fan-shaped; nearly circular; with 40-70 ribbon-like folds deeply slashed $1 / 2-2 / 3$ of distance to base; the margins of the divisions separating into numerous threadlike filaments; petioles $3-5$ feet long, 1-3 inches wide, armed along margins with stout, hooked spines.

FLOWERS. Regular; perfect; minute; in compound clusters 8-10 feet long; appearing from axils of upper leaves; calyx tubular; corolla white, tubular; stamens 6; ovary 3-lobed and 3-celled with a single ovule in each cell.

FRUIT. Drupelike berry; $3 / 8$ inch long; black when ripe in September; ellipsoidal; with a thin, dry, sweet pulp; produced in large quantities. Seed: $1 / 4$ inch long, $1 / 8$ inch wide, pale chestnut-brown.

BARK. Stem with thick barklike rind; narrowly furrowed; pale cinnamon to dull red-brown.

WOOD. Light; soft; spongy and fibrous; yellowish, with numerous, conspicuous, dark orange-colored, fibro-vascular bundles; unimportant.

SILVICAL CHARACTERS. Lower Sonoran zone; moderately tolerant when young, becoming intolerant; reproduction plentiful; long, deep roots; alkaline soils; dry, warm mountain cañons.

GENERAL. This palm is reported from Yuma County, southwestern Arizona, often occurring there in large numbers. Considerable confusion exists as to the nomenclature and classification of the forms of Washingtonia. Apparently there are three southwestern species, $W$. robusta Wendl. (W. sonorae S. Wat.), native to Mexico, and $W$. filifera Wats. (W. filamentosa $\mathrm{O}$. Kuntze), native to California. The characters of the leaf margins, petiole spines, and trunk size, which separates these species, vary so greatly that they are of doubtful value as species criteria. 


\section{GLOSSARY}

Abortive. Imperfectly or not developed; barren.

Accrescent. Increasing in size with age.

Achene. A dry indehiscent, 1-celled and l-seeded fruit or carpel.

Acuminate. Gradually tapering to the apex; long-pointed.

Acute. Sharply pointed, but not drawn out.

Adnate. Descriptive of unlike organs or parts fused together. Alternate. Scattered singly along axis; not opposite.

Ament. A scaly, bracted spike of usually unisexual flowers, frequently deciduous in one piece.

Anther. The pollen-bearing part of the stamen.

Anthesis. The time when fertilization takes place.

Apetalous. Without petals.

Apiculate. Ending in a minute, short, pointed tip.

Apophysis. That part of a cone scale which is exposed when the cone is closed.

Appressed. Lying close and flat against.

Arborescent. Attaining the size or character of a tree.

Aril. An appendage growing out from the hilum and covering the seed partly or wholly.

Attenuate. Slenderly tapering; acuminate.

Awl-shaped. Tapering from the base to a slender and stiff point.

Axil. The upper angle formed by a leaf or branch with the stem.

Axillary. Situated in an axil.

Berry. A fleshy or pulpy fruit with immersed seeds.

Blade. The expanded portion of a leaf.

Bloom. A powdery or waxy substance easily rubbed off.

Bole. The stem of a tree.

Boss. A raised projection, usually pointed.

Bract. A modified leaf subtending a flower or belonging to an inflorescence.

Bractlet. The bract of a pedicel or ultimate flower stalk; a secondary bract. 
$B u d$. The undeveloped state of a branch or flower cluster, with or without scales.

Bud scales. Modified leaves covering a bud.

Bundle (leaf). Strand of fibro-vascular tissue found in cross section of leaf.

Caducous. Falling off very early.

Calyx. The flower-cup or exterior part of a perianth.

Campanulate. Bell-shaped.

Canescent. Gray-pubescent and hoary.

Capsule. A dry fruit of more than one carpel which splits at maturity to release its seeds.

Carpel. A simple pistil or an element of a compound pistil.

Catkin. The same as an ament.

Caudate. Furnished with a tail or with a slender tip.

Cell. The unit of structure of living things; a cavity of an ovary or anther.

Chambered. Said of pith which is interrupted by hollow spaces.

Ciliate. Fringed with hairs on the margin.

Cone. A fruit with woody, overlapping scales.

Coniferous. Pertains to cone-bearing; or the order Coniferales.

Coppice. Growth arising from sprouts at the stump.

Cordate. Heart-shaped.

Coriaceous. Of the texture of leather.

Corolla. Inner part of the perianth, composed of petals.

Corymb. A flat-topped flower cluster, the flowers opening from the outside inward.

Crenate. Dentate with the teeth much rounded.

Crenulate. Diminutive of crenate, finely crenate.

Crown. The upper part of a tree, including the living branches with their foliage.

Cuneate. Wedge-shaped, or triangular with an acute angle downward.

Cuspidate. Tipped with a sharp, rigid point.

Cylindric. Shaped like a cylinder.

Cyme. A flat-topped flower cluster, the flowers opening from the center outward.

Deciduous. Not persistent; falling away as the leaves of a tree in autumn.

Decurrent. Running down, as of the blades of leaves extending down their petioles. 
Decussate. In pairs alternately crossing at right angles.

Dehiscent. The opening of an anther or capsule by slits or valves.

Deltoid. Delta-shaped, triangular.

Dentate. Toothed, with the teeth directed outward.

Denticulate. Minutely toothed.

Diadelphous. Stamens formed into two groups through the union of their filaments.

Dimorphous. Occurring in two forms.

Dioecious. Unisexual, the staminate and pistillate flowers on different individuals.

Disk. A development of the receptacle at or around the base of the pistil.

Dissemination. The spreading abroad of ripe seeds from the parent plant.

Divergent. Spreading apart; pointing away.

Dorsal. Relating to the back or outer surface of an organ; the lower surface of a leaf.

Downy. Clothed with a coat of soft, fine hairs.

Drupaceous. Resembling or relating to a drupe.

Drupe. A stone fruit, such as a plum.

E. A Latin prefix denoting that parts are missing, as eglandular, without glands.

Ellipsoidal. Of the shape of an elliptical solid.

Elliptic. Of the form of an elipse.

Emarginate. Notched at the apex.

Entire. Leaf margin without divisions, lobes or teeth.

Erose. Descriptive of an irregularly toothed or eroded margin.

Excrescences. Warty outgrowths or protuberances.

Exfoliate. To cleave or peel off in thin layers.

Exserted. Prolonged beyond the surrounding organs, as stamens from the corolla.

Falcate. Scythe- or sickle-shaped.

Fascicle. Dense cluster or bundle.

Fibro-vascular. Consisting of woody fibers and ducts.

Filament. The stalk of an anther.

Fluted. Regularly marked by alternating ridges and groovelike depressions.

Foliaceous. Leaflike in texture or appearance. 
Fugacious. Falling or withering away very early.

Fulvous. Tawny; dull yellow with gray.

Furrowed. With longitudinal channels or grooves.

Gibbous. Swollen on one side.

Glabrous. Smooth, not pubescent or hairy.

Gland. Secreting surface or structure; a protuberance having appearance of such an organ.

Glandular. Furnished with glands.

Glaucous. Covered or whitened with a bloom.

Globose. Spherical in form or nearly so.

Habit. The general appearance of a plant; best seen from a distance.

Habitat. The place where a plant naturally grows.

Halberd-like. Like an arrowhead, but with the basal lobes pointing outward nearly at right angles.

Hilum. The scar or place of attachment of a seed.

Hirsute. Covered with rather coarse or stiff, long hairs.

Hoary. Covered with a close, whitish or gray-white pubescence.

Hybrid. A cross between two nearly related species.

Imbricate. Overlapping, like shingles on a roof.

Indehiscent. Not splitting open; remaining closed.

Inferior ovary. Appearing to grow below the adnate calyx.

Inserted. Attached to or growing out of.

Intolerant. Not capable of doing well under dense forest cover.

Involucre. A circle of bracts surrounding a flower cluster.

Irregular flower. Not symmetrical, similar parts of different shapes or sizes.

Keeled. With a central ridge like the keel of a boat.

Laciniate. Cut into narrow, pointed lobes.

Lanceolate. Lance-shaped.

Lateral. Situated on the side; not at apex.

Leaflet. One of the small blades of a compound leaf.

Leaf scar. Scar left on twig by the falling of a leaf.

Legume. Fruit of the pea family; podlike and splitting open by both sutures.

Lenticel. Corky growth on young bark which admits air to the interior of a twig or branch. 
Linear. Long and narrow, with parallel edges.

Lobe. A somewhat rounded division of an organ.

Lobulate. Divided into small lobes.

Lustrous. Glossy, shining.

Membranaceous. Thin and somewhat translucent.

Midrib. The central vein of a leaf or leaflet.

Monoecious. The stamens and pistils in separate flowers but borne on the same individual.

Mucro. A small and abrupt tip to a leaf.

Mucronate. Furnished with a mucro.

Naked buds. Buds without scales.

Nut. A hard and indehiscent, l-seeded pericarp produced from a compound ovary.

Nutlet. A diminutive nut or stone.

$O b$. Latin prefix signifying inversion.

Obconic. Inverted cone-shaped.

Oblanceolate. Lanceolate, with the broadest part toward the apex.

Oblong. About three times longer than broad with nearly parallel sides.

Oblique. Slanting or with unequal sides.

Obcordate. Inverted heart shape.

Obovate. Ovate with the broader end toward the apex.

Obovoid. An ovate solid with the broadest part toward the apex.

Obtuse. Blunt or rounded at apex.

Odd-pinnate leaf. Pinnate with a terminal leaflet.

Orbicular. A flat body circular in outline.

Oval. Broad elliptic, rounded at ends and about $11 / 2$ times as long as broad.

Ovary. The part of a pistil that contains the ovules.

Ovate. Shaped like the longitudinal section of an egg, with the broad end basal.

Ovoid. Solid ovate or solid oval.

Ovule. The part of the flower which after fertilization becomes the seed.

Palmate. Radiately lobed or divided, veins arising from one point. 
Panicle. A loose, compound flower cluster.

Papilionaceous. Butterfly-like; typical flower shape of legumes. Pedicel. Stalk of a single flower in a compound inflorescence. Pedicellate. Borne on a pedicel.

Peduncle. A general flower stalk supporting either a cluster of flowers or a solitary flower.

Peltate. Shield-shaped and attached by its lower surface to the central stalk.

Pendent. Hanging downward.

Pendulous. More or less hanging or declined.

Perfect. Flower with both stamens and pistil.

Perianth. The calyx and corolla of a flower considered as a whole.

Persistent. Remaining attached, not falling off.

Petiolate. Having a petiole.

Petiole. The footstalk of a leaf.

Petiolule. Footstalk of a leaflet.

Pilose. Hairy, with soft and distinct hairs.

Pinnate. A compound leaf with leaflets arranged along each side of a common petiole.

Pistil. Female organ of a flower, consisting of ovary, style, and stigma.

Pistillate. Female flowers without fertile stamens.

Pith. The central, softer part of a stem.

Pollen. The fecundating grains borne in the anther.

Polygamo-dioecious. Flowers sometimes perfect, sometimes unisexual and dioecious.

Polygamo-monoecious. Flowers sometimes perfect and sometimes unisexual, the 2 forms borne on the same individual.

Polygamous. Flowers sometimes perfect and sometimes unisexual.

Pome. An inferior fruit of 2 or several carpels inclosed in thick flesh; an apple.

Prickle. A small spine growing from the bark.

Prostrate. Lying flat on the ground.

Puberulous. Minutely pubescent.

Pubescent. Clothed with soft, short hairs.

Pungent. Terminating in a rigid, sharp point; acrid.

Pyramidal. Shaped like a pyramid.

Raceme. A simple inflorescence of stalked flowers on a more or less elongated rachis. 
Racemose. In racemes; resembling racemes.

Rachis. An axis bearing flowers or leaflets.

Receptacle. The more or less expanded portion of an axis which bears the organs of a flower or the collected flowers of a head.

Recurved. Curving downward or backward.

Reflexed. Abruptly turned downward.

Remotely. Scattered, not close together.

Reniform. Kidney-shaped.

Repand. With a slightly sinuate margin.

Reticulate. Netted.

Retrorsely. Directed backward or downward.

Revolute. Rolled backward, margin rolled toward the lower side.

Rhombic. Having the shape of a rhombus.

Rufous. Red-brown.

Rugose. Wrinkled.

Samara. An indehiscent, winged fruit.

Scabrous. Rough to the touch.

Scarious. Thin, dry, membranaceous, not green.

Scorpioid. A form of unilateral inflorescence circinately coiled in the bud.

Scurfy. Covered with small branlike scales.

Serrate. Toothed, the teeth pointing upward or forward.

Sessile. Without a stalk.

Sheath. A tubular envelope, or enrolled part or organ.

Shrub. A woody, bushy plant, branched at or near the base and usually less than 15 feet in height.

Sinuate. With a strong, wavy margin.

Sinus. The cleft or space between two lobes.

Spike. A simple inflorescence of sessile flowers arranged on a common, elongated axis.

Spine. A sharp, woody outgrowth from a stem.

Spinose. Furnished with spines.

Stamen. The pollen-bearing organ of the male flower.

Staminate. Male flowers provided with stamens but without pistils.

Stellate. Star-shaped.

Sterigmata. Short, persistent leaf bases found on spruces and hemlocks. 
Stigma. The part or surface of a pistil which receives pollen for the fecundation of the ovules.

Stipule. An appendage at the base of the petiole, usually one on each side.

Stoma. An orifice in the epidermis of a leaf used to connect internal cavities with air.

Stomata. Plural of stoma.

Stomatiferous. Furnished with stomata.

Strobile. A cone.

Style. The attenuated portion of a pistil between the ovary and the stigma.

Sub. A Latin prefix denoting somewhat or slightly.

Subtend. To lie under or opposite to.

Subulate. Awl-shaped.

Succulent. Juicy; fleshy.

Superior ovary. Free from and inserted above calyx; hypogynous.

Superposed. Placed above, as one bud above another at a node. Suture. A junction or line of dehiscence.

Syncarp. A multiple fleshy fruit.

Taproot. The primary descending root, which may be either very large or absent at the maturity of the tree.

Terete. Circular in transverse section.

Terminal. Situated at the end of a branch.

Ternate. In groups of three.

Tolerant. Capable of enduring shade.

Tomentose. Densely pubescent with matted wool or tomentum.

Tomentulose. Slightly pubescent with matted wool.

Torulose. Cylindric, with swollen partitions at intervals.

Tree. A plant with a woody stem, unbranched at or near basc, and at least 8 feet in height and 2 inches in diameter.

Truncate. Ending abruptly, as if cut off at the end.

Tubercle. A small tuber or excrescence.

Turbinate. Top-shaped.

Umbel. A simple inflorescence of flowers with pedicels all arising from the same point.

Umbo. A boss or protuberance.

Undulate. With wavy surface or margin. 
Unisexual. Of one sex, either staminate or pistillate.

Valvate. Leaf buds meeting at the edges, not overlapping.

Valve. One of the pieces into which a capsule splits.

Veins. Threads of fibro-vascular tissue in a leaf or other flat organ.

Ventral. Belonging to the anterior or inner face of an organ; the upper surface of a leaf.

Vernal. Appearing in the spring.

Vesicle. A little bladder or cavity.

Villose. Hairy with long and soft hairs.

Whorled. Three or more organs arranged in a circle round an axis.

Wing. A membranous or thin and dry expansion or appendage of an organ.

Woolly. Covered with long and matted or tangled hairs. 


\section{SELEGTED BIBLIOGRAPHY}

The following references, used by the author in preparing the descriptions and distribution maps, are recommended for students desiring to make a thorough study of the trees of this region:

Barkley, F. A. A Monographic Study of Rhus and Its Immediate Allies in North and Central America. Annals of the Missouri Botanical Garden, 1937, Vol. 24, pp. 265-498. Bell, W. H., and E. D. Castetter. The Utilization of Mesquite and Screwbean by the Aborigines in the American Southwest. University of New Mexico, Oct. 1, 1937, Bul. 314.

Britton, N. L. North American Trees. New York, Henry Holt and Company, 1908.

Coulter, J. M. Botany of Western Texas. U. S. Natl. Herbarium, 1891-99, Vol. 2, Nos. 1-3.

- - , and A. Nelson. A New Manual of Botany of the Central Rocky Mountains. American Book Company, 1909.

Dayton, W. A. Important Western Browse Plants. U.S.D.A., Misc. Pub. No. 101, July, 1931.

---, and Others. Range Plant Handbook. U.S.D.A., March, 1937.

Gibson, H. H. American Forest Trees. Chicago, Hardwood Record, 1913.

Harlow, W. M., and E. S. Harrar. Textbook of Dendrology. New York, McGraw Hill Book Co., Inc., 1937.

Kirkwood, J. E. Northern Rocky Mountain Trees and Shrubs. Stanford University Press, 1930.

Longyear, B. O. Trees and Shrubs of the Rocky Mountain Region. New York, G. P. Putnam's Sons, 1927.

Merriam, C. H. and others. North America Fauna. U. S. Biol. Survey, 1890-1917.

No. 3. Biological Survey of Arizona, 1890.

No. 33. Biological Survey of Colorado, 1911.

No. 5. Biological Survey of South-Central Idaho, 1891.

No. 35. Biological Survey of New Mexico, 1913.

Bul. 10. Life Zones and Crop Zones of the United States, 1898.

No. 42. Life Zone Investigations in Wyoming, 1917. 
Rehder, A. Manual of Cultivated Trees and Shrubs. New York, Macmillan Company, 1927.

Rydberg, P. A. Flora of Colorado. Experiment Station, Fort Collins, Colorado, 1906.

- - Flora of Prairies and Plains of Central North America. New York Botanical Garden, 1932.

---. Flora of Rocky Mountains and Adjacent Plains. New York Botanical Garden, 1922.

Sargent, C. S. Manual of the Trees of North America. Boston, Houghton Mifflin Company, 1933.

Shaw, G. R. The Genus Pinus. Publications of the Arnold Arboretum, 1914, No. 5.

Standley, P. C. Trees and Shrubs of Mexico. U. S. Natl. Herbarium, 1920-26, Vol. 23, parts 1-5.

Sudworth, G. B. Check List of the Forest Trees of the United States. U.S.D.A., Misc. Cir. 92, 1927.

- - Trees of the Rocky Mountain Region, U.S.D.A. Bulletins, Nos. 207, 327, 420, 460, 680, 1915-34.

-- - Forest Trees of the Pacific Slope. U.S.D.A., Forest Service, 1908.

Tidestrom, I. Flora of Utah and Nevada. U. S. Natl. Herbarium, 1925, Vol. 25.

Trelease, Wm. The American Oaks. National Academy of Sciences, Memoirs XX, 1924.

Van Dersal, Wm. R. Native Woody Plants of the United States. U.S.D.A., Misc. Pub. 303, 1938.

Wooton, E. O., and P. C. Standley. Flora of New Mexico. U.S. Natl. Herbarium, 1915, Vol. 19. 


\section{INDEX}

Abies, 54

arizonica, 61

balsamea, 57

concolor, 63

grandis, 65

Key to species, 55

lasiocarpa, 59

lasiocarpa arizonica, 61

magnifica, 61

magnifica shastensis, 6I

shastensis, 61

Acacia amentaceae, 201

angustissima, 201

Catclaw, 201

constricta, 201

farnesiana, 201

Greenbarked, 211

greggii, 201

Mescat, 201

Prairie, 201

Texas Catclaw, 201

tortuosa, 201

wrightii, 201

Acer, 230

brachypterum, 235

douglasii, 237

floridanum villipes, 235

glabrum, 237

glabrum douglasii, 237

grandidentatum, 235

Key to species, 231

negundo, 231

negundo arizonicum, 233

negundo interius, 233

negundo violaceum, 233

saccharum grandidentatum, 235

Aceraceae, 230-237

Ailanthus altissima, 223

glandulosa, 223

Alder, New Mexican, 135

Mountain, 129

Sitka, 131

Thinleaf, 129
White, 133

Alders, The, 126

All-thorn, 249

Alnus, 126

Key to species, 127

oblongifolia, 135

rhombifolia, 133

rubra, 126

sinuata, 131

sitchensis, 131

tenuifolia, 129

Alpine Zone, xvi

Amelanchier alnifolia, 175

canadensis. 175

crenata, 175

florida, 175

mormonica, 175

polycarpa, 175

prunifolia, 175

utahensis, 175

Anacahuita, 271

Anacardiaceae, 227

Arbutus arizonica, 257

texana, 257

xalapensis, 257

Arizona, Trees of, xxvii

Artemisia tridentata, 281

Ash, Berlandier, 265

Dwarf, 263

Flowering, 263

Fragrant, 263

Green, 265

Gregg, 269

Littleleaf, 269

Lowell, 269

Red, 265

Singleleaf, 263

Velvet, 267

Ashes, The, 260

Aspen, Golden, 107

Bark, xxvi

Betula, 120

eastwoodae, 125 
fontinalis, 125

glandulosa, 121, 125

kenaica, 123

Key to species, 121

neoalaskana, 125

occidentalis, 125

papyrifera, 123

papyrifera kenaica, 123

papyrifera montanensis, 123

papyrifera occidentalis, 123

papyrifera subcordata, 123

pendula, 120

pendula dalecarlica, 120

Betulaceae, 119-135

Bibliography, lxxi

Bignoniaceae, 273, 275

Birch, Black, 125

Paper, 123

Red, 125

Water, 125

Birches, The, 120

Bird-of-paradise Flower, 205

Blackbrush, 201

Blueberry Elder, 277

Bluewood, 245

Borraginaceae, 271

Boxelder, 233

Broussonetia secundiflora, 213

Buckeye, Mexican, 241

Buckthorn, California, 2.43

Cascara, 243

Hollyleaf, 245

Mountain, 257

Bumelia Brazos, 259

gum, 259

lanuginosa rigida, 259

monticola, 259

Burning Bush, 229

Bursera, 225

microphylla, 225

odorata, 225

Burseraceae, 225

Buttonbush, Common, 275

Cactaceae, 250

Cactus Family, 250

Cactus, Cane, 251

Giant, 251

Caesalpina gilliesli, 205

Canadian Zone, xviii
Canotia holcantha, 229

Caprifoliaceae, 277-279

Caragana arborescens, 207

Carnegiea gigantea, 251

Cascara, Buckthorn, 243

Castanopsis chrysophylla, 155

Castorbean, 225

Catalpa speciosa, 273

Western, 273

Catclaw, 201

Cedar, Incense, 67

Cedar, Shrubby Red, 71

Cedar, Western Red, 67

Celastraceae, 229

Celtis, 158

douglasii, 165

Key to species, 159

laevigata, 163

laevigata brevipes, 163

laevigata texana, 163

occidentalis crassifolia, 161

reticulata, 165

Cephalanthus occidentalis, 275

Cerasus demissa, 195

Cercidium floridum, 211

macrum, 211

microphyllum, 211

torreyanum, 211

Cercis occidentalis, 207

Cercocarpus betuloides, 183 eximius, 183

hypoleucus, 183

ledifolius, 181

ledifolius intricatus, 181

montanus, 183

paucidentatus, 183

Ciereus giganteus, $25 \mathrm{I}$

Cherries, The, 186

Cherry, Bitter, 193

Pin, 191

Southwestern Choke, 197

Western Choke, 195

Wild Red, 191

Chilopsis linearis, 273 saligna, 273

Chinaberry, 239

Chinquapin, Giant, 155 Golden, 155

Chokecherry, 195, 197

Cholla, 251 
Cliffrose, 185

Colorado, Trees of, xxxi

Compositae, 281

Condalia obovata, 245

Coralbean, 213, 217

Cordia boisseri, 271

Cornel, 255

Cornaceae, 255

Cornus nuttallii, 255 californica pubescens, 255 occidentalis, 255

pubescens, 255 stolonifera, 255

Corona de Cristo, 249

Cotton, Arizona Tree, 241

Cottonwood, Fremont, 113

Lanceleaf, 105

Narrowleaf, 103

Northern Black, 99

Plains, 111

Rio Grande, 109

Valley, 109

Cottonwoods, The, 96

Cowania davidsonii, 185

mexicana, 185

stansburiana, 185

Cirataegus, 176

brevispina, 179

chrysocarpa, 177

columbiana, 177

douglasii, 176, 177, 179

douglasii rivularis, 179

erythropoda, 177

Key to species, 177

montivaga, 177

saligna, 177

sticculenta, 177

williamsii, 177

wootoniana, 177

Cupressaceae, 67-91

Ciupressus, 68

arisonica, 71

arizonica bonita, 73

glabra, 73

Key to species, 69

Cypress, Arizona, 71

Smooth, 73

Cypresses, The, 68

Dalea spinosa, 217

Desert-almond, 189
Desertwillow, 273

Diospyros texana, 259

Dogwood, Pacific, 255

Red osier, 255

Western, 255

Douglas-fir, 53

Ebenaceae, 259

Elaeagnaceae, 253

Elaeagnus angustifolia, 253

argentea, 253

commutata, 253

Elaphrium microphyllum, 225

Elbowbush, 269

Elder, Blueberry, 277

Elephanttree, 225

Elm, American, 157

Rock, 157

Siberian, 157

Slippery, 157

White, 157

Emplectocladus fasciculatus, 189

Ericaceae, 257

Erythrobalanus, 136

Erythrina flabelliformis, 217

Euonymus, 229

atropurpureus. 229

occidentalis, 229

Euphorbiaceae, 225

Eysenhardtia, 215

orthocarpa, 215

polystachya, 215

Fagaceae, 136-155

Fir, Alpine, 59

Balsam, 57

Corkbark, 61

Douglas, 53

Grand, 65

Lowland White, 65

Red, 61

Shasta Red, 61

White, 63

Firs, The, 54

Flannelbush, 247

Flowers, xxiv

Forestiera pubescens, 269

Fraxinus, 260

anomala, 263

berlandieriana, 265

campestris, 265 
cuspidata, 263

greggii,

Key to species, 261

lowellii, 269

pennsylvanica, 265

pennsylvanica lanceolata, 265

pistaciaefolia, 267

standleyi, 267

velutina, 267

velutina coriacea, 267

velutina glabra, 267

velutina toumeyi, 267

viridis, 265

Fremont Screwbean, 205

Fremontia, 247

californica mexicana, 247

Fremontodendron californicum, 247

mexicanum, 247

Frijolito, 213

Fruit, xxv

Giant Arborvitae, 67

Giant Cactus, 251

Glossary, lxi

Gossypium thurberi, 241

Gregg's Leadtree, 199

Guaiacum angustifolium, 221

Gum Elastic, 259

Hackberry, 163

Bigleaf, 161

Netleaf, 165

Hackberries, The, 158

Hawthorn, Black, 179

Hawthorns, The, 176

Hemlock, Black, 51

Mountain, 51

Western, 49

Hemlocks, The, 46

Holocantha emoryi, 249

Hophornbeam, 119

Hoptree, 223

Horsebean, 209

Hudsonian Zone, xvi

Huisache, 201

Idaho, Trees of, xxxiv

Incense-cedar, 67

Indigo Bush, 217
Ironwood, 119, 221

Jerusalem thorn, 209

Joshua Tree, 283

Juglandaceae, 95

Juglans major, 95

nigra, 95

rupestris, 95

Juniper, Alligator, 87

Bigberry, 85

Drooping, 89

Dwarf, 74

Mexican, 83

Oneseed, 81

Openseed, 81

Redberry, 91

Rocky Mountain, 79

Sierra, 77

Utah, 85

Western, 77

Junipers, The, 74

Juniperus, 74

communis, 74

communis montana, 74

communis sibirica, 74

erythrocarpa, 91

flaccida, 89

gigantea, 91

gymnocarpa, 81

horizontalis, 74

Key to species, 75

knightii, 85

megalocarpa, 85

mexicana, 81,83

mexicana monosperma, 81

monosperma, 81

occidentalis, 77

pachyphloea, 87

pinchoti, 91

sabina prostrata, 74

sabinoides, 83

scopulorum, 79

utahensis, 85

utahensis megalocarpa, 85

Key to Genera, liii

Kidneywood, 215

Koeberlinia spinosa, 249

Koeberliniaceae, 249

Larch, Alpine, 35 
Eastern, 31

Western, 33

Larches, The, 28

Larix, 28

alaskensis, 31

decidua, 28

Key to species, 29

laricina, 31

lyallii, 35

occidentalis, 33

Leadtree, Gregg's, 199

Littleleaf, 199

Leaves, $\mathrm{xxii}$

Leguminosae, 199-221

Leucaena, 199

greggii, 199

retusa, 199

Leucobalanus, 136

Libocedrus decurrens, 67

Life Zones, xv map of, xvii

Liliaceae, 283

Locust, Black, 219

Southwestern, 219

Logwood, 245

Lower Sonoran Zone, xix

Lysiloma, 199

thornberi, 199

watsoni, 199

Madrone, Arizona, 257

Mexican, 257

Texas, 257

Malvaceae, 241

Maple, Bigtooth, 235

Douglas, 237

Rocky Mountain, 237

Southwestern, 235

Maples, The, 230

Mescalbean, 213

Mesquite, Common, 203 Screwbean, 205

Mexican-buckeye, 241

Mohavethorn, 229

Montana, Trees of, xxxvi

Moraceae, 167

Morus celtidifolia, 167

microphylla, 167

rubra, 167

Mountainash, Western, 173

Mountain-mahogany, Curlleaf, 181
Shaggy, 183

Mulberry, Mexican, 167

Red, 167

Texas, 167

Nannyberry, 279

Nevada, Trees of, xxxviii

New Mexico, Trees of, xl

Nicotiana glauca, 271

Nogal, 95

Oak, Arizona White, 149

Black, 143

Bray's, 155

Bur, 151

Cañon Live, 141

Chestnut, 155

Chinquapin, 155

Emory, 143

Goldencup, 141

Live, 147

Maul, 141

Mexican Blue, 147

Netleaf, 145

Silverleaf, 139

Socorro, 153

Toumey, 149

Utah White, 153

White, 147

Whiteleaf, 139

Oaks, The, 136

Oleaceae, $260-269$

Olive, Russian, 253

Olneya tesota, 221

Opuntia arborescens, 251

fulgida, 251

imbricata, 251

spinosior, 251

versicolor, $25 \mathrm{I}$

Ostrya baileyi, 119

knowltonii, 119

virginiana, 119

Padus virens, 197

Palm, Fanleaf, 285

Palmae, 285

Palo Blanco, 165

Paloverde, Blue, 211

Border, 211

Littleleaf, 211

Paradise Flower, 201

Parkinsonia aculeata, 209 
microphylla, 211

Parosela spinosa, 217

Pea Tree, Siberian, 207

Persimmon, Texas, 259

Picea, 36

abies, 36

canadensis, 41

engelmanni, 43

glauca, 41

glauca albertiana, 41

Key to species, 37

parryana, 45

pungens, 45

mariana, 39

Pinaceae, 2-65

Pine, Apache, 21

Arizona, 21

Bristlecone, 17

Chihuahua, 23

Foxtail, 17

Jack, 27

Jeffrey, 21

Limber, 7

Lodgepole, 25

Mexican Piñon, 13

Mexican White, 11

Nut, 13

Piñon Nut, 15

Ponderosa, 19

Scrub, 27

Shore, 25

Singleleaf Piñon, 15

Sugar, 5

Western White, 5

Western Yellow, 19

Whitebark, 9

Pines, Key to the, 3

The, 2

Pinus, 2

albicaulis, 9

apacheca, 21

aristata, 17

arizonica, 21

ayacahuite, 11

banksiana, 27

brachyptera, 19

cembroides, 13, 15

cembroides edulis, 15

cembroides monophylla, 15 chihuahuana, 23

contorta, 25

contorta latifolia, 25

divaricata, 27

edulis, 15

flexilis, 7

flexilis reflexa, 11

jeffreyi, 17

lambertiana, 5

latifolia, 21

leiophylla, 23

monophylla, 15

monticola, 5

murrayana, 25

ponderosa, 19, 21

ponderosa arizonica, 21

ponderosa scopulorum, 19 strobiformis, 11

Pistache, Texas, 227

Pistacia texana, 227

Platanaceae, 169

Platanus wrightii, 169

Plum, American, 189

Plums, The, 186

Poinciana gilliesii, 205

Poplar, 107

Balsam, 101

Poplars, The, 96

Populus, 96

acuminata, 105

acuminata rehderi, 105

$\mathrm{X}$ andrewsii,* 105

angustifolia, 103

arizonica, 113

balsamifera, 101

balsamifera candicans, 101

deltoides occidentalis, 111

deltoides virginiana, 111

fremontii, 109, 113

fremontii macrodisca, 113

fremontii pubescens, 113

fremontii thornberii, 113

fremontii toumeyi, 113

fremontii wislizeni, 109

Key to species, 97

macdougalii, 133

sargentii, 111

tacamahaca, 101

tremuloides, 107

" An X preceding a species name signifies that it is a hybrid. 
tremuloides aurea, 107

trichocarpa, 99

trichocarpa hastata, 99

wislizeni, 109

Porlieria angustifolia, 221

Prosopis chilensis, 203

chilensis glandulosa, 203

chilensis velutina, 203

juliflora, 203

odorata, 205

pubescens, 205

Prunus, 186-197

americana, 189

andersonii, 189

besseyi, 186

corymbulosa, 186

demissa, 195

emarginata, 193

emarginata villosa, 193

fasciculata, 189

havardii, 186

Key to species, 187

melanocarpa, 195

minutiflora, 186

pennsylvanica, 191

pennsylvanica saximontana, 191

pumila, 186

serotina, 186

valida, 197

virens, 197

virginiana demissa, 195

virginiana melanocarpa, 195

Pseudotsuga glauca, 53

mucronata, 53

taxifolia, 53

Ptelea baldwinii, 223

tomentosa, 223

trifoliata, 223

Pyrus sambucifolia, 173

Quercus, 136-155

annulata, 136

arizonica, 149

brayi, 155

breviloba, 136

canybi, 136

chrysolepis, 141

chrysolepis palmeri, 141

confusa, 136

diversicolor, 145 emoryi, 143

gambelii, 136, 153

gravesii, 139

grisea, 136

gunnisonii, 136

hypoleuca, 139

Key to species, 137

leptophylla, 153

macrocarpa, 151

media, 136

mohriana, 136

mühlenbergii, 155

mühlenbergii brayi, 155

novomexicana, 136

oblongifolia, 147

pauciloba, 136

reticulata, 145

subturbinella, 136

texana chesoensis, 139

texana stellipila, 139

toumeyi, 149

undulata, 136

utahensis, 153

utahensis submollis, 153

virginiana, 147

vreelandii, 136

wilcoxii, 141

Quinine Bush, 185

Redbud, California, 207

Mountain, 207

Retama, 209

Rhamnaceae, 243-245

Rhamnus californica tomentella, 243

crocea ilicifolia, 245

purshiana, 243

Rhus copallina lanceolata, 227

glabra, 227

kearneyi, 227

lanceolata, 227

microphylla, 227

ovata, 227

Ricinus communis, 225

Robinia neo-mexicana, 219

neo-mexicana luxurians, 219

pseudoacacia, 219

rusbyi, 219

Rosaceae, 171-197

Rubiaceae, 275

Russian Olive, 253 
Rutaceae, 223

Sage, Black, 281

Brush, 28I

Salicaceae, 96-117

Salix, 114

amygdaloides, 117

amygdaloides wrightii, 117

bebbiana, 115

bonplandiana toumeyi, 115

exigua, 115

gooddingi, 115

interior, 115

Key to species, 115

laevigata, 115

lasiandra, 115

lasiolepsis, 115

mackenziana, 115

nigra, 115

scouleriana, I15

taxifolia, 115

Sambucus cerulea, 277

cerulea arizonica, 277

cerulea velutina, 277

glauca, 277

mexicana, 277

neo-mexicana, 277

Sapindaceae, 239-241

Sapindus drummondi, 239

Sapium biloculare, 225

Sapotaceae, 259

Serviceberry, Western, 175

Siberian Pea Tree, 207

Silverberry, 253

Silverbush, 253

Silvical Characters, xxvi

Simaroubaceae, 223, 249

Smokethorn, 217

Soapberry, Western, 239

Soapbush, 221

Solanaceae, 271

Sonoran Zone, lower, xix

Sonoran Zone, Upper, xix

Sophora affinis, 213 secundiflora, 213

Texas, 213

Sorbus americana sitchensis, 173 scopulina, 173

sitchensis, 173

Spanish-bayonet, 283

Spanish Buckeye, 241
Spruce, Black, 39

Blue, 45

Colorado, 45

Engelmann, 43

Norway, 36

Western White, 41

White, 41

Spruces, The, 36

Key to, 37

Sterculiaceae, 247

Strombocarpa odorata, 205

Sugarberry, Texas, 163

Sumac, Sugar, 227

Sycamore, Arizona, 169

Tamarack, 31

Tamaricaceae, 247

Tamarisk, 247

Tamarix, gallica, 247 juniperina, 247

Tasajo, 251

Taxaceae, 93

Taxus brevifolia, 93

Tecoma stans, 275

Terminology, xxi

Tesota, 221

Texas, Trees of, xliv

Thornapple, Western, 179

Thuja plicata, 67

Thurberia thespesioides, 241

Transition Zone, xviii

Tree, Characters, $\mathrm{xx}$ definition of, $x x$ name, xxi

Tree of Heaven, 223

Tree Tobacco, 271

Trumpetfower, 275

Tsuga, 46 heterophylla, 49 Key to species, 47 mertensiana, 5l

Twigs, xxvi

Ulmaceae, 157-165

Ulmus americana, 157 fulva, 157

pumila, 157

thomasii, 157

Ungnadia speciosa, 241

Upper Sonoran Zone, xix

Utah, Trees of, xlviii 
Vachellia farnesiana, 201 Vauquelinia, 171

angustifolia, 171 californica, 171 Torrey, 171

Viborquia orthocarpa, 215

Viburnum lentago, 279

Wafer Ash, 223

Wahoo, 229

Western, 229

Walnut, Arizona, 95

Black, 95

Texas, 95

Washingtonia arizonica, 285

filamentosa, 285

filifera, 285

robusta, 285

sonorae, 285
Willow, Desert-, 273

Willow, Black, 115

Peachleaf, 115

Willows, The, 114

Wood, xxvi

Wyoming, Trees of, 1

Yew, Pacific, 93

Western, 93

Yucca brevifolia, 283

elata, 283

Hoary, 283

Mohave, 283

mohavensis, 283

schottii, 283

Soaptree, 283

Torrey, 283

torreyi, 283 